\title{
PALINOLOGIA, BIOESTRATIGRAFIA E PALEOECOLOGIA DA FORMAÇÃO ALAGAMAR-CRETACEO DA BACIA POTIGUAR, NORDESTE DO BRASIL
}

\author{
Rodolfo Dino
}

Orientador: Prof. Dr. Murilo Rodolfo de Lima

\section{TESE DE DOUTORAMENTO}

Programa de Pós-Graduação em Geologia Sedimentar 


\section{UNIVERSIDADE DE SÃO PAULO INSTITUTO DE GEOCIENCIAS}

\section{PALINOLOGIA, BIOESTRATIGRAFIA E PALEOECOLOGIA DA FORMAÇÃO ALAGAMAR-CRETACEO DA BACIA POTIGUAR, NORDESTE DO BRASIL}

Rodolfo Dino

Orientador: Prof. Dr. Murilo Rodolfo de Lima

TESE DE DOUTORAMENTO

\section{COMISSÃO JULGADORA}

nome

Presidente:

Dr. M.R.de Lima

Examinadores:

Dr.J.C.de Castro

Dra M.S.P.Regali

Dr. S.Petri

Dr. P.R.dos Santos ass.

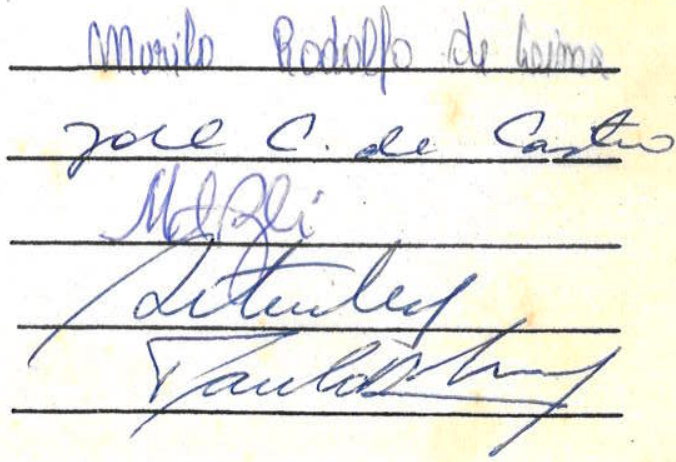




\section{UNIVERSIDADEE DE SÃO PAULO \\ INSTITUTO DE GEOCIÊNCIAS}

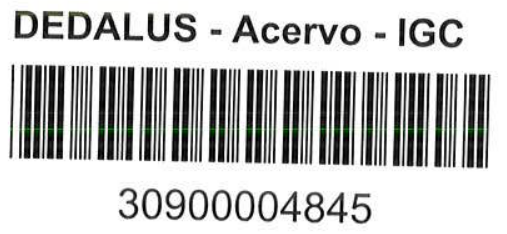

\section{PALINOLOGIA, BIOESTRATIGRAFIA E PALEOECOLOGIA DA FORMAÇÃO ALAGAMAR - CRETÁCEO DA BACIA POTIGUAR, NORDESTE DO BRASIL}

Rodolfo Dino

Orientador; Prof. Dr. Murilo Rodolfo de Lima

\section{TESE DE DOUTORAMENTO}

Programa de Pós-Graduação em Geologia Sedimentar

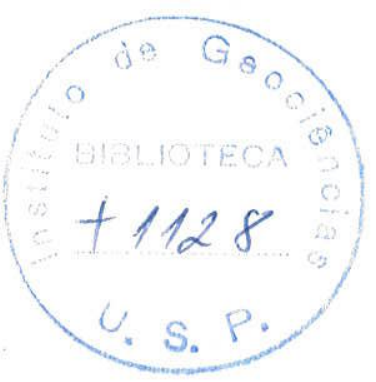

São Paulo 
"Näo conseguimos encontrar respostas para todos os nossos problemas.

As que encontramos apenas nos levaram a formular novas questöes.

Sentimo-nos hoje tão confusos como antes.

Acreditamos, entretanto, que estamos confusos num nível mais alto $e$ sobre coisas mais importantes."

(autor desconhecido) 


\section{SUMÁRIO}

ILUSTRAÇÕES DO TEXTO. iv

AGRADECIMENTOS vi

SINOPSE $\mathrm{ix}$

ABSTRACT. $\mathrm{xi}$

I- INTRODUÇÃO

1) Objetivos do Estudo

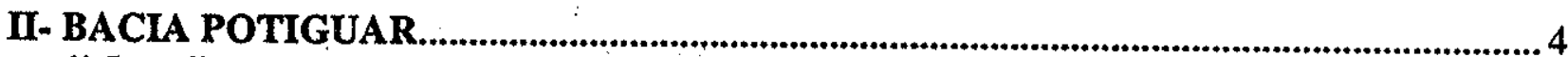

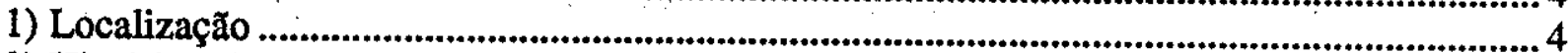

2) Histórico Evolutivo dos Conhecimentos da Bacia.............................................................6

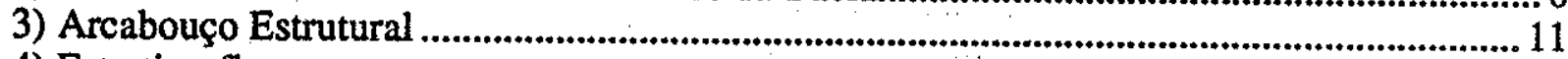

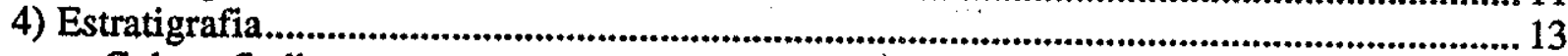

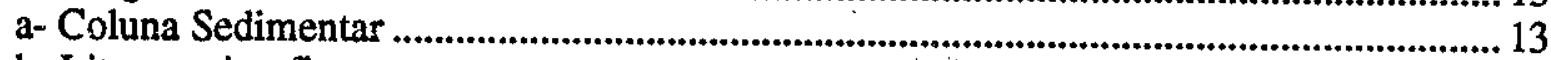

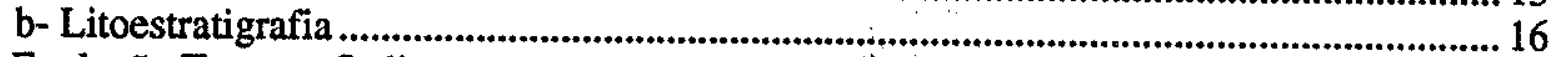

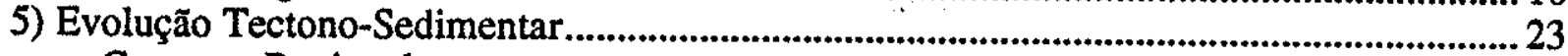

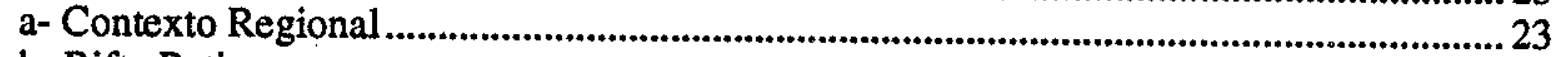

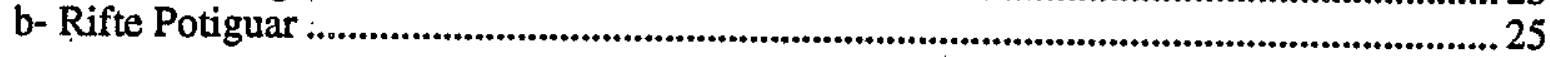

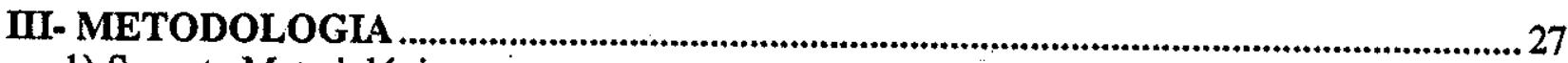

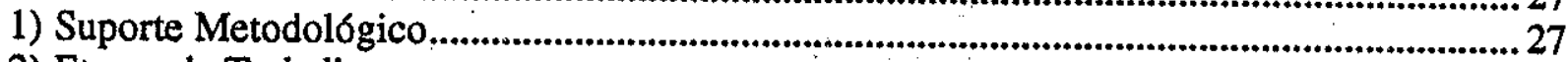

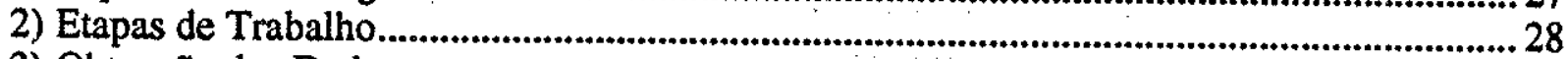

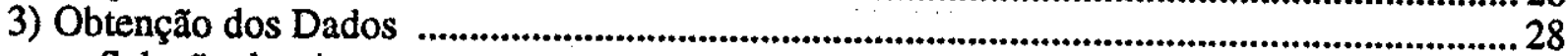

a- Seleção das Amostras ...........................................................................................28

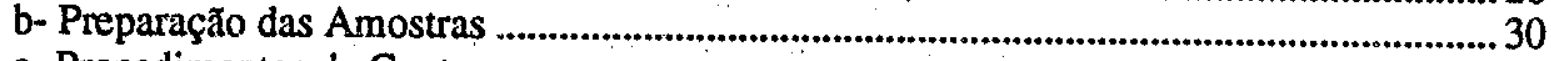

c- Procedimentos de Contagem ....................................................................................30

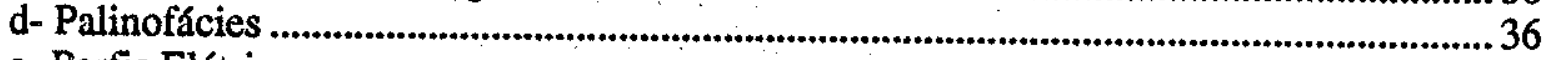

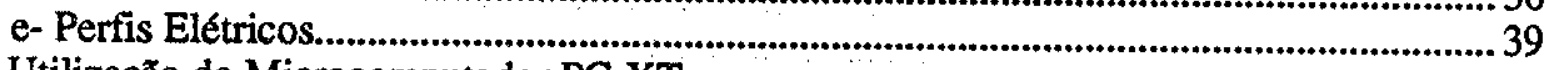

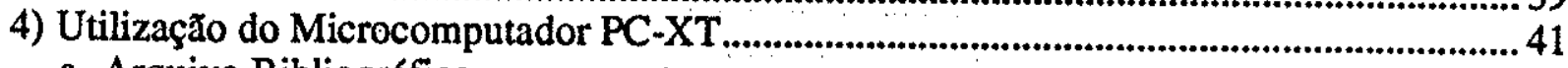

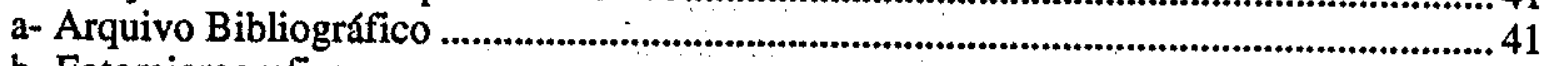

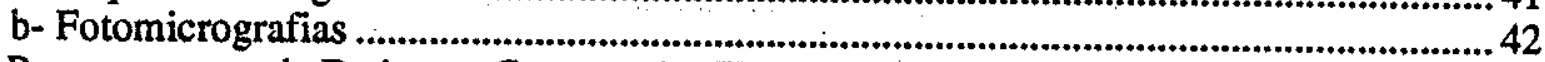

5) Processamento de Dados no Computador IBM-3090 …................................................42 42

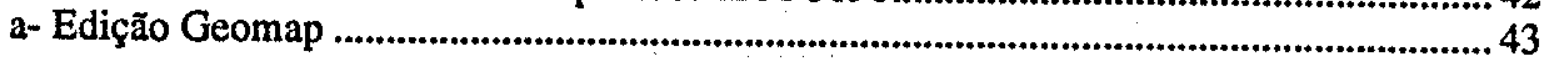

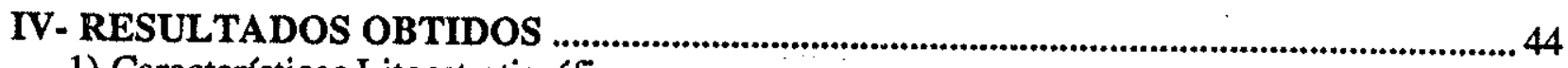

1) Características Litoestratigráficas........................................................................44

a- Fatiamento Grafoelétrico da Formação Alagamar ……….............................................4 44

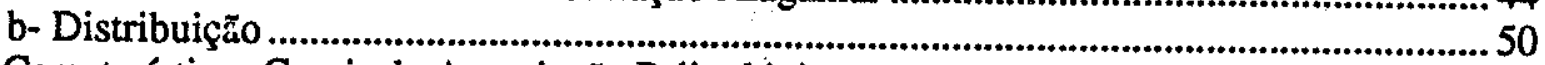

2) Características Gerais da Associação Palinológica..............................................................55

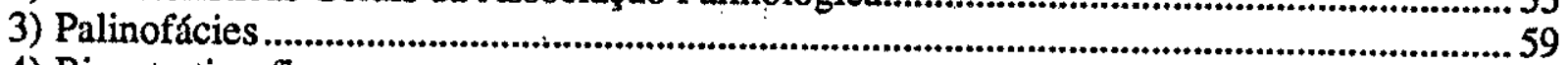

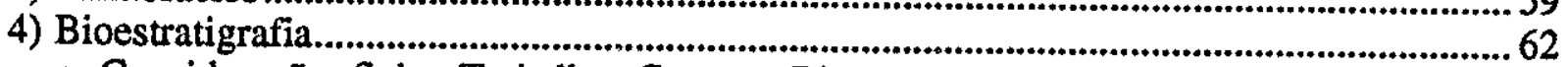

a- Consideraçðes Sobre Trabalhos Crono-e Bioestrat. Prévios da Seção Estudada ...........64 64

O Andar Alagoas ..............................................................................................64

Dados Bioestratigráficos do Andar Alagoas na Bacia Potiguar.......................................66

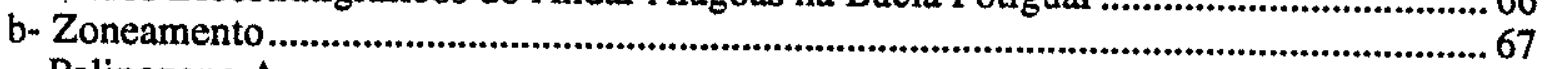

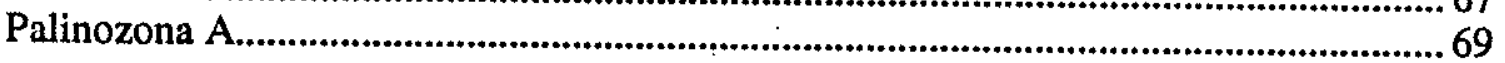




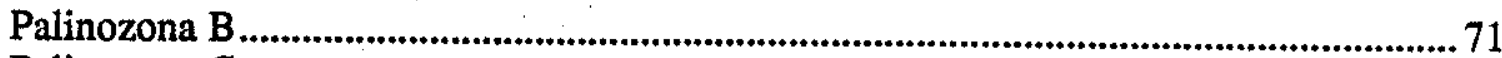

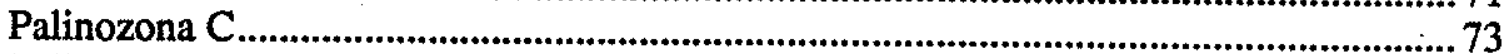

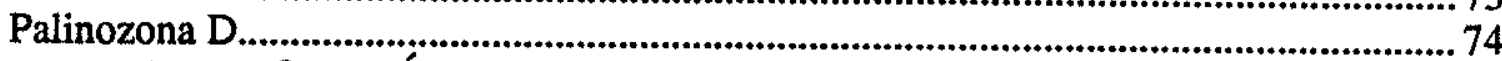

5). Comparaç̃̃o com Outras Áreas Sedimentares Brasileiras.....................................................76

6) Comparação com Áreas Correlatas no Exterior.................................................................78

7) Província Microflorfstica na qual se insere a Associação Estudada ,...................................... 81

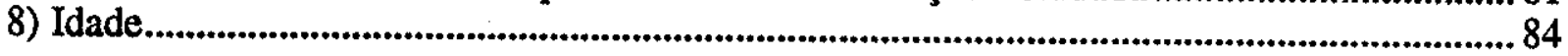

V- INTERPRETAÇÃO PALEOAMBIENTAL..............................................................91

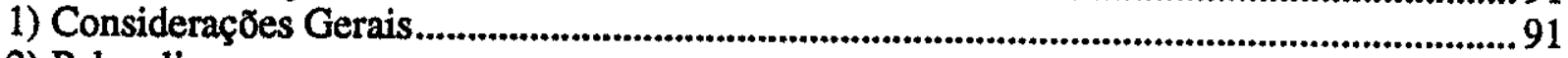

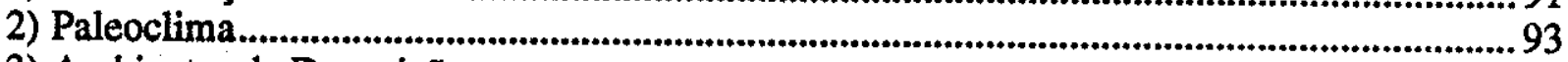

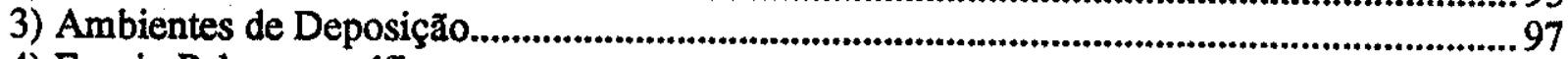

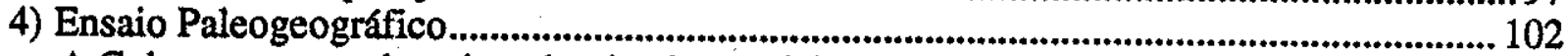

A Cobertura vegetal na área dominada por deltas............................................................ 103

Vegetação das áreas baixas no domínio lacustre........................................................... 104

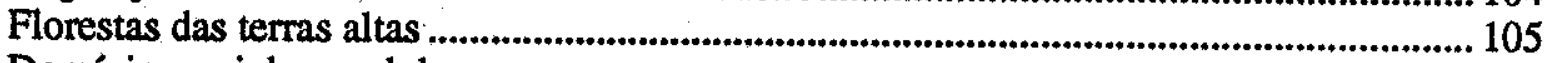

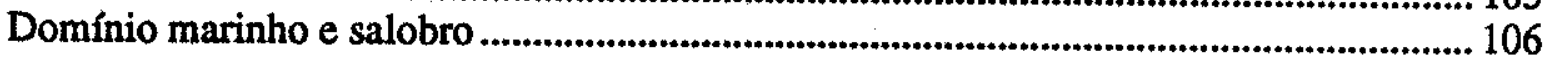

VI- AFINIDADES BOTÂNICAS DA ASSOCIAÇÃO MICROFLORÍSTICA....................107

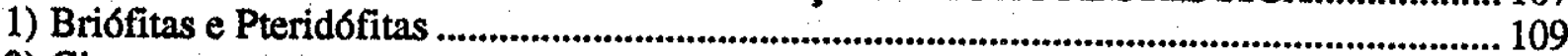

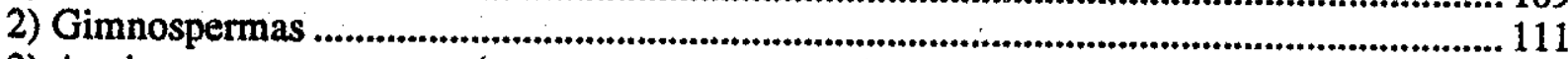

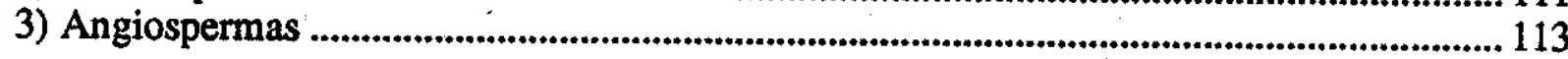

VII- PALEOGEOGRAFIA EOCRETÁCEA DA PROVÍNCIA BORBOREMA ................116

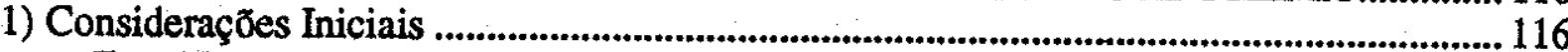

a- Fase Neocomiana (Pre-Alagoas) ........................................................................... 117

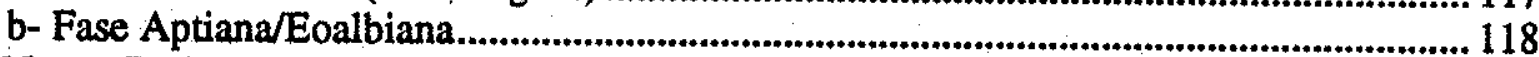

2) Novos Dados....................................................................................................119

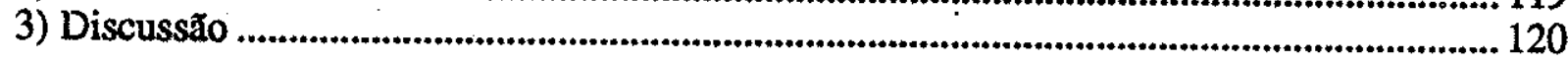

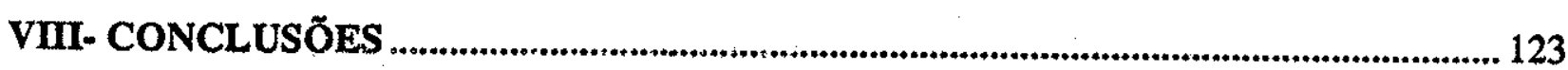

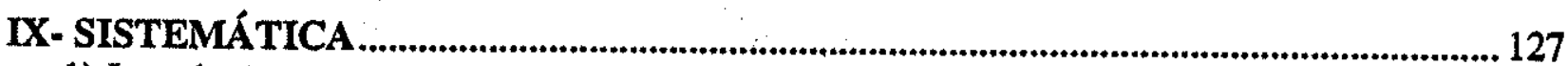

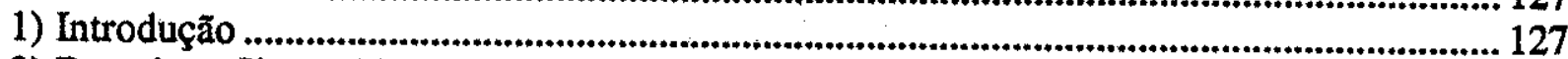

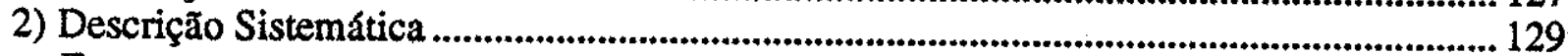

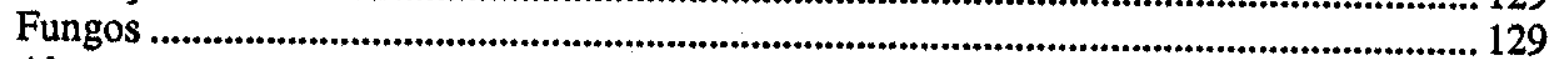

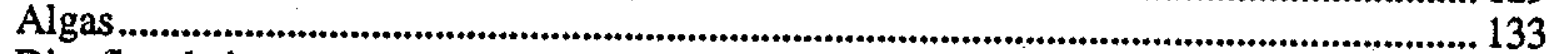

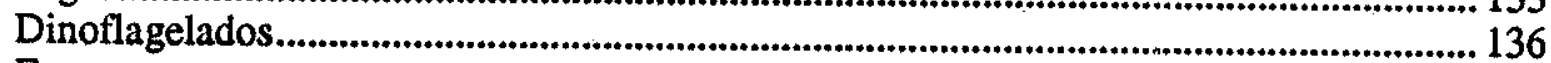

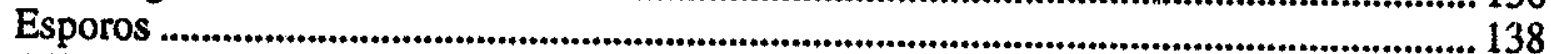

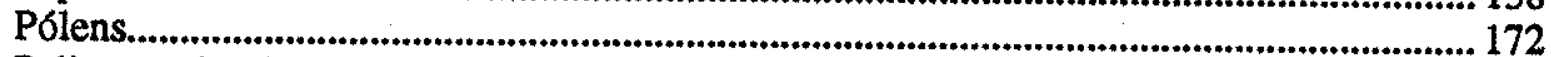

Palinomorfos "Incertae sedis" ....................................................................................... 236

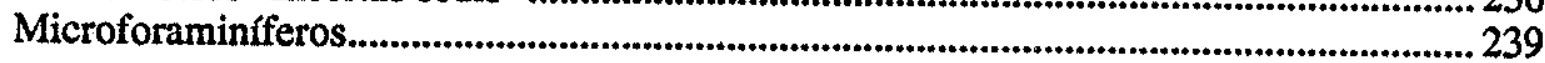

X- REFERENCLAS BIBLIOGRÁFICAS.........................................................................2 240

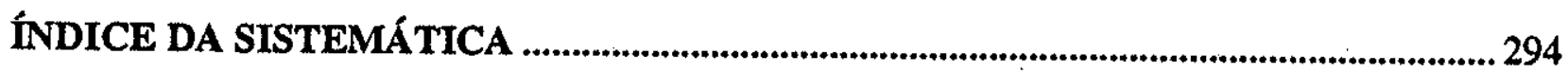

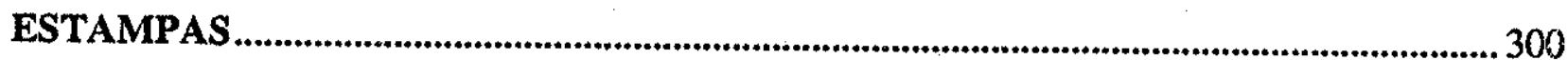




\section{ILUSTRAÇõES DO TEHTO}

Figuras

Páginas

1. Mapa de localização da Bacia Potiguar. .............................................5

2. Mapa índice de poços perfurados e campos de óleo da Bacia Potiguar. ......8

3. Arcabouço estrutural esquemático da Bacia Potiguar. ...........................12

4. Coluna estratigrafica da Bacia Potiguar...........................................15

5. Seção tipo da Formação Alagamar..................................................18

6. Mapa de contorno estrutural do topo da Formação Alagamar..................20

7. Mapa de isópacas da Formação Alagamar.........................................22

8. Metodologia e etapas do trabalho. (Fluxograma) ................................29

9. Testemunhos representativos dos sedimentos do Membro Upanema. Fácies de Fan-Deltas.

10. Testemunhos representativos das Camadas Ponta do Tubarão. Mostrando os depósitos carbonáticos e folhelhos lacustres.

11. Testemunhos representativos do Membro Galinhos. Mostrando Fácies Prodeltaicas e Frente Deltaica Distal.

12. Relação entre o desvio padrão máximo (d), e o número de palinomorfos contados (n).

13. Curva de saturação (Teórica) de uma dada amostra. ................................35

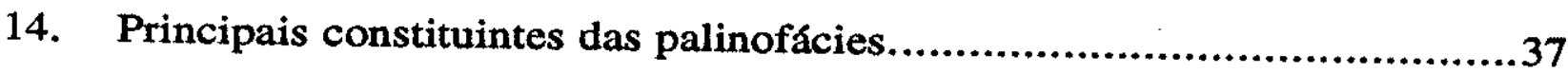

15. Mapa índice dos poços e seções estudadas. ........................................40

16. Seção estratigráfica longitudinal. (SEÇÃo A-A'). - Gráben de Apodi Gráben de Boa Vista.

17. Seção estratigrafica longitudinal. (SEÇÃO B-B'). - Gráben de Apodi Gráben de Umbuzeiro.

18. Seção estratigráfica transversal. (SEÇÃO C-C')

19. Seção estratigrafica transversal. (SEÇÃo D-D')

20. Seção estratigráfica longitudinal. (SEÇÃo E-E'). Ligação Terra - Mar 
21. Seção estratigráfica longitudinal. (SEÇÃO F-F'). Bacia Submersa.. .........54

22. Distribuição quantitativa dos principais grupos de palinomorfos na Formação Alagamar

23. Distribuição dos elementos constituintes das palinofácies nos diferentes ambientes inferidos para a Formação Alagamar

24. Quadro comparativo da correlação entre o Andar Alagoas (LOCAL) com a coluna cronoestratigrafica internacional segundo diferentes autores.

25. Distribuição estratigrafica vertical dos principais palinomorfos identificados na seção estudada.

26. Correlação Bioestratigrafica dos Perfis Estudados

27. Correlação entre distintos esquemas zonais propostos para o Andar Alagoas. (Bacia Potiguar e outras).

28. Correlação do zoneamento proposto com esquemas zonais fora do Brasil.

29. Distribuição estratigrafica dos principais gêneros (especcies) identificados, segundo diferentes autores.

30. Modelo deposicional inferido para a Formação Alagamar .................... 100

31. Prováveis afinidades botânicas da microflora estudada...................... 108

\section{Tabelas}

Páginas

1. Quadro evolutivo das unidades litoestratigraficas da Bacia Potiguar......10

\section{Quadros}

\section{Páginas}

1. Características principais dentre as espécies de Callialasporites identificadas neste neste trabalho

2. Características principais dos diferentes gêneros de grãos de pólen tricolpados com exina reticulada e estrio-reticulada.

3. Características principais que individualizam diferentes gêneros de grãos de pólen inaperturados 


\section{AGRADECIMENTOS}

Este estudo foi realizado grafas à colaboracão conjunta do Centro de Pesquisas Leopoldo A. Miguez de Mello (PETROBRÁS/CEN(PES) e do Departamento de Paleontologia e Estratigrafia do Instituto de Geociências da Zlniversidade de São Paulo (USP). A preparacãa desta tese não seria possivel semo apoio destas entidades.

É praticamente impossivel fazer um estudo desta ordem, sem contribuicões em tempo, esforso, dedicasão e gentileza de muitas pessoas. Reconheso ao final deste trabaffio que o mesmo, apesar de minfia autoria e responsabilidade, não é fruto apenas de meu esforço, mas também do apoio de amigos, familiares e pesquisadores que, de uma maneira ou outtra, acabaram colaborando para a conclusão do projeto.

Gostaria de agradecer ds seguintes instituicôes e pessoas, as quais me ajudaram de diversas maneiras durante o curso deste trabalho:

- d Petróleo Brasileiro S/A - PEIROBRRŹS, pela liberacão do projeto de pesquisa como um todo; e especificamente d Superintendência do Cenpes, na pessoa do geólogo Guilfherme de Oliveira Estrella, pelo apoio prestado durante o transcorrer do mesmo. O suporte da Companfia se refletiul tanto na ajuda financeira, quanto no formecimento e liberacão do material, além do acesso aos equipamentos necessários para a realizacão do mesmo;

- ao Prof. Dr. Murilo Rodoffo de Lima, orientador e amigo, que me introduziu na ciência da palinologia, pela qual me entusiasmei e da qual fiz a minfia profissão; razão pela qual sou-Che extremamente grato. Seus comentários, discussões e observacốes cuidadosas no transcorrer do trabalfo engrandeceram e aperfeicoaram seu conteidio;

- aos responsatveis pelo curso de Pós-Graduacão em Geociências da Ulniversidade de São Paulo, pela compreensão e cooperação dispensadas ao longo de todo o processo de elaboracãa datese; 
- a bióloga Luzia Antonioli, especialmente, meus sinceros agradecimentos pela colaboracão em todas as fases desta pesquisa, desde a preparafão das amostras até a elaborafão das figuras e seçoes. E principalmente, pelo modo como se engajou neste projeto, nele trabalhando como se fosse seu. Além disso, seu entuliasmo, encorajamento e paciência serviram-me de exemplo e sustentaram-me trabalfhando durante as etapas mais dificeis que pareciam intermináveis;

- aos colegas da Divisão de Interpretacão (DEBARDDI (IER e do laboratório (DEBAR/SELABB), do Distrito de Exploracão da Bacia Potiguar (DEBARע pelo apoio e presteza com que sempre atenderam minhtas solicitafôes. Igualmente agradeso aos colegas do Departamento de Explorafão, do Setor das bacias Ceará/Potiguar (DEPEX/SECEPO) e da Divisão de Tratamento de Dados Exploratórios, do Setor de Programacão e Análises (DITREX/SEPRRON;

- ao geólogo e amigo José Henrique Gonsalves de Melo, meus agradecimentos especiais pela amizade, apoio e muitas horas de discussões técnicas sobre temas da geologia e bioestratigrafia, os quais forneceram parte da inspiracão e suporte na viabilizacía deste projeto. $O$ referido colega jamais poupou tempo para me ajudar e apoiar no aprimoramento desta tese, seja revisando o texto e figuras, criticando ou apresentando valiosas sugestôes;

- ao geólogo Namio Zlesugui, pela amizade, por sua valiosa assistência na metodologia de preparação das amostras, pelas discussões sobre o polêmico tema "Andar HLagoas" e peía ajuda na descricão das espécies; sua colaboracão deu-se também através de discussões sobre morfologia e sistemática, onde minfia percepsão sofreu grande avanso;

- d Dra. Edwige Masure da Universidade Pierre-et-Maric-Curie (PARIS VI), pela colaboracão na identificasão e pela revisão da sistemática dos dinoflagelados;

- ao Dr. Joel Castro pelos ensinamentos, assistência e ajuda nas interpretacõos estratigráficas e perfis elétricos, além das criticas e sugestôes sempre construtivas, em relácão aos problemas litoestratigrificos;

- ao geólogo Francisco Celso Ponte pela Leitura crítica, pela amizade, pelos ensinamentos nos trabalfios de campo, e pelas proficuas discussões sobre a evolucão tectono. sedimentar da Provincia Estrutural da Borborema; 
- ao geólogo Gefiard Beurten pelas traducões de descricõos taxonômicas em alemão e por despender significativa parte de seu tempo, inclusive em feriados, ensinando-me pacientemente a utilizacão de softwares para a editoracão e impressão da tese;

- ¿Dra. Marilia Regali pelas confirmacões na identificacão de suas espécies no decorrer deste estudo;

- d Dra. Mary Elisabeth C. B. de Oliveira Babinski que assumiu por um pequeno, porém muito delicado, período a tarefa da orientaç̃o na fase final desta pesquisa. Agradeco por seu apoio e suas sugestões pacientes e encorajadoras em momentos críticos, quando este trabalfo era mais profundamente avaliado;

- d Cart Zeiss, nas pessoas dos Srs. Rui Crujo e Eric Lourenco gerentes de venda, responsáueis pelas áreas cientificas nos Estados de São Paulo e Rio de Janeiro, respectivamente, pelo empréstimo de um microscópio tipo Axiophot, dotado do sistema X Nomarski, o que permitiu a obtencão das fotografias dos palinomorfos, apresentadas na tese;

- a todos os membros da banca do exame de qualificacão, Dr. Setembrino Petri, Dr. Antonio Roberto Saad e Dra. Mary Elizabeth C. B. de Oliveira Babinski, que criticaram construtivamente esta tese, colaborando para o seu aprimoramento;

- damiga Maria Amélia Azevedo dos Santos (Amelinfia), pela sua amizade e alegria que tomaram menos árida esta dificil jomada;

- a mintia família, que me formeceu o tempo e o encorajamento necessários para perseguir o titulo de pós-graduacão em doutoramento. Sem o apoio e a compreensão familiar, este projeto talvez não tivesse logrado êxito;

- finalmente, mas não por último, aos colegas e amigos, que compartilfaram estoicamente da minfia obstinada busca do doutorado, e por me suportar nos momentos de angústia, tão comuns numa tarefa desta natureza. 


\section{SINOPSE}

A Formação Alagamar, limitada por discordâncias erosivas, é a unidade litoestratigráfica que compõe o Andar Alagoas na Bacia Potiguar. Num contexto regional, corresponde ao estágio transicional evaporítico da evolução tectono-sedimentar das bacias costeiras do Brasil. $O$ estudo integrado desta unidade, há muito necessário, foi aqui desenvolvido, permitindo a correlação entre métodos bio- e litoestratigráficos, através da investigação de 291 amostras de 18 poços exploratórios distribuídos por toda a bacia (terra e plataforma).

A análise dos perfis litológicos e diagrafias individualizou eventos transgressivos que limitam cinco intervalos com caráter cronoestratigráfico na bacia.

O exame do resíduo orgânico total permitiu a individualização de quatro tipos de palinofácies, características de distintos ambientes continentais.

Do estudo sistemático da associação microflorística, 228 espécies morfográficas foram identificadas, ilustradas e descritas ou comentadas. Dois novos gêneros, 5 espécies novas e três novas combinações são propostos. A análise quantitativa permitiu constatar, numa reconstrução tentativa da flora, um predomínio de coníferas da família das cheirolepidiáceas e de plantas do grupo das gnetáceas, secundadas pelas pteridófitas e pelas primeiras representantes das angiospermas.

A sucessão palinológica foi subdividida em 4 biozonas e 6 intervalos informais, aplicáveis em toda a bacia. Estas unidades palinoestratigráficas são correlacionáveis aos zoneamentos propostos para outras bacias dentro e fora do Brasil.

Com base na palinologia atribuíram-se idade aptiana para a Formação Alagamar e eo- a mesoalbiana para a base das formações Açu/Ubarana. Além disso, reconheceu-se a correspondência entre o Andar Alagoas (local) e o Aptiano.

Evidências palinológicas, sedimentológicas e tectônicas indicam para a Formação Alagamar um ambiente de deposição continental de terras baixas, dominantemente deltaico-flúvio-lacustre, sob clima quente árido a semi-árido e regime tectônico relativamente estável. Já a deposição da base das formaçōes 
Açu/Ubarana ocorreu em ambiente marinho próximo à costa.

A composição microflorística é bastante similar às observadas nas bacias do nordeste brasileiro e enquadra-se nas características das associações pertencentes a província microflorística do Gondwana-Norte.

Este estudo ressalta a importância da palinologia para a evolução vegetal, a paleoclimatologia e a bioestratigrafia, além de contribuir para um incremento da precisão e confiabilidade da palinoestratigrafia na região. 


\section{ABSTRACT}

The palynostratigraphy of the late Early Cretaceous (Alagoas Stage) Alagamar Formation of the Potiguar Basin has been revaluated on the basis of two hundred ninety one samples from eighteen onshore and offshore wells. The unit is essentially non-marine and bounded by erosional surfaces.

Based on well logs five cronostratigraphic units were individualized. Organic residue analyses allowed recognition of four palynofacies types used in environmental interpretations.

Two hundred and twenty eight species of spores, pollen, fungi and microplankton have been identified and ilustrated. Two new genera and five new species are recognized. Three species are newly combined. A hierarchical zonation consisting of four palynostratigraphical units is proposed, and correlations with zonal schemes from other basins are made.

According to quantitative analyses of the palynological assemblages, the flora consisted chiefly of cheirolepidacean conifers and gnetophytes, followed by pteridophytes and angiosperms as minor components.

Stratigraphic index fossils confirm that the Alagamar Formation (and therefore the Alagoas Stage) are Aptian in age. Ages of the palynological units have been assessed and correlated with palynological sequences from other basins in Brazil and overseas. Comparisons with plant-microfossil assemblages from other continents support the concept of W.A.S.A. microfloristic belt.

Palynological data imply that the Aptian climate in the Potiguar Basin was warm to hot, arid to semi-arid, and that the depositional environments were dominantly fluvial-deltaic-lacustrine. These conclusions agree with previous paleontological and sedimentological studies and are consistent with the high paleolatitudes commonly proposed for this area in the Aptian. 


\section{I- INTRODUÇño}

No universo da micropaleontologia, o método palinológico é o único com alto poder de definição na subdivisão bio- e cronoestratigráfica de sedimentos depositados em ambientes tanto marinhos quanto continentais. Isto é devido à origem polifilética do material palinologico, onde se incluem elementos de distintos ambientes aquáticos e terrestres. Realmente, os palinomorfos são encontrados em quase todas as fácies sedimentares (ao contrário dos foraminíferos, nanofósseis e ostracodes), e podem ser utilizados na datação de depósitos dos mais variados ambientes. Além disso, por não serem totalmente dependentes de fácies, podem ser utilizados como sensíveis indicadores de paleoambientes.

Contudo, o estudo dos grãos de esporos e pólen é particularmente eficiente e adequado para correlações e dataçóes quando se tratam de camadas não-marinhas ou de ambientes transicionais. Nos sedimentos acumulados em ambientes francamente marinhos, métodos mais tradicionais, como o de foraminíferos, por exemplo, são os mais indicados, não só por serem organismos exclusivamente marinhos como também por sua alta resolução bioestratigráfica aliada à facilidade e rapidez no processamento do material.

A importância dos palinomorfos sensu stricto (grãos de pólen e de esporos), na definição bio- e cronoestratigrafica de estratos não-marinhos prendese ao fato de serem elementos de origem terrestre que podem ser transportados para sítios deposicionais marinhos. São, assim, os únicos potencialmente capazes de atuar como elementos de correlação entre depósitos de ambos os ambientes, permitindo a calibração de estratos não-marinhos locais com a escala 
cronoestratigráfica internacional. Nos sedimentitos cretáceos brasileiros, a aplicabilidade da palinologia é inquestionável na definição cronoestratigráfica, visto serem eles dominantemente não-marinhos.

No início deste trabalho, houve a preocupação em selecionar uma área geográfica para estudo onde fosse possível dar uma contribuição efetiva ao conhecimento científico dos depósitos cretáceos brasileiros e que, concomitantemente, possibilitasse ressaltar a importância do método palinológico como ferramenta bioestratigrafica em ambientes continentais. Conseqüentemente, a escolha recaiu sobre depósitos sedimentares do Cretáceo Inferior, por serem largamente distribuídos por todo o país, tanto nas bacias costeiras como nas interiores. Também a origem não-marinha da quase totalidade destes depósitos, apresentando características fluviais, deltaicas, lacustres e lagunares, atende plenamente o aspecto considerado. Além disso, estas camadas são de extrema importância econômica, pois, considerando apenas em termos energéticos, incluem os sedimentos mais ricos em petróleo, tendo sido responsáveis pela geração da quase totalidade das reservas atuais do país.

Dentre as inúmeras unidades litoestratigraficas de idade eocretácea existentes no território nacional, optou-se pelo estudo palinológico da Formação Alagamar da Bacia Potiguar, tendo em vista que essa formação é constituída de sedimentos de origem não-marinha e pouco conhecidos em seus aspectos bioestratigráficos e paleoecológicos, sobretudo pelo fato de ter sua ocorréncia restrita à subsuperfície da bacia.

Sem dúvida, o estudo da Bacia Potiguar revela-se de extrema importância, dada sua localização geográfica, limítrofe entre as bacias da margem leste e as da margem equatorial. Esse fato permite a análise comparativa da evolução deposicional em bacias de ambas as margens, bem como das bacias interiores, visto estar, geneticamente, ligada aos mecanismos formadores das bacias interiores do Nordeste. De particular interesse é o estudo da Formação Alagamar, que alem de apresentar propriedades de rocha geradora, selante e reservatório, documenta o Andar Alagoas na bacia. São sedimentos depositados no final do estágio rifte e ao longo de todo estágio transicional evaporítico da evolução tectono-sedimentar da margem continental brasileira (PoNTE \& AsMus, 1976, 1978; Ponte et alii, 1978; Ojeda, 1982; Asmus \& Baisch, 1983; Chang, et alii, 1988). É neste estágio, representativo de uma fase importante na geração e acumulação de petróleo no Brasil, que estão registrados o final da deposição continental e os primeiros indícios de ingressôes marinhas de idade eocretácea. 


\section{1) Objetivos do Estudo}

A proposta principal a ser desenvolvida nesta tese é a caracterização palinoestratigráfica da Formação Alagamar da Bacia Potiguar. Desse modo, o limite inferior da sequiência sedimentar investigada é representado ora pelo contato com o embasamento, ora pela discordância existente no topo da Formação Pendência (da fase rifte). O limite superior é representado por uma discordância no contato com a Formação Açu, em terra, e com as formações Açu e Ubarana, na parte submersa da bacia.

Os objetivos do presente estudo podem ser resumidos nos seguintes tópicos:

1- Revisão taxonômica dos palinomorfos diagnósticos do Andar Alagoas na Bacia Potiguar (Formação Alagamar);

2- Identificação das formas indicadoras de ambiente $e$ idade, $e$ determinação de sua amplitude local e regional, com vista ao estabelecimento de um zoneamento detalhado para a seqüência eocretácea da fase transicional da bacia;

3- Caracterização da evolução bioestratigráfica das associações pertencentes a Formação Alagamar, através do estudo integrado de palinologia, estratigrafia e perfis elétricos;

4- Caracterização de palinofácies;

5- Determinação do ambiente de deposição e interpretação paleoecológica dos sedimentos do Andar Alagoas na bacia, através da análise dos resultados obtidos na integração dos dados. 


\section{1) Localização}

A Bacia Potiguar, apresenta comportamento de bacia do tipo rifte no Cretáceo Inferior, evoluindo para uma bacia do tipo de margem continental passiva, do Cretáceo Superior ao Cenozóico (BerTani et alii, 1989). Situa-se no extremo nordeste do território brasileiro, abrangendo a metade norte do Estado do Rio Grande do Norte e a parte nordeste do Estado do Ceará, entre os paralelos $4^{\circ} 20^{\prime} \mathrm{S}$ e $5^{\circ} 40^{\prime} \mathrm{S}$ e os meridianos $35^{\circ} 00^{\prime} \mathrm{W}$ e $38^{\circ} 30^{\prime} \mathrm{W}$. A bacia compreende uma área de aproximadamente $41.000 \mathrm{~km}^{2}$, com $21.500 \mathrm{~km}^{2}$ na parte emersa e $19.500 \mathrm{~km}^{2}$ na submersa (Fig. 1).

A área submersa é limitada, em termos operacionais da PETROBRÁS, pela cota batimétrica de $200 \mathrm{~m}$, pelo Alto de Fortaleza no Ceará e pelo paralelo de Natal (SouzA, 1982). Na realidade, a bacia se estende na plataforma e talude continental, em direção ao Atol das Rocas e ao arquipélago Fernando de Noronha (Costa et alii, 1975).

$\mathrm{Na}$ concepção do presente estudo, a bacia é limitada a norte, nordeste e leste pelos limites operacionais da plataforma continental; a sul e sudoeste pelo embasamento cristalino e a noroeste pelo Alto de Fortaleza, que a separa da Bacia do Ceará. 


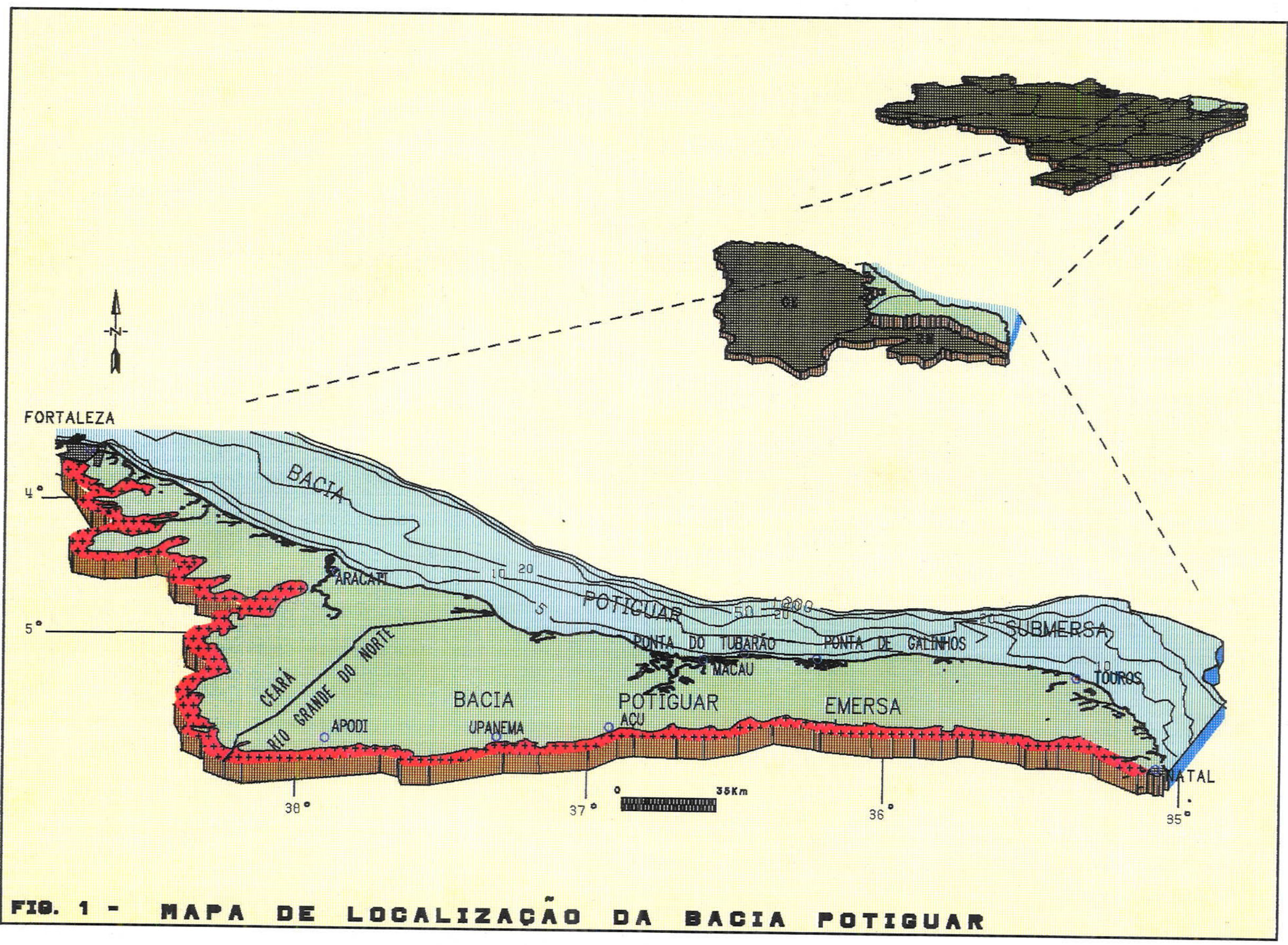




\section{2) Histórico Euolutivo dos Conhecimentos da Bacia}

O registro de rochas sedimentares na região setentrional do Estado do Rio Grande do Norte e nordeste do Ceará data do século XIX e desde então tem sido objeto de investigaçōes científicas. Serão mencionados aqui apenas os trabalhos considerados como de maior relevância e os que envolvem temas complementares ao presente estudo.

As investigaçóes geologicas, que marcaram a primeira fase de interesse na Bacia Potiguar, versaram sobre suas potencialidades aqüíferas e conteúdo fossilífero, período em que se destacaram as pesquisas de: BuRLAMAQUI (1855) que mostrou a existência de depósitos sedimentares na área e registrou a presença de conchas fósseis na Chapada de Apodi; Whrre (1887) que relatou novas ocorrências de macrofósseis na região; CRANDALL (1910) que estudou aspectos geológicos e geográficos para fins de suprimento de água e construção de açudes na área; SOPPER (1913) que esboçou uma primeira tentativa de organização estratigráfica destes depósitos, subdividindo-os em "camadas de arenitos", "camadas calcáreas" e "camadas de areia e argila". Estas camadas foram posteriormente agrupadas sob a denominação de Grupo Apodi por OtrveIRA \& LeOnardos (1943); e MaURy que, em 1924 e 1934, descreveu macrofósseis de invertebrados, sobretudo moluscos e equinóides, em calcáreos, postulando uma idade turoniana para tais sedimentos.

Uma segunda fase de interesse iniciou-se em 1949, quando o Conselho Nacional do Petróleo (CNP) realizou um trabalho de reconhecimento geologico, elaborando um mapa completo da Bacia (KREIDLER, 1949A, B). KREIDLER \& ANDERY (1950), introduziram os termos "Arenito Açu" e "Calcáreo Jandaíra" na região. Esta fase culminou com a perfuração de dois poços para petróleo em 1956, após a realização de um programa sísmico de reconhecimento entre $1951 \mathrm{e}$ 1955 pelo CNP e a PETROBRÁS, respectivamente.

Os estudos estratigráficos prosseguiram com o trabalho de KEGEL (1957), que propôs a divisão do pacote carbonático em três partes, datando de Maestrichtiano a porção superior, Santoniano/Campaniano a parte média e Turoniano/Cenomaniano a parte inferior, além de ter observado pela primeira vez derrames basálticos de idade terciária.

Na década de 60 , a região foi objeto de estudo pelo DNPM, que realizou um reconhecimento fotogeologico, e pela SUDENE (1966), que empreendeu estudos que resultaram num Mapa Hidrogeológico da bacia. BeurLen (1961 A, B; 
1964A, в; 1966; 1967), em trabalhos de cunho estratigráfico e paleontológico, apresentou ampla descrição da fauna então encontrada no "Calcáreo Jandaíra", dividindo-o nas formações Sebastianópolis e Jandaíra.

Pode-se mencionar como o início de uma terceira fase de pesquisa na Bacia Potiguar, o final da década de 60 e principalmente o início da de 70, quando a PETROBRÁS começou, efetivamente, os estudos de avaliação do potencial petrolífero da área.

As pesquisas exploratórias desenvolveram-se tanto na porção emersa da bacia, quanto submersa. Foi constatada a existência de espessa seção sedimentar, não aflorante, contendo camadas geradoras e armazenadoras, além de estruturas favoráveis à acumulação de óleo. Com excelentes descobertas na porção emersa, a Bacia Potiguar tornou-se uma região de intensa pesquisa pela PETROBRÁs. Os resultados mais significativos desta fase inicial, foram as descobertas, no mar, do Campo de Ubarana (1973) e, em terra, do Campo de Mossoro (1979).

A partir de 1983, a PETROBRÁS vem efetuando um intensivo programa exploratório na seqüência continental eocretácea da bacia, constituindose atualmente numa das prioridades da companhia.

A bacia, tanto na porção continental como submarina foi, entre 1981 e 1987, aberta para contratos exploratórios de risco e mini-risco, a companhias nacionais e estrangeiras e conta, at€ o momento, com mais de 3.500 poços perfurados e dezenas de campos em produção (Fig. 2).

As sondagens petrolíferas e levantamentos sísmicos efetuados permitiram precisar as estruturas e as camadas nas porções mais profundas da bacia. Em conseqüência foram alcançados os atuais conhecimentos expressos nos ítens subseqüentes, deste capítulo.

$O$ resultado deste esforço exploratório também está traduzido em diversas dissertações de mestrado e teses de doutorado defendidas dentro e fora do país, além de vários trabalhos publicados no país e no exterior, e de numerosos relatórios internos da companhia (confidenciais ou não) a respeito da geologia (tectônica e estrutural), paleontologia, geoquímica e potencial petrolífero da bacia. Entre os de cunho tectono-sedimentar, estratigráfico e geoquímico, destacam-se os realizados por Sampaio \& Schaller (1968), Cypriano \& Nunes (1968), Miura \& Barbosa (1972), MAYer (1974), Fisher et alii (1975), FALKenhein $e t$ alii (1977), Araújo et alii (1978), Tibana \& Terra (1981), Ojeda \& Santos (1982), Okada (1982), Souza (1982), Rodrigues \& Françolin (1983), Mello et alii (1984), Bertant (1985, 1990), Lima Neto et alii (1986), Françolin \& Szatmari (1987), e Bertan \& Costa (1988). 


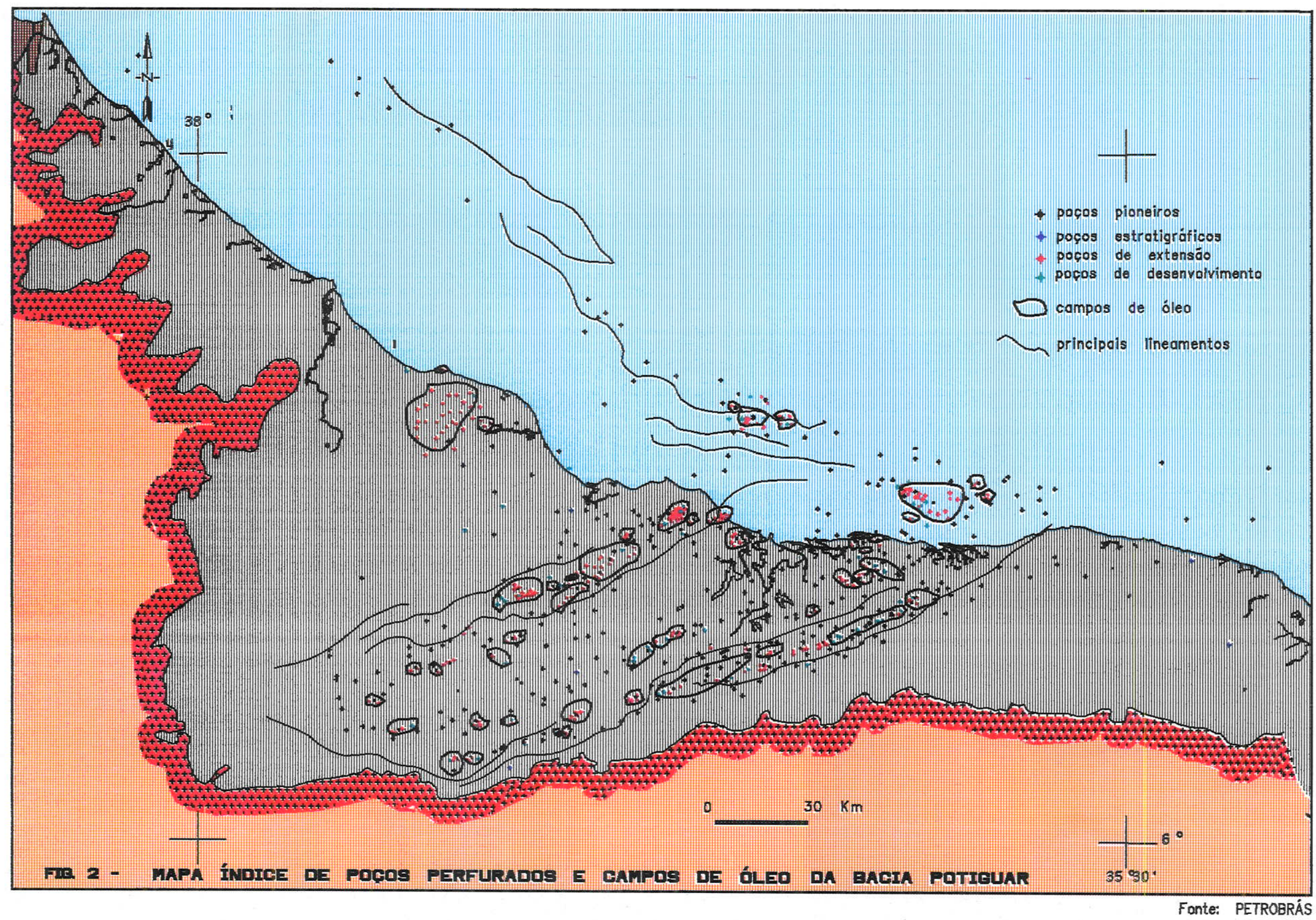


Na tabela 1, é apresentada a evolução dos conhecimentos estratigráficos sobre a Bacia Potiguar desde sua descoberta. Contudo, por se mostrar mais aplicável, até o momento, será utilizada neste trabalho uma coluna mais atualizada. Esta coluna, apresentada no ítem estratigrafia, foi modificada da de Souza (1982), pela Comissão de Estratigrafia da PETROBRÁs, responsável pelas bacias Ceará e Potiguar.

Apesar das inúmeras investigações, relativamente poucas pesquisas de cunho palinologico foram efetuadas na bacia e um número ainda mais restrito foi publicado até o momento, a saber:

Santos \& Uesugur (1967), em relatório interno, empreenderam o primeiro estudo palinologico da Bacia Potiguar, estudando 4 poços e estabelecendo 3 zonas para o intervalo do Andar Alagoas ao Coniaciano. RegAl et alii (1973) elaboraram uma divisão palinoestratigráfica com 7 zonas para o intervalo que vai do Alagoas ao Mioceno Inferior, também em relatório interno da PETROBRÁS; estes dados foram posteriormente incorporados no trabalho de REGALI et alii (1974A, B), válido para toda a plataforma continental. Em 1982, REGALI \& GoNZAGA, através da análise de um grande número de poços das partes emersa e submersa da bacia, aprimoraram o zoneamento palinológico da mesma, com a criação de novas biozonas e o reconhecimento de novos palinomorfos nas biozonas preexistentes. $O$ zoneamento então elaborado passou a conter 10 superzonas e 24 zonas, abrangendo idades do Rio da Serra ao Mioceno. Estes autores apresentaram em 1985 uma atualização do mesmo trabalho. Mais recentemente, PRAÇA \& Hashimoto (1991) realizaram estudos da seção não-marinha da parte emersa da bacia, com base em palinomorfos e ostracodes, elaborando uma divisão bioestratigráfica informal para a seção pré-Albiana. Neste trabalho foram definidas correlaçōes entre as biozonas definidas por ostracodes e palinomorfos, e estabelecidos três horizontes informais para a Formação Pendência. DiNo \& LIMA (1991) apresentaram resultados palinologicos de camadas que abrangem o topo da Formação Açu e a base da Formação Jandaíra, em terra, atribuindo idade cenomaniana às mesmas. E finalmente REGALI (1992) elaborou uma reavaliação da palinoestratigrafia da bacia, apresentando uma nova tabela de distribuição, tendo como modificação o reconhecimento, pela primeira vez, de todas as biozonas do Andar Alagoas, definidas na Bacia de Sergipe-Alagoas. 


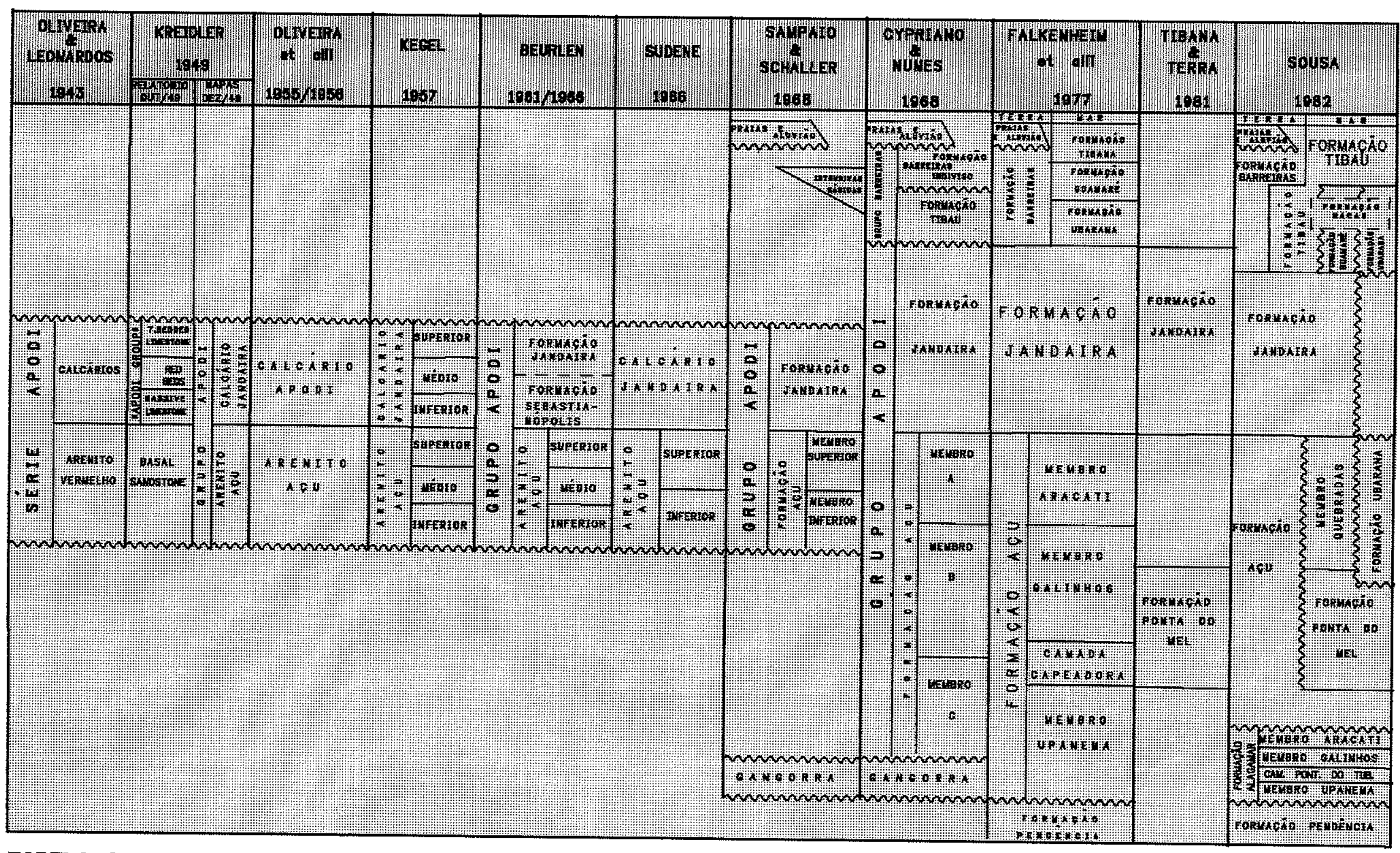

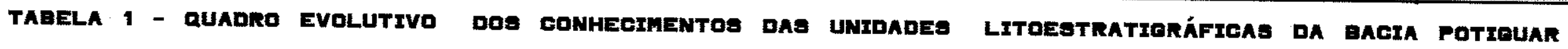




\section{3) Arcabouço Estrutural}

O panorama estrutural da Bacia Potiguar foi estabelecido durante o Cretáceo Inferior. Resultou de uma intensa movimentação tectônica, reativando sistemas de falhamentos antigos, formando grábens profundos e altos internos, cujas principais feições foram entalhadas sob regime de esforços dominantemente extensionais e transtensionais. Tais tipos de estruturas, controladoras de parte da sedimentação nas bacias interiores e costeiras do Nordeste, foram condicionados pela configuração estrutural do escudo Pré-Cambriano da Província da Borborema (Almema et alii, 1977).

Os elementos estruturais da bacia (Fig. 3) estão representados por uma expressiva calha central alongada na direção SW-NE separando duas plataformas de embasamento mais raso: uma situada a leste do gráben central, denominada Alto de Touros, na parte submersa, e Plataforma Leste, em terra; outra a oeste, denominada Plataforma de Baraúnas, em terra e Alto de CapongaAracati, no mar (BERTANI et alii, 1989). O rifte potiguar, que se abre para norte e mergulha em direção ao mar, é constituído em terra, por quatro grábens assimetricos denominados Apodi, Umbuzeiro, Boa Vista e Guamare, separados respectivamente, pelos altos estruturais de Quixaba, Serra do Carmo e Macau. Estes altos são representados por corpos alongados do embasamento, limitados por falhas normais e constituídos por blocos de gnaisses, migmatitos ou xistos. $O$ mais proeminente é o Alto de Macau, situado na porção central da bacia, com área da ordem de $700 \mathrm{~km}^{2}$ e formato aproximadamente triangular. De acordo com Alves et alii (1983), o Alto de Macau atuou como um resistato aos esforços tectônicos, originando a bifurcação do Gráben de Umbuzeiro e a formação do Gráben de Guamaré.

A calha central está limitada a SE por um sistema de falhas normais, denominado Carnaubais, marcando a borda leste dos grábens de Guamaré e Umbuzeiro. A NW, o rifte potiguar é delimitado pelo sistema de falhas de Areia Branca, definindo a borda oeste dos grábens de Boa Vista e Apodi.

O limite sul é feito pela falha de Apodi, na direção NW-SE.

Os principais falhamentos são de direção sudoeste-nordeste na parte terrestre e noroeste-sudeste na área submersa. Os grábens da parte submersa também são assimétricos e têm eixos paralelos à atual linha de costa, cujos limites a sul são marcados por falhas NW-SE e a leste e oeste pelos Altos de Touros e de Fortaleza (Françolin \& Szatmari, 1987). Exceção é o Gráben de 


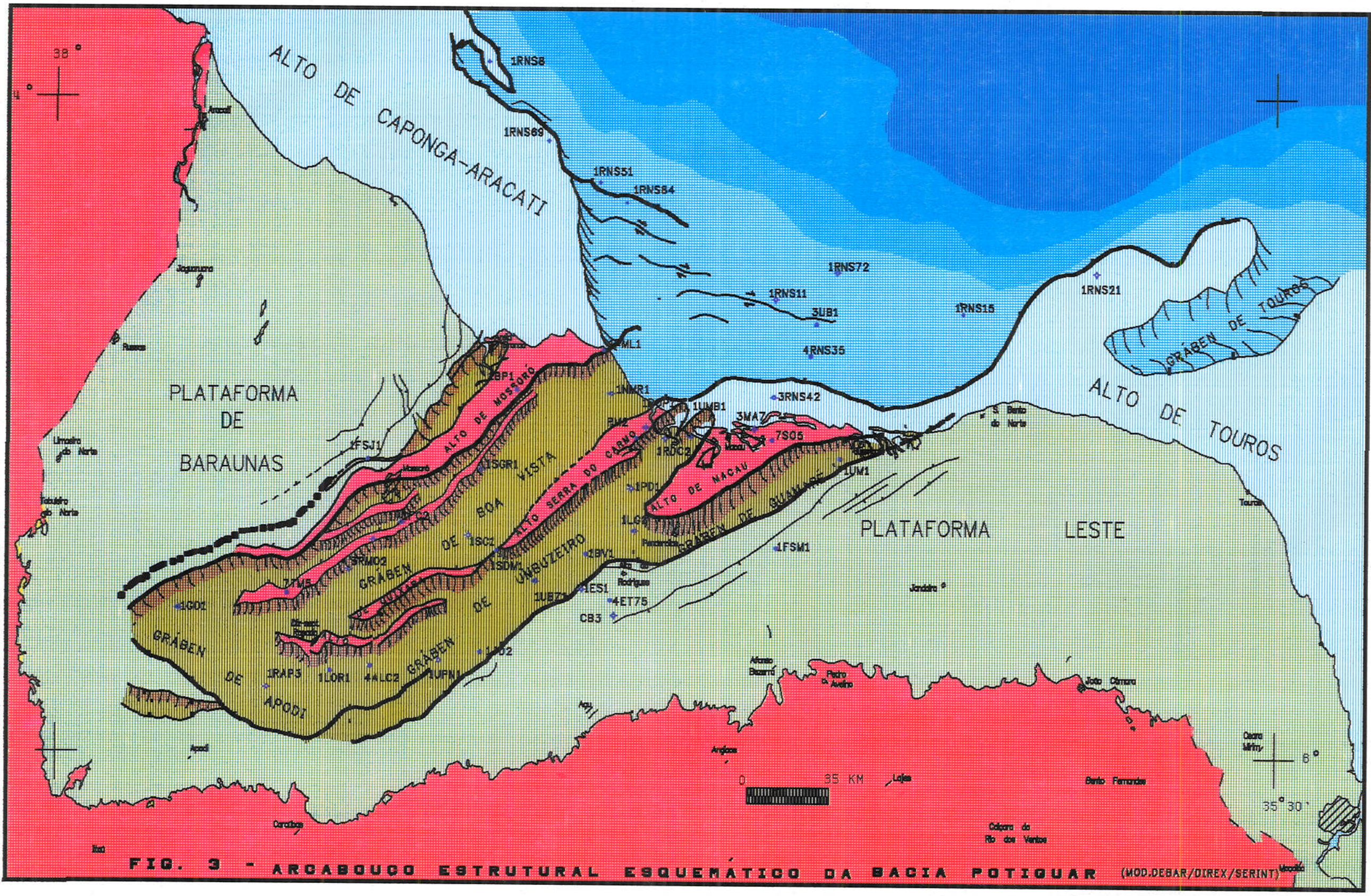


Touros, que a exemplo dos grábens da parte emersa apresenta uma calha alongada na direção NE-SW.

As principais feições estruturais do segmento leste-oeste (marinho) coincidem com a continuação do sistema de fraturas de Fernando de Noronha, enquanto que o gráben orientado na direção noroeste está confinado entre a Zona de Fratura de Romanche e o sistema de fraturas de Fernando de Noronha (BERTANI et alii 1989).

\section{4) Estratigrafia}

Os conhecimentos sobre a estratigrafia da Bacia Potiguar, como visto no histórico evolutivo dos conhecimentos da bacia, avançaram em etapas sucessivas, a partir das primeiras descriçōes do material aflorante. $O$ volume de dados estratigráficos acumulados permitiram a SouzA (1982) propor a mais completa e atualizada coluna estratigráfica da bacia, publicada até o momento.

No entanto, a litoestratigrafia da Bacia Potiguar sofre revisões constantes, em função do esforço exploratório que acarreta grande volume de informações em tempo relativamente curto. Desse modo, algumas seções da bacia sofreram, e vêm sofrendo, modificações litoestratigráficas que ainda não estão formalizadas na literatura geológica brasileira. Entretanto, gozam de uso corrente na PETROBRÁS e mesmo fora do âmbito da companhia, além de constarem em diversos trabalhos publicados.

Devido a este informalismo nas modificações das unidades litoestratigráficas, subseqüentes ao trabalho de SouzA (1982), e de inúmeras publicações contendo detalhadas descrições de unidade por unidade litoestratigráfica da Bacia Potiguar, são descritas a seguir apenas as características das unidades litoestratigráficas consideradas nesta tese.

\section{a- Coluna Sedimentar}

A coluna sedimentar possui espessura máxima estimada em mais de 6000 metros. Uma análise dos dados de poços e de seções sísmicas, pré-existentes no arquivo geral da PETROBRÁS, revela que a mesma se espessa em direção ao mar, onde provavelmente ultrapassa este valor. Mapas de contorno estrutural do 
embasamento Pré-Cambriano, conjugados ao de isópacas da seqüência continental (NEves, 1987), mostram em terra a ocorrência de três depocentros localizados nos grábens de Umbuzeiro, com $6000 \mathrm{~m}$; Apodi, com $5000 \mathrm{~m}$; e ao longo da porção mediana entre os mesmos, com $5000 \mathrm{~m}$ de sedimentos.

A bacia é preenchida por depósitos que vão desde o Cretáceo Inferior até o Recente, interrompidos por três discordâncias erosivas regionais (Fig. 4). A maior parte destes sedimentos são de idade cretácea, sendo o restante terciário. De modo análogo a outras bacias costeiras brasileiras, encontra-se afetada pelo vulcanismo básico mesoźico e terciário, aqui, principalmente, sob a forma de derrames.

As unidades estratigráficas da bacia estão dispostas em quatro grandes ciclos, de acordo com a evolução tectono-sedimentar e conseqüentemente estão associadas às megasseqüências deposicionais principais: continental, transicional e marinha. O primeiro ciclo depositado sobre os terrenos précambrianos, do embasamento, corresponde às rochas sedimentares terrígenas da fase rifte, de idade neocomiana (Rio da Serra a Buracica). Os sedimentos são tipicamente flúvio-lacustres, secundados por depósitos flúvio-deltaicos, com leques conglomeráticos de borda de falha associados, constituindo a Formação Pendência. O segundo, separado do anterior por uma discordância erosiva e angular, compreende sedimentos de idade Alagoas (Aptiano), já na fase transicional. Compõe-se de depósitos deltaicos-lacustres do Membro Upanema, em parte ainda depositados sintectonicamente em sistema rifte; de depósitos lacustres restritos, euxínicos e carbonáticos, das Camadas Ponta de Tubarão e culmina com um leve evento transgressivo, propiciando a formação dos depósitos de águas mais profundas do Membro Galinhos da Formação Alagamar.

Segue-se, no terceiro ciclo, a fase marinha, de idade albiana a eocampaniana, representada pelos sedimentos, predominantemente, fluviais da Formação Açu, interdigitados e/ou sobrepostos pelos depósitos carbonáticos de plataforma das formações Ubarana e Jandaíra e seqüências turbidíticas de parte do Membro Quebradas da Formação Ubarana.

Finalmente, o quarto ciclo, na seqüência marinha regressiva, do Cretáceo Superior ao Terciário, engloba um sistema progradacional formado por arenitos de origem fluvial a litorânea da Formação Tibau, folhelhos marinhos rasos a profundos da Formação Ubarana, com interdigitações e sobreposições de carbonatos de plataforma rasa da Formação Guamaré. Intercalados nas formações 


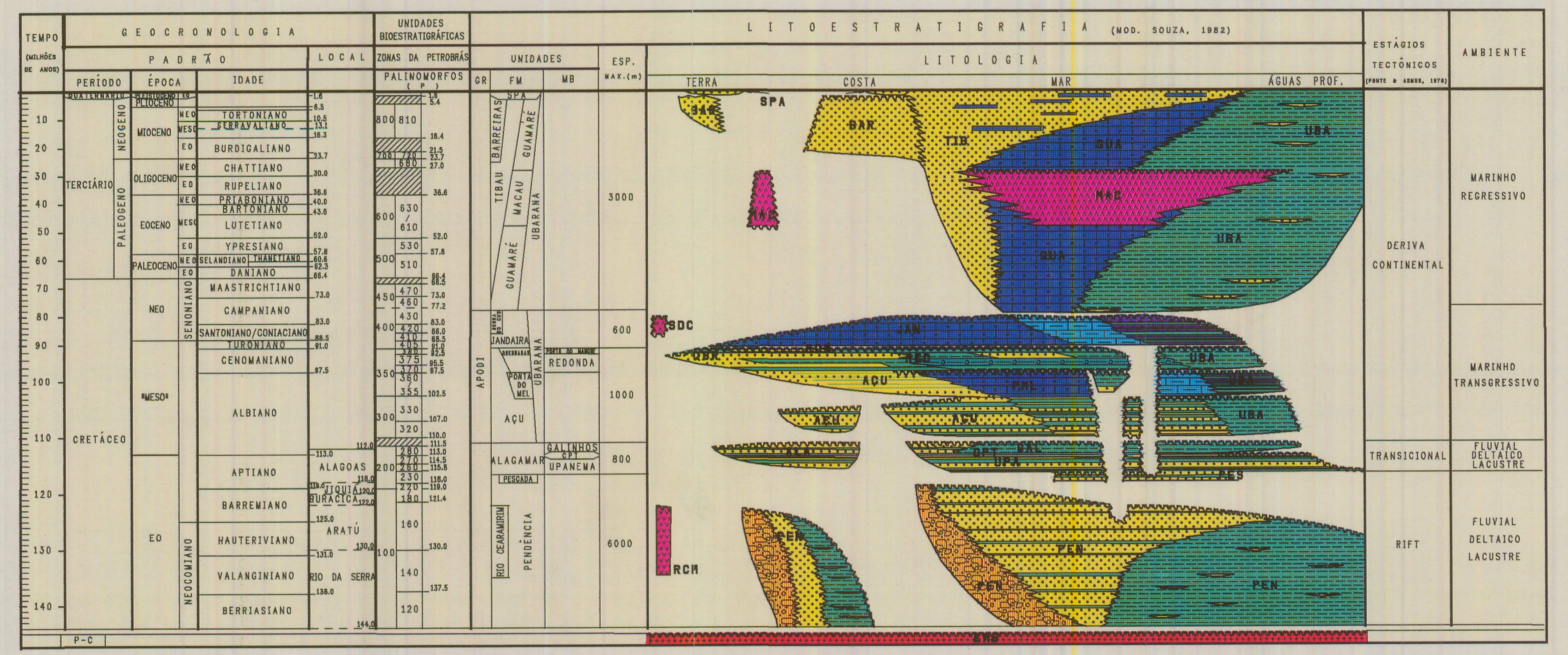

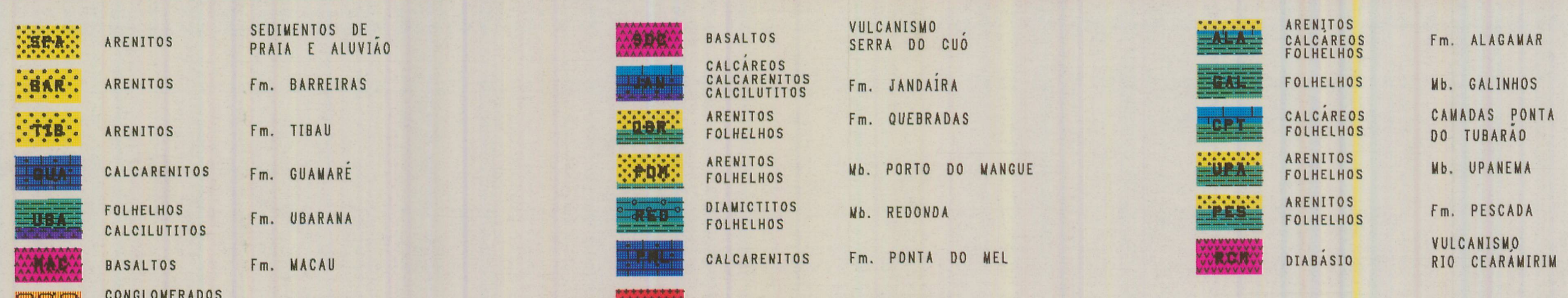

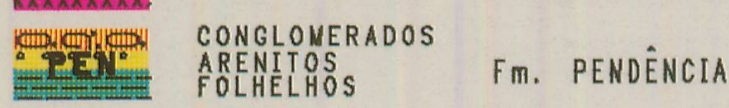

HeneAs

engasauento

FIG. 4 - COLUNA ESTRATIGRÁFICA DA BACIA POTIGUAR (Mo.. conissio Estrat. petrobrís) 
desta seqüência ocorrem derrames de olivina-basaltos da Formação Macau. A parte emersa da bacia está atualmente recoberta pelos depósitos clásticos grosseiros continentais da Formação Barreiras e sedimentos recentes de praias e aluviōes.

Este trabalho envolverá apenas a unidade eqüivalente ao ciclo Transicional Evaporítico, não inteiramente desenvolvido na Bacia Potiguar, que, litoestratigraficamente, corresponde à Formação Alagamar. Esta constitui-se numa seqüência estratigráfica, de acordo com os conceitos da estratigrafia de ciclos T-R (BusCH \& RolLINS, 1984).

\section{b- Litoestratigrafia}

A coluna estratigráfica apresentada (Fig. 4) corresponde à última versão proposta pelos Grupos de Trabalho de Estratigrafia do Distrito de Exploração da Bacia Potiguar (DEBAR) e do Setor das Bacias Ceara-Potiguar do Departamento de Exploração (DEPEX/SECEPO). Embora se encontre sob forma preliminar, com denominações ainda informais, trata-se da coluna mais atualizada disponível.

Estabelecida por Souza (1982), a Formação Alagamar foi posteriormente, de modo informal, modificada por ARARIPE \& FONTES (1985), com a inclusão do Membro Aracati na Formação Açu e não mais na Formação Alagamar, e por TexxerRa (1990) com a criação da "Seção Pescada", também em caráter informal, não considerada no presente trabalho, pois a mesma ainda não foi devidamente investigada na porção emersa da bacia.

\section{Formação Alagamar}

O termo Formação Alagamar foi emprestado da Ilha de Alagamar, situada no litoral do Rio Grande do Norte, tendo como seção-tipo o intervalo 2115-2700 $\mathrm{m}$ do poço 3-UB-1-RNS, compreendendo em ordem ascendente os Membros Upanema, Camadas Ponta do Tubarão, Galinhos e Aracati (Fig. 5). Neste trabalho, o Membro Aracati foi informalmente considerado como fácies distal da Formação Açu, tal como proposto por Araripe \& Fontes (1985) e Costa et alii (1987). Vale salientar que na prática, o termo Aracati foi abandonado e, atualmente, o pacote rochoso equiuvalente faz parte da base da Formação Açu. 
A deposição dos sedimentos da Formação Alagamar iniciou-se sobre uma superfície de discordância erosiva, ora sobre rochas ígneas e metamórficas do embasamento Pré-Cambriano, ora sobre rochas sedimentares da Formação Pendência.

Este contato, além de apresentar uma superfície erosiva, constitui-se numa discordância angular, já que as camadas da Formação Pendência têm mergulhos de direção S/SE e os da Formação Alagamar são subhorizontais. Um dos critérios na identificação desta discordância são as mudanças bruscas nas respostas de algumas diagrafias (RG, DT, Dipmeter). A Formação Pendência, devido à maior compactação dos seus folhelhos, apresenta valores mais baixos de resistividade e de tempo de trânsito. Também os registros de reflexão sísmica detectam esta discordância angular. As análises palinologicas têm na maioria das vezes identificado esta superfície de modo indiscutível, mesmo nos casos onde as semelhanças litologicas entre o Membro Upanema da Formação Alagamar e a Formação Pendência tornam difíceis essa identificação por critérios litológicos, sísmicos ou grafoelétricos. Contudo, este contato é por vezes de difícil precisão, mormente quando partes do Membro Upanema encontram-se confinadas em depressões topograficas, estruturalmente controladas.

Os estudos palinológicos têm demonstrado que esta discordância pós-rifte pode ter idades distintas em cada porção da bacia. Na parte submersa pode ser considerada como de idade intra-Alagoas, pois observa-se sedimentos em calhas estruturais contendo palinomorfos diagnósticos da biozona P-230; já na parte emersa é, na quase totalidade das vezes, pré-Alagoas.

Membro Upanema. Consiste predominantemente de arenitos, com intercalações de folhelhos e delgados leitos de calcáreo, depositados em ambiente fluvial na parte inferior passando a deltaico-lacustre no topo. O termo provém da vila de Upanema, no litoral do Estado do Rio Grande do Norte. Sua seção-tipo é o intervalo de profundidades compreendido entre os $2496 \mathrm{~m}$ e $2700 \mathrm{~m}$ do poço 3-UB-1-RNS. Estudos em diferentes áreas da bacia têm identificado nesta seção litofácies de "fan-delta", fluvial, canais distributários e planície deltaica, além de mostrar, de um modo geral, uma progressiva diminuição no aporte de terrígenos (Lima, 1987). Este fato é corroborado pela análise dos perfis elétricos, que permite reconhecer uma tendência de granodecrescência ascendente.

Camadas Ponta do Tubarão. (informalmente conhecidas como calcilutito-marco ou calcáreo capeador). Constituído por calcilutitos com ostracodes intercalados por folhelhos cinza-esverdeados, ricos em matéria 


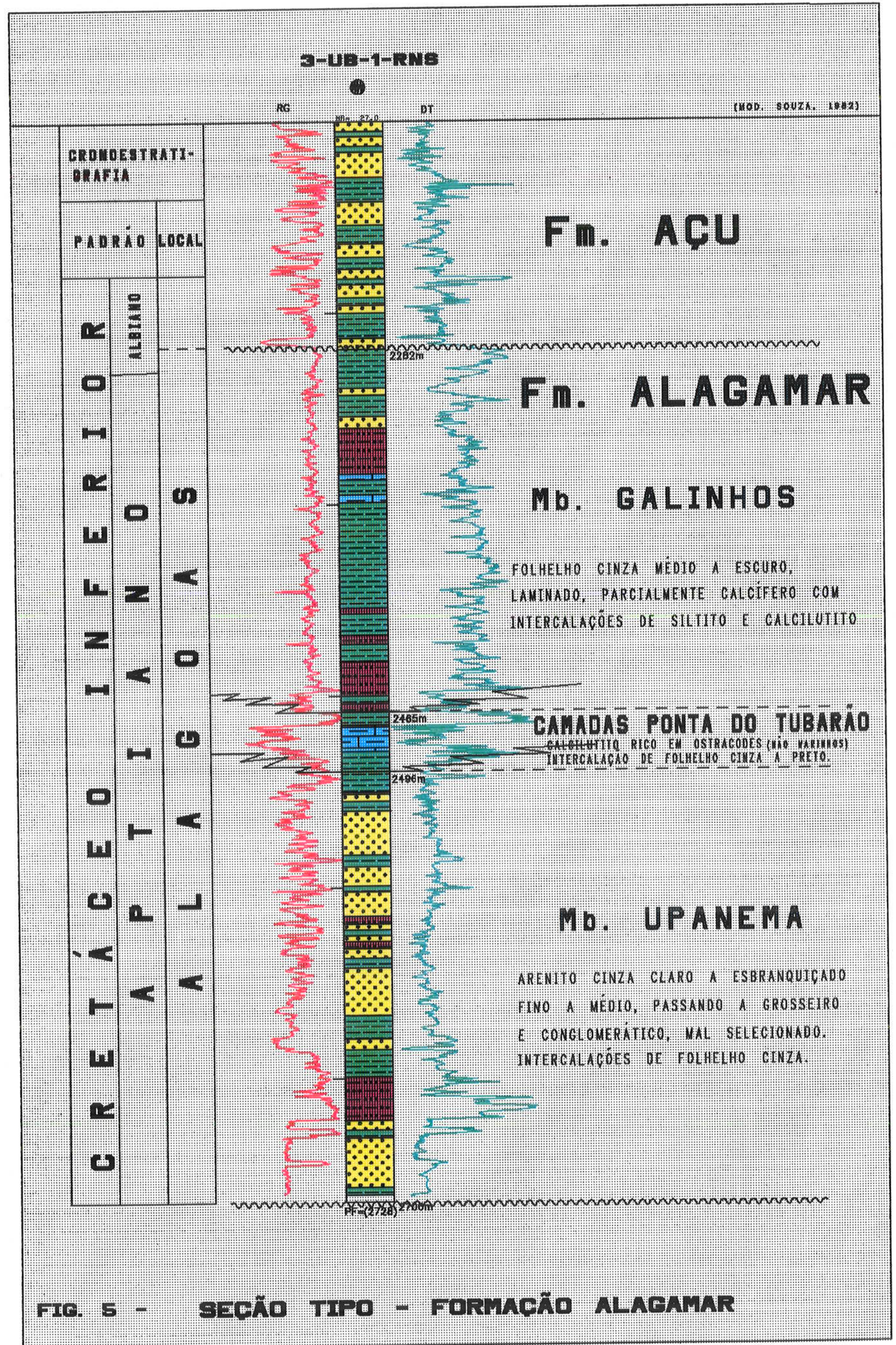


orgânica, euxínicos, depositados em ambiente lacustre. Sua seção-tipo e o intervalo de profundidades entre os $2465 \mathrm{~m}$ e $2496 \mathrm{~m}$ do poço 3-UB-1-RNS. Estas camadas mostram uma notável definição nos perfis elétricos (Fig. 5), além de representarem excelente refletor sísmico, de fácil correlação por quase toda a bacia, com restrições à região do Gráben de Apodi, onde cai sensivelmente sua definição.

Membro Galinhos. Com seção-tipo no intervalo compreendido entre os $2282 \mathrm{~m}$ e $2465 \mathrm{~m}$ do poço 3-UB-1-RNS, consiste de folhelhos cinza-escuros com delgadas intercalações de calcilutitos e arenitos. Representa um sistema deltaico com fácies principalmente prodeltaicas; seu topo é discordante e marca o final da deposição lacustre na bacia, pois os depósitos pós-discordância Alagamar já sofrem influência marinha na deposição. Nos perfis elétricos, notam-se altos valores de raios gama e tempo de trânsito. Aqui registra-se o máximo de transgressão de idade Alagoas, observando-se no mapa de contorno estrutural da Formação Alagamar (Fig. 6), que os Altos de Macau e Quixaba estão quase que completamente cobertos.

Os limites de cada subdivisão litoestratigráfica da Formação Alagamar aqui explicitados foram deduzidos, a partir da análise do perfil composto e do perfil de raios gama do poço 3-UB-1-RNS, pois os mesmos não foram especificados por SouzA (1982), quando da sua definição.

O contato superior com a Formação Açu é nitidamente erosivo na parte emersa. Na parte submersa esse contato também é claramente erosivo na maior parte da bacia. Contudo, ocorrem situações onde esta discordância é de difícil identificação, principalmente com a Formação Ubarana (ARARIPE, COM. PESS.).

Costa et alii (1987) constataram em vários poços mudanças nas direções da deposição entre os Membros Galinhos e Aracati, além de outras diferenças na sedimentação destes estratos, o que os levou a interpretarem os sedimentos do Membro Aracati como pertencentes à seqüência deposicional Açu.

A Formação Alagamar distribui-se por toda a bacia, principalmente na parte submersa, onde atinge espessura máxima da ordem de 800 metros na área de Ubarana. Contudo, como pode-se observar no mapa de isópacas (Fig. 7), ela no geral raramente atinge os 700 metros na parte submersa. Em terra, sua espessura chega a atingir os 500 metros, no Gráben de Boa Vista, fora daí chega a se adelgaçar para valores de menos de 30 metros. 


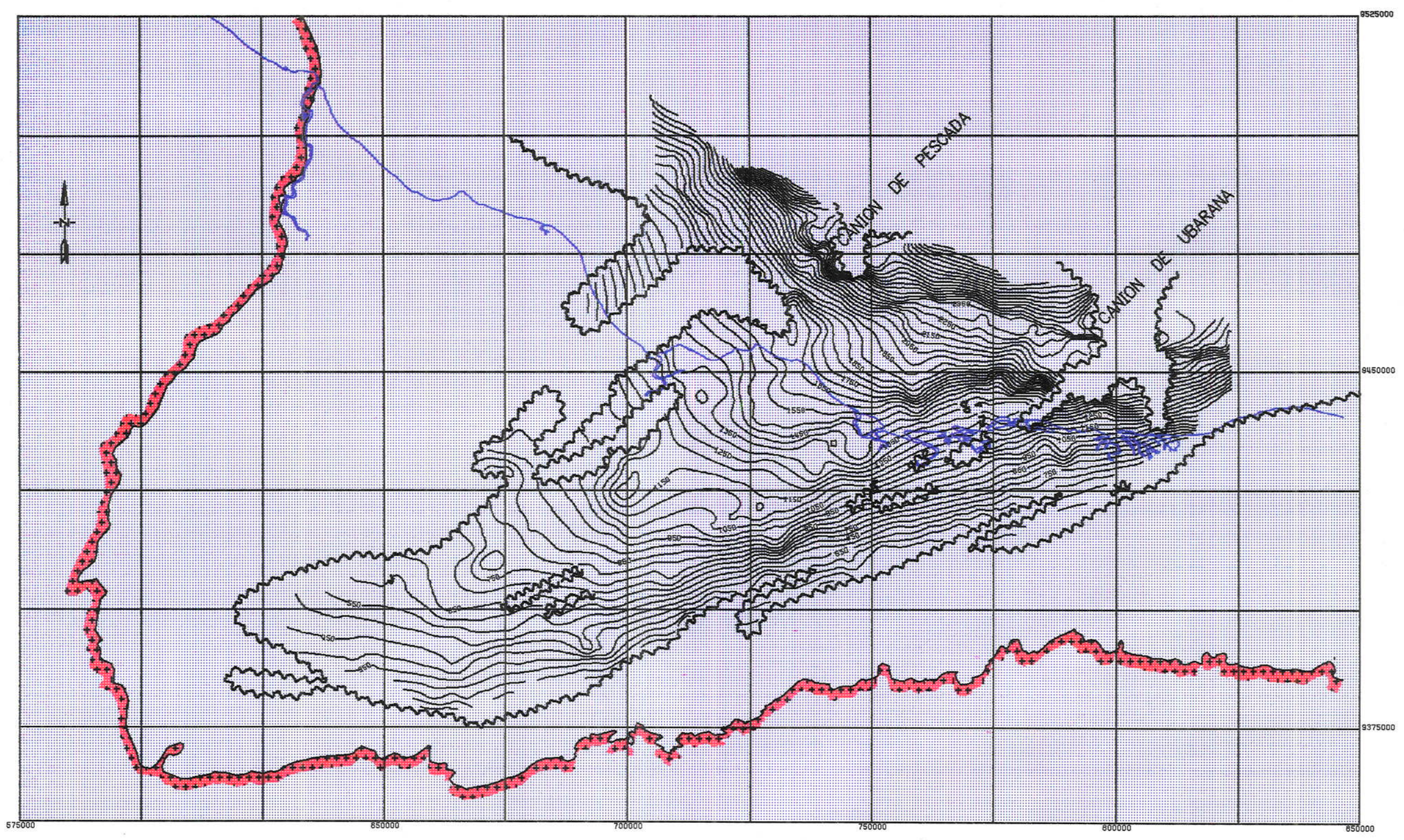

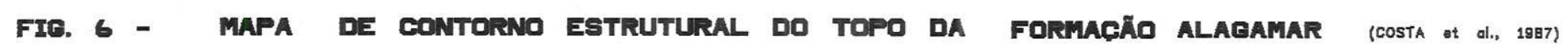


Através da análise do mapa de contorno estrutural (Fig. 6) observa-se que a superfície do topo do Andar Alagoas (topo da Formação Alagamar) está estreitamente ligada ao arcabouço estrutural do embasamento, pois as maiores espessuras ajustam-se como moldes às depressões estruturais, principalmente às custas do Membro Upanema. Portanto, sua deposição desenvolveu-se em dois estágios tectono-sedimentares distintos: a fase tardia do estágio rifte e o estágio de golfo proto-oceânico. Este estilo estrutural, aliado à semelhança litologica, por vezes confunde a interpretação sísmica e grafoelétrica, levando os intérpretes a incluir parte, ou mesmo todo o Membro Upanema na Formação Pendência.

Mapas em fase de elaboração pelos exploracionistas da PETROBRÁS (Sede e Distrito Potiguar) mostram que o arcabouço estrutural do fundo da bacia apresenta um estilo tipicamente tafrogênico; e que o comportamento estrutural do topo da Formação Alagamar reflete, de maneira um pouco atenuada, a estrutura da discordância pré-Alagoas.

Costa et alii (1987) constataram, através de mapa de isópacas do Membro Galinhos, que o mesmo possui distribuição maior que as Camadas Ponta do Tubarão, fato observado também nos poços localizados na borda da bacia (1-FSM-1-RN), mostrando a deposição do Membro Galinhos sobre o embasamento. 


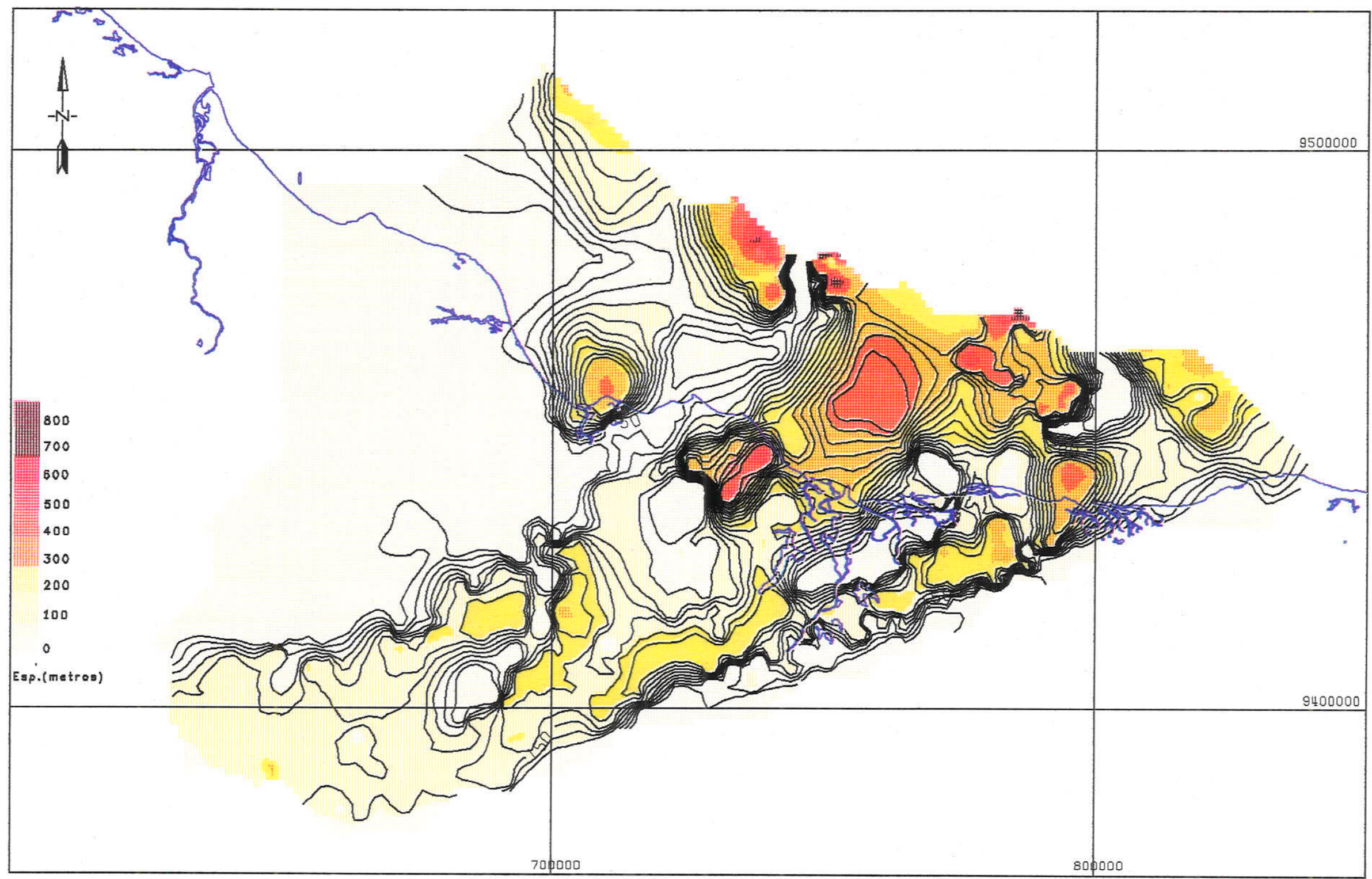

FIG. 7 - MAPA DE ISÓPACAS DA FORMAĈ̣̃O ALAGAMAR 


\section{5) Evolução Tectono-Sedimentar}

\section{a- Conterto Regional}

A história da evolução tectono-sedimentar mesozóica do Nordeste Oriental inicia-se, como de resto em toda a plataforma brasileira, por movimentos tectônicos ocorridos no Neojurássico/Eocretáceo, e culminou na formação do Atlântico Sul e das bacias marginais e interiores. Esses movimentos formam parte do conjunto dos esforços causadores da fragmentação do Gondwana, que incluiu a separação das placas Sul-Americana e Africana.

Modelos de evolução tectônica têm sido apresentados até o momento por pesquisadores brasileiros para explicar a gênese dos nossos riftes continentais. O primeiro, proposto por PonTe et alii (1971, 1978), Estrella (1972), Asmus \& Porto (1972), Asmus (1975) e Ponte \& Asmus (1976), admite a existência de um estágio de arqueamento com soerguimento crustal semelhante ao modelo de DEwEY \& BIRD (1970), com duração do Neopermiano ao Neojurássico. Asmus (op. cit.) e Asmus \& PORTo (1980) advogam a presença de duas feições dômicas que se evidenciaram no imenso geanticlinal então formado; uma situada na região sudeste e outra na região nordeste. Estas áreas altas teriam sofrido contínua erosão durante todo o Triássico e grande parte do Jurássico, destruindo expressiva porção dos depósitos paleozóicos, dos quais restam atualmente poucos remanescentes. No final do Jurássico, na área interdômica ter-se-ia formado, com o avanço do processo de arqueamento e conseqüente ruptura e abatimento da crosta, uma extensa depressão, a Depressão Afro-Brasileira de Ponte et alii (1971), e Asmus \& PorTo (op. cit.), que passou a acolher os sedimentos erodidos das regiões positivas próximas. Constitui evidência desta contribuição a presença de material retrabalhado da idade devoniana nos depósitos da fase pré-rifte e rifte, em várias bacias interiores e costeiras.

Propostas mais recentes atribuem o processo de rifteamento ao estiramento litosférico. Estes estudos procuram quantificar o grau e a distribuição do estiramento, baseando-se em modelos termo-mecânicos (CHANG \& KowsMANN, 1984; Milani, 1985; Lana, 1985; Chang \& Kowsmann, 1986; Ussami et alii, 1986; CAstro, 1987; Mello, 1987; Mohriak et alii, 1990). De acordo com estes autores, seus estudos permitem separar o comportamento e a subsidência das bacias em duas fases, uma associada ao estiramento durante a fase rifte e outra associada a contração térmica subseqüente. 
A diferença básica entre os modelos apresentados $\varepsilon$ a de que o primeiro admite uma fase de arqueamento anterior à implantação do sistema de riftes e o outro considera a ocorrência de um processo contínuo de estiramento.

Através do desenvolvimento destes modelos, Asmus \& Ponte (1973) e PoNTE \& Asmus (1978) postularam que a evolução geologica das bacias mesozбicas brasileiras ocorreu através de estágios sucessivos, por eles denominados de Pré-Rifte, estágio precedente à ruptura crustal, Rifte, estágio de ruptura com formação de grábens, Golfo Proto Oceânico, estágio de quiescência e Mar Aberto. Chang et alii (1988) dividiram a fase rifte em três estágios distintos, denominando a fase pré-rifte (Andar Dom João) de Ponte \& Asmus (op. cit.), de fase Sin-Rifte I e os termos da fase rifte por Sin-Rifte II e III. A fase termal foi subdividida, segundo a classificação de PoNTE \& Asmus (op. cit.), em transicional ou golfo proto-oceânico e de mar aberto ou drifte.

Estes estágios tectônicos são característicos do modelo geológico da tectônica de placas que explica a evolução das margens continentais do tipo Atlântico, segundo os conceitos de Dickinson (1974). Tais modelos conceituais, apesar de formulados principalmente com base em dados oriundos das bacias da margem leste, são também aplicáveis às baciàs da margem equatorial.

Estudos de gênese e evolução tectônica, baseados nos modelos supracitados, porém específicos para a Bacia Potiguar, no contexto tectônico regional, foram efetuados por BERTANI (1985), SzATMARI et alii (1987) e ForTEs (1986), investigando a bacia como um todo; e Matos (1987) e MeLlo (1987), analisando apenas o rifte.

BERTANI (op. cit.), aplicando o modelo de MACKENZIE (1978), postulou uma evolução tectono-sedimentar do rifte potiguar em três estágios: distensão e afinamento crustal, soerguimento e erosão e subsidência térmica, associando-os à coluna sedimentar.

SzATMARI \& FRANÇOLn (op. cit.), com base no modelo de RABINOWITZ \& LABRECQUE (1979), advogam que o rifteamento da bacia ter-se-ia desenvolvido pela rotação entre as placas sul-americana e africana. Tal rotação teria causado no Eocretáceo um esforço distensivo de direção N-S, formando os grábens da bacia por movimentos transtensionais dextrais ao longo de falhas reativadas de direção NE-SW.

Fortes (op. cit.) propôs um modelo de teclas, definidas pela anisotropia estrutural do embasamento, sob regime tectônico essencialmente vertical.

MAtos (op. cit.) admitiu a formação dos riftes da Província 
Borborema de acordo com o modelo de Mackenzre (1978) e postulou que a evolução tectono-sedimentar da bacia ocorreu sob regime distensivo de direção WNW a partir dos andares Rio da Serra e Aratu.

MeLLo (op. cit.) baseado nos modelos teóricos de extensão litosférica, sugeriu uma evolução termo-mecânica para a bacia. Segundo o autor a formação da porção emersa da bacia está vinculada ao modelo de extensão não uniforme, enquanto que a porção referente à plataforma tem sua evolução melhor explicada através do modelo de extensão uniforme (MACKENZE, 1978).

\section{b- Rifte Potiguar}

Os episódios tectono-evolutivos gravaram características particulares nos depósitos sedimentares das bacias marginais brasileiras, permitindo um fácil reconhecimento de cada estágio das mesmas. Através destas constatações, Asmus \& PONTe (1973) e Asmus \& Porto (1980) postularam três mega-unidades estratigráficas, decorrentes da interação entre o regime tectônico e as respostas sedimentares, definindo-as em termos de seqüências deposicionais. Posteriormente, estas unidades estratigráficas foram elevadas à categoria de superseqüências (PoNTE, 1980) ou de megasseqüências (ChANG et alii, 1988), e denominadas da base para o topo de continental, ou do continente; evaporítica transicional, ou do golfo; e plataforma carbonática, ou do mar.

$\mathrm{Na}$ Bacia Potiguar pode-se identificar parte destes estágios, bem como as megasseqüências sedimentares correspondentes.

Não são conhecidos, até o momento, depósitos da fase designada de pré-rifte ou sin-rifte I, na bacia. Sedimentos deste estágio, correspondentes ao Andar Dom João, estão presentes apenas nas bacias nordestinas localizadas ao sul do Lineamento da Paraíba (Ponte et alii, 1990). O início da sedimentação na Bacia Potiguar ocorreu na fase rifte ou sin-rifte II da megasseqüência continental, em ambientes fluvial-deltáico-lacustres, envolvendo deposição sob intensa atividade tectônica. Estes depósitos preencheram a quase totalidade dos grábens formados nas porções emersa e submersa da bacia. São depósitos cronocorrelatos aos da Série Recôncavo e denominados de Formação Pendência. Nas bacias interiores depositavam-se os sedimentos dos grupos Rio do Peixe e Iguatu, nas bacias homônimas, e os da Formação Abaiara do Grupo Vale do Cariri, na Bacia do Araripe (PONTE \& APpI, 1990), todos eles de idade Rio da Serra a Aratu. No final desta fase, em função de um soerguimento generalizado, ocorreu uma discordância regional de caráter erosivo, reconhecida em toda a bacia. Uma provável reativação, após esta fase de peneplanização, propiciou a 
deposição de parte do membro Upanema da Formação Alagamar, principalmente na parte submersa. Em terra sua presença foi detectada, de modo seguro, apenas na região do Gráben de Boa Vista (Ponte \& MAIA, 1987). Nesta fase, de idade Alagoas inferior, já se formava na costa leste o golfo proto-oceânico, com início da deposição de evaporitos.

Na Bacia Potiguar, o estágio do golfo proto-oceânico ou transicional, da megasseqüiência transicional evaporítica propriamente dita, iniciou seu desenvolvimento no Andar Alagoas (Aptiano), sob condições de progressiva quiescência. Ocorre uma expansão da bacia, com os depósitos da Formação Alagamar extravasando os grábens e invadindo as plataformas rasas. Neste estágio, é marcante a deposição das Camadas Ponta do Tubarão, que correspondem, na margem equatorial, às camadas Trairi (Ceará) e Codo (Parnaíba), e na Bacia do Araripe, à Formação Rio da Batateira. A similaridade e ocorrência em tal extensão destes depósitos é notável, e pressupõe a subsistência de condições climáticas e geologicas extremamente similares, durante esta fase, controlando a sedimentação em muitas das bacias sedimentares do nordeste.

Nas bacias da costa leste, as camadas cronocorrelatas são os evaporitos dos membros Ibura (Sergipe/Alagoas), Itaúnas (Espírito Santo) e níveis evaporíticos da Formação Lagoa Feia (Campos).

No final desta fase, tem-se as primeiras evidências de ingressões marinhas, nos depósitos da margem equatorial.

O estágio de mar aberto, ou drifte, da megasseqüência marinha transgressiva, ocorre no Albiano e desenvolve-se até o início do Campaniano. Durante este estágio, ocorreu um provável soerguimento da atual porção emersa, possivelmente devido a "reativação pós-aptiana" de SzATMARI ET ALII (1987), evidenciada pela pouca representatividade dos depósitos das formações Açu, Jandaíra, Ponta do Mel e Ubarana nesta porção da bacia.

Após esta transgressão, ainda no estágio drifte, iniciou-se no Neocampaniano a deposição da megasseqüência marinha regressiva, que corresponde ao entulhamento da bacia, encerrado no Mioceno. Neste estágio, apesar do vulcanismo que originou a Formação Macau, a atividade tectônica foi relativamente menor, quando comparada com a da fase neocomiana, ocorrendo basicamente uma subsidência generalizada, com algum basculamento da bacia para N-NE. Os sedimentos atribuídos ao final desse período (Mioceno), na atual parte emersa, são constituídos por terrígenos continentais de origem fluvio-aluvial, que constituem as formações Barreiras, Serra dos Martins, Macau e Moura. Na parte submersa ocorreu a deposição contínua das formações Tibau, Guamaré, Ubarana e Macau. 


\section{1) Suporte Metodológico}

A filosofia que envolve o presente trabalho caracteriza-se sobretudo por uma visão integrada dos vários campos da estratigrafia, nos quais se insere a bioestratigrafia.

A metodologia desenvolvida baseou-se na concepção de interdependência destes campos. Em conseqüência, vários deles, muito específicos, foram abordados de modo integrado, permitindo-nos tecer considerações no campo da tectônica, litoestratigrafia, geoquímica orgânica e análise de perfis elétricos.

Na medida do possível, procurou-se utilizar esta visão também nas interpretaçס̃es, isto é, com ênfase nas correlaçōes interdisciplinares, sempre atentos às limitações de cada um dos métodos. Entretanto, maior atenção é concedida à ferramenta principal, que é a análise bioestratigráfica atravếs dos estudos palinológicos.

A preocupação com esta abordagem integrada, é a de obter o melhor conhecimento possível a respeito das características paleoambientais e deposicionais que envolveram a sedimentação das camadas pertencentes ao Andar Alagoas na Bacia Potiguar. 


\section{2) Etapas de Trabalho}

O desenvolvimento desta tese envolveu várias etapas interativas entre si, nas quais foram utilizadas diferentes técnicas, que estão apresentadas resumidamente na figura 8 .

Numa primeira fase, ora denominada de laboratório, procedeu-se a escolha dos poços, à seleção das amostras de calha e de testemunhos, ao controle da preparação das mesmas, à leitura das lâminas no microscópio, com identificação preliminar, e à seleção de perfis elétricos.

Numa fase posterior recorreu-se à utilização da microinformática na realização de pesquisas bibliográficas e criação de arquivos através do uso de microcomputadores. Nesta etapa foram redigidos os textos, através do programa WORD, realizadas buscas bibliográficas on line e arquivamento dos dados no sistema BIOEST.

Finalmente, lançou-se mão da utilização do Main Frame IBM 3090. Através dele, obteve-se acesso aos arquivos litológicos e de perfis elétricos de todos os poços aqui utilizados. Foram confeccionados mapas, seções geológicas estratigráficas, diagramas de cerca, blocos-diagrama e ilustrações em geral, aplicando os programas GEOSEC e GEOMAP, da PETROBRÁS, na estação gráfica IBM 5080.

\section{3) Obtenção dos Dados}

\section{a- Seleção das Amostras}

Foram selecionados 18 poços, distribuídos por toda a bacia, tanto em sua porção emersa, como na submersa. A escolha obedeceu à seguinte ordem de prioridade: a) poços com maior representatividade em termos de espessura e variabilidade de fácies da Formação Alagamar; b) poços com testemunhos no intervalo investigado e; c) poços em diferentes posições estruturais e geográficas da bacia.

Foram utilizadas amostras tanto de calha como de testemunhos. Os testemunhos foram analisados primeiro em termos macroscopicos e os resultados 


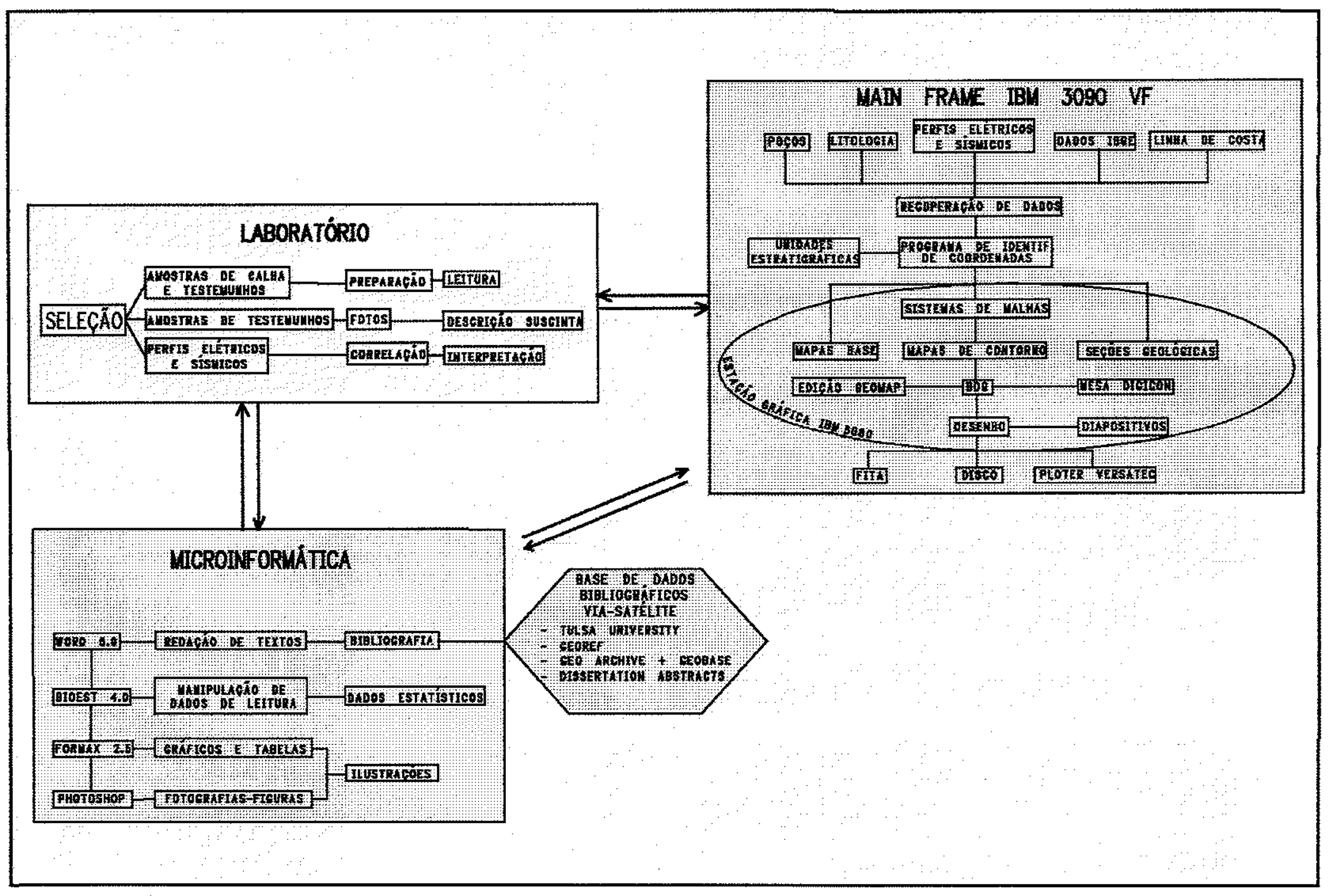

FIE. 8 - METODOLOEIA E ETAPAS DO TRABALHO (FLUXOERAMA) 
usados na calibração das interpretações de perfis de raios gama e da análise da matéria orgânica. Em seguida, foram coletadas amostras em intervalos de um a três metros, excetuando-se os casos onde a litologia era extremamente impropria para a análise palinológica. Um cuidado adicional foi o de amostrar cada membro da Formação Alagamar, bem como a totalidade das fácies litológicas identificadas nesta unidade litoestratigrafica.

As figuras 9, 10, e 11, ilustram testemunhos representativos das rochas de cada Membro da Formação Alagamar. São apresentadas para mostrar os tipos de rocha utilizados no presente trabalho, das quais foram recuperadas as associações palinologicas analisadas.

As amostras de calha foram coletadas em intervalos de $30 \mathrm{em} 30$ metros, indistintamente. Ao todo foram estudadas 291 amostras, sendo $105 \mathrm{de}$ testemunhos e 186 de calha. Deste total apenas $17 \%$ se revelaram estéreis.

Adicionalmente, foram incorporados ao estudo 25 poços, dos quais, apesar de não se ter efetuado um estudo palinológico detalhado como nos anteriores, detinha-se um controle prévio da sua divisão palinoestratigráfica. Estas informações contribuíram para dar maior consistência aos estudos de correlação através dos perfis elétricos.

\section{b- Preparação das Amostras}

As amostras foram preparadas nos laboratórios da PETROBRÁs, utilizando-se às técnicas padronizadas para processamento de amostras palinologicas, segundo Uesugui (1979). Foram montadas lâminas a partir dos resíduos recuperados, encontrando-se, todas elas, no laminário de poços do Setor de Bioestratigrafia e Paleoecologia do Centro de Pesquisas da PETROBRÁs.

\section{c- Procedimentos de Contagem}

São muitos os fatores que afetam a abundância e mesmo a ocorrência de palinomorfos numa dada amostra. Avalia-se que a compreensão do papel e da extensão dos efeitos de cada um desses fatores estão, até o presente, insuficientemente entendidos, e que esta área da palinologia necessita de enormes esforços de estudo. Contudo é inegável que as análises quantitativas têm se revelado extremamente úteis, particularmente em estudos de correlação de detallhe, quando se tem um bom controle da abundância relativa dos tipos polínicos presentes, como é o caso atual. Desse modo, cientes das restrições desta 


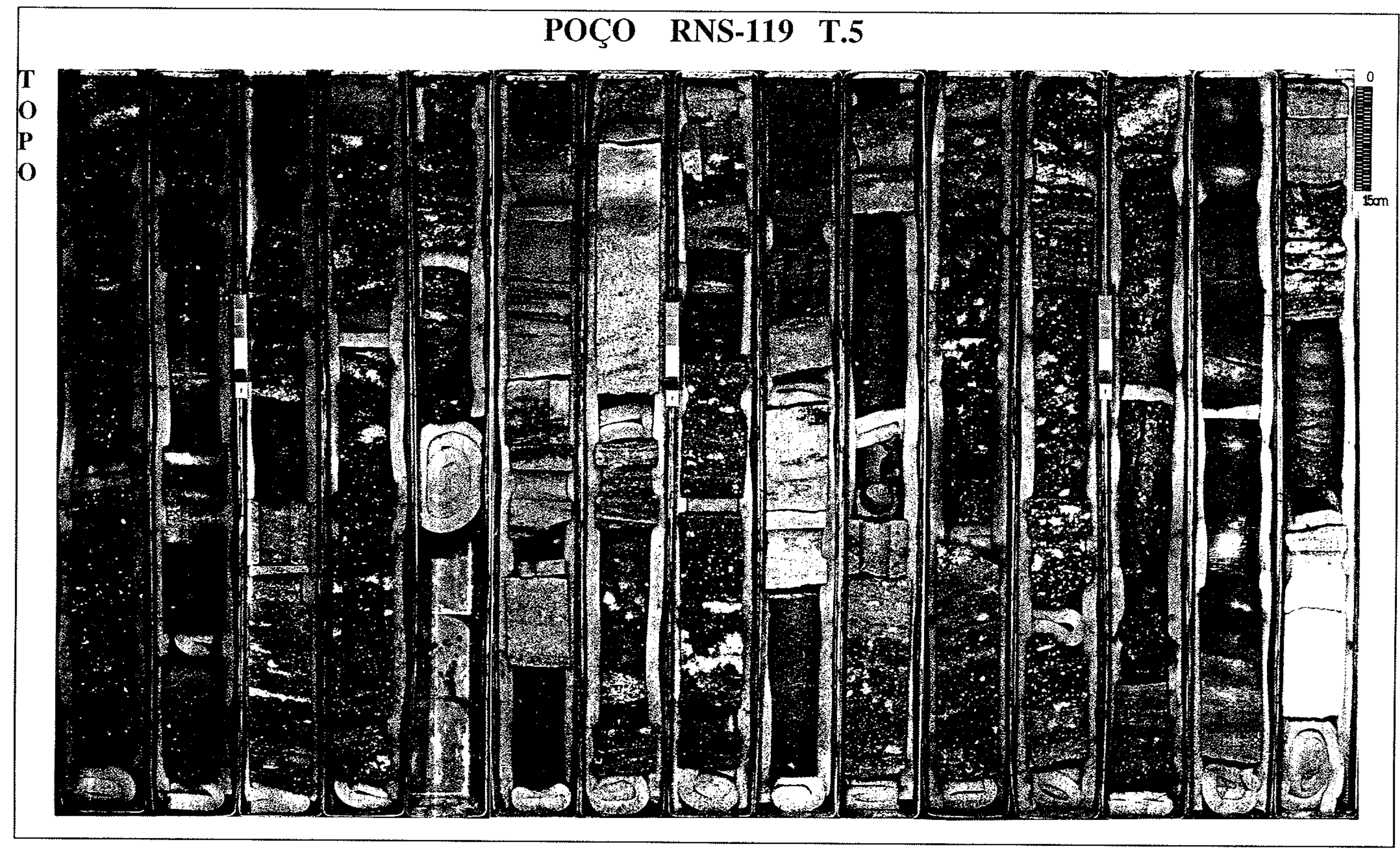

FIG. 9 - Testemunhos representativos dos sedimentos do Membro Upanema. Fácies de fan-deltas. 


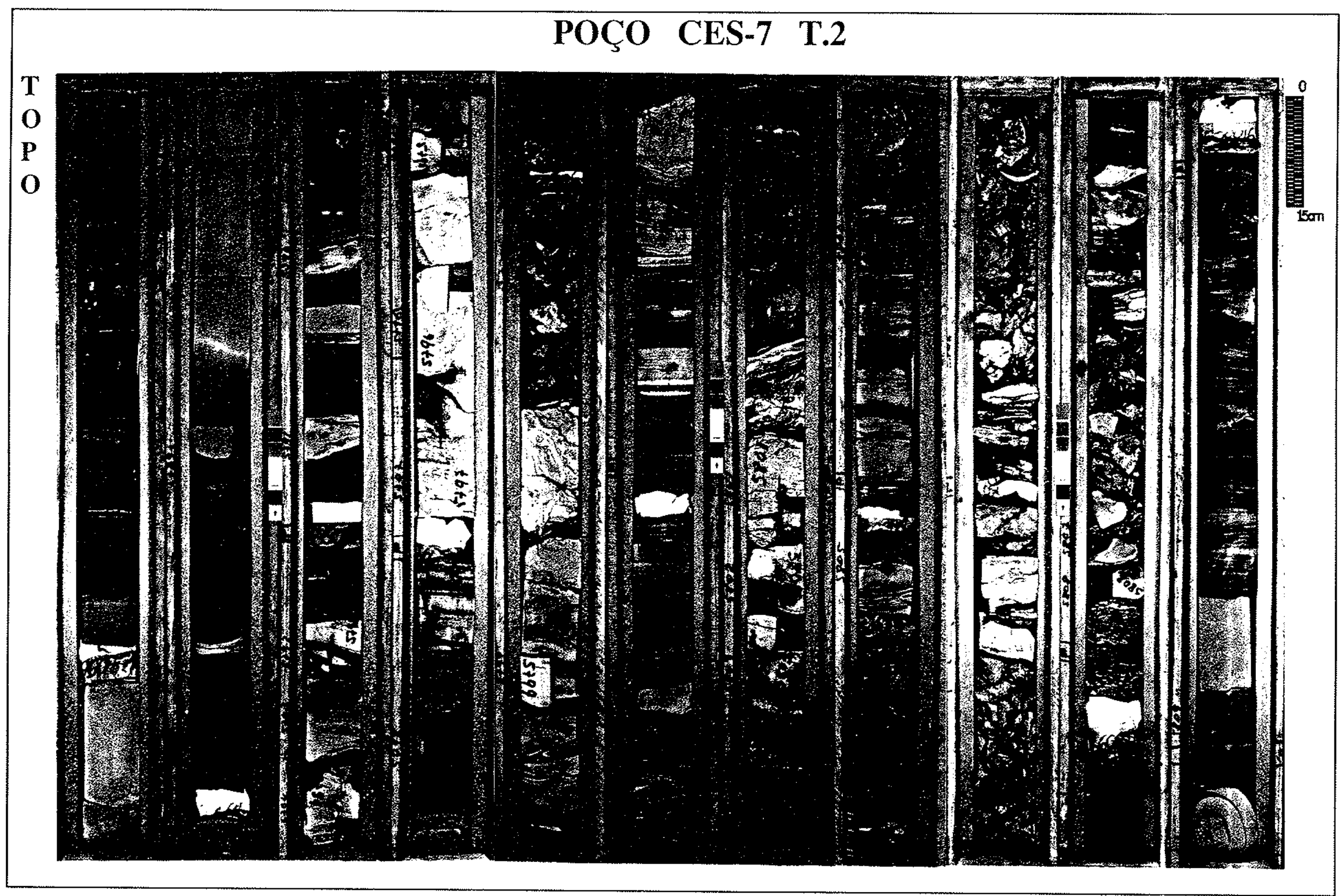

FIG. 10 - Testemunhos representativos das Camadas Ponta do Tubarão. Observar depósitos carbonáticos e folhelhos lacustres. 


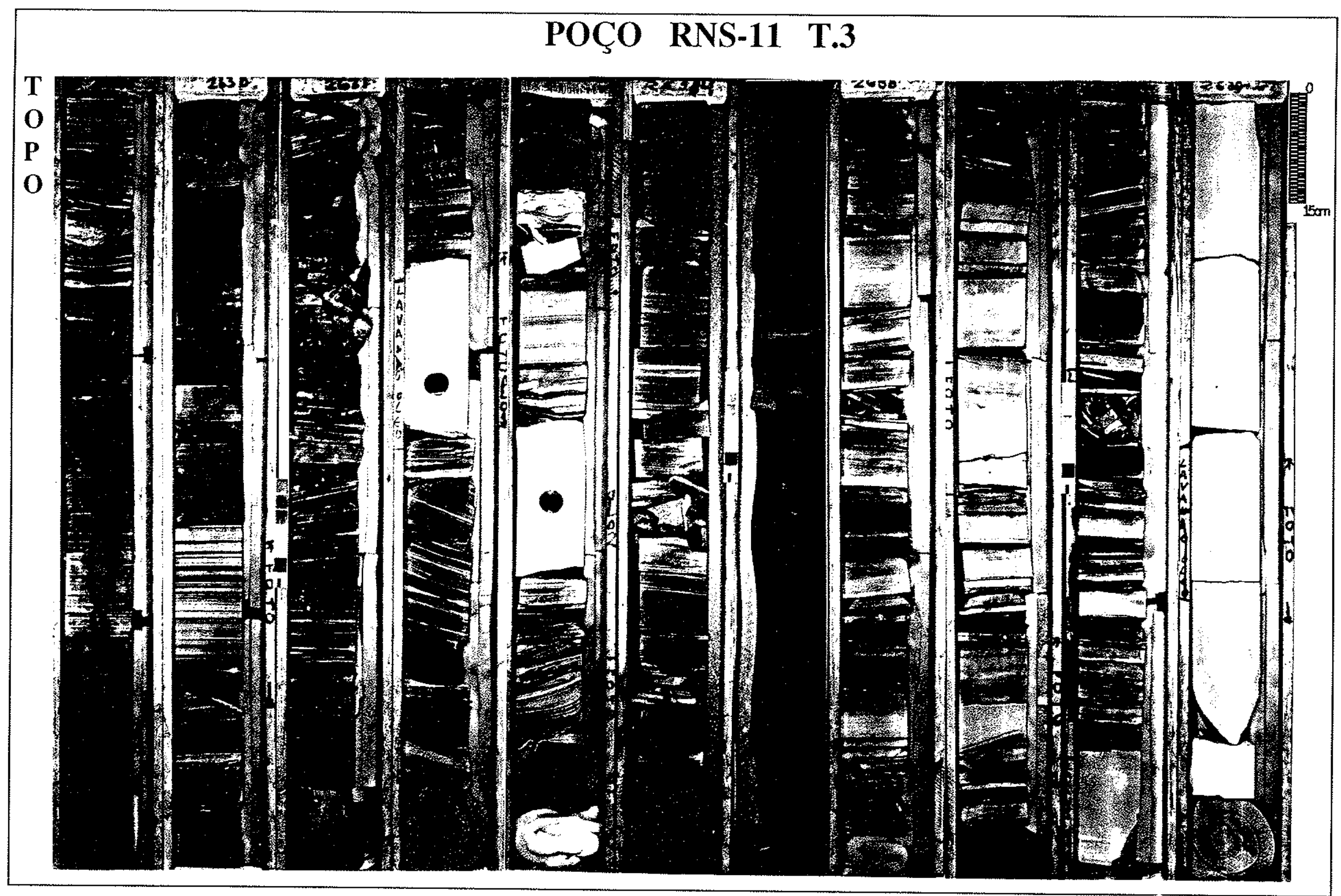

FIG. 11 - Testemunhos representativos do Membro Galinhos. Observar fácies prodeltaicas e frente deltaica distal. 
metodologia, optou-se por aplicar um tratamento estatístico aos dados palinologicos obtidos.

Nas contagens, as lâminas foram analisadas sob microscópio Zeiss a 400x para evitar superposição de campos. Os dados para a contagem de freqüência relativa foram baseados nos primeiros 200 palinomorfos encontrados na lâmina.

Esta decisão baseou-se na argumentação de CHANG (1967), apresentada resumidamente a seguir: 1) o erro de uma porcentagem estimada é inversamente proporcional à raiz quadrada do número de indivíduos da população estudada; 2) o aparecimento de uma espécie e a variabilidade de sua porcentagem são dependentes do número de indivíduos da população; 3) a eficiência do estudo de uma população $\varepsilon$ uma função do número de indivíduos da população; sua precisão aumenta com o incremento assintótico do número de espécimes presentes.

De acordo com Chang (op. cit.), a população ideal de contagem seria 1000. Entretanto o mesmo autor demonstra que, ao contarmos apenas 200 espécimes, estaremos dentro de uma margem de erro de aproximadamente $5 \%$ da população presente (Fig. 12).

Outro parâmetro utilizado no controle da adequação quanto ao número de espécimes contados, foi a elaboração de uma curva de saturação (RuL, 1987), onde plota-se o número de palinomorfos contados no eixo $\mathrm{X}$ contra o número de novos taxa encontrados no eixo Y. Seleciona-se uma amostra com uma grande diversidade de taxa, como é usual para tal propósito (SalgadoLABouriau, com. pess., 1990). A curva "ideal" foi então construída (Fig. 13) através dos pontos obtidos. Esta curva geralmente apresenta um rápido crescimento inicial até infletir num certo ponto, a partir do qual ela tende a se tornar paralela ao eixo $\mathrm{X}$. A somatória (valor no eixo $\mathrm{X}$ ) correspondente ao ponto de inflexão da curva representa normalmente a totalidade dos taxa da amostra. Esta técnica, proposta pela primeira vez por WIISON (1959B), e posteriormente discutida por Tschudy (1969A), tem sido usada freqüentemente na literatura. Os grupos de palinomorfos contados foram, angiospermas (monocolpados e tricolpados), gimnospermas (monossacados, bissacados, rimulados, inaperturados, poliplicados e monocolpados), e pteridófitas (esporos triletes e monoletes), além dos dinoflagelados, acritarcas e incertae sedis. Estes dados estão representados aqui (Cap. 3), por gráficos de composição de freqüência relativa e uma interpretação paleoambiental, a grosso modo, foi feita para cada poço. 


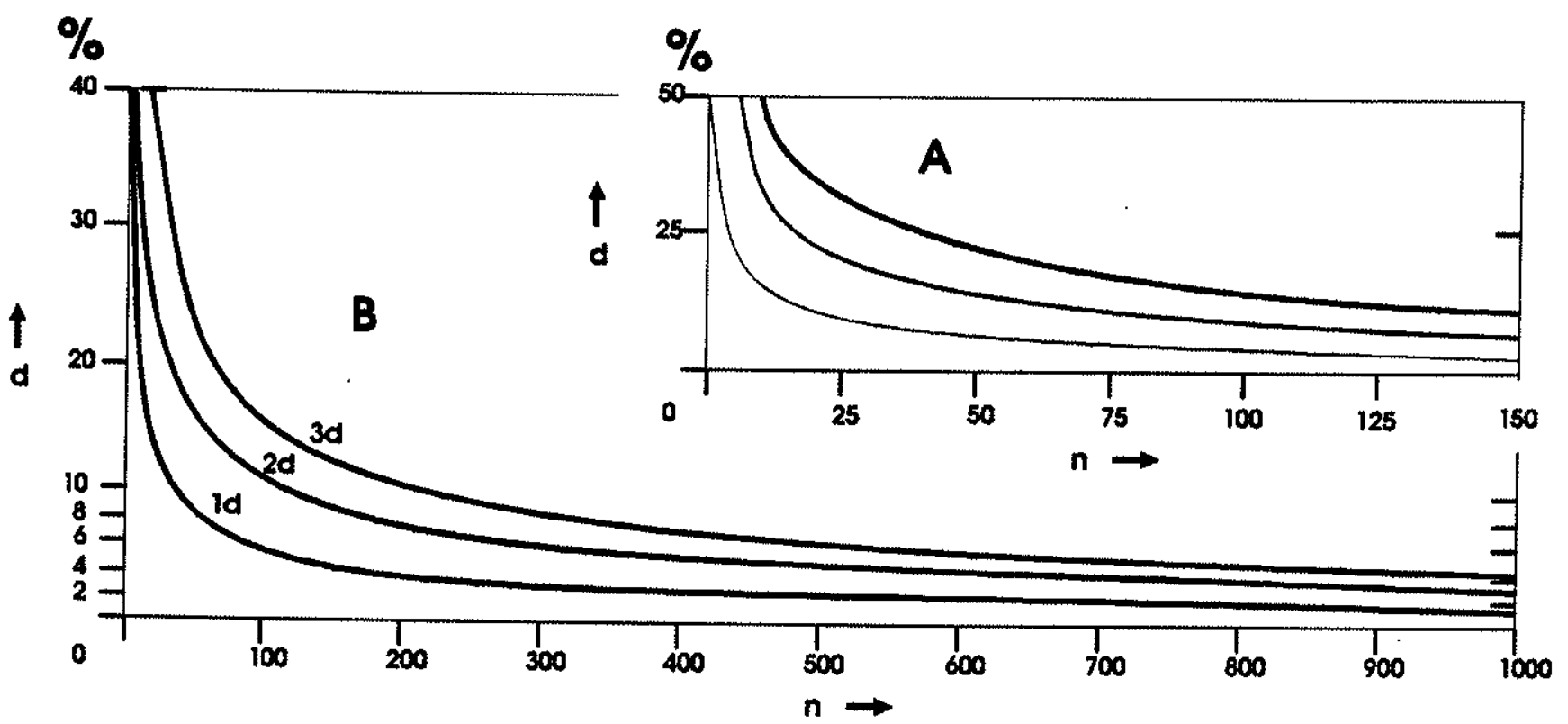

Fig. 12 - Relação do desvio padrão maximo (d) em relação ao número de indivíduos de populaçã̃o (n). Em A, d e n estão na mesma escala. No grăfico $B$ a escala de ñ é dez vezes menor que a de $\underline{d}$. (adaptado de Chang, 1967)

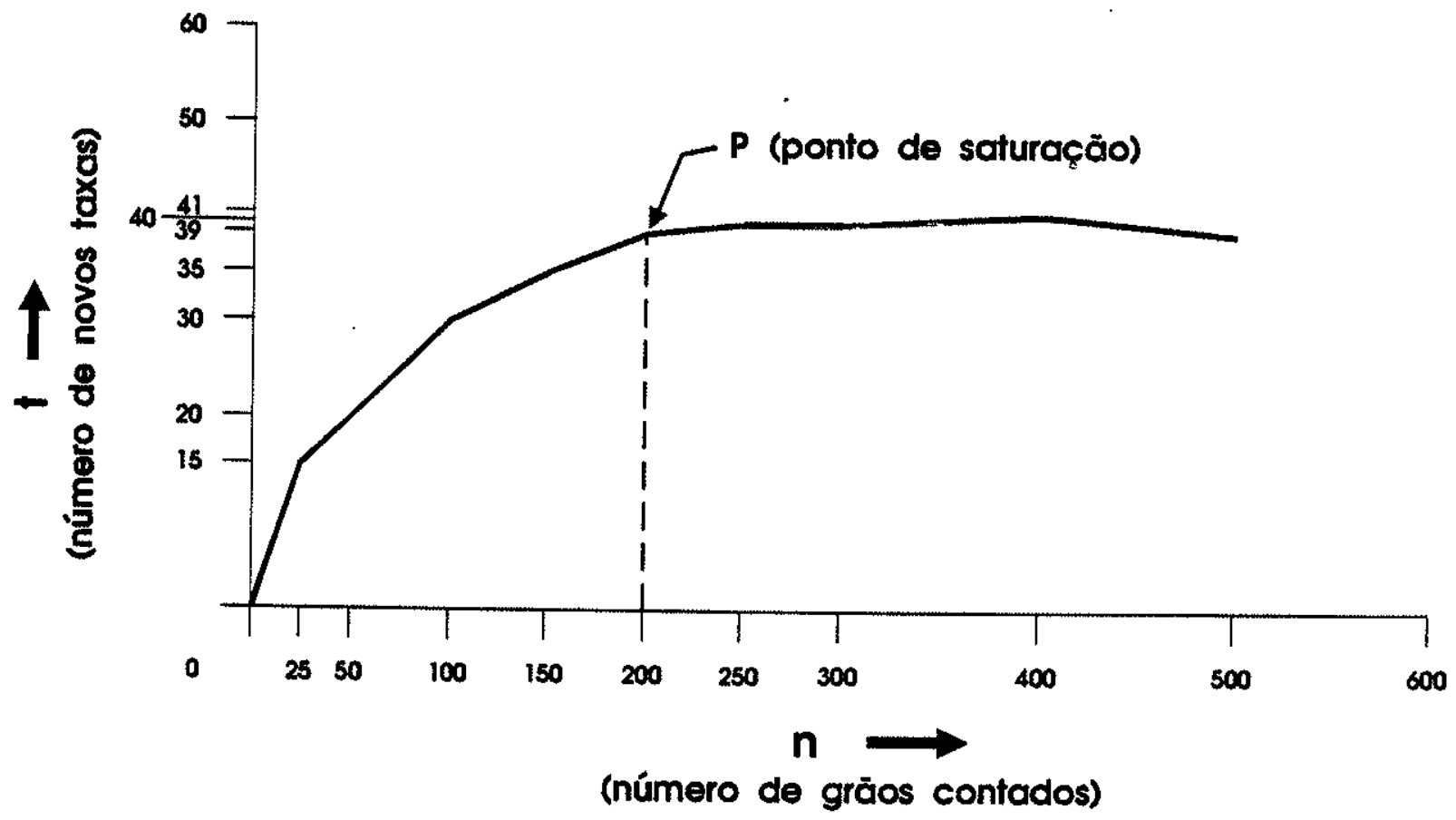

Fig. 13 - Curva de saturação (teórica) de uma dada amostra. (modificado de Rull, 1987) 
A escala de abundância relativa adotada, reserva a classificação de espécie abundante para aquelas com mais de 20 espécimes, o termo comum para a ocorrência de 10 a 20 espécimes; pouco de 5 a 9; e raro de 1 a 4 . A diversidade foi avaliada registrando a presença de todas as espécies numa varredura completa da lâmina.

Especcies e gêneros dos palinomorfos identificados estão listados no apêndice denominado f́ndice da Sistemática.

\section{d- Pallnofácles}

Em contraste com as análises palinoestratigráficas, baseadas somente no conteúdo de palinomorfos da amostra, as análises de palinofácies são feitas através da observação do resíduo orgânico total da amostra; tendo sido empregado pela primeira vez por Combaz (1964). Estes estudos podem ser utilizados, na geoquímica orgânica, objetivando determinar origem, tipo e maturação, bem como auxiliar na interpretação dos ambientes de deposição. Alguns autores (e. g. BAtTen, 1982в) têm utilizado não só as técnicas de luz transmitida, nestes estudos, como também luz refletida e fluorescência. Neste trabalho foi dado ênfase à caracterização das palinofácies presentes, estimando o percentual quantitativo de cada componente, e foram utilizadas como ferramenta de interpretação paleoambiental, utilizando-se apenas do estudo à luz transmitida.

A incursão no campo dos estudos de palinofácies aqui apresentada segue os conceitos e descriçס̃es de Fisher (1980), PARRY et alii (1981), WHITAKER (1984) e Boulter \& RDDICK (1986). Realiza-se aqui, pela primeira vez, uma tentativa de utilizar os conceitos de palinofácies na análise de sedimentos não-marinhos, pois os exemplos disponíveis na literatura tratam de trabalhos em depósitos de ambientes mistos a marinhos.

Os princípios básicos que governam o estudo das palinofácies, preconizam que todo material orgânico de uma lâmina palinológica pode ser dividido em frações alóctones e autóctones (Fig. 14). Os elementos da fração aloctone são caracterizados de acordo com suas capacidades inerentes de flutuação (Richelot \& STReel, 1985). Nesta fração incluem-se os palinomorfos terrestres, tais como os grãos de pólen (sacados ou não), de esporos, algas de água doce e esporos de fungo. 


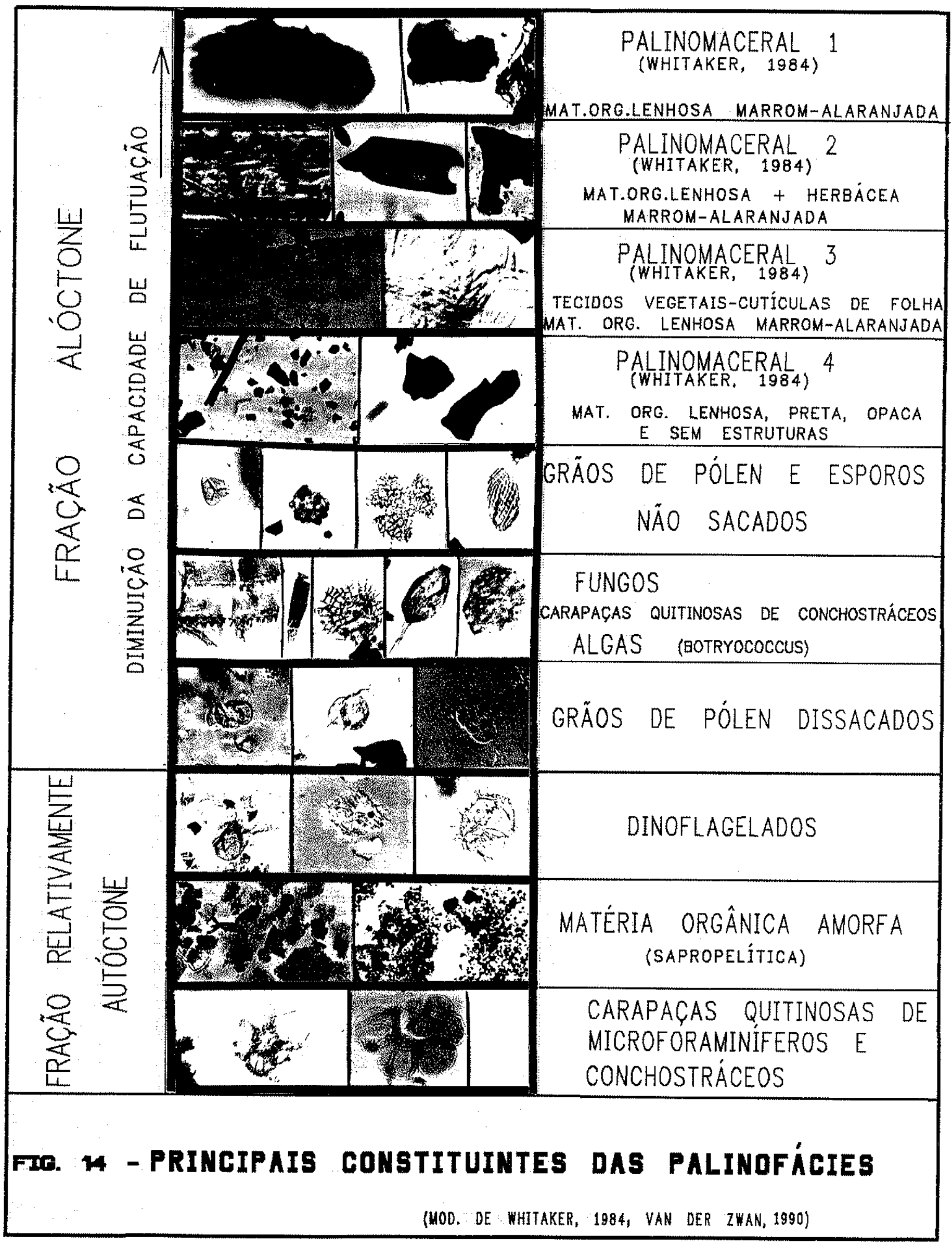


A fração autóctone (ou semi-autóctone) já reflete mais a biota do próprio sítio de deposição. Inclui os dinoflagelados, acritarcas, algas marinhas, testas quitinosas de microforaminíferos, além da materia orgânica amorfa, ou sapropelítica, a qual é massa orgânica resultante da ação das bactérias, e/ou de um processo total de degradação bioquímica. Nesta fração foram incluídos também os esporos das plantas hidrófilas. Foram considerados como autóctones também parte dos fragmentos quitinosos de carapaças de conchostráceos.

Foram caracterizadas, de acordo com a nomenclatura definida por WhrtakER (1984), quatro tipos de palinofácies, descritas a seguir:

PALINOFÁCIES I - Caracterizada pelo baixo conteúdo orgânico. Predomina a matéria orgânica lenhosa, geralmente carbonizada. A matéria orgânica amorfa está quase que totalmente ausente. Os palinomacerais são pequenos $(15-25 \mu \mathrm{m})$, geralmente opacos, pretos e sem estruturas identificáveis. De modo geral, é estéril em palinomorfos.

PALINOFÁCIES II - Caracterizada pela alta freqüência de fragmentos lenhosos pequenos e eqüidimensionais, geralmente opacos, quase sempre sem estruturas, de coloração preta ou quase preta (palinomaceral 4 de WHITAKER, 1984). Esporadicamente observa-se fragmentos grandes $(>45 \mu \mathrm{m})$ de tecidos vegetais. A matéria orgânica amorfa $\epsilon$ encontrada em menor proporção, sendo baixa a percentagem de palinomorfos (geralmente apenas esporos triletes).

PALINOFÁCIES III - Nesta palinofácies predominam os fragmentos cuticulares com estrutura visível (matéria orgânica herbácea), médios (entre 30-45 $\mu \mathrm{m}$ ), grandes e eqüidimensionais, de aparência densa (palinomaceral 1 de Whrtaker, 1984), secundados por fragmentos de tecidos vegetais e por palinomacerais pequenos e eqüidimensionais. Os palinomorfos são freqüentes, inclusive os sacados, e a matéria orgânica amorfa presente chega a atingir proporções equiivalentes às da matéria orgânica lenhosa. A coloração do resíduo como um todo é marron clara a alaranjada.

PALINOFÁCIES IV - Caracterizada pela abundância de matéria orgânica amorfa, globosa ou não, às vezes carbonizada. Não contém estruturas identificáveis, e ocorre em aglomerados amorfos. Ao microscópio, apresenta-se com formas e texturas diversas, com contorno irregular, formando flocos ou 
grumos. Sua coloração varia do amarelo-claro ao marrom, em função do grau de preservação e maturação. Os palinomorfos, quando presentes, são raros e geralmente pequenos (ao redor de $25-30 \mu \mathrm{m}$ ), imersos nos grumos. Em algumas amostras foram encontrados fragmentos quitinosos de carapaças de conchostráceos.

\section{e- Perfls Elétricos}

A utilidade no emprego dos padrões de perfis elétricos ou diagrafias na interpretação da litologia, das fácies sedimentares e de ambientes deposicionais, e mesmo na previsão da geometria de corpos clásticos tem sido demonstrada por diversos autores, como Fisher (1969), Fisher \& Brown (1972), e SeLley $(1972,1976)$. Objetivando consubstanciar as correlações e interpretações ambientais nas seções estudadas, foram efetuadas análises de perfis; notadamente os de raios gama.

A utilização dos perfis de raios gama foi função de sua maior sensibilidade às mudanças litologicas do pacote rochoso estudado, apresentando padrões de curvas características ante cada litofácies atravessada.

Os raios gama mensuram essencialmente a radioatividade natural dos sedimentos, a exemplo de um cintilômetro. Assim são detectados os isótopos radioativos contidos nas rochas, geralmente $\mathrm{Th}, \mathrm{U}$ e $\mathrm{K}$, sendo o mais comum destes is 6topos o potássio-40. Desse modo, os folhelhos, que são compostos de argilo-minerais, mostram-se geralmente muito mais radioativos que os arenitos, e conseqüentemente apresentam altos valores na curva de raios gama. Como os teores de argila decrescem de um modo geral com o aumento da granulometria, os raios gama também são úteis na inferência da granulometria quando trabalhamos com seqüências clásticas.

Estudou-se a seção correspondente à Formação Alagamar dos 43 poços selecionados, permitindo a confecção de seções "cortando" a bacia nas direções transversais e longitudinais (Fig. 15). Desse modo, obteve-se 5 intervalos por correlação das curvas de raios gama, resistividade e tempo de penetração (sonico). 


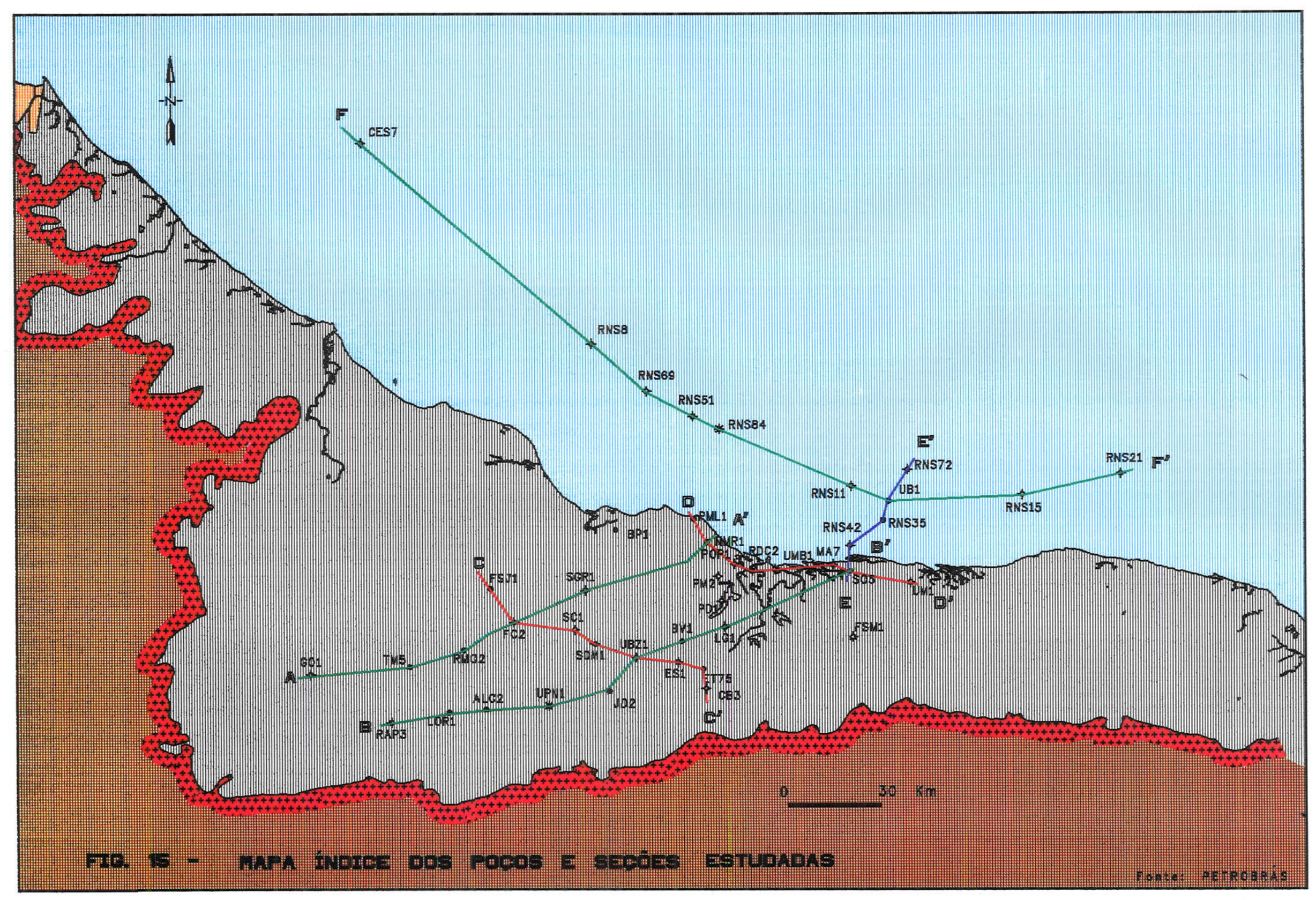




\section{4) Utilização do Microcomputador PC-KT}

Grande parte das informações obtidas na fase de aquisição de dados foram arquivadas e processadas através de programas de microcomputadores da linha PC-XT. Os dados aqui interpretados referentes aos poços estudados, tais como, as divisð̃es lito- e bioestratigráficas, marcos litológicos e elétricos, e as espessuras de cada unidade, foram agrupados por poço e fazem parte de um arquivo específico (ARQUIVO DE DADOS GEOLÓGICOS), utilizado na confecção das seções, malhas etc..

Os dados e interpretaçðes palinológicas foram arquivadas (ARQUTVO BIOEST) através dos programas BIOEST. O sistema BIOEST constitui-se num conjunto de programas de arquivamento e manuseio de dados paleontológicos, desenvolvido no Setor de Bioestratigrafia e Paleoecologia da Divisão de Exploração do CENPES (AzEVEDo et alii, 1991). Entre os programas disponíveis encontram-se o YBIOEST, dirigido ao arquivamento dos taxa identificados em cada amostra; O YBIOTAB, com capacidade de arquivar informações sobre biozonas, idade e paleoambiente de cada poço; e o INBIO, programa que organiza os arquivos de saída do BIOEST, possibilitando o emprego de programas aplicativos à bioestratigrafia quantitativa.

\section{a- Arquivo Blbllográfico}

O arquivo bibliográfico foi construído através do programa MICROISIS. Na formação deste arquivo, contou-se com os serviços do Setor de Informação Técnica da PETROBRÁS (CENPES/SINTEP), que está ligado on line, via satélite, às principais bases de dados bibliográficos internacionais, notadamente os da Tulsa University (ligado ao banco ORBIT), o Georef, Geoarchive, Geobase e o Dissertation Abstracts Online, ligados ao banco DIALOG. Estas bases de dados são atualizadas mensal e até mesmo semanalmente; algumas, como é o caso da Georef possuem dados desde 1795. Desse modo, pela solicitação de busca nestas bases de dados, por meio de palavras chave (foram utilizadas principalmente: pollen, spores, Neocomian, Lower Cretaceous, Cenomanian, Albian, Aptian, Barremian, palynology, palynofacies, biostratigraphy), foram recebidas as referências bibliográficas com os respectivos resumos. Daquelas de maior interesse foram imediatamente solicitadas cópias, também por intermédio do mesmo SINTEP. Desta maneira foi obtida a grande maioria da bibliografia aqui citada. 


\section{b- Fotomicrografias}

Foram tiradas aproximadamente 1000 fotos de palinomorfos previamente selecionados e devidamente localizados com a utilização de lâminas de coordenadas (England Finder), ao microscópio óptico comum da Zeiss. Para tal propósito utilizou-se um fotomicroscópio (Axiophot) da Zeiss, munido do sistema de contraste interferencial diferencial (Nomarski Interference Contrast), e filmes Kodacolor-Gold 100 de $35 \mathrm{~mm}$ da Kodak, de 100 asa. As fotomicrografias da maioria dos palinomorfos foram tiradas com a objetiva de imersão de 100x. Formas muito grandes, tais como, parte dos esporos de pteridofitas e alguns palinomorfos não identificados, foram fotografados com a objetiva de $40 x$, e as palinofácies com a de $25 \mathrm{x}$. A partir desta coleção preliminar de fotos, foram selecionadas as mais representativas para compor as estampas. Estas mostram figuras dos palinomorfos aumentadas de $500 \mathrm{x}-1000 \mathrm{x}$, dispostas de modo a ilustrar as diferenças relativas de tamanho.

\section{5) Processamento de Dados no Computador IBM-3090}

A utilização do computador MAIN FRAME IBM-3090 VF, do Departamento de Exploração da PETROBRÁS, no processamento de dados geológicos foi de vital importância na manipulação dos dados apresentados. Esse main frame atende ao processamento científico da PETROBRÁS na área EXPROPER (Exploração, Produção e Perfuração) e nele estão contidos os arquivos gerais de poços, de dados litológicos, de perfis e de pontos de tiro (sísmica), além de arquivos gráficos, com dados da linha de costa brasileira, mapas ao milionésimo do I.B.G.E. etc.

Através da manipulação de arquivos, obteve-se acesso aos dados do main frame, e passou-se a operar com arquivos préviamente preparados neste sistema. O mesmo dispõe de terminais de vídeo locais e remotos, terminais, estaçōes, impressoras gráficas e plotters. Através do sistema gráfico disponível foi possível confeccionar mapas estratigráficos, mapas de contorno estrutural e de isópacas, seções estratigráficas e estruturais, e figuras em geral. 


\section{a- Edição Geomap}

O sistema Geomap, idealizado e desenvolvido pelo Setor de Programação e Análise do Departamento de Exploração da PETROBRÁS, pela facilidade que proporciona ao geólogo na manipulação de um grande volume de dados e variáveis, tornou-se uma das mais potentes ferramentas de Exploração na PETROBRÁs. É através do Geomap que são gerados, editados, copiados, visualizados e plotados os desenhos, resultantes das interpretações geológicas à luz de diferentes hipóteses de trabalho, em completa interação com o pesquisador e numa linguagem extremamente acessível.

As ilustrações aqui apresentadas foram confeccionadas neste sistema, utilizando fundamentalmente os arquivos das bases de dados gráficos, os quais estão ligados às saídas de processamento e plotagem de mapas, seções, figuras, etc..

A seqüuencia de edição está implantada de forma a oferecer um elenco de alternativas destinadas à alteração e/ou criação de desenhos na estação gráfica IBM 5080. Esta estação está ligada também a uma mesa digitalizadora digigraf, a qual permite a digitalização de mapas ou quaisquer ilustrações criadas pelo usuário. Após a edição final da figura, a estação permite, através da própria tela, que a mesma seja fotografada para a confecção de diapositivos. Conectado a todo o sistema temos um plotter VERSATEC CE 3236, de impressão eletrostática com sistema de representação matricial/raster, colorido, no qual os desenhos e figuras são reproduzidos. Tem-se ainda a opção de saída numa copiadora hard-copy, em papel opaco ou transparências coloridas.

Parte das figuras foram elaboradas no microcomputador Macintosh (Quadra 900), através do programa Photoshop. Desenhos ou fotografias foram digitalizados, (scanning) no digitalizador de imagens Scanner La Cie Silverscaner (Apple), com capacidade máxima de 1.200 dpi e 16 milhões de cores. Após o processamento das imagens tem-se como opções de saída a copiadora Laser Writer 2NT (Apple), colorida, com 600 dpi de capacidade; e a gravadora de slides coloridos QCR-Z (Agfa), com 4.000 linhas de capacidade máxima.

Todos estes recursos foram muito úteis na confecção das ilustraç̃̃es desta tese. 


\section{IV- RESULTADOS OBTIDOS}

\section{1) Características Litoestratigráficas}

A observação macroscópica das rochas da fase transicional da Bacia Potiguar (Formação Alagamar) mostra uma seqüência sedimentar constituída de uma série de corpos conglomeráticos, arenosos grosseiros a finos (flúviodeltaicos), intercalados com intervalos síticos e argilosos (lacustres), bem como depósitos, com episódica exposição subaérea, de carbonatos lacustres. A grosso modo, podemos interpretar estas associaçðes litologicas como resultantes de alternâncias cíclicas de alta e baixa energias, com forte influência de flutuaçð̃es do nível de base (CASTRo et alii, 1981A, B; CASTro et alii, 1987; Costa et alii, 1987).

A análise estratigráfica da Formação Alagamar, que constitui uma seqüuência deposicional no sentido de que é limitada por discordâncias ou suas concordâncias correlativas (VAIL et alii, 1977; VAN WAGONER et alii, 1988; DELlA FAVERA, 1990), foi efetuada em termos da Estratigrafia de Ciclos TransgressivosRegressivos (Ciclos T-R), (Busch \& Roluns, 1984; CAstro, 1989).

\section{a- Fatlamento Grafoelétrico da Formação flagamar}

Com base nos conceitos supracitados e modelos da Estratigrafia de 
Ciclos e de Seqüências, observa-se que a Formação Alagamar se comporta como uma seqüência deposicional, limitada por superfícies erosivas e/ou parcialmente por concordâncias relativas, e composta por estratos depositados em sucessóes cíclicas. Vale ressaltar que GAMA JR. (1985), aplicando estes mesmos conceitos subdividiu toda a Bacia Potiguar, em quatro sequiências. $O$ pacote ora estudado corresponde à seqüência III e parte da subseqüência IV-A desse autor. $O$ limite inferior desta seqüência é a discordância angular entre os depósitos aluviaislacustres da Formação Pendência e os sedimentos flúvio-deltaicos do Membro Upanema da Formação Alagamar. O limite superior e a superfície erosiva pósAlagoas, entre os depósitos fluvio-lacustres do Membro Galinhos e os sedimentos fluviais e marinhos de plataforma das formações Açu e Ubarana. Salienta-se que nem sempre estas superfícies são de fácil caracterização por toda a bacia, principalmente utilizando-se o critério da Estratigrafia de Seqüências, que implica em erosão subaérea; contudo, possuem uma excelente expressão lateral.

Desse modo, dividiu-se tentativamente os depósitos da Formação Alagamar em 5 sucessões cíclicas, limitadas por eventos transgressivos. Estas sucessões resultaram da análise faciologica vertical e da correlação em detalhe das "quebras" características dos perfis elétricos dos poços (notadamente as diagrafias de raios gama). Elas supostamente representam agradações fluviais e progradações deltaico-lacustres seguidas de depósitos retrogradantes e transgressivos, e cuja repetição cíclica possui conotação cronoestratigráfica. Eventos de máxima inundação estão representados por folhelhos relativamente mais radioativos e carbonatos.

Para fins de correlação foram consideradas como limites das sucessões os "picos" de folhelhos radioativos. Foram construídas seções estratigráficas, no intuito de subdividir o intervalo estudado, identificar as sucessões cíclicas da sedimentação através da análise sequencial, e correlacionar estratigraficamente os poços, para posterior amarração com as biozonas e palinofácies. O resultado deste estudo é retratado nas seções A-A', B-B', C-C', D-D', E-E' e F-F' (Figs. 16-21).

As sucessões transgressivas podem ser detectadas nos perfis radiativos ( $R G$ ) quando estes mostram uma curva assimétrica, cujo padrão é caracterizado por um contato basal brusco, topo gradacional ou não, e tendência à uma diminuição granulométrica em direção ao topo (feição de "sino normal"). As sucessões progradantes ou regressivas são observadas pelo contato basal gradacional, aumento da razão arenito-folhelho para cima, e topo abrupto (feição de "sino invertido"), refletindo aumento na granulometria em direção ao topo. Os intervalos texturalmente mais homogêneos mostram contatos bruscos, tanto 


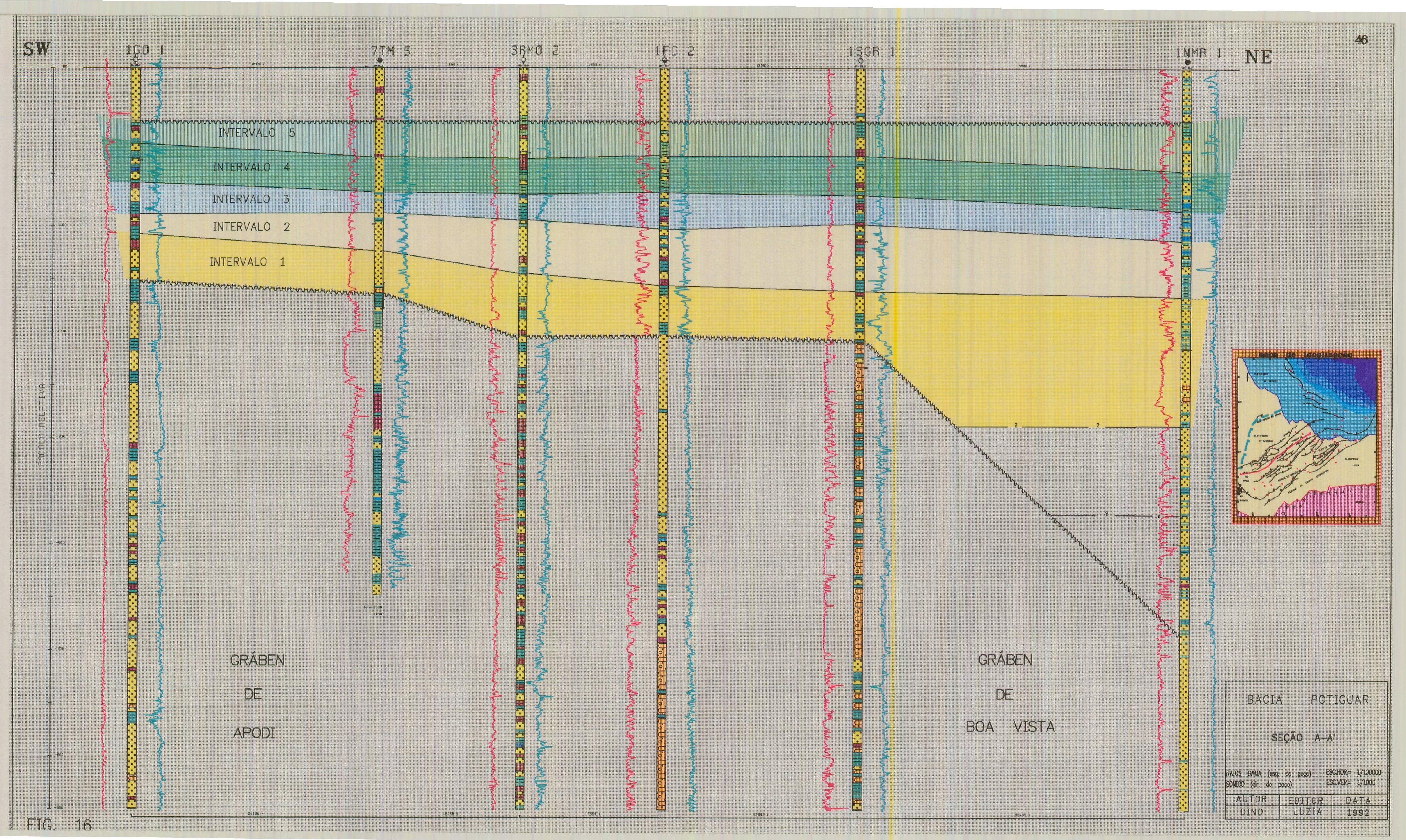





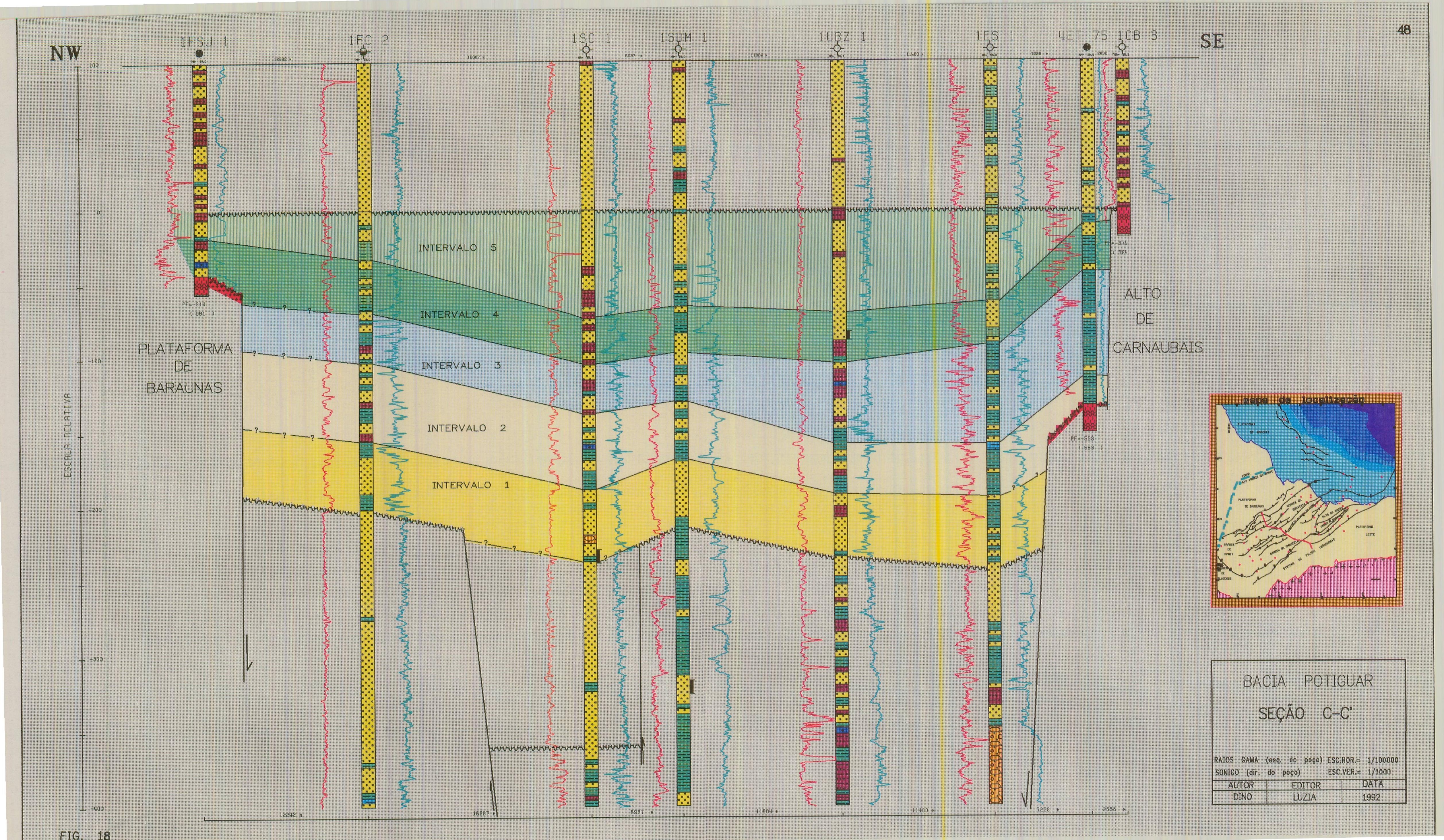


no topo quanto na base, e tipificam principalmente depósitos de canais fluviais (forma de "caixa").

Numa visualização global de toda a deposição Alagamar, no sentido vertical, verifica-se que ocorre inicialmente uma grande sucessão transgressiva, mostrando a grosso modo diminuição da granulometria em direção ao topo. Esta sucessão corresponde, litoestratigraficamente, ao Membro Upanema e às Camadas Ponta do Tubarão. Segue-se uma grande sucessão regressiva, caracterizada por um aumento geral da granulometria em direção ao topo, correspondendo aos depósitos das Camadas Ponta do Tubarão e ao Membro Galinhos. A distribuição dos intervalos cíclicos é progressivamente ampliada no sentido da base para o topo, expandindo, cada vez mais a bacia. Esta configuração caracteriza um onlap progressivo às margens da bacia (Figs. 18, 19 e 21).

Desta maneira, foram identificados regionalmente os eventos transgressivos que permitiram fatiar, cronoestratigraficamente, a Formação Alagamar em intervalos deposicionais contemporâneos, denominados da base para o topo de intervalo 1 a intervalo 5 .

Por excederem o escopo do trabalho, não foram confeccionados mapas de isópacas e de fácies (razão areia/folhelho, isólitas de areia etc.) para estes intervalos.

Com base na análise das seções estratigráficas e nos intervalos criados, fazem-se as seguintes considerações, de ordem estratigráfico-ambiental:

(a) a parte inferior da Formação Alagamar ainda apresenta caraterísticas deposicionais compartimentadas, típicas da fase rifte, o que impossibilitou sua subdivisão estratigráfica através do rastreamento dos eventos transgressivos. Geralmente são depósitos conglomeráticos a areno-argilosos, fluviais a deltaicos. Correspondem em parte à biozona $\mathbf{A}$ e aos sedimentos denominados de "Seção Pescada" de TexxeIrA (1990), e representam a porção inferior do Membro Upanema. Em terra, foram identificados somente no Gráben de Boa Vista, poço NMR-1, seção A-A' (Figs. 16 e 19). Na plataforma, são observáveis, em ocorrências restritas, nas áreas dos poços CES-7 e RNS 84, seção F-F' (Fig. 21). É possível que, à época inicial da sedimentação Alagamar, ainda ocorressem falhamentos ativos controlando estes depósitos, pois estes são restritos apenas a grábens da fase anterior.

(b) Os intervalos 1 e 2 são os intervalos mais basais que já podem ser rastreados. De natureza agradante-progradante, geralmente representam o 
início da deposição Alagamar no continente, onde são muito menos restritos que o pacote anterior. Trata-se de arenitos e folhelhos fluviais a deltaicos das porções média e superior do Membro Upanema.

(c) Os intervalos sobrepostos indicam uma expansão da área de sedimentação da bacia, alcançando o embasamento, nas porções marginais (Figs. 18, 19 e 21), provavelmente graças a uma subsidência lenta, gradual e contínua. No intervalo 3 se observa a deposição de calcilutitos, calcarenitos e folhelhos euxínicos das Camadas Ponta do Tubarão, com ampliação da bacia e evidências de deposição lacustre rasa a subáerea (trata-se do paradoxo estratigráfico de DeLra FAVERA 1990). No intervalo 4, imediatamente acima, tambem se faz presente uma associação litológica argilo-carbonática, transgressiva, melhor visualizada na área entre os altos de Macau e Serra do Carmo (seção B-B', Fig. 17), já identificada anteriormente por MOREIRA (1987). O intervalo 5 evidencia um pacote dominantemente arenoso, deltaico-regressivo, na maior parte das seções. Estes intervalos (4 e 5), correspondem aos sedimentos do Membro Galinhos. De acordo com LiMA (1987) a porção mais superior do Membro Galinhos, em alguns poços, apresenta características sedimentológicas transicionais.

(d) Em termos espaciais, inferem-se condições relativamente mais "proximais" em certas áreas da bacia, onde predominam conglomerados e arenitos fluviais, com raras intercalaçoes "transgressivas" de folhelhos lacustres. Tais áreas são evidentes na porção oeste da bacia (poços RAP-3 e TM-5, seções A-A' e B-B' no Gráben de Apodi). Já outras áreas apresentam-se com características mais "distais", indicadas nas seções pelo domínio de folhelhos e carbonatos, atestando condições deposicionais lacustres mais permanentes. Estas areas são mais evidentes na região dos poços ES-1, ET-75, MA-7 e POP-1, seções C-C' e D-D' (áreas a norte, Gráben de Guamaré, e leste da bacia, Alto de Macau).

\section{b- Distribuição}

O mapa de isópacas da Formação Alagamar (Fig. 7) mostra uma distribuição bastante uniforme, com padrão geométrico tabular, onde se ressaltam os depocentros principais. Vale salientar que algumas fontes secundárias poderiam ter sido os próprios altos internos da bacia e suas plataformas adjacentes. Através do mapa de contorno estrutural do topo da Formação Alagamar (Fig. 6) e da seção estratigráfica B-B' (Fig. 17), podemos observar que a sedimentação Alagamar ocorreu em toda a calha central da área emersa da bacia, iniciando-se 
nos resquícios dos grábens formados pelo rifteamento do Cretáceo Inferior (Formação Pendência). Com a expansão da bacia, alcançou também os altos estruturais e extravasou um pouco alem da calha central, atingindo praticamente toda a plataforma continental. Encontra-se ausente apenas nas plataformas rasas, em terra (plataformas de Aracati e de Touros), e em áreas truncadas erosionalmente por canions, no mar (canions de Ubarana e Pescada). O espessamento da unidade decorre do maior volume de sedimentos do Membro Upanema (até 320m no Gráben de Boa Vista, no poço NMR-1). Os depocentros principais encontram-se a norte, no Gráben de Boa Vista (em terra) e nas áreas de Ubarana e Pescada, na plataforma. Em terra, o depocentro da calha do Gráben de Guamare também é expressivo. Observa-se que as maiores espessuras, de modo geral, amoldam-se às depressões estruturais (grábens). A Formação Alagamar adelgaça-se e desaparece sobre os altos internos e as plataformas. Nos altos internos do gráben central a Formação Alagamar mostra espessura reduzida, em geral advinda da ausência de sua porção basal, já que esta é restrita aos baixos herdados da discordância pós-neocomiana. 


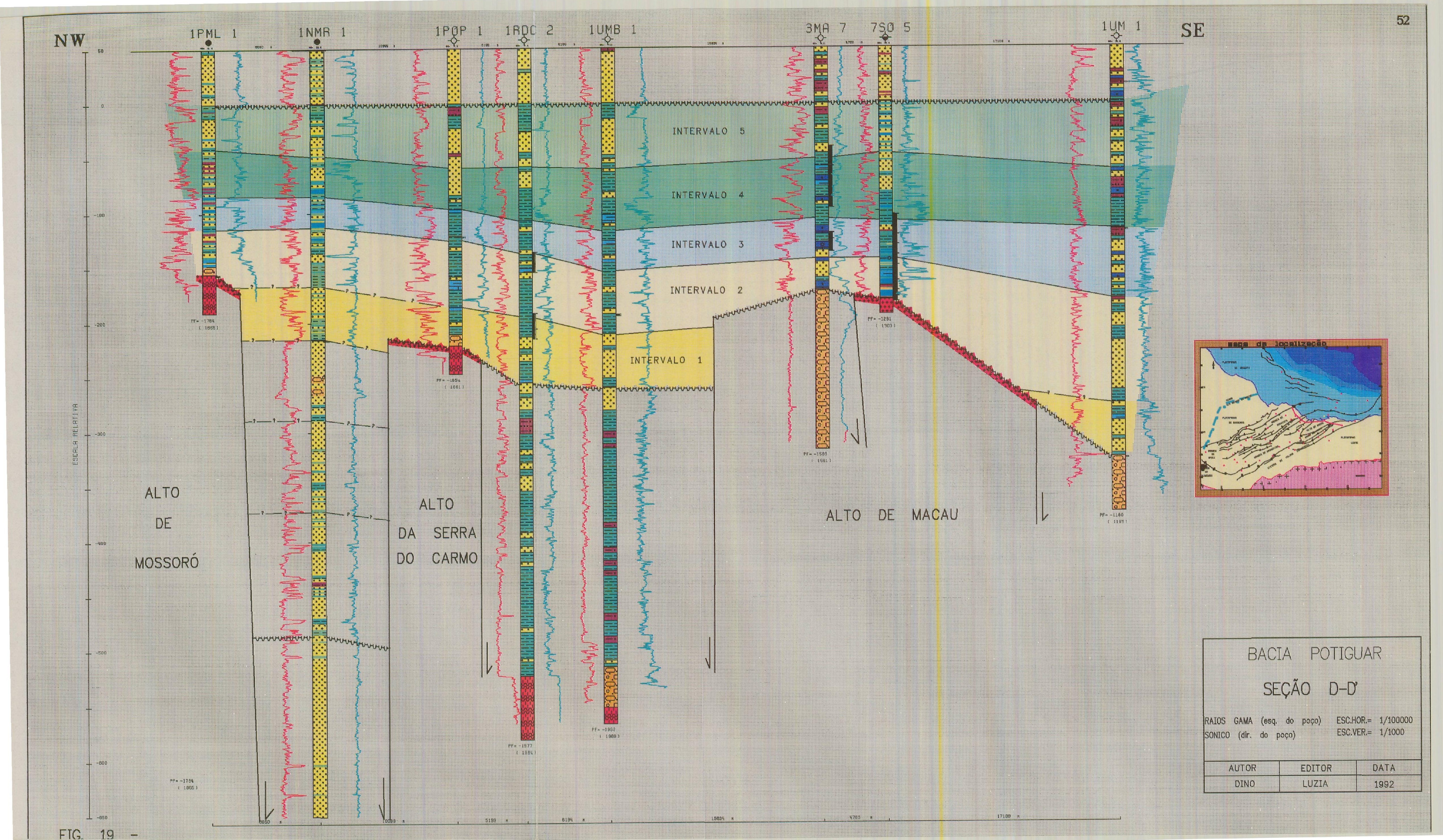




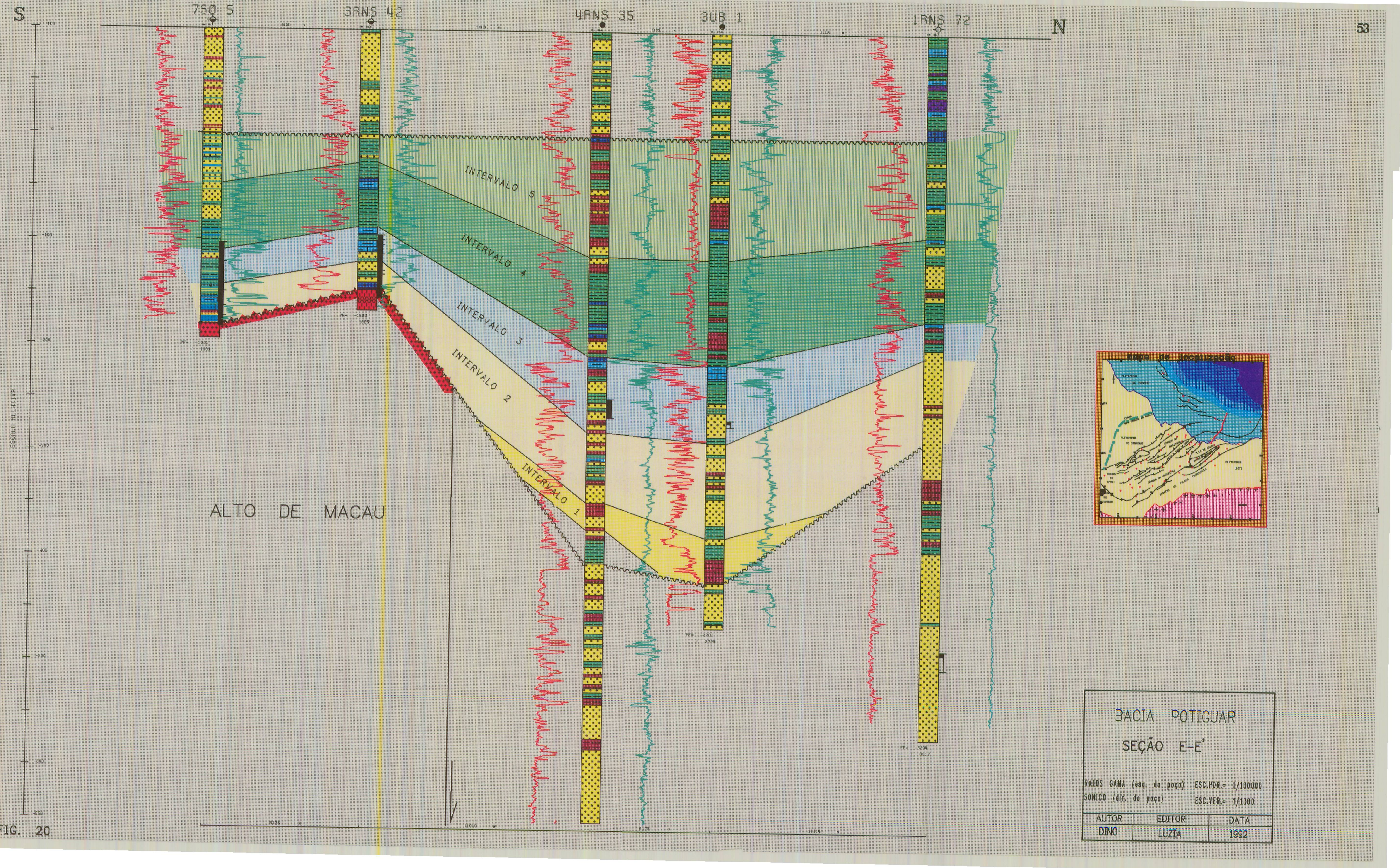




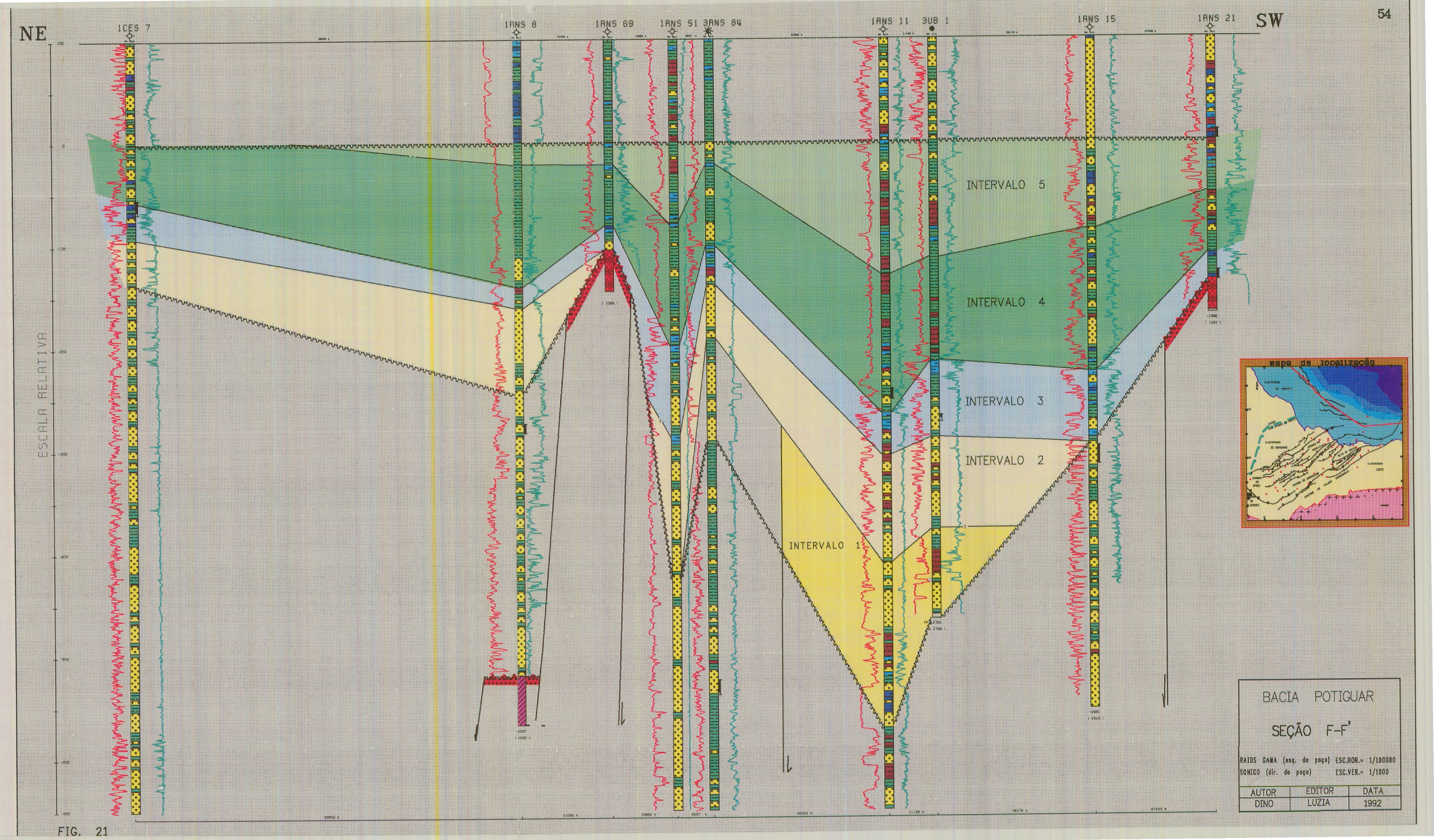




\section{2) Caracteristicas Gerais da Associação Palinológica}

A Formação Alagamar contém uma rica e diversificada microflora, tendo sido identificadas 228 espécies em 18 poços exploratórios.

As amostras analisadas neste estudo possuem associações palinologicas essencialmente não-marinhas, conforme evidenciado pela ausência de formas do microplâncton marinho e pela abundância em grãos de pólen e de esporos, carapaças de conchostráceos e resíduo orgânico de origem continental. Apenas acima da discordância regional, portanto em depósitos basais das formações Açu/Ubarana, é que se constata a presença de dinoflagelados e microforamińferos quitinosos, associados aos grãos de pólen e esporos. Ademais são observadas evidências sedimentológicas de pequenas transgressões ou flutuações da lâmina d'água, acima desta superfície discordante (LIMA, 1987).

A evolução dos processos geologicos é refletida em mudanças na abundância relativa nos grupos de palinomorfos. A figura 22 mostra a distribuição dos principais grupos palinológicos em cada poço. Constata-se a existência de níveis estéreis, intercalados a outros extremamente diversificados. Na sua grande maioria, estas mudanças refletem a energia de sedimentação, pois geralmente as litologias mais grosseiras são menos fossilíferas. Já os argilitos, folhelhos e siltitos são bastante férteis. A exemplo das litologias mais grosseiras, não foram recuperados muitos palinomorfos em carbonatos. Estas diferenças quantitativas são diretamente correlacionáveis com as variações das palinofácies.

As variações estatísticas verticais das abundâncias relativas dos grupos esporo-polínicos individualizados apresentam-se menos intensas do que o esperado, ralvez, em função do curto espaço de tempo geológico envolvido. Entretanto, mesmo num exame sumário da distribuição dos diferentes grupos analisados (Fig. 22) podem-se ressaltar os seguintes resultados:

- Triletes lisos - O grupo dos esporos triletes lisos ocorre em todo o pacote analisado, apesar de estar ausente em alguns níveis. Contudo, constitui-se num grupo de pouca expressão percentual, em geral nunca excedendo os $5 \%$, salvo à profundidade de $1852 \mathrm{~m}$ do poço $\mathrm{BP}-1$, onde atinge os $10 \%$, obviamente representando uma anomalia de características locais. Foram identificados 6 gêneros e 8 espécies deste grupo, que é representado por Cyathidites e Deltoidospora, seus gêneros mais comuns; 
Thr $\square \square \square$
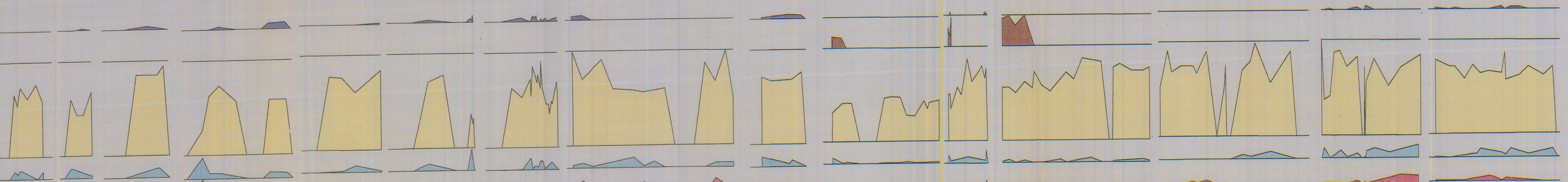

$m \wedge$

玍

z

等

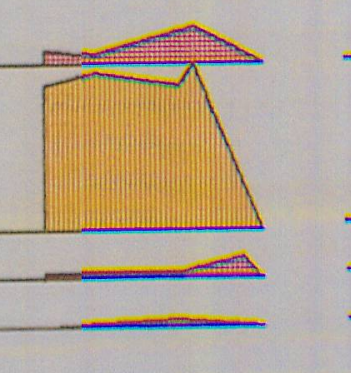

Miln

$\Delta$

目

ant

11 然

Min

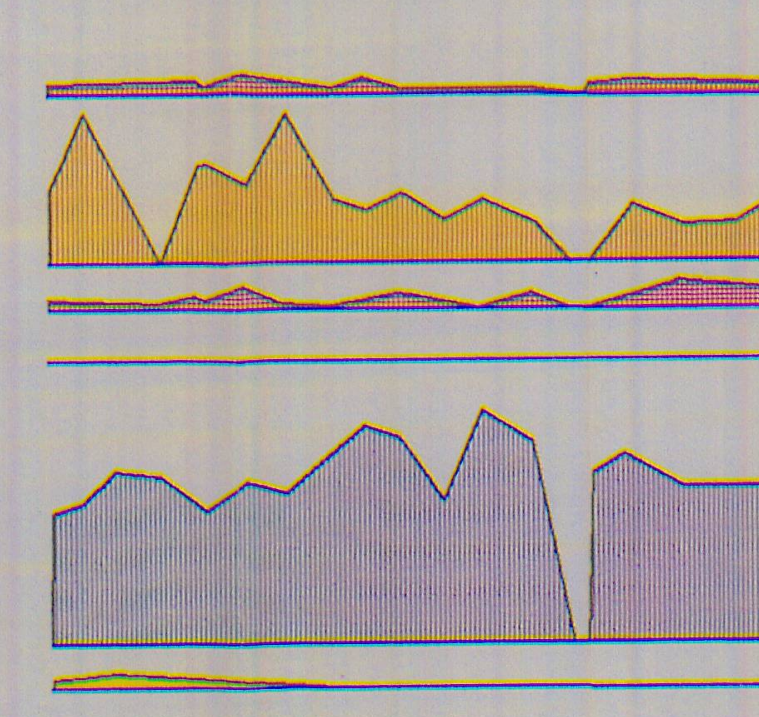

$\stackrel{5}{\overline{1 / m}}$

$\longrightarrow$

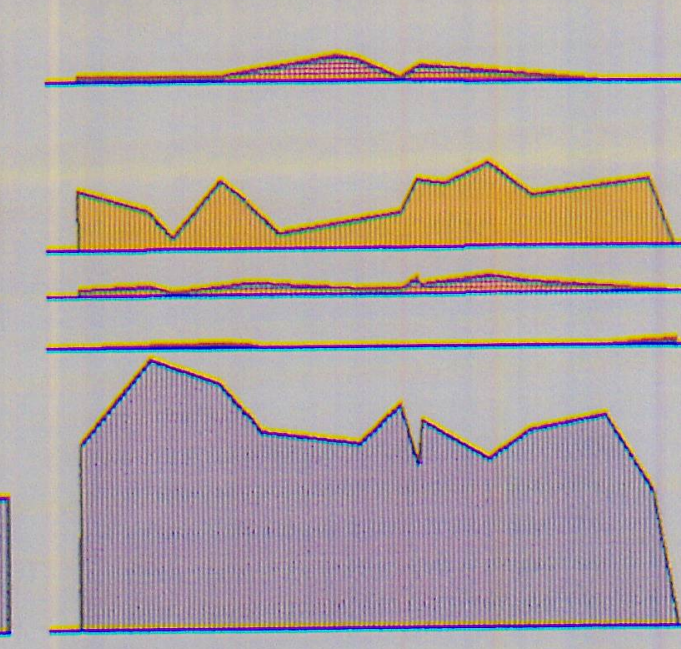

M $M$

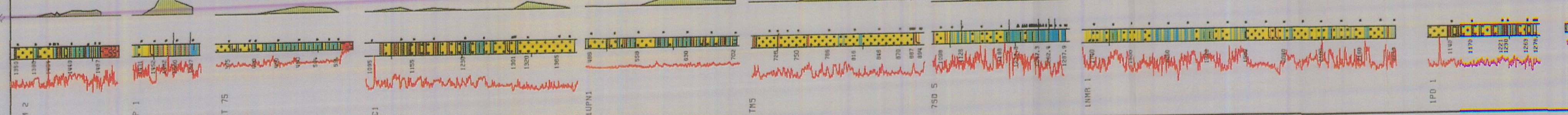


- Triletes ornamentados - Este grupo está bem representado por 28 gêneros e 55 espécies, ocorrendo ao longo de toda a seção. Apesar disso, distribui-se um tanto irregularmente, com valores percentuais oscilando de 5 a 30\%. Destacam-se os gêneros Cicatricosisporites e Appendicisporites, bastante freqüentes;

- Triletes perisporados - Grupo representado por 2 gêneros e 3 espécies, ocorrente também em toda a coluna analisada. Merece menção o gênero Crybelosporites, com 3 espécies, sendo a mais comum C. pannuceus. Apresenta distribuição bastante irregular e pouco expressiva em termos percentuais (entre 0 e $5 \%$ );

- Monoletes - Grupo expressivo, em termos qualitativos, porém de ocorrência apenas ocasional. Está representado por 6 gêneros e 6 espécies, os quais quantitativamente não ultrapassam os $3 \%$;

- Sacados - Grupo representado por 5 gêneros e 15 espécies. Em termos quantitativos não ultrapassam $10 \%$ da associação. Os monossacados distribuem-se regularmente por toda a coluna, sendo Callialasporites o gênero mais representativo do grupo. Quanto aos bissacados, sua distribuição é bastante irregular, com níveis esporádicos na parte inferior da seção e leve aumento percentual no topo; destaca-se o gênero Vitreisporites;

- Inaperturados - Grupo representado por 7 gêneros e 17 espécies, com presença regular em toda a coluna. Sua distribuição quantitativa é significativa, sendo o grupo melhor representado após os rimulados. Apresentam valores percentuais da ordem dos 30 a $40 \%$, apesar de leves flutuações. Ressaltam-se os gêneros Sergipea e Inaperturopollenites, com 4 espécies cada;

- Rimulados - Grupo dominante quantitativamente, com percentuais da ordem dos 50\%. Contudo, apresentam baixa diversidade, sendo representados por apenas 2 gêneros e 4 espécies;

- Poliplicados - Este grupo está muito bem representado, com 7 gêneros e 31 espécies presentes em toda a seção, apesar de mais diversificados na parte superior. Apresenta percentuais variando irregularmente 
entre $5-25 \%$, com valores médios ao redor dos $20 \%$. Outro fato observável é seu comportamento alternante em relação aos Classopollis, pois a cada pico de abundância apresentado por um geralmente corresponde, no mesmo nível, uma escassez relativa do outro. Este comportamento é interpretado por diversos autores como consequiência de uma competição entre as plantas produtoras destes grãos pelo mesmo habitat;

- Monocolpados - Grupo representado em toda a seção por 8 gêneros e 26 espécies. Seu gênero mais representativo é Cycadopites. Seus valores percentuais raramente atingem os $10 \%$;

- Tricolpados-Representado por 7 gêneros e 18 espécies, este grupo é inexpressivo na base da seção. Encontra-se melhor representado tanto em termos de percentuais quanto de diversidade na porção mais superior da coluna, onde chega a atingir os $15 \%$ (e.g. poço SC-1);

- Porados - Grupo representado apenas pelo gênero Exesipollenites, com 3 espécies, de distribuição irregular e pouco expressiva;

- Microplâncton - Grupo representado apenas na parte mais superior das seçס̃es, em estratos basais da Formação Ubarana (apenas 3 poços no mar). Chega a atingir valores máximos de $20 \%$ (e. g. poço RNS-21).

Os poços RAP-3, FSM-1 e FC-2, por apresentarem poucas amostras com significado estatístico, não foram incluídos na figura 22. Os resultados estatísticos obtidos revelam pequena variação, que no entanto é plenamente aceitável em termos de valores quantitativos relativos. Eles demonstram que a associação esporo-polínica da Formação Alagamar é bastante homogênea e similar, em termos de composição e abundância relativa, às associações documentadas por LiMA (1978A) para a Formação Santana da Bacia do Araripe, e à denominada flora de Afropollis (REGAL, 1989B), da margem equatorial brasileira. 


\section{3) Palinofácies}

Os procedimentos de documentação e registro de dados em estudos de palinofácies variam bastante de autor para autor e de acordo com o objetivo do trabalho. Aliás, o próprio uso dos termos palinofácies e palinomaceral, ou (palinomacerais) no estudo do resíduo orgânico total gerou controversias durante o VII IPC, 1988, em Brisbane, Austrália, sem se chegar a um consenso.

No tocante a quantificação dos palinomacerais, também não existe consenso. Alguns autores (e. g. WHTTAKER, 1984; e GORIN \& STEFFEN, 1991) preferem trabalhar com valores percentuais, enquanto que outros (e. g. BATTEN, 1982A, B; e Batten \& Lister, 1988), como é o caso aqui adotado, têm utilizado parâmetros de abundâncias relativas, através de avaliações visuais. De acordo com BATTEN (COM. PEss. 1992), as bases conceituais para a seleção dos palinomacerais ainda não são consensuais e dependem da razão do estudo e da preferência pessoal do autor.

A palinofácies representa uma interpretação geológica do material orgânico sedimentar (WHITAKER, 1984). Seu estudo está em geral intimamente ligado às interpretações sedimentológicas, e reflete os ambientes e o clima a Época de deposição (BATten \& MACLennan, 1984; BAtten, 1975; BAtTen et alii, 1984; BatTEN \& LiWENBEN, 1987).

Sedimentos depositados em ambientes de alta energia (e.g. barras arenosas, fácies proximais de fandeltas, etc.), tendo sido depletados da maioria dos seus constituintes orgânicos originais, preservam apenas baixos teores de material orgânico. Depósitos de áreas distais em relação às fontes de palinofácies, geralmente áreas subaquosas profundas ou protegidas, de baixa energia, são ricos em material orgânico.

Num sistema fluvio-deltaico-lacustre, apesar da complexidade dos subambientes envolvidos, é possível identificar e correlacionar as palinofácies com as condições de acumulação. Sucessões flúvio-deltaicas de alta energia possuem menores quantidades de matéria orgânica, em contraste com depósitos lamosos e argilosos de canais abandonados ou lacustres. Estas observações, constatadas de modo geral no presente estudo, podem ser visualizadas na figura 23, que sintetiza o estudo integrado de palinofácies.

Verificou-se no presente estudo que, a grosso modo, a abundância relativa dos palinomorfos decresce com o aumento da matéria orgânica amorfa, quando esta se apresenta bem preservada. 
Para avaliar ambientes de deposição dos diferentes tipos de palinofácies foi elaborada uma calibração entre as litofácies, as palinofácies e o ambiente deposicional integrado, para cada um dos poços analisados. Na figura 22 está representada, além dos valores percentuais dos grupos de palinomorfos, a divisão das palinofácies identificadas para cada poço.

As palinofácies I e II foram observadas em ambientes de alta energia, geralmente em sedimentos arenosos finos a grosseiros (e.g. poço SC1 , test.1, 1296-1302m). Os esporos, quando presentes, são os constituintes relativamente mais pesados do grupo dos triletes (Cicatricosisporites, Appendicisporites); os palinomacerais dominantes são pequenos, quebrados, não arredondados, pretos e uniformemente opacos. Palinofácies destes tipos são representadas e explicadas em termos de ambientes de deposição representativos de barras arenosas e canais fluviais por WALKER (1984) e GAYNOR \& SWrFT (1988). Nestas fácies a matéria orgânica amorfa é quase ausente e geralmente derivada da matriz fina dos sedimentos mais grosseiros (VAN DER ZWAN, 1990). Estas palinofácies refletem ambientes proximais.

A palinofácies III foi observada principalmente em siltitos e arenitos finos, de alta a moderada energia. Aqui ocorre a grande maioria dos palinomorfos presentes; a presença de matéria orgânica amorfa e lenhosa se verifica em proporções complementares, de acordo com os subambientes; geralmente os menores valores de matéria orgânica amorfa (e.g. poço RNS-21, test. 2, 1882$1885 \mathrm{~m}$ ) resultam de condições de fundo melhor oxigenadas, talvez mais rasas. Os palinomacerais são relativamente maiores do que nas outras palinofácies descritas.

A palinofácies IV está presente normalmente nos argilitos, folhelhos e siltitos das fácies lacustres distais ou de planícies lamosas de inundação, ou ainda de áreas protegidas, (e.g. poço CES-7, calha, 2160-2169m). A abundância em matéria orgânica amorfa é, geralmente, característica de condições de fundo estagnantes. Nesta fácies, os palinomorfos bissacados são mais freqüientes, enquanto que os outros são pequenos e raros, bem como o restante dos palinomacerais. Ocasionalmente podem estar presentes fragmentos de carapaças de conchostráceos, o que poderia indicar em função do seu transporte a presença de correntes. Em conseqüuência, as condições de fundo não eram permanentemente disaeróbicas, e sim alternadamente disaeróbicas e aeróbicas, o que explicaria os eventos cíclicos da sedimentação. 


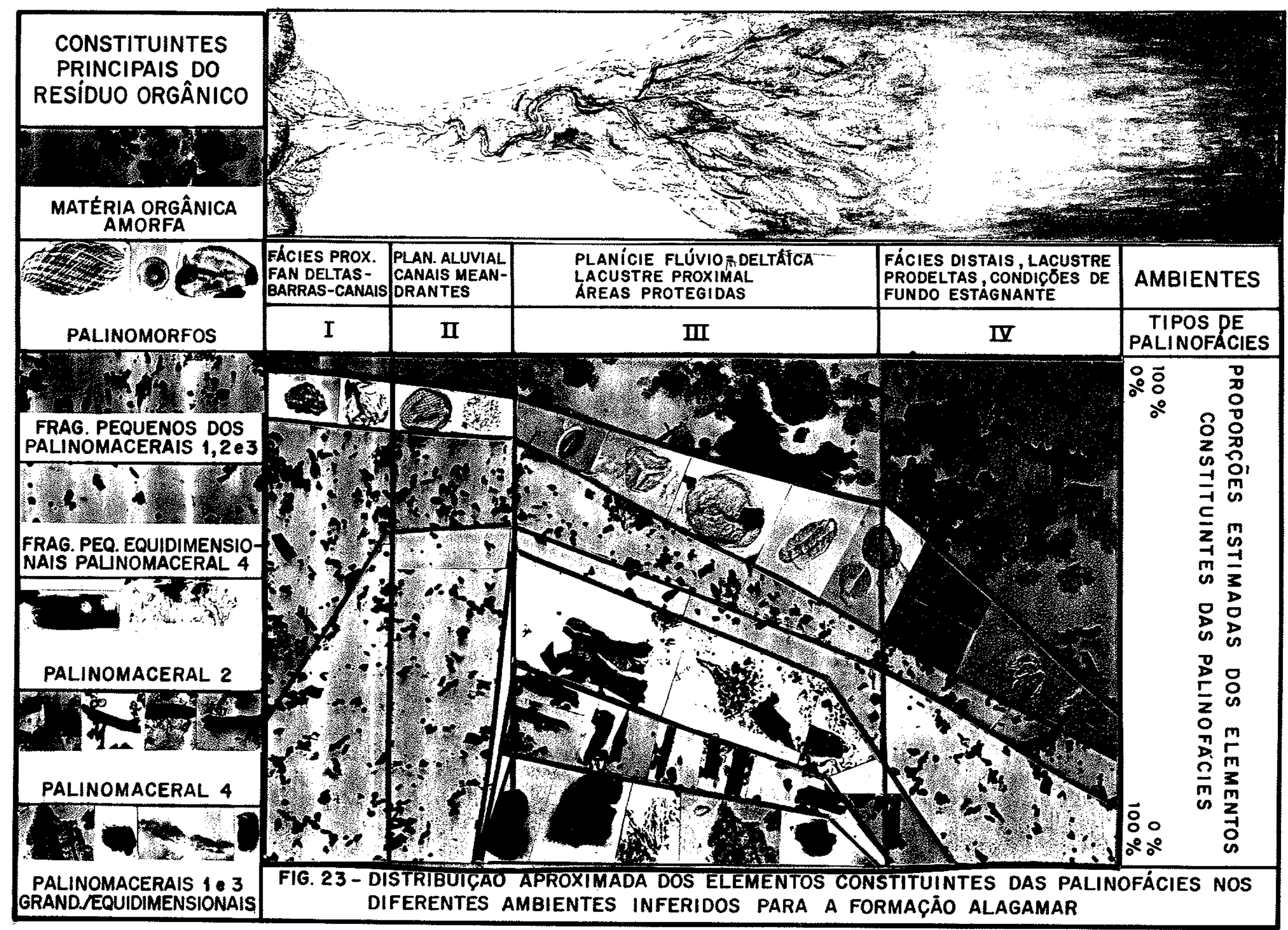


Da visualização conjunta das seções estratigráficas e da figura 22, pode-se concluir que existe uma correlação muito próxima entre as palinofácies definidas para cada poço e os eventos transgressivos identificados nas seções. Não foi possível obter a exata natureza desta correlação, dada a distância entre os poços. Contudo, observou-se que geralmente os poços das áreas consideradas como mais "distais" apresentam com maior freqüência as palinofácies III e IV, enquanto que nos das áreas mais "proximais" predominam as palinofácies I e II.

Estudos recentes (GORIN \& STEFFEN, 1991), têm mostrado que: (a) a diversidade e abundância dos palinomorfos como um todo tendem a crescer com as transgressões e decrescer com as regressões; (b) a deposição de folhelhos pretos, ricos em matéria orgânica amorfa, parece coincidir com períodos de transgressões marinhas globais; (c) e importantes ocorrências de carvões parálicos, ricos em matéria orgânica continental, estão geralmente correlacionadas com períodos regressivos no mundo todo. Tais constatações, aliadas a correspondência entre as curvas de palinofácies e as dos eventos transgressivos, propicia a interpretação das palinofácies também em termos de seqüência estratigráfica.

No presente estudo não foi possível uma verificação precisa desta correspondência, apesar de se acreditar que ela ocorra em alguns níveis.

\section{4) Bioestratigrafia}

Métodos de aplicação da palinologia na resolução de problemas estratigráficos têm sido discutidos por diversos autores (e. g. Couper, 1958; Bolkhovitina, 1959; Pocock, 1962, Busnardo \& Taugourdeau, 1964; Singh, 1964; Boltenhagen, 1965; Baltes, 1967 A, B; Tschudy, 1969A; Medus, 1970; Batten, 1973A, B; Reyre, 1973; Bebout, 1981). Depreende-se destes trabalhos que o objetivo dos estudos palinoestratigráficos é a determinação da idade relativa dos estratos, apoiada na correlação entre o nível de certeza da identificação dos palinomorfos e sua precisa localização na coluna estratigráfica. Para tanto, são necessários cuidadosos estudos de classificação sistemática. Uma acurada identificação de espécies em palinologia é tarefa difícil e, portanto, nem sempre bem executada, fato que se observa na literatura pelo significativo número de espécies incorretamente classificadas. Estas identificações errôneas têm limitado, e por vezes, até mesmo anulado os esforços no sentido de se estabelecer zoneamentos. Tentativas de utilização de palinomorfos, taxonomicamente mal definidos nos 
estudos bioestratigráficos, certamente produzirão conclusões estratigráficas enganosas.

Outro aspecto do problema está ligado ao fato de muitas descrições serem tão gerais e abrangentes, ou mesmo incompletas, que resultam na impossibilidade do uso estratigráfico de espécies potencialmente úteis. Além disso, a inclusão de uma grande variedade de tipos morfologicos sob designações específicas únicas, as quais são assim definidas de forma muito abrangente, ocasiona uma expansão tal de suas amplitudes bioestratigraficas que restringe por demais sua utilidade prática.

Taxons definidos incorretamente requerem emendas para o estabelecimento de sua posição taxonômica e, conseqüentemente, de sua distribuição estratigráfica. Classificar sistematicamente ou emendar uma descrição sistemática, além de largo conhecimento, requer tempo, requisitos estes geralmente não disponíveis aos palinoestratígrafos.

Embora problemas de ordem taxonômica existam em graus variados em todos os estudos paleontologicos, e não apenas na palinologia, eles parecem ser mais evidentes neste campo. Isto se verifica pelo fato de ser esta ciência ainda relativamente jovem, e porque o pequeno tamanho dos palinomorfos os situa no limite máximo de resolução da microscopia ótica, o que impede por vezes boas observações. Devido a estes fatôres, controles bioestratigráficos precisos em palinologia não têm sido plenamente realizados. Contudo, vários trabalhos atuais levados a cabo por palinologos cuidadosos e atentos a estes problemas têm conduzido a soluções satisfatórias, incrementando a resolução estratigráfica do registro sedimentar em todo o mundo.

Propõe-se no presente estudo um zoneamento palinoestratigráfico informal para o Cretáceo Inferior da Bacia Potiguar, objetivando atingir um avanço no atual estágio dos conhecimentos através de uma classificação sistemática acurada. 


\section{a- Considerações Sobre Trabalhos Crono- e Bioestratigráficos Prévios da Seção Estudada}

\section{O Andar Alagoas}

Os sedimentos que compõem a Formação Alagamar são também parte integrante do Andar Alagoas. Acredita-se que este andar local corresponda a partes dos andares Aptiano e Albiano da coluna cronoestratigrafica internacional (HARLAND et alii, 1982); contudo, ainda hoje é discutível esta correlação.

A ausência de fósseis marinhos nos estratos eocretáceos do Brasil, inviabilizando sua correlação com os estratotipos dos andares internacionais, levaram SCHALLER (1969) e VIANA et alii (1971) a formalizarem andares locais brasileiros. O Andar Alagoas, de particular interesse neste estudo, foi definido na Bacia de Sergipe-Alagoas (SCHALler, 1969), através de critérios litológicos e grafoelétricos. Posteriormente foi estendido à quase totalidade das bacias cretáceas brasileiras através de correlações palinológicas. A história deste andar tem sido confusa ao longo dos anos, em virtude da utilização do termo Alagoas tanto crono- quanto bioestratigraficamente. DiAs Brito et alii (1987) e LmM et alii (1991) inventariam, sumariam e discutem com propriedade o histórico, os limites e a caracterização paleontológica do andar e de suas subdivisões, expondo com clareza as dúvidas que ainda persistem sobre o problema. Vale salientar que os mais importantes estão relacionados a: 1) duração em milhões de anos; 2) posição dos limites em termos de idade; 3) valores absolutos de seus limites.

Quanto à correlação com as unidades internacionais, atualmente o mais aceito pelos bioestratígrafos brasileiros é que a quase totalidade do andar equivale ao Aptiano Superior. Alguns autores admitem a inclusão de partes do Aptiano inferior e/ ou Albiano inferior neste andar. Os trabalhos mais recentes acerca dos aspectos bio- e cronoestratigráficos do Andar Alagoas são os de Mabesoone et alii (1981), Mabesoone (1984), Regali \& Viana (1986, 1988, 1989), Dias Brro et alii (1987), Arai et alii (1989) e Lima et alii (1991). A figura 24 mostra um quadro comparativo das propostas dos limites do Andar Alagoas segundo diferentes autores.

Considerou-se neste trabalho que o Andar Alagoas corresponde ao intervalo Aptiano/Eoalbiano, com duração aproximada de 6 milhões de anos, de acordo com Beurlen (1982), Regali \& Viana (1988) e Arai et alii (1989). 


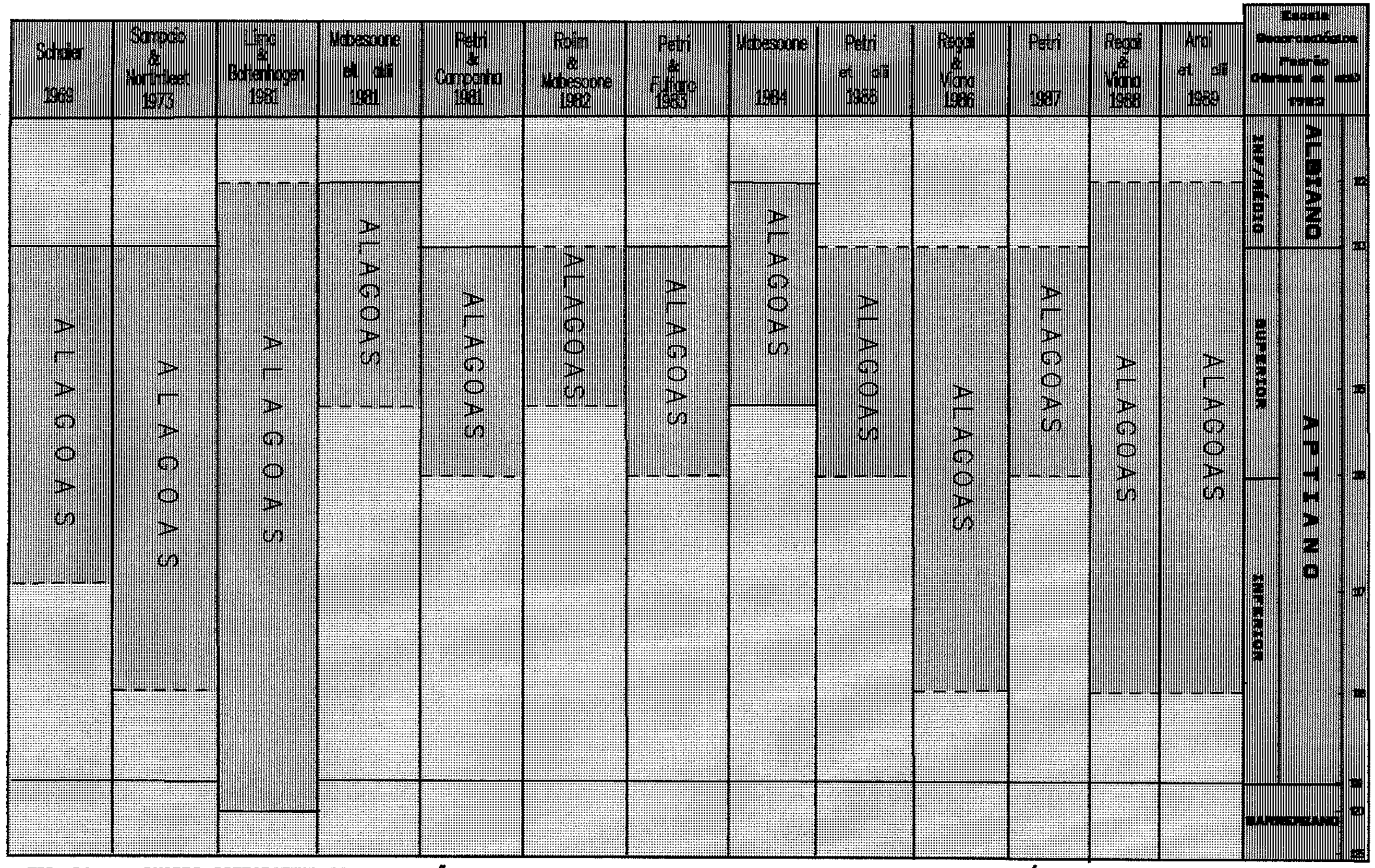

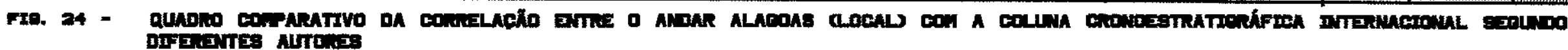




\section{Dados Bioestratigráficos do Andar Alagoas na Bacia Potiguar}

REGALI \& GONZAGA (1985) caracterizaram palinologicamente o Andar Alagoas na Bacia Potiguar, correlacionando-o com a Formação Alagamar. Nesta caracterização os autores reconheceram para a seção cinco biozonas (designadas Clavatipollenites crisopolensis = Transitoripollis crisopolensis), P-230; Foveotriletes sp., P-250; Inaperturopollenites turbatus, P-260; Sergipea variverrucata, P-270 e Caytonipollenites? sp. 1, P-280), definidas na Bacia de Sergipe-Alagoas; todas em uso atualmente. Posteriormente, Regali (1992) após reavaliar palinoestratigraficamente vários poços da bacia, apresentou uma nova tabela de distribuição do Berriasiano ao Aptiano, válida para a parte submersa, onde está assinalada a ocorrência de apenas três intervalos bioestratigráficos: um inferior, correspondente à biozona Tucanopollis crisopolensis (P-230), um intermediário, englobando as biozonas Inaperturopollenites curvimuratus ( $\mathrm{P}-240)$ a Sergipea variverrucata ( $\mathrm{P}-270$ ), sendo que a Inaperturopollenites curvimuratus, não tinha sido considerada no trabalho anterior; e por último um intervalo superior, correspondente à biozona Complicatisaccus cearensis (P-280).

Este andar é caracterizado também por uma biozona de ostracodes denominada "Cytheridea" (?) sp. gr. 201/218 (RT-011), de acordo com PRAÇA \& Hashmoto (1991).

Regali (1992) assinalou a ocorrência estratigráfica dos principais palinomorfos guias da bacia. Além disso, posicionou o limite entre o Aptiano inferior e superior no topo da biozona Tucanopollis crisopolensis (P-230), listando como presentes nesta biozona os seguintes palinomorfos-guias:

Brenneripollis peroreticulatus GÓCZÁN \& JUHÁsZ

Araucariacites australis (COOKSON) COUPER

Callialasporites dampieri (BALME)

Exesipollenites tumulus BALME

Afropollis operculatus DOYLE

Afropollis zonatus DOYLE

Tucanopollis crisopolensis REGALI

à zona.

Destes, apenas a espécie Tucanopollis crisopolensis REGALI é restrita

Sobreposto à biozona Tucanopollis crisopolensis a autora apresenta 
um intervalo referido ao Aptiano superior, para o qual indica tacitamente a presença de todas as biozonas (Inaperturopollenites curvimuratus a Caytonipollenites? sp.1 = Complicatisaccus cearensis ) definidas por REGALI et alii (1974) para todo o Brasil. Considera o topo deste intervalo como o limite Aptiano superior/ Albiano inferior/médio, e relaciona os seguintes palinomorfosguias como retritos a este intervalo:

\author{
Sergipea variverrucata Regal et alii \\ Pilosisporites sp. Regali et alii \\ Disaccites sp. 16 \\ Penetetrapites mollis HEDUND \& NORRIS \\ Triporoletes singularis MTCHEDLISHVILI \\ Inaperturopollenites turbatus BALME \\ Foveotriletes sp. Regali et alii
}

Ressalta-se que a presença de elementos do microplancton marinho são assinalados apenas a partir da biozona P-280, imediatamente acima.

\title{
b- Zoneamento
}

Devido à frequiente mistura de material desabado que comumente se constata nas amostras de calha de poços petrolíferos, geralmente apenas as ocorrências mais altas nos poços (a última ocorrência na seção estratigráfica) e os picos de abundância dos taxa têm significado bioestratigráfico. Neste estudo, os limites superiores das biozonas descritas, sempre que possível, foram definidos através de primeiras ocorrências sucessivas no poço (zonas de intervalo superior). O problema da contaminação das amostras foi minimizado pela utilização de testemunhos, com o exame cuidadoso de todas as associações, bem como de variações na abundância, preservação e coloração tanto dos palinomorfos como do resíduo orgânico como um todo.

A biozonação palinológica aqui proposta (Fig. 25) foi definida essencialmente para aplicação regional. Entretanto guarda íntimas analogias com os zoneamentos gerais e locais propostos para depósitos contemporâneos em bacias da margem continental brasileira (Regali et alii, 1974A, B, 1980, 1985; Regali, 1992). 


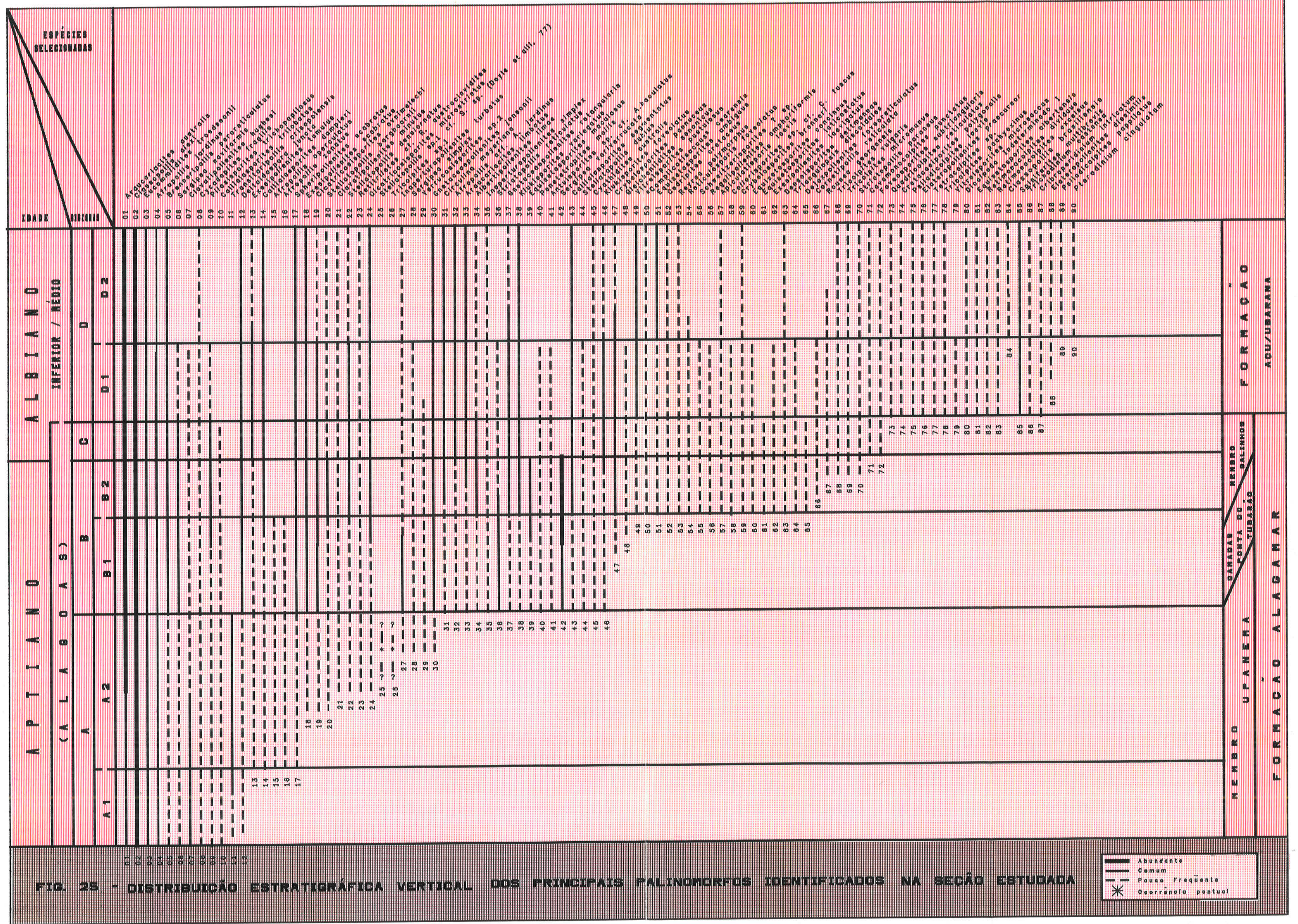


As zonas palinoestratigráficas discutidas abaixo, denominadas A, B, C e D da mais antiga para a mais nova, foram definidas em função das características das associações identificadas, com base nos seguintes criterios:

As palinozonas A, B e D, são palinozonas de intervalo, do tipo "amplitude diferencial superior", definidas com base no nível de extinção de espécies diagnósticas, e caracterizadas com base na presença de uma espécie importante, que no caso das biozonas $\mathbf{A}$ e $\mathbf{B}$ são restritas à mesma.

A palinozona $\mathbf{C}$ é também uma zona de intervalo, porém do tipo "amplitude parcial". Esta é definida pelo segmento da amplitude de uma espécie presente em toda a zona, com base e topo delimitados, respectivamente, pela extinção e surgimento de outras duas espécies (não presentes na zona), como exemplificado no código estratigráfico americano (N.A.C.S.N., 1983, P.863, FiG.4C2).

\section{Palinozona A}

Categoria: Zona de intervalo superior

Definição: $O$ seu limite inferior é definido pela extinção de Aequitriradites spinulosus. O limite superior é caracterizado pelo nível de extinção de Transitoripollis crisopolensis.

Caracterização: Contém como elementos característicos esporos dos gêneros Cicatricosisporites e Appendicisporites. Os grãos de polen dos grupos dos poliplicados e inaperturados são pouco freqüentes. A associação em geral é pobre.

Seção de Referência: Intervalo 2520-2700 metros do poço 3-UB-27-RNS.

Idade Atribuída: eo- a mesoaptiana (= eoalagoas).

Comentários: $\mathrm{Na}$ prática, o limite inferior da palinozona A pode ser marcado pela discordância erosiva, detectável em quase toda a bacia. Em termos bioestratigráficos, devido à ocorrência restrita da espécie Aequitriradites spinulosus na bacia, o limite inferior pode ser detectado também pelo nível de extinção de Dicheiropollis etruscus. Esta biozona corresponde em termos litoestratigráficos à maior parte da porção inferior e média do Membro Upanema. Foi reconhecida na porção 
emersa da bacia, apenas no Gráben de Boa Vista; na porção submersa ela possui distribuição restrita, sem grande continuidade lateral.

Não se encontram elementos marinhos nesta parte da seção.

Foi constatada a presença de apenas 28 espécies na mesma, caracterizando-se uma associação de baixa diversidade. Associados aos palinomorfos ocorrem níveis ricos em fragmentos de carapaças de conchostráceos. Apesar da escassez de testemunhos que atravessam esta biozona na bacia, o controle de sua posição estratigráfica é assegurado por um grande número de dados. Os únicos especimens de Tricolpites sp. 1 e de Stellatopollis sp. 1 aff. S. sp. (Doyle et alii 1977, P. 470, PLATE 1, FIG. 10), documentados atualmente por ocorrências únicas neste intervalo, poderão no futuro constituir-se em palinomorfos-guias adicionais para esta biozona.

Em termos quantitativos observa-se alta porcentagem de grãos rimulados (entre $65 \%$ e $40 \%$ ), seguidos dos triletes ornamentados, notadamente do gênero Cicatricosisporites (cerca de 30\%); os poliplicados, geralmente pequenos, são relativamente mal representados em relação às biozonas superiores. Os grupos restantes apresentam baixos percentuais e distribuição irregular.

Vale salientar que esta biozona corresponde à biozona Inaperturopollenites crisopolensis = Clavatipollenites crisopolensis = Tucanopollis crisopolensis $(\mathrm{P}-230)$ de REGALr et alii $(1974 \mathrm{~A}, \mathrm{~B} ; 1989 \mathrm{~F})$, definida originalmente para a Bacia de Sergipe-Alagoas e estendida às demais bacias marginais brasileiras.

Com base na abundância e diversidade das espécies presentes, a zona A pode ser subdividida em 2 intervalos informais, caracterizados como se segue:

Intervalo A1 - Correspondendo à porção mais basal da seção analisada, este intervalo é muito pobre e representado por apenas 12 espécies, das quais apenas Transitoripollis crisopolensis é característica. Seu limite inferior é o mesmo definido para a zona $\mathrm{A}$. O intervalo é reconhecido na prática por sua baixa diversidade microflorística, ausência de formas tricolpadas e resíduo orgânico relativamente mais carbonizado. Litologicamente corresponde aos horizontes arenosos e sílticos do Membro Upanema, tanto na área do Gráben de Boa Vista em terra 
como em partes dos campos de Ubarana, Agulha e Pescada na plataforma.

Intervalo A2 - Este intervalo difere do anterior pela maior quantidade e diversidade dos palinomorfos. São encontradas aqui 29 formas, das quais apenas a espécie-guia $T$. crisopolensis é característica. E expressivo o aumento do número de formas em relação ao intervalo A1, principalmente dos grãos de pólen dos gêneros Afropollis e Brenneripollis. Caracteriza-se pelo surgimento de 16 especies, das quais a mais importante é Tricolpites sp. Trata-se do primeiro e mais antigo registro de formas tricolpadas na seção; devido à detecção de sua ocorrência em apenas um poço, sua restrição ao topo do membro Upanema e ao intervalo A2 não pôde ser determinada. O limite superior do intervalo é marcado pelo desaparecimento da espécie Transitoripollis crisopolensis.

Litologicamente, corresponde aos níveis de siltitos e folhelhos escuros da parte superior do Membro Upanema e apresenta distribuição, em área, idêntica à subzona A1.

\section{Palinozona B}

Categoria: Zona de intervalo superior

Definição: Seus limites inferior e superior são marcados, respectivamente, pelas últimas ocorrências estratigráficas (mais altas ocorrências nos poços) das espécies Transitoripollis crisopolensis e Sergipea variverrucata.

Caracterização: O palinomorfo-guia que define o topo desta biozona, Sergipea variverrucata, possui ocorrência restrita à mesma. Além disso, a unidade pode ser caracterizada pela ocorrência conjunta de: Afropollis operculatus, Striatopollis reticulatus e Albertipollenites limae, além de grande điversidade específica da microflora.

Seção de Referência: Intervalo 1158-1288 metros do poço 7-SO-5-RN.

Idade Atribuída: neoaptiana (= neoalagoas).

Comentários: Esta palinozona corresponde em termos litoestratigráficos aos 
sedimentos do topo do Membro Upanema, às Camadas Ponta do Tubarão e a grande parte do Membro Galinhos. Esta parte da seção é rica em palinomorfos. Porém, a maioria destes possui ampla distribuição vertical, ultrapassando os limites do intervalo. Qualitativamente, esta biozona inclui pelo menos 62 espécies. Quantitativamente, apesar das variações locais, observa-se:

-predomínio total dos grãos de polen rimulados e inaperturados, chegando os primeiros a atingir $75 \%$ da associação, e os segundos ate $50 \%$, apesar de variações locais;

-percentagens variáveis, entre 5\% a 35\%, de poliplicados;

-pequena percentagem relativa de esporos triletes.

Esta biozona apresenta ampla distribuição por praticamente toda a bacia, tendo-se consequientemente um posicionamento estratigráfico seguro, já que o controle através de testemunhos é grande. A exemplo da biozona sotoposta, não foram encontrados elementos marinhos, sendo constatada a presença de raras carapaças de conchostráceos em alguns níveis. Apresenta horizontes ricos em ostracodes do Grupo "Cytheridea" (?) sp. 201/218.

Esta biozona corresponde à biozona Sergipea variverrucata (P-270) de Regali et alii (1974), definida para a Bacia de Sergipe-Alagoas e posteriormente estendida para todas as bacias marginais brasileiras.

Com base na abundância e no surgimento de espécies, a zona $\mathbf{B}$ pode ser subdividida em dois intervalos informais, caracterizados como se segue:

Intervalo B1 - Este intervalo é caracterizado pelo surgimento de 15 espécies, do total de 44 espécies presentes. Particularmente interessante $\varepsilon$ o primeiro aparecimento das espécies Sergipea variverrucata, Striatopolis reticulatus, Antulsporites sp. cf. A. baculatus e Albertipollenites limae. As duas primeiras, já evidenciadas por Regal et alii (1974), estão presentes em várias outras bacias; as demais poderão vir a se constituir em importantes espécies-guias deste intervalo, já que foram identificadas em vários poços, e seguramente também estão presentes em depósitos contemporâneos de outras bacias. Vale ressaltar também que a última ocorrência das espécies Afropollis operculatus e Afropollis zonatus na bacia ocorre ao longo deste intervalo. Apesar de rico em 
palinomorfos, ele exibe índices de abundância e diversidade inferiores aos do imediatamente superior, sendo menor aqui o número de espécimens de Sergipea variverrucata. Em termos litologicos, corresponde principalmente aos calcilutitos e carbonatos dos membros da Formação Alagamar.

Intervalo B2 - Este intervalo é caracterizado por um marcante aumento na quantidade e diversidade das espécies dos gêneros Sergipea e Callialasporites, bem como de poliplicados de um modo geral. Aqui ocorre o surgimento de 22 espécies, das 60 identificadas. Particularmente significativa $\in$ a presença mais evidente de grãos de pólen tricolpados, devida ao surgimento de formas muito pequenas (e.g. Tricolpites micromunus e Striatopollis paraneus). O limite superior do intervalo é marcado pela extinção da espécie Sergipea variverrucata, que será aqui arbitrado como o limite Aptiano/Albiano na bacia.

\section{Palinozona $\mathrm{C}$}

Categoria: Zona de intervalo de amplitude parcial

Definição: Os limites desta zona são coincidentes com os limites da amplitude parcial da espécie Sergipea naviformis, com limite inferior definido pelo nível de extinção da espécie Sergipea variverrucata (intervalo da amplitude local de $S$. naviformis limitado inferiormente pelo nível de extinção de Sergipea variverrucata). Seu limite superior é definido pelo nível da ocorrência coincidente entre a amplitude parcial de Sergipea naviformis e o surgimento da espécie Cretacaeiporites polygonalis.

Caracterização: Ocorrem associadas as formas Exesipollenites tumulus, Albertipollenites limae, Vitreisporites pustulosus, apesar de não the serem exclusivas.

Seção de Referência: Intervalo 1753-1790 metros do poço 1-RNS-21-RN.

Idade Atribuída: eoalbiana (= neoalagoas). 
Comentários: Esta palinozona compreende aproximadamente os sedimentos do terço superior do Membro Galinhos. Um critério prático de identificação desta biozona muito próximas das da zona anterior (maior conteúdo em matéria orgânica lenhosa e maior grau de maturação) e distintas da seção superior (mais imatura). Observa-se neste trabalho que a discordância regional (topo do Andar Alagoas), que em termos litologicos marca o topo da Formação Alagamar em praticamente toda a bacia, trunca (por vezes) o topo desta biozona.

VIVIERs (COM. PEss. 1992), através de estudos em vários poços da seção submersa da bacia, observa que nesta seção, ocasionalmente, são encontrados gastrópodos e ostracodes marinhos. Em todos os outros aspectos esta biozona é similar à anterior.

Convém ressaltar que esta biozona é de difícil identificação e rastreamento em amostras de calha. Contudo é indubitável a existência de estratos, mesmo que pouco espessos, com estas características bioestratigráficas na bacia. Na parte terrestre da bacia é geralmente reconhecida na prática como o pacote de rocha compreendido entre o nível de extinção da Sergipea variverrucata e a discordância regional que marca o topo do Alagoas e da Formação Alagamar. Acima desta discordância, em terra, ocorrem comumente sedimentos geralmente estéreis; ou do Cenomaniano/Turoniano, ou bem mais raramente, do Albiano médio/superior.

Corresponde aproximadamente à biozona P-280 de ReGalr et alii (1974), e à parte basal da biozona Complicatisaccus cearensis $(\mathrm{P}-280)$ de Regali (1989c, 1992).

\section{Palinozona D}

Categoria: Zona de intervalo superior

Definição: Seu limite inferior é definido pelo nível da ocorrência coincidente entre a amplitude parcial de Sergipea naviformis e o surgimento de Cretacaeiporites polygonalis; e o seu limite superior é marcado pelo nível de extinção da espécie Elateropollenites jardinei.

Caracterização: Contém as espécies Cretacaeiporites polygonalis, Elateropollenites praecursor, Elateropollenites dissimilis, Exesipollenites 
tumulus, Psiladicolpites laevis, Tetracolpites reticulatus, Vitreisporites pustulosus, Spiniferites spp. e Trichodinium castanea. $\mathrm{O}$ surgimento de espécies elateradas, poliporadas e tetracolpadas se verifica junto, ou próximo a base desta zona e o desaparecimento de Sergipea naviformis se dá no âmbito desta uniđade. Seu limite inferior coincide com o aparecimento dos primeiros foraminíferos planctônicos na bacia (VIVIERs, COM. PESS., 1992).

Seção de Referência: Intervalo 1710-1753 metros do poço 1-RNS-21-RN.

Idade Atribuída: eo-mesoalbiana.

Comentários: Corresponde à parte inferior das formações Açu, em terra e Açu/Ubarana, no mar. É caracterizada principalmente pelo aparecimento de elementos marinhos, os quais incluem os dinoflagelados e microforaminíferos quitinosos. Qualitativamente esta biozona é representada por 78 espécies. De acordo com VIVIERs (COM. PESS. 1992), a posição bioestratigráfica desta zona é equivalente à da parte inferior da biozona Favusella washitensis (F. 110).

Corresponde parcialmente às biozonas P-280 e P-320 (Elateropollenites jardinei) de REgALI et alii (1974) e P-280 REGALI (1989c).

Com base na abundância e điversidade das espécies presentes, a Zona D pode ser subdividida em 2 intervalos, caracterizados a seguir:

Intervalo D1 - Este intervalo é caracterizado pela marcante presença de elementos do microplâncton marinho, notadamente dinoflagelados, pelo primeiro aparecimento de grãos de pólen afins com os elaterados, e pelos primeiros grãos poliporados e tetracolpados. Seu limite inferior é definido pelo surgimento da espécie Cretacaeiporites polygonalis. É importante notar que seu limite superior é caracterizado pelo nível de extinção do gênero Sergipea na bacia.

Intervalo D2 - Este intervalo tem seu limite inferior definido pelo nível de extinção dos grãos de pólen do gênero Sergipea e caracterizado pelo surgimento da espécie Psiladicolpites papillatus. Em todos os outros aspectos esta subzona é similar à subzona sotoposta. 
Uma detalhada biozonação da Formação Alagamar é difícil de ser desenvolvida devido ao relativamente curto intervalo de tempo geológico representado, cerca de 7 milhões de anos de acordo com estimativas de BeURLEN (1982), baseado em. VAll et alii (1977). Também, essencialmente todas as especies de palinomorfos com significado bioestratigráfico a nível mundial têm amplitudes verticais que ultrapassam o limite superior do Aptiano, enquanto que outras são endêmicas da província, impossibilitando assim uma resolução mais acurada. Uma aproximação de um arcabouço zonal pôde ser sugerido; todavia, obviamente este esquema não deve ser considerado final, até que se investiguem novas seções, especialmente mais completas e com testemunhagens contínuas ou conjugadas, que atravessem toda a seção.

O diagrama de cerca apresentado na figura 26 mostra distribuição, em área, das palinozonas denifidas na bacia; notar a distribuição restrita da palinozona A.

\section{5) Comparação com Outras f́reas Sedimentares Brasileiras}

Sedimentos da megasseqüência transicional evaporítica, cronocorrelatos aos da Formação Alagamar, são encontrados em quase todas as bacias da plataforma continental brasileira, bem como em algumas bacias interiores. Todos os depósitos referentes às bacias costeiras, têm sido investigados através de palinologia e ostracodes pelos paleontólogos e bioestratígrafos da PETROBRÁS (Hashimoto et alii, 1987; Uesugui, 1987; Uesugut \& Dino, 1987; Regali, 1989a). Os depбsitos das bacias interiores, têm sido tradicionalmente investigados na Universidade de São. Paulo (LIMA, 1971, 1976A, 1978D, 1979B, c, 1982, 1990; LIMA \& Perinoto, 1984; Lima \& Coelho, 1987). De modo geral, são englobados nas biozonas palinologicas codificadas de.P-230 a P-280, e na biozona de ostracodes RT. 011 ex T-010/011 (Troersen, 1967), válidas para todo o Brasil. No presente trabalho, considera-se que a biozona A corresponde à biozona P-230 ex PC-23 (Regali et alii, 1974); a biozona B corresponde à biozona P-270 ex PC-27 (Regali et alii, 1974), e as biozonas C e D, à biozona P-280 (Regali, 1989c).

Entre outros zoneamentos realizados em sedimentos mesozóicos brasileiros, com base em associações afins à aqui estudada, destacam-se os de Múlier (1966), Herngreen (1973, 1974, 1975A, в) e Lima (1978A). 

O trabalho de Mưller (1966) envolveu estudos no Cretáceo da região Norte e Nordeste do Brasil. As zonas de Mơller correlacionáveis às aqui definidas são as biozonas I e J. Correspondência maior é verificada entre a zona B e o topo da zona I, pela presença de baixas percentagens de tricolpados reticulados; e entre as zonas $\mathbf{C}+\mathbf{D}$ e zona J, principalmente pelo surgimento dos primeiros microfosseis marinhos. Em relação aos trabalhos de HERNGREen, acreditamos que a quase totalidade dos intervalos aqui definidos situam-se estratigraficamente abaixo dos estudados pelo mesmo, podendo haver correspondência, talvez, entre a porção mais superior da zona $D$ e a zona I deste autor.

LiMA (1978A), em estudos na Bacia do Araripe, realizou o mais completo levantamento palinológico, a nível específico, nos depósitos cretáceos do Brasil. A partir desta valiosa contribuição, muitas espécies até então desconhecidas, e mesmo algumas já descritas, passaram a ser utilizadas com maior segurança em virtude de seu correto posicionamento sistemático. Além disso, a melhor definição nas amplitudes verticais de várias espécies utilizadas em zoneamentos das bacias da margem continental permitiu a partir daí o aprimoramento dos mesmos tanto em termos bioestratigráficos quanto de datação. No material ora analisado foram identificadas 35 espécies em comum com as identificadas por Lima (op. cit.) na Formação Santana da Bacia do Araripe. Entretanto, considera-se que apenas a porção mais superior da associação aqui identificada correlaciona-se com a biozona 1 deste autor, estando o restante de sua associação num nível estratigráfico pouco acima do aqui estudado.

A figura 27 mostra a correspondência entre os esquemas de zoneamentos de estratos brasileiros, contemporâneos e correlatos aos aqui elaborados.

\section{6) Comparação com Áreas Correlatas no Exterior}

Dentre os esquemas palinoestratigráficos disponíveis na literatura para sedimentos correlatos, fora do Brasil, merecem menção os zoneamentos de JARDINÉ \& MAGLOIRE (1965); DOYLe et alii (1977), no continente africano, e MỨLER et alii (1987), no continente sul-americano.

Depósitos de idade eocretácea das bacias costeiras da África 
Equatorial, principalmente os do Sistema Cocobeach do Gabão e seus equivalentes no Congo, têm sido utilizados para correlação com os depósitos no Brasil pela sua similaridade litológica, bioestratigráfica e cronológica (VIANA, 1966; Krömmelbein \& Wenger, 1966; Grekoff \& Krömmelbein, 1967; KLASZ \& Micholet, 1972; Jardine, Biens \& Doerenkamp, 1974; Delteil, Fournier \& Micholet, 1975). JARDINE \& MAGLOIRE (1965) apresentaram importante contribuição à palinologia do Cretáceo, das bacias do Senegal e Costa do Marfim. Contudo, estudos comparativos mais acurados só puderam ser realizados após o trabalho de Doxte et alii (1977), que delinearam as linhas mestras do zoneamento palinológico elaborado e utilizado pelos palinoestratígrafos da ELF no Cretáceo Inferior das bacias costeiras africanas. De imediato, em função das espécies em comum e da idade estabelecida, verifica-se a correspondência entre as biozonas ora identificadas com as palinozonas C VII, C VIII e C IX de Doyte et alii (1977). Segundo estes autores, a palinozona C VII, caracteriza-se pelo primeiro aparecimento da espécie Afropollis jardinus e de formas tricolpadas e pelo acme de "Inaperturopollenites" crisopolensis; além disso, verifica-se a presença dos gêneros Stellatopollis e Liliacidites, e de 2 a $5 \%$ de grãos de pćlen afins com as angiospermas e do domínio dos gêneros Classopollis e Equisetosporites. Cumpre mencionar que todas estas características são observáveis na biozona A. A correspondência entre as palinozonas brasileiras $\mathbf{B}$ e $\mathrm{C}$ e as palinozonas $\mathbf{C ~ V I I I ~ e ~}$ C IX da África Equatorial, é evidenciada pelos seguintes aspectos: (a) maior diversificação das angiospermas monosulcadas e tricolpadas; (b) aparecimento do gênero Striatopollis; (c) aumento na abundância relativa de Brenneripollis peroreticulatus; e (d) outras espécies em comum, como Retimonocolpites dividuus (PIERCE), Clavatipollenites hughesi (COUPER), Tricolpites georgensis (BRENNER) e Striatopollis paraneus (NoRrus).

Esta associação apresenta similitude com as seqüências XI e XII de JARDINE \& MAGLORE (1965), caracterizadas por uma freqüência entre 30 a $60 \%$ de Classopollis e de 5 a $20 \%$ de grãos de pólen poliplicados.

Mưller, Di Giacomo \& VAN ERVE (1987) propuseram um zoneamento bioestratigráfico para o intervalo do Cretáceo ao Recente, válido para toda a área norte da América do Sul, abrangendo o Brasil, Colombia, Guiana, Suriname, Trinidad e Venezuela. Das 10 superzonas e 31 zonas palinológicas propostas, 6 superzonas e 13 zonas referem-se ao Cretáceo. Comparando-se os dados palinológicos do presente estudo com os apresentados neste zoneamento, constatase correspondência com as superzona II (parte superior), zona 4 "Inaperturopollenites" crisopolensis, pelo primeiro aparecimento de formas 
tricolpadas e da espécie Reyrea polymorphus, presença de Afropollis, e limite superior definido pela extinção de "Inaperturopollenites" crisopolensis. Com a superzona III, zona 5 - "Tricolpites" - Exesipollenites tumulus, a correspondência estabelecida pelo primeiro aparecimento do gênero Striatopollis, boa representatividade dos grãos de pólen dos gêneros Equisetosporites e Gnetaceaepollenites, e significativo aumento na diversidade dos grãos de pólen afins com as angiospermas.

E apresentada na figura 28 , a correlação entre o zoneamento ora proposto e os esquemas zonais supra mencionados.

Cumpre salientar que Dejax (1987) apresenta importante contribuição aos estudos palinologicos do Cretáceo, em sua tese de doutorado em sedimentos do. Congo. Este estudo se deu em intervalos estratigráficos eqüivalentes em tempo e inseridos na mesma faixa microflorística dos aqui estudados; contudo, o autor não estabeleceu um zoneamento, ainda que informal, de modo a possibilitar uma correlação mais detalhada.

\section{7) Província Microflorística na qual se insere a Associação Estudada}

Autores como Brenner (1976), Vakhrameev (1978), e Herngraen \& Chlonova (1981) propuseram modelos de divisão do globo, no eocretáceo, em províncias microflorísticas. Das quatro estabelecidas por BRENNER (1976), o material aqui estudado insere-se na Província Norte-Gonduanense, que abrange as porções norte e nordeste da África e América do Sul, com as seguintes características:

- virtual ausência de grãos de pólen bissacados;

- predomínio de Classopollis (compreendendo entre 60 a $80 \%$ das associaçőes);

- presença abundante de grãos de pólen poliplicados (entre 10 a $20 \%$ das associações);

- presença abundante de grãos de pólen monossulcados, afins das gimnospermas;

- relativa diversidade de esporos de pteridófitas;

- primeiro aparecimento de grãos de pólen de afinidades angiospérmicas no Barremiano superior/Aptiano superior. 


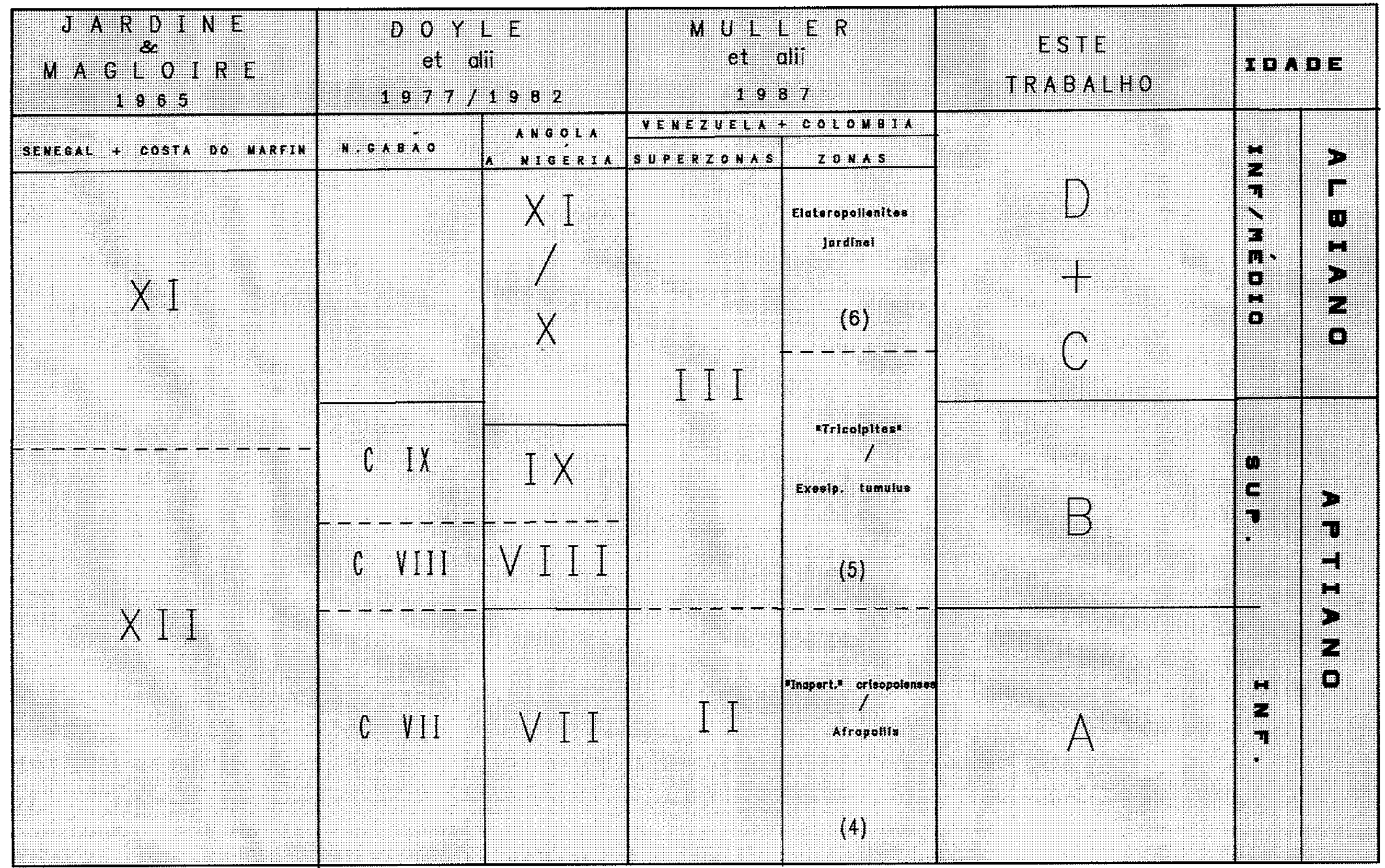

FIO. 28 - CORRELACẼ̃o dO ZONEAMENTO PROPOSTO COM ESqUEMAS zONAIS FORA DO BRASIL 
VAKHRAMEEV (1978) individualizou no hemisfério norte duas zonas climáticas latitudinais, com base em dados litológicos: uma zona úmida a norte e uma zona árida a sul. Posteriormente, através de dados paleobotânicos, estabeleceu três províncias microflorísticas, sobre estas duas zonas. Embora originalmente criadas para o hemisfério norte, muitos elementos em comum são encontrados entre o material ora analisado e a província tropical árida deste autor. Caracterizada litofaciologicamente por camadas avermelhadas, depósitos evaporíticos e camadas de gipso, esta provícia abrange o sul dos Estados Unidos, o norte da América do Sul, a Arábia, o Oriente Médio e o sul da Ásia (exceto a Indochina e a Indonésia). Dejax (1987) sugere que os limites meridionais desta província nas Américas e África devam ser deslocados para uma posição mais a Sul, de modo a englobar o Oeste da África central. A Província Tropical Árida caracteriza-se palinologicamente por conter até 50 a $70 \%$ de grãos de pólen do gênero Classopollis em suas associações. Possivelmente as associações do extremo norte e nordeste do Brasil poderiam fazer parte desta província.

Herngreen \& Chlonova (1981) também definiram três províncias microflorísticas. Destas, a Província Oeste- Africana/Sul-Americana (W.A.S.A), que abrange as porções centro-norte da África e da América do Sul, é a que inclui à área estudada. Caracteriza-se por:

- predomínio de grãos de pólen de gênerc Classopollis, representado por 50 a $80 \%$ das associações;

- presença abundante de grãos de pólen poliplicados, variando entre 5 a $60 \%$ das associações;

- presença de esporos de pteridófitas;

- presença rara de grãos de pólen bissacados (menos de $2 \%$ nas associações);

- surgimento de grãos de pólen afins com as angiospermas.

Uma análise comparativa entre os dados palinológicos da Formação Alagamar da Bacia Potiguar, e os indicados pelos autores destas províncias microflorísticas, mostra claramente os seguintes aspectos:

- os grãos de esporos de pteridófitas são abundantes e diversificados, com representantes dos gêneros Gleicheniidites, Cicatricosisporites, Appendicisporites, Pilosisporites e Aequitriradites. Também os perisporados são freqüentes, sendo os mais comuns os dos gêneros Crybelosporites e Perotrilites. 
- os grãos de polen inaperturados apresentam-se abundantes, sendo mais representativos os gêneros Araucariacites e Callialasporites.

- os grãos de pólen bissacados, apesar de raros, ocorrem em vários níveis, sendo representados pelos gêneros Vitreisporites e Cedripites.

- presença, apesar de rara, de espécies restritas à "província", a exemplo de Reyrea polymorphus.

- alta freqüência e diversidade de grãos de polen poliplicados dos gêneros Equisetosporites, Gnetaceaepollenites e Steevesipollenites.

- alta freqüência, em toda a seção, dos grãos de pólen rimulados, representados pelos Classopollis, com grande diversidade.

- os grãos de pólen afins com as angiospermas são pouco diversificados e de baixa freqüência. Ocorrem principalmente na parte superior da seção, com seus representantes mais primitivos (monocolpados e tricolpados); são muito raras as formas tetracolpadas. Resssalta-se os gêneros Tricolpites, Albertipollenites, Liliacidites, Clavatipollenites e Transitoripollis.

Do acima exposto, nota-se que, de modo geral, a associação é facilmente correlacionável com esquemas palinoestratigráficos apresentados em diferentes regiōes do mundo para sedimentos não-marinhos de idade aptiana a eoalbiana. Além disto, apresenta-se perfeitamente compatível com os modelos de "Faixa Microflorística" disponíveis na literatura, que englobam a posição geográfica da Bacia Potiguar. Entretanto, a exemplo do citado por LimA (1978) para a Bacia do Araripe, é evidente que pequenas variações devam ser esperadas, principalmente em função da escassez de conhecimentos palinológicos na província (W.A.S.A.); bem como pelos limites cronoestratigráficos impostos ao presente estudo.

\section{8) Idade}

Determinadas espécies de grãos de esporos e pólen com amplitude vertical restrita e larga distribuição são muito úteis para correlação intra- e 
intercontinentais. Contudo, devido à ocorrência simultânea de ambientes heterogêneos em diferentes lugares da Terra, uma espécie pode não aparecer no registro fossil em toda a parte ao mesmo tempo. Igualmente, por causa da dinâmica climática inerente à Terra, uma espécie pode se tornar extinta mais cedo num local e sobreviver por um maior período de tempo em outro. Assim, barreiras geográficas impedem a distribuição uniforme de especcies, e condições ambientais restringem sua presença a certas áreas no mundo. Conseqüentemente, a firm de se estabelecer a amplitude geológica total para uma espécie, é necessário estabelecer seu nível de aparecimento, sua amplitude geológica local, e a sua zona de apogeu em cada região onde ocorre no mundo. Quando muitas espéciesíndices com amplitudes geológicas conhecidas são encontradas numa camada ou formação, então a idade desta camada ou formação pode ser determinada com um excelente grau de acurácia (SINGH, 1964).

A associação microflorística da Formação Alagamạ, de um modo geral, contém, na sua grande maioria, espécies eocretáceas de grande amplitude vertical, as quais são de pequeno ou nenhum valor diagnóstico de idade. A nível genérico ela apresenta, qualitativamente, uma microflora transicional, com palinomorfos representativos do Aptiano que adentram o Albiano, de modo a confirmar o posicionamento das camadas analisadas no Aptiano/Albiano inferior a médio.

Conseqüientemente, apenas aquelas espécies com nível de aparecimento previamente registrado no Aptiano (Alagoas) e Albiano, ou aquelas espécies restritas à Formação Alagamar, serão mencionadas na discussão abaixo.

Estudos palinológicos prévios da Formação Alagamar da Bacia Potiguar (Regali \& Gonzaga, 1985; Regalı, 1992) têm estabelecido uma idade Alagoas (Aptiano) para esta formação. A correlação, baseada unicamente nos elementos microflorísticos nele contidos, pode ser feita com outras bacias da margem continental (REGALI et alii, 1974, 1985; REGALI, 1992).

Na biozona A os eventos mais característicos são a presença dòs gêneros Afropollis, Sergipea, Stellatopollis, Clavatipollenites e Transitoripollis, e o surgimento do gênero Tricolpites. A presença de formas poliplicadas é constante, porém são pequenos e geralmente do gênero Equisetosporites.

De acordo com Doyle et alii $(1977,1982)$, Hochuli (1981), Penny (1986), e Hughes \& MCDougall (1990), o gênero Afropollis tem sua mais velha ocorrência datada como Aptiano. Doyse et alii (1982) posicionam o surgimento deste gênero na zona C-VII (do Gabão), baseados em datações de camadas 
marinhas, através de foraminíferos, da Argélia (JARDINÉ et alii, 1974). Ainda em relação a este gênero, vale ressaltar que os autores, apesar de desconsiderar o dado, citam a ocorrência de Afropollis em camadas de idade barremiana no Canada, (STONe \& Williams APUd Doyle et alii, 1982).

Doyne et alii (1982), consideram que as espécies $A$. operculatus e $A$. zonatus, presentes nesta biozona, são indicadores de idade eoaptiana.

REGaLI (1987B) e REgaLI \& VIANA (1989) consideram que o surgimento deste gênero, no Brasil, se dá no Barremiano superior.

O gênero Stellatopollis tem seu primeiro aparecimento em depósitos do Barremiano?-Aptiano (DoYne et alii, 1977, 1982; HUGHEs et alii, 1979; Gưbelr et alii, 1984; PENNY, 1986; Regali, 1987c).

O aparecimento dos gêneros Clavatipollenites e "Inaperturopollenites" (= "Clavatipollenites"; = Tucanopollis; = Transitoripollis), atribuídos as primeiras angiospermas, ocorre no Barremiano (DoYLe et alii, 1977, 1982; Depeche et alii, 1986; Arax et alii, 1989; REgALu \& VIANA, 1989).

O gênero Sergipea, erigido no Brasil por ReGALI et alii (1974), tem seu surgimento no Andar Alagoas (biozona P-230), considerada de idade eoaptiana, segundo Regali (1987A). AraI et alii (1989), atestam que este gênero surge no Andar Aratu, considerado como de idade barremiana.

Doyle et alii (1977) dataram como de provável idade aptiana os sedimentos que contêm os primeiros grãos de pólen tricolpados. BRENNER (1976) em estudos palinológicos em Israel considerou que os tricolpados podem ter surgido no Barremiano.

As pesquisas mais recentes sobre a origem e evolução das angiospermas (HUGHES \& MACDOUGALL, 1987, 1990; TREVISAN, 1988; WARD, et alii, 1989) indicam que o surgimento dos grãos de pólen dos gêneros Clavatipollenites, Retimonocolpites, Liliacidites e Stellatopollis, representantes das primeiras angiospermas, tenha se verificado já em estratos de idade valanginiana (Itália) e hauteriviana (Inglaterra). Entretanto, é evidente, pelas pesquisas supracitadas, além dos trabalhos de Brenner (1974), Burger (1971, 1974, 1980), Chlonova (1977, 1986) e HiCKEY \& DoYLe (1977), que as primeiras ocorrências mais comuns destas angiospermas está restrita ao Barremiano superior/Aptiano. Desse modo conclui-se que a idade mais provável para a seção abrangida pela biozona $\mathrm{A}$ é eoaptiana. 
Também os poliplicados (presentes desde o início da sedimentação dos estratos em questão) têm, consensualmente, seu surgimento ao redor do Barremiano/Aptiano (REYRE, 1973; Sultan, 1986; SCHRANK, 1987).

Na biozona B, destaca-se o aparecimento e extinção da especie Sergipea variverrucata. Outros eventos observados incluem a extinção da espécie Transitoripollis crisopolensis, a diversificação dos grãos de polen poliplicados e tricolpados, e o surgimento dos primeiros tricolpados com ornamentação estriada e estrio-reticulada.

A extinção de Transitoripollis crisopolensis é posicionada no limite do Aptiano inferior/Aptiano superior pela quase totalidade dos autores (Doyz et alii, 1977, 1982; Regali \&. Viana, 1986, 1988, 1989; DejaX, 1987; Regali, 1992). Exceção é feita ao trabalho de Lima \& Boltenhagen (1981), que a posiciona no Barremiano superior.

Dorte et alii (1982), consideram que a presença de Afropollis jardinus e $A$. aff. $A$. jardinus, espécies freqüentes nesta biozona, são diagnósticos de idade neo-aptiana a cenomaniana.

A amplitude vertical da espécie Sergipea variverrucata, é considerada como restrita ao Aptiano superior (Lima \& Boltenhagen, 1981; Doyle et alii, 1982; Regal. \& Viana, 1989).

No presente trabalho, a extinção desta espécie foi convencionada como coincidente com o limite Aptiano/Albiano na bacia. Tal procedimento está de acordo com as conclusões de Lima \& Boltenhagen (1981) e DeLla-Favera et alii (1984).

O aparecimento de grãos de pólen de angiospermas é de considerável significado evolutivo e estratigráfico. Grãos de pólen tricolpados de origem angiospérmica têm seu primeiro aparecimento no Aptiano (Regalı et alii, 1974; J ARDINE et alii, 1974; DoYle et alii, 1977, 1982; MórLER, 1966, 1970; BRENNER, 1976; Gưber et alii, 1984; SCHRANK, 1991), nas províncias microflorísticas que abrangem a atual região setentrional da América do Sul e África. Na América do Norte, seu aparecimento está bem documentado apenas em camadas de idade albiana (Brenner, 1963; Davis, 1963; Pannella, 1966; Norris, 1967; Hedlund \& Norris, 1968; Singh, 1971; Srivastava, 1977; Wingate, 1980). O mesmo se verifica em outras regióes do mundo, como Peru (BrenNer, 1968); África (JARDINe \& MAGLorRe, 1965); América Central e África (Couper, 1964); Australia (Dettmann \& Playfdord, 1968); Nova Zelandia (Couper, 1958); Inglaterra (KEMP, 1968); Inglaterra e Sul da 
França (LAing, 1975, 1976); Portugal (Groor \& Groot, 1962B) e Russia (Bolkovitina, 1953).

Apesar da pouca diversidade, o presença de grãos de pólen tricolpados nesta porção da Formação Alagamar sustenta, por si sర6, uma idade neo-aptiana, a despeito da ausência de microfósseis marinhos. Das espécies de angiospermas com primeiro aparecimento nesta parte da Formação Alagamar, Tricolpites micromunus (GROot \& PeNNY) é citada por DoYre et alii, 1977, como presente na zona C-VII. O mesmo se verifica para as espécies Rousea georgensis (Brenner) Dettmann e Liliacidites dividuus (Pierce) Brenner, bem como para gêneros de tricolpados estriados e estrio-reticulados, surgidos nas biozonas C-VII e C-IX, de idade neo-aptiana.

Não foram encontradas espécies restritas à biozona $\mathbf{C}$, fato que dificulta sobremaneira sua datação, pois a grande maioria das espécies contidas na biozona B, ultrapassam esta biozona e avançam para a biozona $\mathrm{D}$. Em função da ausência da espécie Sergipea variverrucata (aqui convencionada como tendo nível de extinção coincidente com o topo do Aptiano), considera-se que a biozona $\mathbf{C}$ é de idade eoalbiana. Contudo, não se observa eventos microflorísticos que assegurem esta assertiva. Como seu limite superior $\hat{\varepsilon}$ truncado pela superfície discordante que limita a Formação Alagamar e tamberm o Andar Alagoas, considerase igualmente que equivale em tempo ao neoAlagoas.

A biozona D é marcada pelo surgimento dos primeiros grãos de pólen elaterados, tetracolpados e poliporados, além da indubitável presença de elementos marinhos na associação. Este pacote situa-se acima da discordância erosional que limita o topo a Formação Alagamar; consequientemente pertence já à megasseqüência marinha transgressiva (Formação Açu, em terra, e formaçōes Açu/Ubarana, no mar). O aparecimento de espécies elateradas é considerado unanimemente, como indicativo de idade eo- a mesoalbiana (JARDINE \& MAGLORE, 1965; BRENNER, 1968, 1976; JARDNÉ et alii, 1972; REGALI et alii, 1974; JARDINÉ et alii, 1974A, 1974b; Herngreen, 1974, 1975; Lima, 1981; Lima \& Boltenhagen, 1981; Doyle et alii, 1982; Hochuli, 1981; Gübel et alii, 1984; Dejax, 1987; Aral et alii, 1989; SCHRANK, 1991; Salard-CheboldaefF \& Dejax, 1991).

Regali (1989A, c) e Regali \& Viana (1989), posicionam as espécies Elateropollenites dissimilis REGALI e Elateropollenites praecursor REGALI na biozona P-280 basal, como redefinida por Regali (1989c). Consideram que as mesmas têm seu nível de surgimento no topo do Andar Alagoas, atribuindo idade neo-aptiana a este nível. Vale salientar que ocorrem ali (evento verificado 
neste estudo) espécies poliporadas, elateradas e tetracolpadas, as quais no mundo todo, e em todas as províncias microflorísticas já definidas, são consideradas como formas características do Albiano, mais propriamente do Albiano médio.

A figura 29, mostra a distribuição vertical na escala internacional dos principais grupos, gêneros e espécies diagnósticos de idade, apresentados por diferentes autores e que definem a amplitude máxima, em termos de idade, das camadas analisadas.

Os depósitos brasileiros atribuídos sem muitas dúvidas ao Aptiano são mais evidentes, até o momento, apenas na Bacia de Sergipe-Alagoas. BEURLEN et alii (1987); Koursoukos (1989) e Bengston \& Koursoukos (1991) apresentam dataçס̃es baseadas principalmente em nanofosseis, foraminíferos e amonoides, reconhecendo o Aptiano superior em áreas desta bacia. Contudo, acredita-se na existência de camadas equivalentes em outras bacias, já que normalmente elas representam a porção mais superior do Andar Alagoas. Esta caracteriza-se pela ocorrência contemporânea de ostracodes (zona Cytheridea (?) sp. gr. 201/218), e de palinomorfos (topo da superzona Exesipollenites tumulus), definindo unidades bioestratigráficas comumente identificadas na maioria das bacias cretáceas do Brasil. Esta seção, segundo a palinologia, abrange geralmente a porção mais superior da biozona P-270, e/ou a biozona P-280. Porém, nunca apresentou, até o momento, palinomorfos de origem marinha, diagnósticos de idade. Como documenta ambientes transicionais, marcados pelas primeiras conexões marinhas do Cretáceo brasileiro, a caracterização paleontológica deste pacote é difícil, em função das associaçðes micropaleontológicas geralmente pouco diagnósticas e da pouca espessura sedimentar. A porção superior, pré discordância, dos estratos aqui analisados são correlatos aos destes sedimentos.

Em resumo, pelo acima exposto, pode-se concluir que o início da deposição dos estratos da Formação Alagamar deu-se entre o Aptiano inferior (Membro Upanema) e o Aptiano superior (parte superior do Membro Upanema, Camadas Ponta do Tubarão e Membro Galinhos). O Albiano inferior/médio pode ser inferido para pequenas porções do topo da Formação Alagamar (biozona C). O Albiano inferior/médio está documentado pelas camadas marinhas aqui definidas, pertencentes às formações Açu/Ubarana (Biozona D).

Salienta-se que a aparente continuidade destes depósitos, como sugerida pela idade ora atribuída, prende-se ao baixo poder de resolução dos métodos bioestratigráficos neste pacote, pois a discordância litológica é indubitável. 


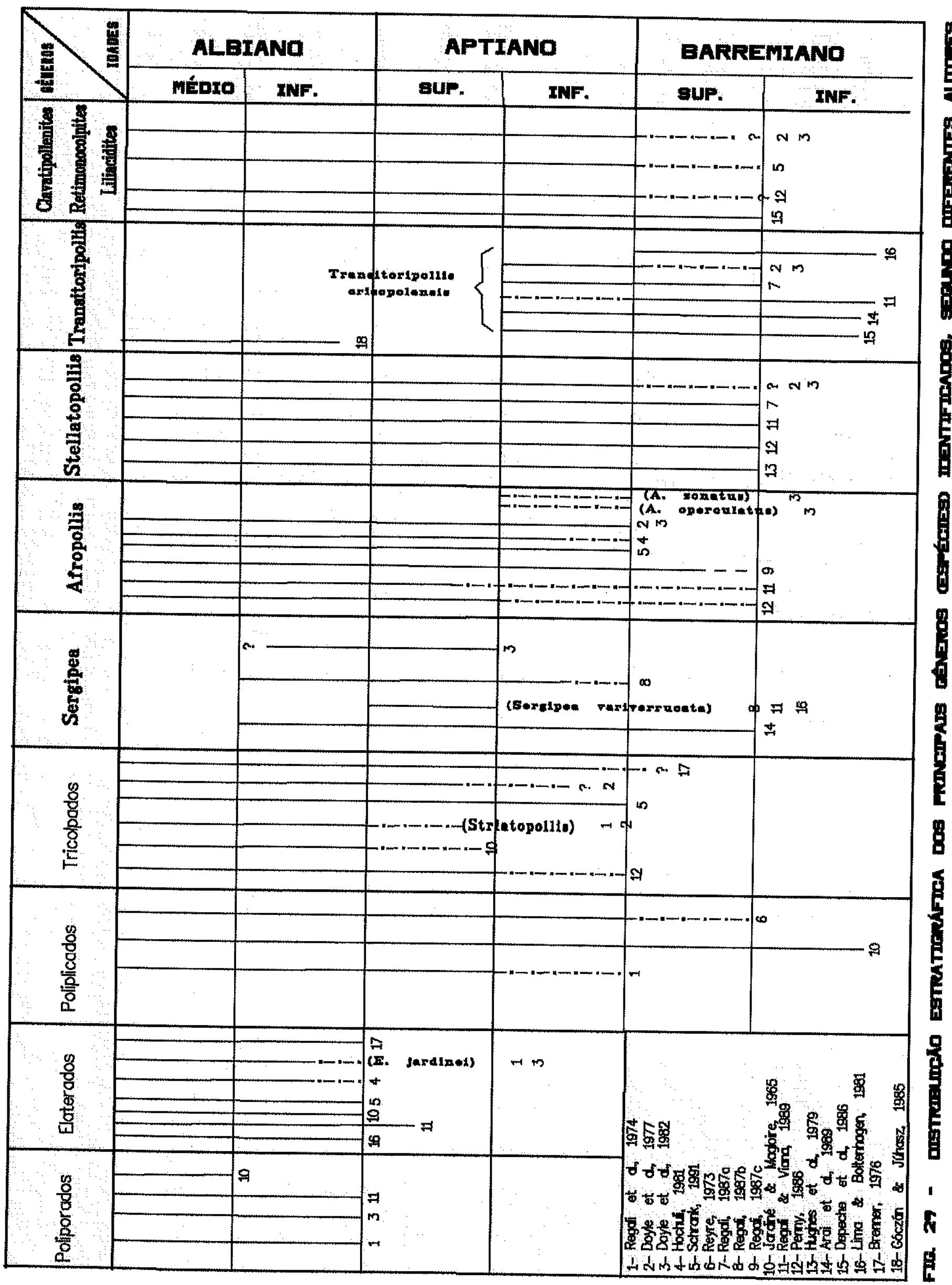




\section{U- INTERPRETAÇÃO PALEOAMBIENTAL}

\section{1) Considerações Gerais}

Ao se iniciarem estudos de reconstituição e interpretação paleoambientais, paleoecológicas e paleogeográficas, deve-se ter em mente as dificuldades e limitações em se deduzir, avaliar, ou concluir com acurácia a situação ecológica do passado. Isto é particularmente verdadeiro, quando tratamos de sedimentos pré-terciários, e ainda mais válido quando se trabalha exclusivamente com palinomorfos, apesar da significativa ajuda que os mesmos têm fornecido na elaboração destas interpretações.

O primeiro passo é conhecer os parâmetros que caracterizam o universo microflorístico que servirá de base nas interpretações, ou seja, o conjunto dos palinomorfos.

Uma associação microflorística pode ser determinada pelas seguintes variáveis (Clapham, 1972): 1) abundância das plantas na flora local, 2) quantidade relativa de produção de esporomorfos pela planta, 3) distância entre os locais onde as plantas cresceram e o sítio de deposição, 4) média de distância transportada envolvida, 5) preservação seletiva, 6) procedimentos de preparação das amostras.

A ausência de um dado táxon numa amostra pode indicar que a planta mãe não estava presente na flora contemporânea ou que a probabilidade de ser encontrada é extremamente baixa, embora a planta-mãe vivesse neste tempo. De modo similar, a abundância de um dado táxon pode ser devido à 
grande produção de grãos da planta na flora local, excesso de produção polínica, ou proximidade do sítio de deposição. Estas variáveis aparentemente distorcem o quadro real da flora contemporânea e complicam a interpretação.

Existem ainda algumas questões em aberto, com as quais vêm se defrontando os palinólogos empenhados na reconstituição de paleoambientes. Elas estão geralmente ligadas às dúvidas seguintes: (a) se os atuais grupos de plantas vivem hoje nos mesmos ambientes em que suas ancestrais viviam há 100 milhōes de anos atrás; (b) se a morfologia dos grãos de pólen e esporos teria permanecido estável dentro dos seus grupos de plantas, durante todo o tempo envolvido, mesmo se admitindo um controle acurado a nível de família; e (c) até que ponto os grupos representados num determinado sítio deposicional refletem a flora da área próxima a ele, isto $e$, quantos tipos seriam provenientes de outras áreas e portanto deveriam ser desconsiderados.

Dentre várias restrições e pressuposiçōes, que normalmente devem ser levadas em conta num estudo paleoambiental e paleoecologico, ressaltam-se as seguintes:

- A maioria dos grãos de pólen e esporos pré-pliocênicos não podem ser atribuídos a gêneros botânicos viventes, com um grande grau de certeza (TRAVERSE, 1982).

- Na paleopalinologia do pré-Quaternário os gêneros e espécies de palinomorfos habitualmente usados são artificiais e baseados em várias diferenças morfologicas, as quais podem ou não refletir relações naturais.

- Pressupõe-se como verdade que o táxon palinomórfico identificado foi produzido por uma população homogênea de indivíduos morfologicamente próximos, os quais compartilham condições ambientais similares.

- Admite-se que as plantas que produzem grãos de pólen e esporos fósseis similares aos dos táxons atuais reagem a um dado ambiente de modo muito próximo ao de suas análogas modernas. Tal fato se transformaria em um sério desafio se a amplitude de tolerância ambiental das plantas antigas fosse significativamente diferente da de suas equivalentes atuais. Por exemplo, HICKEY (1977, P. 970) afirmou que qualquer associação fóssil inclui um número de formas, cujas análogas modernas são apenas resquícios que ocupam hoje uma pequena fração de suas amplitudes geográficas e tolerâncias climáticas iniciais.

- Considera-se que uma rica associação florística, usando-se tantos táxons quanto possível, fornecerá uma estimativa qualitativa das condiçōes climáticas no sítio de deposição quando uma flora particular predominava.

- Presume-se que as microfloras fósseis derivaram de várias fontes de vegetação ao redor do sítio de deposição. Por conseguinte a associação 
palinologica presente representa uma associação coletiva de toda a flora da região. E ainda que esta vegetação estava adaptada ao clima reinante na área na qual ela cresceu.

Certas evidências do registro fóssil têm respondido parcialmente a algumas das questões acima, e conseqüentemente aumentado o grau de segurança na obtenção de interpretações verossímeis; entre as mais importantes citam-se:

- As plantas são de um modo geral consideradas como sendo organismos bastante sensíveis às alterações dos fatores ecológicos terrestres. ANDREws (1961) constatou que, sob condições de mudanças climáticas, as plantas estão muito mais aptas a migrarem para um local mais favorável do que se adaptarem a sua atual posição. Por conseguinte, uma mudança climática e outras condições ambientais podem alterar, em muito, a flora num relativamente curto espaço de tempo. Inversamente, se admitirmos que mudanças nas associações florísticas refletem variação das condições climáticas e ecológicas, a análise das floras fósseis fornecerá valiosas informações na interpretação do paleoclima e da paleoecologia a elas contemporânea.

- Muitos grupos de plantas ainda existentes estão restritas a determinados ambientes (por ex: Droseraceae, Sphagnaceae, etc.).

Enfim, se considerações adequadas são tomadas em relação a estas variáveis e se uma análise cuidadosa da associação palinológica ê feita com base em métodos estatísticos, um quadro paleoflorístico bastante fidedigno pode ser obtido.

\section{2) Paleoclima}

As plantas que viveram no Cretáceo Inferior, na sua quase totalidade, representam espécies e gêneros extintos há longo tempo. Por isso, tentativas de se traçar analogias entre regimes climáticos atuais de baixa latitude e regimes de latitudes similares durante o Eocretáceo constituem hipótese bastante temerária. Entretanto, inferências baseadas na totalidade da paleoflora (vinculada tão próximo quanto possível às análogas ainda existentes) presumivelmente permitirão uma razoável estimativa do tipo de paleoclima existente no tempo da deposição.

Se uma identificação taxonômica correta é possível, pelo menos a nível de família, então interpretações podem ser delineadas a grosso modo, particularmente quando usadas em sintonia com modelos paleoclimatológicos 
teóricos. Brenner (1976) e Herngreen \& Chlonova (1981), utilizando dados palinologicos do mundo todo na interpretação de paleoclimas globais durante o Cretáceo, estabeleceram cinturões microflorísticos com significado climatológico. A área objeto do presente estudo, pelo seu conteúdo esporo-polínico e posição geográfica, insere-se na Província "Norte-Gonduânica" de BrENNER (op. cit.), que $\varepsilon$ essencialmente a mesma "Província pre-Albiana oeste-africana e sulamericana" (W.A.S.A.) de Herngreen \& ChLONOva (op. cit.). Estas províncias ocupavam uma faixa de aproximadamente $15^{\circ}$ de latitude em ambos os lados do paleoequador, e são tidas, como representativas de ambientes de clima quente e seco.

Análises estatísticas das composições polínicas foram utilizadas neste trabalho também para avaliar o paleoclima reinante na época Alagoas na Bacia Potiguar. Os resultados indicam que predominavam durante o Alagoas os elementos xerofíticos (essencialmente grãos de pólen dos gêneros Classopollis e Equisetosporites). Elementos higrofitos tais como esporos de samambaias, notadamente dos gêneros Cyathidites, Cicatricosisporites e Perotrilites, estão também presentes em proporções menores. Desse modo, o paleoambiente inferido para a Formação Alagamar é o de um clima predominantemente árido, não só pelo domínio dos elementos xerofíticos, como pela presença de carbonatos que marcam estes depósitos, a exemplo do que ocorre em muitos dos estratos brasileiros deste intervalo de tempo.

Calcados na análise da distribuição percentual dos grupos de palinomorfos (Fig. 22) presentes na seção estudada, destacamos os mais representativos e o seu papel na influência climática desta seção, fornecendo os subsídios para as supracitadas conclusões paleoclimáticas.

\section{- Rimulados}

Predominantes em toda a seção, com leve tendência a decrescer na parte superior da mesma.

O habitat destas gimnospermas xerofíticas da familia extinta das Cheirolepidiaceae tem sido objeto de vários estudos e especulações (Pococx \& J ANSONIUS, 1961; Thompson, 1969; Reyre et alii, 1970; VAKhrameev, 1970; De Jersey, 1973; Lima, 1976в, 1978B; Srivastava, 1976A, в; Courtinat, 1980). Representadas quase que exclusivamente pelo gênero Classopollis, são consideradas como dominantes em regiōes áridas de baixa paleolatitudes, com ocorrência fóssil em sedimentos que mostram clara tendência à aridez (HUGHEs, 1973; BRENNER, 1976; UPCHURCH \& 
DoYLE, 1981). São também comumente consideradas como melhor adaptadas a climas secos e possivelmente a condições de solos salinos próximos à costa (Pocock \& J Jnsonius, 1961; Pocock, 1970A, B; Filatoff, 1975).

Alvin (1982) atribui a Frenelopsis e Pseudofrenelopsis a produção dos Classopollis, árvores que segundo RETALLACK \& DILCHER (1986) eram amplamente disseminadas na vegetação das regióes tropicais no Eocretáceo. Possuiam várias características das atuais plantas que habitam ambientes secos ou salinos, tais como: caules nodados, brotos suculentos, reduzida cobertura foliar, espessas cutículas papiladas e aberturas estomatais deprimidas.

No entanto, de acordo com DoyLe et alii (1982), é difícil imaginar como estas Cheirolepidiaceae poderiam dominar totalmente as palinofloras, a menos que elas constituissem a maioria da vegetação regional, e não apenas a das áreas próximas à costa ou ao redor de lagunas. Ainda segundo estes autores, existem igualmente boas evidências de que estas plantas não eram obrigatoriamente xerofíticas e/ou halofíticas.

\section{- Inaperturados}

Presentes com relativa abundância em toda a seção, são indicativos de climas secos. Segundo Doyle et alii (1982), os grãos inaperturados, mormente os ligados às Araucariaceae, habitavam regióes presumidamente tropicais. Krassilov (1978), concluiu que as Araucariaceae dominavam num cinturão de baixas latitudes em climas de verão seco com formação de red-beds.

\section{- Triletes}

Apresentando grande diversidade e relativa freqüência em toda a seção, indicam de uma maneira geral a existência de condições úmidas, a exemplo das suas representantes atuais. De acordo com Schrank (1987), as pteridofitas cresciam em habitats úmidos próximos aos rios e lagos de águas rasas.

Dentro da prupo, as Cyatheaceae (Cyathidites), Matoniaceae (Matonisporites), Osmundaceae (Biretisporites) e Schizaeace (Cicatricosisporites) preferem climas quentes (Lima, 1978 A; PoNs 1988).

- Poliplicados

A abundância de grãos de pólen atribuíveis às Ephedrales/Gnetales, 
presentes com relativa abundância em toda a seção, tem sido usada como uma evidência para aridez na Província Gondwana Norte, com base no seu caráter xerofítico. Doyxe et alii (1982), ao notar a presença abundante de Cheirolepidiaceae associada às Ephedrales, sugere que ambas estavam adaptadas a condiçôes semelhantes de faixa climática e que provavelmente dividiam o ambiente em relação a algum outro fator qualquer, sendo as Ephedrales menos tolerantes às condições salinas. Estes autores sugerem uma divisão de habitat para ambos os grupos, sugerindo que as Gnetales podiam talvez dominar habitats arenosos e pantanosos em ambientes flúvio-deltaicos, enquanto que as Cheirolepidiaceae dominavam áreas de não deposição e melhor drenadas.

\section{- Bissacados}

Presentes em percentagens inexpressivas na associação, tornam-se mais representativos em direção ao topo da seção. Tal escassez é geralmente indicativa do domínio de climas não tropicais (LIMA, 1978A).

JARDIÉ et alii (1974) e Doyle et alii (1977), interpretaram que o quase desaparecimento dos grãos de pólen bissacados durante o BarremianoAptiano, mormente os ligados às podocarpáceas, era uma forte evidência a favor do aumento de aridez nesta fase. Contudo, Doys et alii (1982) reavaliaram que a mais provável explicação para este sensível declínio seja a destruição erosional das terras altas, mais frias e úmidas, pelos últimos estágios da evolução rifte.

\section{- Angiospermas}

A exemplo dos bissacados, os grãos de pólen atribuídos às angiospermas são escassos, a despeito do seu significativo aumento na parte superior da seção. Doyle et alii (1982) e Retallack \& Dilcher (1986) sugerem que as angiospermas teriam ocupado tanto as áreas costeiras como as interiores, com amplo espectro climático. Estudos realizados por Retallack \& Dilcher (1986) em diferentes regiōes da América do Norte confirmam a ocorrência de angiospermas em vários ambientes costeiros, inclusive de mangues.

Em resumo, do quadro acima exposto, pode-se inferir pelo domínio dos elementos xerofíticos, que o clima reinante durante o tempo Alagoas na Bacia Potiguar, a exemplo das bacias de todo o nordeste, era predominantemente quente, árido a semi-árido (embora vegetações de microclimas úmidos subsistissem em nichos localizados). Também os dados litologicos, tais como: a presença de 
carbonatos e de smectitas, com estes últimos implicando em longos períodos secos e curtos episódios úmidos para a fixação dos óxidos e hidróxidos na sua formação (RAMOs, 1980), constituem forte indicação deste tipo de clima.

Esta conclusão está de acordo com os demais dados disponíveis para esta seção e suas cronocorrelatas regionais (LIMA, 1976A, B; 1978A, B, 1979B, C; 1982; 1983, 1990; Petri, 1983; 1987; Ramos, 1980; Regali, 1987c, D; Regali, 1989в, D, E; Regali \& Gonzaga, 1985; Viana, 1986; Beurlen \& Regali, 1987; Viviers \& Regali, 1987). Corrobora também a quase totalidade das discussões e inferências versando sobre as particularidades da flora do Gondwana Norte, que têm concluído por um clima árido ou semi-árido (sazonalmente seco). Evidências para tal são propiciadas pelo domínio de Classopollis e grãos de pólen de Ephedrales, subordinados a esporos de samambaias, e pela presença de depósitos de sal nas bacias de tipo rifte do Atlântico Sul (BRENNER, 1968, 1976; JARDINÉ et alii, 1974; DoYue et alii, 1977, 1982).

\section{3) Ambientes de Deposição}

Os palinomorfos de um modo geral comportam-se como partículas detríticas que são carreadas para o ambiente de deposição, através de correntes de ar e principalmente de água. A maioria destes palinomorfos (sensu lato) possuem dimensões de silte. Por conseguinte, alguns parâmetros válidos para os sedimentos podem ser aplicados às associações palinológicas objetivando chegar a algumas conclusões paleoambientais. Dados de KuYL et alii (1955) e MUuner (1959) no oeste venezuelano, de $W_{A L L}$ (1965) na Inglaterra, e de DALE (1976) na Noruega, sugerem fortemente que ambientes sedimentares podem ser interpretados a partir de parâmetros estatísticos em associações palinológicas. Em importante pesquisa no delta do Orenoco, Schening \& PFeFFerkorn (1984) também estudaram os processos de soterramento e preservação de restos detríticos de plantas terrestres num ambiente deltaico de deposição. Assim, as interpretações paleoambientais ora postuladas levaram em conta também os dados geologicos obtidos.

Como visto na evolução tectono-sedimentar, a fase em que se formaram os depósitos aqui estudados caracteriza-se pelo declínio da atividade tectônica, pela peneplanização das áreas altas e pelo preenchimento nos baixios ou partes não entulhadas dos grábens pelas bacias lacustres, antecedendo a forte 
transgressão marinha do Cretáceo médio/superior.

Numa visão global da composição microflorística recuperada, inserida no contexto geológico supracitado, observa-se que sobre a superfície peneplanizada (horizonte erosivo discordante que marca o limite inferior do pacote estudado) iniciou-se uma deposição sob condições de ambiente subaquático continental, deduzida pela ausência de elementos do microplâncton marinho e presença de palinomorfos continentais. Além da presença de carapaças de conchostráceos e ostracodes não-marinhos. A riqueza em esporos e grãos de pólen, ligados à variedade do resíduo orgânico (cutículas + tecidos vegetais) e a uma microflora dominantemente gimnospérmica, sugerem depósitos em ambientes deltaico continental. A presença dos grãos de pólen inaperturados e monossacados, crescente em direção ao topo do Membro Upanema, sugere a ocorrência dc excelentes condições de drenagem durante sua deposição. As terras emersas, ou os deltas adjacentes deviam ser inicialmente secos ou drenados suficientemente para sustentar o domínio de uma flora de gimnospermas (Araucariaceae, Cheirolepidiaceae, Gnetaceae). Um aspecto relevante é a virtual ausência ou a relativa insignificância, na seção, de grãos de pólen bissacados, que raramente excedem $3 \%$ do total contado. Esta escassez e/ou ausência indica que o número de coníferas na planície costeira, frente deltaica ou pântanos (subambientes inferidos para o Membro Upanema por: SouzA, 1982; Costa et alii, 1987; LimA, 1987; Ponte \& MAIA, 1987), era extremamente baixo na bacia ou nas suas proximidades. A presença de condições subaquáticas (lacustres) localizadas é atestada pela maior diversidade e abundância de palinomorfos; além de carapaças de conchostráceos e palinofácies I (abundantes em alguns níveis).

Conchostráceos são atualmente encontrados em poças temporárias, áreas rasas e lagos, seja em climas úmidos ou semi-áridos ( $\mathrm{TASCH}_{\mathrm{ASC}}$ 1980).

Numa sucessão normal e gradacional em sistema dominantemente lacustre, iniciou-se a deposição das Camadas Ponta de Tubarão. Nestes estratos observa-se, em alguns poços, que os esporos sofrem sutil queda percentual em relação ao topo do Membro Upanema, sugerindo decréscimo das condições de umidade. Contudo, em alguns níveis ocorrem concentrações significativas dos mesmos, indicando a existência, nesta fase, de nichos relativamente mais úmidos de deposição ao redor do lago. O contínuo domínio dos grupos xerofíticos indica que as condições gerais eram continuamente áridas ou semi-áridas. O domínio dos Classopollis nestas camadas encontra explicação nas constatações de que as plantas produtoras destes grãos de pólen também floresciam em 
estratos lamosos (Oldham, 1976; Retallak \& Dilcher, 1986), lagunas salobras (Doludenko, 1978; Retallak \& Dilcher, 1986), e lagunas tropicais hipersalinas (Daghlian \& Person, 1977; Perkins et alii, 1979; Retallak \& Dilcher, 1986). A presença repetida ou cíclica de níveis carbonáticos implica oscilações eustáticas da lâmina d'água culminando em fases de ressecamento do sistema lacustre e eventuais períodos de exposição subaérea (indicados por estruturas em teepee). Condições pantanosas também podem ser aventadas para partes localizadas das Camadas Ponta do Tubarão, como parece indicar o aumento de estratos carbonosos e a presença de níveis extremamente delgados de carvão. A presença de algas (Botryococcus), matéria orgânica amorfa (palinofácies IV), e ausência de elementos marinhos são geralmente indicativas de habitats não-marinhos de águas estagnadas, rasas e mais ou menos mesotroficas, o que é também atestado pela riqueza em ostracodes.

Estudos prévios têm considerado hipóteses de que as Camadas Ponta do Tubarão tenham sido sedimentadas em ambientes de planície marginal de sistemas lacustres (Lima, 1987) e/ou planície de maré do tipo "sabkhas", formadoras da plataforma argilo-carbonática, como sugerido por CARVALHO (1985) para a deposição das Camadas Trairi, da Bacia do Ceará, correlatas às Camadas Ponta do Tubarão. De acordo com THL (1978), este ambiente resulta de um sistema deposicional litorâneo de baixa energia, dominado por planícies de maré, sob clima árido ou semi-árido, com pequenas variações de relevo.

Assoreando o lago representado pelos sedimentos dominantemente argilosos e carbonáticos das Camadas Ponta do Tubarão, depositaram-se clásticos mais grosseiros e folhelhos de água mais profunda do Membro Galinhos, evidenciando progradação máxima.

A presença de esporos das famílias Schizaeaceae e Gleicheniaceae indica a existência de ambientes pantanosos ou brejos, bem como de ambientes abertos bem drenados, à semelhança dos habitats atuais das samambaias destas famílias (TRYON \& TRYON, 1982).

LIMA, 1987; Ponte \& MAIA, 1987; Costa et alii 1987, consideram que os depósitos do Membro Galinhos refletem progradações deltaicas. Lima (1987) postula que se trata de deltas lacustres do tipo GLBBeRT, em resposta a oscilações tectônicas e climáticas ao final do tempo Alagoas.

Um quadro do sistema deposicional ocorrido na "bacia Alagamar" $\varepsilon$, a grosso modo, sugerido na figura 30 . Resumidamente, teríamos um ambiente de terras baixas, com planícies provavelmente marcadas por lagos, charcos e pântanos, e atravessada por cursos d'água, de modo geral altamente sinuosos, em função do baixo gradiente, com área montanhosa distante. 


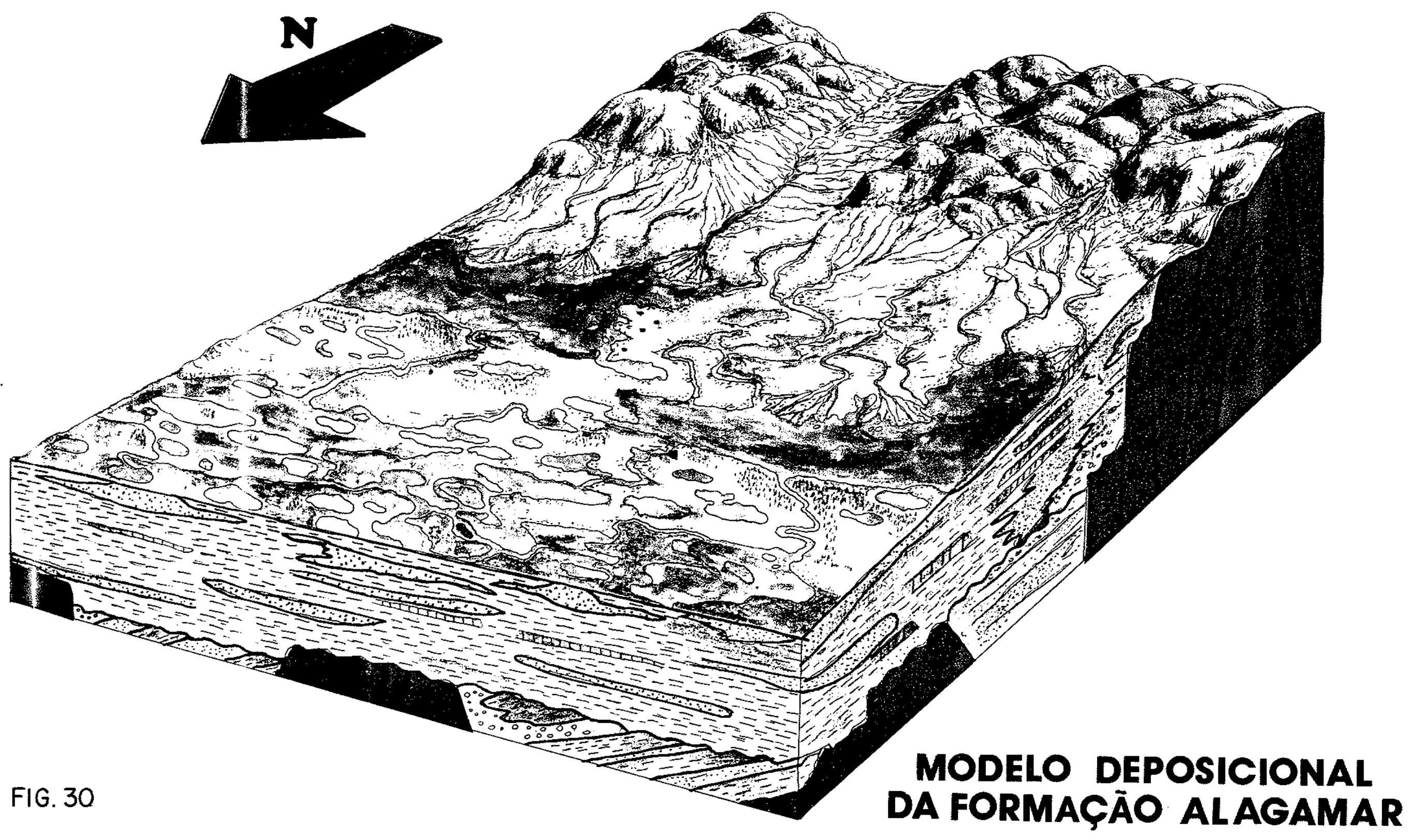


Dinoflagelados marinhos e microforaminíferos quitinosos ocorrem na parte mais superior da seção, já na base das formações Açu/Ubarana, indicando influência marinha relativamente contínua nesta parte da seção. Embora a maioria das amostras estudadas apresente baixas porcentagens destes elementos (menos que $3 \%$ ), algumas mostram picos de ate $20 \%$, indicando que as condiçðes marinhas flutuavam em grande escala. $O$ elevado número de grãos de pólen e esporos associados aos dinoflagelados, neste caso, provavelmente indicam condições salobras.

A abundância de palinomorfos de origem terrestre, aliados aos palinomacerais indicam uma posição muito próxima da linha de costa nesta parte da seção. Contudo a pujança dos folhelhos e a presença de dinoflagelados sugere deposição em ambiente marinho próximo à costa; ou em corpos de água parada comunicando-se intermitentemente com o mar através de canais de maré (lagunas?).

Em resumo, a presença esporádica de delgados níveis de carvão, aliada a presença de algas do gênero Botryococcus e de fragmentos quitinosos de carapaças de conchostráceos, assim como a ausência de qualquer elemento do microplâncton marinho, permitem inferir um ambiente de deposição essencialmente não-marinho para a Formação Alagamar.

Contrapondo-se a estas evidências, estudos geoquímicos (MELLo ET.ALII, 1984, 1988; Mello \& MAXWELL, 1991) calcados em feições isotópicas e moleculares (biomarcadores), têm considerado a existência de ambiente marinho evaporítico à época da sedimentação das Camadas Ponta do Tubarão e Membro Galinhos.

Avalia-se neste trabalho que tais dados refletem muito mais aumento de salinidade da água do lago (concentração de sais por evaporação), que propriamente ingressão do mar.

As condições marinhas iniciam-se na deposição dos estratos das formações Açu/Ubarana, evidenciadas pela presença de dinoflagelados e carapaças quitinosas de microforaminíferos. Corroborando estes dados, VIVIERS (COM. PEss.) em estudos de dezenas de poços da bacia encontra elementos micropaleontológicos marinhos apenas nos depósitos acima da discordância erosional que separa a Formação Alagamar das formações Açu/Ubarana.

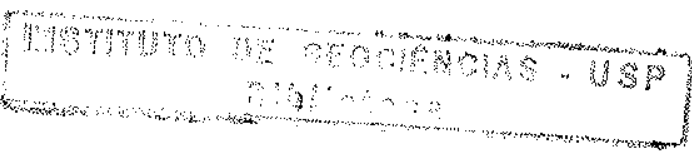




\section{4) Ensaio Paleogeográfico}

Informações de ordem paleontológica, sedimentológica e tectônica para o Alagoas em particular e para o Cretáceo brasileiro como um todo, têm sido interpretadas na literatura. Reflexões sobre o paleoambiente no Cretáceo brasileiro a nível geral foram feitos por Petri (1983, 1987), Lima (1983), Viana (1986) e Regali (1986). Estes autores sugerem que o clima no tempo Alagoas (Aptiano) era quente e seco com períodos mais úmidos, similar à vegetação vivente que floresce atualmente abaixo dos $25^{\circ} \mathrm{N}$ de latitude.

Regali \& Gonzaga (1985), Viviers \& Regali (1985) e Castro et alii (1987), discutiram generalizadamente os paleoambientes, com base nos palinomorfos e foraminíferos bentônicos da Bacia Potiguar.

No presente estudo, aproximadamente 70 gêneros de esporos foram observados, sugerindo uma diversificada flora de samambaias, licopodios e briófitas nas porções úmidas do habitat. A vegetação dominante consistia de gimnospermas (rimulados, inaperturados, monossacados e poliplicados) florescendo num clima relativamente quente e seco do sistema flúvio-deltaicolacustre da Formação Alagamar. Os grãos de polen produzidos pelas angiospermas formam um componente bem reduzido de toda a palinoflora. Os grãos de pólen bissacados de gimnospermas são interpretados como originários parcialmente das porções melhor drenadas deste sistema, e das regiōes mais elevadas, distantes, situadas provavelmente ao sul.

A alta diversidade da vegetação encontrada nestas camadas sugere um clima com altas temperaturas, um tanto quanto similar aos climas contemporâneos de baixas latitudes e ao da própria posição atual da bacia.

Mapas paleogeográficos (BRIDEN et alii, 1974; HABICHT, 1979), mostram que durante o Aptiano o nordeste brasileiro parece ter estado aproximadamente na mesma posição em relação ao equador que a atual, indicando que as condições climáticas não deveriam ser tão diferentes das de hoje.

Evidências de uma origem tropical das angiospermas e subseqüuente migração em direção aos pólos, como sugerido por AXELROD (1952, 1959, 1970), RAVEN \& Axelrod (1974) e Hughes (1977), são consistentes com a presença pouco diversificada dos grãos de pólen de angiospermas ora verificadas.

Pode-se afirmar que no Membro Upanema a sedimentação ocorreu primordialmente em ambiente flúvio-deltaico; que nas Camadas Ponta do Tubarão dominaram ambientes lacustres e que no Membro Galinhos a deposição foi 
essencialmente deltaico-lacuștre. Entretanto, deduz-se pela composição microflorística da seção que todos estes ambientes estão documentados ao longo de toda a seção.

Discutem-se abaixo, os palinomorfos presentes em correlação com suas possíveis produtoras, e os nichos particulares em que as mesmas floresciam no sistema flúvio-deltaico-lacustre da Formação Alagamar.

\section{- A Cobertura vegetal na área dominada por deltas}

Atualmente, em deltas de climas temperados, são geralmente as plantas tipicamente herbáceas que colonizam as áreas abertas. Porém, em regiões tropicais, estas áreas virgens, são ocupadas por várias espécies de árvores de mangue, devido ao seu mecanismo vivíparo de dispersão, à sua adaptabilidade em sobreviver a rápidos soterramentos, e à resistência a altas salinidades (SHANE, 1984).

Apesar de não se considerar como ambiente próximo a costa, este quadro parece ser bastante próximo ao existente no início da deposição Alagamar, numa fase pós-peneplanização, e que persistiu mais restritamente até o final do Ciclo Alagoas.

Por outro lado, espécies viventes de mangue pertencem às angiospermas, um grupo de plantas que não dominava o registro fóssil de baixas latitudes antes do Cenomaniano. Ademais, parece improvável que os mangues tenham existido antes do Mioceno (MớLER, 1981).

As mais antigas angiospermas nos depósitos brasileiros, bem como as poucas formas primitivas da Bacia Potiguar, eram muito provavelmente excedidas pelas numerosas samambaias que integravam as plantas que colonizaram e ocuparam áreas próximas ou dentro do delta.

Talvez tenham existido árvores de aptianas não angiospérmicas, com hábitos similares às viventes nos mangues atuais e que podem futuramente vir a ser identificadas em paleodeltas através de pesquisas palinológicas e paleobotânicas. Estas deverianı ser árvores tolerantes a altas salinidades e a flutuações de profundidade da lâmina d'água (quadro similar ao deduzido para a deposição Galinhos).

As angiospermas certamente não constituíam a flora primária da área dos deltas da Formação Alagamar. Elas parecem ter sido um pequeno componente durante o Aptiano-eoAlbiano na região. A cobertura vegetal muito provavelmente era dominada por gimnospermas e pteridofitas, provavelmente 
arbóreas e/ou herbáceas e a margem destes deltas teriam provavelmente aparência similar a de alguns deltas atuais de clima temperado, sem mangues.

As plantas produtoras de grãos de pólen do gênero Classopollis têm sido concebidas como do tipo de mangue (BatTen, 1975). Outros autores têm tamberm considerado que as plantas-mães destes grãos habitavam as faixas costeiras (WALL, 1965; Hughes \& MOODY-STUART, 1966; HUGHEs, 1973), enquanto alguns sugerem uma comunidade florística vivendo desde a planície até as terras altas (Medus \& Pons, 1967; Vakhrameev, 1970; Srivastava, 1977). Outras interpretações (UPChURCh \& Dorue, 1981) consideram que Classopollis não pode ser usado isoladamente para indicar ambientes costeiros.

Existe abundância de Classopollis nos sedimentos brasileiros do Aptiano. Como eștes sedimentos, na Bacia Potiguar, não afloram, não se observou até o momento a presença de raízes ou troncos de plantas nos mesmos. Ademais, apesar da presença freqüente de fragmentos de caule e folhas e níveis de carvão nestes depósitos, observados em testemunhos, (LiMA, COM. PESs., 1992), inexistem estudos paleobotânicos desta formação.

Conclui-se desse modo que a vegetação que colonizou estas áreas deltaicas não era similar às atuais plantas de mangue. Contudo, a melhor concepção para estas colonizadoras seria a de plantas herbáceas, eurialinas, que poderiam estar relacionadas aos licopódios, samambaias e/ou a árvores relacionadas às Cheirolepidiaceae e Ephedrales/Gnetales, já que os rimulados e poliplicados dominam a associação. Como estão bem representadas e não possuem hábitos de mangue, as coníferas e as pteridofitas, parecem ser as outras opções disponíveis, na colonização desta área deltaica continental.

\section{- Vegetação das áreas baixas no domínio lacustre}

Além da cobertura vegetal da área de frente deltaica, presume-se que uma vegetação mista de matas e pântanos ocupava as áreas prodeltaicas e lacustres, mais úmidas. Riachos distributários e canais deltaicos, provavelmente meandrantes, cruzavam as áreas próximas ao lago. Devido a isto é provável que esta vegetação mista tenha contribuído com a maioria dos grãos de esporos e pólen identificados neste estudo. A maior ocorrência de grupos particulares, localizados nos poços, seja de pteridófitas, seja de gimnospermas, provavelmente derivaram desta área. A pobreza em grãos de pólen de angiospermas sugere que muito poucas plantas com flores ocupavam esta área. Por outro lado, a maioria dos palinomorfos documentam uma alta diversificação das samambaias, e em 
menor escala de licopodiáceas e briofitas, todas provavelmente abundantes tanto na planície de inundação como nas bordas do lago. Áreas protegidas, rasas e quentes, nas bordas e no interior do lago eram povoadas pelos conchostráceos e ostracodes.

\section{- Florestas das terras altas}

Supõe-se que alimentando o sistema deltaico, provavelmente em direção ao sul, existiam terras altas, as quais deveriam estar a poucas dezenas de quilômetros, a julgar pelo afluxo persistente de sedimentos arenosos e conglomeráticos na área estudada. Estas áreas altas (Fig. 30) provavelmente sustentavam uma floresta de coníferas, que forneceram os grãos de pólen dos gêneros Vitreisporites, Cedripites, Callialasporites e Araucariacites. Apesar dos grãos bissacados destas coníferas serem pouco significativos em termos percentuais, eles atestam a presença destas plantas e de porções secas e emersas na região. Como possivelmente estas terras emersas adentravam o sistema deltaico, a vegetação de coníferas, invadindo estas áreas, propiciava a fonte das formas sacadas detectadas, nas contagens, nas áreas mais distais dos deltas e interiores do lago. Infelizmente não existem registros identificados de folhas, raízes, ou troncos nos depósitos desta idade no nordeste brasileiro, que pudessem documentar a presença das macrofloras aqui aventadas. Restos de coníferas têm sido reportados de depósitos mais antigos.

Pode-se argumentar que estes grãos de pólen de coníferas foram carreados ao longo de distributários, ou que os grãos de pólen foram transportados a longa distância pelo vento ou água. Contudo, tem sido demonstrado que partes aéreas das plantas são depositadas relativamente próximas da planta-mãe (SPICER, 1980, 1981). A maioria dos palinomorfos contados devem ter vindo de poucos quilômetros de onde foram sepultados (isto se aplica mais diretamente aos esporos). Traverse \& Ginsberg (1966, p.428) afirmam que "... deve-se assinalar que a grande massa de grãos de pólen de Pinus, ou qualquer outro grão de pólen, cai dentro de poucas milhas das árvores de origem, a menos que o ar esteja muito turbulento." Eles também indicam que a deposição de grãos de pólen de pinus e geralmente maior próximo à fonte, decrescendo à medida que se afasta da mesma. Tschudy (1969B, P. 80) diz que "...experimentos com chuvas de grãos de pólen atuais sugerem que a maioria dos grãos de pólen que ocorrem como fósseis têm sido transportados a curtas distâncias antes de se incorporarem aos sedimentos". Além disso cita que plantas crescendo dentro de uma bacia, ou 
numa área de deposição, podem depositar seus grãos de pólen ou esporos praticamente in situ. A aplicação destes critérios foi usada aqui para interpretar os tipos de vegetação das áreas dentro e nas proximidades do sistema deltaicoflúvio-lacustre da Formação Alagamar. Obviamente, prevê-se que uma fração dos grãos de pólen e esporos contados são provenientes de grandes distâncias.

\section{- Domínio marinho e salobro}

Dinoflagelados e microforaminíferos quitinosos ocorrem nas amostras do topo da seção, acima do nível de discordância que limita litoestratigraficamente a Formação Alagamar. Embora documentada em apenas três poços e em baixas porcentagens, suas presenças indicam que as bases das formações Açu/ Ubarana registram episódicas inundações por águas do mar. Sugerem um baixo relevo, próximo ao nível do mar provavelmente representando ambientes de águas salobras.

Finalmente, em discussões versando sobre paleoclima, paleoecologia e paleogeografia de uma dada região, com os conhecimentos atuais, não pode prescindir de pelo menos menções sobre possíveis influências de fatores extraterrestres. Vários autores têm especulado sobre a possível influência destes fatores extraterrestres no paleoclima da Terra.

GribBin (1979), em estudos paleoclimáticos, discute com propriedade as mudanças climáticas em função de parâmetros como flutuações na radiação solar, explosões solares, estações cósmicas e variações na excentricidade da órbita terrestre. Alvarez et alii $(1980,1982)$, em estudos no limite Cretáceo/Terciário, apresentam evidências de que eventos extraterrestres influenciaram o paleoclima terrestre.

Consideramos contudo, que estes eventos são, no momento, especulativos e de difícil demonstração. E que ainda mais difícil é reconhecer seus efeitos na flora e fauna terrestre através do tempo geológico. Por conseguinte, nenhuma abordagem, além destas considerações, pode ser feita no sentido de documentar um possível evento desta natureza afetando o clima e a palinoflora dos depósitos aptianos da Bacia Potiguar. 


\section{UI- AFINIDADES BOTÂNICAS DA ASSOCIAÇÃO MICROFLORÍSTICA}

As afinidades botânicas de gêneros e especcies paleopalinológicas têm sido estabelecidas através de comparações morfológicas, ou seja, pela semelhança com palinomorfos atuais ou pelo seu reconhecimento in situ em meio aos megafósseis vegetais. De acordo com SiNGH (1964), os grãos de pólen e esporos fósseis só podem ser correlacionados seguramente com sua planta-mãe quando obtidos de frutificações ligadas aos restos daquela.

Como esperado, as opiniões dos diferentes autores com respeito a tais afinidades são conflitantes. Procurou-se aqui apresentar as conclusões mais aceitas na literatura, inclusive nos casos onde existem mais de uma afinidade freqüentemente atribuída.

As interpretações paleoambientais e paleoecológicas foram baseadas nas associações entre os grãos de pólen e esporos e suas respectivas plantas-mãe. Entretanto essas correlaçðes guardam elevado grau de incerteza, particularmente no caso da Formação Alagamar, onde desconhecem-se macrofosseis vegetais.

A figura 31 mostra as correlações definidas entre os grãos de pólen e esporos identificados ua associação e seus tipos vegetais correspondentes, bem como o tipo de estrato da planta e seus hábitats atuais. Tais dados levaram em conta a opinião de diversos autores e foram considerados quando das interpretações ambientais e paleoecológicas. 


\begin{tabular}{|c|c|c|c|c|c|}
\hline orvrah̆o & ORDEM & FantLra & DÊNERO & & \\
\hline \multirow[b]{2}{*}{ ERYOPHITA } & \multirow[b]{2}{*}{ SPHAGNALES } & \multirow[b]{2}{*}{ SPHAGNACEAE } & \multirow[b]{2}{*}{$\begin{array}{l}\text { Clnoutrllotes } \\
\text { Antulapartiton } \\
\text { Aequiterfradteos }\end{array}$} & $\begin{array}{l}\text { Estreto } \\
\text { de vequteoäo }\end{array}$ & cuma \\
\hline & & & & harbiono & tropleal imtao \\
\hline \multirow[t]{12}{*}{ PTERDOPHYTA } & \multirow[t]{9}{*}{ FILICALES } & SCHIZAEACEAE & 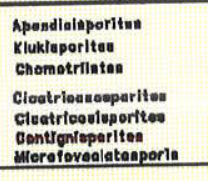 & nerbáaoo & $\begin{array}{l}\text { traploat } \\
\text { eubtropioal }\end{array}$ \\
\hline & & CYATHEACEAE & 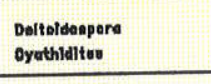 & arbiareo & $\begin{array}{l}\text { tropleal } \\
\text { oubtropical }\end{array}$ \\
\hline & & GLETCHENIACEAE & 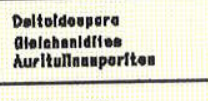 & norbiose & $\begin{array}{c}\text { Eraplaal } \\
\text { ouplaal } \\
\text { oubtrapea }\end{array}$ \\
\hline & & OSMUNDACEAE & 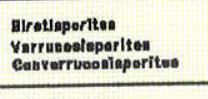 & Herbatos & $\begin{array}{c}\text { tropleal } \\
\text { emeerede }\end{array}$ \\
\hline & & MATONIACEAE & 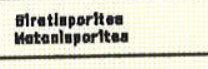 & herbieso & sropleal \\
\hline & & POL.YPODIACEAE & 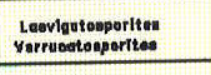 & & $\begin{array}{l}\text { traptaal } \\
\text { euptrapiose }\end{array}$ \\
\hline & & DrCKSONIACEAE & $\begin{array}{l}\text { Eyathleltos } \\
\text { Dolterdeupora }\end{array}$ & arbiras & $\begin{array}{l}\text { troploal } \\
\text { tomporade }\end{array}$ \\
\hline & & DICKSONIACEAE & Trlllabouparitao & arbares & troptont \\
\hline & & INCERTAE SEDIS & $\begin{array}{l}\text { Muroupere } \\
\text { Pllouinporiteo }\end{array}$ & & \\
\hline & SELAGINELLALES & SELAGINELLACEAE & 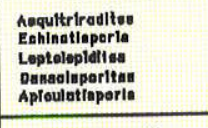 & herbaoes & tropleal \\
\hline & LYCOPODIALES & LYCOPODIACEAE & 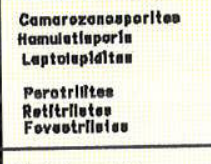 & norbioes & $\begin{array}{l}\text { traptaal } \\
\text { suberaptaal }\end{array}$ \\
\hline & MARSILEALES & MARSILIACEAE & 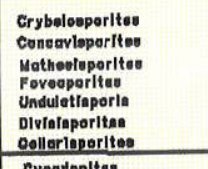 & $\begin{array}{l}\text { torbiacos } \\
\text { (equátlous) }\end{array}$ & $\begin{array}{c}\text { tropleal } \\
\text { auberoploal }\end{array}$ \\
\hline \multirow[t]{8}{*}{ FYMNOSPERMAE } & \multirow[t]{2}{*}{ CYCADALES } & CYGADACEAE & 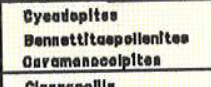 & arboreo & troploal/aubtroplaal \\
\hline & & CHEIROLEPIDACEAE & $\begin{array}{l}\text { Clausopollits } \\
\text { Oarallaria }\end{array}$ & arbires & traploal/oubsropleal \\
\hline & \multirow[t]{3}{*}{ CONIFERAE } & $\begin{array}{l}\text { TAXODIACEAE/TAXACEAE } \\
\text { /OWFRISSACENE }\end{array}$ & 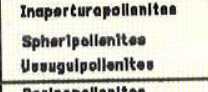 & lonthoodarboroo & \\
\hline & & TAXODIACEAE & 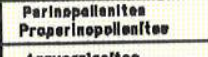 & lonthoos/arbiras & \\
\hline & & ARAUCARIACEAE & 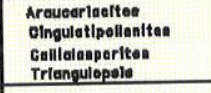 & arbires & tomperado \\
\hline & \multirow[t]{3}{*}{ CAYTONIALES } & CAYTONIACEAE & Vitraloporiten & arbioras & tamporad D \\
\hline & & PINACEAE & \begin{tabular}{|l}
$\begin{array}{l}\text { Altaperitios } \\
\text { Gedrfilteo }\end{array}$ \\
\end{tabular} & arbäreo/arbuative & tomperude \\
\hline & & $\begin{array}{c}\text { EPHEDRACEAE } \\
\text { GNETACEAE } \\
\text { WELWITSCHIAGEAE } \\
\end{array}$ & 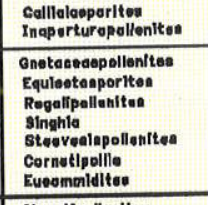 & $\begin{array}{c}\text { arboreo } \\
\text { lonkeso } \\
\text { erbuettro } \\
\text { eomitrapadelra }\end{array}$ & tomparodo \\
\hline \multirow[t]{7}{*}{ ANOIOSPERMAE } & \multirow{6}{*}{$\begin{array}{l}\text { LILIIFLORAE } \\
\text { GERANIALES } \\
\text { SALICALES } \\
\text { TUBIFLORAE } \\
\text { CENTROSPERMAE } \\
\text { PIPERALES } \\
\text { PRINCIPES } \\
\text { (?) }\end{array}$} & LILIACEAE & 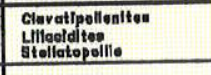 & horbiogo & $\begin{array}{l}\text { troptad } \\
\text { temperede }\end{array}$ \\
\hline & & $\begin{array}{c}\text { EUPHORBIACEAE } \\
\text { SALICAGEAE }\end{array}$ & stallatopalllı & & tropleal \\
\hline & & $\begin{array}{l}\text { SALICACEAE } \\
\text { SOLANACEAE } \\
\end{array}$ & Rousou & arbo,raram,arbuet. & tomporado \\
\hline & & \begin{tabular}{|l} 
SOLANACEAE \\
CNRTOPM/AMWRANTHACENE
\end{tabular} & strlatopollia & lorb.arbuat.arb. & tropleal \\
\hline & & 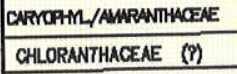 & Crataoolopariton & & \\
\hline & & GUNNERACEAE & 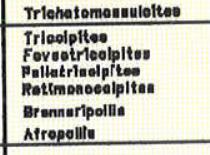 & aquátleo & tropleal/subtropieal \\
\hline & DICOTYLEDONEAE(?) & & \begin{tabular}{|l|} 
Quadrloolpliteo \\
Penutrotapitao \\
Reyres \\
\end{tabular} & & \\
\hline
\end{tabular}




\section{1) Briófitas e Pteridófitas}

Os grãos de esporos relacionados às briofitas e pteridofitas constituem um dos importantes elementos da associação, presentes em todos os níveis da seção analisada. Incluem-se aqui os grãos de esporos monoletes e triletes, representados por $\mathbf{4 2}$ gêneros e 73 especies correspondendo às seguintes famílias botânicas:

(a) triletes lisos - as plantas produtoras destes grãos são briofitas ou pteridófitas ligadas às famílias Cyatheaceae, Sphagnaceae, Gleicheniaceae, Matoniaceae, Osmundaceae, Dicksoniaceae;

(b) triletes ornamentados - grupo extremamente variado, com representantes principalmente nas pteridofitas, sendo raras as formas ligadas às briofitas. São correlacionáveis, além das famílias citadas para os triletes lisos, com às famílias Sellaginelaceae, Marsileaceae, Lycopodiaceae e Schizeaceae. Esta última é a mais importante família representante da flora de pteriđofitas no Cretáceo Inferior a médio, que inclui esporos cicatricosos, reticulados, rugulados e alguns verrucados.

(c) triletes perisporados - correlacionáveis à família Marsileaceae, que representa formas aquáticas.

(d) monoletes - também representantes das pteridofitas, principalmente das famńlias Polypodiaceae e Schizeaceae.

CYATHEACEAE - Samambaias de grande porte (estrato arboreo). Estão confinadas preferencialmente nas florestas das montanhas de regiōes tropicais a subtropicais, com algumas espécies em áreas temperadas, especialmente no hemisfério sul. Vivem principalmente em florestas úmidas. No nordeste brasileiro vivem nas sombras das matas serranas.

DICKSONLACEAE - Samambaias arborescentes, a exemplo das Cyatheaceae, e importantes fontes de xaxim. Embora a maioria das especies sejam tropicais, umas poucas são encontradas também em regiōes temperadas. 
GLEICHENIACEAE - Plantas constituintes do estrato herbáceo. São cosmopolitas, encontradas nas regioes tropicais e subtropicais; preferem de modo geral habitat seco. São as samambaias mais freqüentes no Brasil todo; ocorrem no Nordeste habitando as encostas ensolaradas das regiões serranas.

LYCOPODIACEAE - Plantas de pequeno porte (estrato herbáceo). Cosmopolitas, são encontradas atualmente em hábitats de clima tropical, temperado e até ártico. Porém, a exemplo de outras pteridófitas, geralmente preferem hábitats úmidos e sombreados. Preferencialmente ocorrem em florestas tropicais a subtropicais. Distribuem-se por todo o Brasil (gênero Lycopodium), inclusive no Nordeste, onde habitam as serras.

MARSILEACEAE - Plantas constituintes do estrato herbáceo. Apresentam vasta distribuição, quase cosmopolita (rara na América do Norte). Possuem hábito aquático, vivendo inteiramente submersas ou crescendo em terrenos brejosos, caso em que as folhas são aéreas.

MATONIACEAE - Constituintes do estrato herbáceo. Atualmente são representadas pelos gêneros Phanerosorus e Matonia, e estão confinadas à Malásia, Bornéo e Nova-Guiné. Trata-se de samambaias termófilas, porém praticamente desaparecidas da flora tropical atual.

OSMUNDACEAE - Família habitante das regiões tropicais a temperadas, desenvolve-se preferencialmente em matas fechadas e florestas úmidas. Plantas com hábito geralmente terrestre ou subaquático, raramente arborescentes.

SCHIZEACEAE - Plantas constituintes do estrato herbáceo. Habitam preferencialmente as regióes tropicais e subtropicais, embora algumas espécies de Schizea e Ligodium sejam encontradas próximos aos pólos. Esta família atingiu seu clímax em abundância e diversidade no Cretáceo. Os gêneros Schizaea, Lygodium e Aneriia acham-se representados no Brasil, sendo os dois últimos encontrados no Nordeste, onde habitam as serras.

SELAGINELLACEAE - Plantas de pequeno porte (estrato herbáceo). Cosmopolita, esta família é preferencialmente tropical e melhor adaptada a locais levemente úmidos e sombreados. Distribuem-se por todo o Brasil; no Nordeste coabita com as espécies xerófilas na caatinga e com as 
higrófilas nas serras.

SPHAGNACEAE - Musgos cosmopolitas, constituintes do estrato herbáceo. Ocorrem numa grande variedade de hábitats, terrestres ou subaquáticos. São especialmente comuns como plantas pioneiras em rochas nuas ou em superfícies terrestres de regióes úmidas. Vivem em solos ácidos, sujeitos a inundações, tais como atoleiros, brejos, charcos e pântanos. São encontrados também em lagoas rasas e lagos, formando densas e extensas colonias e até turfeiras. Indicam áreas de terras baixas e úmidas. $\mathrm{Na}$ região Nordeste, habitam atualmente o alto das serras. Existem mais de 300 espécies distribuídas no mundo todo.

\section{2) Gimnospermas}

Os palinomorfos afins as gimnospermas são os elementos dominantes na associação microflorística analisada. Incluem os grãos de pólen monossacados, bissacados, inaperturados, poliplicados, rimulados e a grande maioria dos monocolpados. Estão representados na associação por 29 gêneros e 90 espécies, correspondentes às seguintes famílias botânicas:

(a) monossacados - as plantas produtoras destes grãos são principalmente coníferas das famílias Podocarpaceae e Araucariaceae;

(b) bissacados - grãos produzidos pelas plantas das famílias Podocarpaceae, Caytoniaceae e Pinaceae;

(c) inaperturados - grupo de presença significativa na associação. Estão ligados às famílias Cupressaceae, Taxaceae, Taxodiaceae e Araucariaceae;

(d) poliplicados - grupo gom presença marcante em todos os níveis da şę̧ão. Correspondem às gimnospermas da Ordem Gnetales, das famílias Gnetaceae e Ephedraceae;

(e) monocolpados - embora alguns morfotipos sejam atribuídos com segurança às angiospermas, a maioria dos grãos de pólen monocolpados são de origem gimnospérmica, correspondendo ao complexo Cycadales, Bennettitales e Ginkgoales; 
(f) rimulados - grupo mais abundante em toda a associação, e em todos os níveis. Trata-se de grãos produzidos pelas Cheirolepidiaceae, uma famflia extinta de coníferas.

ARAUCARIACEAE - Plantas arborreas de grande porte que habitam as zonas mais frias, mesmo nos trópicos. Espécies exclusivas do Hemisfério Sul, com representantes na América do Sul (Brasil, Chile, Argentina) e com um gênero presente na Austrália.

CAYTONIACEAE - Única família de um grupo inteiramente fóssil, aparentemente extinto no Cretáceo Superior. Apresenta as mesmas características das pináceas.

CHEIROEEPIDIACEAE - Estas plantas atingiram seu apogeu no cinturão árido. Estas coníferas preferiam climas tropicais a subtropicais, um tanto áridos. Cresciam não apenas ao longo da costa, mas também no interior, nos planos e encostas das terras altas.

CYCADALES/BENNETTITALES/GINKGOALES - São plantas de porte arbóreo, semelhantes a palmeiras. Algumas espécies de cicadáceas ocorrem exclusivamente nas regiठ́es tropicais e subtropicais. Atualmente podem ser encontradas em regióes áridas, porém a presença abundante de Nilssonia e Ptilophylum (impressões foliares) em camadas de carvão no mundo todo indica que as cicadáceas não estavam restritas às zonas áridas no passado, podendo indicar também climas subtropicais a temperados quentes. Condições aproximadamente idênticas são atribuídas às Ginkgoales, que conta com uma espécie viva (Ginkgo biloba), originária da China. As Bennettitales se extinguiram no Mesozóico, e acredita-se que tenham tido comportamento semelhante ao das cicadáceas. Este grupo atingiu seu zênite no Aptiano, relacionado aos climas quentes;

CUPRESSACEAE - Plantas lenhosas de porte arbóreo ou mais raramente arbustivas. São cosmopolitas, predominando atualmente nas regióes temperadas e frias do Hemisfério Norte. Apenas dois gêneros ocorrem nos Andes chilenos, um na África e alguns na Austrália. Nenhum é nativo no Brasil. 
EPHEDRACEAEJGNETACEAE - Trata-se de plantas lenhosas arbustivas ou semitrepadeiras. São encontradas como manchas espalhadas em regióes tanto quentes como muito frias, áridas, montanhosas, rochosas ou desérticas. Parecem ter se adaptado aos climas extremos, de quentes e frios de solos secos. As Ephedraceae possuem um único gênero (Ephedra) com espécies distribuídas em regiôes áridas da Zona Subtropical em ambos os hemisférios. No Brasil habita o Rio Grande do Sul.

PINACEAE - Plantas arboreas ou arbustivas lenhosas. Habitam as regióes montanhosas de clima temperado. São indicativas de climas frios ou de terras altas, úmidas. Possui seu centro de dispersão no Hemisfério Norte, existindo dois gêneros confinados à China. Ocorrem também na América do Norte, Ásia Oriental, Europa, Norte da África e nos Himalaias Ocidentais.

PODOCARPACEAE - Plantas de grande porte (estrato arboreo). Esta família, como as coníferas em geral, estão largamente distribuídas das regiōes árticas a subtropicais. Habitam preferencialmente áreas montanhosas das regiões temperadas. A maioria das espécies pertencem ao Hemisfério Sul (Brasil e África); atualmente no Brasil são encontradas nos estados do sul.

TAXACEAE - Plantas arbustivas lenhosas, ou árvores pequenas. Ocorre esporadicamente na Europa, Ásia, Norte da África e América do Norte e Central.

TAXODIACEAE - Plantas lenhosas arbóreas. Algumas espécies vivem em terrenos brejosos e alagadiços. Inclui atualmente o gênero Sequoia. Possui um gênero nativo no Hemisfério Sul (Tasmânia), sendo a maioria concentrada na África Oriental e na América do Norte.

\section{3) Angiospermas}

Os grãos de pólen afins às angiospermas são elementos menores na associação microflorística da Formação Alagamar. Este fato vem ao encontro das hipóteses que sustentam o surgimento das plantas angiospérmicas nesta faixa do tempo geológico. São ainda controversos os critérios para a determinação dos grãos de pólen indubitavelmente atribuíveis às angiospermas, mormente as 
mais primitivas. Contudo, são consideradas como pertencentes a este grupo plantas produtoras de grãos de pólen tricolpados, além de grande parte dos monocolpados e monosulcados. Estão representados na associação por 11 gêneros e 37 espécies, correspondentes às seguintes famńlias botânicas:

(a) monocolpados - As plantas produtoras deste tipo de grão estão geralmente associadas às famílias Liliaceae e Chlorantaceae;

(b) monosulcados - Os grãos identificados na associação estão ligados principalmente à familia Euphorbiaceae e Palmae.

(c) tricolpados - As plantas produtoras deste tipo de grão são geralmente as dicotiledôneas das famúlias Aceraceae, Salicaceae, Solanaceae e Gunneraceae.

ACERACEAE - Plantas dicotiledôneas, arbóreas ou arbustivas, geralmente indicativas de clima temperado. A grande maioria floresce nas regióes montanhosas ou terras altas do Hemisfério Norte, sendo presente nos E.U.A. e China Central.

CHLORANTACEAE - Trata-se de plantas arbustivas, herbáceas ou arbóreas. Famńlia tropical e subtropical, presente da América tropical, prolongando-se para norte até o México. Atualmente, no Brasil, vive nas matas pluviais tropicais.

EUPHORBLACEAE - Dicotiledôneas cosmopolitas, habitam preferencialmente as regiōes tropicais. Os maiores centros de dispersão encontramse nas Américas e África, sendo muito bem representada na flora brasileira. São plantas de hábito bastante variado, existindo ervas, subarbustos, árvores e também trepadeiras. Existem muitas espécies xerofilas vivendo em regið̄es áridas da África, onde ocupam nichos semelhantes aos das cactáceas na América. Na caatinga nordestina espécies deste gênero são conhecidas como pau-de-leite ou cipo-de-fogo.

GUNNERACEAE - Plantas aquáticas ou de terrenos brejosos e alagadiços. Largamente distribuídas em todos os continentes, porém predominantes no Hemisfério Sul. Possuem algumas espécies indígenas nos E.U.A. 
LILIACEAE - Angiospermas monocotiledôneas, geralmente herbáceas. Apresentam uma larga distribuição no mundo. São particularmente abundantes nas regiōes tropicais e temperadas quentes, apesar de poucas espécies atuais habitarem os tropicos.

PALMAE - Monocotiledôneas arbóreas, podendo atingir porte arbustivo. Habitam climas tropicais a subtropicais, com poucos representantes nas regiōes temperadas quentes; crescem em charcos, lagos rasos e rios meandrantes de muito baixo fluxo. Existem gêneros nos E.U.A. São freqüentes na Região Amazônica e presentes também no nordeste brasileiro.

SALICACEAE - Plantas de porte arbóreo, raramente arbustivas. Quase cosmopolita, tendo como centro de dispersão as atuais regiões temperadas e subárticas.

SOLANACEAE - Plantas herbáceas, arbustivas ou arbóreas, cosmopolitas e especialmente abundantes nas Américas. Essencialmente distribuídas na América tropical e América do Sul.

A partir dos dados fornecidos pelas afinidade botânicas, apesar das restriçōes mencionadas no início deste capítulo e do pequeno intervalo de tempo considerado, podemos avaliar que durante a deposição da Formação Alagamar a vegetação que circundava a bacia era bem distribuída, em seus estratos arbóreo e arbustivo, com o componente herbáceo também presente. A associação mostra uma abundância de grãos de pólen inaperturados e monossacados, especialmente os atribuíveis aos gêneros Araucariacites e Callialasporites, marcantes do estrato arbóreo. Também a considerável abundância de grãos de pólen poliplicados, principais representantes das plantas de porte arbustivo, assinalam a presença deste estrato da vegetação na área. $O$ estrato herbáceo ê representado apenas por alguns géneros de esporos triletes e monoletes. 


\section{UII- PALEOGEOGRAF IA EOCRETÁCEA DA PROUÍNCIA BORBOREMA}

\section{1) Considerações Iniciais}

Área intrigante no período Juro-Cretáceo da história geológica brasileira, a província da Borborema tem suscitado inúmeras investigações sob os mais variados aspectos. Os mais desafiadores, sem dúvida, envolvem duas questð̃es controversas, quais sejam: a) os depósitos sedimentares atualmente preservados são fragmentos remanescentes de uma única vasta bacia pretérita, ou não? (dada a existência de grande número de diminutas bacias e "manchas" sedimentares espalhadas por toda área em questão); b) quando teria ocorrido o início da influência marinha na sedimentação, e por qual caminho, ou caminhos, esse mar incipiente teria iniciado sua invasão até atingir o interior do continente? (dado o registro indubitável de influência marinha na Bacia do Araripe e provavelmente, até em áreas mais remotas do interior, como a Bacia Sanfranciscana).

A resposta a estas questões requer uma análise conjunta de dados e teorias nos campos da tectônica, estratigrafia e paleontologia. Curiosamente as informaçð̃es estratigráficas e paleontológicas são, neste caso, mais utilizadas nas argumentações que as tectônicas, deste modo é fornecido um quadro atualizado dos dados neste campo.

As considerações tectônicas são exigidas em função do consenso de que toda esta área foi fragmentada como resposta aos eventos tectônicos responsáveis pela separação dos atuais continentes Sul-Americano e Africano e a conseqüente formação do Atlântico. 
Os atuais modelos tectônicos, ou estudos versando sobre o mecanismo e a cinemática da separação dos continentes, consideram que a deriva iniciou-se no Juro-Cretáceo, (em função da idade dos depósitos). No entanto, divergem quanto ao modo pelo qual tal separação se processou, sendo postuladas as seguintes alternativas: 1) rotação horária da placa Sul-Americana em relação à Africana, ao redor de um polo, com formação inicial do rifte da margem leste e, um pouco mais tarde, do rifte da margem equatorial (RABINowrtz \& LABRECQUE, 1979); 2) rotação horária da placa Sul Americana em relação a Africana, ao redor de um polo (diferente do proposto por RABINOwITZ \& LABRECQUE, 1979), formando inicialmente o rifte da margem leste e posteriormente um rifte na margem equatorial (Szatmari et alii, 1984, 1985; Françolin \& SzatMari, 1987); 3) progressão simultânea de 2 riftes independentes: um na margem leste evoluindo de sul para norte, e outro na margem equatorial, se propagando de oeste para leste (CONCEÇÃo et alii, 1988); 4) existência de um único rifte, se propagando de sul para norte na margem leste até o Golfo do Niger, infletindo daí para oeste até o Platô de Demarara (Nứnnerg \& MớleR, 1991); 5) Françolin (1992) postulou a rotação horária do continente Sul-Americano em relação ao Africano, resultando em reativação direcional de falhas. Ao longo de falhas leste-oeste o movimento era levógiro, já ao longo das falhas de direção nordeste era dextrógiro. Estes movimentos teriam formado a fossa de Benue, a Bacia Potiguar e a Bacia do Rio do Peixe.

Outro aspecto a ser considerado na abordagem do problema é o tempo envolvido, pois a região esteve submetida a regimes tectônicos distintos nas fases rifte e transicional, com diferentes respostas sedimentares em cada fase, como discutido a seguir.

\section{a- Fase Neocomiana (Pré-Alagoas)}

Os registros sedimentares presentes na maior parte das bacias interiores, além da Bacia Potiguar, são de idade Rio da Serra a Aratu, intervalo considerado como de maior atividade tectônica.

Durante esta fase, a sedimentação foi totalmente continental e ocorreu a formação de todas as pequenas bacias do interior do nordeste, pois exceto pela Bacia do Araripe, nenhuma contém depósitos mais antigos que Rio da Serra (parte superior). Acredita-se aqui, em função da intensa movimentação 
sofrida pela região nesta época e pelas características das bacias (todas possuidoras de um ciclo sedimentar completo), que as mesmas não formavam neste tempo uma grande e única bacia, mas sim que, desde o início, eram bacias isoladas, com limites aproximadamente iguais aos atuais.

Esta região, que engloba o gráben de Pendência e as bacias do Médio Jaguaribe, Rio do Peixe e Araripe, é a área norte de MACHADo JR. et alii (1990), que segundo estes autores (Fig. 4, p.475) e contrário ao ora postulado, pelo menos em períodos menos ativos desta fase, estariam interligados.

\section{b- Fase Aptlana/Eoalbiana}

Em regime tectónico diferente, esta fase caracteriza-se pela quiescência em praticamente toda a Província Borborema, estando a evolução do rifteamento se desenvolvendo apenas na atual margem equatorial, principalmente a oeste da Bacia Potiguar.

A deposição ocorrida nesta fase encontra-se registrada apenas nas bacias Potiguar e Araripe. A sedimentação se deu inicialmente em ambientes continentais, e apenas no final desta fase é que são encontradas as primeiras evidências paleontológicas de camadas marinhas na região.

Da interpretação dos modelos tectônicos, com base nos dados da literatura, constata-se que: a) a formação do Atlântico Norte iniciou-se no decorrer do Jurássico; b) a individualização da América do Sul e África, com a conseqüente formação do Atlântico Sul teve seu início no decorrer do Eocretáceo, e; c) o Atlântico Equatorial instalou-se ao final do Aptiano/início do Albiano.

As hipóteses a respeito da entrada do mar no interior da Província Borborema, são basicamente os segintes: 1) BEURLEN (1963, 1966, 1971A, 1971B), e Braun (1966), advogaram que a entrada se deu através da Bacia do Parnaíba, principalmente pelas características marinhas da Formação Codo;. 2) BEURLEN (1971c), TinOCo \& MABEsoONE (1973) e BrTo (1976), postularam a entrada deste mar através da Bacia de Sergipe Alagoas, haseados na presença dos depósitos marinhos desta bacia; 3) LIMA (1978A) apresentou uma nova hipótese, sugerindo que o mar teria atingido o interior nordestino através da Bacia Potiguar, baseando-se principalmente na existência de blocos tectônicos orientados de modo a indicar uma ligação entre as duas bacias. 


\section{2) Nouos Dados}

LIMA (1978A) apresentou um quadro comparativo entre estas hipóteses da proveniência do mar no interior e discutiu em detalhe os prós e contras de cada uma. Grande parte dos dados não sofreram modificações desde então; contudo novas informações recentemente obtidas são ora apresentadas, objetivando fornecer mais subsídios e tornar mais consistente as conclusões sobre o problema.

Fatrhead (1986) constatou que a fossa de Benue, na África Ocidental, tamberm foi invadida por águas marinhas a partir do Albiano.

Os registros mais antigos de depósitos indubitávelmente marinhos no Brasil são os assinalados por BEuRLEN et alii (1987) e Koursoukos (1989) em depósitos da Bacia de Sergipe Alagoas, atribuídos ao neo-Aptiano.

Na margem equatorial, REgAl (1989D) estabeleceu a ecozona Subtilisphaera spp., de ambiente marinho bastante raso, no topo da biozona Sergipea variverrucata (P.270), de idade neo-aptiana.

Na Becia Potiguar, Regali \& Gonzaga (1982) e o presente trabalho, registram camadas marinhas no Eoalbiano.

$\mathrm{Na}$ Bacia do Araripe constatou-se existência de camadas não marinhas de idade Dom João, Rio da Serra (parte superior) e Aratu (parte inferior). No tocante ao ambiente deposicional, vários trabalhos têm sido apresentados, apesar de discutíveis, indicando camadas marinhas de idade neoaptiana nesta bacia, abaixo do Membro Romualdo (Arar \& Combra, 1990; Regal, 1990; Pons et alii, 1990).

Deu-se recentemente a descoberta do remanescente sedimentar do Riacho do Padre, no município de Padre Marcos, Estado do Piauí, em posição geograficamente intermediária entre as Bacias do Araripe e Parnaíba (PonTE et alii, 1991). Sedimentos, oriundos desta localidade, analisados pelo autor deste trabalho, revelaram-se estéreis em palinomorfos. Além disso, apesar de conter moldes de conchostráceos e ostracodes visíveis no campo, análises laboratoriais, realizadas por micropaleontólogos da PETROBRÁs, se revelaram estéreis também sob estes métodos. Em termos litológicos, tais sedimentos, assemelham-se bastante aos folhelhos do Membro Crato da Formação Santana.

КАттAн (1992), baseada em datações palinologicas e presença de radiolários, postulou um ambiente marinho de idade albiana para as camadas superiores do Grupo Areado, da Bacia Sanfranciscana.

Françolin (1992) concluiu que as bacias do Rio do Peixe, Potiguar e a Fossa de Benue são o resultado de um mesmo evento tectônico ligado a 
formação do Atlântico.

\section{3) Discussão}

Com a incorporação dos dados mais recentes (pós- LIMA 1978A), supracitados, na discussão, observa-se que continuam a surgir evidências que apontam ora para uma hipótese ora para outra, a saber:

Quanto à instalação do mar na margem equatorial, os dados tectônicos, sedimentológicos e paleontológicos apontam de modo unânime para a faixa de idade entre o neo-Aptiano e o eoAlbiano. Contudo, em relação ao sentido da abertura, as hipóteses tectônicas postulam que ela teria ocorrido, ou de oeste para leste (a mais aceita), ou de leste para oeste. No primeiro caso, o mar teria atingido primeiro as bacias do Parnaíba e Ceará e posteriormente a Bacia Potiguar e a Fossa de Benue; favorecendo a idéia do mar ter avançado continente adentro pela Bacia do Parnaíba. No segundo caso, ao contrário, o mar teria atingido primeiro a Bacia Potiguar, privilegiando a hipótese da ingressão em direção aos baixos interiores ter se dado por esta bacia.

As datações mais precisas, indicando a presença de depósitos marinhos de idade neo-aptiana/eoalbiana nas bacias do Ceará e Potiguar, reforçam a hipotese via Bacia Potiguar.

A ocorrência de camadas marinhas neo-aptianas/eoalbianas na Bacia do Araripe corrobora tanto as hipoteses da vinda do mar via bacias do Parnaŕba e Potiguar quanto pela Bacia de Sergipe-Alagoas.

A descoberta do remanescente sedimentar de Riacho do Padre, com área de ocorrência ainda não delimitada, derruba um dos argumentos contrários à ingressão do mar na Bacia do Araripe ter ocorrido via Bacia do Parnaíba, pela região de Araripina, apresentada por Lima (1978A). Torna-se, assim, um dado extremamente importante na elucidação das relações estratigráficas entre estas duas bacias.

A descoberta de sedimentos marinhos de idade albo-aptiana na Bacia Sanfranciscana traz um novo elemento no quadro reconstrutivo da paleogeografia da região. КАттAH (1992) sugere que o mar atingiu o oeste de 
Minas Gerais, a partir das bacias do Parnaíba e/ou Araripe. Interessante notar que Fúlaro \& Barcelos (1992, p.116), em estudos sobre o Cretáceo das bacias do centro e sudeste do Brasil afirmam que ..."No intervalo de tempo Jurássico Superior?/Cretáceo Inferior [sic], um grande rio precursor do São Francisco, se estenderia desde o centro-oeste de Minas Gerais até a plataforma continental do Maranhão. Esse complexo sistema fluvial foi responsável pelo transporte e deposição das seqüências areno-argilosas que constituem a Bacia Sanfranciscana..." Se esta premissa for válida, torna-se bastante plausível a hipótese deste rio precursor ter sido o duto para o seaway que atingiu as bacias do Araripe e Sanfranciscana.

A tese defendida por Françolin (1992), concluindo pela existência da ligação genética entre as Bacias do Rio do Peixe, Potiguar e Benue, vem ao encontro das observações realizadas por LiMA (op. cit.) quanto a tese da proveniência do mar através da Bacia Potiguar, apesar do autor considerar que o mar equatorial teria vindo no sentido oeste-leste.

Outro aspecto muito importante neste contexto é que análises palinológicas têm constatado a presença de material retrabalhado de idade devoniana, nos depósitos cretáceos de algumas bacias interiores, inclusive na Bacia do Araripe e em bacias costeiras como as do Ceará e Potiguar. A bacia paleozóica mais próxima de todas, com depósitos desta faixa de idade, é a Bacia do Parnaíba. Há muito tempo discute-se se os depósitos arenosos basais de muitas bacias interiores, entre elas a do Araripe (Formação Mauriti, ou Tacaratu), não seriam os resquícios de uma Bacia do Parnaíba bem maior, avançando sobre toda a Província Borborema e que teria sido posteriormente erodida em função do arqueamento da crosta, como preconiza a hipótese de PonTE et alii, (1972). Françoldn (COM. PESS., 1992) postula que toda a área da Província Borborema quando da fase rifte, e em conseqüência da fase formadora das bacias nordestinas, esteve submetida a uma compressão de direção leste-oeste que resultou em leve arqueamento da crosta, e que permaneceu elevada desde então. A atual borda leste da Bacia do Parnaíba é truncada por falhas, relacionadas a eventos tectônicos de idade neocomiana. Na região das Serras de Ibiapaba e Grande, a Formação Serra Grande apresenta espessuras da ordem de centenas de metros, enquanto que no limite sul da bacia, sua espessura é de poucas dezenas de metros. Tal fato é significativo, pois sugere que a bacia paleozóica do Parnaíba, avançava sobre a Província Borborema. Com o soerguimento da região, os depósitos devonianos (provavelmente das formações Pimenteira e Longá) foram erodidos, fornecendo sedimentos para as bacias do interior do Nordeste e Potiguar durante, 
pelo menos o Neocomiano. O que se observa atualmente na coluna sedimentar da região é que a mesma se inicia com os resquícios da sedimentação eopaleozóica que se preservou nos baixos (arenitos das formaçðes Mauriti e/ou Tacaratu), seguidos diretamente pelos sedimentos neocomianos.

Considerando-se o atual quadro, e bastante coerente a hipótese de que na realidade as bacias interiores do Nordeste não estiveram interligadas, nem na fase neocomiana, nem na fase albo-aptiana. Muito provavelmente estas pequenas bacias teriam se formado pela intensa movimentação tectônica reinante, porém permanecendo topograficamente altas; seriam, assim, verdadeiras bacias "suspensas". Para comprovação desta hipótese, seriam necessários estudos de paleocorrentes nas mesmas, para observar a presença ou não de um padrão centrípeto no afluxo sedimentar. No caso de se tratarem realmente de bacias entalhadas em "altos", a hipótese da proveniência do mar através da Bacia Potiguar seria descartada, e a procedência mais plausível seria pela Bacia do Parnaíba.

De qualquer modo, $e$ certo que este acesso marinho era restrito a um seaway estreito e raso, possivelmente até intermitente, já que estas primeiras camadas marinhas são pouco espessas e pobres em fósseis. Finalmente, não se pode deixar de ter em mente a possibilidade de o mar ter invadido $o$ interior nordestino, através de mais de um caminho. 
O estudo integrado dos palinomorfos, palinofácies, e perfis elétricos dos sedimentos constituintes do Andar Alagoas na Bacia Potiguar permitiu chegar-se a várias conclusões, de ordem litoestratigráfica, palinoestratigráfica, palinofaciológica, paleoambiental e paleoecológica. Tais conclusões são apresentadas a seguir:

- A análise conjunta dos perfis elétricos e da sucessão palinológica, além da observação de seções sísmicas (previamente interpretađas pelos geofísicos da PETROBRÁS), passando pelos poços estudados, permitiu a constatação das discordâncias regionais que limitam a Formação Alagamar, representante do Andar Alagoas na bacia.

- A análise das diagrafias e perfis litológicos indica que a Formação Alagamar se comporta como uma seqüência deposicional, de acordo com os conceitos da Estratigrafia de Ciclos ( $T-R)$. Assim, foram identificados na formação 5 eventos transgressivos que abrangem 5 intervalos com conotação cronoestratigráfica e distribuição regional. Os intervalos 4 e 5 correspondem ao Membro Upanema, o intervalo 3 às Camadas Ponta do Tubarão e os intervalos 1 e 2 ao Membro Galinhos.

- Os carbonatos, mormente os das Camadas Ponta do Tubarão, por apresentarem marcas de ressecamento, são considerados como resultantes de períodos de exposição subaérea na bacia.

- Pelas suas características litológicas, conteúdo palinológico, 
idade, posição estratigráfica e ambiente deposicional, a Formação Alagamar é estreitamente correlacionável aos seguintes estratos: Formação Codó (bacias de Barreirinhas e Parnaíba), Formação Rio da Batateira (Bacia do Araripe) e Camadas Trairi (Bacia do Ceara). Isto evidencia a existência de um ambiente constante e similar por grande parte da Província Estrutural Borborema nesta época.

- O estudo do resíduo orgânico total permitiu o reconhecimento dos principais constituintes palinomacerais. A partir daí, individualizaram-se quatro palinofácies características de diferentes ambientes continentais.

- Foi possível correlacionar as palinofácies com os componentes litológicos, e os ambientes de deposição. As palinofáciès I e II estão geralmente ligadas as litologias mais grosseiras e aos ambientes proximais de alta energia, e as palinofácies III e IV às litofácies pelíticas e aos ambientes distais de baixa energia.

- Correlações entre as palinofácies e a abundância relativa dos palinomorfos puderam ser traçadas. As palinofácies I e II são extremamente pobres em palinomorfos. Estes quando presentes, são os relativamente mais densos, tais como Cicatricosisporites e Appendicisporites. A palinofácies III sempre se apresenta rica em palinomorfos, enquanto a palinofácies IV também é pobre, e os palinomorfos presentes são bissacados ou então relativamente pequenos.

- O tratamento taxonômico acurado dos palinomorfos revelou-se crucial para o desenvolvimento de esquemas zonais e correlações confiáveis, sendo imprescindíveis na realização dos trabalhos de base. Neste sentido, este estudo contribui para um melhor conhecimento da palinologia e bioestratigrafia do Cretáceo Inferior da região Nordeste do Brasil.

- Estabeleceu-se um zoneamento da Formação Alagamar válido para toda a bacia, através da identificação e ilustração de 228 taxa palinologicos. Dois novos gêneros, 5 novas espécies e 3 novas combinações são propostas.

- Foram reconhecidas 4 biozonas e 6 intervalos informais, definidas a partir de características palinológicas utilizáveis em toda a bacia.

- As palinozonas definidas mostram boa correspondência com as estabelecidas em trabalhos prévios, relativos a diversas bacias do interior e da plataforma continental brasileira.

- Das zonas definidas, a mais superior (D) é visivelmente a mais nova, correspondendo ao Albiano inferior a médio. Litoestratigraficamente, não pertence mais à Formação Alagamar e sim às formações Açu, em terra, e Açu/Ubarana, no mar.

- Parece claro que a aplicação de todas as biozonas do Andar Alagoas, definidas para a Bacia de Sergipe-Alagoas, não pode ser realizada na 
Bacia Potiguar. Esta dificuldade envolve principalmente as biozonas baseadas nos surgimentos e extinções de esporos (ex: biozona Foveotriletes sp.).

- As análises quantitativas permitiram uma visualização de toda a composição microflorística da Formação Alagamar. Constatou-se aqui o domínio dos rimulados e inaperturados, com valores ao redor de $50 \%$ da associação, seguidos dos poliplicados com ate $30 \%$, e dos esporos triletes com valores da ordem de $15 \%$. Os grãos de pollen com afinidades angiospérmicas, apesar de presentes deste o início da deposição da sequiência analisada, constituem sempre menos de $10 \%$ do total das espécies da associação.

- A composição da associação microflorística da Formação Alagamar e bastante similar à das microfloras essencialmente gimnospermicas contemporâneas, da mesma faixa microflorística, de outras partes do mundo (Colômbia, Venezuela, Peru, Congo, Gabão, Egito, China, Israel). Insere-se perfeitamente nos cinturões microflorísticos "Norte-Gondwanense" e "OesteAfricano Sul-Americano" (W.A.S.A.).

- O estudo das prováveis afinidades botânicas da microflora Alagamar permitiu concluir que a mesma deriva de um complexo de gimnospermaspterodofitas, com as angiospermas ocupando uma pequena proporção na flora.

- A despeito da ausência de fósseis marinhos na seção, a presença dos primeiros grãos de pólen tricolpados e a das espécies Afropollis operculatus, Afropollis zonatus, Transitoripollis crisopolensis e Sergipea variverrucata asseguram a idade aptiana para a Formação Alagamar.

- A base das formações Açu/Ubarana é posicionada no Albiano inferior, em função do surgimento de espécies elateradas e poliporadas.

- Reconhece-se a correspondência entre o Andar Alagoas, unidade cronoestratigrafica local, e os andares internacionais Aptiano e Albiano. A quase totalidade do pacote rochoso pertencente ao Andar Alagoas na Bacia Potiguar corresponde ao Aptiano. Apenas estratos com poucos metros de espessura no topo do Andar Alagoas (abaixo da discordância regional), são atribuíveis ao Albiano inferior.

- A espécie Transitoripollis crisopolensis revelou-se importante espécie-guia para o Aptiano inferior (= Alagoas inferior) na bacia. Já a espécie Sergipea variverrucata o é para o Aptiano superior (= Alagoas superior).

- A presença de algas do gênero Botryococcus e de fragmentos quitinosos de carapaças de conchostráceos, assim como a ausência de qualquer elemento do microplâncton marinho, permitem inferir um ambiente de deposição essencialmente não marinho para a Formação Alagamar. 
- A abundância de palinomorfos de origem continental, aliada à presença freqüente de dinoflagelados e carapaças quitinosas de microforaminíferos, permite concluir que o início da deposição dos estratos das formaçōes Açu/Ubarana ocorreu sob condições marinhas costeiras.

- A presença de elementos higrofíticos e xerofíticos na palinoflora permite concluir pela existência de uma flora de clima quente, árido a semi-árido, com nichos úmidos numa latitude bastante próxima da atual. A distribuição relativamente uniforme da microflora implica na atuação relativamente constante deste clima, ao longo do intervalo de tempo analisado.

- A teoria que preconiza uma origem eocretácea tropical para as angiospermas e posterior migração das mesmas em direção aos pólos é corroborada pelo surgimento, pobreza e baixa diversidade dos grãos de pólen com tais afinidades nesta fase deposicional.

- A invasão do mar na bacia ocorreu em definitivo apenas no Eoalbiano, no tempo deposicional das formações Açu/Ubarana. Assim, conclui-se que a ligação da bacia com o Atlântico Sul data desta época.

- Apesar de não concludente, a constatação da invasão marinha da Bacia Potiguar no Eoalbiano corrobora a hipótese da entrada do mar na Bacia do Araripe, via Bacia Potiguar, nesta idade, como aventada por Lrma (1978A). Contudo, evidências de ordem tectono-estrutural discutidas no texto tornam uma conexão direta do mar entre estas bacias, pouco provável.

- O emprego de distintas metodologias no presente estudo foi fator determinante para um conhecimento mais completo da história deposicional dos estratos da Formação Alagamar. 


\section{1) Introdução}

O sistema de nomenclatura palinologica foi fundado sobre os princípios, regras e recomendações do Código Internacional de Nomenclatura Botânica (C.I.N.B.), válido para todos os grupos do reino vegetal, atuais ou fósseis. Desse modo, o mais indicado seria simplesmente utilizar o sistema natural de classificação. Contudo, no caso dos fósseis, muitas vezes torna-se impossível a subordinação do gênero dos grãos de pólen e esporos dispersos aos vegetais que os produzem, sendo necessária a utilização de um sistema artificial. Os inconvenientes e as vantagens da utilização de uma ou outra destas classificações suscitam ainda inúmeras discussões. VaKHRAMEev (1964) elaborou uma análise crítica com este propósito, insistindo nas diferenças existentes entre os gêneros e as espécies botânicas e os gêneros e espécies-forma; e alertando para o perigo de se determinar esporos e grãos de pólen fósseis dispersos sob as normas da nomenclatura botânica. Por outro lado Traverse (1957), após estudo detalhado, mostrou as objeções e justificativas concernentes à utilização dos termos botânicos na denominação dos grãos de pólen e esporos fósseis. Ademais, na nomenclatura do material fóssil é frequente também a utilização de classificações semiartificiais. Adicionalmente, vale ressaltar a existência de inúmeras classificações diferentes criadas para o material fóssil, a partir da primeira estabelecida por 
Naumova (1939). Entretanto, não é escopo do presente estudo entrar no mérito desta discussão. Considera-se que entre todas as classificações disponíveis, as sinopses elaboradas por Potonie (1956-1975), propiciam a classificação mais adequada, pois o autor faz uma recapitulação dos taxa fósseis conhecidos passíveis de serem classificados no sistema natural; classifica os grãos de pólen e esporos dispersos de modo artificial, porém levando em conta sua semelhança com as formas análogas atuais. Em virtude disso, será adotada tal classificação no presente trabalho.

Apresentam-se aqui os palinomorfos recuperados das amostras analisadas da Formação Alagamar, classificados sistematicamente de acordo com sua afinidade inferida com os principais grupos taxonômicos das plantas. $O$ tratamento na nomenclatura a nível de gênero para os palinomorfos segue as regras do Código Internacional de Nomenclatura Botânica (STAFteu et alii, 1978). As designações genéricas foram portanto baseadas na regra de prioridade. Os palinomorfos identificados foram classificados nos seguintes grupos principais: fósseis afins das algas verdes; cistos de dinoflagelados; esporos de fungos; microforaminíferos quitinosos, fragmentos quitinosos de carapaças de conchostráceos; esporos de briofitas e pteridofitas; grãos de pólen e palinomorfos de afinidade botânica incerta. Descrições detalhadas foram feitas para os palinomorfos não previamente descritos. As espécies são apresentadas, dentro de cada gênero, na seguinte ordem: primeiro a especie-tipo, quando houver; em seguida e em ordem alfabética, as outras espécies; posteriormente as espécies não identificadas e finalmente as espécies novas. Tal procedimento é válido também para os esporos de fungos e os palinomorfos de afinidade botânica incerta.

Das 228 espécies de palinomorfos listadas neste estudo, 2 são fósseis afins das algas verdes; 4 são cistos de dinoflagelados; 6 são fragmentos de carapaças atribuíveis aos conchostráceos; 1 é de carapaça quitinosa de microforaminífero, 7 são esporos de fungo, 74 são esporos de briófitas e pteridófitas; 131 são de grãos de pólen e 3 são palinomorfos de afinidade botânica incerta. O total inclui 218 espécies previamente descritas, dois gêneros novos, 5 novas espécies, e 3 espécies recombinadas.

Serão também apresentadas as seguintes informações, sempre que necessárias, a cada táxon: 
1- Designação genérica e específica para cada espécie previamente descrita;

2- Referências relevantes;

3- A designação da espécie-tipo;

4- Comentários sobre tópicos pertinentes à taxonomia.

\section{2) Descrição Sistemática}

\section{FUNGOS}

\section{DIVISÃO EUMYCOPHYTA}

Comentários iniciais: A classificação sistemática dos fungos é baseada puramente em termos morfologicos das Sphaeropsidales. É caracterizada pelos seguintes aspectos: a) forma e simetria; b) ausência ou presença e número de aberturas; c) ausência ou presença e número de septos; d) camadas da exina e ornamentação e; 5) dimensões (ElsiK, 1976, 1978).

\section{Esporo de Fungo Tipo A}

Estampa I, fig. 1

Descrição: Esporo de fungo, unicelular, não septado, liso. Âmbito em forma de gota e com poro apical.

Dimensões: $\mathrm{C}=22-25 \mu \mathrm{m} . \mathrm{L}=18-20 \mu \mathrm{m}$. (5 exemplares). 
Comentários: O exemplar ilustrado assemelha-se ao gênero Lacrimasporonites Elsik. Contudo, as formas erigidas por CLARKE (1965) e ELSIK (1968A, B) sob esta designação genérica, apesar de não estarem claramente representadas nas figuras exibidas pelos autores, apresentam uma cicatriz basal; marca não observada no material ora descrito.

\title{
DIVISÃO BASIDIOMYCOTA CLASSE BASIDIOMYCETES
}

\author{
Esporo de Fungo Tipo B \\ Estampa I, fig. 2
}

Descrição: Esporo de fungo, bicelular, monoseptado, liso. Âmbito fusiforme, simétrico, diporado. Poros pequenos, um em cada "polo" do grão.

Dimensões: $\mathrm{C}=28-30 \mu \mathrm{m} . \mathrm{L}=13-15 \mu \mathrm{m}$. (3 exemplares).

Comentários: A espécie ora descrita assemelha-se bastante às atribuídas ao gênero Dyadosporonites ELSK (1968), diferindo pelas dimensões dos poros.

Gênero DIPORISPORITES VAN DER HAMMEN, 1954

Espécie-tipo: Diporisporites elongatus VAN DER HAMMEN, 1954

\section{Diporisporites sp. 1}

Estampa I, fig. 8

Descrição: Esporo de fungo, unicelular, não septado, psilado. Contorno elíptico a fusiforme, diporado (poros grandes), parede espessa, freqüentemente "rachada".

Dimensões: $\mathrm{C}=70-80 \mu \mathrm{m} . \mathrm{L}=45-50 \mu \mathrm{m}$. (7 exemplares). 


\title{
Diporisporites sp. 2
}

Estampa I, fig. 4

Descrição: Esporo de fungo, unicelular, não septado, psilado. Contorno elíptico a fusiforme, diporado, parede espessa.

Dimensões: $\mathrm{C}=50-60 \mu \mathrm{m} . \mathrm{L}=30-35 \mu \mathrm{m}$. (3 exemplares).

Comentários: Difere de Diporisporites sp. 1, pelas dimensões gerais menores, e poros menos desenvolvidos.

Gênero PLURICELLAESPORITES VAN DER HAMMEN, 1954

Espécie-tipo: Pluricellaesporites typicus VAN DER HAMMEN, 1954.

Pluricellaesporites sp. cf. P. psilatus CLARKE

Estampa I, figs. 5, 6

Vide WILsoN (1978, P. 149) para descrição.

Dimensões: $20-80 \mu \mathrm{m}$. ( 9 exemplares).

Comentários: Esta espécie é caracterizada por possuir várias células uniseriadas, com um poro terminal e possuir os septos bidentados. Apresenta-se freqüentemente quebrada.

\author{
DIVISÃO DEUTEROMYCOTA \\ FAMÍLIA MICROTHYRIACEAE \\ ORDEM MONILIALES
}

Gênero MICROTHALLITES DILCHER, 1965

Espécie-tipo: Microthallites lutosus Ducher, 1965 


\section{Microthallites sp.}

Estampa I, fig. 10

Vide Elsix (1978, P. 338) e DILCHER (1965, P. 15-16) para diagnose, descrição e comentários do gênero.

Dimensões: $55-66 \mu \mathrm{m}$. ( 5 exemplares).

Comentários: Este gênero é caracterizado pela sua forma circular, estrutura interna radial e presença de ostíolo. De acordo com ELsik (1978) os fungos atribuídos às Microthyriaceas distribuem-se do Cretáceo Inferior (Wealden) ao Recente, existindo muito poucos registros no Cretáceo.

\section{Hifa de Fungo}

Estampa I, fig. 12

Obs: Distinguem-se as hifas das espécies de Pluricellaesporites fragmentadas pela proporção das células. De acordo com Wrurans (1984), as células de hifa são de comprimento mais de quatro vezes maior que a largura, enquanto que as células de Pluricellaesporites spp. apresentam sempre o comprimento aproximadamente igual a largura.

Dimensões: As hifas não possuem limite de tamanho. A ilustrada na figura 8 possui cerca de $100 \mu \mathrm{m}$. 


\begin{abstract}
ALGAS
DIVISÃO: Chlorophycophyta

CLASSE: Chlorophyceae
\end{abstract}

ORDEM: Chlorococcales MARCHAND emend. PASCHER 1915

FAMflIA: Botryococcaceae

Gênero: BOTRYOCOCCUS KUTZING 1849

Espécie Tipo: Botryococcus braunii KuTzING 1849

\title{
Botryococcus braunii KUTZING
}

Estampa I, figs. 3, 9, 14.

Obs: Ocorre com frequiência no material estudado. TrAVERSE (1955) tem reportado evidências da ocorrência deste gênero do Mississipiano ao Presente, sugerindo que o mesmo deva ocorrer desde o Ordoviciano.

\section{DIVISÃO PRASINOPHYTA \\ ORDEM PTEROSPERMATALES \\ FAMfLIA CYMATIOSPHAERACEAE}

Gênero SCHIZOSPORIS COOKSON \& DETTMANN, 1959.

Espécie-tipo: Schizosporis reticulatus Cookson \& DetTMANN, 1959.

Schizosporis cooksoni Pocock

Estampa I, fig. 11

Vide Pocock (1962, Р. 76) para descrição e comparaçōes.

Dimensões: $\mathrm{C}=30-40 \mu \mathrm{m}$. (5 exemplares).

Comentários: Esta forma é similar a $S$. parvus, contudo possui exina bem mais fina e superfície psilada. 
Schizosporis scabratus STANLEY

Estampa 1, fig. 7

Vide StANLEY (1965, P. 284) para descrição e comparaçס̃es.

Dimensões: $\mathrm{C}=30 \mu \mathrm{m} . \mathrm{L}=21 \mu \mathrm{m}$. (1 exemplar).

Comentários: Esta espécie é caracterizada pela sua forma subesférica, pequena e exina escabrada.

Gênero OVOIDITES POTONIÉ, 1951 ex KRUTZSCH, 1959 emend. POTONIÉ, 1966

Espécie-tipo: Ovoidites ligneolus PoTonne, 1951 ex KRUTZSCH, 1959

Obs: Do que se pode depreender da literatura, parece haver uma superposição entre quatro gêneros que possuem forma oval a elíptica e uma tendência a se dividir em duas "valvas" ao longo do equador do grão. Os gêneros em questão são: Ovoidites, Schizosporis, Pilospora e Schizophacus. O gênero Ovoidites foi criado por KRUTzSCH, 1959A. No mesmo ano e aproximadamente a mesma época, Cookson \& Detrmann, criaram o gênero Schizosporis, que parecem conter feições comuns com Ovoidites. PotonIE (1966) emendou o gênero Ovoidites e considerou que o mesmo difere de Schizosporis, por ter um contorno elíptico e um diferente número de camadas de exina. Contudo, a espécie $S$. parvus, apresenta âmbito visivelmente elíptico; desse modo a emenda de Poronı́, não justifica a criação de dois gêneros tão próximos. VenKatachala \& $\mathrm{K}_{\mathrm{AR}}$ (1968) restringiram o gênero Schizosporis a formas ornamentadas, de âmbito circular a subcircular e criaram o gênero Psilospora, para acomodar formas psiladas de contorno oval a elíptico. Sugeriram ainda que Ovoidites pode ser caracterizado por sua ornamentação rugulada a reticulada e contorno oval a elíptico. Pierce (1976), examinou em detalhe a morfologia da espécie-tipo do gênero Schizosporis ( $S$. reticulatus) de Cookson \& Detrmann (1959) e emendou o gênero, incluindo formas com exinas de densas porções internas; transferindo para o gênero Schizophacus todas as outras espécies previamente colocadas em Schizosporis. Neste trabalho foram considerados válidos ambos os gêneros (Ovoidites e Schizosporis), sendo o gênero Ovoidites utilizado como conceituado por VenKaTACHALA \& KAR (1968). 


\section{Ovoidites sp.}

Estampa I, fig. 13

Vide Potonie (1966, P. 201) para descrição do gênero.

Descrição: Palinomorfo de âmbito elíptico-alongado, dividido por uma sutura equatorial em duas "valvas", provavelmente iguais. Exina fina de superfície reticulada a rugulada. Lumina variáveis em forma e tamanho e muri muito baixos.

Dimensões: $\mathrm{C}=57-62 \mu \mathrm{m} . \mathrm{L}=28-30 \mu \mathrm{m}$. (2 exemplares).

Comentários: Esta espécie caracteriza-se pela sua ornamentação reticulada, com muri baixos. E similar a Ovoidites ligneolus e $O$. microligneolus KRUTzCH (1959A), diferindo por possuir dimensões menores e exina mais fina. 


\title{
DINOFLAGELADOS
}

\author{
DIVISÃO PYRROPHYTA PASCHER, 1914 \\ CLASSE DINOPHYCEAE FRITSCH, 1935
}

Gênero PTERODINIUM EISENACK, 1958 emend. YUN, 1981

Espécie-tipo: Pterodinium aliferum ErsenAck, 1958

Pterodinium cingulatum (WETZEx, 1933) BELOW, 1981

Estampa XXI, fig. 22

Vide Yun (1981, p. 12) para descrição.

Dimensões: $\mathrm{C}=50-60 \mu \mathrm{m} . \mathrm{L}=45-55 \mu \mathrm{m}$. (3 exemplares).

Comentários: Esta espécie é subdividida em inúmeras subespécies. Têm sido reportada como presente em estratos do Cretáceo Inferior (Hauteriviano) ao Pleistoceno de várias partes do mundo.

FAMIILIA SPINIFERITACEAE SARJEANT e DOWNIE emend. MORRIS, 1978

Gênero SPINIFERITES MANTELL, 1850 emend. SARJEANT, 1970 Espécie-tipo: Spiniferites ramosus (EHRENBERG, 1938), LOEBLICH \& LOEBLICH 1966

Spiniferites multibrevis (DaveY \& WILLAMS) LENTIN \& WILLIAMs, 1973 Estampa XXI, figs. 17, 19

Vide Davey \& Williams (IN Davey et alii, 1965, P. 35) para descrição.

Dimensões: $\mathrm{C}=52-60 \mu \mathrm{m} . \mathrm{L}=37-40 \mu \mathrm{m}$. (5 exemplares).

Comentários: Também classificada como subespécie da espécie $S$. ramosus. Têm sido registrada como presente em camadas do Valanginiano ao Eoeoceno de várias partes do mundo (DAVEY \& VERDIER, 1974). 


\section{FAMIILIA PAREODINIACEAE GOCHT, 1957}

Gênero TRICHODINIUM EISENACK e COOKSON, 1960 emend. CLARKE \& VERDIER, 1967

Espécie-tipo: Trichodinium pellitum ErsenACK \& CoOKson, 1960

Trichodinium castanea (DEFLANDRE, 1935) CLARKE \& VERDIER Estampa XXI, figs. 18, 21

Vide Clarke \& Verdier (1967, p. 19) para descrição.

Dimensões: $C=46-53 \mu \mathrm{m} . \mathrm{L}=39-43 \mu \mathrm{m}$. (5 exemplares).

\section{ORDEM GONYAULACALES TAYLOR, 1980}

Gênero CRIBROPERIDINUM NEALE \& SARJEANT, 1962

Espécie-tipo: Cribroperidinium sepimentum NEALE \& SARJEANT, 1962

Cribroperidinium intricatum DAVEY, 1969 (SENSU HELENES, 1984, P. 125 - ESTAMPA 3, FIGs. 4-6)

Estampa XXI, fig. 20

Vide Helenes (1984, P. 125) para comentários.

Dimensões: $\mathrm{C}=90-110 \mu \mathrm{m} . \mathrm{L}=80-90 \mu \mathrm{m}$. Chifre Apical $=15-20 \mu \mathrm{m} .(3$ exemplares). 
SPORITES H. POTONIÉ, 1893.

Anteturma PROXIGERMINANTES R. POTONIÉ, 1975.

Turma TRILETES AZONALES (REINSCH, 1881) POTONIÉ \& KREMP, 1954.

Subturma AZONOTRILETES (LUBER, 1935) DETTMANN, 1963.

Infraturma LAEVIGATI, QUASILAEVIGATI (BENNIE \& KIDSTON, 1886) POTONIÉ, 1956.

Gênero BIRETISPORITES (DELCOURT \& SPRUMONT), 1955 emend. DELCOURT, DETTMANN \& HUGHES, 1963.

Espécie-tipo: Biretisporites potoniaei Delcourt \& SPRUMONT, 1955.

Biretisporites potoniaei DELCOURT \& SPRUMONT

Estampa II, figs. 1-2

Vide DeLcourt et alii (1963, P. 284) para sinonímia e descrição.

Dimensões: $30-38 \mu \mathrm{m}$. (5 exemplares).

Comentários: Espécie caracterizada pelo contorno triangular a subtriangular arredondado, exina lisa e espessa, e laesuras com lábios espessados e elevados.

Gênero UNDULATISPORITES PFLUG, 1953

Espécie-tipo: Undulatisporites microcutis Pfug, 1953

Undulatisporites undulapolus BRENNER

Estampa II, fig. 3

Vide BrenNeR (1963, p. 72) para descrição.

Dimensões: $25-32 \mu \mathrm{m}$. (3 exemplares). 
Gênero DELTOIDOSPORA (MINER, 1935) emend. POTONIE, 1956.

Espécie-tipo: Deltoidospora hallii Miner, 1935.

\section{Deltoidospora hallii MiNER \\ Estampa II, fig. 11}

Vide PotonIE (1956, p. 13) para descrição genérica.

Dimensões: $38 \mu \mathrm{m}$. ( 1 exemplar).

Comentários: De acordo com Deucourt et alii (1963), Deltoidospora caracteriza-se por possuir contorno triangular e lados retos; difere de Cyathidites Couper (1953), que apresenta lados côncavos e de Leiotriletes (NAUMOva Ex Ischenko, 1952), que têm contorno triangular e lados convexos. Obviamente, como observado na literatura, a distinção ou os limites entre côncavo, reto e convexo não são bem definidos, variando bastante de autor para autor. Pocock (1970) estima que Deltoidospora seja um sinônimo sênior de Cyathidites e Leiotriletes. Neste estudo, considera-se Deltoidospora como sendo esporo trilete, de contorno triangular arredondado, com lados retos, levemente convexos, ou levemente côncavos, laesuras simples, relativamente longas, exina moderadamente espessa, psilada.

\section{Deltoidospora juncta (KARA-MURZA, 1956) SINGH}

Estampa II, figs. 5, 6, 9, 14

Vide SiNGH $(1964$, P. 81) para sinonímia e descrição.

Dimensões: $22-31 \mu \mathrm{m}$. (20 exemplares).

Comentários: Esporos triletes com lados variando de côncavos a convexos, ou mesmo retos e apresentando leves espessamentos transversais aos ápices do grão, têm sido reportados sob diversas designações. As espécies mais próximas de $D$. juncta, que comumente tem sido utilizadas são: Cibotiumspora jurienensis (BALME) Fratofr; Concavisporites juriensis Balme an Norrus, 1969; e Obtusisporis juncta (KARA MurZA) Pocock, 1970. 
Gênero CYATHIDITES COUPER, 1953

Espécie-tipo: Cyathidites australis COUPER, 1953

\section{Cyathidites australis COUPER}

Estampa II, figs. 19, 21

Vide SiNGH (1964, P. 70) para sinonímia e diagnose genérica.

Dimensões: $55-75 \mu \mathrm{m}$. (12 exemplares).

\section{Cyathidites crassiangulatus BALME}

Estampa II, fig. 15

Vide Balme (1957, P. 22) para descrição e comentários.

Dimensões: $40 \mu \mathrm{m}$. ( 1 exemplar).

\section{Cyathidites minor COUPER}

Estampa II, figs. 13, 18

Vide SINGH (1971, P. 71) para sinonímia e descrição.

Dimensões: $25-40 \mu \mathrm{m}$. (6 exemplares).

Gênero CONCAVISPORITES PFLUG, 1953

Espécie-tipo: Concavisporites rugulatus PfuUG, 1953.

Concavisporites sp. Regali, Uesugut \& Santos Estampa II, fig. 4

Descrição: Esporo trilete, âmbito triangular, lados levemente côncavos a retos. Laesuras distintas, retas e longas, atingindo $3 / 4$ da distância radial grão, com espessamentos em suas margens, formando um margo, mas sem atingir a borda do grão. Exina espessa, lisa a finamente granular. 
Dimensões: $36-55 \mu \mathrm{m}$. (8 exemplares).

Comentários: Esta espécie foi documentada pela primeira vez por REGALI et alii (1974, ESTAMPA I, No N $^{\circ}$ nos depósitos eocretáceos da plataforma continental brasileira.

Gênero DIVISISPORITES PFLUG, 1953.

Espécie-tipo: Divisisporites divisus Pfuug, 1953.

Divisisporites sp.

Estampa VII, fig. 9

Dimensões: $55-70 \mu \mathrm{m}$. (4 exemplares).

Comentários: Caracterizam este gênero o visível espessamento de cada raio da laesura e a divisão apresentada pelas mesmas em cada terminação. A descrição original de Pflug (1953) especifica que o ângulo entre os ramos terminais que se dividem é obtuso. Tal fato não é observado nos exemplares mostrados, porém os mesmos são perfeitamente enquadráveis neste gênero. Difere de Bellisporites (BoLkHovrrina) Pocock, 1970, que também apresenta laesuras bifurcadas, pelo contorno circular e margo mais estreito deste último.

Infraturma APICULATI BENNIE \& KIDSTON, 1886 emend. POTONIÉ, 1956. Subinfraturma VERRUCATI DYBOWA e JACHOWIKS, 1957.

Gênero LEPTOLEPIDITES COUPER, 1953.

Espécie-tipo: Leptolepidites verrucatus COUPER

Leptolepidites verrucatus COUPER

Estampa II, figs. 7, 8

Vide Couper (1953, P. 28) para descrição. 
Dimensões: $35-40 \mu \mathrm{m}$. ( 8 exemplares).

\section{Leptolepidites psarosus NoRRIs \\ Estampa II, fig. 10}

Vide NoRRIs (1968, P. 316) para descrição e comentários.

Dimensões: $33-36 \mu \mathrm{m}$. ( 2 exemplares).

Comentários: Esta espécie é muito próxima de Converrucosisporites proxigranulatus BRENNER (1963), diferindo pela ornamentação mais densa, coalescência das verrugas, e ornamentação em ambas as faces.

Gênero VERRUCOSISPORITES IBRAHIM 1933 emend. POTONIÉ \& KREMP, 1955

\section{Verrucosisporites sp. 1}

Estampa IV, fig. 1

Descrição: Esporo trilete, laesura distinta, pequena, extremamente fina, sinuosa, acompanhada por lábios grossos de cerca de 3,0 $\mu \mathrm{m}$. Âmbito circular a subcircular. Exina espessa, densamente ornamentada por verrugas de tamanho variável $(2,0-8,0 \mu \mathrm{m})$ que por vezes coalescem.

Dimensões: $33-35 \mu \mathrm{m}$. ( 2 exemplares).

Comentários: Esta espécie difere de $V$. rotundus SRIVASTAVA, sua espécie mais próxima, por possuir menor tamanho e verrugas maiores e em menor número.

\section{Verrucosisporites sp. 2 \\ Estampa VIII, figs. 1, 2}

Descrição: Esporo trilete, marca trilete pouco visível, pequena; não atingindo a metade do raio do grão. Contorno equatorial circular. Ambas as faces, proximal 
e distal densamente ornamentada por "verrugas" achatadas de tamanhos variando entre $0,5-3,0 \mu \mathrm{m}$. Estas "verrugas" muitas vezes se coalescem tomando um formato irregular; além disso, possuem uma ou mais perfurações, dando um aspecto de alga ao grão.

Dimensões: $45-65 \mu \mathrm{m}$. (10 exemplares).

Comentários: Os exemplares aqui descritos possuem exina espessa. A marca trilete observada em alguns especimens prova que se tratam realmente de esporos. Os elementos esculturais parecem se tratar de verrugas e estão presentes nas faces distal e proximal, permitindo o enquadramento genérico. Contudo, não foi identificada, na literatura consultada, nenhuma espécie descrita com características semelhantes às do material estudado. Difere de Verrucosisporites sp. 1, pela ornamentação característica.

\section{Verrucosisporites sp. 3}

Estampa VIII, figs. 8, 9, 14

Descrição: Esporo trilete. Contorno equatorial circular a subcircular. Marca trilete indistinta, fina, sinuosa e longa, quase atingindo o equador. Ambas as faces são ornamentadas por verrugas, redondas-ovaladas, achatadas e punctadas. $\mathrm{Na}$ face distal, as verrugas são em menor número e mais espaçadas. A área entre as verrugas $E$ lisa.

Dimensões: $30-38 \mu \mathrm{m}$. (5 exemplares).

Comentários: Nos exemplares descritos, a marca trilete e de difícil reconhecimento, porém não resta dúvida que se tratam de esporos triletes. A exemplo dos especimens de Verrucosisporites sp. 2, a ornamentação verrucosa assegura a classificação ao nível de gênero. Difere de Cicatricosisporites sp. 2 , pelo tamanho, espaçamento e não coalescência das verrugas. 
Gênero CONVERRUCOSISPORITES POTONIÉ \& KREMP, 1954 Espécie-tipo: Converrucosisporites triquetrus POTONIE \& KREMP 1954

\section{Converrucosisporites proxigranulatus BRENNER \\ Estampa III, figs. 6, 9, 10}

Vide BRENNER (1963, P. 60) para descrição e discussão.

Dimensões: $30-35 \mu \mathrm{m}$. (5 exemplares).

Comentários: Considera-se aqui o gênero Converrucosisporites (PoTONIE \& KREMP), não pela variabilidade do contorno equatorial, e sim por apresentar face distal bastante ornamentada em relação a proximal. Os exemplares presentes no material estudado assemelham-se bastante, ao ilustrado por BURGER 1966, estampa 15, figura 3 .

Subinfraturma NODATI DYBOWA \& JACHOWICZ, 1957.

Gênero APICULATISPORITES POTONIÉ \& KREMP, 1954. Espécie-tipo: Apiculatisporites aculeatus (IBRAhIM) Potoní \& KREMP.

Apiculatisporis laevis BALME \& HeNnely

Estampa II, figs. 12, 17

Vide Balme \& Hennely (1956, P. 246) para descrição.

Dimensões: $30-40 \mu \mathrm{m}$. (15 exemplares).

Apiculatisporis sp. 1

Estampa II, figs. 16, 20

Descrição: Esporo trilete, âmbito circular a semicircular, laesuras retas longas e visíveis, que se estendem até o equador. Exina fina, ornamentada por espinhos 
longos, esparsos e homogeneamente distribuídos por toda a superfície do grão.

Dimensões: $35-38 \mu \mathrm{m}$. ( 2 exemplares).

Comentários: Difere de Apiculatisporis levis Balme \& Hennely pelos espinhos mais longos e mais esparsamente distribuídos.

Apiculatisporis sp. 2

Estampa III, fig. 1

Descrição: Esporo trilete, âmbito circular a semicircular, laesuras retas longas e visíveis, sem atingir o equador do grão. Exina espessa, ornamentada por espinhos longos, com base mais alargada, esparsamente distribuídos.

Dimensões: $75 \mu \mathrm{m}$. ( 1 exemplar).

Comentários: Difere das espécies anteriormente descritas, pelo tamanho maior e por possuir espinhos com base larga.

Gênero ECHINATISPORIS KRUTZSCH, 1959

Especie-tipo: Echinatisporis longechinus KRUTzsch, 1959

Echinatisporis longechinus KRUTZSCH

Estampa III, figs. 8, 11

Vide KRUTzSCH (1959, P. 133) para descrição.

Dimensões: $60-80 \mu \mathrm{m}$. ( 3 exemplares).

Comentários: Este gênero caracteriza-se por apresentar espinhos espessos, longos e flexuosos. Os espinhos possuem geralmente base larga e distribuição irregular na superfície do grão. 


\section{Echinatisporis varispinosus (Pocock) SRIVASTAVA Estampa III, fig. 5}

Vide Pocock (1962, P. 36) para descrição original e Srivastava (1975, P. 38-39) para sinonímia e observações.

Dimensões: $25-35 \mu \mathrm{m}$. (8 exemplares).

Comentários: Esta espécie caracteriza-se por possuir espinhos como elementos esculturais, sendo em maior número na face distal que na proximal. Geralmente os espinhos apresentam uma base em bulbos.

Echinatisporis sp. aff. E. varispinosus (Pocock) SRrvastava Estampa III, figs. 2, 3

Vide Pocock (1962, P. 36) para descrição original e SRIVAStava (1975, P. 38) para sinonímia e observações.

Dimensões: $35-65 \mu \mathrm{m}$. ( 4 exemplares).

Comentários: Os exemplares do material estudado diferem, no aspecto geral, formato e dimensões, dos ilustrados por SRIVASTAVA (1975). Entretanto apresentam face proximal escabrada e com poucos espinhos, e face distal mais ornamentada, com espinhos de base bulbosa, como descrito pelo autor.

Gênero PILOSISPORITES DELCOURT \& SPRUMONT, 1955. Espécie-tipo: Pilosisporites trichopapillosus (THIEGART) DELCOURT \& SPRUMONT

Pilosisporites trichopapillosus (THIEGART) DeLcourt \& SPRUMONT Estampa III, fig. 7

Vide Srivastava (1975, P. 54-55) para descrição e observações. 
Dimensões: $60-80 \mu \mathrm{m}$. ( 8 exemplares).

Comentários: Considera-se aqui o conceito emitido por DEJAX (1987), a respeito do gênero Pilosisporites, o qual considera como esporo de contorno variando de triangular a circular, e espinhos de tamanho variando entre $2-15 \mu \mathrm{m}$.

\section{Pilosisporites sp.}

Estampa III, fig. 4

Descrição: Esporo de âmbito circular ovalado, laesuras não visíveis, exina espessa, densamente ornamentada por espinhos longos (ate $12,0 \mu \mathrm{m}$ ), flexuosos e com base em bulbos.

Dimensões: $70-80 \mu \mathrm{m}$. (3 exemplares).

Comentários: Difere das outras espécies enquadradas neste gênero, pela exina mais espessa, dimensões gerais mais elevadas e contorno.

Infraturma MURORNATI POTONIÉ \& KREMP, 1954.

Gênero CICATRICOSISPORITES POTONIÉ \& GELLETICH, 1933. Espécie-tipo: Cicatricosisporites dorogensis PoTONIE \& GELLETCH.

\section{Cicatricosisporites avnimelechi HoROWIIZ}

Estampa IV, figs. 11, 14, 15

Vide HoRowrrz (1970, P. 164) para descrição.

Dimensões: $23-36 \mu \mathrm{m}$. (15 exemplares).

Comentários: Espécie comum no material analisado. Distingue-se por suas dimensões reduzidas. Trata-se da espécie Cicatricosisporites sp. ilustrada por Regali, Uesugut \& Santos (1974, P. 265, est. VI, Fig. 4). 


\section{Cicatricosisporites brevilaesuratus COUPER \\ Estampa IV, figs. 7, 8}

Vide COUPER (1958, P. 136) para descrição.

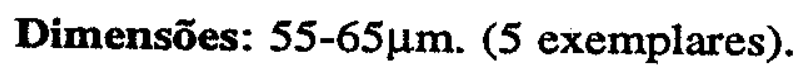

Comentários: As dimensões apresentadas pela especie são menores que às descritas por COUPER (op. cit.), contudo, sua similaridade é grande. Também em relação aos exemplares ilustrados por LiMA (1978), possuem grande semelhança e dimensões compatíveis.

\section{Cicatricosisporites crassistriatus BURGER Estampa $V$, fig. 1}

Vide BuRger (1966, P. 241-242) para descrição.

Dimensões: $65 \mu \mathrm{m}$. (1 exemplar).

Comentários: Esporo bastante raro no material, ornamentação muito característica, com canais largos entre as costelas. A menos das dimensões, aqui, um tanto mais elevadas, apresenta as características gerais descritas por BURGer (1966) para a espécie.

\section{Cicatricosisporites microstriatus J JRDINÉ \& MAGLORE. Estampa IV, figs. 16, 17}

Vide JARDINÉ \& MAGLORE (1965, P. 202) para descrição.

Dimensões: $60-85 \mu \mathrm{m}$. (10 exemplares).

Comentários: Espécie relativamente comum no material, muito característica e de dimensões elevadas. Individualiza-se das demais atribuídas ao gênero, pelo número e largura de suas costelas. 


\section{Cicatricosisporites nuni HOROWIrz}

Estampa IV, figs. 12, 13

Vide HoRowrrz (1970, P. 164) para descrição.

Dimensões: $35 \sim 47 \mu \mathrm{m}$. (15 exemplares).

Comentários: Os exemplares aqui apresentados assemelham-se muito aos enquadrados por HoRowrrz na especie em questão. Contudo, não foi observada a reticulação sobreposta às costelas, comumente reportada para esta espécie.

\section{Cicatricosisporites sp. cf. C. sternum VAN AMEROM Estampa IV, fig. 18}

Vide Dejax (1987, p. 43) para descrição e comentários.

Dimensões: $68-73 \mu \mathrm{m}$. ( 3 exemplares).

Comentários: Tipo raro no material analisado. Possui todas as características dos especimens ilustrados por DejAX (1987, P. 43, EST. V, FIGS. 2A-2B).

\section{Cicatricosisporites sp. ef. C. sp. 1 LiMA \\ Estampa IV, fig. 5}

Vide Lima (1978, P. 147) para descrição e comentários.

Dimensões: $75-85 \mu \mathrm{m}$. (5 exemplares).

Comentários: Os esporos ora apresentados nesta espécie, possuem as características descritas por Lima (1978, P. 148, est. X, FIG. 4) e denominada de Cicatricosisporites sp. 1. Assemelha-se também, tanto pela descrição quanto pelas ilustrações a espécie C. salardii, mostrada por DejaX (1987, P. 43, EST. V, FIGS. 3A-3B). 


\section{Cicatricosisporites sp. 1}

Estampa IV, figs. 3, 4

Descrição: Esporo trilete, contorno triangular arredondado, lados convexos a retos, sem espessamentos apicais. Marca trilete simples, visível, com as laesuras atingindo mais da metade do raio do grão. Faces proximal e distal ornamentadas por costelas largas $(3-4 \mu \mathrm{m})$, separadas por canais finos a médios $(0,5-2 \mu \mathrm{m})$. Os elementos esculturais da face proximal são arranjados de modo a conter de 4-6 costelas paralelos à respectiva área interradial. Próximo ao equador ocorre a coalescência destas costelas, formando uma espiral que se prolonga na face distal. Na face distal as costelas, em número de 12-15, tornam-se subparalelas, formando um único conjunto que atravessa toda a face do esporo.

Dimensões: $60-80 \mu \mathrm{m}$. (5 exemplares).

Comentários: Os exemplares aqui descritos assemelham-se muito aos enquadrados por Singh (1971, P. 70, est. 8, figs. 1-6) na espécie $C$. sp. cf. Anemia exilioides; diferindo na ausência de espessamentos apicais e número de costelas. Assemelhase também a espécie C. neumanii Boltenhagen (1976, P. 3, est. 1, figs. 1-3), diferindo no número e na espessura das costelas. É próxima também da espécie Cicatricosisporites sp. descrita por VAN AMERon (1965, P. 108, est. 4, FIGS. 3A-3B).

\section{Cicatricosisporites sp. 2}

Estampa IV, fig. 2

Descrição: Contorno equatorial subtriangular-convexo, bordas arredondadas, sem espessamentos. Marca trilete simples e nítida, com laesuras finas e longas, atingindo $3 / 4$ do comprimento do raio. Face proximal ornamentada por costelas tênues. Face distal com costelas grossas (ao redor de $5 \mu \mathrm{m}$ ) e pouco numerosas. As costelas são paralelas aos lados, ramificando-se por vezes e formando triângulos no polo.

Dimensões: $45-50 \mu \mathrm{m}$. ( 2 exemplares).

Comentários: Os exemplares em questão são bastante semelhantes a $C$. sp. 5 ilustrados por ARCHANGELSKY, et alii (1983, P. 208, EST. IV, FIGs. 1-2). 


\section{Gênero CHOMOTRILETES NAUMOVA, 1939 \\ Espécie-tipo: Chomotriletes vedugensis NAUMOVA}

Obs. A sinonímia entre os gêneros Chomotriletes, Concentricystes e Pseudoschizaea é exaustivamente discutida por Fensome et alii 1990 (P. 142 A 146, 152 e 153, e 422), que avaliam inclusive as espécies atribuídas a cada gênero. Estes autores, de acordo com ChristopHer (1976), concluíram que os dois últimos gêneros são sinônimos, considerando Concentricystes como nomen nudum Ademais, Playford e Dring (1981) consideram a espécie-tipo de Chomotriletes como sendo um acritarca; e Pocock (1962) considera o gênero como comportando formas aletes. No presente trabalho, de acordo com FeNSOME et alii (OP.CTT.), tratou-se Concentricystes e Pseudoschizaea como sinônimos júniores de Chomotriletes e este, tal como definido por NAUMOva (1939), apesar de não se constatar marca trilete nos especimens aqui mostrados.

\section{Chomotriletes almegrensis Pocock, 1962 \\ Estampa IV, figs. 6, 9}

Vide Pocock (1962, P. 38) para descrição.

Dimensões: $35-45 \mu \mathrm{m}$. ( 3 exemplares).

\section{Chomotriletes fragilis Pocock \\ Estampa IV, fig. 10}

Vide Pocock (1962, P. 39) para descrição.

Dimensões: $28-32 \mu \mathrm{m}$. (4 exemplares).

Comentários: Difere de $C$. almegrensis por seu tamanho menor e estrias mais finas. Não foram observadas marca trilete, nem estruturas de deiscência de qualquer tipo. 
Gênero RETITRILETES (PIERCE, 1961) emend. DÖRING, KRUTZSCH, MAI \& SCHULZ, 1963.

Espécie-tipo: Retitriletes globosus PIERCE, 1961

\section{Retitriletes sp. cf. $R$. austroclavatidites (Cookson) KRUTzsch}

Estampa V, fig. 4

Vide Dettmann (1963, P. 44) para descrição e sinonímia.

Dimensões: $48 \mu \mathrm{m}$. ( 1 exemplar).

Comentários: Esta espécie é distinta das outras do gênero, pela sua ornamentação reticulada na face distal. Os muri são altos e os lumina largos. Este esporo tem sido freqüentemente identificado na literatura como Lycopodiumsporites austroclavatidites (Cookson) PoTONIE, 1956. Entretanto, KRUTzSCH (1963) apresenta evidências (as quais aceita-se no presente trabalho), que invalidam o uso deste gênero, a favor de Retitriletes.

Gênero KLUKISPORITES COUPER, 1958.

Espécie-tipo: Klukisporites variegatus Couper.

Obs: Os gêneros Dictyotriletes NaUmova (1939), Ischyosporites Balme (1957) e Klukisporites COUPER (1958) têm sido utilizados para acomodar esporos do Jurássico e Cretáceo, os quais ostentam ornamentação foveo-reticulada. Dictyotriletes não deveria ser considerado, pois alem de ter sido criado para formas do Paleozóico, apresenta ornamentação claramente reticulada e não foveo-reticulada. Já a sinonímia dos outros dois gêneros é discutida exaustivamente por vários autores, sendo objeto de controvérsia. Schulz, 1967; Tralau, 1968; GuY, 1971; Van Koninnenburg-Van Cittert, 1981; e Backhouse, 1988 (principalmente os três últimos), após análise percuciente destes gêneros, concluíram que os mesmos são idênticos; sendo Klukisporites sinônimo júnior de Ischyosporites. Dettmann, 1963 e Filatoff, 1975 distinguem estes gêneros, com base na ausência de margo e no desenvolvimento de crassitudes radiais em Ischiosporites. Concorda-se aqui com estes últimos autores e considera-se, 
pela ausência dos elementos esculturais citados, que os exemplares ilustrados enquadram-se no gênero Klukisporites.

\section{Klukisporites variegatus COUPER \\ Estampa V, figs. 9, 13}

Vide Pocock (1964A, P. 193-194) para descrição posterior.

Dimensões: $36-45 \mu \mathrm{m}$. (8 exemplares).

Comentários: Os exemplares observados não apresentam, muito claramente a ornamentação granulosa na face proximal, como evidenciado por Singur. Contudo, enquadram-se perfeitamente no conceito de SRrvastava (1975), para a espécie.

\section{Klukisporites foveolatus Pocock}

Estampa V, fig. 11

Vide Pocock (1964A, P. 194) para descrição.

Dimensões: $50 \mu \mathrm{m}$. ( 2 exemplares).

Comentários: Considerou-se neste trabalho os conceitos de SRIVASTAVA (1975), na classificação destas espécies.

\section{Klukisporites pseudoreticulatus COUPER \\ Estampa V, figs. 2, 3, 8}

Vide COUPER (1958, P. 138) para descrição.

Dimensões: $40-48 \mu \mathrm{m}$. ( 2 exemplares).

Comentários: Classificação do gênero, sensu SRrvastava (1975). Os exemplares observados assemelham-se bastante aos ilustrados por AGASIE (1969, P. 18, EsT. 2, FIGS. 1-2) 
Gênero FOVEOSPORITES BALME, 1957.

Espécie-tipo: Foveosporites canalis BALME, 1957.

Obs: O gênero Foveosporites foi erigido para acomodar esporos triletes de âmbito circular ou triangular arredondado, com foveolas irregulares, enquanto que Foveotriletes têm contorno triangular, com lados côncavos ou retos e exina com fina ornamentação foveo-reticulada. Ambos diferem de Sestrosporites pela ausência de crassitude interradial.

\section{Foveosporites canalis BALME \\ Estampa V, figs. 6, 7}

Vide BALME (1957, P. 17) para descrição.

Dimensões: $33-38 \mu \mathrm{m}$. (3 exemplares).

Foveosporites subtriangularis (BRENNER) PHILIPS \& FeLIX, 1971 Estampa V, fig. 5

Vide Phulaps \& Feux (1971A, p. 318) para descrição e comentários.

Dimensões: $35 \mu \mathrm{m}$. ( 1 exemplar).

\section{Foveosporites sp. 1}

Estampa V, fig. 10

Descrição: Esporo trilete de âmbito subtriangular arredondado, laesuras retas, estendendo-se a $2 / 3$ do raio do grão. Exina fina, ornamentada por fovéolas grandes $(5,0 \mu \mathrm{m})$ homogeneamente distribuídas por toda a superfície do grão.

Dimensões: $48 \mu \mathrm{m}$. (1 exemplar).

Comparações: Esta espécie difere das demais descritas para o gênero, por possuir exina relativamente mais espessa e pelas maiores dimensões das fovéolas. 


\section{Gênero COLLARISPORITES DEÁK, 1964. Espécie-tipo: Collarisporites fuscus, DeAK, 1964.}

Collarisporites sp. cf. C. fuscus DeAK Estampa VII, figs. 10, 13, 14

Descrição: Esporo trilete, contorno subtriangular arredondado, lados levemente côncavos, com grandes verrugas na região equatorial. Face proximal lisa, ou fracamente ornamentada por pequenas verrugas. Face distal ornamentada por inúmeras verrugas irregulares, de diâmetro variando de 2,0 a 5,0 $\mu \mathrm{m}$.

Dimensões: $35-40 \mu \mathrm{m}$. (4 exemplares).

Comentários: A presença característica das verrugas na região equatorial do grão, faces proximal lisa e distal verrucada, asseguram o enquadramento neste gênero. Difere de Collarisporites fuscus DEAK, pelo contorno do "corpo central" e pelo tamanho das laesuras, que aqui não atingem o equador do grão.

Gênero MATTHESISPORITES DÖRING, 1964. Espécie-tipo: Matthesisporites tumulosus, DöRNG, 1964.

\section{Matthesisporites sp. 1}

Estampa VII, fig. 7

Descrição: Esporo trilete de contorno subcircular, face distal ornamentada com proeminentes elementos tuberiformes e verrugas irregulares. Face proximal escabrada e com ornamentação pobremente desenvolvida.

Dimensões: $30-38 \mu \mathrm{m}$. (4 exemplares).

Comentários: A ornamentação tuberosa proeminente e dominantemente na face distal da forma em questão permite sua inclusão neste gênero. Autores como Srivastava (1975), entre outros, consideram que apenas o maior tamanho e altura das ornamentaçðes são insuficientes para se erigir um gênero, preferindo 
considerar estas variações como intraespecíficas. Desse modo consideram Matthesisporites DörING, como sinônimo júnior de Leptolepidites NorRIs. A singularidade que as formas deste material apresentam justifica a utilização do gênero de Döring.

Gênero HAMULATISPORIS KRUTZSCH emend. SRIVASTAVA, 1972. Espécie-tipo: Hamulatisporis hamulatis KRUTzSCH, 1959.

Obs: Este gênero, como emendado por Srrvastava (1972A), é restrito aos esporos azonotriletes, rugulados e sem crassitudes interradiais. Apresentam geralmente contorno circular e os elementos esculturais estão presentes em ambas as faces, proximal e distal. De acordo com Jansonius \& Hirls (1976), Hamulatisporites NaKoman (1966) é sinônimo júnior de Hamulatisporis. Hamulatisporis é considerado por alguns autores com subgênero de Camarozonotriletes, como tratado por KRUTzSCH (1963B); outros como sinônimo júnior de Lycopodiacidites, segundo KLAUs (1960). Para maiores detalhes taxonômicos, ver comentários aprofundados de SRIVASTAVA (1975), pois o gênero é aqui considerado na sua acepção.

\title{
Hamulatisporis albertensis SRTASTAVA \\ Estampa V, fig. 18
}

Vide Srivastava (1972A, P. 17) para descrição.

Dimensões: $28-30 \mu \mathrm{m}$. ( 2 exemplares).

Comentários: Os exemplares aqui ilustrados, apesar de apresentarem exina menos espessa, assemelham-se consideravelmente aos apresentados pelo autor.

\author{
Hamulatisporis sp. 1 \\ Estampa V, figs. 21, 22
}

Descrição: Esporo trilete, contorno circular a ovalado. Marca trilete pouco visível, com laesuras curtas. A exina na face distal é fortemente rugulada. As 
rugulas são bastante sinuosas e largas (ao redor de $3 \mu \mathrm{m}$ ).

Dimensões: $40-48 \mu \mathrm{m}$. (5 exemplares).

Comentários: Apesar dos exemplares aqui descritos apresentarem os elementos esculturais ultrapassando as bordas do grão, suas características de contorno e ornamentação permitem o enquadramento dos mesmos no gênero em questão.

Infraturma TRICRASSATI DETTMANN, 1963.

Gênero GLEICHENIIDITES ROSS, 1949 emend. Skarby, 1964. Espécie-tipo: Gleicheniidites senonicus Ross.

Vide Detrmann (1963, P. 64) para sinonímia e emenda na diagnose do gênero.

\section{Gleicheniidites senonicus Ross emend. SKARBY Estampa.V, figs. 14, 15}

Vide SKARBY (1964, p. 65) para sinonímia e revisão da diagnose.

Dimensões: $25-30 \mu \mathrm{m}$. (5 exemplares).

Comentários: As especies identificadas possuem todas as características indicadas por SkARBY (1964) na revisão do gênero. Mostram consideráveis variações no tamanho e forma de G. senonicus, incluindo na designação da espécie esporos triangulares com crassitudes equatoriais interradiais, descontínuas nos cantos. BoLKHOVITINA $(1966,1967)$, apresenta importantes aspectos sobre a morfologia e taxonomia dos esporos da família Gleicheniaceae.

Gênero CAMAROZONOSPORITES PANT, 1954 ex POTONIÉ, 1956. emend. KLAUS 1960.

Espécie-tipo: Camarozonosporites cretaceus (Wenland e KRIEGER) PoTONÉ, 1956. 
Vide Klaus (1960, P. 35) para emenda da diagnose e SRIVAstava (1972A, P. 6) para sinonímia.

\section{Camarozonosporites sp. cf. C. insignis NORRIs Estampa V, fig. 19}

Vide NoRrss $(1967$, P. 96, 97) para descrição e comentários.

Dimensões: $35-43 \mu \mathrm{m}$. ( 2 exemplares).

Comentários: Os exemplares aqui apresentados apresentam rugulas finas na face distal, como da definição da espécie, contudo sua ornamentação atinge o equador do grão.

Camarozonosporites sp. 1

Estampa V, figs. 12, 17

Descrição: Esporo trilete de contorno subcircular. Face proximal lisa. Laesuras retas, atingindo a borda do grão que apresenta pequeno espessamento na região equatorial.

Dimensões: $36-45 \mu \mathrm{m}$. (8 exemplares).

Comentários: Estes grãos apresentam rugulas irregularmente sinuosas, altas.

\section{Camarozonosporites sp. 2}

Estampa V, fig. 16

Descrição: Esporo trilete, circular. Face proximal lisa. Laesuras pouco visíveis, retas, não atingindo o equador do grão. Face distal fortemente ornamentada por rugulas sinuosas e cíngulo estreito.

Dimensões: $32 \mu \mathrm{m}$. ( 2 exemplares). 
Comentários: Difere dos exemplares anteriormente citados pelo tamanho relativamente menor e pela ornamentação mais densa.

Gênero TRILOBOSPORITES PANT, 1955 ex POTONIÉ, 1956.

Espécie-tipo: Trilobosporites hannonicus (Delcourt \& SpRUmont) PotonIE, 1956.

Vide DeLcourt et alii (1963, P. 288) para a descrição do gênero e Singh (1983, P. 36-37) para sinonímia e discussão.

\section{Trilobosporites apiverrucatus COUPER \\ Estampa VII, figs. 6, 12}

Vide COUPER (1958, P. 142) para descrição.

Dimensões: $55-80 \mu \mathrm{m}$. ( 6 exemplares).

Comentários: Considerou-se no presente estudo o gênero Trilobosporites sensu Pocock (1962), onde o contorno do grão é triangular, com lados podendo variar desde fortemente côncavos a retos. VenxatachnLA et alii (1968) criaram o gênero Impardecispora, para acomodar as espécies sem valvas previamente atribuídas a Trilobosporites, restringindo assim este último, apenas a formas com valvas. SINGH (1983) discorda de tal procedimento, argumentando que estritamente falando nenhuma forma atribuída ao gênero Trilobosporites pode ser considerada "com valva", e considera que a ornamentação de Impardecispora é similar e indistinguível da de Trilobosporites. Consideramos válidos os argumentos de SiNGH (1983), por ser praticamente impossível discernir valvas em espécies tão densamente ornamentadas, como o são as deste gênero, pois o próprio aumento no tamanho e na concentração da ornamentação (verrugas, muros) nas regiões apicais dos grãos aparenta um espessamento.

Os exemplares ora apresentados assemelham-se bastante aos ilustrados por ArChangelsky \& GaMerro (1966B, P. 229, est. 1, Fig. 1)

Trilobosporites sp. cf. T. humilis DeLCOURT \& SpRUMONT

Estampa VII, figs. 16, 17 
Vide Couper: (1958, P. 142) para descrição e Venkatachala et alii (1968A, P. 124) para sinonímia.

Dimensões: 50-60 $\mu \mathrm{m}$. ( 5 exemplares).

Comentários: Esta espécie é facilmente reconhecível pelo seu contorno triangular e ornamentação homogeneamente verrucada nas áreas interradiais. Os exemplares identificados obedecem a descrição geral de BreNNER (1963), contudo são de dimensões bem mais reduzidas.

\section{Trilobosporites minor Pocock \\ Estampa VII, fig. 18}

Vide Pocock (1962, P. 44) para descrição.

Dimensões: $22-35 \mu \mathrm{m}$. ( 3 exemplares).

Subturma ZONOTRILETES WALTZ, 1935

Infraturma CINGULATI POTONIÉ \& KLAUS, 1954, emend. DETTMANN, 1963.

Gênero CINGUTRILETES PIERCE, 1961, emend. DETTMANN, 1963

Espécie-tipo: Cingutriletes congruens PIERCE

Obs: Cingutriletes ê um gênero que tem sido restrito a formas cinguladas de âmbito subcircular a circular.

\section{Cingutriletes sp.}

Estampa VII, figs. 15, 20

Descrição: Esporo trilete cingulado, de contorno subcircular, com laesuras retas, partindo de uma área circular pequena, do centro do grão e atingindo o equador. Exina lisa, em ambas as faces, espessa e escura. 
Dimensões: $60 \mu \mathrm{m}$. ( 2 exemplares).

Comentários: Forma muito rara no presente material. Sua caracterização específica é difícil, em função da simplicidade do grão, onde na maioria das vezes as variaçס̃es ocorrem apenas nas dimensões do mesmo.

\title{
Gênero ANTULSPORITES ARCHANGELSKY \& GAMERRO, 1966 Especie-tipo: Antulsporites baculatus ARCHANGELSKY \& GaMerro.
}

\author{
Antulsporites sp. cf. A. baculatus ArCHANGELSKY \& GAMERRo \\ Estampa VIII, figs. 5, 6, 10, 12, 16
}

Vide ARChANGelsky \& GAMERro (1966A, P. 203) para descrição original.

Dimensões: $45-65 \mu \mathrm{m}$. (10 exemplares).

Comentários: A presença de cíngulo fino e radialmente estriado, aliado à presença de forte ornamentação na face distal, em relação a proximal, são características do gênero. As espécies aqui ilustradas, apesar de serem próximas à diagnose da espécie-tipo, diferem pela ausência de espinhos próximo ao cíngulo, e pelas dimensões gerais menores. Contudo, não se considera que seja caso de criação de uma nova espécie, no momento, pelo número reduzido de exemplares bem preservados; e pelo fato dos autores, quando da definição da mesma, não terem enfatizado esta ornamentação. Difere de A. varigranulatus (D ANZÉ-CORSIN \& LAVEINE) REISER \& WILliams (1969), por não apresentar a grande variação nas dimensões da ornamentação desta última, e também pelas dimensð̃es gerais menores. Difere de A. distaverrucosus (BrenNer) ArChangelsky \& Gamerro (1966c), pelo tamanho e formato das verrugas.

Este gênero foi inicialmente designado de Heliosporites, porém, este nome já havia sido préviamente utilizado por Schulz (1962, P. 311). Posteriormente Archangelsky \& GaMERro (1966c, P. 369) o substituiram por Antulsporites. 
Gênero CONTIGNISPORITES DETTMANN, 1963.

Espécie-tipo: Contignisporites glebulentus DetTManN.

\section{Contignisporites sp. 1}

Estampa VII, fig. 19

Descrição: Esporo trilete, contorno triangular arredondado. As laesuras da marca trilete possuem leve espessamento e atingem a borda do grão. $O$ equador $E$ marcado por um cíngulo muito estreito. A face proximal é lisa a finamente escabrada. Os elementos esculturais da face distal são constituídos de 6 a 9 costelas subparalelas, de $2-3 \mu \mathrm{m}$ de espessura, coalescendo no cíngulo.

Dimensões: $30-35 \mu \mathrm{m}$. (2 exemplares).

Comentários: Os exemplares aqui descritos caracterizam-se por possuir cíngulo pouco evidente e pequenas dimensठ̃es. O exemplar, Contignisporites sp., ilustrado por Reiser \& Williams, (1969, P. 12, est. 5, Figs. 3-4) é bastante próximo aos ora apresentados.

Gênero MUROSPORA SOMERS, 1952

Espécie-tipo: Murospora kosankei, SOMERs, 1952

\section{Murospora sp. 1}

Estampa VII, figs. 8, 11

Descrição: Esporo trilete, âmbito subtriangular arredondado. Laesuras finas, sinuosas, atingindo a borda do corpo central. Exina muito espessa, lisa. Apresenta cíngulo extremamente desenvolvido, atingindo $10 \mu \mathrm{m}$ nas áreas mais espessas.

Dimensões: $35-40 \mu \mathrm{m}$. ( 2 exemplares).

Comentários: Difere das demais espécies do gênero pelo contorno extremamente irregular do cíngulo. Difere de Murospora florida, a espécie mais reportada na literatura, pelo "corpo central" triangular e fortemente concavo desta última. 
Infraturma AURICULATI SCHOPF, 1938 emend. DETTMANN, 1963.

Gênero MATONISPORITES COUPER, 1958.

Espécie-tipo: Matonisporites phlebopteroides COUPER, 1958.

\section{Matonisporites silvai LIMA}

Estampa V, fig. 20

Vide LIMA $(1978$, p. 165, 166) para diagnose e descrição.

Dimensões: $60-85 \mu \mathrm{m}$. (5 exemplares).

Comentários: O exemplar ilustrado assemelha-se bastante à especie de LIMA (1978); possuindo todas as características do gênero em questão. É próximo também da espécie Matonisporites equiexinus COUPER, diferindo apenas na espessura da exina.

Gênero AURITULINASPORITES NILSSON, 1958.

Espécie-tipo: Auritulinasporites scanicus Nısson

\section{Auritulinasporites sp. 1}

Estampa VI, fig. 1

Descrição: Esporo trịlete, âmbito triangular. Lados levemente côncavos e cantos arredondados. Exina muito espessa, lisa. Marca trilete pequena, com distinto margo que se prolonga em direção aos ápices do grão.

Dimensões: $65 \mu \mathrm{m}$. ( 1 exemplar).

Comentários: Com características sempre claramente observáveis, este gênero é de fácil identificação. Entretanto sua classificação específica é dificultada, pois as diferenças geralmente se prendem apenas às dimensões gerais e espessura 
da exina.

Gênero APPENDICISPORITES WEILAND \& KRIEGER, 1953.

Espécie-tipo: Appendicisporites tricuspidatus WEILAND \& KRIEGER.

Appendicisporites sp. cf. A. insignis (MARKova) ChLonova, 1976 Estampa VIII, fig. 4

Vide SINGH (1983, p. 36) para descrição e comentários.

Dimensões: $45-55 \mu \mathrm{m}$. ( 4 exemplares).

Comentários: $O$ exemplar apresentado contém as características que definem a espécie em questão, à exceção das dimensões dos apêndices, que são bem menores.

\section{Appendicisporites sp. 1}

Estampa VIII, figs. 3, 7

Descrição: Esporo trilete, com as laesuras (retas) atingindo a borda do grão, acompanhadas de um pequeno margo. Contorno triangular com raios convexos. Vista proximal contendo de três a quatro costelas em cada área interrradial. Estas costelas medem de 3-4 $\mu \mathrm{m}$ de espessura e se dispõem paralelas ao lado do grão, coalescendo nas áreas apicais. A superfície distal é ornamentada por 5-8 costelas subparalelas, oblíquas em relação às da face proximal.

Dimensões: $38-45 \mu \mathrm{m}$. (5 exemplares).

Comentários: Esta forma é caracterizada pelos apêndices bastante curtos e pelo pequeno número de costelas ao longo de cada área interrradial. 


\title{
Infraturma ZONATI POTONIÉ \& KREMP, 1954
}

\section{Gênero AEQUITRIRADITES DELCOURT \& SPRUMONT, 1955 emend. DETTMANN, 1963. \\ Espécie-tipo: Aequitriradites dubius DeLCoURT e Sprumont}

\author{
Aequitriradites sp. 1 \\ Estampa VI, figs. 3, 7
}

Descrição: Esporo trilete zonado, âmbito subtriangular arredondado. Corpo central subcircular a triangular arredondado, nem sempre bem delineado. Laesuras longas sinuosas e espessadas, ultrapassando a zona e alcançando o equador. Freqüentemente um dos raios da laesura é menor ou apresenta-se segmentado. Exina escabrada a microgranulada. Zona, pouco mais fina que o corpo central,

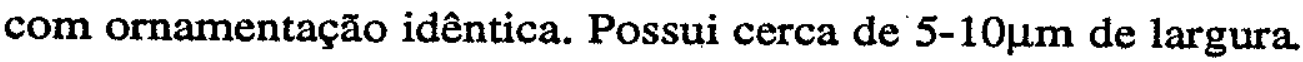

Dimensões: $45-75 \mu \mathrm{m}$. (8 exemplares).

Comentários: Alguns especimens deste estudo são semelhantes, no aspecto geral, à espécie $A$. dubius (Delcourt \& Sprumont) Delcourt, Dettmann \& HuGHES (1963); entretanto não se observa a ornamentação granular-verrucosa, presente na face distal de $A$. dubius.

Aequitriradites sp. 2

Estampa VI, figs. 9, 10

Descrição: Esporo trilete escabrado. Contorno subtriangular arredondado, com lados convexos. Corpo central triangular arredondado. Os raios da marca trilete se estendem em direção a zona atingindo o equador do grão. As laesuras são levemente sinuosas e um tanto espessadas. Zona com cerca de $5,0 \mu \mathrm{m}$ de largura e com exina pouco mais fina que a do corpo central.

Dimensões: $30-33 \mu \mathrm{m}$. (5 exemplares).

Comentários: Difere de Aequitriradites sp. 1, pelas dimensões gerais menores, ornamentação da exina, nitidez do corpo central e marca trilete conspícua. 
Infraturma PERINOTRILITI ERDTMANN, 1947 emend. DETTMANN, 1963

Gênero DENSOISPORITES (WEYLAND \& KRIEGER, 1953) DETTMANN, 1963 Espécie-tipo: Densoisporites velatus (WeYLAND \& KrIEGER) Krasnova.

\section{Densoisporites dettmannae (SRTVASTAVA) DejaX}

Estampa VI, figs. 5, 11, 14

Vide Dejax (1987, P. 53) para descrição, discussão e observações.

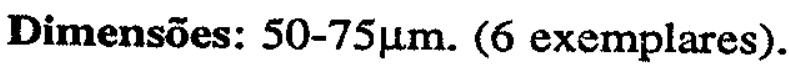

Comentários: Os exemplares acima mencionados são idênticos aos descritos e ilustrados por Dejax (1987). E como observado pelo autor, possuem um aspecto de grão monossacado, tendo sido classificado por DRUGG (1967) sob a denominação de Applanopsis dettmannae.

Gênero PEROTRILITES (ERDTMANN, 1947) ex COUPER, 1953 emend. EvANs, 1970.

Espécie-tipo: Perotrilites granulatus CouPER.

Obs: Este gênero é aqui utilizado, segundo a redefinição de Evans (1970, P. 66), que designa Perotrilites como esporos triletes zonados. (ver observações na designação genérica de Crybelosporites).

Perotrilites sp. 1

Estampa VI, fig. 4

Descrição: Esporo trilete. Contorno triangular arredondado, exina espessa, escura e lisa. Marca trilete visível, simples e longa, com laesuras chegando próximo a borda do grão. Envolvendo o grão observa-se uma espécie de perispório ou zona, também espessa, com ornamentação escabrada. 


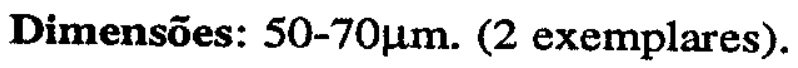

Comentários: Estes exemplares são de difícil caracterização, não permitindo o enquadramento no gênero Crybelosporites, pelas suas características gerais. Não foi possível distinguir que o mesmo é zonado ou perisporado.

\section{Gênero CRYBELOSPORITES DETTMANN, 1963.}

Espécie-tipo: Crybelosporites striatus (Cookson \& DetTMAnn) DetTManN.

Obs: Detrmann (1963) criou o gênero Crybelosporites, para acomodar esporos triletes perinados, onde parte da exina (esculpitina ?) é cavada na face proximal. Distinguindo desse modo do gênero Perotrilites Evans, que 6 um esporo zonado. (Maiores detalhes são discutidos por SINGH (1983, P. 39-40) e DeJAX (1987, P. 54 A 57$)$.

\section{Crybelosporites striatus (Cookson \& Detrmann) Dettmann. Estampa VII, figs. 1, 2}

Vide Detrmann (1963, P. 81) para descrição.

Dimensões: $30-50 \mu \mathrm{m}$. (8 exemplares).

\section{Crybelosporites brenneri PLAYFORD \\ Estampa VII, figs. 3, 4, 5}

Vide Playford (1971, P. 550) para descrição.

Dimensões: $22-30 \mu \mathrm{m}$. (10 exemplares).

Crybelosporites pannuceus (BRENNER) SRrVASTAVA

Estampa VI, figs. 2, 6, 8, 12, 13

- Vide Brenner (1963, P. 66) para descrição e SRIVAstava (1975, P. 35) para sinonímia. 
Dimensões: Diâmetro Total: 45-65 $\mu \mathrm{m}$; Corpo Central: $35-50 \mu \mathrm{m}$.

\section{ESPORO TRILETE INDETERMINADO \\ Estampa V, fig. 23}

Descrição: Esporo trilete de contorno subtriangular a circular. Marca trilete longa, com as extremidades das laesuras formando curvaturas que as ligam entre si; formando áreas de contato nítidas. Possui um espessamento na região equatorial (cíngulo?). A exina é bastante espessa e sem ornamentação.

Dimensões: $45 \mu \mathrm{m}$. ( 1 exemplar).

Comentários: Forma rara, de difícil enquadramento genérico. Por ilustração, pode ser atribuído aos gêneros Retusotriletes e Cadiospora, restritos ao Paleozoico. É também similar na maioria dos aspectos ao gênero Bellisporites, diferindo apenas nas dimensões, aqui maiores. $O$ único exemplar encontrado não permite contudo uma classificação genérica.

TURMA MONOLETES IBRAHIM, 1933

Subturma AZONOMONOLETES LUBER, 1935

Infraturma LAEVIGATOMONOLETI DYBOWA \& JACHOWICZ, 1957

Gênero LAEVIGATOSPORITES (IBRAHIM, 1933) SCHOPF, WILSON \& BENTALL 1944

Espécie-tipo: Laevigatosporites vulgaris (IBRAHIM, 1932) IвRAHIM, 1933.

Laevigatosporites ovatus WILSON \& WEBSTER

Estampa VIII, fig. 13

Vide SINGH (1964, P. 99) para sinonímia e descrição. 
Dimensões: $\mathrm{C}=28-45 \mu \mathrm{m} . \mathrm{L}=23-36 \mu \mathrm{m}$.

Infraturma ORNATI Potonie, 1956

Gênero MICROFOVEOLATOSPORIS KRUTZSCH 1959 emend. POTONIÉ, 1966 Espécie-tipo: Microfoveolatosporis pseudodentatus KrUTzsch, 1959

\author{
Microfoveolatosporis daukiensis KAR \& SINGH \\ Estampa VIII, fig. 15 \\ Estampa IX, fig. 4
}

Vide KAR \& SinGH (1986, p. 106) para descrição.

Dimensões: $\mathrm{C}=65-85 \mu \mathrm{m} . \mathrm{L}=35-45 \mu \mathrm{m}$. (8 exemplares).

Comentários: Alguns autores, tais como, Potonie (1966) e Srivastava (1971), entre outros, têm posicionado o gênero Reticulosporis KRUTzSCH, como sinônimo júnior de Microfoveolatosporis KRuTzsCH. Neste trabalho considerou-se o conceito de SINGH (1983), que valida ambos os gêneros, aceitando a diagnose de KRUTZSCH que caracteriza Microfoveolatosporis como esporos monoletes densamente microfoveolados, cujas foveolas são diminutas, podendo se confluir e formar um padrão vermiculado. Os especimes ilustrados enquadram-se perfeitamente na descrição genérica e específica aqui atribuída.

Gênero RETICULOSPORIS KRUTZSCH, 1959

Espécie-tipo: Reticulosporis miocenicus (SELLNG) KRUTzSCH, 1959

Reticulosporis foveolatus (PIERCE) SKARBY

Estampa IX figs. 2, 3, 5

Vide Singh (1983, P. 50) para discussão do gênero. 
Dimensões: $\mathrm{C}=65-80 \mu \mathrm{m} . \mathrm{L}=35-40 \mu \mathrm{m}$. (6 exemplares).

Comentários: O gênero Reticulosporis foi erigido por KRUTzSCH (1959), para acomodar esporos monoletes com elementos esculturais reticulados. Os lumina podem ser circulares ou poligonais e os muri tectados.

Gênero CICATRICOSOSPORITES PFLUG \& THOMSON 1953

Espécie-tipo: Cicatricososporites eocenicus (SELLng) Poronte 1956.

Cicatricososporites sp. cf. C. norrisii SRIVASTava Estampa IX, fig. 9

Dimensões: $\mathrm{C}=75 \mu \mathrm{nh} . \mathrm{L}=40 \mu \mathrm{m}$. (1 exemplar).

Obs: Espécie de fácil reconhecimento pela ornamentação cicatricosa da exina e pelo seu aspecto reniforme. A marca monolete não é visível nos exemplares observados neste estudo, contudo notam-se os polos mais densos e escuros. Este táxon possui uma nomenclatura historicamente controversa. Publicada em detalhes no catálogo de J ANsontus \& HiLls, 1976, tem sua discussão iniciada com os gêneros Schizaeoisporites Potonif (1951) e Delcourt \& Sprumont (1955), e Cicatricososporites Pfug \& Thomson in Thomson \& Pflug (1953). Resumidamente, ambos os primeiros autores se referem à mesma espécie-tipo, Sporites dorogensis. Potonî(1934), para seus respectivos gêneros, Schizaeoisporites e Cicatricososporites. Schizaeoisporites foi proposto informalmente em 1951 por PoTONE e validado em 1955 por Delcourt \& Sprumont. EM 1953, Thomson \& Pflug publicaram validamente o gênero Cicatricososporites. Por conseguinte, em estrita obediência às regras de prioridade, Schizatoisporites é obrigatoriamente um sinônimo júnior de Cicatricososporites.

Gênero VERRUCATOSPORITES (PFLUG, 1953) POTONIÉ, 1956 Espécie-tipo: Verrucatosporites alienus (Potonit) THOMson \& Pflug, 1953. 


\section{Verrucatosporites chalonerii KREMP}

Estampa VIII, fig. 11

Vide $\mathrm{KEMP}(1970$, P. 112) para descrição, comentários e sinonímia.

Dimensões: $\mathrm{C}=40 \mu \mathrm{m} . \mathrm{L}=23 \mu \mathrm{m}$. (2 exemplares).

Gênero SCHWEITZERISPORITES KAISER, 1976

Espécie-tipo: Schweitzerisporites maculatus KAISER

Schweitzerisporites? sp.

Estampa IX, figs. 1, 6

Descrição: Esporo monolete, elipsoidal. Laesura longa, quase atingindo o equador, fechada e com lábios muito finos. Exina com duas camadas, espessa. Ornamentação, em toda a superfície do grão, constituída de um retículo

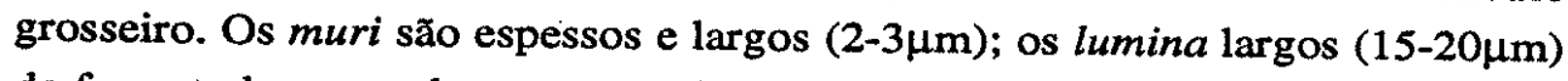
de formato hexagonal a pentagonal,"com lados desiguais.

Dimensões: $\mathrm{C}=90-95 \mu \mathrm{m} . \mathrm{L}=70 \mu \mathrm{m}$. (5 exemplares).

Comentários: KAISER (1976) erigiu o gênero Schweitzerisporites, para incorporar esporos monoletes do Paleozóico Superior com ornamentação reticulada, onde os lumina são irregulares, poligonais e muito largos (20-30 $\mu \mathrm{m}$ na espécie-tipo). Os exemplares aqui descritos enquadram-se com ressalvas na descrição do gênero, uma vez que os lumina são um pouco menores, e os muri mais espessos que os da espécie-tipo. Desse modo, optou-se por atribuir aos espécimens do Cretáceo do Brasil classificação genérica duvidosa. 


\section{POLLENITES}

Anteturma VARIEGERMINANTES R. POTONIÉ, 1975

Turma SACCITES ERDTMAN, 1947

Subturma MONOSACCITES CHITALEY, 1951 emend. POTONIE \& KREMP, 1954

Infraturma SACCIZONATI BHARADWAJ, 1957.

Gênero CALLIALASPORITES DEV, 1961.

Espécie-tipo: Callialasporites trilobatus (BALME) Dev, 1961.

Obs: São vários os gêneros utilizados, por diferentes autores, na designação das formas monossacadas de aspecto lenticular e contorno circular ondulado (Applanopsis, Calliallasporites, Zonallapollenites, Pflugipollenites, Tsugaepollenites, etc.). No presente trabalho, considerou-se que a designação mais adequada a este gênero é a de Callialasporites, por avaliar como corretos e válidos os argumentos de Pocock (1968, P. 639) mostrando que dentre os diferentes nomes utilizados, os gêneros Zonallapollenites e Callialasporites têm prioridade. Callialasporites foi criado por DEv (1961), para formas mesozbicas, enquanto que Zonallapollenites foi originalmente estabelecido para grãos de pólen do Terciário, os quais assemelham-se a certas espécies modernas de Tsuga.

Estudos em detalhe realizados por REYRe (1973) e FiLATOFF (1975) têm revelado que a razão entre o diâmetro do corpo central e o diâmetro total se apresenta relativamente constante dentre as espécies de Callialasporites, sendo um parâmetro útil na definição e distinção das espécies. FILAToff apresenta um diagrama mostrando estas relações, utilizando este e outros elementos, tais como contorno do corpo central, transparência e dobras da exina na delimitação das espécies. Dada a presença abundante e grande diversidade apresentada por este gênero no material estudado, apresenta-se um quadro semelhante para sumariar as diferenças entre as espécies de Callialasporites aqui identificadas (quadro 1). A dimensão total dos grãos não $\epsilon$, de modo geral, considerada diagnóstica; contudo foi incluída no quadro geral, pois as formas presentes no material estudado apresentam dimensð̃es globais um pouco menores $(48-65 \mu \mathrm{m})$ que as apresentadas comumente na literatura. 


\begin{tabular}{|c|c|c|c|c|c|c|c|c|}
\hline & $\begin{array}{l}\text { Calliclosporites } \\
\text { minus } \\
\text { (RALAU) GUY, } 11\end{array}$ & $\begin{array}{l}\text { Callialasporifes } \\
\text { segmentatus } \\
\text { (BALME) SRRVASTAVA, } 63\end{array}$ & $\begin{array}{l}\text { Collialasporites } \\
\text { microvelatus } \\
\text { SCHuzZ, } 36\end{array}$ & $\begin{array}{c}\text { Callialasporites } \\
\text { triangularis } \\
\text { (IEVE-CARETE REYRE, } 73\end{array}$ & $\begin{array}{l}\text { Callialasporites } \\
\text { (Ucidus } \\
\text { (POCOCX) REYRE, } 73\end{array}$ & $\begin{array}{l}\text { Callialasporites } \\
\text { turbatus } \\
\text { (BALME) SCHULZ, 67 }\end{array}$ & $\begin{array}{l}\text { Callialasponites } \\
\text { trilobatus } \\
\text { (BALME) DEV, } 61\end{array}$ & $\begin{array}{l}\text { Callialasponifes } \\
\text { dampieri } \\
\text { (BALME) DEV. } 61\end{array}$ \\
\hline $\begin{array}{l}\text { RAZÄO } \\
\text { C. CENTRAL } \\
\text { DIÂM. TOTAL } \\
\end{array}$ & $3 / 4-7 / 8$ & $5 / 4 \cdot 7 / 8$ & $7 / 8$ & $1 / 2-3 / 4$ & $2 / 3-3 / 4$ & $1 / 3-3 / 4$ & $2 / 3-3 / 4$ & $>T / 2<3 / 4$ \\
\hline $\begin{array}{l}\text { CONTORNO } \\
\text { DO GRAO }\end{array}$ & SUBCIRCULAR & SUBCIRCULAR-OVAL & CIRCULAR & $\begin{array}{l}\text { TRIANGULAR } \\
\text { ARREDONDADO }\end{array}$ & SUBTRIANGULAR & $\begin{array}{c}\text { TRIANGULAR } \\
\text { ARREDONDADO } \\
\text { SUBCIRCULAR }\end{array}$ & $\begin{array}{l}\text { IRILOBADO } \\
\text { IRIANGULAR }\end{array}$ & $\begin{array}{c}\text { CIRCULAR } \\
\text { IIRANGULAR } \\
\text { ARREDONDADO }\end{array}$ \\
\hline $\begin{array}{l}\text { CONTORNO DO } \\
\text { C. CENTRAL }\end{array}$ & CIRCULAR & CIRCULAR-OVAL & CIRCULAR & IRIANGULAR & $\begin{array}{l}\text { SUBSRIANGULAR } \\
\text { ARREDONDADO }\end{array}$ & $\begin{array}{l}\text { POIYGONAL } \\
\text { TRIANGULAR }\end{array}$ & IRIANGULAR & $\begin{array}{c}\text { CIRCULAR A } \\
\text { SUBTRIANGULAR }\end{array}$ \\
\hline $\begin{array}{l}\text { NITIDEZ DO } \\
\text { C. CENTRAL }\end{array}$ & DISINTO - INDISTINTO & INDISTINTO & DISTINTO - INOISTINTO & DISTINTO - INDISTINIO & DISINIO & DISTINTO & DISTINIO & DISTINTO - INDISTINTO \\
\hline $\begin{array}{l}\text { COLORAÇĀO DO } \\
\text { C. CENTRAL }\end{array}$ & ESCURO & ESCURO & ESCURO & CLARO & CLARO & ESCURO-CLARO & ESCURO & ESCURO \\
\hline $\begin{array}{c}\text { DOBRAS DA } \\
\text { EXINA }\end{array}$ & $\begin{array}{l}\text { ESCASSAS E } \\
\text { CONVOLUTAS }\end{array}$ & $\begin{array}{l}\text { ABUNDANIES E } \\
\text { CONVOLUTAS }\end{array}$ & $\begin{array}{c}\text { ESCASSAS E } \\
\text { CONNOOULTAS } \\
\text { (NO EQUADOR) } \\
\end{array}$ & $\begin{array}{c}\text { ESCASSAS E } \\
\text { CONVOLITAS A } \\
\text { RADIAIS } \\
\end{array}$ & $\begin{array}{c}\text { ESCASSAS } \\
\text { INDISIINASAS A } \\
\text { AUSENTES } \\
\end{array}$ & AUSENTES & $\begin{array}{c}\text { ESCASSAS } \\
\text { CONVOLUUAS A } \\
\text { RADIAIS }\end{array}$ & $\begin{array}{c}\text { ABUNDANIES } \\
\text { CONVOUUTAS A } \\
\text { RADIAIS } \\
\end{array}$ \\
\hline $\begin{array}{l}\text { DIMENSĀO MÉDIA } \\
\text { DO GRÄO }\end{array}$ & $48 \mathrm{um}$ & $55 \mathrm{\nu m}$ & $62 \mu \mathrm{m}$ & $53 \mathrm{um}$ & $55 \mathrm{um}$ & $60 \mathrm{um}$ & $50 \mathrm{dm}$ & $50 \mathrm{um}$ \\
\hline & $\frac{5}{2}$ & & & & & & & at \\
\hline
\end{tabular}

QUADRO 1 - CARACTERÍSTICAS PRINCIPAIS DENTRE AS ESPÉCIES DE Callialasporites IDENTIFICADAS NESTE TRABALHO. 


\section{Callialasporites trilobatus (BALME) DEV \\ Estampa X, fig. 4}

Vide Balme (1957, P. 33) para descrição.

Dimensões: 50-65 $\mu \mathrm{m}$. ( 3 exemplares).

Comentários: Esta espécie é caracterizada por apresentar saco fortemente trilobado e um corpo marcadamente triangular escuro. Os exemplares identificados neste estudo não apresentam o corpo central escuro, contudo pelas demais características são perfeitamente enquadráveis na espécie em questão.

\section{Callialasporites dampieri (BALME) DEv}

Estampa IX, figs. 7, 8, 11

Vide BaLme (1957, P. 32) para descrição genérica e diagnose específica; e SiNGH (1971, p. 175) para comentários e sinonímia.

Dimensões: $40-55 \mu \mathrm{m}$. (20 exemplares).

Comentários: Ocorre grande variação no formato do corpo central e nas dobras radiais presentes nesta espécie. No material estudado a maioria apresenta corpo central subcircular a circular, escuro.

\section{Callialasporites lucidus (Pocock) REYRE}

Estampa IX, figs. 13, 15

Vide REYRE (1973, P. 172) para descrição.

Dimensões: $50-55 \mu \mathrm{m}$. (3 exemplares).

Comentários: Caracteriza-se pela exina fina quase transparente. O corpo central é finamente escabrado, claro e de formado triangular arredondado, possuindo três lobos eqüidistantes. Apesar de próximo à C. trilobatus BALME, difere 
pelas dimensões gerais um pouco menores, ornamentação da exina, corpo central mais triangular e escuro, além da natureza dos lobos laterais deste último.

\section{Callialasporites microvelatus ScHuLZ}

Estampa X, fig. 8

Vide Schulz (1966, p. 138) para descrição.

Dimensões: $50-65 \mu \mathrm{m}$. (5 exemplares).

Comentários: Espécie caracterizada pelo corpo central circular a oval. Exina fina. Normalmente sem dobras, contudo alguns exemplares apresentam-se levemente dobrados na região equatorial. Espécie muito próxima de Inaperturopollenites simplex REGALI et alii (1974); nota-se porem, em alguns exemplares diferenças na inserção dos sacci.

\section{Callialasporites minus (TRALAU) GUY \\ Estampa X, fig. 1}

Vide FiLAtoff (1975, P. 83) para descrição.

Dimensões: $45-48 \mu \mathrm{m}$. (2 exemplares).

Comentários: Forma de modo geral menor que as outras do gênero, morfologicamente situa-se numa posição intermediária entre as espécies $C$. dampieri e C. segmentatus.

Callialasporites segmentatus (BALME) SRTVASTAVA

Estampa $X$, figs. 2, 3, 17

Vide BALME (1957, P. 33) para descrição.

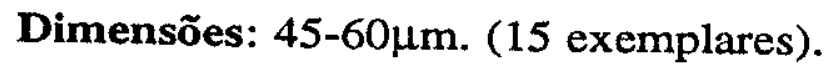


Comentários: Espécie caracterizada pelas dobras convolutas e pelo corpo central indistintamente delimitado.

\section{Callialasporites triangularis (LEVET-CARETTE) REYRE \\ Estampa IX, figs. 12, 14}

Vide ReYRe (1973, P. 171) para descrição.

Dimensões: $53-60 \mu \mathrm{m}$. (5 exemplares).

Comentários: Espécie cuja característica principal é a de apresentar, não um corpo central verdadeiro, mas sim, uma área central (leptoma?) delimitada pelas "vesículas" lobadas do grão.

\section{Callialasporites turbatus (BALME) ScHUZ Estampa X, fig. 7}

Vide Schulz (1967, P. 537) para diagnose e discussão.

Dimensões: 55-57 ب̣m. ( 2 exemplares).

Comentários: Esta espécie caracteriza-se por não apresentar dobras, sugerindo ausência de adesão da camada externa com o corpo central.

Gênero PROPERINOPOLLENITES MAHESHWARI, 1974. Espécie-tipo: Properinopollenites singhii MAHESHWARI

\section{Properinopollenites sp. LMA}

Estampa IX, fig. 10

Vide Lima (1978, P. 188-189) para descrição e comentários.

Dimensões: $63 \mu \mathrm{m}$. (1 exemplar). 
Comentários: O exemplar em questão é bastante similar ao descrito por Lima, diferindo apenas no tamanho que é bem menor.

SACCIZONATI gen. inc.

\author{
"Complicatisaccus" cearensis REGALI \\ Estampa X, figs. 5, 6, 9
}

Descrição: Grão de pólen monossacado, contorno equatorial oval a grosseiramente elíptico. Corpo central com formato aproximadamente igual ao do grão; geralmente bem distinto e com ornamentação escabrada a microreticulada. $O$ saco liga-se equatorialmente ao corpo central na face proximal; na face distal cobre totalmente o corpo central. O saco apresenta ornamentação intrareticulada. O diâmetro do lumina do saco é geralmente menor que $1,0 \mu \mathrm{m}$.

Dimensões: C. total $=36-55 \mu \mathrm{m}$. C. c.c. $=25-36 \mu \mathrm{m}$.

L. total $=35-40 \mu \mathrm{m}$. L. c.c. $=25-32 \mu \mathrm{m}$.

Comentários: Trata-se da espécie inicialmente atribuída por REGALr et alii (1985) a Vitreisporites signatus LESCHIK. Posteriormente, Regali (1989c) denominou-a Complicatisaccus cearensis REgAL. Contudo, conclui-se no presente trabalho, através da observação do holótipo e de outros exemplares, que a espécie não deve ser enquadrada no gênero Complicatisaccus por se tratar de uma forma monossacada. Por esta razão e também pelo fato de não se ter conseguido classificá-la, a nível de gênero, optou-se por deixar, provisóriamente, em aberto sua posição sistemática.

Subturma DISSACCITES COOKSON, 1947. Infraturma DISACCIATRILETI LESCHICK, 1955 emend. POTONIÉ, 1958.

Gênero VITREISPORITES (LESCHICK, 1956) JANSONIUS, 1962.

Espécie-tipo: Vitreisporites signatus LEschICK, 1956 


\section{Vitreisporites microsaccus JERSEY}

Estampa X, figs. 10, 14

Vide DE JERSEY (1964, P. 10) para descrição.

Dimensões: C. $\mathrm{t} .=30-32 \mu \mathrm{m}$. C. c.c. $=18-20 \mu \mathrm{m}$. C. saco $=10-12 \mu \mathrm{m}$.

L. t. $=18-20 \mu \mathrm{m}$. L. c.c. $=18-20 \mu \mathrm{m}$. L. saco $=18-20 \mu \mathrm{m}$. (5 exemplares).

Comentários: Este gênero caracteriza-se pelas suas dimensões gerais pequenas, $(<35 \mu \mathrm{m})$ e exina fina. $V$. microsaccus, difere de $V$. pallidus, pelas dimensões e foram dos sacci, visivelmente maiores.

\section{Vitreisporites pustulosus REGALI}

Estampa X, figs. 12, 15, 19, 20

Vide RegaLI (1987D, P. 649) para descrição.

Dimensões: C. $\mathrm{t} .=35-38 \mu \mathrm{m}$. C. c.c. $=18-23 \mu \mathrm{m}$. C. saco $=12-20 \mu \mathrm{m}$.

L. $t .=23-30 \mu \mathrm{m}$. L. c.c. $=21-30 \mu \mathrm{m}$. L. saco $=23-30 \mu \mathrm{m}$. (10 exemplares).

Comentários: A espécie V. pustulosus difere das demais espécies do gênero, pela presença de pústulas na face proximal do grão.

Vitreisporites sp. 1

Estampa X, figs. 11, 13, 16, 18

Descrição: Grão de pólen dissacado, levemente diploxylenoide. Sacos lisos. Corpo central liso a finamente granulado, com exina fina e de dimensões um pouco menor que os sacci.

Dimensões: C. t. $=37-40 \mu \mathrm{m}$. C. c.c. $=20-22 \mu \mathrm{m}$. C. $\mathrm{saco}=13-17 \mu \mathrm{m}$. L. $t .=22-24 \mu \mathrm{m}$. L. c.c. $=22-24 \mu \mathrm{m}$. L. saco $=20-22 \mu \mathrm{m}$. $(8$ exemplares $)$.

Comentários: Esta espécie, apesar das dimensões um pouco maiores, enquadra-se perfeitamente no gênero Vitreisporites. 
Gênero CEDRIPITES WODEHOUSE, 1933

Espécie-tipo: Cedripites eocenicus WoDEHOUSE, 1933

\section{Cedripites cretaceus Pocock \\ Estampa X, figs. 21, 24}

Vide Pocock (1962, p. 63) para descrição.

Dimensões: C. $\mathrm{t} .=55-65 \mu \mathrm{m}$. C. c.c. $=33-40 \mu \mathrm{m}$. C. $\mathrm{saco}=20-25 \mu \mathrm{m}$.

L. $\mathrm{t} .=35-45 \mu \mathrm{m}$. L. c.c. $=35-40 \mu \mathrm{m}$. L. saco $=35-45 \mu \mathrm{m}$. ( 5 exemplares $)$.

Comentários: Espécie caracterizada pela forma e ornamentação dos sacci, finamente reticulado a granuloso. Os exemplares do material estudado apresentam dimensões gerais menores que os ilustrados por Pocock, 1962.

TUIMA ALETES, KRIPTAINAPERTURATES IBRAHIM, 1933.

Subturma AZONALETES (LUBER, 1935) POTONIÉ e KREMP, 1954.

Infraturma PSILONAPITI ERDTMAN, 1947

Gênero INAPERTUROPOLLENITES (PFLUG, 1952 ex THOMSON \& PFLUG, 1953, POTONIÉ, 1958) POTONIÉ, 1966.

Especie-tipo: Inaperturopollenites dubius (Potonie \& Ventrz) Thomson \& Prug.

Obs: Estão incluídos neste gênero, apenas as formas inaperturadas de dimensões acima de $40 \mu \mathrm{m}$, segundo o ponto de vista de KRUTZSCH (1971).

Inaperturopollenites giganteus GóCZN, 1964

Estampa XI, fig. 12

Vide GOCZAN (1964, P. 247) para descrição. 
Dimensões: $\cdot 80 \mu \mathrm{m}$. ( 1 exemplar).

Comentários: Especie em tudo comparável a $I$. giganteus GóczÁ, apenas as

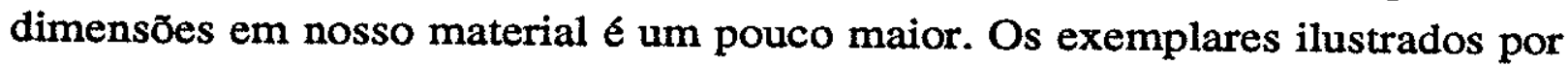
REYRE (1973, P. 163, EST. 31, FIGs. 2-5), mostram uma ornamentação escabrada, bastante visível, diferindo do exemplar aqui encontrado.

Inaperturopollenites simplex REGAL, UESUGUI \& SANTOS.

Estampa XI, figs. 13, 17, 18

Vide Rkgali Uesugur \& SANTos (1974, P. 270) para descrição.

Dimensões: $58-75 \mu \mathrm{m}$. (10 exemplares).

Inaperturopollenites turbatus BALME (sENSU REGALI et alii, 1974)

Estampa XI, figs. 11, 14, 15, 16

Vide Balme (1957, P. 35) para descrição e Regali Uesugur \& SANtos (1974, est. V, FiG. 1) para ilustração.

Dimensões: $55-80 \mu \mathrm{m}$. (15 exemplares).

Comentários: Os especimens brasileiros atribuídos a $I$. turbatus coincidem, em grande parte, a menos das dobras freqüentes, com as descrições de BALME (1957). Contudo, não se enquadram nas formas ilustradas por este autor. Segundo UESUGUI (COM. PESs.) trata-se na realidade de espécies ou mesmo gêneros diferentes. Em provável concordância com o conceito de Uesugur; ScHurz (1967) transferiu as formas de I. turbatus BALME (op. cit.) para Callialasporites turbatus Schulz (1967). Não obstante, preferiu-se neste trabalho denominar de I. turbatus sensu Ragali et alii (1974) os exemplares apresentados na estampa $\mathrm{XI}$, pois os mesmos são idênticos aos apresentados por REGAL (op. cit.) e se tratam, sem dúvida de grãos de pólen atribuíveis ao gênero Inaperturopollenites. 
Infraturma GRANULONAPITI COOKSON, 1947.

Gênero ARAUCARIACITES COOKSON, 1947 ex COUPER, 1953.

Espécie-tipo: Araucariacites australis Cookson et alii

\section{Araucariacites australis Cookson}

Estampa XII, figs. 1, 2, 3, 13

Vide Cookson (1947, P. 130) para descrição.

Dimensões: 55-80 $\mu \mathrm{m}$. (20 exemplares).

Comentários: Espécie abundante em nosso material, estando presente em frequências relativamente altas nas associaçð̃es jurássicas e cretáceas do mundo.

Araucariacites guianensis VAN DER HAMMEN \& BURGER. Estampa XII, figs. 4, 5

Vide Van der Hammen \& Burger (1966, P. 178) para descrição, discussão e comparações.

Dimensões: $65-75 \mu \mathrm{m}$. ( 5 exemplares).

Comentários: Espécie pouco comum no material estudado. Caracteriza-se pela ornamentação fortemente escabrada e dimensões elevadas.

Araucariacites limbatus (BALME) HABIB.

Estampa XII, fig. 6

Vide LiMA (1978, P. 199) para descrição, discussão e comparações.

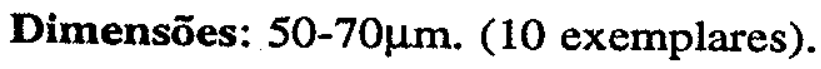

Comentários: Espécie caracterizada pelo afinamento da exina na área central do grão. 
Gênero TRIANGULOPSIS DÖRING emend. POCOCK

Espécie-tipo: Triangulopsis discoidalis DöRng, 1961.

\section{Triangulopsis discoidalis DöRING \\ Estampa XII, figs. 7, 10, 11}

Vide Pocock (1970, P. 73) para descrição e discussão do gênero e espécie.

Dimensões: $50-70 \mu \mathrm{m}$. (8 exemplares).

Comentários: Nossos exemplares são similares em todus os aspectos a $T$. discoidalis DóRING. SiNGH (1971) considera Triangulopsis como sinônimo júnior de Callialasporites, porém sem apresentar argumentos. Preferiu-se aqui manter a utilização deste gênero, de acordo com os conceitos de Pocock (1970).

Triangulopsis minor Pocock, 1970

Estampa XII, fig. 8, 12

Vide Pocock (1970, P. 74) para descrição.

Dimensões: $30-40 \mu \mathrm{m}$. ( 3 exemplares).

Comentários: $T$. minor difere de $T$. discoidalis por apresentar dimensões menores. Os exemplares apresentados neste trabalho são relativamente menores que os mostrados por Pocock, 1970.

Gênero CINGULATIPOLLENITES SAAD \& GHAZALY, 1976 Espécie-tipo: Cingulatipollenites aegyptiaca SAAD \& GHAZALY

Cingulatipollenites sp. cf. C. aegyptiaca SAAD \& GHAZALY

Estampa XII, fig. 9 
Descrição: Grão de pólen inaperturado de contorno circular. Exina espessa na região equatorial, formando um cíngulo, que por vezes apresenta estrias. A exina é lisa a finamente escabrada, freqüentemente apresentando um afinamento na área central do grão.

Dimensões: $40-48 \mu \mathrm{m}$. (3 exemplares).

Comentários: Nossos exemplares são em tudo comparáveis aos descritos por SAAD \& GHAZALY, apesar de apresentarem dimensões gerais menores.

\section{Gênero SPHERIPOLLENITES COUPER, 1958}

Espécie-tipo: Spheripollenites scabratus CoUPER, 1958

Obs: Neste gênero estão incluídas apenas as formas circulares a subcirculares e menores que $40 \mu \mathrm{m}$, que sob a microscopia ótica, não apresentam leptomas, poros ou pseudoporos. Este conceito restringe o gênero apenas para as formas inaperturadas, diferindo um pouco do normalmente utilizado, já que alguns estudiosos destas formas (E.G. BURGER, 1966), incluem também tipos com "poro pouco desenvolvido". COUPER (1958), considerou como deste gênero apenas formas menores que $45 \mu \mathrm{m}$. Manteve-se aqui o limite máximo de $40 \mu \mathrm{m}$, para diferenciar de Inaperturopollentes, aos quais arbitrou-se, de acordo com KRUzSCH (1971), diâmetro mínimo $40 \mu \mathrm{m}$. Vale ressaltar que, no material aqui observado, esta dimensão separa bastante bem os gêneros supracitados.

\section{Spheripollenites scabratus COUPER \\ Estampa X, figs. 22, 23 \\ Estampa XI, figs. 1, 2}

Descrição: Grão de pólen inaperturado, escabrado, contorno circular a oval. Exina relativamente espessa (densa), uniformemente ornamentada. Algumas formas apresentam uma área central levemente mais fina; outras podem conter dobras na exina.

Dimensões: $33-37 \mu \mathrm{m}$. (12 exemplares). 
Comentários: Apesar de alguns exemplares apresentarem uma área central mais clara (afinamento da exina ?), nada indica a presença de poro ou leptoma. As formas descritas apresentam pequena variação nas dimensões, que por sua vez correspondem aos valores médios considerados pela espécie.

\section{Spheripollenites subgranulatus COUPER Estampa XI, fig. 9}

Vide COUPER (1958, P. 158) para descrição.

Dimensões: $17-22 \mu \mathrm{m}$. (5 exemplares).

Comentários: Essa espécie é comparativamente rara em nosso material. Caracteriza-se pelas dimensões sensivelmente pequenas; normalmente abaixo de $20 \mu \mathrm{m}$.

\section{Gênero UESUGUIPOLLENITES nov. gen.}

Derivação do nome: Nome dado em homenagem ao geólogo Namio Uesugui, palinólogo da Petrobrás, em reconhecimento a sua grande contribuição ao estudo da palinologia no Brasil.

Espécie-tipo: Uesuguipollenites callosus gen. e sp. nov.

Diagnose: Grão de pólen inaperturado, contorno circular. Presença característica de uma calota espessada na região central.

Descrição: Grão de pólen inaperturado de dimensões reduzidas (30-40 $\mu \mathrm{m})$. Exina visivelmente escabrada. Apresenta um espessamento circular na area central (calota central) de contorno mal definido.

Comparações: Uesuguipollenites nov. gen. difere de todos os gêneros mesozóicos de grãos de pólen inaperturados, pela presença de uma calota central espessada. 


\section{Uesuguipollenites callosus nov, sp. \\ Estampa XI, figs. 3, 4, 5, 6, 7, 8, 10}

Derivação do nome: Nome derivado da ornamentação espessada da exina, na área central do grão.

Holótipo: Preparação PD-1; lâmina 02151; coordenadas (england finder): W40. Estampa XII, fig. 6.

Estrato típico: Formação Alagamar, Bacia Potiguar.

Descrição: Grão de polen inaperturado, forma lenticular. Exina com ornamentação variando de fina a fortemente escabrada, com espessura de cerca de $1-2 \mu \mathrm{m}$. Apresenta na maioria dos exemplares um espessamento equatorial da ordem de $2-3 \mu \mathrm{m}$. Possui uma calota central circular, onde a exina é bem mais espessa e escura, com dimensões da ordem de $1 / 2$ do raio do grão e com limites mal definidos; porém nunca com poro ou pseudoporo, nem espessamento anelar central. Em direção ao equador torna-se clara, tornando a se espessar. na borda.

Dimensões: diâmetro total $=30-40 \mu \mathrm{m}$. calota central $=15-18 \mu \mathrm{m} .(25$ exemplares $)$.

Comentários: Esta espécie difere de $S$. scabratus por apresentar área central espessada central e dimensões gerais maiores. Difere das formas do gênero Exesipollenites por não apresenta poros ou pseudoporos. Não se compatibiliza com algumas espécies de Araucariacites (por ex. A. hungaricus DEAK) pela presença do espessamento central nem com algumas espécies de Inaperturopollenites (por ex. I. turbatus BALMe sensu REGALI et al.), por possuir calota central mais espessa e dimensões gerais menores.

Gênero SERGIPEA (REGALI, UESUGUI \& SANTOS) emend. REGALI 1987 Espécie-tipo: Sergipea naviformis Regal,, Uesugul \& SANTos, 1974

Sergipea naviformis Regali, Uesugur \& Santos

Estampa XIII, figs. 1, 2, 3, 4, 7, 9 
Vide REGALI et alii (1974, P. 273) para descrição e comparações.

Dimensões: $\mathrm{C}=30-70 \mu \mathrm{m} . \mathrm{L}=15-45 \mu \mathrm{m}$. (20 exemplares).

Comentários: Apesar da grande variação nas dimensões, fato já mostrado por Regali et alii (1974), notamos exemplares bem menores, talvez exigindo a criação de uma variedade minor para a espécie.

\section{Sergipea simplex REGALI \\ Estampa XIII, figs. 10, 12, 13, 17}

Vide Regali (1987A, P. 619) para descrição e comparações.

Dimensões: $\mathbf{C}=23-38 \mu \mathrm{m}$. (15 exemplares).

Comentários: Esta espécie caracteriza-se pelas dimensões reduzidas e ausência de verrugas. Apresenta exina variando de lisa a fortemente escabrada a granular.

\section{Sergipea tenuiverrucata REGALI}

Estampa XIII, figs. 19, 21

Vide Regali (1987A, P. 618) para descrição e comparações.

Dimensões: C. $=50-80 \mu \mathrm{m}$. L. $=30-50 \mu \mathrm{m} .(5$ exemplares $)$.

Comentários: Espécie caracterizada pelo reduzido número de verrugas e grandes dimensões das mesmas.

Sergipea variverrucata REGALI, UESUGU \& SANTOS emend. REGALI

Estampa XIII, figs. 5, 6, 8, 11, 14, 15, 16, 18, 20

Vide Regali (1987A, P. 616) para descrição e comparações.

Dimensões: $30-45 \mu \mathrm{m}$. (20 exemplares). 
Comentários: É notável a gama de variações, em termos de tamanho e número de verrugas (característica principal) que esta espécie apresenta. Mesmo a complementação e ampliação da diagnose realizada por REGALI (1987A) não é suficiente para enquadrar todos os especimens presentes no material.

Infraturma CIRCUMPOLLINI KLAUS, 1960.

Gênero CLASSOPOLLIS PFLUG, 1960.

Espécie-tipo: Classopollis classoides PFuG.

Classopollis alexi BURGER

Estampa XIV, fig. 1

Vide LMA (1978, P. 202) para descrição e comentários.

Dimensões: $35-40 \mu \mathrm{m}$. (5 exemplares).

Comentários: Espécie abundante no material analisado. Caracteriza-se pelo elevado número de estrias e pela exina fina e escabrada.

\section{Classopollis torosus (REISSINGer) COUPER \\ Estampa XIV, fig. 2}

Vide Lima (1978, P. 202) para descrição e comentários.

Dimensões: $25-35 \mu \mathrm{m}$. (5 exemuplares).

Comentários: Espécie caracterizada pela exina relativamente mais espessa, menor número de estrias e dimensões levemente menores. Esta espécie é muito próxima de $C$. classoides, diferindo pelas características acima mencionadas. 


\section{Classopollis brasiliensis HERNGREEN}

Estampa XIV, fig. 3

Vide HeRngreen (1975, P. 59) para descrição e comentários.

Dimensões: $40-65 \mu \mathrm{m}$. (5 exemplares).

Comentários: Espécie caracterizada pela exina fina, ausência de rímula, poro e área triangular na região central. Rara, sendo encontrada apenas na porção superior da seção, pós discordância Alagamar.

Gênero COROLLARIA MALYAWKINA, 1953

Espécie-tipo: Corollaria annularis MaLYAwKINA.

Corollaria annularis Malyawkina

Estampa XIV, fig. 4

Vide LiMA (1978, P. 206) para descrição e comentários.

Dimensões: $25-30 \mu \mathrm{m}$. ( 5 exemplares).

Comentários: Espécie caracterizada pelo forte espessamento da exina na face proximal, banda equatorial lisa e ausência do leptoma triangular.

. Subturma APENDICIFERENTES POTONIÉ, 1970.

Gênero ELATEROPOLLENITES HERNGREEN, 1972

Espécie-tipo: Elateropollenites jardinei HERNGREEN emend. REGALI 1989. 


\section{Elateropollenites dissimilis REGALI}

Estampa XVI, figs. 3, 4, 6, 11

Vide Ragali (1989A, P. 146-147) para descrição e comentários.

Dimensões: C. $=38-50 \mu \mathrm{m}$. L. $=20-25 \mu \mathrm{m} .(3$ exemplares $)$.

Comentários: As extremidades nitidamente mais curtas caracterizam esta espécie, individualizando-a das demais descritas para o gênero. Foram encontradas apenas nos estratos superiores da seção analisada.

\section{Elateropollenites praecursor REGALI \\ Estampa XVI, fig. 9}

Vide Regali (IN: Regali \& VianA, 1989, p. 38-39) para diagnose, descrição e comparação.

Dimensões: C. $=42 \mu \mathrm{m}$. L. $=22 \mu \mathrm{m} .(1$ exemplar $)$.

Comentários: Forma rara no material analisado, sendo encontrada apenas nas camadas mais superiores da seção.

Turma PLICATES (NAUMOVA, 1937, 1939) POTONIÉ, 1960

Subturma COSTATES POTONIÉ, 1970

Infraturma COSTATI, POTONIÉ, 1970

Observações Preliminares: Na associação estudada o grupo dos grãos de pólen poliplicados está relativamente bem representado, a exemplo da grande maioria dos depósitos de Idade Albiana e Aptiana Superior das bacias brasileiras. Apesar desta representatividade, não se estendeu aqui sobre a analise crítica e histórica das definições genéricas, nem sobre a aceitação ou utilização das mesmas pela literatura. Por se considerarem válidos e adequados, foram utilizados os conceitos emitidos por LIMA (1980) para a sistemática do grupo. 
Gênero EQUISETOSPORITES (DAUGHERTY, 1941) emend. SINGH, 1964. Espécie-tipo: Equisetosporites chinleana DAUGHERTY, 1941

Vide LMA (1978, P. 209-214), para histórico, taxonomia, descrição e comparações, dos diferentes gêneros do grupo.

\section{Equisetosporites albertensis SINGH}

Estampa XIV, fig. 12

Vide SINGH $(1964$, p. 133) para descrição.

Dimensões: $\mathrm{C}=103-115 \mu \mathrm{m} . \mathrm{L}=38-45 \mu \mathrm{m}$. (4 exemplares).

Comentários: Forma de grandes dimensões. Difere de E. concinnus, por possuir extremidades de mesma largura.

\section{Equisetosporites ambiguus (HEDLUND) SINGH}

Estampa XIV figs. 5, 8, 11

Vide Lima (1978, P. 218-219) para descrição, comparação e discussão.

Dimensões: C. $=45-65 \mu \mathrm{m}$. L. $=15-25 \mu \mathrm{m}$. (6 exemplares).

Comentários: Esta espécie é caracterizada pelo descolamento entre as camadas da exina. Observa-se no material estudado uma grande variedade nas dimensões. Além disso, é interessante registrar que alguns exemplares parecem apresentar "costelas", na parte descolada da exina.

\section{Equisetosporites concinnus SINGH}

Estampa XIV fig. 23

Estampa XV fig. 5

Vide SINGH (1964, P. 132) e LIMA (1978, P. 218-219) para descrição, comparação e discussão. 
Dimensões: C. $=75-100 \mu \mathrm{m}$. L. $=33-55 \mu \mathrm{m}$. (6 exemplares).

Comentários: Espécie de grandes dimensões, pouco freqüente no material estudado. Caracteriza-se por possuir extremidades de larguras desiguais.

\section{Equisetosporites dudarensis (DEAK) LIMA \\ Estampa XIV, fig. 19}

Vide Lima (1978, P. 216, 217) para descrição e comentários.

Dimensões: C. $=32-40 \mu \mathrm{m}$. L. $=18-22 \mu \mathrm{m}$. (5 exemplares).

\section{Equisetosporites laticostatus LIMA \\ Estampa XIV, fig. 13}

Vide LimA (1978, P. 230) para descrição, discussão e comparações.

Dimensões: C. $=25-30 \mu \mathrm{m}$. L. $=19-23 \mu \mathrm{m}$. ( 2 exemplares $)$.

\section{Equisetosporites leptomatus LIMA \\ Estampa XIV, fig. 10}

Vide LIMA (1978, P. 226) para descrição, discussão e comparações.

Dimensões: C. $=26-30 \mu \mathrm{m}$. L. $=13-17 \mu \mathrm{m} .(3$ exemplares $)$.

Comparações: Nossos exemplares assemelham-se bastante com os descritos por LIMA (op. cit.), apesar de apresentar dimensões gerais menores.

\section{Equisetosporites luridus LIMA}

Estampa XIV, figs. 14, 25

Descrição: Grão de pólen de contorno elipsoidal. Exina com duas camadas, sendo a interna lisa e a externa ornamentada por numerosas costelas 
longitudinais, separadas por depressões finas. Algumas costelas apresentam bifurcações e não atingem as extremidades do grão, formando conseqüentemente uma área lisa em cada proximidade dos polos de até 5,0 $\mu \mathrm{m}$. A exina é igualmente espessa.

Vide LIMA (1980, p. 26) para discussão e comparações.

Dimensões: $\mathrm{C}=45-75 \mu \mathrm{m} . \mathrm{L}=30-41 \mu \mathrm{m}$. (2 exemplares).

Comentários: Espécie pouco comum no material estudado. Assemelha-se à espécie E. minuticostatus, individualizando-se pelas dimensões gerais maiores e área lisa nas extremidades.

\section{Equisetosporites minuticostatus LIMA \\ Estampa XIV, fig. 6}

Vide LIMA (1978, Р. 227) para descrição e comparações.

Dimensōes: C. $=35-45 \mu \mathrm{m}$. L. $=20-30 \mu \mathrm{m} .(2$ exemplares $)$.

Equisetosporites ovatus (PIERCE) SINGH Estampa XIV fig. 21

Vide SINGH (1964, P. 133) para descrição e comentários.

Dimensões: C. $=28-42 \mu \mathrm{m}$. L. $=20-28 \mu \mathrm{m}$. ( 2 exemplares $)$.

$$
\begin{gathered}
\text { Equisetosporites sp }=\text { Ephedripites sp (artefato) DEJAX } \\
\text { Estampa XIV, fig. } 24
\end{gathered}
$$

Vide Dejax (1987, P. 68-70) para descrição, discussão e comparações.

Dimensões: $\mathrm{C}=40-65 \mu \mathrm{m} . \mathrm{L}=15-30 \mu \mathrm{m}$. (10 exemplares).

Comentários: Em função do processo de fossilização atuando nos grãos de 
pólen poliplicados (de acordo com os conceitos de DejAX, 1987), os mesmos podem ser preservados de variadas formas, dando a impressão de se tratar de espécies ou mesmo gêneros diferentes. Exemplos desse tipo são apresentadas também na estampa XV, figuras $10,21,24,25$ e 26.

HUYNH (1974) aborda o problema da polaridade dos grãos de pólen poliplicados.

\section{Incertae Sedis = Equisetosporites? sp. \\ Estampa XIV, fig. 18}

Descrição: Grão de pólen de contorno oval. Exina com duas camadas, sendo a interna lisa a escabrada, totalmente separada da externa, formando um corpo central espesso e escuro. A camada externa é fina e transparente, não apresenta costelas. $O$ descolamento é marcante, tornando-se maior ainda nas extremidades, onde se observa áreas de até $6,0 \mu \mathrm{m}$.

Dimensões: $\mathrm{C}=58 \mu \mathrm{m} . \mathrm{L}=29 \mu \mathrm{m} . \mathrm{CC}-\mathrm{C}=40 \mu \mathrm{m} . \mathrm{L}=29 \mu \mathrm{m} .(1$ exemplar $)$.

Comentários: A característica principal desta espécie é a ausência de costelas e o descolamento entre as camadas da exina. Difere de E. ambiguus Hedund pela ausência das plicas. Considera-se também que esta forma pode perfeitamente não se enquadrar no grupo dos poliplicados.

\section{Equisetosporites maculosus nov. sp.}

Estampa XIV, figs. 7, 9, 15, 16, 17

Derivação do nome: $O$ nome refere-se a existência de uma área lisa, mais espessa e escura, com aspecto de uma mancha, no centro de uma das faces.

Holótipo: preparação SO-5, lâmina 8901895, coordenadas: E58-1. Estampa XVI, fig. 10

Estrato típico: Formação Alagamar, Bacia Potiguar.

Diagnose: Contorno elíptico, dimensð̃es medianas. Exina com duas camadas, sendo a interna lisa, escura e de contorno mal definido. 
Descrição: Grão de pólen poliplicado de contorno oval a elíptico. Exina fina com duas camadas, sendo a interna lisa, mais espessa e escura, de contorno mal definido e restrita a região central. As dimensões deste "corpo central" variam de $1 / 4$ a $1 / 2$ do comprimento e de aproximadamente $1 / 2$ da largura total do grão. A camada externa é ornamentada por um grande número de costelas, pouco nítidas, paralelas, sem ramificação e que atravessam todo o comprimento do grão. As costelas medem menos de 1,0 $\mu \mathrm{m}$ e não se fundem nas extremidades.

Dimensões: $\mathrm{C}=35-45 \mu \mathrm{m} . \mathrm{L}=16-21 \mu \mathrm{m}$. (20 exemplares).

Discussão e comparações: Esta especie difere de todas as outras existentes para o gênero, pela presença de uma área lisa, mais espessa e escura, e sem contorno nítido, na região central do grão.

Gênero SINGHIA SRIVASTAVA, 1968

Espécie-tipo: Singhia diversus (STOVER) SRIVASTAVA, 1968

Singhia crenulata LMA

Estampa XIV, fig. 22

Vide LiMA (1980, P. 34) para discussão e comparações.

Dimensões: $\mathrm{C}=23-28 \mu \mathrm{m} . \mathrm{L}=15-18 \mu \mathrm{m}$. (2 exemplares).

Singhia elongata (HoRowrrz) LIMA

Estampa XIV, fig. 20

Vide LIMA (1980, p. 30-31) para descrição, discussão e comparações.

Dimensões: C. $=70-80 \mu \mathrm{m}$. L. $=15-20 \mu \mathrm{m} .(4$ exemplares $)$. 


\section{Singhia multicostata (BRENNER) LIMA \\ Estampa XV, fig. 3}

Vide LIMA (1980, p. 30) para diagnose e descrição.

Dimensões: C. $=60-75 \mu \mathrm{m}$. L. $=17-30 \mu \mathrm{m} .(3$ exemplares $)$.

Gênero CORNETIPOLLIS POCOCK \& VASANTHY, 1988

Espécie-tipo: Cornetipollis reticulata Pocock \& VASANTHY, 1988

Cornetipollis perforata (LIMA) nov. comb.

Estampa XVI, figs. 5, 8, 16

Vide LmA (1978, P. 245-246), para diagnose e descrição.

Dimensões: $45-55 \mu \mathrm{m}$. (5 exemplares).

Comentários: Ilustrada pela primeira vez, de modo informal, por HERNGREEN (1973, est. VIL, fig. 7), com o nome de "Ephedripites sp. com foveolas", esta espécie foi criada por LIMA (1978A; 1980), sob a denominação de Gnetaceaepollenites perforatus, identificando-a na Bacia do Araripe. Na PETROBRÁS, ela tem sido reportada em várias bacias da margem equatorial brasileira, principalmente, após sua inclusão na divisão bioestratigráfica da Bacia de Barreirinhas (Regaul et alii, 1985). Esta espécie é geralmente confundida com Striatopollis reticulatus, por esta última se apresentar freqüentemente fragmentada, contendo apenas um dos colpos. Alguns autores (DEJAX, 1987) chegam a duvidar da sua existência. Entretanto suas características, a exemplo do conceito emitido por Lama (1978A, P. 253) ao comentar sobre a especie Steevesipollenites sp. 2, reveste-se de suma importância, por representar uma possível convergência de algumas espécies de gimnospermas para as angiospermas, via Ephedrales.

Obs: Esta espécie foi aqui transferida para o gênero Cornetipollis Pocock \& VASANTHY, 1988, devido a sua ornamentação reticulada. 
Gênero GNETACEAEPOLLENITES THIEGART, 1938.

Espécie-tipo: Gnetaceaepollenites ellipticus THEGART.

\section{Gnetaceaepollenites barghoornii (Pocock) LIMA \\ Estampa XV, figs. 1, 13}

Vide LIMA (1978, p. 239) para descrição, discussão e comparaçð̃es.

Dimensões: $\mathrm{C}=35-53 \mu \mathrm{m} . \mathrm{L}=17-30 \mu \mathrm{m}$. (7 exemplares).

\section{Gnetaceaepollenites chlatratus STOVER}

Estampa XV, figs. 14, 15, 16

Vide STOVER (1964в, P. 149-150) para diagnose, descrição e discussão.

Dimensões: $\mathrm{C}=28-34 \mu \mathrm{m} . \mathrm{L}=\mathrm{i} .7-25 \mu \mathrm{m}$. ( 6 exemplares).

Comentários: Como já referido por STOVER (op. cit.) existe grande variação no padrão desta espécie, com formas de esférica a elipsoidal.

\section{Gnetaceaepollenites jansonii (Pocock) LIMA}

Estampa XV, figs. 4, 27

Vide Lima (1978, P. 238) para descrição, discussão e comparações.

Dimensões: $\mathrm{C}=65-90 \mu \mathrm{m} . \mathrm{L}=35-47 \mu \mathrm{m}$. ( 5 exemplares).

\section{Gnetaceaepollenites mollis (SRIVASTAVA) LIMA}

Estampa XV, fig. 8

Vide Lima (1978, P. 239-240) para descrição e comentários.

Dimensões: $\mathrm{C}=50-65 \mu \mathrm{m} . \mathrm{L}=35-40 \mu \mathrm{m}$. ( 2 exemplares). 


\section{Gnetaceaepollenites retangularis LMA \\ Estampa XV, figs. 9, 12, 23}

Vide Lima (1978, P. 243) para diagnose e descrição.

Dimensões: $\mathrm{C}=20-40 \mu \mathrm{m} . \mathrm{L}=17-25 \mu \mathrm{m}$. (5 exemplares).

\section{Gnetaceaepollenites uesuguii}

Estampa XV, figs. 2, 6, 7

Vide LIMA (1978, P. 242) para diagnose e descrição.

Dimensões: $\mathrm{C}=30-45 \mu \mathrm{m} . \mathrm{L}=28-33 \mu \mathrm{m}$. (5 exemplares).

Gnetaceaepollenites undulatus (REGAIr, UESUGU \& SANTOS), LIMA Estampa XV, fig. 11

Vide Lima (1978, P. 240) para descrição e comentários.

Dimensões: $\mathrm{C}=21-40 \mu \mathrm{m} . \mathrm{L}=17-25 \mu \mathrm{m}$. (5 exemplares).

\section{Gnetaceaepollenites sp. 1}

Estampa XV, fig. 20

Descrição: Grão de pólen de contorno oval, ornamentado contendo de 8 a 11 costelas por face do grão. As costelas possuem cerca de $2-3 \mu \mathrm{m}$ de largura, tocando-se nas extremidades, sem que haja fusão. São subparalelas, retas, e apresentam fortes constrições na porção mediana.

Dimensões: $\mathrm{C}=27-35 \mu \mathrm{m} . \mathrm{L}=25-30 \mu \mathrm{m}$. ( 3 exemplares).

Comentários: Esta espécie é caracterizada pela ocorrência de constrições na parte média das costelas. Difere de G. undulatus Regali et alii (1974), a espécie mais proxima, por seu contorno ovalado, menor número de cristas, 
não afinamento das mesmas nas extremidades e constrições restritas ao meio do grão.

Gênero STEEVESIPOLLENITES STOVER, 1964. Espécie-tipo: Steevesipollenites multilineatus STOVER.

Steevesipollenites sp. $\mathrm{cf}$ S. binodosus STOVER. Estampa XV, figs. 17, 18, 22

Vide StOVER (1964A, P. 151) para diagnose e descrição.

Dimensões: $\mathrm{C}=45-55 \mu \mathrm{m} . \mathrm{L}=20-25 \mu \mathrm{m}$. (4 exemplares).

Comentários: Esta espécie é caracterizada pela largura e espessamentos polares, grandes para o gênero.

Steevesipollenites cupuliformis AZEMA \& BOLTHENHAGEN Estampa XV, fig. 19

Vide AzEma \& Bolthenhagen (1974, P. 27) para diagnose, descrição e comparações.

Dimensões: $\mathrm{C}=85-95 \mu \mathrm{m} . \mathrm{L}=20-30 \mu \mathrm{m}$. ( 2 exemplares $)$.

Comparações: Espécie relativamente rara em nosso material, mas enquadram-se perfeitamente nesta espécie.

Gênero REGALIPOLLENITES LIMA, 1978.

Espécie-tipo: Regalipollenites amphoriformis (REGALI, UesUGU \& SANTOS), LIMA

Vide LIMA (1978, p. 254) para diagnose e discussão do gênero. 


\section{Regalipollenites amphoriformis (Regal, Uesugur \& SANTOS), Lima Estampa XVI, figs. 1, 2}

Vide Lima (1978, P. 255) para descrição e comentários.

Dimensões: $\mathrm{C}=45-65 \mu \mathrm{m} . \mathrm{L}=25-28 \mu \mathrm{m}$. (5 exemplares).

Comentários: Espécie de fácil reconhecimento, pelo espessamento extremamente desigual das calotas hemisféricas.

\section{POLIPLICADO NÃO IDENTIFICADO}

Estampa XVI, fig. 7

Descrição: Grão de pólen poliplicado de contorno fusiforme. Exina com duas camadas, sendo a externa ornamentada por grande número de costelas paralelas, finas $(1,0-1,5 \mu \mathrm{m})$, separadas por canais igualmente finos. As costelas não se bifurcam e são sinuosas em toda a sua extensão; nas extremidades do gräo elas se fundem, formando uma área circular, levemente mais espessa e lisa, dando a impressão de formar uma aurícula.

Dimensões: C. $=45 \mu \mathrm{m}$. L. $=25 \mu \mathrm{m} .(1$ exemplar $)$.

Comentários: Esta espécie difere das demais descritas para o grupo dos grãos de pólen poliplicados, pelas costelas sinuosas e formação de "aurículas", nas extremidades.

Subturma PRAECOLPATES POTONIÉ \& KREMP, 1954.

Gênero EUCOMMIIDITES (ERDTMAN, 1948) HUGUES, 1961.

Espécie-tipo: Eucommiidites troedssonii (ERDTMAN) Hugues. 
Obs: A morfologia deste gênero ainda não esta perfeitamente esclarecida. Eucommiidites foi erigido por ERDTMAN (1948) e considerado como uma forma tricolpada, de origem angiospérmica e comparado com os grãos de pólen de Eucommia ulmoides Ourv. Este gênero foi reconhecido e emendado por COUPER (1958), que reestudando o material original de ERDTMAN descartou sua afinidade angiospérmica, e sugeriu um vinculo às gimnospermas para estes grãos e considerou-os como sendo monosulcados. PoToNIE (1958) acomodou este gênero no grupo da gimnospermas praecolpates (JANSONIUs \& HiLLs, 1976 consideram que Potonne, 1958, validou este gênero). Hưhes (1961), discutiu a validade e emendou Eucommiidites considerando-o como grão de pólen oval, tendo um longo sulco com terminações arredondadas numa das faces e um sulco anelado (ring-furrow) próximo à margem, na face oposta (zonisulcado). BRENNER (1967) discute a afinidade gimnospérmica do gênero.

\section{Eucommiidites troedssonii (ERDTMAN) HUGUES}

Estampa XVI, figs. 15, 18, 20

Vide Hughes (1961, P. 292) para descrição. Vide COUPER (1958, P. 160-165) para comparações detalhadas deste gênero com grãos de pólen de gimnospermas e DoYLE et alii (1975) para detalhes observados sob microscopia eletrônica.

Dimensões: $\mathrm{C}=33-40 \mu \mathrm{m} . \mathrm{L}=18-28 \mu \mathrm{m}$. (5 exemplares).

Comentários: Esta espécie caracteriza-se pela exina espessa. Difere de E. hughesii, por possuir dimensões maiores. É muito próxima de E. minor.

Eucommiidites sp. 2 LiMA, 1978.

Estampa XVI, fig. 10, 21

Vide Lima (1978, P. 259) para descrição e comentários.

Dimensões: $\mathrm{C}=20-28 \mu \mathrm{m} . \mathrm{L}=12-18 \mu \mathrm{m}$. (3 exemplares).

Comentários: Os exemplares identificados são comparáveis em todos os aspectos aos exemplares descritos por Lima (1978), sob a designação de E. sp. 2. 


\section{SUBTURMA MONOCOLPATES (MONOSULCITES) e ZONOCOLPATES POTONIÉ, 1970 \\ INFRATURMA QUAESILAEVIGATI POTONIÉ, 1970 \\ Subinfraturma ACAVATI LIMA, 1978}

Gênero CYCADOPITES WODEHOUSE, 1933 ex WILSON \& WEBSTER, 1946.

Espécie-tipo: Cycadopites follicularis WIISON \& WeBster ex POTONIE, 1958.

Vide Singh (1964, p. 103) para sinonímia e diagnose genérica.

Cycadopites carpentieri (DELCOURT \& SPRUMONT) SINGH Estampa XVI, fig. 13

Vide SINGH (1964, P. 104) para sinonímia e descrição.

Dimensões: $\mathrm{C}=53-59 \mu \mathrm{m} . \mathrm{L}=19-23 \mu \mathrm{m} .(6$ exemplares $)$.

Comentários: Esta espécie caracteriza-se pelo alargamento do sulco nas extremidade longitudinais e exina lisa. Os exemplares ora apresentados assemelham-se bastante com os descritos e ilustrados por SiNGk, 1964.

\section{Cycadopites, fragilis SiNGH \\ Estampa XVI, fig. 14}

Vide SINGH (1964, p. 103-104) para descrição e observações.

Dimensões: $\mathrm{C}=30-36 \mu \mathrm{m} . \mathrm{L}=18-23 \mu \mathrm{m}$. ( 3 exemplares).

Comentários: Esta espécie caracteriza-se pelas dimensões pequenas a pela exina, bastante fina.

Cycadopites nitidus (BALME) DE JERSEY

Estampa XVI, fig. 12 
Vide BALME (1957, P. 30) para descrição.

Dimensões: $\mathrm{C}=22-30 \mu \mathrm{m} . \mathrm{L}=15-20 \mu \mathrm{m}$. ( 3 exemplares).

Comentários: Os especimens presentes em nosso material difere bastante do exemplar ilustrado por LIMA (1978), apesar da descrição e dimensões serem compatíveis.

\section{Gênero DEJAXPOLLENITES nov. gen.}

Derivação do nome: Nome dado em homenagem ao Dr. Jean Dejax, do Museum National d'Histoire Naturelle, descobridor desta forma, em sedimentos eocretáceos do Congo.

Espécie-tipo: Dejaxpollenites foveoreticulatus gen. e sp. nov.

Diagnose: Grão de pólen radialmente simétrico, levemente anisopolar, constituído de duas partes. Corpo central envolto numa parede microfoveolada, ambas caracteristicamente zonocolpadas.

Descrição: Grão de pólen zonocolpado, de âmbito ovóide a elipsoidal. Exina fina, com duas camadas, ocorrendo uma diferenciação entre as mesmas, de modo a formar duas partes; um corpo central interno, zonocolpado, envolto numa parede externa, também zonocolpada. O colpo é longo, estendidos por toda a área equatorial do grão.

Comparações: Dejaxpollenites nov. gen. difere de todos os gêneros mesozóicos de grãos de polen zonocolpados, por se constituir de duas partes distintas, ambas zonocolpadas.

Dejaxpollenites foveoreticulatus nov. sp.

Estampa XIX, figs. 1 a 10

Derivação do nome: Nome derivado da ornamentação microfoveolada da exina da parte externa do grão. 
Holótipo: Preparação CES-7; lâmina 9101563; coordenadas: E37-3. Estampa XIX, figs. $1,2$.

Estrato típico: Formação Alagamar, Bacia Potiguar.

Diagnose específica: Grão de pólen, zonocolpado, de âmbito oval a fusiforme, contendo um corpo central distinto. A forma é separada por um colpo equatorial contínuo, dividindo o grão em duas partes iguais, subobladas. $O$ corpo central É liso, mais espesso e escuro. A camada externa tem exina mais fina ornamentada por microfoveolas distribuídas por toda a superfície do grão.

Descrição: Grão de pólen zonocolpado, constituído de um corpo central, envolto numa camada externa de borda lisa, com uma estreita margem. Contorno oval a fusiforme. Possui um colpo equatorial contínuo, que divide o grão em duas partes iguais, subobladas. Corpo central: $O$ corpo central, zonocolpado, possui exina lisa, mais espessa e escura que a camada externa. Cada hemisfério deste corpo central apresenta um pseudocolpo, perpendicular ao plano da zonocolpa, formando uma abertura ulcerada (aparato germinal?), grande e alongada na direção dos polos. Camada externa: Zonocolpada, exina fina, cerca de 1,0$1,5 \mu \mathrm{m}$, densamente ornamentada por microfovéolas homogeneamente distribuídas por toda a superfície do grão. Estas microfovéolas são diminutas na parte central do grão $(<1,0 \mu \mathrm{m})$, e aumentam gradativamente em direção as bordas do mesmo, onde atingem mais de $1,5 \mu \mathrm{m}$. Em alguns exemplares chega a assumir um aspecto reticulado nas bordas.

Dimensões: C. total $=40-45 \mu \mathrm{m}$. L. total $=23-30 \mu \mathrm{m}$. C. c.c. $=32-35 \mu \mathrm{m}$. L. c.c. $=15-23 \mu \mathrm{m}$.

Gênero CONFERTISULCITES ANDERSON, 1960. Espécie-tipo: Confertisulcites knowltoni ANDERSON, 1960 
Confertisulcites sp. LIMA, 1978

Estampa XVI, fig. 24

Vide Lima (1978, P. 266) para descrição, discussão e comparações.

Dimensões: $C=80 \mu \mathrm{m} . \mathrm{L}=45 \mu \mathrm{m} .(1$ exemplar $)$.

Comentários: O exemplar ora apresentado é comparável em quase todos os aspectos, ao ilustrado por LmA (1978, ESTAMPA XXIV, FIG. 19), diferindo apenas nas dimensões, aqui um pouco maiores.

Gênero BENNETTITAEPOLLLENITES THIEGART, 1949 emend. POTONIÉ, 1958.

Espécie-tipo: Bennettitaepollenites lucifer THIEGART, 1949

Vide SiNGH $(1964$, p. 106) para sinonímia e descrição genérica.

Bennetitaepollenites regalii nov. sp.

Estampa XVI, figs. 22, 23

Derivação do nome: Nome dado em homenagem a Dra. Marnlia Regali, palinóloga da Petrobrás, em reconhecimento a sua contribuição ao estudo da palinologia no Brasil.

Holótipo: Preparação NMR-1. Lâmina, 8909769. Coordenadas: G49. Estampa XXI, fig. 10.

Estrato típico: Formação Alagamar, Bacia Potiguar.

Diagnose: Grão de pólen monosulcado, fusiforme, sulco longo, atravessando toda a superfície longitudinal do grão e caracteristicamente mais aberto nas extremidades.

Descrição: Grão de pólen monosulcado de contorno elipsoidal, exina espessa, 
lisa a micropunctada. O sulco é representado por um leptoma bastante estreito que percorre todo o comprimento da face distal do grão, se abrindo nas extremidades. Acompanham o sulco, lábios marginais espessos e com até $10 \mu \mathrm{m}$ de largura.

Dimensões: $\mathrm{C}=100-105 \mu \mathrm{m} . \mathrm{C}=38-43 \mu \mathrm{m}$. (10 exemplares).

Comentários: A característica principal desta espécie são suas dimensões, bastante grandes para o gênero. Esta espécie assemelha-se bastante aos especimens Cycadopites sp. 2 e Cycadopites sp. SingH 1964, ilustrados respectivamente por Boltenhagen \& Salard-Cheboldaeff (1987), Dejax (1987) e Singh (1964). A existência dos lábios marginais ao sulco (sacos não funcionais?) justifica a inclusão no gênero Bennettitaepollenites, como definido por ThIEGArt. A presença desta espécie em estratos aproximadamente contemporâneos no Brasil e África indica se tratar de forma com bom potencial estratigráfico.

Subinfraturma CAVATI LIMA, 1978.

Gênero CAVAMONOCOLPITES LIMA, 1978

ESPÉCIE-TIPO: Cavamonocolpites punctatus LIMA, 1978

\section{Cavamonocolpites punctatus LimA}

Estampa XVIII, figs. 9-10

Vide LiMA (1978, p. 268-269) para diagnose, descrição e comparações do gênero e da espécie.

Dimensões: $C=23-28 \mu \mathrm{m} . \mathrm{L}=15-20 \mu \mathrm{m}$. (5 exemplares).

Comentários: A espécie-tipo caracteriza-se pela exina fina e punctada, com o colpo longo mais largo nas extremidades. Esta espécie está presente apenas nos estratos superiores da Formação Alagamar (Membro Galinhos). 
Cavamonocolpites sp. 1

Estampa XVIII, figs. 7, 8

Descrição: Grão de pólen monocolpado, de contorno circular a ovalado. Exina fina, com duas camadas, interligadas por columelas, cavado. O colpo é longo, estendidos por todo o grão. A exina apresenta pequenas foveolas de diâmetro variado, porém sempre menores que $1,0 \mu \mathrm{m}$ e dispostas de modo esparso.

Dimensões: $25 \mu \mathrm{m}$. ( 2 exemplares).

Comentários: Esta espécie é caracterizada pela exina microfoveolada, ocorre raramente nos níveis mais altos da seção. Difere de C. punctatus LiMA pelo caráter foveolado e de Foveomonosulcites elegans REGALI, pelas foveolas diminutas e esparsas.

\section{Infraturma SCULPATI POTONIÉ, 1970.}

Gênero CLAVATIPOLLENITES COUPER, 1958

Espécie-tipo: Clavatipollenites huguesi COUPER.

Obs: O gênero Clavatipollenites engloba grãos de pólen monosulcados, de contorno elíptico a subesférico com dupla camada de exina. Uma das camadas é lisa e dela se elevam os elementos esculturais da segunda camada, que é ornamentada por pequenas e densas clavas. As clavas se fundem de modo a formar um microretículo e uma exina tectada. Os lumina deste microretículo são mais ou menos uniformes no tamanho e formato, e quase sempre menores que $1,0 \mu \mathrm{m}$. Geralmente esses grãos apresentam um aspecto granular ao microscópio. DoYue et alii (1975) em estudos sobre o gênero à luz da microscopia eletrônica discutiram seus aspectos morfológicos e sua afinidade angiospérmica. KeMP (1968, P. 424), emendou a diagnose de Clavatipollenites hughesii COUPER, descrevendo a presença de báculas e não de clavas. Contudo, este tipo de escultura também pode ser observada nos espécimens de CouPER (1958), razão pela qual não se considerou, aqui a emenda de KeMP (op. cit.). JuHÁsz \& GOCZAN (1985, P.154-155), discutem com propriedade as particularidades deste gênero. 


\section{Clavatipollenites hughesii COUPER \\ Estampa, XVIII, figs. 1, 6}

Vide COUPER (1958, P. 159) para diagnose genérica e SINGH (1971, P. 180) para comentários posteriores.

Dimensões: $20-35 \mu \mathrm{m}$. (10 exemplares).

Comentários: KeMP (1968) realizou um abrangente estudo sobre esta espécie, mostrando através de diagramas e histogramas que ela tende a ser elíptica. Clavatipollenites hughesii foi reportada pela primeira vez por COUPER (1958), em estratos barremianos da Inglaterra; e é provavelmente a mais velha ocorrência de formas afins às angiospermas bem documentada até o momento.

\section{Clavatipollenites minutus BRENNER \\ Estampa XVIII, figs. 2 a 4}

Vide BrenNER (1963, P. 95) para descrição.

Dimensões: $\mathrm{C}=15-20 \mu \mathrm{m} . \mathrm{L}=11-15 \mu \mathrm{m}$. (7 exemplares).

Comentários: BrenNer (1963) separou $C$. minutus da espécie $C$. hughesii COUPER, apenas com base no tamanho menor e exina mais fina da primeira. Com base nos diagramas de KEMP (1968, p. 427) é óbvia a gradação existente entre estas duas espécies.

\section{Clavatipollenites tennelis PADEN-PhILlPs \& Felx Estampa XVIII, fig. 5}

Vide Paden-Phillips \& Felix (1971в, P. 466) para descrição e comentários. Dimensões: $25-30 \mu \mathrm{m}$. (6 exemplares).

Comentários: Esta espécie caracteriza-se pelo seu contorno circular a subcircular e sulco largo e pouco distinto. Os exemplares da Formação Alagamar, exceto pela exina mais espessa, enquadram-se perfeitamente na descrição original. 
Gênero STELLATOPOLLIS DOYLE, VAN CAMPO \& LUGARDON, 1975. Espécie-tipo: Stellatopollis barghoornii DoyL

\section{Stellatopollis barghoornii DOYLE}

Estampa XVII, figs. 21, 22

Vide DoYne et al. (1975, p. 462-470) para descrição e discussão.

Dimensões: $\mathrm{C}=45-85 \mu \mathrm{m} . \mathrm{L}=35-45 \mu \mathrm{m}$. (5 exemplares).

Comentários: Esta espécie caracteriza-se pela presença de numerosas clavas na ornamentação.

Stellatopollis araripensis LIMA

Estampa XVII, figs. 16, 17

Vide Lima (1978, P. 272-272) para descrição, comentários e diagrama morfológico.

Dimensões: $\mathrm{C}=30-70 \mu \mathrm{m} . \mathrm{L}=20-45 \mu \mathrm{m}$. (5 exemplares).

Comentários: Esta espécie caracteriza-se pelos ápices agudos das projeções de seção triangular (que se agrupam em séries de 6), que ornamentam o grão.

\section{Stellatopollis densiornatus LMA \\ Estampa XVII, fig. 14}

Vide LIMA (1978, p. 273-274) para descrição, comparações e discussão.

Dimensões: $\mathrm{C}=40-50 \mu \mathrm{m} . \mathrm{L}=25-35 \mu \mathrm{m}$. (5 exemplares).

Comentários: Esta espécie assemelha-se à $S$. araripensis, diferindo apenas por possuir ornamentação mais densa e ter os ápices das projeções triangulares arredondados. 


\section{Stellatopollis dubius (LIMA, 1978) LIMA}

Estampa XVII, fig. 3

Vide LMA (1978, P. 274) para descrição, discussão e comparaçס̃es.

Dimensões: $\mathrm{C}=50-70 \mu \mathrm{m} . \mathrm{L}=30-40 \mu \mathrm{m}$. ( 3 exemplares)

Comentários: Espécie caracterizada por apresentar áreas lisas no corpo do grão e ornamentação levemente mais densa nas proximidades do sulco.

Stellatopollis sp. 1 aff. S. sp. Doyle et al., 1977 Estampa XVII, fig. 20

Descrição: Grão de pólen monosulcado de contorno elipsoidal. Sulco estendendose longitudinalmente de um lado a outro do grão. Exina densamente ornamentada por processos claviformes de seção triangular, arranjados em grupos de 6 ao redor de lumina circulares. Ocorrem alternadamente, em alguns casos, outros processos retangulares em número de 1 ou 2, menores, paralelamente aos claviformes.

Dimensões: $\mathrm{C}=95 \mu \mathrm{m} . \mathrm{L}=55 \mu \mathrm{m}$. ( 1 exemplar).

Comentários: Grãos com ornamentação semelhante ao aqui descrito foram apresentados por Doyle et alii (1977), Dejax (1987) e Pons (1988), diferindo enormemente nas dimensões. Por ter sido encontrado apenas um exemplar, enquadrou-se provisoriamente como próxima a ilustrada por Doye et alii (1977, P. 460, EST. I, FIG. 10).

\section{Stellatopollis sp. 2 \\ Estampa XVII, fig. 6}

Descrição: Grão de pólen provavelmente monosulcado, ornamentado por processos claviformes de seção triangular arredondada, densamente arranjados em grupos de 4-6 ao redor dos lumina circulares, e suportados por um infraretículo poligonal a circular. Processos claviformes grandes $(2,5-5,0 \mu \mathrm{m})$, muri do infraretículo espesso $(1,0-2,5 \mu \mathrm{m})$ e lumina grandes $(2,5-7,0 \mu \mathrm{m})$. 
Dimensões: $\mathrm{C}=80 \mu \mathrm{m} . \mathrm{L}=60 \mu \mathrm{m} .(1$ exemplar $)$.

Comentários: A espécie em questão, pela presença de processos arredondados, assemelha-se a S. densiornatus LiMA (1978). Contudo, as dimensões e a visível presença do "infraretículo" a difere de todas as espécies descritas para o gênero. É similar a S. largissimus SINGH (1983).

Gênero RETIMONOCOLPITES PIERCE emend. JUHÁSZ \& GÓCZÁN, 1985 Espécie-tipo: Retimonocolpites dividuus PIERCE, 1961

Obs: Este gênero engloba grắos de pólen monocolpados e reticulados com retículo mais ou menos uniforme. Quando da definição desde gênero PIERCE (1961) não teceu comentários a respeito da variação no tamanho do retículo; e sua ilustração não sugere diferenças entre retículos finos a grosseiros. SINGH (1971) transferiu as espécies de PIERCE de Retimonocolpites para Liliacidites. DorLe et alii (1975) preferiram manter distintos estes dois gêneros com base na presença de retículo uniforme em Retimonocolpites e reticulado não uniforme em Liliacidites. Contudo, estes autores não formularam uma emenda formal para Retimonocolpites. JuHÁSZ \& GÓCZÁN (1985) emendaram a diagnose de Retimonocolpites, considerando neste gênero as formas com retículo delicado, mais ou menos regular e com os lumina aproximadamente uniformes em toda a superfície do grão e com infratectum baculado. O gênero Liliacidites, como emendado por estes mesmos autores, difere de Retimonocolpites, entre outros aspectos, por possuir diâmetro dos lumina mais largos na parte central do grão, como conceituado por DoYLe et alii (op. cit.).

\section{Retimonocolpites dividuus PIERCE \\ Estampa XVIII, fig. 11}

Vide KeMP (1968, P. 424) e SINGH (1971, P. 185-186) para descrição.

Dimensões: $23-25 \mu \mathrm{m}$. (8 exemplares).

Comentários: Como referenciado acima este gênero foi criado por PIERCE (1961) 
para designar grãos de pólen monosulcados reticulados, tem sido motivo de controvérsia. Ainda não estão descritos de modo claro e indubitável todos os parâmetros que individualizam os gêneros Retimonocolpites, Clavatipollenites e Liliacidites. Depreende-se da literatura que é senso comum a necessidade de emendas e refinamentos na sistemática destes gêneros, a fim de limitar os tipos de reticulados e monosulcados que devem ser incluídos em cada um. WARD (1986) sugere que formas tais como $R$. exelsus, por apresentarem retículo gigante requerem um novo gênero. A espécie em questão já foi designada sob os gêneros Retimonocolpites (PIERCE, 1961); Liliacidites Couper (1963); e Clavatipollenites (KEMP, 1968).

\section{Retimonocolpites crassatus (SINGH) SINGH \\ Estampa XVIII, figs. 26, 27}

Vide SiNGH (1971, p. 184) para descrição e comentários.

Dimensões: $\mathrm{C}=23-30 \mu \mathrm{m} . \mathrm{L}=23-28 \mu \mathrm{m}$. (8 exemplares).

Comentários: A ornamentação justifica plenamente a inclusão de nossos exemplares na espécie mencionada, apesar das dimensões um pouco maiores das nossas formas.

Retimonocolpites excelsus WARD

Estampa XVIII, figs. 17, 18, 23, 25

Vide WARD (1986, P. 34) para descrição e observaçð̃es.

Dimensões: $\mathrm{C}=35-50 \mu \mathrm{m} . \mathrm{L}=20-41 \mu \mathrm{m}$. (4 exemplares).

Comentários: Esta espécie caracteriza-se pela sexina com espessa columela e reticulado grosseiro. 
Vide PIERCE (1961, P. 47) para descrição.

Dimensões: $\mathrm{C}=24-27 \mu \mathrm{m} . \mathrm{L}=18-20 \mu \mathrm{m}$. ( 2 exemplares).

\section{Retimonocolpites textus (NoRRIs) SINGH \\ Estampa XVIII, fig. 16}

Vide NoRrus (1967, P. 106) para descrição.

Dimensões: $\mathrm{C}=25-30 \mu \mathrm{m} . \mathrm{L}=17-21 \mu \mathrm{m}$. ( 3 exemplares).

Comentários: Esta espécie é bastante semelhante a B. reticulatus, porém apresenta tamanho e reticulado maiores.

Retimonocolpites sp. (sensu Retisulc-Cand- crochet de HugHes et al., 1979) Estampa XVIII, figs. 22, 24

Vide Hugres, Drewry \& Laing (1979, P. 518-522), para descrição, ilustração e chave de identificação.

Dimensões: $35-40 \mu \mathrm{m}$. (6 exemplares).

Comentários: HuGHEs et alii (1979), apresentaram espécies não formalmente descritas de grãos de pólen monocolpados reticulados. Um dos tipos apresentados foi identificado como "RETISULC-CAND(CROCHET)", no seu esquema de classificação e tabulação morfológica. A ornamentação dos exemplares aqui estudados permite que os enquadremos nesta classificação, apesar das formas do nosso material serem bem maiores.

\section{Retimonocolpites sp. 1}

Estampa XVIII, figs. 19, 28

Descrição: Grão de pólen monosulcado de forma elipsoidal. O sulco é reto abrangendo todo o comprimento do grão. As bordas do sulco são espessas $(2-4 \mu \mathrm{m})$. A nexina é lisa e espessa, a sexina é fina e reticulada. O reticulado apresenta os muros frouxamente arranjados, delimitando os lumina 
aproximadamente poligonais.

Dimensões: $\mathrm{C}=35-38 \mu \mathrm{m} . \mathrm{L}=15-20 \mu \mathrm{m}$. (5 exemplares).

Comentários: Os exemplares descritos caracterizam-se pelo reticulado delicado e aparentemente desprendido do "corpo central". Tal característica pode ser conseqüência da fossilização, já que os especimens não se encontram bem preservados.

Gênero MONOCOLPOPOLLENITES THOMSOM \& PFLUG, 1953 emend. NICHOLS, AMES \& TRAVERSE, 1973.

Espécie-tipo: Monocolpopollenites tranquillus (PotoniE) THOMSON \& PFLug.

Obs: Este gênero, de acordo com a emenda de Nichols et alii (19/3), refere-se aos grãos de pólen monocolpados, nos quais os sulcos se apresentam mais largos nas extremidades ou possuem terminações arredondadas, com ou sem margo e com ornamentação psilada, escabrada ou ainda reticulada.

Monocolpopollenites spheroidites JARDINE \& MAGLORE Estampa XVI, fig. 19

Vide J ARDINE \& MAGLORE (1965, P. 211) para descrição.

Dimensões: $18-22 \mu \mathrm{m}$. (5 exemplares).

Comentários: Os exemplares aqui identificados são em tudo similares aos ilustrados pelos autores da espécie.

Gênero TRANSITORIPOLLIS GÓCZÁN \& JUHÁSZ, 1984 Espécie-tipo: Transitoripollis anulisulcatus GOCZAN \& JuHÁsz, 1984 


\section{Transitoripollis crisopolensis REGALI 1989 nov. comb. Estampa XXI, figs. $10,11,12,13,14$}

Vide Regali (1989, P. 396 A 398), para diagnose e descrição.

Dimensões: $28-35 \mu \mathrm{m}$. (6 exemplares).

Comentários: Esta espécie foi publicada pela primeira vez por Regali et alii (1974), sob a denominação de Inaperturopollenites crisopolensis. Posteriormente, DoYs et alii $(1977,1982)$ questionam o posicionamento sistemático desta espécie, sugerindo o enquadramento provisório da mesma no gênero "Clavatipollenites". Dejax (1987) também exprime suas dúvidas em relação à classificação desta espécie, classificando-a como "Inaperturopollenites". Contudo, Dejax (op. cit.) concorda que ela possa ser enquadrada em Clavatipollenites, chegando mesmo a traçar uma convergência entre as espécies de "I". crisopolensis e C. hughesi, apesar de não se decidir quanto ao gênero da mesma. REGALI (1987c), aceitando a sugestão de DoYle et alii (1977), transfere esta espécie para o gênero Clavatipollenites, emendando sua diagnose genérica e específica. Finalmente, Regali (1989F) reemenda a diagnose genérico-específica da forma em questão, criando para a mesma um novo gênero denominado de Tucanopollis, tendo como especie-tipo Tucanopollis crisopolensis.

Da análise cuidadosa da literatura, observa-se que as diagnoses, genéricas e específicas de Regali (1987c, 1989F), de Dorne et alii $(1977,1982)$, de DejaX (1987) e de GóCZÁN \& JUHÁsz (1984, 1985), são basicamente as mesmas assim como as respectivas ilustrações. Conclui-se, pois, que se trata da mesma espécie. Neste caso, apesar da grande antecedência com que as formas foram descobertas, o gênero Transitoripollis e um sinônimo sênior de Tucanopollis.

Esta espécie difere das demais descritas por GócZÁN \& JuHÁsz $(1984,1985)$, em particular a espécie-tipo, sua espécie mais próxima, por possuir dimensões gerais maiores. Vale ressaltar que os especimens brasileiros são em geral maiores, com dimensð̃es médias as redor de 33,0 $\mathrm{m}$ (exceção feita à formas identificadas na Formação Areado, Lima, 1979c), enquanto que as formas descritas na África (Doyle et alii, 1977), estão as redor de $27-30 \mu \mathrm{m}$ e as da Hungria (Góczán \& Juhász, 1984, 1985) e Colômbia Pons (1988), são bem menores, variando entre $15-22 \mu \mathrm{m}$.

Importante registrar que KASKA (1989), em pesquisas de poços petrolíferos 
na região central do Sudão, apresenta um zoneamento palinológico da área citando a presença de uma espécie denominada Coptospora crisopolensis. O interessante $e$ que trata-se de depósitos de mesma idade e ambiente que os brasileiros em que ocorre a espécie Transitoripollis crisopolensis, além de pertencer ao mesmo cinturão microflorístico. Como o autor não fornece nenhuma indicação, não foi possível identificar quem criou a espécie, e nem se o gênero é uma nova combinação de "Inaperturopollenites" REGALI, ou "Clavatipollenites" RegALI Através da bibliografia citada, também não foi possível se chegar ao autor da espécie. A figura ilustrada (p.81, est.1, fig.10), parece encaixar-se na descrição do gênero Coptospora Detrmann (1963) e difere bastante da espécie ora transferida para o gênero Transitoripollis.

Obs: Esta espécie foi aqui transferida para o gênero Transitoripollis, em função de sua descrição geral ser a mesma e ter a prioridade de publicação.

\section{INFRATURMA RETICULATI PONS, 1988}

Obs: Pons (1988) criou esta infraturma para acomodar grãos de pólen, nos quais, parte do tectum apresentam elementos esculturais distinguíveis à microscopia ótica. A autora inclui sob esta infraturma os gêneros Brenneripollis, Afropollis, Liliacidites, Clavatipollenites e Retimonocolpites. Apesar de acreditar que estes três últimos gêneros ainda não estão claramente definidos, nos seus aspectos esculturais, em função de sua diminuta ornamentação; optou-se aqui por considerar sob esta infraturma apenas os gêneros Afropollis e Brenneripollis, que são os mais problemáticos em termos de definição ao microscópio ótico.

Gênero BRENNERIPOLLIS JÚHASZ \& GỌCZÁN, 1985

Espécie-tipo: Brenneripollis pellitus JưÁsz \& GÓCZAN, 1985

Vide JUHÁSZ \& GOCZZÁN (1985, P.148-152), para descrição e discussão do gênero e espécie-tipo. 


\section{Brenneripollis peroreticulatus (BRENER) JUUASZ, \& GOCZAN Estampa XVIII, figs. 12, 13, 14}

Vide Brenner (1963, P. 94), Doyle, Van Campo \& Lugardon . (1975, P, 456-462) e JÚHASZ \& GOOCZAN (1985, P. 150) para descrição e discussão;

$\therefore$

Dimensões: $\mathrm{C}=13-20 \mu \mathrm{m} . \mathrm{L}=10-18 \mu \mathrm{m}$. (10 exemplares).

Comentários: Brenneripollis peroreticulatus difere de sua espécie mais próxima, $B$. reticulatus, por apresentar tamanho menor e reticulado (lumina) maiores. Estas observações feitas por BRENNER, foram confirmadas por DoYle et alii (1975), com a constatação da existência de grande variação dentre ambas as espécies. No material do presente trabalho, observou-se variações ñ tamanho geral dos grãos e no diâmetro dos lumina, o que dificultou, por vezes, a identificação prescisa de alguns espécimens.

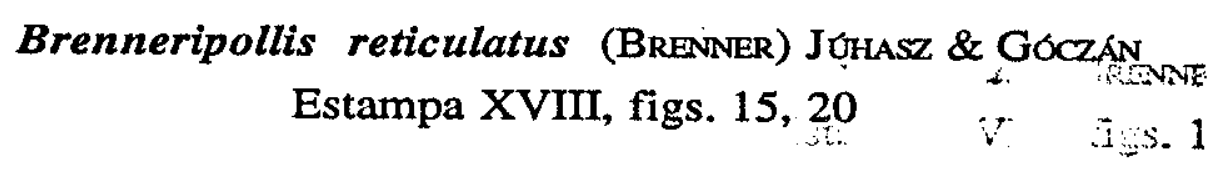

Vide Brenner (1963, p. 94), Doyle, Van Campo \& Lugardon (1975, P. 456-462) e JÚHASZ \& GOCZAN (1985, P. 151) para descrição e discussão. chis e

Dimensões: $C=17-23 \mu \mathrm{m} . \mathrm{L}=15-21 \mu \mathrm{m}$.

Comentários: Difere de $B$. peroreticulatus por apresentar tamanho um pouco maior e e retículo menor. Esta e outras pequenas diferenças, foram gbservadas em MEV, por Doyle, Van Campo \& Lugardon (1976), Hưghes, Drewky \& Laing (1979), e WARD (1986).

Gênero AFROPOLLIS DOYLE, JARDINÉ \& DOEREN KAMP, 1982 Especie-tipo: Afropollis jardinus (BRENNER, 1968) DoYLE, J ARDNE \& DQERENKAMP, 1982 
Afropollis jardinus (BRENNER, 1968) DOYLE, JARDINé \& DOERENKAMP Estampa XVII, figs. 1, 2, 4

Vide Dơne et alii (1982, P. 45-46) para descrição e discussão.

Dimensões: $35-48 \mu \mathrm{m}$. (15 exemplares).

Comentários: Gênero importante do cinturão microflorístico W.A.S.A. A espécie e freqüente no material analisado.

Afropollis sp. aff. A. jardinus DoyL, JARDINé \& DoERENKAMP Estampa XVII, figs. 5, 8, 9

Vide DoYne et alii (1982, P. 47) para descrição.

Dimensões: $35-50 \mu \mathrm{m}$. (15 exemplares).

Comentários: Os exemplares aqui ilustrados são idênticos aos descritos por DoYLe et alii (1982), contudo alguns especimens apresentam dimensões um pouco maiores, chegando a atingir $50 \mu \mathrm{m}$. Afropollis aff. A. jardinus, difere de $A$. jardinus, por apresentar maior heteropolaridade, e uma maior área de reticulado mais fino.

\section{Afropollis operculatus DoYLe, JARDINe \& DOERENKAMP Estampa XVII, figs. 7, 12, 13, 15}

Vide DoyLe et alii $(1982$, P. 47, 48) para descrição e discussão.

Dimensões: D. total $=30-40 \mu \mathrm{m}$. D. operc. $=15-20 \mu \mathrm{m} .(5$ exemplares $)$.

Comentários: Esta espécie é relativamente mais rara que $A$. jardinus e $A$. aff. A. jardinus. Os especimens observados, não continham o "corpo central"; estando os opérculos isolados, e com contorno ovalado. Neste estudo foi constatada sua presença apenas na porção basal da seção. 


\title{
Afropollis zonatus DOYLE, J ARDINE \& DOERENKAMP
}

Estampa XVII, figs. 10, 11, 18, 19

Vide DoYn et alii $(1982$, p. 48, 49) para descrição e discussão.

Dimensões: $35-42 \mu \mathrm{m}$. (5 exemplares).

Comentários: A exemplo de Afropollis operculatus, esta espécie é relativamente rara no material estudado e presente apenas na porção basal da seção.

Subturma DICOLPATES POTONIÉ, 1966

Gênero PSILADICOLPITES REGALI, 1989

Espécie-tipo: Psiladicolpites laevis REGALI

\section{Psiladicolpites laevis RegaLI}

Estampa XIX, fig. 12

Vide REgALI (1989c, P. 242) para diagnose e descrição.

Dimensões: C. $=25-32 \mu \mathrm{m} . \quad$ L. $=20-25 \mu \mathrm{m} .(3$ exemplares $)$.

\author{
Psiladicolpites papillatus ReGALI \\ Estampa XIX, fig. 11
}

Vide REGALI (1989c, P. 242) para diagnose e descrição.

Dimensões: C. $=25-30 \mu \mathrm{m}$. L. $=20-23 \mu \mathrm{m}$. ( 3 exemplares $)$. 


\section{DICOLPADO INDETERMINADO I}

Estampa XIX, figs. 13, 14, 15

Descrição: Grão de pólen dicolpado, colpos longos, paralelos e opostos. Exina fina com ornamentação variando de fina a fortemente escabrada.

Dimensões: C. $=35-43 \mu \mathrm{m} . \quad$ L. $=18-23 \mu \mathrm{m} .(5$ exemplares $)$.

Comentários: Esta espécie caracteriza-se por sua ornamentação visivelmente escabrada e dimensões relativamente grandes. Não se conseguiu enquadrar esses grãos na classificação sistemática consultada e devido ao pequeno número de exemplares considera-se prematura a criação de novo gênero para tal.

\section{DICOLPADO (?) INDETERMINADO II}

Estampa XIX, fig. 21

Descrição: Grão de pólen dicolpado, colpos longos, paralelos e opostos. Exina espessa com ornamentação foveolada, com as foveolas diminutas $(<1,0 \mu \mathrm{m})$.

Dimensões: $30 \mu \mathrm{m}$. (1 exemplar).

Comentários: Esta espécie caracteriza-se por sua ornamentação microfoveolada, exina espessa e dimensões relativamente grandes. Não se conseguiu enquadrar esse grão na classificação sistemática consultada e como se trata de um único exemplar fica aqui apenas o registro. Vale salientar que não se descarta a possibilidade de se tratar de uma forma diporada.

Subturma TRIPTICHES NAUMOVA, 1939

Infraturma ISOTRICOLPATI POTONIÉ, 1970

Gênero PSILATRICOLPITES VAN der HAMMEN, 1956

Espécie-tipo: Psilatricolpites incomptus VAN DER HAMMEN

Obs: O gênero Psilatricolpites foi erigido para enquadrar grãos de pólen tricolpados lisos. Contudo, a espécie-tipo foi baseada em grãos de pólen de 
plantas atuais. POTONIE (1966), considerou Psilatricolpites psilatus (PIERCE, 1961) como sendo a espécie-tipo do gênero. Entretanto, de acordo com o artigo 7, do C.I.N.B. não é permitida a validação posterior de um gênero através de grãos de pólen fósseis. Este gênero é aqui mantido em função de sua aplicabilidade e devido a sua boa aceitação em grande número dos trabalhos consultados, que contém estas formas.

\section{Psilatricolpites pachyexinus COUPER Estampa XIX, figs. 16, 17}

Vide COUPER (1953, P. 62) para descrição.

Dimensões: $30-38 \mu \mathrm{m}$. ( 8 exemplares).

Comentários: Os exemplares encontrados enquadram-se perfeitamente na descrição de $P$. pachyexinus; esta espécie é encontrada na parte superior da seção estudada.

\section{Gênero CUPULIFEROIDAEPOLLENITES POTONIÉ, THOMSON \& THIERGART, 1950}

Especie-tipo: Cupuliferoidaepollenites liblarensis THOMSON, 1950

Obs: Este gênero foi criado por Potoní, Thomson \& ThIERGart para enquadrar grãos de pólen tricolpados pequenos (menores que $18-20 \mu \mathrm{m}$ ), com exina lisa a levemente escabrada.

\section{Cupuliferoidaepollenites parvulus (GROOT \& PENNY) DETTMANN Estampa XIX, fig. 19}

Vide Groot \& Penny (1960, P. 232) para descrição, e Dettmann (1973, p. 12), e SiNGH $(1971$, p. 199) para sinonímia e comentários.

Dimensões: $13-15 \mu \mathrm{m}$. (4 exemplares). 
Comentários: Esta especie é caracterizada pelas suas dimensões diminutas e ornamentação psilada. Tem sido registrada comumente em depósitos de Idade Albiana a Turoniana da América do Norte e Australia.

\section{Gênero TRICOLPITES COOKSON ex COUPER emend. JARZEN \& DETTMANN, 1989 \\ Espécie-tipo: Tricolpites reticulatus COOKSON 1947, ex Couper, 1953.}

Vide Jarzen \& Dettmann (1989, p. 99) para diagnose, e Srivastava (1975, P. 98) para sinonímia do gênero.

Observações preliminares: A presença de grande diversidade de grãos de pólen tricolpados a partir do Aptiano Superior-Albiano Inferior em várias partes do mundo levou à necessidade de criação de diferentes gêneros para acomodar estas formas.

Após a criação do gênero Tricolpites Cookson ex Couper (1953), grande confusão se estabeleceu, notadamente para os de exina reticulada. Vários subgêneros foram criados, a maioria dos quais atualmente inválidos (por ex. Bacutricolpites).

Um dos mais importantes, Retitricolpites, foi inicialmente proposto por Van der Hammen (1956) como um subgênero de Tricolpites ERdTMan (1947) para os grãos de pólen tricolpados reticulados. Prerce (1961) elevou-o à categoria de gênero; contudo utilizou como espécie-tipo um grão de pólen recente de Neea macrophylla, invalidando-o.

Dada a grande variedade na ornamentação reticulada destas formas tricolpadas, o termo Retitricolpites ainda é utilizado erroneamente por alguns autores. No entanto, como se pode constatar nos trabalhos de Potonté (1966), Kemp (1968), Srivastava (1969), Singh (1971), Dettmann (1973), entre outros, Retitricolpites é sinônimo júnior de Tricolpites. Este último, não deve ser utilizado como emendado por Belsky, Boltenhagen e Potonie (1965), que preferiram englobar no gênero as formas grosseiramente reticuladas; mas sim a emenda de Jarzen \& DetTMann (1989), que restringe o gênero para grãos de pólen tricolpados reticulados, com malha uniforme de até $1,0 \mu \mathrm{m}$ ( $\varepsilon$ o conceito atualmente mais usado na literatura, onde incluem-se também as formas microreticuladas, subgranuladas e escabradas, excluindo as com ornamentação supramural). Para acomodar grãos de pólen tricolpados com outros tipos de 
reticulado, foram criados diferentes gêneros, como retratado no quadro 2.

Por outro lado, alguns autores (e.g. NoRTON \& HALL, 1969) têm restringido Tricolpites para tricolpados oblados e globosos e usado o gênero Tricolpopollenites Pfug \& Thomson (1953), para formas tricolpadas proladas. Entretanto esta é uma distinção arbitrária e temerária, dado que uma mesma espécie de pólen pode variar de oblada a prolada. Ademais, Tricolpopollenites foi criado para grãos de pólen tricolpados de forma e ornamentação variadas, e incluem ainda formas tricolporoidadas. Segundo KrUTzsch (1959), a espécie-tipo do gênero é mais propriamente tricolporada que tricolpada.

Deve-se reservar Tricolpopollenites para formas tricolporoidadas, embora formas normalmente tricolpadas possam, às vezes mostrar um sugestivo desenvolvimento de um oroide.

\section{Tricolpites micromunus (GROOT \& PENNY) SINGH}

Estampa XIX, fig. 20

Vide Groot \& Penny (1960, P. 232), Brenner (1963, P. 93), Singh (1971, P. 209) para descrição e Doyle, VAN CAMPo \& Lugardon (1975, P. 470-474) para descrição e discussão.

Dimensões: $20-22 \mu \mathrm{m}$. (6 exemplares).

Comentários: Os especimens identificados apresentam reticulado variável, sugerindo uma possível heterogeneidade do grupo, como observado por WARD (1986). Assim como mostram uma grádação como no gênero Rousea, apesar de mais sutil.

Tricolpites microreticulatus BeLsKY, BOLTENHAGEN \& POTONIE Estampa XIX, fig. 18

Vide Belsky, Boltenhagen \& Potonie (1965, P. 75-76) para descrição e discussão e BRENNER (1968, P. 366) para comentários.

Dimensões: $20-30 \mu \mathrm{m}$. (4 exemplares). 


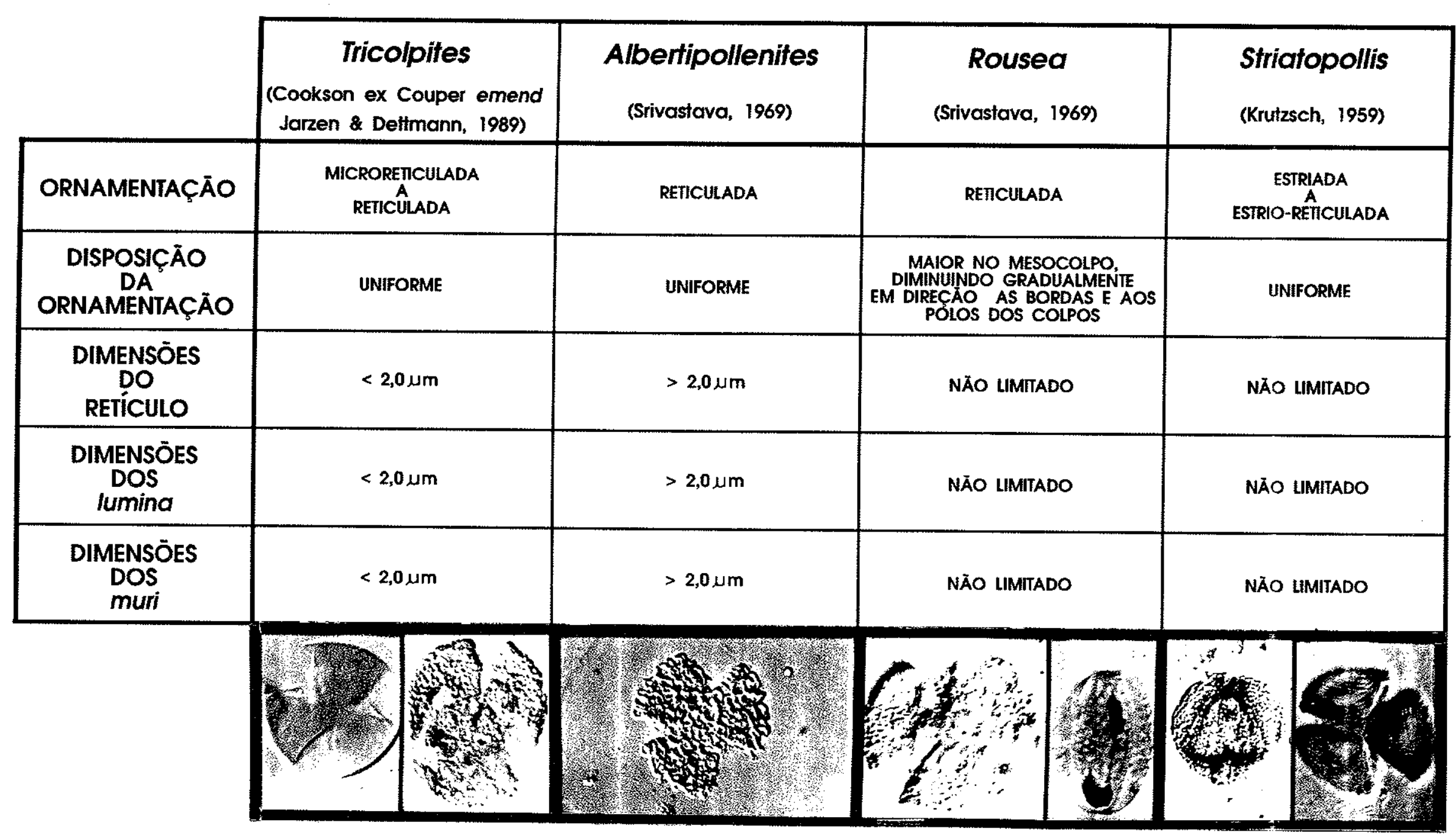

QUADRO 2 - CARACTERÍSTICAS PRINCIPAIS DOS DIFERENTES GÊNEROS DE GRĀOS DE PÓLEN TRICOLPADOS COM EXINA RETICULADA E ESTRIO-RETICULADA. 
Comentários: Espécie de fácil reconhecimento, por apresentar manchas escuras nas áreas polares e bordas dos colpos. Não consideramos válida a nova combinação desta espécie realizada por BRENNER (1968), em razão do exposto por Srivastava (1975, P. 98) para o gênero em questão.

\section{Tricolpites minutus (BRENNER) DetTMANN \\ Estampa XIX, figs. 22, 23}

Vide Brenner (1963, P. 93), DetTmann (1973, P. 13) e Doyle, Van Campo \& Lugardon (1976, P. 470-474), para descrição e discussões.

Dimensões: $15-17 \mu \mathrm{m}$. ( 3 exemplares).

Comentários: Tricolpites minutus é outra espécie de tricolpados pequenos (a exemplo de $T$. parvus e $T$. micromunus) com desenvolvimento de retículo variado, sugerindo um possível agrupamento de formas heterogêneas. Esta espécie, bem como T. micromunus, que são morfologicamente muito próximas, apresentam, as vezes, aspecto psilado ao microscópio.

Tricolpites vulgaris (PIERCE) SRIVASTAVA

Estampa XIX, figs. 26, 27

Vide SRIVAStaVA (1975, P. 102) para descrição e comparações entre os especimens ao MEV e microscópio óptico.

Dimensões: Diâmetro equatorial $=25-30 \mu \mathrm{m}$. Eixo polar $=20-25 \mu \mathrm{m} .(5$ exemplares).

Comentários: Espécie caracterizada por apresentar colpos longos. SRIVASTAVA (1975), observou a presença de báculas na estrutura infratectal, porém estas esculturas são visíveis somente ao microscópio eletrônico.

Tricolpites sp. 1

Estampa XIX, fig. 30 
Descrição: Grão de pólen tricolpado, colpos largos, quase atingindo os polos do grão. Nexina lisa, sexina ornamentada com um padrão reticulado, sendo os lumina pequenos $(<1,0 \mu \mathrm{m})$, e de formato irregular.

Dimensões: $37 \mu \mathrm{m}$. ( 1 exemplar).

Comentários: O padrão irregular formando, por vezes, canalículos no retículo, bem como as dimensões desta espécie, a tornam semelhante a $T$. maximus WARD (1986). Contudo, por se tratar de um único exemplar e com má preservação não foi enquadrado nesta espécie. Esta espécie é a forma tricolpada mais baixa da seção.

Tricolpites ? sp. 2

Estampa XIX, fig. 24

Descrição: Grão de pólen de âmbito subcircular a subtriangular, colpos largos e longos, atingindo $1 / 2$ do raio do grão e arredondados nas bordas. Apresenta possíveis oroides nos colpos. Exina escabrada a granulada, moderadamente espessa.

Dimensões: $18-23 \mu \mathrm{m}$. ( 4 exemplares).

Comentários: Esta espécie foi identifịcada como tricolpada com dúvidas, por apresentar possíveis oroides não bem definidos nos colpos, sugerindo ser tricolporoidada. A falta de exemplares em maior quantidade e melhor preservados impede um melhor enquadramento genérico-específico.

Gênero ROUSEA SRIVASTAVA, 1969

Espécie-tipo: Rousea subtilis Srivastava, 1969

Observações preliminares: Este gênero foi criado para acomodar grãos de pólen tricolpados reticulados, sendo que a malha do retículo se torna gradativamente menor em direção aos polos e às margens dos colpos. 


\section{Rousea charma WARD}

Estampa XIX, fig. 25

Vide WARD (1986, p. 45) para descrição e comparações.

Dimensões: $20 \mu \mathrm{m}$. ( 2 exemplares).

Comentários: Esta espécie é caracterizada pela extrema sutileza na diminuição do retículo em direção aos polos e bordas dos colpos. Trata-se porém indubitavelmente do gênero Rousea.

\section{Rousea georgensis (BRENNER) DETTMANN \\ Estampa XIX, figs. 28, 29}

Vide Brenner (1963, p. 91-92) e DettMann (1973, P. 14-15) para descrição e discussão.

Dimensões: $20-22 \mu \mathrm{m}$. (4 exemplares).

Comentários: De acordo com Ward (1986) esta espécie inclui uma gama de grãos de pólen "rouseoide", com dimensões variando de $15-36 \mu \mathrm{m}$; tendo também variaç̃̃es no tamanho dos lumina.

Gênero STRIATOPOLLIS KRUTZSCH, 1959 Especie-tipo: Striatopollis sarstedtensis KRUTzsch, 1959

Obs: A primeira forma-gênero criada para abrigar grãos de pólen tricolpados com exina estriada foi Tricolpites subgênero Striatricolpites VAN DER HAMMEN (1956). Entretanto, o holotipo da espécie-tipo, T. (S.) virgulatus VAN DER Hammen (1956), é um grão de pólen atual de Acer platanoides. Gonzalez-Guzman (1967) elevou o táxon à categoria de gênero, conservando a espécie-tipo original, ilegitimando, em conseqüência, o nome-gênero Striatricolpites. KRUTzscH (1959) propos o gênero Striatopollis baseado em grãos de pólen tricolpados estriados do terciário. Rouse (1962) criou o gênero Striopollenites para acomodar polens tricolpados estriados, que por conter basicamente a mesma descrição geral e publicação posterior, foi considerado sinônimo júnior de Striatopollis por 
Potonié (1966).

Singh (1971) e DetrmanN (1973) incorporaram tanto as formas estriadas como as estrio-reticuladas no gênero Striatopollis KrUTZSCH (1959).

Rutihesperipites SRrvastaVA (1977), estabelecido para formas tricolpadas, obladas e estriadas de exina fina, foi considerado um sinônimo júnior de Striatopollis por WARD (1986) devido ao inválido status nomenclatural do gênero.

\section{Striatopollis paraneus (NoRRIs) SINGH \\ Estampa XX, fig. 14}

Vide Norris (1967, P. 109) e SingH (1971, P. 206) para descrição.

Dimensões: $17 \mu \mathrm{m}$. ( 1 exemplar).

Comentários: Espécie caracterizada pelas suas diminutas dimensões.

Striatopollis reticulatus (REgALI, UesUguI \& SANTos) nov. comb. Estampa XX, figs. 6 a 12

Obs: Esta espécie foi aqui transferida para o gênero Striatopollis KruTzsch, 1959, devido a sua ornamentação estria-reticulada.

Vide REGAul et alii (1974, p. 279) para descrição.

Dimensões: $38-53 \mu \mathrm{m}$. (20 exemplares).

Comentários: Os grãos desta espécie apresentam-se quase sempre fragmentados, em função do seu caráter sincolpado.

\section{Striatopollis sp. 1 \\ Estampa XX, fig. 13}

Descrição: Grão de pólen tricolpado estriado, pequeno. Radialmente simétrico, isopolar. Contorno em vista polar trilobado, subesférico. Colpos largos e 
longos, alcançando mais de $3 / 4$ do raio do grão. A estriação, muito fina, abrange todo o grão e dispõe-se perpendicularmente ao eixo polar.

Dimensões: $25 \mu \mathrm{m}$. ( 1 exemplar).

Comentários: Esta espécie caracteriza-se por possuir estrias muito finas, dispostas perpendicularmente ao eixo polar. Rara no material.

Gênero ALBERTIPOLLENITES SRIVASTAVA, 1969

Espécie-tipo: Albertipollenites rosalindae SRIVASTAVA, 1969

Obs: O gênero Albertipollenites Srivastava (1969) foi proposto originalmente para acomodar gräos de pólen tricolpados, os quais apresentam sexina uniformemente reticulada, com ambos, lumina e muri, maiores que 1,0 $\mu \mathrm{m}$ de largura. E para distinguir de Retitrescolpites SAH (1967), que se aplica a grãos de pólen reticulados com lumina maiores que $1,0 \mu \mathrm{m}$ e muri menores que $1,0 \mu \mathrm{m}$ e que possuem papilas nos muri. Que esta distinção serve a algum propósito útil, é uma questão em aberto, contudo, pelo menos serve para individualizar grãos de polen tricolpados com retículos grandes e grosseiros.

\section{Albertipollenites limae nov. sp. Estampa XX, figs. 1 a 5}

Derivação do nome: Nome dado em homenagem ao Dr. Murilo Rodolfo de Lima, palinólogo do Instituto de Geociências da USP, em reconhecimento a sua contribuição ao estudo e ensino da palinologia no Brasil.

Holótipo: Preparação- RNS-35; Lâmina 9102153; coordenadas: U32-1. Estampa $\mathrm{XX}$, fig. 1.

Estrato típico: Formação Alagamar, Bacia Potiguar.

Diagnose: Grão de pólen tricolpado, de contorno trilobado a subesférico. Exina ornamentada por reticulado grosseiro, lumina muito largos e muri espessos. 
Descrição: Grão de pólen tricolpado, grande, reticulado. Radialmente simétrico, isopolar.âmbito trilobado a subesférico, colpos largos e longos, atingindo 2/3 do diâmetro do grão. Exina com duas camadas, sendo a interna lisa. A externa, espessa, tectada, apresentando um reticulado uniforme, grosseiro, com muri espessos $(>1,5 \mu \mathrm{m})$ que se espessam ainda mais na junção do retículo. Os lumina são largos $(3,0-8,0 \mu \mathrm{m})$, com formas irregulares poligonais a ovaladas.

Dimensões: Diâmetro equatorial $=45-55 \mu \mathrm{m} .(20$ exemplares $)$.

Comentários: Espécie caracterizada pelas dimensões, lumina larga e muri espessos. Difere de Tricolpites anguloluminosus ANDERson (1960), sua especie mais próxima, pelas dimensões bem menores e muri finos e delicados deste último. Esta espécie foi ilustrada por Regali (1989c), e denominada de Retitricolpites sp. 4.

Subturma TRICHOTOMOSULCATES ERDTMAN, 1954.

Gênero TRICHOTOMOSULCITES COUPER emend. JUHÁSZ \& GÓCZÁN, 1985 Espécie-tipo: Trichotomosulcites subgranulatus COUPER

Vide JUHÁZZ \& GÓCZAN (1985, P. 159), para descrição e discussão da emenda na diagnose do gênero.

\section{Trichotomosulcites subgranulatus COUPER} Estampa XVI, fig. 17

Vide COUPER (1953, P. 64) para descrição.

Dimensões: $28-30 \mu \mathrm{m}$. (2 exemplares).

Comentários: Os exemplares apresentados foram acomodados neste gênero em função do contorno e da abertura. Contudo, apresentam dimensões menores, exina mais espessa e ornamentação mais grosseira que as espécies descritas 
para este gênero. Estes exemplares assemelham-se bastante a Asteropollis asteroides HEDLUND E NORRIs (1968), diferindo pela ornamentação mais delicada e dimensões menores deste último.

\title{
Gênero TETRACOLPITES VIMAL ex SRIVASTAVA, 1966 Espécie-tipo: Tetracolpites reticulatus SRrvastaVA
}

\section{Tetracolpites sp. 1}

Estampa XX, fig. 15

Descrição: Grão de pólen tetracolpado, colpos longos, até a metade do grão. Bordas convexas, proporcionando um contorno arredondado. A exina Possui ornamentação visivelmente scabrada a microrugulada.

Dimensões: $25-30 \mu \mathrm{m}$. (2 exemplares).

Comentários: Espécie rara em nosso material. Presente apenas na porção superior da seção estudada.

\author{
Gênero QUADRICOLPITES WINGATE, 1980 \\ Espécie-tipo: Quadricolpites reticulatus WINGATE
}
Quadricolpites reticulatus WINGATE
Estampa XX, figs. 16, 20

Vide Wingate (1980, P. 44) para descrição e observações.

Dimensões: vista equatorial- $\mathrm{C}=50-65 \mu \mathrm{m} . \mathrm{L}=33-45 \mu \mathrm{m}$. ( 3 exemplares).

Comentários: Espécie rara no material analisado, presente apenas na porção mais superior da seção. 


\section{Subturma POLYPTICHES NAUMOVA, 1939 Infraturma PERICOLPATI POTONIÉ, 1975}

Gênero PENETETRAPITES HEDLUND \& NORRIS, 1968

Espécie-tipo: Penetetrapites mollis HEDLUND \& NORRIS

\section{Penetetrapites mollis HEDUUND \& NORRIS Estampa XX, figs. 17, 19}

Vide HEDLund \& NoRRIs (1968, P. 152) para descrição.

Dimensões: $28-35 \mu \mathrm{m}$. (8 exemplares).

Comentários: Os especimens ora ilustrados são bastante semelhantes aos apresentados por LIMA (1978, EST. XXV, FIGS. 5-6). Foram enquadrados nesta espécie, apesar de não ser observada a quarta abertura característica da espécie.

Penetetrapites incipiens LaviA

Estampa XX, fig. 18

Vide Lima (1978, P. 284-285) para descrição, discussão e comparações.

Dimensões: $28-33 \mu \mathrm{m}$. ( 3 exemplares). ,

Comentários: Os exemplares encontrados no material estudado assemelham-se em tudo a espécie descrita por Lima (1978).

Turma POROSES (NAUMOVA, 1939) POTONIÉ, 1960

Subturma MONOPORINES (NAUMOVA, 1939), POTONIÉ, 1960

Observações Preliminares: Grãos de pólen pequenos (20-35 $\mu \mathrm{m})$, esféricos, sejam inaperturados, porados ou pseudoporados, ou mesmo apresentando pequenos grânulos esféricos (orbiculas?), são geralmente considerados como elementos 
produzidos por plantas das famílias das Cupressaceas, Taxodiáceas e Taxacéas, em função da sua similaridade com os grãos de pólen produzidos atualmente por estas plantas (Staplin et alii, 1967; ReYre, 1968, 1970, 1973; Pocock, 1970). Diferentes gêneros foram criados para acomodar estes palinomorfos a saber: Exesipollenites BALME, 1957; Spheripollenites COUPER, 1958; Inaperturopollenites Thomson \& Pflug, 1953; Cupressacites Bolkhovtrina, 1956; Taxacites ReYRE, 1973 e Perinopollenites CoUper, 1958.

Por outro lado, autores como Van Koninnenburg-Van Cirtert, 1971, têm sugerido que parte dos grãos de pólen classificados nos gêneros Exesipollenites e Spheripollenites, podem representar "corpos internos" de polens do tipo Classopollis. NORRIs (1969) sugerindo a mesma filiação, assinala que as especies E. tumulus e E. scabrosus encontradas no seu material ocorrem associadas a presença abundante de Classopollis. Fn_ATofr (1975) em análise estatística de 100 especimens de grãos atribuíveis ao gênero Exesipollenites, cita que $75 \%$ dos especimens observados continham um pseudoporo distinto; $20 \%$ mostravam um espessamento distal na exina e $25 \%$ possuíam marca trilete. Além disso, assinala que em $80 \%$ observa-se a presença de uma intraestrutura e que $50 \%$ continham grânulos esféricos em sua superfície.

Pelo acima exposto podemos notar que a afinidade botânica, tanto quanto a classificação sistemática destes grãos, em função da sua aparente simplicidade, E extremamente difícil, principalmente, com base apenas nas observações ao microscópio optico.

Grãos de pólen deste tipo foram encontrados em altas porcentagens no material aqui estudado, a exemplo de diversos depósitos jurássicos e eocretáceos do mundo. Pela presença abundante de diferentes tipos, perfeitamente distintos a luz da microscopia ótica; por acreditar na potencialidade estratigráfica na distinção destas formas; e da confusa classificação sistemática observada na literatura, foi realizada tentativamente uma individualização destas formas.

Pela impossibilidade de observar os gêneros e espécies-tipo descritos, nem analisar o material com base na microscopia eletrônica, não será feita uma análise histórica e crítica das definiçóes genéricas e específicas destas formas, bem como da aceitação ou não destes gêneros pelos diferentes autores. A partir do histórico das definições de cada gênero, extraídas da literatura, foi elaborado o quadro $3 \mathrm{com}$ as principais características que delimitam cada gênero aqui considerado. 


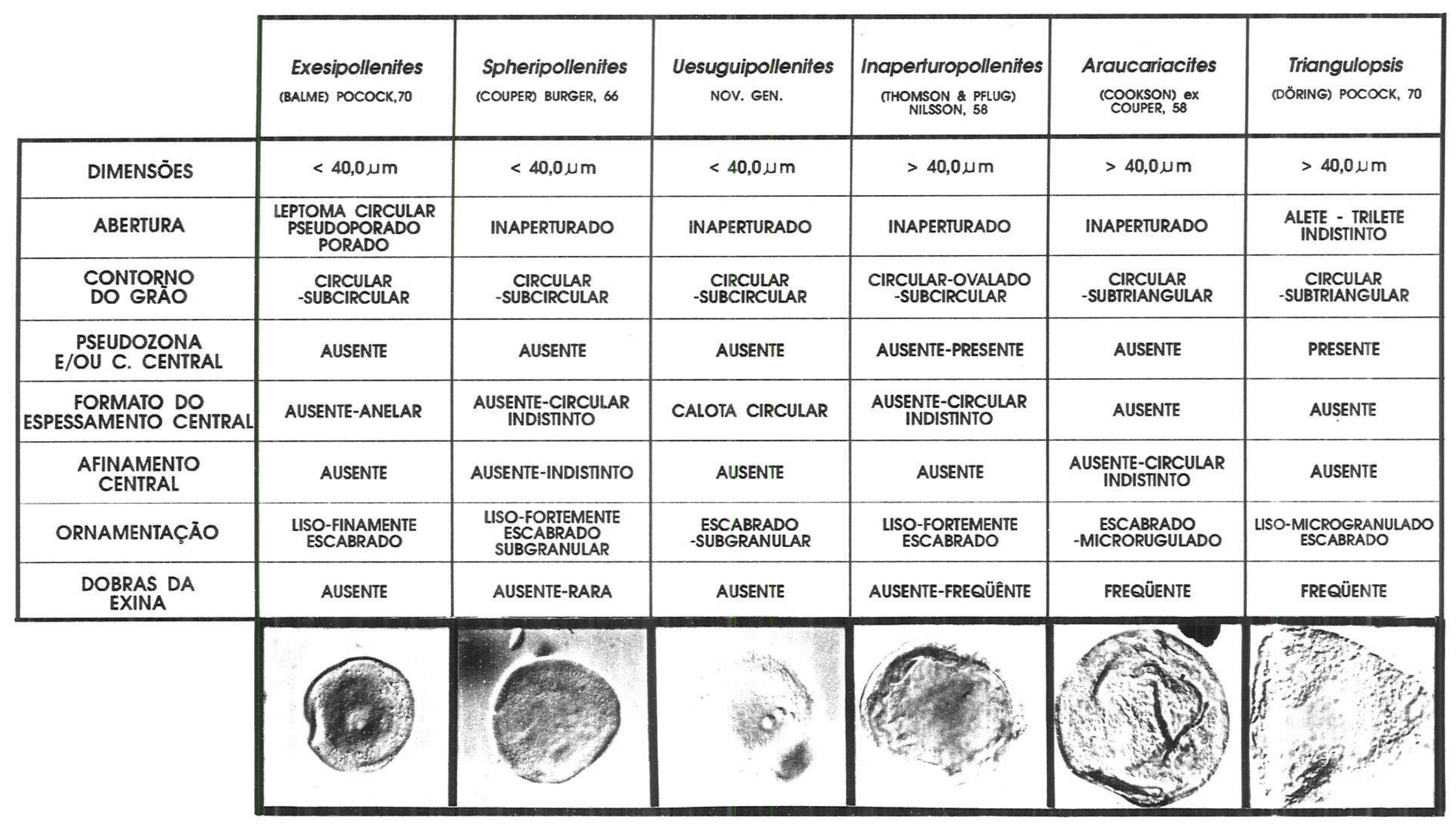

QUADRO 3 - CARACTERÍSTICAS PRINCIPAIS QUE INDIVIDUALIZAM OS DIFERENTES GÊNEROS DE GRĀOS DE PÓLEN INAPERTURADOS. 
Gênero EXESIPOLLENITES BALME, 1957.

Espécie-tipo: Exesipollenites tumulus BALME.

Obs: Neste gênero estão incluídas apenas as formas que sob a microscopia ótica, apresentam indubitavelmente leptomas circulares, pseudoporos ou poros, circundados ou não por um espessamento anelar da exina. Exatamente como o conceituado por BALME, 1957.

\section{Exesipollenites tumulus BALME \\ Estampa XXI, figs. 1, 2, 3}

Descrição: Grão de pólen de contorno circular, oval a subtriangular arredondado, exina lisa ou com pequenos grânulos. Contém um poro ou pseudoporo circundado por uma área anelar mais espessa e escura. Em direção ao equador, a exina volta a apresentar uma coloração mais clara. Quando observado do polo que não contém o poro, é nítida apenas a região espessada da área anelar do outro polo.

Dimensões: $28-33 \mu \mathrm{m}$. (10 exemplares).

Comentários: Os exemplares observados enquadram-se perfeitamente na descrição de BALME (1957) e apresentam uma notável regularidade de forma e tamanho. Nota-se que grande parte dos exemplares desta espécie, principalmente os mal preservados, sofrem um afinamento da exina em direção ao equador; tornando-se tão fino que na prática, não se consegue medir a espessura da borda do grão.

\section{Exesipollenites laevigatus Pocock \\ Estampa XXI, figs. 6, 7, 8}

Vide Pocock (1970, p. 101) para descrição, discussão e comparação.

Dimensões: $18-22 \mu \mathrm{m}$. ( 3 exemplares).

Comentários: Os exemplares observados são bastante semelhantes aos descritos por Pocock. Trata-se de uma forma relativamente rara em nosso material. 


\section{Exesipollenites scabratus (COUPER) POCOCK}

Estampa XXI, figs. 4, 5, 9

Descrição: Grão de pólen de contorno circular a oval, exina finamente escabrada. Apresenta um poro perfeitamente distinto num dos polos não contém área anelar espessada.

Dimensões: $23-30 \mu \mathrm{m}$. (15 exemplares).

Discussão e comparaçóes: Assemelha-se em muito com as formas de Pocock (1970), apesar do mesmo descrever a espécie como aporada. Difere de $E$. tumulus Balme, pela ausência do espessamento ao redor do poro e pela ornamentação distintamente escabrada.

Subturma POLYPORINES (NAUMOVA, 1939) POTONIÉ, 1960

Gênero CRETACAEIPORITES HERNGREEN, 1973

Espécie-tipo: Cretacaeiporites polygonalis (JARDINE \& MAGLORE, 1965)

HERNGREEN, 1973

Cretacaeiporites polygonalis (JARDINE \& MAGLORE, 1965) HERNGREEN, 1973 Estampa XXI, fig. 15

Vide Hernareen (1973, P. 552) para diagnose e comentários.

Dimensões: $25-35 \mu \mathrm{m}$. (3 exemplares).

Comentários: Forma rara no material estudado, sendo encontrada apenas nos estratos superiores da seção. 


\title{
GRÃOS DE PÓLEN "INCERTAE SEDIS"
}

\author{
Gênero REYREA HERNGREEN, 1973 \\ Espécie-tipo: Reyrea polymorphus HERNGREEN, 1973
}

\author{
Reyrea polymorphus HERNGREEN \\ Estampa XXI, fig. 16
}

Vide Herngreen (1973, P. 546) para descrição.

Dimensões: $38-50 \mu \mathrm{m}$. ( 2 exemplares).

Comentários: Forma rara no material estudado. Esta espécie é importante na caracterização das associações microflorísticas da província W.A.S.A.

\section{PALINOMORFOS 'INCERTAE SEDIS”}

\section{INCERTAE SEDIS I}

Estampa XXII, fig. 8

Comentários: Estes palinomorfos apresentam-se caracteristicamente como vesículas ocas, com uma parede fina, de uma so camada, geralmente com pequenas dobras e sempre aberto em uma das extremidades. A forma e tamanho destas vesículas são regulaies, e aliado a abertura num dos "polos", lembra os quitinozórios. BATTEN, 1992 (com. pess.), acredita que se trata de protozoários não-marinhos do gênero Folliculinideos.

Dimensões: C. $=200-220 \mu \mathrm{m}$. L. $=80-90 \mu \mathrm{m} .(5$ exemplares $)$. 


\section{INCERTAE SEDIS II}

Estampa XXII, fig. 9

Comentários: Forma cujo aspecto geral que lembra uma espinha de peixe. E formada por um arranjo linear de 18 "placas" em forma de crescente, isoorientadas ao longo de um eixo, que intercepta cada elemento sucessivo alternadamente a $1 / 3$ e $2 / 3$ do seu comprimento.

Dimensões: C. $\mathrm{t} .=180 \mu \mathrm{m}$. L. t. $=70 \mu \mathrm{m}$. C. indiv. $=50-55 \mu \mathrm{m}$. L. indiv. $=$ 10-15 $\mu \mathrm{m}$. (1 exemplar).

\section{INCERTAE SEDIS III \\ Estampa XXII, figs. 1, 5}

Comentários: Trata-se de palinomorfos de corpos circulares, com estriações radiais. Apresentam uma área central sem estrutura, circundada por um anel espesso, escuro e radiado:

Estruturas bastante próximas a estas são apresentadas por WATson \& BATTEN (1990), como diagramas nodais de equisetales fosseis. Segundo estes autores, corpos como "rodas", com estruturas radiais a partir do centro, apresentam sem dúvida similaridade com os diagramas nodais apresentados por quase todas as espécies de equisetales fósseis. Contudo, as dimensões apresentadas por estes diagramas nodais são extremamente maiores. BATTEN (COM. PEss., 1992), em função das dimensões acredita que pode não se tratar de "nodulos" de equisetales. Talvez estes exemplares possam representar fragmentos de algas filamentosas.

Dimensões: $45-50 \mu \mathrm{m}$. ( 2 exemplares).

\section{INCERTAE SEDIS IV}

Estampa XXII, figs. 2, 3, 4, 6, 7, 10

Comentários: Trata-se de fragmentos de composição quitinosa muito provavelmente oriundos de carapaças de conchostráceos. Constituem-se de 
uma parede com espessura variando, desde homogeneamente muito fina (fig. 4), a fina com gradativo espessamento em direção as margens (figs: 1-2). A parede pode ser psilada ou mostrar um retículo homogêneo (fig. 3). Todas apresentam níveis ondulados, orientados, e com formatos diversos, provavelmente representam linhas de crescimento. De acordo com Regalr (1989D) estes fragmentos devem ser de conchostráceos do gênero Cyzicus (= "Estheria"), pois este $\epsilon$ o gênero mais freqüentemente encontrado nos depósitos mesozóicos brasileiros.

Dimensões: Apresentam dimensões extremamente variáveis, tanto no comprimento quanto na largura. 
ORDEM FORAMINIFERA d'ORBIGNY, 1826.

SCYTINASCIA DEÁK, 1964.

Gênero RHODONASCIA DEÁK, 1964

Espécie-tipo: Rhodonascia majzoni DEAK

Rhodonascia sp. cf. R. bontei DEAK

Estampa I, fig. 15

Vide DEAk (1964, P. 105) para descrição.

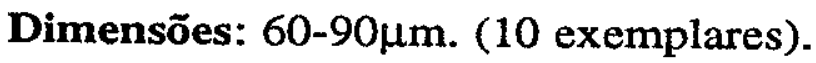




\section{h- REFERÊNCIAS BIBLIOGRÁFICAS}

AGASIE, J.M. - 1969 - Late Cretaceous palynomorphs from northeastern Arizona. Micropaleont., Columbia, v.15, n.1, p.13-30.

ALMEIDA, F.F.M. \& HASUI, Y. - 1984 - O Pré-Cambriano do Brasil. São Paulo. Blücher, 378p.

ALMEIDA, F.F.M.; HASUI, Y.; BRITO NEVES, B.B. \& FUCK, R.A. - 1977 - Províncias estruturais brasileiras. In: SIMP. GEOL. NORDESTE, 7, Campina Grande, Atas... Simp. Geol. Nord., Recife, SBG/NNE, p.363-392.

ALVAREZ, L.W; ALVAREZ, W.; ASARO, F. \& MICHEL, H. - 1980 - Extraterrestrial causes for the Cretaceous-Tertiary extinctions. Science, Washington, n.208, p.1095-1108.

ALVAREZ, L.W; ALVAREZ, W.; ASARO, F. \& MICHEL, H. - 1982 - Current status of the impact theory for the terminal Cretaceous extinction. Geol. Soc. of America, Special Paper. Boulder, n.190, p.305-315.

ALVES, A.C.; NEVES, C.A.O.; CAINELLI, C.; SANTOS, E.R.; LIMA NETO, F .F.; FRANÇOLIN, J.B.L.; MATOS, R.M.D. \& SILVA, S.R.P. - 1983 - Estudo da área de Macau. Natal. PETROBRÁS/DEBAR/DINTER DIRNOE/SECEPO. 244p. Relatório interno.

ALVIN, K.L. - 1982 - Cheirolepidiaceae: biology, structure and palaeoecology. Rev. Palaeobot. Palynol., Amsterdam, v.37, n.2, p.71-98.

ANDERSON, R.Y. - 1960 - Cretaceous-Tertiary palynology, eastern side of the San Juan Basin, New Mexico. Bur. Mines Min. Res. Mem., New Mexico, n.6, p.1-56. 
ANDREWS, H.N. - 1961 - Studies in Paleobotany. New York. Wiley, 487 p.

ARAI, M. \& COIMBRA, J.C. - 1990 - Análise paleoecológica do registro das primeiras ingressões marinhas na Formação Santana (Cretáceo Inferior da Chapada do Araripe). In: SIMP. SOBRE A BACIA DO ARARIPE E BACIAS INTERIORES DO NORDESTE, 1, Crato 1990. Atas..., Crato, DNPM, p.225-240.

ARAI, M.; HASHIMOTO, A.T. \& UESUGUI, N. - 1989 - Significado cronoestratigráfico da associação microflorística do Cretáceo Inferior do Brasil. Bol. Geoc. Petrobrás, Rio de Janeiro, v.3, n.1-2, p.87-103.

ARARIPE, P. \& FONTES, F. - 1985 - Coluna litoestratigráfica da Bacia Potiguar. Rio de Janeiro. PETROBRÁS/DIRNOE/DEBAR, 22p. Relatório interno.

ARAÚJO, M.B.; GOMES, J.B. \& SOUZA, S.M. - 1978 - Bacia Potiguar, aspectos gerais e perspectivas petrolíferas. Offshore Brazil. Rio de Janeiro, n.78, p.02.2-02.3. Separatas.

ARCHANGELSKY, S. \& GAMERRO, J. C. - 1965 - Estudio Palinológico de la Formación Baqueró (Cretácico), Provincia de Santa Cruz. I. Ameghiniana, Buenos Aires, v.4, a.5, p.159-167.

ARCHANGELSKY, S. \& GAMERRO, J.C. - 1966a - Estudio Palinológico de la Formación Baqueró (Cretácico), Provincia de Santa Cruz. II. Ameghiniana, Buenos Aires, v.4, n.6, p.201-209.

ARCHANGELSKY, S. \& GAMERRO, J.C. - 1966b - Estudio Palinológico de la Formación Baqueró (Cretácico), Provincia de Santa Cruz. III. Ameghiniana, Buenos Aires, v.4, n.7, p.329-336.

ARCHANGELSKY, S. \& GAMERRO, J.C. - 1966c - Estudio Palinológico de la Formación Baquero (Cretácico), Provincia de Santa Cruz. IV. Ameghiniana, Buenos Aires, v.4, n.10, p.363-370.

ARCHANGELSKY, S. \& GAMERRO, J.C. - 1967 - Spore \& pollen types of the Lower Cretaceous in Patagonia (Argentina). Rev. Palaeobot. Palynol., Amsterdam, v.1, n.1-4, p.211-217.

ARCHANGELSKY, S.; BALDONI, A.; GAMERRO, J.C. \& SEILLER, J. - 1983 Palinología estratigráfica del Cretácico de Argentina austral. II. Descripciónes Sistemáticas. Ameghiniana, Buenos Aires, v.20, n.4, p.199-226.

ASMUS, H.E. - 1975 - Controle estrutural da deposição mesozóica nas bacias da margem continental brasileira. Rev. Bras. Geoc., São Paulo, v.5, n.3, p.160175.

ASMUS, H.E. \& BAISCH, P.R. - 1983 - Geological evolution of the Brazilian continental margin. Episodes, Otawa, n.4, p.3-9. 
ASMUS, H.E. \& PONTE, F.C. - 1973 - The Brazilian marginal basins In: NAIRN, A.E.M. \& STEHILI, F.G. (eds.), The Ocean Basins and Margins. New York, Plenum. p.87-133.

ASMUS, H.E. \& PORTO. R. - 1972 - Classificação das bacias sedimentares brasileiras segundo a tectônica de placas. In: CONGR. BRAS. GEOL., 26, Belém, 1972. Anais..., Belém, SBG, v.2, p.67-90.

ASMUS, H.E. \& PORTO, R. - 1980 - Diferença nos estágios iniciais da evolução tectônica da margem continental brasileira: possíveis causas e implicações. In: CONGR. BRAS. GEOL., 31, Baln. Camboriú, 1980. Anais..., Baln. Camboriú, SBG, v.1, p.225-239.

AXELROD, D.I. - 1952 - A theory of angiosperm evolution. Evolution, Boulder, n.6, p.29-60.

AXELROD, D.I. - 1959 - Poleward migration of early angiosperm flora. Science, Washington, n.130, p.203-207.

AXELROD, D.I. - 1970 - Mesozoic paleogeography and early angiosperm history. Bot. Rev., New York, v.36, n.3, p.277-319.

AZEMA, C. \& BOLTENHAGEN, E. - 1974 - Pollen du Crétacé Moyen du Gabon attribué aux Ephédrales. Paleobiol. Continent., Montpellier, v.5, n.1, p.1-37.

AZEMA, C. \& TERS, M. - 1971 - Étude palynologique preliminaire du gisement Cenomanien de la Bironniere. Vendée (França). Rev. Palaeobot. Palynol, Amsterdam, v.11, n.4, p.267-282.

AZEVEDO, R.L.; SAVINI, R.R.; ARAI, M. \& COELHO, P.S.M. - 1991 - O Estágio atual de desenvolvimento do Sistema Bioest: programas para microcomputadores destinados a estudos bioestratigráficos e paleoecológicos, e exemplos de sua utilização. Rio de Janeiro. PETROBRÁS / CENPES / DIVEX/ SEBIPE. 42p. Relatório interno.

BACKHOUSE, J. - 1988 - Late Jurassic and Early Cretaceous palynology of the Perth Basin, Western Australia. West. Australia Geol. Survey Bull., Adelaide, n.135, p.1-233.

BALME, B.E. - 1957 - Spores and pollen grains from the Mesozoic of Western Australia. C.S.I.R.O. Aust., Commonwealth Scientific and Industrial Reasearch Organization. Coal Res. Sect. Reference, Melbourne, T.C., v.25, p.1-48.

BALME, B.E. - 1963 - Plant microfossils from the Lower Triassic of Western Australia. Palaeontology, London, v.6, n.1, p.12-40. 
BALME, B.E, \& HENNELY, J.P.F. - 1956 - Monolete, monocolpate and alete sporomorphs from Australian Permian sediments. Aust. Journ. Bot., n.4, p.54-67.

BALTES, N. - 1966 - Cretaceous microfloristic complexes from the Moesic Platform, Rumania. Pollen et Spores, Paris, v.8, n.3, p.565-571.

BALTES, N. - 1967a - Albian microplankton from Mesozoic Platform, Rumania. Micropaleont., Columbia, n.13, p.327-336.

BALTES, N. - 1967b - The microflora of the Albian "Green Sands" in the Moesic Platform, Rumania. Rev. Palaeobot. Palynol., Amsterdam, v.5, n.1-4, p.183197.

BANERJI, J. \& MAHESHWARI, K. - 1974 - Palynology of the Panchet Group exposed in the Nonia Nala near Asansol, West Bengal. The Palaeobotanist, Lucknow, v.21, n.3, p.368-372.

BARRON, E.J.; THOMPSON, S.L. \& SCHNEIDER, S.H. - 1982 - An ice-free Cretaceous? Results from climate model simulations. Science, Washington, n.212, p.501-508.

BATTEN, D.J. - 1973a - Use of palynologic assemblage-types in Wealden correlation. Palaeontology, London, v.16, n.1, p.1-40.

BATTEN, D.J. - 1973b - Palynology of Early Cretaceous soil beds and associated strata. Palaeontology, London, v.16, n.2, p.399-424.

BATTEN, D.J. - 1975 - Wealden palaeocology from the distribution of plant fossils. Geologists Association, London. Proceedings..., n.85, p.433-458.

BATTEN, D.J. - 1982a - Palynofacies and salinity in the Purbeck and Wealden of Southern England. In: BANNER, F.T.\&LORD, A.R. (eds.). Aspects of Micropalaeontology. London, p.278-308.

BATTEN, D.J. - 1982b - Palynofacies, palaeoenvironments and petroleum. Journ. Micropalaeont., London, n.1, p.107-114.

BATTEN, D.J. \& LI, W. - 1987 - Aspects of palynomorph distribution, floral provinces and climate during the Cretaceous. Geol. Jahrb. Reihe A., Stuttgart, n.96, p.219-237.

BATTEN, D.J. \& LISTER, J.K. - 1988 - Evidence of freshwater dinoflagellates and other algae in the English Wealden (Early Cretaceous). Cretaceous Res., London, n.9, p.171-179. 
BATTEN, D.J. \& MACLENNAN, A.M. - 1984 - The palaeoenvironmental significance of the conifer family Cheirolepidiaceae in the Cretaceous of Portugal. In: REIF, W.E. AND WESTPHAL, F. (eds.). Third Symposium on Mesozoic Terrestrial Ecosystems, Atteempto, Tübingen. p.7-12. Short Papers.

BATTEN, D.J.; CREBER, G.T. \& ZHOU, Z. - 1984 - Fossil plants and other organic debris in Cretaceous sediments from Deep Sea Drilling Project Leg 80: their palaeoenvironmental significance and source potential. Init. Rep. Deep Sea Drill. Proj., Washington, v.80, p.629-641.

BEBOUT, J.W. - 1981 - An informal palynologic zonation for the Cretaceous System of the United States Mid-Atlantic (Baltimore Canyon area) outer continental shelf. Palynol., Dallas, v.5, p.159-194.

BELOW, R. - 1981 - Dinoflagellaten-Zysten aus dem oberen Hauterive bis unteren Cenoman Süd-West-Marokkos. Palaeontog. Abt. B, Stuttgart, v.176, n.1-4, p.1-145.

BELSKY, C.Y.; BOLTENHAGEN, E. \& POTONIÉ, R., - 1965 - Sporae Dispersae der Oberen Kreid von Gabon, aequatoriales Africa. Paläeont. Zeit., Stuttgart, v.39, n.1-2, p.72-83.

BENGTSON, P. \& KOUTSOUKOS, E.A.M. - 1991 - Ammonite and Foraminiferal dating of the first marine connection between the Central and South Atlantic. Colloque de Stratigraphie et de Paléogeographie des Bassins Sedimentaires Ouest-Africains, 1, Gabon, p.32. Resumos.

BERTANI, R.T. - 1985 - A evolução tecto-sedimentar e o habitat do óleo na Bacia Potiguar emersa. Natal. PETROBRÁS/DEBAR, 15p. Relatório interno.

BERTANI, R.T. - 1990 - Síntese das condiçōes geológicas e modelos de exploração da Bacia Potiguar ,emersa. Natal. PETROBRÁS/DEBAR. $11 \mathrm{p}$. Comunicação técnica.

BERTANI, R.T. \& COSTA, L.G. - 1988 - Strutural styles and petroleum habitats related to the Cretaceous Potiguar Basin, Northeast Brazil. In: AMERICAN ASSOCIATION OF PETROLEUM GEOLOGIST ANNUAL CONGRESS, Proceedings..., Houston, n.73.

BERTANI, R.T.; COSTA, L.G. \& MATOS, R.M.D. - 1989 - A evolução tectonosedimentar, estilo estrutural e "habitat" do petróleo na Bacia Potiguar. SINTEX - I Seminário de Interpretação Exploratória. Rio de Janeiro, PETROBRÁS/DEPEX. p.87-96. (Distrib. restrita).

BEURLEN, G. - 1982 - Bioestratigrafia e geohistória da seção marinha da margem continental brasileira. Bol. Téc. Petrobrás, Rio de Janeiro, v.25, n.2, p.77-83. 
BEURLEN, G. \& REGALI, M.S.P. - 1987 - O Cretáceo da plataforma continental do Maranhão e Pará, Brasil: bioestratigrafia e evolução paleoambiental. Bol. Geoc. Petrobrás, Rio de Janeiro, v.1, n.2, p.135-155.

BEURLEN, G.; FREITAS, L.C. da S.; KOUTSOUKOS, E.A.M. \& UESUGUI, N. - 1987 - Paleoecologia do Baixo São Francisco. I- Area do Brejo GrandeCarapitanga. Rio de Janeiro. PETROBRÁS/CENPES/DIVEX, p.1-30. (Relatório interno, n.811).

BEURLEN, K. - 1961a - Observações geo-paleontológicas no Cretáceo do Rio Grande do Norte e Ceará, com descrição de Amonóides. Rio de Janeiro. Pongetti. (Coleção Mossoroense, sér.B, n.58, p.1-12.).

BEURLEN, K. - 1961b - O Turoniano marinho no Nordeste do Brasil. Bol. Soc. Bras. Geol., São Paulo, v.10, n.2, p.39-52.

BEURLEN, K. - 1963 - Geologia e estratigrafia da Chapada do Araripe. In: CONGR. NAC. GEOL., 17, Recife 1963. Recife, SBG, Publ. SUDENE, 47p.

BEURLEN, K. - 1964a - A fauna do Calcário Jandaíra da região de Mossoró, Rio Grande do Norte. Rio de Janeiro. Pongetti. p.1-215. (Coleção Mossoroense, n.12).

BEURLEN, K. - 1964b - Novas observações sôbre o Cretáceo no Rio Grande do Norte. Bol. Paranaense de Geogr., Curitiba, p.173-178. (separatas, 10-15).

BEURLEN, K. - 1966 - Novos equinóides no Cretáceo do Nordeste do Brasil. An. Acad. bras. Ciênc., Rio de Janeiro, v.38, n.3-4, p.455-464.

BEURLEN, K. - 1967 - Geologia da região de Mossoró. Rio de Janeiro. Pongetti. 173p. (Coleção Mossoroense, sér.C., v.18).

BEURLEN, K. - 1971 a - A paleontologia na geologia do Cretáceo do nordeste do Brasil. An. Acad. bras. Ciênc., Rio de Janeiro, (supl.) v.43, p.89-101.

BEURLEN, K. - 1971b - As condições ecológicas e faciológicas da Formação Santana na Chapada do Araripe (nordeste do Brasil). An. Acad. bras. Ciênc., Rio de Janeiro, (supl.) v.43, p.411-415.

BEURLEN, K. - 1971c - Bacias sedimentares no bloco brasileiro. Estudos sedimentológicos, Recife, v.1, n.2, p.7-32.

BHARADWAJ, D.C. \& SRIVASTAVA, S.C. - 1969 - Triassic microflora from India. Palaeontog. Abt. B, Stuttgart, v.125, n.3-6, p.119-149.

BIERHORST, D.W. - 1971 - Morphology of Vascular Plants. New York, MacMillan. 560p. 
BOLKHOVITINA, N.A. - 1953 - Spore and pollen characteristics of Cretaceous deposits of central regions of U.S.S.R. Trudy Inst. Geol. Akad. Nauk. SSSR, (Geol. Ser.), Moscow, v.145, n.61, 184p.

BOLKHOVITINA, N.A. - 1956 - Atlas of spores and pollen from the Jurassic and Lower Cretaceous deposits of the Vilyui Basin. Trudy Inst. Geol. Akad. Nauk. SSSR, Moscow, v.18, n.2, 188p.

BOLKHOVITINA, N.A. - 1959 - Spores and pollen complex from the Mesozoic sediments of the Vilyui Basin and their stratigraphic interpretation. Trudy Inst. Geol. Akad. Nauk. SSSR, Moscow, v.24, 185p.

BOLKHOVITINA, N.A. - 1966 - Distribution of the ferns of the family Gleicheniaceae in the past. The Palaeobotanist, Lucknow, v.15, n.1-2, p.1-15.

BOLKHOVITINA, N.A. - 1967 - The fossil spores of the family Gleicheniaceae (morphology and taxonomy). Rev. Palaeobot. Palynul., Amsterdam, v.3, n.2, p.59-64.

BOLKHOVITINA, N.A. - 1971 - Distribution of schizeaceous spores in Jurassic and Lower Cretaceous deposits of Eurasia. Journ. Palynol., Tucson, n.7, p.9-15.

BOLTENHAGEN, E. - 1965 - Introdution à la palynologie stratigraphique du bassin sedimentaire de l'Afrique Equatoriale. Mém. Bur. Rech. Geol. Min., Orléans, n.32, p.305-326.

BOLTENHAGEN, E. - 1967 - Spores et pollen du Crétacé Supérieur du Gabon. Pollen et Spores, Paris, v.9, n.2, p.335-355.

BOLTENHAGEN, E. - 1976 - Senonian pollen and spores of Gabon. Cahiers de Micropaléont., CNRS, Paris, n.3, p.1-21.

BOLTENHAGEN, E. \& SALARD-CHEBOLDAEFF, M. - 1987 - Étude palynologique du sel Aptien du Congo. Mém. Trav. E.P.H.E., Inst. Montpellier, Montpellier. n.17, p.273-293.

BOND, T.A. - 1972 - A Lower Cretaceous (Aptian-Albian) palynological assemblage from the Dequeen Formation, Pike Couty, Arkansas. Pollen et Spores, Paris, v.14, n.2, p.173-186.

BOULTER, M.C. \& RIDDICK, A. - 1986 - Classification and analysis of palynodebris from the Palaeocene sediments of the Forties Field. Sedimentology, Oxford, n.33, p.871-886.

BRAUN, O.P.G. - 1966 - Estratigrafia dos sedimentos da parte interior da região Nordeste do Brasil (Bacias de Tucano-Jatobá, Mirandiba e Araripe). Bol. DNPM - Div. Geol. Mineral., Rio de Janeiro. n.236, p.1-75. 
BRENNER, G.J. - 1963 - The spores and pollen of the Potomac Group of Maryland. Bull. Mines and Water Resources, Maryland, (Dep. Geol. Mines. and Natur. Resour.), Baltimore, n.27, p.215 .

BRENNER, G.J. - 1967 - The gymnospermous affinity of Eucommidites Erdtman, 1948. Rev. Palaeobot. Palynol., Amsterdam, v.5, n.1-4, p.123-127.

BRENNER, G.J. - 1968 - Middle Cretaceous spores and pollen from northeastern Peru. Pollen et Spores, Paris, v.10, n.2, p. 341-383.

BRENNER, G.J. - 1974 - Winteraceous pollen in the Lower Cretaceous of Israel: early evidence of a magnoliacean angiosperm family. Science, Washington, v. 220, n.4603, p.1273-1275.

BRENNER, G.J. - 1976 - Middle Cretaceous floral provinces and early migrations of angiosperms. In: BECK, C.B. (ed.). Origin and early evolution of angiosperms. New York, Columbia University, p.23-47.

BRIDEAUX, W.W. - 1971a - Palynology of the lower Colorado Group, Central Alberta, Canada. I. Introductory remarks, geology, and microplankton studies. Palaeontog. Abt. B, Stuttgart, v.135, n.3-6, p.53-114.

BRIDEAUX, W.W. - $1971 \mathrm{~b}$ - Palynological evidence for a very late Cretaceous age of Little Bear and East Fork Formation, District of Mackenzie, Canada. Geol. Surv. Can., Ottawa, Paper 71-1B, p.86-91.

BRIDEAUX, W.W. - 1977 - Taxonomy of Upper Jurassic-Lower Cretaceous microplankton from the Richardson Montains District of Mackenzie, Canada. Geol. Surv. Can. Bull., Ottawa, n.281, p.1-89.

BRIDEAUX, W.W. \& MCINTYRE, D.J. - 1975 - Miospores and microplankton from Aptian-Albian Rocks along Horton River, District of Mackenzie, Canada. Geol. Surv. Can. Bull., Ottawa, n.252, p.1-85.

BRIDEN, J.C.; DREWRY, G.E. \& SMITH, A.G. - 1974 - Phanerozoic equal-area world maps. Journ. Geol., Chicago, n.82, p.555-574.

BRITO, I.M. - 1976 - História geológica das bacias sedimentares do Nordeste do Brasil. An. Acad. bras. Ciênc., Rio de Janeiro, v.48, n.3, p.463-474.

BRUGMAN, W.A. - 1985 - Middle Triassic (Anisian-Ladinian) palynomorphs. Journ. Micropalaeont., Chichester, v.4, n.1, p.102-111.

BUJAK, J.P. \& WILLIAMS, G.L. - 1978 - Cretaceous palynostratigraphy of Offshore Southeastern Canada. Geol. Surv. Can. Bull., Ottawa, n.297, p.1-19. 
BURGER, D. - 1966 - Palynology of uppermost Jurassic and lowermost Cretaceous strata in the eastern Netherlands. Leidse Geol. Med., Leiden, n.5, p.209-276.

BURGER, D. - 1971 - Early Cretaceous angiospermous pollen grains from Queensland. Bull. Bur. Miner. Resour. Geol. Geophys., Canberra, n.116, p.1-10.

BURGER, D. - 1973 - Palynological observations in the Carpentaria Basin, Queensland. Bull. Bur. Miner. Resour. Geol. Geophys., Canberra, n.140, p.27-44.

BURGER, D. - 1974 - Palynology of subsurface Lower Cretaceous strata in the Surat Basin, Queensland. Bull. Bur. Miner. Resour. Geol. Geophys., Canberra, n.150, p.27-42.

BURGER, D. - 1980 - Palynology of the Lower Cretaceous in the Surat Basin. Bull. Bur. Miner. Resour. Geol. Geophys., Canberra, n.189, p.106.

BURLAMAQUI, F.L.C. - 1855 - Notícias acerca dos animais de raças extintas, descobertos em vários pontos do Brasil. Rio de Janeiro, Sociedade Vellosiana. 114p. (Trabalhos- Biblioteca Guanabarense. Seção de Geologia, publ.1).

BUSCH, R.M. \& ROLLINS, H.B. - 1984 - Correlation of Carboniferous strata using a hierarchy of transgressive-regressive units. Geology, Boulder, n.12, p.471-474.

BUSNARDO, R. \& TAUGORDEAU, J. - 1964 - Intercalations végétales dans le Flysch Albien de Los Vilares (Jean, Andalousie): introduction stratigraphique et étude palynologique. Rev. Micropaléont., Paris, v.7, n.3, p.164-179.

CARATINI, C. \& GUINETE, P. - 1974 - Pollen et spores d'Afrique tropicale. Talence Association des Palynologues de Langue Francaise, C.N.R.S., Paris, 283p.

CARVALHO, M.D. - 1985 - Aumento de produtividade do Calcário Trairi. Rio de Janeiro. PETROBRÁS/CENPES. 38p. Relatório interno.

CASTRO, A.C. - 1987 - Northeastern Brazil and Gabon Basins: a double rifting system associated with multiple crustal detachment surfaces. Tectonics, Washington, n.6, p.727-738.

CASTRO, J.C. - 1989 - Marcos Estratigraficos: um estado-de-Arte. In: CONGR. BRAS. PALEONT., 11, Curitiba 1989. Anais..., Curitiba, SBG, v.2, p.943-960.

CASTRO, J.C.; BARROCAS, S.L.S. \& CRUZ, W.M. - 1981a - Fácies, diagênese e modelos de acumulação da Formação Açu, parte emersa da Bacia Potiguar. Rio de Janeiro. PETROBRÁS/CENPES. 24p. Relatório interno. 
CASTRO, J.C.; BARROCAS, S.L.S. \& CRUZ, W.M. - 1981b - Fácies, diagênese e reservatórios do Campo de Ubarana. Rio de Janeiro. PETROBRÁS/CENPES. (2v), 75p. Relatório interno.

CASTRO, J.C.; VIVIERS, M.C. \& REGALI, M.S.P. - 1987 - Análise estratigráfica do Cretáceo marinho: margem leste da Bacia Potiguar. Rio de Janeiro. PETROBRÁS/CENPES. 30p. Relatório interno.

CHANG, H.K. \& KOWSMANN, R.O. - 1984 - Subsidência térmica e espessura crustal da Bacia de Santos. In: CONGR. BRAS. GEOL., 32, Rio de Janeiro 1984. Anais..., Rio de Janeiro, SBG, v.5, p.1602-1614.

CHANG, H.K. \& KOWSMANN, R.O. - 1986 - Espessura crustal da Bacia de Sergipe-Alagoas. In: CONGR. BRAS. GEOL, 34, Goiânia 1986. Anais..., Goiânia, SBG, v.1, p.110-121.

CHANG, H.K. ; KOSMANN, R.O. \& FIGUEIREDO, A.M.F. - 1988 - New concepts of the development of East Brazilian marginal basins. Episodes, Otawa, n.11, p.194-202.

CHANG, L. - 1965 - Spore-pollen complex of the Yima coal-bearing series in western Hunan Province. Acta Paleont. Sinica, Beijing, n.13, p.160-196.

CHANG, Y.M. - 1967 - Accuracy of fossil percentage estimation. Journ. Paleont., Tulsa, v.41, n. 2, p.500-502.

CHLONOVA, A.F. - 1962 - Some morphological types of spores and pollen grains from Upper Cretaceous of eastern part of west Siberian Lowland. Pollen et Spores, Paris, v.4, n.2, p.297-309.

CHLONOVA, A.F. - 1976 - Palynological characteristics of Cretaceous deposits, Kya River (West Siberia). Acad. Sci. U.S.S.R., Trans. Inst. Geol. Geophys., Novosibirsk, n.312, p.5-103.

CHLONOVA, A.F. - 1977 - First finding of the pollen of Clavatipollenites in West Siberian Cretaceous deposits. Palaeont. Journ., Moscow, n.2, p.115-121.

CHLONOVA, A.F. - 1986 - Distribution of several morphologic pollen types of the Cretaceous angiosperms. Rev. Palaeobot. Palynol., Amsterdam, v.48, n.3-4, p.365-372.

CHRISTOPHER, R.A. - 1976 - Morphology and taxonomic status of Pseudoschizea Thiergart \& Fritz ex R. Potonie emend. Micropaleont., Columbia, v.22, n.2, p.143-150.

CLAPHAM Jr., W.B. - 1972 - Numerical analysis and group information in palynology. Geosci. and Man, Baton Rouge, n.4, p.73-85. 
CLARKE, R.F.A. - 1965 - Keuper miospores from Worcestershire, England. Palaeontology, London, n.8, p.294-321.

CLARKE, R.F.A. \& VERDIER, J.P. - 1967 - An investigation of microplankton assemblages from the Chalk of the Isle of Wight, England. Verhandelingen der Koninklijke Nederlandse Akademie van Wetenschappen, Afd. Natuurkunde, Eerste Reeks. v.24, p.1-96.

CLARKE, R.T. - 1965 - Fungal spores from Vermejo Formation coal beds (Upper Cretaceous) of central Colorado. Mountain Geol., Denver, n.2, p.85-93.

COMBAZ, A. - 1964 - Les Palynofacies. Rev. Micropaléont., Paris, v.7, n.3, p.205-218.

CONCEIÇĀO, J.C.J.; ZALAN, P.V. \& WOLFF, S. - 1988 - Mecanismo, evolução e cronologia do rift sul-atlântico. Bol. Geoc. Petrobrás, Rio de Janeiro, v.2, n.2-4, p.255-265.

COOKSON, I.C. - 1947 - Plant microfossils from the lignites of Kerguelen Archipelago. Science Repts., British-Australian-New Zealand Antarctic Research Expedition 1929-1931, Ser. A., Adelaide, v.2, n.8, p.127-142.

COOKSON, I.C. \& DETTMANN, M.E. - 1958 - Some trilete spores from Upper Mesozoic deposits in the Eastern Australian region. Proc. Royal Soc. Victoria, Melbourne, n.70, p.95-128.

COOKSON, I.C. \& DETTMANN, M.E. - 1959 - On Schizosporis, a new form genus from Australian Cretaceous deposits. Micropaleont., Columbia, n.5, p.213-216.

COOKSON, I.C. \& DETTMANN, M.E. - 1961 - Reappraisal of the Mesozoic microspore genus Aequitriradites. Palaeontology, London, n.4, p.425-427.

COOKSON, I.C. \& EISENACK, A. - 1958 - Microplankton from Australian and new Upper Mesozoic sediments. Proc. Royal Soc. Victoria, Melbourne, n.70, p.19-79.

COOKSON, I.C. \& EISENACK, A. - 1960 - Microplankton from Australian Cretaceous sediments. Micropaleont., Columbia, n.6, p.11-18.

COOPER, M.R. - 1977 - Eustasy during the Cretaceous: its implications and importance. Palaeogeogr. Palaeoclimatol. Palaeoecol., Amsterdam, v.22, p.1-60.

CORNET, B. \& TRAVERSE, A. - 1975 - Palynological contributions to the chronology and stratigraphy of the Hartford Basin in Connecticut and Massachusetts. Geosci. and Man, Baton Rouge, n.11, p.1-33. 
COSTA, I.G; ARARIPE, P. \& LIMA NETO, F.F. - 1987 - Projeto Alagamar. Rio de Janeiro. PETROBRÁS/ DEPEX / DEBAR, 45p. Relatório interno.

COSTA, M.P.A.; MELLO, U.T.; GUAZELLI, W. \& REHIN, A.A.A. - 1975 - Possibilidades econômicas dos Platôs e Ilhas do Nordeste Brasileiro. In: Projeto REMAC, Rio de Janeiro, v.5, p.118. (res.).

COUPER, R.A. - 1953 - Upper Mesozoic and Cainozoic spores and pollep grains from New Zealand. New Zealand Geol. Surv. Paleont. Bull., Lower Hutt, n.22, p.1-77.

COUPER, R.A. - 1958 - British Mesozoic microspores and pollen grains: a systematic and stratigraphic study. Palaeontogr. Abt. B, Stuttgart, v.103, n.4-6, p.75-179.

COUPER, R.A. - 1960 - New Zealand Mesozoic and Cainozoic microfossils. New Zealand Geol. Surv. Paleont. Bull., Lower Hutt, n.32, p.1-87.

COUPER. R.A. - 1964 - Spore-pollen correlation of the Cretaceous rocks of the Northern and Southern Hemispheres. In: Palynology in Oil Exploration. Soc. Ec. Paleont. and Mineral. Tulsa Spscial Publ, n.11, p.131-142. .

COUPER, R.A., THOMPSON, G.G., \& ZAITTZEFF, J.B. - 1966 - Source and distribution of palynomorphs in bottom sediments, southern part of Gulf of California. Marine Geology, New Jersey, n.4, p.467-524.

COURTINAT, R.A. - 1980 - Structure d'adherence des grains de pollen en tétrade du genre Classopollis Pflug 1953 de l'Hettangien de Saint-Fromont, Manche (France). Géobios, Lyon, v.13, n.2, p.209-229.

COUSMINER, H.L. \& MANSPEIZER, W. - 1976 - Triassic pollen date Moroccan High Atlas and the incipient rifting of Pangea as Middle Carnian. Science, Washington, n.191, p.943-945.

CRANDALL, R. - 1910 - Geografia, geologia, suprimento de água, transporte e açudagem nos Estados da Paraíba, Rio Grande do Norte, Ceará. Rio de Janeiro. IFOCS. Serviço Geológico, 131p. (sér.I, D.E., 4).

CYPRIANO, J.L. \& NUNES, A.B. - 1968 - Geologia da Bacia Potiguar. Rio de Janeiro. PETROBRÁS/ DEXPRO. 74p. Relatório interno.

DAGHLIAN, C.P. \& PERSON, C.P. - 1977 - The cuticular anatomy of Frenelopsis varians from the Lower Cretaceous of central Texas. Amer. Journ. Bot., Columbus, n.64, p.564-569. 
DALE, B. - 1976 - Cyst formation, sedimentation and preservation: factors affecting dinoflagellate assemblages in Recent sediments from Trondheimsfjord, Norway. Rev. Palaeobot. Palynol., Amsterdam, v.22, n.1, p.39-60.

DAVEY, R.J. \& VERDIER, J.P. - 1974 - Dinoflagellate cysts from the Aptian type sections at Gargas and La Bédoule, France. Palaeontology, London, n.17, p.623-653.

DAVEY, R.J; DOWNIE, C.; SARJEANT, W.A.S \& WILLIAMS, G.L - 1966 - Studies on Mesozoic and Cainozoic dinoflagellate cysts. Bull. British Mus. (Nat. Hist.), Geol. Supl., London, n.3, 248p.

DAVIS, P.N. - 1963 - Palynology and stratigraphy of the Lower Cretaceous rocks of northern Wyoming. Norman, University of Oklahoma, 238p. Ph. D. Thesis.

DEÁK, M.H. - 1959 - Observations concernant le changement de forme des spores triletes. Rev. Micropaléont., Paris, v.2, n.1, p.28-30.

DEÁK, M.H. - 1963 - Quelques spores striées de l'étage Aptien. Rev. Micropaléont., Paris, v.5, n.4, p.251-156.

DEÁK, M.H. - 1964 - Contribution à l'etude palynologique de Groupe d'argiles à Munieria de l'étage Aptien. Act. Bot. Acad. Sci. Hungar., Budapest, v.10, n.1-2, p.95-126.

DEÁK, M.H. - 1965 - Recherches palynologiques des dépôts Aptiens de la Montagne Central de Transdanubie. Geol. Hung. Ser. Paleont., Budapest, n.29, p.9-105.

DEÁK, M.H. \& COMBAZ, A. - 1967 -."Microfossiles Organiques" du Wealdien et du Cénomanien dans un sondage de Charente-Martime. Rev. Micropaléont., Paris, v.10, n.2, p.69-96.

DEJAX, J. - 1987 - Une étude palynologique dans de Crétacé Inferieur du Congo. Université Paris 6, Paris., 87p. These de Doctorat.

DELCOURT, A.F. \& SPRUMONT, G. - 1955 - Les spores et grains de pollen du Wealdien du Hainaut. Soc. Bẻlge Geol. Paleont., Bruxelles, sér.4, p.73.

DELCOURT, A.F; DETTMANN, M. \& HUGHES, N.F. - 1963 - Revision of some Lower Cretaceous microspores from Belgium. Palaeontology, London, n.6, p.282-292.

Della FAVERA, J.C. - 1990 - Tempestitos da Bacia do Parnaíba. Universidade Federal do Rio Grande do Sul, Porto Alegre, 243p. Tese de Doutoramento. Inédita. 
DELLA FAVERA, J.C.; MEDEIROS, R.A.; APPI, C.J.; BEURLEN, G.; VIVIERS M.C. \& HASHIMOTO, A. - 1984 - Análise estratigráfica do Andar Alagoas na Bacia do Ceará. Rio de Janeiro. PETROBRÁS/CENPES/DIVEX. 67p. Relatório interno.

DELTEIL, J.R.; LE FOURNIER, J. \& MICHOLET, J. - 1975 - Schéma d'évolution sédimentaire d'une marge continentale stable: exemple-type du Golfe de Guinee, de l'Angola au Cameroun. In: CONGR. INT. DE SÉDIMENTOLOGIE, IX, Nice, 1975, v.4, p.91-97.

DEPECHE, F.; CAMPOS, D. \& BERTHOU, P.Y. - 1986 - Mise en évidence du Barrémien dans la Série de Reconcavo (État de Bahia, Brésil): apport des ostracodes, des spores et des pollens. Rev. Micropaléont., Paris, v.29, n.2, p.93-102.

DETTMAN, M.E. - 1959 - Upper Mesozoic microfloras in well cores from Woodside and Hadley. Proc. Royal Soc. Victoria N.S., Melbourne, v.71, n.2, p.99-105.

DETTMAN, M.E. - 1963 - Upper Mesozoic microfloras from southeastern Australia. Proc. Royal Soc. Victoria N.S., Melbourne, v.77, n.1, p.1-148.

DETTMAN, M.E. - 1973 - Angiospermous pollen from Albian to Turonian sediments of eastern Australia. Geol. Soc. Austr. Spec. Publs., Sydney, n. $4,34 \mathrm{p}$.

DETTMAN, M.E. - 1986 - Early Cretaceous palynoflora of subsurface strata correlative with the Koonwarra Fossil Bed, Victoria. Mem. Assoc. Australasian Palaeontologists, Sydney, n.3, p.79-110.

DETTMAN, M.E. \& PLAYFORD,G. - 1968 - Taxonomy of some Cretaceous spores and pollen grains from Eastern Australia. Proc. Royal Soc. Victoria, N.S., Melbourne, v.81, n.2, p.69-93.

DEV, S. - 1961 - The fossil flora of the Jabalpur Series-3. spores and pollen grains. The Palaeobotanist, Lucknow, v.8, n.1-2, p.43-56.

DEWEY, J.F. \& BIRD, J.M. - 1970 - Plate tectonics and geosynclines. Tectonophysics, Amsterdam, v.10, n.5-6, p.625-638.

DIAS BRITO, D.; UESUGUI, N. \& HASHIMOTO, A.T. - 1987 - Uma reflexão histórica em torno do Andar Alagoas: importante unidade cronestratigráfica do Cretáceo Inferior do Brasil. Bol. Geoc. Petrobrás, Rio de Janeiro, v.1, n.1, p.111-114.

DICKINSON, W.R. - 1974 - Plate tectonics and sedimentation. In: Tectonics and Sedimentation. SEPM - Soc. Econ. Paleont. Mineral., Tulsa, Oklahoma. Spec.Publ. n.22, p.1-27. 
DILCHER, D.L. - 1965 - Epiphyllous fungi from Eocene deposits in western Tennesse, U.S.A. Palaeontog. Abt. B, Stuttgart, v.116, n.1-4, p.1-54.

DINO, R. \& LIMA, M.R. - 1991 - Palinomorfos cretáceos da Bacia Potiguar na região de Limoeiro do Norte, Estado do Ceará. An. Acad. bras. Ciênc., Rio de Janeiro, v.63, n.4, p.381-388.

DOERENKAMP, A.; JARDINE, S. \& MOREAU, P. - 1976 - Cretaceous and Tertiary palynomorph assemblages from Banks Island and adjacent areas (N.W.T.). Bull. Can. Petrol. Geol., Calgary, v.24, p.372-592.

DOLUDENKO, M.P. - 1978 - The genus Frenelopsis (Coniferas) and its occurrence in the Cretaceous of the U.S.S.R. Paleont. Journ., New York, n.3, p.384-398.

DONN, W.L. - 1982 - The enigma of high-latitude paleoclimate. Palaeogeogr. Palaeoclimatol. Palaeoecol., Amsterdam, n.40, p.199-212.

DORF, E. - 1955 - Plants and their geologic time scale in the crust of the Earth. Geol. Soc. of America, Colorado, n.62, p.575-592.

DORF, E. - 1964 - The use of fossil plants in paleoclimatic interpretation. In: NAIRN, A.E.M. (ed.), Problems in Paleoclimatology. London, Interscience, p.13-31.

DÖRHÖFER, G. - 1977 - Palynologie und Stratigraphie der Bückederg Formation (Berriasium-Valanginium) in der Hilsmulde (Nw-Deutschland). Geol. Janrb., Hannover, n.42, p.1-122.

DÖRHÖFER, G. \& NORRIS, G. - 1975 - Discrimination and correlation of highest Jurassic and lowest Cretaceous terrestrial palynofloras in north-west Europe. Palynol., Dallas, v.1, p.79-93.

DÖRING, H. - 1964 - Trilete Sporen aus dem oberen Jura und dem Wealden Norddeutschlands. Geologie, Berlin, v.13, n.9, p.1099-1129.

DÖRING, H. - 1965 - Die sporenpaläontologische Gliederung des Wealden in Westmecklenburg (Struktur Werle). Geologie, Berlin, v.14, n.47, p.1-118.

DOUKAGA, A.M. - 1980 - Étude palynoplanctologique dans le Crétacé inférieur et moyen du bassin sedimentaire du Gabon. Lille, Univ. Sci. Techn. Lille., v.I. II., n.823, 174p. These $3^{\text {eme }}$ cycle.

DOYLE, J.A. -1983 - Palynological evidence for Berriasian age of basal Potomac Group sediments, Crisfield well, eastern Maryland. Pollen et Spores, Paris, v.25, n.3-4, p.499-530. 
DOYLE, J.A. \& ROBBINS, E.I. - 1977 - Angiosperm pollen zonation of the continental Cretaceous of the Atlantic Coastal Plain and its application to deep wells in the Salisbury embayment. Palynol., Dallas, v.1, p.43-78.

DOYLE, J.A.; BIENS, P.; DOERENKAMP, A. \& JARDINÉ, S. - 1977 - Angiosperm pollen from the pre-Albian Lower Cretaceous of Equatorial Africa. - Bull. Cent. Rech. Explor. Prod. Elf-Aquitaine, Pau, v.1, n.2, p.451-473.

DOYLE, J.A.; JARDINÉ, S. \& DOERENKAMP, A. - 1982 - Afropollis, a new genus of early angiosperm pollen, with notes on the Cretaceous palynostratigraphy and paleoenvironments of Northern Gondwana. Bull. Cent. Rech. Explor. Prod. Elf-Aquitaine, Pau, v.6, n.1, p.39-117.

DOYLE, J.A.; VAN CAMPO, M. \& LUGARDON, B. - 1975 - Observation on exine structure of Eucommidites and Lower Cretaceous angiosperm pollen. Pollen et Spores, Paris, v.17, n.3, p.429-486.

DRUGG, W.S. - 1967 - Palynology of the Upper Moreno Formation (Late Cretaceous-Paleocene), Escarpado Canyon, California. Palaeontog. Abt. B, Stuttgart, v.120, n.1-4, p.1-71.

DUXBURY, S. - 1977 - A palynostratigraphy of the Berriasian to Barremian of the Speeton Clay of Speeton, England. Palaeontog. Abt. B, Stuttgart, v.160, n. 1-4, p.17-67.

EDIGER, V.S. - 1981 - Fossil fungal and algal bodies from Thrance Basin, Turkey. Palaeontog. Abt. B, Stuttgart, v.179, n.1-4, p.87-102.

EHRENBERG, C.G. - 1938 - Die Phosphoritknollen der Bernsteinformation als überlieferer tertiären Planktons. Schriften der Physikalisch-ökonomischen Gesellschaft zu Könignsberg, v.7Q, n.2, p.181-188.

EISENACK, A. - 1958 - Mikroplankton aus dem norddeutschen Apt nebst einigen Bemerkungen über fossile Dinoflagellaten. Neues Jahrb. Geol. Paläont. Abh., Stuttgart, v.106, n.3, p.383-422.

ELSIK, W.C. - 1968a - Palynology of a Paleocene Rockdale Lignite, Milam County, Texas. I. Morphology and taxonomy (end). Pollen et Spores, Paris, v.10, n.2, p.263-314.

ELSIK, W.C. - 1968b - Palynology of a Paleocene Rockdale Lignite, Milam County, Texas. II. Morphology and taxonomy. Pollen et Spores, Paris, v.10, n.3 p.599-664.

ELSIK, W.C. - 1976 - Microscopic fungal remains and Cenozoic palynostratigraphy. Geosci. and Man, Baton Rouge, n.15, p.115-120. 
ELSIK, W.C. - 1978 - Classification and geologic history of the microthyriaceous Fungi. INTERNATIONAL PALYNOLOGICAL CONFERENCE, 4, Lucknow, (1976-1977) Proceedings..., v.1, p.331-342.

ERDTMAN, G. - 1947 - Suggestions for the classification of fossil and Recent pollen grains and spores. Svensk Bot. Tidskr., Uppsala, n.41, p.104-114.

ERDTMAN, G. - 1948 - Did dicotyledoneous plants exist in Early Jurassic times? Geol. Foren. Stockholm Forh., Stockholm, n.70, p.265-271.

ERDTMAN, G. - 1952 - Pollen morphology and plant taxonomy. Angiosperms. In: ALMQVIST \& WIKSELL (eds.). An Introduction to Palynology. Stockholm I, p.1-539.

ESTRELLA, G.O. - 1972 - O estágio rifte nas bacias marginais do Leste brasileiro. In: CONGR. BRAS. GEOL., 26, Belém 1972. Anais..., Belém, SBG, v.3, p.29-34.

EVANS, P.R. - 1970 - Revision of the miospore genera Perotrilites Erdtman ex Couper and Diaphanospora Balme \& Hassel. Bull. Miner. Res. Geol. Geophys., Canberra, n.116, p.65-82.

FAEGRI, K. - 1978 - What is the polar axis? Grana, Stockholm, n.17, p.15-16.

FAIRHEAD, J.D. - 1986 - Geophysical controls on sedimentation within the African Rift System. In: Sedimentation in the African Rifts. Geol. Soc., Spec. Publ. Oxford, n.25, p.19-28.

FALKENHEIN, F.U.H.; ARAUJO, M.B.; SOUZA, S.M.; GOMES, J.B. \& SOUZA M.M. - 1977 - Relatório Geológico da Bacia Potiguar. Rio de Janeiro. 0. 29p. Relatório Interno.

FENSOME, R.A.; WILLAMS, G.L.; BARSS, M.S.; FREEMAN, J.M. \& HILL, J. M. - 1990 - Acritarchs and fossil prasinophytes: An index to genera, species and infraspecific taxa. AASP - Contrib. Series. Dallas, n.25, 771p.

FILATOFF, J. - 1975 - Jurassic palynology of Perth Basin, Western Australia. Palaeontog. Abt. B., Stuttgart, v.154, n.1-4, p.1-113.

FISHER, W.J. - 1969 - Facies characterization of Gulf Coast Basin: delta systems, with Holocene analogues., Geol. Soc. Gulf Coast Assoc. New York, n.9, p.239-261.

FISHER, W.J. - 1972 - Triassic palynosuccession in England. Geosci. and Man, Baton Rouge, n.4, p.101-109.

FISHER, W.L. - 1980 - Kerogen distribution and depositional environments in the Middle and Upper Jurassic of Yorkshire, U.K. In: INTERNATIONAL PALINOLOGY CONFERENCE, 6, Lucknow, 1976, n.2, p.574-580. 
FISHER, W.L. \& BROWN Jr., L.F. - 1972 - Clastic depositional systems: a genetic approach to facies analysis., Bureau of Economic Geology. The University of Texas at Austin. Austin, p.5-24.

FISHER, W.L.; ESTRELLA, G.O. \& GOMES, J.B. - 1975 - Depositional systems of Santonian to Miocene Formations in the Potiguar Basin: their relationship to oil and gas exploration. Rio de Janeiro. PETROBRÁS/DEXPRO. Relatório interno.

FORTES, F.P. - 1986-A tectônica de teclas da Bacia Potiguar. Natal. PETROBRÁS/DEBAR. 25p., Relatório interno.

FRANÇOLIN, J.B.L. - 1992 - Analyse structurale du Bassin du Rio do Peixe (Brésil). Rennes. L'Université de Rennes I, (UF.R. S.P.M.), Rennes. n.806, 240p. Thèse de Doctorat.

FRANÇOLIN, J.B.L. \& SZATMARI, P. - 1987 - Mecanismo de rifteamento da porção oriental da margem norte brasileira. Rev. Bras. Geoc., São Paulo, v.17, n.2, p.195-207.

FÚLFARO, V.J. \& BARCELOS, J.H. - 1992 - O Cretáceo sedimentar do centro e sudeste do Brasil. In: SIMP. SOBRE AS BACIAS CRETÁCICAS BRASILEIRAS, 2, Rio Claro 1992. Res. Expand..., Rio Claro, UNESP, p.115-117.

GAMA Jr., E.G. - 1985 - Estratigrafia genética e classificação global da Bacia Potiguar (RN) e ambiência do petróleo nas bacias mesozóicas do nordeste brasileiro. Rio Claro. Universidade Estadual Paulista "Júlio de Mesquita Filho"- UNESP, 133p. Tese de Livre Docência.

GAYNOR, G.C. \& SWIFT, D.J.P. - 1988 - Shannon Sandstone depositional model: sand ridge dynamics on the Campanian western interior shelf. Journ. Sediment. Petrol., Tulsa, v.58, n.5, p.868-880.

GERMERAAD, J.H.; HOPING, C.A. \& MÜLLER, J. - 1968 - Palynology of Tertiary sediments from tropical areas. Rev. Palaeobot. Palynol., Amsterdam, v.6, n.3-4, p.189-348.

GOCZÁN, F. - 1964 - Stratigraphic palynology of the Hungarian Upper Cretaceous. Acta Geologica, Budapest, v.8, n.1-4, p.229-264.

GÓCZÁN, F. \& JUHÁSZ, M. - 1984 - Monosulcate pollen grains of angiosperms from Hungarian Albian sediments I. Acta Bot. Hungar., Budapest, v.30, n.3-4, p.289-319.

GÓCZÁN, F. \& JUHÁSZ, M. - 1985 - Monosulcate pollen grains of angiosperms from Hungarian Albian sediments, II. Acta Bot. Hungar., Budapest, v.31, n.1-4, p.69-88. 
GONZALEZ GUZMAN, A.E. - 1967 - A palynological study on the Upper Los Cuervos and Mirador Formations. (Lower and Middle Eocene; Tibu Area, Colombia). Leiden, E.J. Brill, 68p.

GORIN, G.E. \& STEFFEN, D. - 1991 - Organic facies as a tool for recording eustatic variations in marine fine-grained carbonates - example of the Berriasian stratotype at Berrias (Ardeche, SE France). Palaeogeogr. Palaeoclimatol. Palaeoecol., Amsterdam, v.85, n.1991, p.303-320.

GRAY, J. - 1960 - Fossil chlorophycean algae from the Miocene of Oregon. Journ. Paleont. Tulsa, n.34, p.435-463.

GRAY, T.C. \& GROOT, J.J. - 1966 - Pollen and spores from the marine Upper Cretaceous formations of Delaware and New Jersey. Palaeontog. Abt. B, Stuttgart, v.117, n.4-6, p.114-134.

GRÉKOFF, N. \& KRÖMMELBEIN, K. - 1967 - Étude comparée des ostracodes mésozoïques continentaux des Bassins Atlantiques - Série de Cocobeach, Gabon et Série de Bahia, Brésil. Rev. Inst. Fr. Pétrole. Paris, v.22, n.9, p.1307-1353.

GRIBBIN, J. - 1979 - Climatic change. Cambridge University. Cambridge, New York. 191p.

GROOT, J.J. \& GROOT, C.R. - 1962a - Some plant microfossils from the Bright Seat Formation (Paleocene) of Maryland. Palaeontog. Abt. B, Stuttgart, v.111, n.4-6, p.161-173.

GROOT, J.J. \& GROOT, C.R. - 1962b - Plant microfossils from Aptian, Albian and Cenomanian deposits of Portugal. Comun. Serv. Geol. Port., Lisboa, n.46, p.133-171.

GROOT, J.J. \& PENNY, J.S. - 1960 - Plant microfossils and age for non-marine Cretaceous sediments of Maryland and Delaware. Micropaleont., Columbia, n.6, p.225-236.

GROOT, J.J.; PENNY, J.S. \& GROOT, C.R. - 1961 - Plant microfossils and age of the Raritan, Tuscaloosa and Magothy Formations of the Eastern U.S. Palaeontog. Abt. B, Stuttgart, v.108, n.3-6, p.121-140.

GÜBELI, A.A.; HOCHULI, P.A. \& WILDI, W. - 1984 - Lower Cretaceous turbiditic sediments from the Rif Chain (Northern Morocco); palynology, stratigraphy and paleogeographic setting. Geologische Rundschau, Stuttgart, v.73, n.3, p.1081-1114.

GUY, D.J.E. - 1971 - Palynological investigations in the Middle Jurassic of the Vilhelmsfält boring, southern Sweden. Publs. Quat. Geol. Univ. Lund. Insts. Mineralogy Palaeont. Sweden, n.168, p.1-104. 
HABIB, D. - 1969 - Middle Cretaceous palynomorphs in a deep sea core from the seismic reflector horizon A outcrop area. Micropaleont., Columbia, v.15, n.1, p.85-101.

HABIB, D. - 1970 - Middle Cretaceous palynomorphs assemblages from clays near horizon beta deep-sea outcrop. Micropaleont., Columbia, v.16, n.3, p.345-349.

HABIB, D. - 1975 - Neocomian dinoflagellate zonation in the Western North Atlantic. Micropaleont., Columbia, v.21, p.373-392.

HABICHT, J. - 1979 - Paleoclimate, paleomagnetism, and continental drift. Amer. Assoc. Petrol. Geol., Stud. Geol., Tulsa, n.9, 43p.

HALLAM, A. - 1984 . Continental humid and arid zones during the Jurassic and Cretaceous. Palaeogeogr. Palaeoclimatol. Palaeoecol, Amsterdam, n.47, p.195-223.

HARADWAJ, D.C. - 1957 - The palynological investigations of the Saar Coals. Palaeontogr. Abt. B, Sttutgart, v.101, n.5-6, p.73-125.

HARLAND, W.B.; COX, A.V.; LEWELLYN, P.G.; PICKTON, G.A.G.; SMITH A.G. \& WALTERS, R. - 1982 - A Geologic Time Scale. Cambridge University, Cambridge, New York, $131 \mathrm{p}$.

HASHIMOTO, A.T.; APPI, C.J.; SOLDAN, A.N. \& CERQUEIRA, J.R. - 1987 -

O Neo-Alagoas nas Bacia do Ceará, Araripe e Potiguar (Brasil): - Caracterização Estratigráfica e Paleoambiental. Rio de Janeiro. AFTROBRÁS/CENPES. Relatório interno. Inédito.

HEDLUND, R.W. - 1966 - Palynology of the Red Branch Member of the Woodbine Formation (Cenomanian), Bryan County, Oklahoma. Bull. Oklah. Geol. Surv., Tulsa, n.112, p.1-69.

HEDLUND, R.W. \& NORRIS, G. - 1968 - Spores and pollen grains from Fredericksburgian (Albian) Strata, Marshall County, Oklahoma. Pollen et Spores, Paris, v.10, n.1, p.129-159.

HELENES, J. - 1984 - Morphological analysis of Mesozoic-Cenozoic Cribroperidinium (Dinophyceae), and taxonomic implications. Palynol., Dallas, v.8, p.107-137.

HERNGREEN, G.F.W. - 1971 - Palynology of a Wealden section (Lower Cretaceous) in the "Carriere de Longueville", the Boulonnais (France). Rev. Palaeobot. Palynol., Amsterdam, v.12, n.4, p.271-302.

HERNGREEN, G.F.W. - 1973 - Palynology of Albian - Cenomanian strata of borehole 1-QS-1, State of Maranhão (Brazil). Pollen et Spores, Paris, v.15, n.3-4, p.515-555. 
HERNGREEN, G.F.W. - 1974 - Middle Cretaceous palynomorphs from Northeastern Brazil. Results of a palynological study of some boreholes and comparison with Africa and the Middle East. Bull. Sci. Geol., Strasbourg, v.27, n.1-2, p.101-116.

HERNGREEN, G.F.W. - 1975a - An Upper Senonian pollen assemblage of borehole 3-Pia-10-Al, State of Alagoas, Brazil. Pollen et Spores, Paris, v.17, n.1, p.93-140.

HERNGREEN, G.F.W. - 1975b - Palynology of Middle and Upper Cretaceous strata in Brazil. Meded. Rijks Geol. Dienst N.S., Gravenhage, v.26, n.3, p.39-91.

HERNGREEN, G.F.W. \& CHLONOVA, A.F. - 1981 - Cretaceous microfloral Provinces. Pollen et Spores, Paris, v.23, n.3-4, p.441-555.

HICKEY, L.J. - 1977 - Stratigraphy and paleobotany of the Golden Valley Formation of western North Dakota. Geol. Soc. of America Mem., Boulder, n.150, 181p.

HICKEY, N.F. \& DOYLE, J.A. - 1977 - Early Cretaceous fossil evidence for angiosperm evolution. Bot. Rev., New York, n.43, p.1-104.

HOCHULI, P.A. - 1981 - North Gondwanan floral elements in lower to middle Cretaceous sediments of the Southern Alps (southern Switzerland, northern Italy). Rev. Palaeobot. Palynol., Amsterdam, v.35, n.2-4, p.337-358.

HOCHULI, P.A. \& KELTS, K. - 1980 - Palynology of middle Cretaceous black clay facies from Deep Sea Drilling Project Sites 417 and 418 of the western north Atlantic. Init. Rep. Deep Sea Drill. Proj., Washington, v.51, p.897-935.

HOPKINS Jr., W.S. - 1971 - Palynology of the Lower Cretaceous Isachsen Formation on Melville Island, District of Franklin. Geol. Surv. Can. Bull., Ottawa, n.197, p.109-133.

HOPKINS Jr., W.S. - 1973 - Some preliminary palynological conclusions on the Albian and Upper Cretaceous strata of Amund and Ellef Ringnes Islands, District of Franklin. Geol. Surv. Can., Ottawa, Paper 73-1B, p.179-180.

HOPKINS Jr., W.S. - 1974 - Some spores and pollen from the Christopher Formation (Albian) of Ellef and Amund Ringnes Islands and northwestern Melville Island, Canadian Arctic Archipelago. Geol. Surv. Can., Ottawa, Paper 73-12, p.1-39.

HOPKINS Jr. W.S. \& BALKWILL, H.R. - 1973 - Description, palynology and paleoecology of the Hassel Formation (Cretaceous) on eastern Ellef Ringnes Island, District of Franklin. Geol. Surv. Can., Ottawa, Paper 72-37, p.1-31. 
HOROWITZ, A. - 1970 - Jurassic microflora from the northern Negev, Israel. Isr. Journ. Earth Sci., Jerusalem, v.19, n.3-4, p.153-182.

HOROWITZ, A. - 1973 - Triassic miospores from southern Israel. Rev. Palaeobot. Palynol., Amsterdam, v.16, n.3, p.176-207.

HUGHES, N.F. - 1961 - Further interpretation of Eucommidites Erdtman 1948. Palaeontology, London, n.4, p.292-299.

HUGHES, N.F. - 1973 - Mesozoic and Tertiary distributions and problems of landplant evolution. In: Organisms and continents through time. Spec. Pap. Palaeont., London, n.12. p.311-379.

HUGHES, N.F. - 1977 - Palaeo - succession of earliest angiosperm evolution. Bot. Rev., New York, v.43, n.1, p.105-127.

HUGHES, N.F. \& COUPER, R.A. - 1958 - Palynology of the Brora Coal of the Scottish Middle Jurassic. Nature, New York, n.181, p.1482-1483.

HUGHES, N.F. \& CROXTON, C.A. - 1973 - Palynologic correlation of the Dorset "Wealden". Palaeontology, London, v.16, n.3, p,567-601.

HUGHES, N.F. \& MACDOUGALL, A.B. - 1987 - Records of angiospermid pollen entry into the English Early Cretaceous sucession. Rev. Palaeobot. Palynol., Amsterdam, v.50, n.3, p.255-272.

HUGHES, N.F. \& MACDOUGALL, A.B. - 1990 - Barremian - Aptian angiospermid pollen records from southern England. Rev. Palaeobot. Palynol., Amsterdam, v.65, n.2, p.145-151.

HUGHES, N.F. \& MOODY-STUART, J. - 1966 - Description of schizaeaceous spores taken from early Cretaceous macrofossils. Palaeontology, London, v.9, n.2, p.274-289.

HUGHES, N.F. \& MOODY-STUART, J. - 1967 - Palynological facies and correlation in the English Wealden. Rev. Palaeobot. Palynol., Amsterdam, v.1, n.1-4, p.259-268.

HUGHES, N.F.; DREWRY, G.E. \& LAING, J.F. - 1979 - Barremian earliest angiosperm pollen. Palaeontology, London, v.22, n.3, p.513-535.

HUYNH, K.L. - 1974 - Le problème de la polarité du pollen d'Ephedra. Pollen et Spores, Paris, v.16, n.4, p.470-474.

INSTITUTO DE PESQUISAS TECNOLOGGICAS DO ESTADO DE SÃO PAULO S.A.-IPT. - 1988 - A reativação Wealdeniana no Brasil: uma revisão sobre o Nordeste Oriental. São Paulo, Relatório interno, $n^{\circ} 26566,3 v$. 
IOANNIDES, N.S. \& MCINTYRE, D.J. - 1980 - A preliminary palynological study of the Caribou Hills outcrop section along the Mackenzie river, District of Mackenzie. Geol. Surv. Can., Ottawa, Paper 80-1A, p.197-208.

JAIN, R.K. - 1968 - Middle Triassic pollen grains and spores from minas de petroleo beds of the Cacheuta Formation (Upper Gondwana), Argentina. Palaeontog. Abt. B, Stuttgart, v.122, n.1-4, p.1-47.

JAN DU CHÊNE, R.E.; DE KLASZ, I. \& ARCHIBONG, E.E. - 1978 Biostratigraphic study of the borehole OJO - 1, S.M. Nigeria: with special emphasis on the Cretaceous microflora. Rev. Micropaléont., Paris, v.21, n.3, p.123-139.

JANSONIUS, J. - 1962 - Palynology of Permian and Triassic sediments, Peace River area, Western Canada. Palaeontog. Abt. B, Stuttgart, v.110, n.1-4, p.35-98.

JANSONIUS, J. - 1976 - Paleogene fungal spores and friting bodies of the Canadian Arctic. Geosci. and Man, Baton Rouge, n.15, p.129-132.

JANSONIUS, J. \& HILLS, L.V. - 1976 - Genera file of fossil spores and pollen. Calgary University, Dep. of Geology, Calgary, 3431 cards. Spec. Publ.

JARDINÉ, S. \& MAGLOIRE, L. - 1965 - Palynologie et stratigraphie du Crétacé des basins du Sénégal et de Côte d'Ivoire. Mém. B.R.G.M., Orléans, n.32, p.187-245. ( $1^{\text {er }}$ Coll. Afr. Micropaléont., Dakar, 1963).

JARDINÉ, S.; BIENS, P. \& DOERENKAMP, A. - 1974 - Dicheiropollis etruscus: un pollen charactéristique de Crétacé inférieur afro-sud-américain. Conséquences pour l'évaluation des unités climatiques et implications dans la dérive des continents. In: Palynologie et dérive des continents. Sci. Geol. Bull., Strasbourg, v.27, n.1-2, p.87-100.

JARDINÉ, S.; DOERENKAMP, A. \& LEGOUX, O. - 1972 - Le genre Hexaporotricolpites Boltenhagen, 1967: morphologie, systématique, stratigraphie et extension géographique. In: COLL. AFR. MICROPALÉONT., 4, Abdjan, 1970, Proceedings..., Nice, p.175-191.

JARDINÉ, S.; KIESER, G. \& REYRE, Y - 1974 - L'individualisation progressive du Continent Africain à travers les donnés Palynologiques de l'ère Secondaire. Sci. Geol. Bull., Strasbourg, v.27, n.1- 2, p.69-85.

JARZEN, D.M. - 1978 - The terrestrial palynoflora from the Cretaceous-Tertiary transition, Alabama. Pollen et Spores, Paris, v.20, n.4, p.535-553.

JARZEN, D.M. \& DETTMANN, M.E. - 1989 - Taxonomic revision of Tricolpites reticulatus Cookson ex Couper, 1953 with notes on the biogeography of Gunnera L. Pollen et Spores, Paris, v.31, n.1-2, p.97-112. 
JARZEN, D.M. \& NORRIS, G. - 1975 - Evolutionary significance and botanical relationships of Cretaceous angiosperm pollen in the Western Canadian Interior. Geosci. and Man, Baton Rouge, n.11, p.47-60.

JERSEY, N.J. DE - 1964 - Triassic spores and pollen grains from the Bundamba Group. Publs. Geol. Surv. Queensland, Brisbane, n.321, p.1-21.

JERSEY, N.J. DE - 1973 - Rimulate pollen grains from the Lower Mesozoic of Queensland. Geol. Soc. Aust.Spec.Publ., Sydney, n.4, p.127-140.

JUHÁSZ, M. - 1972 - Study of Trilites formgenus in Lower Cretaceous deposits. Acta Biol. Szeged, Szeged, v.18, n.1-4, p.43-53.

JUHÁSZ, M. \& GÓCZÁN, F. - 1985 - Comparative study of Albian monosulcate angiosperm pollen grains. Acta Biol. Szeged, Szeged, v.31, n.1-4, p.147-172.

KAISER, N. - 1976 - Die permische Mikroflora der Cathaysia-Schichten von Nordwest-Schansi, China. Palaeontog. Abt. B, Stuttgart, v.159, n.4-6, p.123.

KAR, R.K. \& SINGH, R.S. - 1986 - Palynology of the Cretaceous sediments of Meghalaya, India. Palaeontog. Abt. B, Stuttgart, v:202, n.1-6, p.83-153.

KARA MURZA, E.N. - 1960 - Palynological basis of stratigraphical subdivision of the Mesozoic deposits of the Khatanga Depression. Trudy Nauchno-Issled. Inst. Geol. Arkt., Leningrad, n.109, p.1-134.

KASKA, H.V. - 1989 - A spore and pollen zonation of early cretaceous to tertiary nonmarine sediments of Central Sudan. Palynol, Dallas, v.13, p.79-90.

KATTAH, S.S. - 1992 - Novas considerações sobre o Aptiano-Albiano da Bacia Sanfranciscana. In: SIMP. SOBRE AS BACIAS CRETÁCICAS BRASILEIRAS, 2, Rio Claro 1992. Res. Expand..., Rio Claro, UNESP, p.118-119.

KEDVES, M. - 1961 - Études palynologiques dans le Bassin de Dorog. Pollen et Spores, Paris, v.3, n.1, p.101-153.

KEDVES, M. \& SIMONCSICS, P. - 1964a - Microstratigraphy of the carbonate manganese ore layers of the shaft III of Urkut on the basis of palynological investigations. Acta Min. Petrogr. Univ. Szeged, Szeged. v.16, n.2, p.3-48.

KEDVES, M. \& SIMONCSICS, P. - 1964b - Spores nouvelles extraités de minerai de manganese jurassique de la region d'Urkut (Hungrie). Pollen et Spores, Paris, v.6, n.2, p.605-610.

KEGEL, W. - 1957 - Contribuição ao estudo da bacia costeira do Rio Grande do Norte. Bol. DNPM - Div. Geol. Mineral., Rio de Janeiro. n.170, p.1-52. 
KEMP, E. M. - 1968 - Probable angiosperm pollen from the British Barremian to Albian strata. Palaeontology, London, n.11, p.421-434.

KEMP, E. M. - 1970 - Aptian and Albian miospores from southern England. Palaeontog. Abt. B, Stuttgart., v.131, n.1-4, p.73-146.

KEMP, G.O.W. - 1977 - Lower Cretaceous palynological literature: six hundred implemented references. Palynodata. Tucson, Paleo data banks, n.8, 61p.

KIESER, G. - 1967 - Quelques aspects particuliers de la Palynologie du Crétacé Supérieur du Senegal. Rev. Palaeobot. Palynol., Amsterdam, v.5, n.1-4, p.199-210.

KIMYAI, A. - 1966 - New plant microfossils from the Raritan Formation (Cretaceous) in New Jersey. Micropaleont., Columbia, n.12, p.461-476.

KIMYAI, A. - 1974 - Jurassic plant microfossil from Iran. In: SIMP. STRAT. PALYN. BIRBAL, Sahni Inst, Birbal, v.1, p.1-8.

KLASZ, I. de \& MICHOLET, J. - 1972 - Eléments nouveaux concernant la biostratigraphie du bassin gabonais. In: COLL. INTERNAT. AFRICAIN DE MICROPALEONT., 4, Abdjan (1970). p.109-143.

KLAUS, W. - 1960 - Sporen der karnischen Stufe der östalpinen Trias. Jahrb. Geol., B.A. (Wien), Sonderber. n.5, p.107-183.

KOUTSOUKOS, E.A.M. - 1989 - Mid - to late Cretaceous microbioestratigraphy, palaeoecology and palaeogeography of the Sergipe Basin, Northeastern Brazil - Polytechnic South West, England, Plymouth, 680 p. Ph. D. Thesis.

KRASSILOV, V.A. - 1978 - Araucariaceae as indicators of climate and paleolatitudes. Rev. Palaeobot. Palynol., Amsterdam, v.26, n.2, p.113-124.

KREIDLER, W. - 1949a - Final geological report on the sedimentary coastal belt of the States of Rio Grande do Norte and that part at the State of Ceará south and east of Fortaleza. Rio de Janeiro. PETROBRÁS/DEPEX. 105p. Relatório interno.

KREILLER, W. - 1949b-Mapas de reconhecimento geológico da área sedimentar costeira do Rio Grande do Norte e Ceará. Rio de Janeiro. Publicação do Conselho Nacional do Petroleo. (Arquivo B, GD-82-87-U).

KREIDLER, W. \& ANDERY - 1950 - Mapa geológico da área sedimentar costeira do Estado do Rio Grande do Norte e parte do Ceará. Rio de Janeiro. Publicação do Conselho Nacional do Petróleo. (Relatório de 1949). 
KRÖMMELBEIN, K. \& WERGER, R. - 1966 - Sur quelques analogies remarquables dans de microfaunes crétacées du Gabon et du Brésil Oriental (Bahia et Sergipe). In: REYRE, D. (ed.). Sedimentary Basins of the African Coasts Symposium, Assoc. Sen. Geo. Africains, Paris, v.1, p. 193-196.

KRUTZSCH, W. - 1959a - Mikropaläontologische (sporenpaläontologische) Untersuchungen in der Braunkohle des Geiseltales. I. Die zu Sporites gestellten Formeinheiten der Sporae Dispersae der mitteleozänen Braunkohle des mittleren Gleiseltales (Tagebau-Neumark-West i w.s.), unter Berücksichtigung und Revision weiterer Sporenformen aus der bisheringen Literatur. Geologie, Berlin, v.8, n.21-22, p.1-425.

KRUTZSCH, W. - 1959b - Einige neue Formgattungen und -arten von Sporen und Pollen aus der Mitteleuropäischen Oberkreide und dem Tertiär. Paläeontog. Abt. B, Stuttgart, v.105, p.125-157.

KRUTZSCH, W. - 1963a - Atlas der mittel-und jungtertiären dispersen Sporenund Pollen sowie der Mikroplanktonformen des nördlichen Mitteleuropas. Liefg. II, Die Sporen der Anthocerataceae und der Lycopodiaceae. Deutscher Verlag Wiss., Berlin, 141p.

KRUTZSCH, W. - 1963b - Atlas der mittel-und jungtertiären dispersen Sporenund Pollen-sowie der Mikroplanktonformen des nördlichen Mitteleuropas. Liefg. IV, Sphagnaceoide und Selaginellaceoide Sporenformen. Deutscher Verlag Wiss., Berlin, 128p.

KRUTZSCH, W. - 1969 - Taxonomie syncolp(or)ater und morphologish benachbarter Pollengattungen und- arten (Sporae Dispersae) aus der Oberkreide und dem Tertiär. Teil II. Syncolp(or)ate und syncolp(or)atoide Pollenformen. Pollen et Spores, Paris, v.11, n.2, p.397-424.

KRUTZSCH, W. - 1971 - Atlas der mittel- und jungtertiären dispersen Sporen und Pollen-sowie der Mikroplanktonformen des nördlichen Mitteleuropas. Liefg. VI, Coniferenpollen (Saccites und "Inaperturates"). Deutscher Verlag Wiss., Berlin, 234 p.

KUYL, O.S.; MÜLLER, J. \& WATERBOLK, H. - 1955 - The application of palynology to oil geology with reference to western Venezuela. Geol. Mijnbow, Gravenhage. v.3, n.17, p.49-75.

LAING, J.F. - 1975 - Mid-Cretaceous angiosperm pollen from southern England and northern France. Palaeontology, London, v.18, n.4, p.775-808.

LAING, J.F. - 1976 - The stratigraphic setting of early angiosperm pollen. In: FERGUSON, I.K. \& MULLER, J. (eds.). THE EVOLUTIONARY SIGNIFICANCE OF THE EXINE. London, Academic Press, (Linn. Soc. London Symp. Series n.1), p.15-26. 
LANA, M.C. - 1985 - Rifteamento na Bacia de Sergipe-Alagoas, Brasil. Ouro Preto, Universidade Federal de Ouro Preto. 124p. Dissertação de Mestrado.

LANTZ, J. - 1958a - Étude des spores et pollens d'un échantillon Purbeckien de l'île d'Oleron. Rev. Micropaléont., Paris, v.1, n.1, p.33-37.

LANTZ, J. - 1958b - Étude palynologique de quelques échantillons mésozö̈ques du Dorset (Grand-Bretagne). Inst. Fr. Pétrole, Paris, v.13, n.6, p.917-943.

LEFFINGWELL, H.A. - 1970 - Palynology of the Lance (Late Cretaceous) and Fort Union (Paleogene) Formations of the type Lance area, Wyoming. Geol. Soc. of America Spec. Pap., Boulder, n.127, p.1-64.

LENTIN, J.K. \& WILLIAMS, G.L. - 1973 - Fossil dinoflagellates: index to genera and species. Geol. Surv. Can., Ottawa, Paper 73-42, 176 p.

LIMA, M.O. - 1987 - Evoiução tectono-sedimentar da Formação Alagamar na área do Alto de Macau e Gráben de Guamaré, Bacia Potiguar, RN. Ouro Preto. Universidade Federal de Ouro Preto. 115p. Dissertação de Mestrado.

LIMA, M.R. - 1971 - Contribuição palinológica à estratigrafia do Cretáceo do Nordeste do Brasil: análise da perfuração GSB1, Serra Branca, PE. Porto Alegre, Universidade Federal do Rio Grande do Sul. 74p. Dissertação de Mestrado (inédita).

LIMA, M.R. - 1976a - Crotonipollis, a new pollen genus from Santana Formation, Cretaceous of northeástern Brazil. Bol. Assoc. Latinoamer. Paleobot. Palinol., Buenos Aires, n.3, p.14-20.

LIMA, M.R. - 1976b - O gênero Classopollis e as bacias mesozoicas do Nordeste do Brasil. Ameghiniana, Buenos Aires, v.13, n.3-4, p.226-234.

LIMA, M.R. - 1978a - Palinologia da Formação Santana (Cretáceo do Nordeste do Brasil). São Paulo. Instituto de Geociências, USP. São Paulo. 338p. Tese de Doutoramento.

LIMA, M.R. - 1978b - Caracterização palinológica do Albiano no Brasil. Bol. Inst. Geoc. - USP, São Paulo, v.9, p.140-143.

LIMA, M.R. - 1978c - Palinologia da Formação Santana (Cretáceo do Nordeste do Brasil). Introdução geológica e descrição sistemática dos esporos da subturma Azonotriletes. Ameghiniana, Buenos Aires, v.15, n.3-4, p.333-365.

LIMA, M.R. - 1978d - Microfósseis da Formação Exu, Cretáceo do Nordeste do Brasil. In: CONGR. BRAS. GEOL., 30, Recife 1978. Anais..., Recife, SBG, v.2, p.965-969. 
LIMA, M.R. - 1979a - Palinologia da Formação Santana (Cretáceo do Nordeste do Brasil). II. Descrição sistemática dos esporos da subturma Zonotriletes e turma Monoletes, e dos polens das turmas Saccites e Aletes. Ameghiniana, Buenos Aires, \%16, n.1-2, p.27-63.

LIMA, M.R. - 1979b - Considerações palinológicas a respeito de correlação estratigráfica entre formaçōes cretáceas do Nordeste do Brasil. In: CONGR. LATINO-AMERICANO PALEONT., 1, Buenos Aires 1979. Atas..., Buenos Aires, v.5, p.227-233.

LIMA, M.R. - 1979c - Palinologia dos calcáreos laminados da Formação Areado, Cretáceo de Minas Gerais. SIMP. REGIONAL GEOL, 2, Rio Claro 1979. Atas..., Rio Claro, v.1, p.203-216.

LIMA, M.R. - 1980 - Palinologia đa Formação Santana (Cretáceo do Nordeste do Brasil). III. Descrição sistemática dos pólens da turma Plicates (subturma Costates). Ameghiniana, Buenos Aires, v.17, n.1, p.15-47.

LIMA, M.R. - 1981 - Palinologia do Mesozóico brasileiro: uma síntese. In: VOLKHEIMER, W. (ed.) Cuencas sedimentarias del jurassico y Cretácico de America del Sur., Buenos Aires. v.2, p.445-460.

LIMA, M.R. - 1982 - Palinologia da Formação Codó, na região de Codo, Maranhão. Bol. Inst. Geoc., USP, São Paulo, v.13, p.116-128.

LIMA, M.R. - 1983 - Paleoclimatic reconstruction of the Brazilian Cretaceous based on palynological data. Rev. Bras. Geoc., São Paulo, v.13, n.4, p.223-228.

LIMA, M.R. - 1984 - Palinologia do linhito de Jatobá (Cretáceo do Nordeste do Brasil). I - Introdução, contexto estratigráfico, identificação de espécies cretáceas. In: CONGR. BRAS. GEOL., 26, Rio de Janeiro 1984. Anais..., Rio de Janeiro, SBG, v.2, p.536-547.

LIMA, M.R. - 1990 - Estudo palinológico de sedimentos da Bacia de Ico, Cretáceo do Estado do Ceará, Brasil. Bol. Inst. Geoc. - USP. São Paulo, (Série Cient.), v.21, p.35-46.

LIMA, M.R. \& BOLTENHAGEN, E. - 1981a - Estudo comparativo da evolução das microfloras afro-sul-americanas I - O Cretáceo Inferior. In: CONGR. LATINO-AMERICANO PALEONT., 2, Porto Alegre 1981. Anais..., Porto Alegre, SBG, v.1, p.321-341.

LIMA, M.R. \& BOLTENHAGEN, E. - 1981b - Estudo comparativo da evolução das microfloras afro-sul-americanas II - O Cretáceo Superior. In: CONGR. LATINO-AMERICANO PALEONT., 2, Porto Alegre, 1981. Anais..., Porto Alegre, SBG, v.1, p.373-383. 
LIMA, M.R. \& COELHO, M.P.C.A. - 1987 - Estudo palinol6gico da sondagem estratigrafica de Lagoa do Forno, Bacia do Rio do Peixe, Cretáceo do Nordeste do Brasil. Bol. Inst. Geoc. - USP, São Paulo, n.18, p.67-83. (Série Cient.).

LIMA, M.R. \& PERINOTTO, J.A.J. - 1984 - Palinologia de sedimentos da parte superior da Formação Missão Velha, Bacia do Araripe. Geociências, São Paulo, n.3, p.67-76.

LIMA, M.R.; PEDRÃO, E. \& OLIVEIRA, S.F. - 1991 - Análise palinológica da seção-tipo do Andar Alagoas. São Paulo. PETROBRÁS/ CENPES/DIVEX/SEBIPE. 34p. Relatório interno.

LIMA NETO, F.F.; MATOS, R.D.B; PRAÇA, U.M. \& HASHIMOTO, A.T. - 1986 - Análise estratigráfica da Formação Pendência. Natal. PETROBRÁS/DEBAR. Relatório interno.

LOEBLICH Jr., A.R. \& LOEBLICH, A.R. - 1966 - Index to the genera, subgenera, and sections of the Pyrrophyta. Studies in Tropical Oceanography, Miami, n.3, 94p.

MABESOONE, J.M. - 1984 - Episódios tectônicos, seqüências deposicionais, e sua integração, com exemplos do Nordeste brasileiro. In: CONGR. BRAS. GEOL., 33, Recife 1984, Anais..., Recife, SBG, v.2, p.918-933.

MABESOONE, J.M.; FÚlFARO, V.J. \& SUGUIO, K. - 1981 - Phanerozoic sedimentary sequences of the South American Platform. Earth-Sci. Rev., Amsterdam, n.17, p.49-67.

MACHADO Jr., D. L.; DEHIRA, L.K.; CARNEIRO, C.D.R. \& ALMEIDA, F.F.M - 1989 - Reconstruções paleoambientais do Juro-Cretáceo no Nordeste Oriental brasileiro. Rev. Bras. Geoc., São Paulo, v.19, n.4, p.470-485.

MACKENZIE, D.P. - 1978 - Some remarks on the development of sedimentary basins. Earth and Planetary Sci. Letters, Amsterdam, v.40, n.1, p.25-32.

MÄDLER, K. - 1963 - Die figurierten organischen Bestandteile der Posidonienschiefer. Beih. Geol. Jb., Hannover, n.58, p.287-406.

MAHESHWARI, H.K. - 1974 - Lower Cretaceous palynomorphs from the Bansa Formation, South Rewa, Gondwana Basin. Palaeontog. Abt. B, Stuttgart, v.146, n.1-2, p.21-55.

MATOS, R.M.D. - 1987 - Sistema de riftes cretáceos do nordeste brasileiro. Rio de Janeiro. PETROBRÁS/DEPEX/DEBAR. 34p. Relatório interno. 
MAURY, C.J. - 1924 - Fósseis terciários do Brasil, com descrição de novas formas cretácicas. Rio de Janeiro. Serv. Geológico e Mineralógico do Brasil, 698p. (monografia 4).

MAURY, C.J. - 1934 - Fossil invertebrates from northeastern Brazil. Amer. Mus. Nat. Hist. Bull., New York, n.67, p.123-179.

MAY, F. - 1975 - Dichastopollenites reticulatus, gen. and sp. nov. - potential Cenomanian guide fossil from southern Utah and northeastern Arizona. Journ. Paleont., Tulsa, v.49, n.3, p.528-533.

MAY, F.E. \& TRAVERSE, W. - 1973 - Palynology of the Dakota Sandstone (Middle Cretaceous) near Canyon National Park, Southern Utah. Geosci. and Man, Baton Rouge, n.7, p.57-64.

MAYER, E. - 1974 - Estratigrafia preliminar da plataforma continental da Bacia Potiguar. Rio de Janeiro. PETROBRÁS/DEPEX, Relatório interno.

MCGREGOR, D.C. - 1965 - Triassic, Jurassic, and Lower Cretaceous spores and pollen of Arctic Canada. Geol. Surv. Can., Ottawa, Paper 64-55, p.1-32.

MCINTYRE, D.J. \& BRIDEAUX, W.W. - 1980 - Valanginian miospore and microplankton assemblages from the Northern Richardson Mountains, District of Mackenzie, Canada. Geol. Surv. Can. Bull., Ottawa, n.320, p.1-57.

MEDUS, J. - 1970 - A palynological method for stratigraphical correlations. Grana, Stockholm, n.10, p.149-158.

MEDUS, J. \& PONS, A. - 1967 - Étude palynologique du Crétacé PyrineoProvençal. Rev. Palaeobot. Palynol., Amsterdam, v.2, n.1-4, p.111-117.

MEDUS, J. \& TRIAT, J.M. - 1969 - Le Cenomanien Supérieur de la coupe de Laundun (Yard, France): étude palynologique et donnés sédimentologiques. Rev. Palaeob. Palynol., Amsterdam, v.9, n.3-4, p.213-228.

MELLO, M.R. \& MAXWELL, J.R. - 1991 - Organic geochemical and biological marker characterzation of source rocks and oils derived from lacustrine environments in the Brazilian continental margin. In: KATZ, B.J. (ed.) Lacustrine Basin Exploration - Case Studies and Modern Analogs. AAPG Memoir 50. Tulsa, p.77-99.

MELLO, M.R.; CERQUEIRA, J.R.; SOLDAN, A.L. \& ARARIPE, P.T. - 1984 - Avaliação geoquímica da plataforma continental da Bacia Potiguar. Rio de Janeiro. PETROBRÁS/CENPES. 98p. Relatório interno.

MELLO, M.R.; GAGLIANONE, P.C; BRASSEL, S.C. \& MAXWELL, J.R. - 1988 - Geochemical and biological marker assessment of depositional environment using Brazilian offshore oils. Marine Petrol. Geol., Tulsa, n.5, p.205-223. 
MELLO, U.T. - 1987 - Evolução termomecânica da Bacia Potiguar e implicações na manutenção do petróleo. Ouro Preto. Universidade Federal de Ouro Preto. 186p. Dissertação de Mestrado.

MIKI, A. - 1972 - Palynological study of the Kuji Group in Northeastern Honshu, Japan. Journ. Fac. Sci. Hokkaido Univ., Hokkaido, v.15, n.3-4, p.513-604. (Geol. Miner., Ser. IV)

MILANI, E.J. - 1985 - Aspectos da evolução tectônica das bacias do Recôncavo e Tucano Sul, Bahia, Brasil. Ouro Preto, Universidade Federal de Ouro Preto, 124p. Dissertação de Mestrado.

MILLIOUD, M. - 1967 - Palynological study of the type localities of Vallangin and Hauterive. Rev. Palaeobot. Palynol., Amsterdam, v.5, n.1-4, p.155-167.

MIURA, K. \& BARBOSA, J.C. - 1972 - Geologia da plataforma continental do Maranhão, Piauí, Ceará e Rio Grande do Norte. In: CONGR. BRAS. GEOL., 26, Belém 1972, Anais..., Belém, SBG, v.2, p.57-66.

MOHRIAK, W.U.; MELLO, M.R.; DEWEY, J.F. \& MAXWELL, J.R. - 1990 - Petroleum geology of the Campos Basin, offshore Brazil. In: BROOKS, J. (ed.). Classic Petroleum Provinces, 1990. Geol. Soc. Spec. Publ., Oxford, n.50, p.119-141.

MORBEY, S.J. - 1975 - The palynostratigraphy of the Rhaetian Stage, Upper Triassic in the Kendelbachgraben, Austria. Palaeontog. Abt. B, Stuttgart, v.152, n.1-4, p.1-75.

MOREIRA, C.A.A. - 1987 - Análise estratigráfica das formações Alagamar (Pós-CPT) e Açu (parte inferior) na região de Macau-Ubarana: a transição Aptiano (não marinho) - Albiano (marinho), na Bacia Potiguar. Ouro Preto, Universidade Federal de Oưro Preto. 77p. Dissertação de Mestrado.

MORGAN, R. - $1978-26$. Albian to Senonian palynology of site 364, Angola Basin. Init. Rep. Deep Sea Drill. Proj., Washington, v.40, p.915-951.

MÜLLER, H. - 1966 - Palynologycal investigations on Cretaceous sediments in northeastern Brazil. In: VAN HINTE, J.E. (ed.) Coll. West African Micropaleont., 2, Ibadan, 1965. , Proceedings..., Leiden, p.123-136.

MÜLLER, J. - 1959 - Palynology of Recent Orinoco delta and shelf sediments. Rep. of the Orinoco Shelf Expedition, 5. Micropaleont., Columbia, n.5, p.1-32.

MÜLLER, J. - 1968 - Palynology of the Pedawan and Plateau Sandstone Formations (Cretaceous-Eocene) in Sarawak, Malaysia. Micropaleont., Columbia, v.14, n.1, p.1-37. 
MÜLLER, J. - 1970 - Palynological evidence on early differentiation of angiosperms. Biol. Rev., Cambridge, n.45, p.417-450.

MÜLLER, J. - 1981 - Fossil pollen records of extant angiospems. Bot. Rev., New York, n.47, p.1-142.

MÜLLER, J.; DI GIACOMO, E. \& VAN ERVE, A. - 1987 - A palynological zonation for the Cretaceous, Tertiary, and Quaternary of northern South America. AASP-Contributions Series, Dallas, n.19, p.7-76.

MURILLO, M.T. \& BLESS. M.J.M. - 1974 - Spores of Recent Colombian Pteridophyta. I. Trilete spores. Rev. Palaeobot. Palynol., Amsterdam, v.18, n.3-4, p.223-269.

MURILLO, M.T. \& BLESS, M.J.M. - 1978 - Spores of Recent Colombian Pteridophyta. II. Monolete spores. Rev. Palaeobot. Palynol., Amsterdam. v.25, n.5, p.319-365.,

N.A.C.S.N. - 1983 - North American Stratigraphic Code. North American Commission on Stratigraphic Nomenclature. AAPG. Bull., Tulsa, Oklahoma, v.67, n.5, p.841-875.

NAKOMAN, E. - 1964 - Étude palynologique de quelques échantillons de lignite provenant du Bassin de Thrace (Turquie). Ann. Soc. Geol. du Nord, Lille, v.84, n.2, p.289-302.

NAKOMAN, E. - 1966 - Contribution a l'étude palynologique des formations tertiaires du Bassin de Thrace. I. étude qualitative. Ann. Soc. Geol. du Nord, Lille, v.86, n.1, p.65-107.

NAUMOVA, S.N. - 1939 - Spores and pollen of the coals of the US.S.R. In: INTERN. GEOL. CONGRESS., 17, Moscow, 1937, v.1, p.353-364.

NEVES, C.A.O. - 1987 - Análise regional do trinômio geração-migraçãoacumulação de hidrocarbonetos na seqüência continental eocretácica da Bacia Potiguar emersa, Nordeste do Brasil. Ouro Preto, Universidade Federal de Ouro Preto. 71p. Dissertação de Mestrado.

NEWMAN, K.R. - 1965 - Upper Cretaceous-Paleocene guide palynomorphs from northwestern Colorado. Studies Earth Sci., Denver, Ser.2, p.1-21.

NICHOLS, D.J.; AMES, H.T. \& TRAVERSE, A. - 1973 - On Arecipites Wodehouse, Monocolpopollenites Thomson \& Pflug and the species "Monocolpopollenites tranquillus". Taxon, Utrecht, v.22, n.2-3, p.241-256.

NORRIS, G. - 1967 - Spores and pollen from the lower Colorado Group (Albian-?Cenomanian) of central Alberta. Palaeontog. Abt. B, Stuttgart, v.120, n.1-4, p.72-115. 
NORRIS, G. - 1968 - Plant microfossils from the Hawks Crag Breccia, South-West Nelson, New Zealand. New Zeal. Journ. Geol. Geophys., Wellington, v.11, n.2, p.312-344.

NORRIS, G. - 1969 - Miospores from the Purbeck beds and marine Upper Jurassic of southern England. Palaeontology, London, v.12, n.4, p.574-620.

NORRIS, G.; TELFORD, P.G. \& VOS, M.S. - 1976 - An Albian microflora from the Mahagamt Formation, James Bay Lowlands, Ontario. Can. Journ. Earth Sci., Ottawa, v.13, n.2, p.400-403.

NORTON, N.J. \& HALL, J.W. - 1967 - Guide sporomorphae in the Upper Cretaceous - Lower Tertiary of Eastern Montana (USA). Rev. Palaeobot. Palynol., Amsterdam, v.2, n.1-4, p.99-110.

NORVICK, M.S. \& BURGER, D. - 1976 - Palynology of the Cenomanian of Bathurst Island, Northern Territory, Australia. Bull. Bur. Miner. Resour. Geol. Geophys., Melbourne, n.151, p.21-113.

NÜRNBERG, D. \& MÜLLER, R.D. - 1991 - The tectonic evolution of the South Atlantic from Late Jurassic to present. Tectonophysics, Amsterdam, n.191, p.27-53.

OJEDA, H.A.O. - 1982 - Strutural framework, stratigraphy and evolution of Brazilian marginal basins. Amer. Assoc. Petrol. Geol. Bull., Tulsa, n.66, p.732-749.

OJEDA, H.A.O. \& SANTOS, R.R. - 1982 - Bacia Potiguar (parte emersa). Integração geológica regional de dados exploratórios. Rio de Janeiro. PETROBRÁS/DEPEX, 43p. Relatorio interno.

OKADA, A.H. - 1982 - Facies, petrogpaphic, and engineering analysis of Lower Cretaceous Upanema reservoirs. Ubarana Field, Potiguar Basin, Brazil. Austin, University of Texas at Austin, 192p. MS. Thesis.

OLDHAM, T.C.B. - 1976 - Flora of the Wealden plant debris beds of England. Palaeontology, London, n.19, p.437-502.

OLIVEIRA, A.I. \& LEONARDOS, O.H. - 1943 - Geologia do Brasil. Rio de Janeiro, 2ed. Brasil. Ministério da Agricultura/Serviço de Informação Agrícola. 813p. (Série Didática 2).

OLTZ, D.F. - 1969 - Numerical analysis of palynological data from Cretaceous and Early Tertiary sediments in east central Montana. Palaeontog. Abt. B, Stuttgart, v.128, n.3-6, p.90-166. 
ORLANSKY, R. - 1971 - Palynology of the Upper Cretaceous Straight Cliffs Sandstone, Garfield County, Utah. Utah Geol. Miner. Survey Bull., Salt Lake City, n.89, p.1-57.

PACLTOVÁ, B. - 1961 - On some plant microfossils from fresh water sediments of the Upper Cretaceous (Senonian) in the South Bohemian Basin. Part. 1. (Sborn. Ustredn Ustav Geol.) Palaeontology, London, n.26, p.47-102.

PACLTOVÁ, B. - 1966 - Pollen grains of angiosperms in the Cenomanian Peruc Formation in Bohemia. The Palaeobotanist, Lucknow, v.15, n.1-2, p.52-54.

PADEN-PHILLIPS, P. \& FELIX, C.J. - 1971 a - A study of lower and middle Cretaceous spores and pollen from the southeastern United States. I. Spores. Pollen et Spores, Paris, v.13, n.2, p.279-348.

PADEN-PHILLIPS, P. \& FELIX, C.J. - 1971b - A study of lower and middle Cretaceous spores and pollen from the southeastern United States. II. Pollen. Pollen et Spores, Paris, v.13, n.3, p.447-473.

PANNELLA, G. - 1966 - Palynology of the Dakota Group and Graneros Shale of the Denver Basin. Boulder, University of Colorado, 173p. Ph. D. Thesis.

PANT, D.D. - 1954 - Suggestions for the classification and nomenclature of spores and pollen grains. Bot. Rev., New York, n.20, p.33-60.

PARRISH, J.T.; ZIEGLER, A.M. \& SCOTESE, C.R. - 1982 - Rainfall patterns and the distribution of coals and evaporites in the Mesozoic and Cenozoic. Palaeogeogr. Palaeoclimatol. Palaeoecol., Amsterdam, n.40, p.67-101.

PARRY, C.C. ; WHITLEY, P.H.J. \& SIMPSON, R.D.H. - 1981 - Integration of palynological and sedimentological methods in facies analysis of the Brent Formation. In: ILLING, L.V. \& HOBSON, D.D. (ed.) Petroleum Geology of the Continental shelf of Northon West Europe. London, Inst. Pet., HeydenLondon, , p.205-215.

PAUTSCH, M.E. - 1971 - Sporomorphs of the Upper Triassic from a borehole at Trzciana near Mielic (S. Poland). Acta Palaeobot., Budapest, v.12, n.1, p.3-59.

PAUTSCH, M.E. - 1973 - Upper Triassic spores and pollen from the Polish Carpathian Foreland. Micropalaeont., Columbia, v.19, n.2, p.129-149.

PENNY, H.J. - 1986 - An Early Cretaceous angiosperm pollen assemblage from Egypt. Palaeontology, London, n.35, p.121-134. Special Paper. 
PERKINS, B.F.; LANGSTON, W. \& STONE, J.F. - 1979 - Lower Cretaceous shallow marine environments in the Glen Rose Formation: dinosaur tracks and plants. In: ANNUAL MEETING OF THE AMERICAN ASSOCIATTON OF STRATTGRAPHIC PALYNOLOGISTS, 12, Dallas, 55p. (Fields Trip Guide).

PETRI, S. - 1983 - Brazilian Cretaceous paleoclimates: evidence from clay minerals, sedimentary structures and palynomorphs. Rev. Bras. Geoc., São Paulo, v.13, n.4, p.215-222.

PETRI, S. - 1987 - Cretaceous paleogeographic maps of Brazil. Palaeogeogr. Palaeoclimatol. Palaeoecol., Amsterdam, n.59, p.117-168.

PETRI, S. \& CAMPANHA, V.A. - 1981 - Brazilian continental Cretaceous. Earth-Sci. Rev., Amsterdam, v.17, p.69-85.

PETRI, S. \& FÚlFARO, V.J. - 1983 - Geologia do Brasil (Fanerozóico). São Paulo. Queiroz, T.A./EDUSP.

PETRI, S.; COIMBRA, A.M.; AMARAL, G. \& PONÇANO, W.L. - 1986 - Guia de nomenclatura estratigráfica. Rev. Bras. Geoc., São Paulo, v. 16, n.4, p.376-415.

PFLUG, H. - 1953 - Zur Entstehung und Entwicklung des angiospermiden Pollens in der Erdgeschichte. Palaeontog. Abt. B, Stuttgart, v.95, n.4-6, p.60-171.

PHILLIPS, L. - 1974 - Reworked Mesozoic spores in Tertiary leaf-beds on Mull, Scotland. Rev. Palaeobot. Palynol., Amsterdam, v.17, n.3-4, p.221-232.

PIERCE, R.L. - 1961 - Lower Upper Cretaceous plant microfossils from Minnesota. Minnesota Geol. Surv. Bull., Minneapolis, n.42, p.1-86.

PIERCE, S.T. - 1976 - Morphology of Schizosporis reticulatus Cookson and Dettmann 1959. Geosci. and Man, Baton Rouge, n.15, p.25-33.

PLAYFORD, G. - 1971 - Palynology of basal Cretaceous (Swan River) strata of Saskatchewan and Manitoba. Palaeontology, London, n.14, p.533-565.

PLAYFORD, G. \& CORNELIUS, K.D. - 1968 - Palynological and lithostratigraphic features of the Razerback Beds, Mount Morgan District. Queensland. Univ. Queensl. Press, Brisbane, v.6, n.3, p.83-96.

PLAYFORD, G. \& DETTMANN, M.E. - 1965 - Rhaeto-Liassic plant microfossils from the Leigh Creek Coal Mesures, South Australia. Senckenberg. Lethaea, Frankfurt, v.46, n.2-3, p.127-181.

PLAYFORD, G. \& DRING, R.S. - 1981 - Late Devonian acritarchs from de Carnavon Basin, Western Australia. Palaeontology, Special Papers, Oxford, n.27, p.1-78. 
POCOCK, S.A.J. - 1961 - The microspore genus Cingulatisporites Thomsom 1953. Journ. Palaeontology, Tulsa, v.35, n.6, p.1235-1236.

POCOCK, S.A.J. - 1962 - Microfloral analysis and age determination of strata at the Jurassic-Cretaceous boundary in the Western Canada Plains. Palaeontog. Abt. B, Stuttgart, v.111, n.1-3, p.1-95.

POCOCK, S.A.J. - 1964a - Pollen and spores of Chlamidospermaceae and Schizeaceae from Upper Mannville strata of the Saskatoon area of Saskatchewan. Grana, Stockholm, v.5, n.2, p.129-209.

POCOCK, S.A.J. - 1964b - Palynology of the Kootenay Formation at its type sections. Bull. Can. Petrol. Geol., Calgary, n.12, p.500-512.

POCOCK, S.A.J. - 1968 - Zonalapollenites Pflug 1953 and related genera. Taxon, Utrecht, v.17, n.6, p.639-641.

POCOCK. S.A.J. - 1970a - Palynology of the Jurassic sediments of Western Canada. Part. I - Terrestrial species. Palaeontog. Abt. B, Stuttgart, v.130, n.1-2, p.12-72.

POCOCK, S.A.J. - 1970b - Palynology of the Jurassic sediments of Western Canada. Part. I (continued) - Terrestrial species. Palaeontog. Abt. B, Stuttgart, v.130, n.3-6, p.73-136.

POCOCK, S.A.J. - 1972 - Palynology of the Jurassic sediments of Western Canada. Part. II - Marine species. Palaeontog. Abt. B, Stuttgart, v.137, n.3-4, p.85153.

POCOCK, S.A.J. \& JANSONIUS, J. - 1961 - The pollen genus Classopollis Pflug 1953. Micropaleont., Columbia, n.7, p.439-449.

POCOCK, S.A.J. \& VASANTHY, G. - 1988 - Cornetipollis reticulata, a new pollen with angiospermide features from the Upper Triassic (Carnian) sediments of Arizona (U.S.A.) with notes on Equisetosporites. Rev. Palaeobot. Palynol., Amsterdam, v.55, n.4, p.337-356.

PONS, D. - 1988 - Le mésozö̈que de Colombie - Macroflores et Microflores. Cahiers de Paléontologie. CNRS. Paris, p.1-168.

PONS, D.; BERTHOU,P.Y. \& CAMPOS, D.A. - 1990 - Quelques observations sur la palynologie de l'Aptien supérieur et le l'Albien du Bassin d'Araripe (NE du Brésil). In: SIMP. SOBRE A BACIA DO ARARIPE E BACIAS INTERIORES DO NORDESTE, 1, Crato 1990. Atas..., Crato, DNPM, p.241-252.

PONTE, F.C. (coord.) - 1971 - Evolução paleogeológica do Brasil Oriental e da África Ocidental. Salvador. PETROBRÁS/SEPES/SETUP/BA., $4^{\circ}$ Curso de Projetos Especiais em Geologia. (CPEG IV), 73p. (Publicação restrita.) 
PONTE, F.C. - 1980 - A ambiência do petróleo nas bacias sedimentares da margem continental brasileira. In: SIMP. SOBRE EXPLORAÇÃO DE PETRÓLEO, Rio de Janeiro, 1980. Pre-print. Apresentado na VI Semana de Geologia da UFR.

PONTE, F.C. \& APPI, C.J. - 1990 - Proposta de revisão da coluna estratigráfica da Bacia do Araripe. In: CONGR. BRAS. GEOL., 36, Natal 1990. Anais..., SBG, v.1, p.211-226.

PONTE, F.C. \& ASMUS, H.E. - 1976 - The Brazilian marginal basins: current state of knowledge. In: Proc. Int. Symp. on Cont. Margins of Atlantic type. An. Acad. bras. Ciênc. Suplemento, n.48, p.215-239.

PONTE, F.C. \& ASMUS, H.E. - 1978 - Geological framework of the Brazilian continental margin. Geolog. Rundschau, Stuttgart, v.67, n.1, p.201-235.

PONTE, F.C. \& MAIA, P.H.P. - 1987 - Análise estratigráfica do Andar Alagoas na área de Areia Branca-Porto do Mangue na Bacia Potiguar - Estado do Rio Grande do Norte. Salvador, 61p. RelatórioTécnico. (não publ.).

PONTE, F.C. ; HASHIMOTO, A.T. \& DINO, R. - 1991 - Geologia das bacias sedimentares mesozóicas do interior do NE do Brasil. Rio de Janeiro. PETROBRÁS/CENPES/DIVEX/SEBIPE. Relatório interno.

PONTE, F.C.; PORTO, R. \& DAUZACKER, M.V. - 1978 - Origem e acumulação de petróleo nas bacias sedimentares brasileiras. In: CONGR. BRAS. PETRÓLEO, Rio de Janeiro 1978. Anais..., Rio de Janeiro, SBG, v.2, n.1, p.121-147.

PONTE, F.C.; DINO, R.; ARAI, M. \& SILVA TELLES Jr., A. - 1990 - Estratigrafia comparada das bacias sedimentares mesozóicas do interior do Nordeste do Brasil: uma síntese. In: SIMP. SOBRE BACIAS CRETÁCICAS BRASILEIRAS, 1, Rio Claro 1990. Bol. Resum., Rio Claro, UNESP, p.70-73.

POTONIÉ, R. - 1951 - Revision stratigraphisch wichtiger Sporomorphen des mitteleuropäischen Tertiärs. Palaeontog. Abt. B, Stuttgart, v.91, p.131-151.

POTONIÉ, R. - 1956 - Synopsis der Gattungen der Sporae dispersae. I. Teil: Sporites. Beih. Geol. Jahrb., Hannover, n.23, p.1-103.

POTONIÉ, R. - 1958 - Synopsis der Gattunger der Sporae dispersae. II. Teil: Sporites (Nachträge), Saccites, Aletes, Praecolpites, Polyplicates, Monocolpites. Beih. Geol. Jahrb., Hannover, n.31, p.1-114.

POTONIE, R. - 1960 - Synopsis der Gattungen der Sporae dispersae. III. Teil: Nachträge Sporites, Fortsetzung Pollenites mit General-register zu Teil I-II. Beih. Geol. Jahrb., Hannover, n.39, p.1-189. 
POTONIÉ, R. - 1966 - Synopsis der Gattungen der Sporae dispersae. IV. Teil: Nachträge zu allen Gruppen (Turmae). Beih. Geol. Jahrb., Hannover, n.72, p.1-244.

POTONIÉ, R. - 1970 - Synopsis der Gattungen der Sporae dispersae. V. Teil: Nachträge zu allen Gruppen (Turmae). Beih. Geol. Jahrb., Hannover, n. 87, p.1-172.

POTONIÉ, R. - 1975 - Synopsis der Gattungen der Sporae dispersae. VII. Teil: Nachträge zu allen Gruppen (Turmae). Fortschr. Geol. Rheinld. Westfalen, Krefeld, n.25, p.23-151.

POTONIÉ, R. \& KLAUS, W. - 1954 - Einige Sporegattungen des alpinen Salzgebirges. Beih. Geol. Jahrb., Hannover, n. 68, p.517-544.

POTONIÉ, R. \& KREMP, G.O.W. - 1954 - Die Gattungen der paläozoischen Sporae dispersae und ihre Stratigraphie. Beih. Geol. Jahrb., Hannover, n.69, p.111-194.

POTONIÉ, R. \& KREMP, G.O.W. - 1955 - Die Sporae dispersae des Ruhrkarbons. Teil. I. Palaeontog. Abt. B, Stuttgart, v.98, n.1-3, p.1-136.

POTONIÉ, R.; THOMSON, P.W. \& THIERGART, F. - 1950 - Zur Nomenclatur und Klassifikation der neogenen Sporomorphae (Pollen und Sporen). Beih. Geol. Jahrb., Hannover, n.65, p.35-70.

PRAÇA, U.M. \& HASHIMOTO, A.T. - 1991 - Análise bioestratigráfica da Formação Pendência - Bacia Potiguar, parte emersa. Rio de Janeiro. PETROBRÁS /CENPES/DIVEX/SEBIPE. 69p. Relatório interno.

RABINOWITZS, P.D. \& LABRECQUE, J. - 1979 - The Mesozoic South Atlantic Ocean and evolution of its continental margins. Journ. Geophys. Res., New York, v.84, n.11, p.5973-6002.

RAHMENI, R.A. \& HOPKINS Jr, W.S. - 1977 - Geological and palynological interpretation of Eureka Sound Formation on Sabine Peninsula, Northern Melville Island, District of Franklin. Geol. Surv. Can., Ottawa, Paper 77-1B, p.185-189.

RAKOSI, L. - 1942 - Palynologie des formations paleogenes du Bassin de Dorg. Ann. Inst. Geol. Publ. Hang., Budapest, v.55, n.3, p.498- 576.

RAMANUJAM, C.G.K. \& SRISAILAN, T. - 1974 - Palynology of the carbonaceous shales from a borehole at Kattavakkan near Conyevaran, Tamil Navu, India. Pollen et Spores, Paris, v.16, n.1, p.67-102. 
RAMOS, A.N. - 1980 - Argilominerais e diagênese da sequiência clástica do Cretáceo Inferior da Bacia Potiguar: aspectos estratigráficos e ambientais. Rio de Janeiro, PETROBRÁS/CENPES/DINTEP ( Série Ciência - Técnica - Petróleo. Seção: Exploração de Petróleo. Publ. n.10).

RAVEN, P.H. \& AXELROD, D.I. - 1974 - Angiosperm biogeography and past continental movements. Ann. Missouri Bot. Gard, St. Louis, n.61, p.539-673.

REGALI, M.S.P. - 1980 - Palinoestratigrafia da Bacia do Ceará. In: CONGR. BRAS. GEOL., 31, Baln. Camburiú 1980. Anais..., Baln. Camburiú, SBG, v.5, p.31183128.

REGALI, M.S.P. - 1986 - Paleoambientes do Cretáceo em bacias do Norte e Nordeste do Brasil. In: CONGR. BRAS. GEOL., 34, Goiânia 1986. Anais..., Goiânia, SBG, v.1, p.122-130.

REGALI, M.S.P. - 1987a - O gênero Sergipea e a sua estratigrafia no Eocretáceo do Brasil. In: CONGR. BRAS. PALEONT., 10, Rio de Janeiro 1987. Anais..., Rio de Janeiro, SBG, v.2, p.615-623.

REGALI, M.S.P. - 1987b - O gênero Afropollis, Doyle, Jardiné et Doerenkamp, 1982 e sua distribuição no Cretáceo do Brasil. In: CONGR. BRAS. PALEONT., 10, Rio de Janeiro 1987. Anais..., Rio de Janeiro, SBG, v.2, p.625-635.

REGALI, M.S.P. - 1987c - Palinomorfos do Barremiano/Albiano brasileiro - Parte I. In: CONGR. BRAS. PALEONT., 10, Rio de Janeiro 1987. Anais..., Rio de Janeiro SBG, v.2, p.637-645.

REGALI, M.S.P. - 1987d - Palinomorfos do Barremiano/Albiano Brasileiro - Parte II. In: CONGR. BRAS. PALEONT., 10, Rio de Janeiro 1987. Anais..., Rio de Janeiro SBG, v.2, p.647-655.

REGALI, M.S.P. - 1989a - Sistemática, bioestratigrafia e paleogeografia do gênero Elateropollenites Herngreen, 1973, na margem equatorial brasileira. Bol. Inst. Geoc. - USP, São Paulo, n.7, p.45-153. (Publ. especial).

REGALI, M.S.P. - 1989b - Evolução da paleoflora no Cretáceo das margens equatorial e nordeste do Brasil. Rev. Esc. Minas, Ouro Preto, v.42, n.4, p.17-33.

REGALI, M.S.P. - 1989c-Complicatisaccus cearensis: uma palinozona do Eocretáceo do Brasil. In: CONGR. BRAS. PALEONT., 11, Curitiba 1989. Anais..., SBP., v.1, p.235-274.

REGALI, M.S.P. - 1989d - Primeiros registros da transgressão neoaptiana na margem equatorial brasileira. In: CONGR. BRAS. PALEONT., 11, Curitiba 1989. Anais..., SBP., v.1, p.275-293. 
REGALI, M.S.P. - 1989e - A idade dos evaporitos da plataforma continental do Ceará, Brasil e sua relação com os outros evaporitos das bacias nordestinas. Bol. Inst. Geoc. - USP, São Paulo, n.7, p.139-143. Publ. Esp.

REGALI, M.S.P. - 1989f - Tucanopollis, um gênero novo das angiospermas primitivas. Bol. Téc. Petrobrás, Rio de Janeiro, v.3, n.4, p.395-402.

REGALI, M.S.P. - 1990 - Biocronoestratigrafia e paleoambiente do Eocretáceo das bacias do Araripe (CE) e Rio do Peixe (PB), NE - Brasil. In: SIMP. SOBRE A BACIA DO ARARIPE E BACIAS INTERIORES DO NORDESTE, 1, Crato 1990. Atas..., Crato, DNPM, p.163-171.

REGALI, M.S.P. - 1992 - Palinoestratigrafia do Berriasiano ao Aptiano - Bacia Potiguar (parte submersa). Tabela de Distribuição. Rio de Janeiro. PETROBRÁS/SEDES. (Circulação interna).

REGALI, M.S.P. \& GONZAGA, S.M. - 1982- Palinocronoestratigrafia da Bacia Potiguar. Rio de Janeiro. PETROBRÁS/CENPES/SEPALE, 18p. Relatório interno.

REGALI, M.S.P. \& GONZAGA, S.M. - 1985 - Palinocronoestratigrafia da Bacia Potiguar. In: CONGR. BRAS. PALEONT., 8, Rio de Janeiro. Coletânea de Trabalhos Paleont. p.443-460. (MME-DNPM, Brasília. Série Geologia, n.27, Seção Paleont. e Estrat., n.2).

REGALI, M.S.P. \& VIANA, C.F. - 1986 - Sedimentos do Neojurássico Eocretáceo do Brasil e a escala cronoestratigráfica internacional. Rio de Janeiro. PETROBRÁS/CENPES/DIVEN. 35p. Relatório interno.

REGALI, M.S.P. \& VIANA, C.F. - 1988 - Sedimentos do NeojurássicoEocretáceo do Brasil: idade e correlação com a escala internacionalPETROBRÁS/SEDES. Pré-print.

REGALI, M.S.P. \& VIANA, C.F. - 1989 - Sedimentos do NeojurássicoEocretáceo do Brasil: idade e correlação com a escala internacional. Edição bilingüe - Rio de Janeiro, PETROBRÁS/SEDES. 59p. (Distribuição restrita.)

REGALI, M.S.P.; UESUGUI, N. \& LIMA, E.C. - 1985 - Palinoestratigrafia da Bacia de Barreirinhas. In: CONGR. BRAS. PALEONT., 8, Rio de Janeiro. Coletânea de Trabalhos Paleont. p.461-470. (MME-DNPM, Brasília. Série Geologia, n. 27, Seção Paleont. e Estrat., n.2).

REGALI, M.S.P.; UESUGUI, N. \& SANTOS, A.S. - 1973 - Palinologia dos sedimentos meso-cenozóicos do Brasil. Salvador. PETROBRÁS/RPBA. 2v., n.1632, Relatório interno. 
REGALI, M.S.P.; UESUGUI, N. \& SANTOS, A.S. -1974a- Palinologia dos sedimentos meso-cenozóicos do Brasil. I. Bol. Téc. Petrobrás, v.17, n.3, p.177-190.

REGALI, M.S.P.; UESUGUI, N. \& SANTOS, A.S. - 1974b- Palinologia dos sedimentos meso-cenozóicos do Brasil. II. Bol. Téc. Petrobrás, v.17, n.4, p.263-301.

REINECK, H.E. \& SINGH, I.B. - 1980 - Depositional sedimentary environments: - with reference to terrigenous clastics. New York, SpringerVerlag, 2 ed. 549p.

REISER, R.F. \& WILLIAMS, A.J. - 1969 - Palynology of the Lower Jurassic sediments of the northern Surat Basin, Queensland. Geol. Surv. Queensland, Brisbane, p.1-24. Palaeont. Pap., 15 (Queensland, 339).

REISSINGER, A. - 1950 - Die "Polienanalyse" ausgedehnt auf alle Sedimentgesteine der geologischen Vergangheit, II. Palaeontog. Abt. B, Stuttgart, v.90, p.99-126.

REMAC - 1977 - Mapa batimétrico da plataforma submarina brasileira. (PETROBRÁS/DNPM/CPRM/DHN/CNPQ), v.5. Rio de Janeiro. Escala 1: 5.000.000.

RETALLACK, G.J. \& DILCHER, D.L. - 1986 - Cretaceous angiosperm invasion of North America. Cretaceous Res., London, n.7, p.227-252.

REYRE, Y. - 1964 - Première contribution à l'étude des spores et pollens du Secondaire Saharien. Rev. Micropaléont., Paris, v.6, n.4, p.196-210.

REYRE, Y. - 1966 - Palynologie du Crétacé moyen du Sahara tunisien. Rev. Micropaléont., Paris, v.9, n.1, p.3-18.

REYRE, Y. - 1968 - Précisions sur la structure et la morphologie des prépollens du genre de forme Classopollis (Pflug) Pocock \& Jansonius. Conséquences paléobotanique et stratigraphique. C. R. Acad. Sc., Paris, n.266, sér.D, p.12331235.

REYRE, Y. - 1970 - Stereoscan observation on the pollen genus Classopollis. Palaeontology, London, v.13, n.2, p.303-321.

REYRE, Y. - 1973 - Palynologie du Mesozoïque saharien. Mem. Mus. nat. Hist. nat., Paris, sér.C, n.27, p.1-284.

REYRE, Y.; KIESER, G. \& PUJOL, C. - 1970 - Intérêt stratigraphique de quelques espèces du genre Classopollis (Pflug) Reyre. Rev. Micropaléont., Paris, v.13, n.3, p.146-154. 
RICH, F.J.; KUEHN, D. \& DAVIES, T.D. - 1982 - The paleoecological significance of Ovoidites. Palynol., Dallas, v.6, p.19-28.

RICHELOT, C. \& STREEL, M. - 1985 - Transport et sedimentation du pollen par les courants aériens, fluviatiles et marins à Calvi (Corse). Pollen et Spores, Paris, v.27, n.3-4, p.349-364.

RODRIGUES, R. \& FRANÇOLIN, J.B.L. - 1983 - Avaliação geoquímica preliminar da Bacia Potiguar terrestre. Rio de Janeiro. PETROBRÁS/CENPES. 67p. Relatório interno.

ROLIM, J.L. \& MABESOONE, J.M. - 1982 - Um modelo de grande rio para as bacias rift do Recôncavo-Tucano-Jatobá (Purbeckiano-Aptiano, Nordeste do Brasil). In: CONGR. BRAS. GEOL, 32, Salvador 1982. Anais..., Salvador, SBG, v.4, p.1406-1412.

ROMANS, R.C. - 1975 - Palynology of some Upper Cretaceous coals of Black Mesa, Arizona. Pollen et Spores, Paris, v.17, n.2, p.273-330.

ROSS, N.E. - 1949 - On a Cretaceous pollen and spore-bearing clay deposit of Scania. Geol. Inst. Uppsala Univ. Bull., Uppsala, v.34, p.25-43.

ROUSE, G.E. - 1959 - Plant microfossils from Kootenay coal-measures strata of British Columbia. Micropaleont., New York, v.5, p.303-324.

ROUSE, G.E. - 1962 - Plant microfossils from Burrad Formation of Western British Columbia. Micropaleont., New York, v.8, p.187-218.

ROUSE, G.E. \& SRIVASTAVA, S.K. - 1972 - Palynological zonation of Cretaceous and Early Tertiary rocks of the Bonnet Plume Formation, Northeastern Jukon, Canada. Can. Journ. Earth Sci., Otawa, v.9, p.1163-1179.

RULL, V. - 1987 - A note on pollen counting in palaeoecology. Centro de Ecologia y Ciencias Ambientales. I.VI.C., Caracas, v.29, n.4, p.471-480.

SAAD, S.I. - 1978 - Palynological studies in the Egyptian Western Desert: Umbarka IX Borehole. Pollen et Spores, Paris, v.20, n.25, p.261-301.

SAAD, S.I. \& GHAZALY, G. - 1976 - Palynological studies in Nubia Sandstone. Pollen et Spores, Paris, v.18, n.3, p.407-470.

SAH, S.C.D. - 1967 - Palynology of an Upper Neogene profile from Rusizi Valley (Burundi). Ann. Mus. R. Afr. centr. Sci. Geol., Tervuren, n.57, 173p. (sér.8). 
SALARD-CHEBOLDAEFF, M. \& DEJAX, J. - 1991 - Evidence of Cretaceous to Recent.West African intertropical vegetation from continental sediment sporepollen analysis. Journ. of African Earth Sci., Elmsford, v.12, n.1-2, p.353361.

SAMPAIO, A.V. \& NORTHFLEET, A. - 1973 - Estratigrafia e correlação das bacias sedimentares brasileiras. In: CONGR. BRAS. GEOL., 27, Aracaju 1986. Anais..., Aracaju, SBG, v.3, p.189-206.

SAMPAIO, A.V. \& SCHALLER, H. - 1968 - Introdução à estratigrafia cretácea da Bacia Potiguar. Bol. Téc. Petrobrás, Rio de Janeiro, v.11, n.1, p.19-44.

SANTOS, A.S. \& UESUGUI, N. - 1967 - Distribuição de esporomorfos na Bacia Potiguar. Maceió. PETROBRÁS/RPNE, 15p. Relatório interno.

SARJEANT, W.A.S. - 1970 - The genus Spiniferites Mantell, 1850 (Dinophyceae). Grana, Stockholm, v.10, p.74-78.

SARJEANT, W.A.S. \& DOWNIE, C. - 1966 - The classification of dinoflagellate cysts above generic level. Palynol., Dallas, v.6, p.503-527.

SARJEANT, W.A.S. \& DOWNIE, C. - 1974 - The classification of dinoflagellate cysts above generic level: a discussion and revision. In: SAH, S.C.D. \& CROSS, A.T. (eds.) SYMP. STRAT. PALYNOL., BIRBAL SAHNI INST., The Palaeobotanist, Spec. Publ., Lucknow, n.3, p.9-32.

SATO, S. - 1961 - Pollen analysis of carbonaceous matter from the Hakoduchi Group in the Emdbetsu District, Northern Hokkaiodo, Japan. Palynological study on Cretaceous sediments. Geol. Miner.,Hokkaido, v.11, n.1, p.77-93. (Journ. Fac. Sci. Hokkaido Univ. Ser., IV).

SAVIN, S. - 1977 - The history of the Earth's surface temperature during the past 100 million years. Ann. Rev. Earth Planet. Sci., Palo Alto, v.5, p.319-355.

SCHALLER, H. - 1969 - Revisão estratrigráfica da Bacia Sergipe/Alagoas. Bol. Téc. Petrobrás, Rio de Janeiro, v.12, p.21-86.

SCHEIHING, M. \& PFEFFERKORN, H.W. - 1984 - The taphonomy of land plants in the Orinoco Delta: a model for incorporation of plant parts in clastic sediments of Late Carboniferous age of Euramerica. Rev. Palaeobot. Palynol., Amsterdam, v.41, n.2, p.205-240.

SCHRANK, E. - 1987 - Biostratigraphic importance of microfloras from the Late Cretaceous clastic series of Northwestern Sudan. Cretaceous Res., London, n.8, p.29-42. 
SCHRANK, E. - 1991 - Mesozoic palynology and continental sediments in NE Africa (Egypt and Sudan) - a review. Journ. of African Earth Sci., Elmsford, v.12, n.1-2, p.363-373.

SCHULZ, E. - 1966 - Über einige neue Sporae dispersae aus dem älteren Mesophyticum Deutschlands. Geologie, Berlin, v.15, n.55, p.130-151.

SCHULZ, E. - 1967 - Sporenpaläontologische Untersuchungen rätoliassischer Schichten im Zentralteil des Germanischen Beckens. Paläont. Abh. B, Berlin, v.2, n.3, p.544-633.

SCOTT, L. - 1960 - Pollen of Ephedra from the Chinle Formation (Upper Triassic) and the genus Equisetosporites. Micropaleont., New York, v.6, n.3, p.271-276.

SCOTT, L. - 1976 - Palynology of Lower Cretaceous deposits from the Alagoas Basin (Republic of South Africa). Pollen et Spores, Paris, v.18, n.4, p.563-610.

SELLEY, R.C. - 1972 - Ancient sedimentary environments. Science Paperbacks. 2. ed. $287 \mathrm{p}$.

SELLEY, R.C. - 1976 - Subsurface environment analysis of North Sea sediments. AAPG. Bull., Tulsa, v.60, n.2, p.184-195.

SENANT, J. \& POPOFF, M. -1989 - Les bassins du Rio do Peixe (NE Brésil): extension intracontinentale crétacée et réactivation des grands cisaillements ductiles pan-africains. C.R. Acad. Sci., Paris, t.308, p.1613-1619, sêr.II.

SHANE, J.D. - 1984 - The palynology, biostratigraphy and paleoecology of the Umiat Delta Complex (middle Albian - early Cenomanian) North Slope, Alaska. Arizona State University. Arizona, 360p. Ph. D. Thesis.

SHEFFY, M.V. \& DILCHER, D.L. - 1971 - Morphology and taxonomy of fungal spores. Palaeontog. Abt. B, Stuttgart, v.133, n.1-3, p.34-51.

SINGH, C. - 1964 - Microflora of the Lower Cretaceous Mannville Group, eastcentral Alberta. Res. Council Alberta Bull., Edmonton, n.15, 239p.

SINGH, C. - 1971 - Lower Cretaceous microfloras of the Peace River area, northwestern Alberta. Res. Council Alberta Bull., Edmonton, v.28, n.1-2. 540p.

SINGH, C. - 1975 - Stratigraphic significance of early angiosperm pollen in the mid-Cretaceous strata of Alberta. Geol. Assoc. Can., Toronto, n.13, p.365-389. Spec. Paper.

SINGH, C. - 1983 - Cenomanian microfloras of the Peace River area, northwestern Alberta. Res. Council Alberta Bull., Edmonton, v44, 322p. 
SINGH, H.P. - 1966 - Reappraisal of the mioflora from the Jabalpur series of India with remarks on the age of of the beds. The Palaeobotanist, Lucknow, v.15, n.1-2, p.87-92.

SINGH, H.P. - 1969 - On some species of Rouseisporites Pocock occuring in the Jabalpur Series (Lower Cretaceous) of India.The Palaeobotanist, Lucknow, v.18, p.8-11.

SIRKIN, L.A. - 1974 - Palynology and stratigraphy of Cretaceous strata in Long Island, N.Y. and Block Island, R.I. Journ. Res. U.S. Geol. Surv., New York, v.2, n.4, p.431-440.

SKARBY, A. - 1964 - Revision of Gleicheniidites senonicus Ross. Acta Univ. Stockholm., Uppsala, n.11, p.59-77.

SMILEY, C.J. - 1966 - Cretaceous floras from Kuk River area, Alaska: stratigraphic and climatic interpretations. Geol. Soc. Amer. Bull., Boulder, v.77, p.1-14.

SMITH, A.H.V. \& BUTTERWORTH, M.A. - 1987 - Miospores in the coal seams of the Carboniferous of Great Britain. Spec. Pap. Palaeont., London, n.1, p.1-324.

SOLE DE PORTA, N. - 1972 - Palinología de la Formación Cimarrona (Maastrichtiense) en el Valle Médio del Magdalena, Colombia. Studia Geol., Salamanca, n.4, p.103-143.

SOLIMAN, H.A. - 1975 - Spores and Pollens rencontrés dans le forage $n^{\circ} 8, E 1$ Kharga, désert d'Ouest (Egypte). Rev. Micropaléont., Paris, v.18, n.1, p.5357.

SOPPER, R.H. - 1913 - Geologia e suprimento d'agua subterrânea do Rio Grande do Norte e Paraiba. Bol. IFOCS, Insp. Obras Contra Secas. n.26, sér.ID, (2 ed.), p.1-62.

SOUZA, S.M. - 1982 - Atualização da litoestratigrafia da Bacia Potiguar. In: CONGR. BRAS. GEOL., 31, Florianópolis 1982. Anais..., Florianópolis, SBG (Impresa Oficial do Estado), p.2392-2406.

SPICER, R.A. - 1980 - The importance of depositional sorting to the biostratigraphy of plant megafossils. In: DILCHER, D.L. \& TAYLOR, T.N. (eds.). Biostratigraphy of fossils plants. Dowden, Hutchinson \& Ross, Inc. Pennsylvania, p.171-183.

SPICER, R.A. - 1981 - The sorting and deposition of allochthonous plant material in a modern environment at Silwood Lake, Silwood Park, Berkshire, England. U.S. Geol. Surv. Prof. Pap, New York, n.1143, p.1-77. 
SRIVASTAVA, S.K. - 1966 - Upper Cretaceous microflora (Maastrichtian) from Scollard, Alberta, Canada. Pollen et Spores, Paris, v.8, n.3-4, p.497-552.

SRIVASTAVA, S.K. - 1967 - Palynology of Late Cretaceous mammal beds, Scollard, Alberta, (Canada). Palaeogeog. Palaeoclimatol. Palaeoecol., Amsterdam, n.46, p.1485-1490.

SRIVASTAVA, S.K. - 1968 - Ephedralean pollen from the Upper Cretaceous Edmonton Formation of Alberta (Canada) and their paleoecological significance. Can. Journ. Earth Sci., Ottawa, n.5, p.211-221.

SRIVASTAVA, S.K. - 1969 - Some angiosperm pollen from the Edmonton Formation (Maestrichtian), Alberta, Canada. Journ. Sen Memorial, Calcutta. In: Journ. Sen Mem. Committ. \& Bot. Soc. Bengal., p.47-67. Spec. Publ.

SRIVASTAVA, S.K. - 1970 - Pollen bioestratigraphy and paleoecology of the Edmonton Formation (Maastrichtian), Alberta, Canada. Palaeogeogr. Paleoclimatol. Palaeoecol., Amsterdam, n.7, p.221-276.

SRIVASTAVA, S.K. - 1971 - Monolete spores from the Edmonton Formation (Mastrichtian), Alberta, Canada. Rev. Palaeobot. Palynol., Amsterdam, v.11, n.3-4, p.251-265.

SRIVASTAVA, S.K. - 1972a - Systematic description of some spores from the Edmonton Formation (Mastrichtian), Alberta, Canada. Palaeontog. Abt. B, Stuttgart, v.139, n.1-4, p.1-46.

SRIVASTAVA, S.K. - 1972b - Some spores and pollen from the Paleocene Oak Hill Member of the Naheola Formation, Alabama (USA). Rev. Palaeob. Palynol., Amsterdam, n.14, p.217-285.

SRIVASTAVA, S.K. - 1975 - Microspores from the Fredericksburg Group (Albian) of the southern United States. Paleobiol. Continent., Montpellier, v.6, n.2, p.1-119.

SRIVASTAVA, S.K. - 1976a - Biogenic infection in Jurassic spores and pollen. Geosci. and Man, Baton Rouge, n.15, p.95-100.

SRIVASTAVA, S.K. - 1976b - The fossil pollen genus Classopollis. Lethaea, Norway, Oslo, n.9, p.437-457.

SRIVASTAVA, S.K. - 1977 - A new fossil pollen genus Rutihesperipites. Pollen et Spores, Paris, v.19, n.4, p.531-543.

SRIVASTAVA, S.K. - 1984 - Barremian dinoflagellate cysts from southeastern France. Cahiers de Micropaléont., Paris, n.2, p.3-90. 
STAFLEU, F.A.; BONNER, C.E.B.; MACVAUGH, R.; MEIKLE, R.D.; ROLLINS R.C.; ROSS, R.; CHOPF, J.M.; SCHULZE, G.M.; VILMORIN, R. \& VOSS, E.G. - 1978 - International Code of Botanical Nomenclature. Bohn, Scheltema, and Holkema, Utrecht. 457 p. (Adopted by the XII International Botanical Congress, Leningrad, July, 1975.)

STANLEY, E.A. - 1965 - Upper Cretaceous and Paleocene plant microfossils and Paleocene dinoflagellates and hystrichosphaerids from northwestern South Dakota. Bull. Amer. Paleont., Ithaca, v.49, n.222, p.179-384.

STAPLIN, F.L.; POCOCK, S.A. \& JANSONIUS, J. - 1967 - Relationships among gymnospermous pollen. Rev. Palaeobot. Palynol., Amsterdam, v.3, n.1-4, p.297-310.

STEEVES, N.W. \& BARGHOORN, E.S. - 1959 - The pollen of Ephedra. Journ. Arnold Arbor., Boston, v.40, n.3, p.221-225.

STEEVES, N.W. \& WILKINS, L.R. - 1967 - Spores and pollen from the Lower Cretaceous of Saskatchewan, Canada. Can. Journ. Bot., Ottawa, n.45, p.2329-
2365 .

STONE, J.F. - 1973 - Palynology of the Almond Formation (Upper Cretaceous), Rock Springs Uplift, Wyoming. Bull. Amer. Paleont., Ithaca, n.64, p.1-135.

STOUGH, J.B. - 1968 - Palynomorphs from South America. Univ. Kansas Paleont. Contrib., Topeka, n.5, p.1-11.

STOVER, L.E. - 1962 - Taurucosporites, a new trilete spore genus from the Lower Cretaceous of Maryland. Micropaleont., Columbia, v.8, n.1, p.55-59.

STOVER, L.E. - 1963 - Some Middle Cretaceous palynomorphs from West Africa. Micropaleont., Columbia, v.9, n.1, p.85-94.

STOVER, L.E. - 1964a - Comparison of three Cretaceous spore-pollen assemblages from Maryland and England. In: Palynology in Oil exploration. Amer. Ass. Petrol. Geol. Spec. Publ., Tulsa, n.11, p.143-152.

STOVER, L.E. - 1964b - Cretaceous ephedroid pollen from West Africa. Micropaleont., Columbia, v.10, n.2, p.145-156.

SUDENE - 1966 - Mapa hidrogeológico preliminar da Bacia Potiguar. Recife.

SULTAN, I.Z. - 1986 - Palynology of Albian-Cenomanian strata in Mersa Matruh well, western Desert, Egypt. Journ. of African Earth Sci., Elmoford, v.6, n.5, p.665-675. 
SZATMARI, P.; CONCEIÇÃO, J.C.J.; LANA, M.S.; MILANI, E.J. \& LOBO, A. P. - 1984 - Mecanismo tectônico do rifteamento sul-atlântico. In: CONGR. BRAS. GEOL., 33, Rio de Janeiro 1984. Anais..., Rio de Janeiro, SBG, v.4, p.1529-1601.

SZATMARI, P.; FRANÇOLIN, J.M.B.; ZANOTTO, O. \& WOLFF, S. - 1987 Evolução tectônica da margem equatorial brasileira. Rev. Bras. Geoc., São Paulo, v.17, n.2, p.180-188.

TAKAHASHI, K. - 1974 - Palynology of the Upper Aptian Tanohata Formation of the Miyako Group, Northeast Japan. Pollen et Spores, Paris, v.16, n.4, p.535-564.

TASCH, P. - 1980 - Paleobiology of the invertebrates: data retrieval from the fossil record. New York, Wiley, (2 ed.), 975p.

TAUGOURDEAU - LANTZ, J. - 1974 - Palynologie et dérive des continents au Trias. Bull. Sci. Geol., Strasbourg, v.27, n.1-2, p.59-67.

TEIXEIRA, L.B. - 1990 - Reinterpretação sísmica do "3D" da área de Pescada e adjacências. Rio de Janeiro. PETROBRÁS/DIRNOE/SECEPO. 12p. Relatório interno.

THIEGART, E. - 1949 - Der stratigraphische Wert mesozoicher Pollen und Sporen. Palaeontog. Abt. B, Stuttgart, v.89, n.1-3, p.1-34.

THOMPSON, G.G. - 1969 - Paleoecology of palynomorphs in the Mancos Shale, southwestern Colorado. Geology Michigan State University, East Lansing. 200p. Ph. D. Thesis.

THOMSON, P.W. \& PFLUG, H. - 1953 - Pollen und Sporen des mitteleuropäischen Tertiärs. Gesamtübersicht über die stratigraphisch und paläontologisch wichtigen Formen., Palaeontog. Abt. B, Stuttgart, v.94, n.1-4, p. $1-138$.

TIBANA, P. \& TERRA, G.J.S. - 1981 - Sequências carbonáticas do Cretáceo na Bacia Potiguar. Bol. Téc. Petrobrás, Rio de Janeiro, v.24, n.3, p.174-183.

TILL, R. - 1978 - Arid shorelines: In: READING, H.G. (ed.). Sedimentary environments and facies. Oxford, Blackwell Scientific Publ. p.178-208.

TOKUNAGA, S. - 1958 - Palynological study on Japanese coal II. Rep. Geol. Surv. Japan, Hisamato, n.181, p.1-50.

TRALAU, H. - 1968 - Botanical investigation into the fossil flora of Eriksdal in Fyledalen, Scania. III. The Middle Jurassic microflora. Sverig. Geol. Undersökn., Stockholm, n.633, p.1-185. (sér.C.). 
TRAVERSE, A. - 1955 - Occurrence of the oil forming alga Botryococcus in lignites and other Tertiary sediments. Micropaleont., Columbia, n.1, p.343350.

TRAVERSE, A. - 1957 - The nomenclatural problem of plant microfossil species belonging to extant genera. Micropaleont., Columbia, v.3, n.3, p.255-258.

TRAVERSE, A. - 1982 - Response of world vegetation to Neogene tectonic and climatic events. Alcheringa, Sydney, n.6, p.197-209.

TRAVERSE, A. \& GINSBURG, R.N. - 1966 - Palynology of the surface sediments of Great Bahama Bank, as related to water moviment and sedimentation. Marine Geol., Amsterdam, n.4, p.417-459.

TREVISAN, L. - 1980 - Ultrastructural notes and considerations on Ephedripites, Eucommiidites and Monosulcites pollen grains from Lower Cretaceous sediments of southern Tuscany (Italy). Pollen et Spores, Paris, v.22, n.1, p.85-132.

TREVISAN, L. - 1988 - Angiospermous pollen (monosulcate-trichotomosulcate phase) from the very early Lower Cretaceous of Southern Tuscany (Italy): some aspects. In: INTERNAT. PALYNOL. CONGR., 7, Brisbane, Abstr..., p.165.

TRYON, R.M. \& TRYON, A.F. - 1982 - Ferns and allied plants with special references to tropical America. New York. Springer-Verlag, Berlin, Heidelberg, 857 p.

TROELSEN, J.C. - 1967 - Zonas concorrentes, baseadas na amplitude local aproximada de ostracoides diagnósticos, seção não marinha, bacias de Sergipe e Alagoas. Maceio, PETROBRÁS/RPNE. Relatório interno, n.30292/67, $47 \mathrm{p}$.

TSCHUDY, B.D. - 1973 - Palynology of the upper Campanian (Cretaceous) Judith River Formation, North-central Montana. U. S. Geol. Surv. Prof. Paper, Reston, n.770, 42p.

TSCHUDY, R.H. - 1961 - Palynomorphs as indicators of facies environments in Upper Cretaceous and Lower Tertiary strata, Colorado and Wyoming. Wyoming Geol. Assoc. Guidebook, 16. Laramie Ann. Field Conf., p.53-57.

TSCHUDY, R.H. - 1969a - Applied Palynology. In: TSCHUUY, R.H. \& SCOTT, R.A., (eds.). Aspects of Palynology. New York. p.103-126.

TSCHUDY, R.H. - 1969b - Relationship of palynomorphs to sedimentation. In: TSCHUDY, R.H \& SCOTT, R.A., (eds.). Aspects of Palynology. New York. p.79-96.

TSCHUDY, R.H. \& SCOTT, R.A. - 1969 - Aspects of Palynology. New York. Wiley Interscience, USA. p.1-510. 
UESUGUI, N. - 1979 - Palinologia - Técnicas de tratamento de amostras. Bol. Téc. Petrobrás, Rio de Janeiro, v.22, n.4, p.229-240.

UESUGUI, N. - 1987 - Posição estratigráfica dos evaporitos da Bacia de SergipeAlagoas. Rev. Bras. Geoc., São Paulo, v.17, n.2, p.131-134.

UESUGUI, N. \& DINO, R. - 1989 - Amplitude vertical de Exesipollenites tumulus Balme nos sedimentos cretácicos do Brasil. Bol. Geoc. Petrobrás, Rio de Janeiro, v.3, n.1-2, p.123-124.

UPCHURCH, G.R. \& DOYLE, J.A. - 1981 - Paleoecology of the conifers Frenelopsis and Pseudofrenelopsis (Cheirolepidiaceae) from the Cretaceous Potomac Group of Maryland and Virginia. In: ROMANS, R.C.(ed). Geobotany II. New York. , Plenum, p.167-202.

UPSHAW, C.F. - 1959 - Ocurrence of Aequitriradites in the Upper Cretaceous of Wyoming. Micropaleont., Columbia, v.9, n.4, p.427-431.

USSAMI, N.; GAREY, D.K. \& BOTT, M.H.P. - 1986 - Crustal detachment during South Atlantic rifting and formation of Tucano-Gabon basin system. Nature, New York, v.332, n.6080, p.629-632.

VAGVOLGY, A. \& HILLS, L.V. - 1969 - Microflora of the Lower Cretaceous McMurray Formation, northeast Alberta. Bull. Can. Petrol. Geol., Calgary, v.17, n.2, p.155-181

VAIL, P.R.; MITCHUM, R.M. \& THOMPSON, S. III - 1977 - Seismic stratigraphy and global changes of sea level. Part 4: Global cycles of relative changes of sea level. In: AAPG Mem. - Seismic Stratigraphy - Applications to Hydrocarbon Exploration, Tulsa, n.26, p.83-97.

VAKHRAMEEV, V.A. - 1964 - Jurassic and Early Cretaceous floras of Eurasia and the palaeofloristic provinces of this period. Trudy Geol. Inst. Akad. Nauk. SSSR, Moscow, n.102.

VAKHRAMEEV, V.A. - 1970 - Range and paleoecology of Mesozoic conifers. The Cheirolepidiaceae. Paleont. Journ., New York, v.4, n.1, p.11-25.

VAKHRAMEEV, V.A. - 1978 - The climates of the northern hemisphere in the Cretaceous in the light of paleobotanical data. Paleont. Journ., New York, n.2, p.3-17.

VAN AMEROM, H.W.J. - 1965 - Upper Cretaceous pollen and spores assemblages from the so-called "Wealden" of the province of Leon (Northern Spain). Pollen et Spores, Paris, v.7, n.2, p.93-133. 
VAN CAMPO, M. \& SIVAK, J. - 1972 - Structure alvéolaire de l'ectexine des pollens à ballonets des Abiétacées. Pollen et Spores, Paris, v.14, n.2, p.115141.

VAN DER HAMMEN, T. - 1954 - The development of Colombian flora throughout geological periods. I. Maestrichtian to Lower Tertiary. Bol. Geol., Bogotá, v.2, n.1, p.49-106.

VAN DER HAMMEN, T. - 1956 - Nomenclatura palinológica sistemática. Bol. Geol., Bogota, v.4, n.2-3, p.23-62.

VAN DER HAMMEN, T. \& BURGER, D. - 1966 - Pollen flora and age of the Takutu Formation (Guyana). Leidse Geol. Med., Leiden, n.38, p.173-180.

VAN DER HAMMEN, T. \& WIJMSTRA, T.A. - 1964 - A palynological study on the Tertiary and Upper Cretaceous of British Guiana. Leidse Geol. Med., Leiden, n.30, p.183-241.

VAN DER ZWAN, C.J. - 1990 - Palyńostratigraphy and palynofacies reconstruction of the Upper Jurassic to lowermost Cretaceous of the Draugen Field, offshore mid Norway. Rev. Palaeobot. Palynol., Amsterdam, v.62, n.1-2, p.157-186.

VAN ERVE, A.W. - 1977 - Palynological investigation in the Lower Jurassic of the Vicentinian Alps (Northeastern Italy). Rev. Palaeobot. Palynol, Amsterdam, v.23, n.1, p.1-117.

VAN HINTE, J.E. - 1976 - A Cretaceous time scale. Am. Assoc. Petrol. Geol. Bull., Tulsa, v.60, n.3, p.498-516.

VAN HOEKEN-KLINKENBERG, P.M.J., - 1964 - A palynological investigation of some Upper Cretaceous sediments in Nigeria. Pollen et Spores, Paris, v.6, n.1, p.209-231.

VAN KONIJNENBURG-VAN CITTERT, J.H.A. - 1971 - In situ gymnosperm pollen from the Middle Jurassic of Yorkshire. Acta Bot. Neerl., v.20, n.1,
p.1-96.

VAN WAGONER, J.C.; POSAMENTIER, H.W; MITCHUM, R.M, Jr.; VAIL, P.R. SARG, J.F.; LOUTIT, T.S. \& HARDENBOL, J. - 1988 - An overview of the fundamentals of sequence stratigraphy and key definitions. In: WILGUS, C. et.alii. (eds.). Sea Level Changes: an integrated approach. SEPM.Spec. Publ., Houston, n.42, p.227-247.

VARMA, C.P. \& RAWAT, M.S. - 1963 - A note on some diporate grains from Tertiary horizons of India and their potential marker value. Grana Palynol:, Stockholm, n.4, p.130-139. 
VENKATACHALA, B.S. - 1966 - Mesozoic operculate pollen and their morphology. The Palaeobotanist, Lucknow, v.15, n.1-2, p.98-101.

VENKATACHALA, B.S. - 1968 - Palynology of the Mesozoic sediments of Kutch4. Spores and pollen from the Bhuj exposures near Bhuj Gujarat District. The Palaeobotanist, Lucknow, v.17, n.2, p.209-219.

VENKATACHALA, B.S. \& KAR, R.K. - 1968 - Psilospora gen. nov., a new fossil pollen genus from the Mesozoic rocks of Kutch, W. India. Cur. Sci., Middletown, n.37, p.442-443.

VENKATACHALA, B.S.; KAR, R.K. \& RAZA, S. - 1969a - Palynology of the Mesozoic sediments of Kutch, India; 3 -Morphological study and revision of the spore genus Trilobosporites Pant ex Potonie, 1956. The Palaeobotanist, Lucknow, v.17, n.1, p.123-126.

VENKATACHALA, B.S.; KAR, R.K. \& RAZA, S. - 1969b - Palynology of the Mesozoic sediments of Kutch, India; 5 -Spores and pollen from Katrol exposures near Bjuj, Kutch District, Gujarat State. The Palaeobotanist, Lucknow, v.17, n.2, p.184-207.

VENKATACHALA, B.S.; SHARMA, K.D. \& JAIN, A.K. - 1972 - Palynological zonation of Jurassic-Lower Cretaceous sediments in the subsurface of the Cauvery Basin. In: GHOSH, A.K., et alii (eds.). SEM. PALEOPAL. AND IND. STRAT., Calcutta 1971. Proceedings..., p.172-187.

VIANA, C.F. - 1966 - Correspondência entre os ostracodes das Séries Cocobeach (Gabão) e Bahia (Brasil). Bol. Téc. Petrobrás, Rio de Janeiro, v.9, n.3-4, p.367-382.

VIANA. C.F. - 1986 - Evolução paleoambiental eocretácica nas bacias marginais do Brasil. In: CONGR. BRAS. GEOL., 34, Goiânia 1986. Anais..., Goiânia, SBG, v.1, p.1-7.

VIANA, C.F.; GAMA Jr, E.G.; SIMÃO, I.A.; MOURA, J.A.; FONSECA, J.R. \& ALVES, R.J. - 1971 - Revisão estratrigráfica da Bacia Recôncavo/Tucano. Bol. Téc. Petrobrás, Rio de Janeiro, v.14, n.3-4, p,157-192.

VIVIERS, M.C. \& REGALI, M.S.P. - 1987 - Estudo paleoambiental do Cretáceo da Bacia Potiguar. Rev. Bras. Geoc., São Paulo, v.17, n.2, p.123-130.

VOLKHEIMER, W. - 1971 - Algunos adelantos en la microbioestratigrafia del Jurásico en la Argentina y comparación con otras regiones del hemisfério austral. Ameghiniana, Buenos Aires, v.8, n.3-4, p,341-355.

VOLKHEIMER, W. - 1972 - Estudio palinológico de un carbón caloviano de Neuquén y consideraciones sobre los paleoclimas jurásicos de la Argentina. Rev. Mus. La Plata Paleont., Buenos Aires, v.6, n.40 p.101-157. 
VOLKHEIMER, W. - 1973 - Palinología del Jurásico de la Sierra de Chacai Có y adyacencias (Cuenca Neuquina, Republica Argentina). I. Estratigrafia de las formaciones Sierra Chacai Co (Pliensbachiano), Los Molles (Toarciano, Aaleniano), Cura Niyeu (Bayociano) y Lajas (Caloviano inferior). Ameghiniana, Buenos Aires, v.10, n.2, p.105-131.

VOLKHEIMER, W. - 1974 - Palinología del Jurássico de la Sierra de Chacai Co y adyacencias (Cuenca Neuquina, Republica Argentina). II. Descripción de los palinomorfos del Jurásico Inferior y Aaleniano (Formaciones Sierra Chacaicó y Los Molles). Ameghiniana, Buenos Aires, v.11, n.2, p.135-172.

VOLKHEIMER, W. \& QUATTROCCHIO, M. - 1974 - Palinologia estratigráfica del Titoniano del área de Caichique (Cuenca Neuquina). Parte A: Espécies terrestres. Ameghiniana, Buenos Aires, v.12, n.3, p.193-241.

VOLKHEIMER, W. \& SALAS, A. - 1975 - The oldest angiosperm palynoflora in Argentina from the type locality of the Lower Cretaceous Huitrin Formation, Neuquen Basin. Microfloristic association and biostratigraphic significance. Neues Jahrb. Geol. Paläeont., Monatsh., Stuttgart, n.7, p.424-436.

WALKER, J.W. - 1984 - Facies models. 7. Shallow marine sands. In: WALKER, R.G. Facies Models, Geological Assoc. of Canada, Toronto, p.75-90 (Geocience Canada Repr. Series).

WALKER, J.W. \& DOYLE, J.A. - 1975 - The bases of angiosperm phylogeny: palynology. Ann. Missouri Bot. Gard., St. Louis, v.62, n.3, p.664-723.

WALKER, J.W. \& WALKER, A.G. - 1984 - Ultrastructure of Lower Cretaceous angiosperm pollen and the origin of early evolution of flowering plants. Ann. Missouri Bot. Gard., St. Louis, v.71, n.2, p.464-521.

WALL, D. - 1965 - Microplankton, pollen and spores from the Lower Jurassic in Britain. Micropaleont., Columbia, n.11, p.90-151.

WARD, J.V. - 1986 - Early Cretaceous angiosperm pollen from the Cheyenne and Kiowa Formations (Albian) of Kansas, U.S.A. Palaentog. Abt. B, Stuttgart, v.202, n.1-6, p.1-81.

WARD, J.V.; DOYLE, J.A. \& HOTTON, C.L. - 1989 - Probable granular magnoliid angiosperm pollen from the Early Cretaceous. Pollen et Spores, Paris, v.31, n.1-2, p.113-132.

WATSON, J. \& BATTEN, D.J. - 1990 - A revision of the English Wealden Flora, II. Equisetales. Bull. Br. Mus. Nat. Hist. (Geol), London, v.46, n.1, p.37-60.

WEYLAND, H. \& GREIFELD, G. - 1953 - Über strukturbietende Blätter und pflanzliche Mikrofossilien aus den untersenonen Tonen der Gegend von Quedlinburg. Palaeontog. Abt. B, Stuttgart, v.95, n.1-3, p.30-52. 
WHITE, A.C. - 1887 - Contribuição à paleontologia do Brasil. Arquivos do Museu Nacional, Rio de Janeiro, n.7, p.45-52.

WHITAKER, M.F. - 1984 - The usage of palynostratigraphy and palynofaceis in definition of Troll Field Geology. In: Offshore Northern Seas - Reduction of Uncertainties by Innovative Reservoir Geomodelling. Norsk Petroleumsforening, Oslo, Article G6, p.1-47.

WILLIANS, C.A. - 1984 - Palynology of Upper Cretaceous and Lower Tertiary strata from the Northern Raton Basin, South-Central Colorado. Boulder, University of Colorado. 269p. Ph. D. Thesis.

WILLIANS, G.L. \& BRIDEAUX, W.W. - 1975 - Palynologic analysis of Upper Mesozoic and Cenozoic rocks of the Grand Banks, Atlantic Continental Margin. Bull. Geol. Surv. Can., Ottawa, n.236, p.1- 164.

WILSON, L.R. - 1959a - Geologic history of the Gnetales. Oklahoma Geol. Notes, Tulsa, v.19, p.35-40.

WILSON, L.R. - 1959b - A method of determining a useful microfossil assemblage for correlation. Oklahoma Geol. Notes, Tulsa, v.24, n.6, p.138-143.

WILSON, M.A. - 1978 - Palynology of three sections across the uppermost Cretaceous/Paleocene boundary in the Yukon Territory and District of Mackenzie, Canada. Palaeontog. Abt. B, Stuttgart, v.166, n.4-6, p.99-183.

WILSON, L.R. \& WEBSTER, R.M. - 1946 - Plant microfossils from a Fort Union Coal of Montana. Am. Journ. Bot., Lancaster, v.33, n.4, p.271-278.

WINGATE, F.H. - 1980 - Plant microfossils from the Denton Shale Member of the Bokchito Formation (Lower Cretaceous, Albian) in southern Oklahoma. Oklahoma Geol. Surv. Bull., Norman, n.130, p.1-93.

WODEHOUSE, R.P. - 1933 - Tertiary pollen. II. The oil shales of the Eocene Green River Formation. Bull. Torrey Bot. Club., New York, n.60, p.479-524.

WODEHOUSE, R.P. - 1936 - Evolution of pollen grains. Bot. Rev., New York, v.2, n.1, p.67-84.

WOODS, R.D. - 1955 - Spores and Pollen - a new stratigraphic tool for the oil industry. Micropaleont., Columbia, n.1, p.368-375.

YUN, H.S. - 1981 - Dinoflagellaten aus der Oberkreide (Santon) von Westfalen. Palaeontog. Abt. B, Stuttgart, v.177, n.1-4, p.1-89. 


\section{INDICE DA SISTEMÁTICA}

Pág. Est. Fig.

圆

Aequitriradites sp. 1.............................................................................................. 165

Aequitriradites sp. 2.......................................................................................... 165

Afropollis sp. aff. A. jardinus Dorle, JARDINE \& DOERENKAMP................. 217

Afropollis jardinus (BRENNER) DoYLE, JaRdiNÉ \& DoERENKAMP................ 217

Afropollis operculatus DoYLE, JARDNE \& DOERENKAMP.............................. 217

Afropollis zonatus DoyLE, JaRdNÉ \& DoERENKAMP...................................... 218

Albertipollenites limae nov. sp.......................................................................... 228

Antulsporites sp. cf. A. baculatus ARCHANGELSKY \& GAMERRO.................. 161

Apiculatisporis laevis BALME \& HeNNELY..................................................... 144

Apiculatisporis sp. 1.......................................................................................... 144

Apiculatisporis sp. 2...................................................................................... 145

Appendicisporites sp.cf..A. insignis (MarKova) ChLonova..................... 164

Appendicisporites sp. 1...................................................................................... 164

Ȧraucariacites australis Cooxso N................................................................. 181

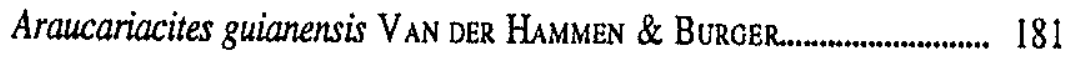

Araucariacites limbatus (BALME) $\mathrm{H}_{\mathrm{ABB}}$....................................................... 181

Auritulinasporites sp. 1........................................................................................ 163

B

Bennettitaepollenites regalii nov. sp............................................................... 204

Biretisporites potoniaei DeLCoURT \& SPRUMONT........................................... 138

Botryococcus braunii KUTZING.........................................................................133

Brenneripollis peroreticulatus (BRENAR) JUHASZ \& GOCZAN..................... 216

Brenneripollis reticulatus (BRENNER) DoYLE................................................. 216

C

Callialasporites dampieri (BALME) Dev........................................................ 174

Callialasporites lucidus (Pocock) ReYRe..................................................... 174

Callialasporites microvelatus Schulz........................................................... 175

Callialasponites minus (TRALAU) GUX...................................................... 175

Callialasporites segmentatus (BALME) SRIVASTAVA...................................... 175

Callialasporites triangularis (Levet-CARETTE) ReYRE.................................. 176

Callialasporites trilobatus (BALME) DEv..................................................... 174

Callialasporites turbatus (BALME) SchULZ.................................................... 176

Camarozonosporites sp. 1................................................................................. 158

$\begin{array}{rr}\text { VI } & 3,7 \\ \text { VI } & 9,10 \\ \text { XVII } & 5,8,9 \\ \text { XVII } & 1,2,4 \\ \text { XVII } & 7,12,13,15 \\ \text { XVII } & 10,11,18,19 \\ \text { XX } & 1-5 \\ \text { VIII } & 5,6,10,12,16 \\ \text { II } & 12,17 \\ \text { II } & 16,20 \\ \text { III } & 1 \\ \text { VIII } & 4 \\ \text { VIII } & 3,7 \\ \text { XII } & 1,2,3,13 \\ \text { XII } & 4,5 \\ \text { XII } & 6 \\ \text { VI } & 1\end{array}$

XVI

XVIII

$12,13,14$

XVIII

15,20

IX

$7,8,11$

IX

13,15

$\mathrm{X}$

$\mathrm{X}$

$\mathrm{X}$ 1 
Camarozonosporites sp. 2 .

Camarozonosporites sp.cf. C. insignis NorRIs......................................... 158

Cavamonocolpites punctatus LIMA

Cavamonocolpites sp. 1.

Cedripites cretaceus Pocock.

Chomotriletes almegrensis Pocock.

Chomotriletes fragilis Pocock

Cicatricosisporites avnimelechi HoRowrTz............................................... 147

Cicatricosisporites brevilaesuratus CovPER................................................ 148

Cicutricosisporites sp. cf. C. stemum VAN AMEROM............................... 149

Cicatricosisporites crassistriatus BURGER.................................................. 148

Cicatricosisporites microstriatus JARDINE \& MAGLOIRE............................. 148

Cicatricosisporites nuni HoROWIrZ....................................................... 149

Cicatricosisporites sp. 1..................................................................... 150

Cicatricosisporites sp. 2 .

Cicatricosisporites sp. cf. C. sp. 1. Lima................................................. 149

Cicatricososporites sp.cf. C. norrisii SRIVASTaVA.................................... 170

Cingulatipollenites sp.cf. C. aegyptiaca SAAD \& GHAZALY..................... 182

Cingutriletes sp.

Classopollis alexi BURGER.

Classopollis brasiliensis Herngreen.

Classopollis torosus (REISSINGER) COUPER.................................................. 187

Clavatipollenites hughesii COUPER............................................................ 207

Clavatipollenites minutus BRENNER....................................................... 207

Clavatipollenites tennelis PADEN-PHLLIPS \& FELX.................................... 207

Collarisporites sp. cf. C. fuscus DEÁk................................................. 155

"Complicatissacus" cearensis RegaLi......................................................... 177

Concavisporites sp. ReGal, UesUgu \& SANTOS......................................... 140

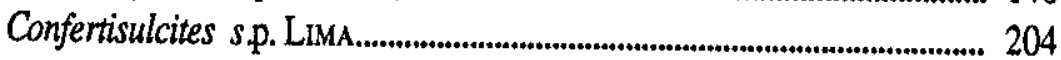

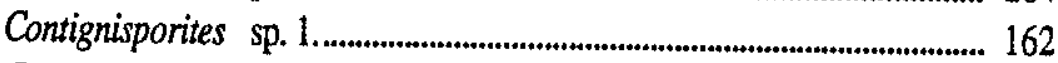

Converrucosisporites proxigranulatus BRENNER........................................ 144

Cornetipollis perforata (LMA) Nov. COMB................................................. 195

Corollaria annularis MALYAWKINA........................................................ 188

Cretacaeiporites polygonalis (JaRdné \& MAGLoIRE) HERNGREEN............ 235

Cribroperidinium intricatum DAVEY (sENSU HELENES, 1984)...................... 137

Crybelosporites brenneri PLAYFORD...................................................... 167

Crybelosporites pannuceus (BrenNeR) SRrvastava.................................. 167

Crybelosporites striatus (Cookson \& DetTMAN........................................ 167

Cupuliferoidaejollenites parvulus (GRoor \& PENNY) DetTMANN............. 220

Cyathidites australis COUPER.................................................................... 140

Cyathidites crassiangulatus BALME......................................................... 140

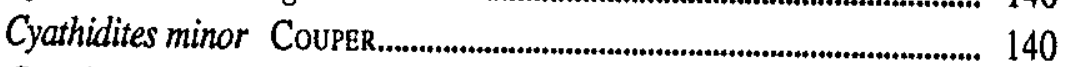

Cycadopites carpentieri (DelcourT \& SpRUMONT) SINGH.......................... 201

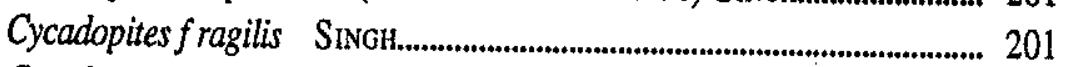

Cycadopites nitidus (BALME) DE JERSEY................................................... 201

$\begin{array}{rr}\text { V } & 16 \\ \text { V } & 19 \\ \text { XVIII } & 9,10 \\ \text { XVIII } & 7,8 \\ \text { X } & 21,24 \\ \text { IV } & 6,9 \\ \text { IV } & 10 \\ \text { IV } & 11,14,15 \\ \text { IV } & 7,8 \\ \text { IV } & 18 \\ \text { V } & 1 \\ \text { IV } & 16,17 \\ \text { IV } & 12,13 \\ \text { IV } & 3,4 \\ \text { IV } & 2 \\ \text { IV } & 5 \\ \text { IX } & 9 \\ \text { XII } & 9 \\ \text { VII } & 15,20 \\ \text { XIV } & 1 \\ \text { XIV } & 3 \\ \text { XIV } & 2 \\ \text { XVIII } & 1,6 \\ \text { XVIII } & 2,3,4 \\ \text { XVIII } & 5 \\ \text { VII } & 10,13,14 \\ \text { X } & 5,6,9 \\ \text { II } & 4 \\ \text { XVI } & 24 \\ \text { VII } & 19 \\ \text { III } & 6,9,10 \\ \text { XVI } & 5,8,16 \\ \text { XIV } & 4 \\ \text { XXI } & 15 \\ \text { XXI } & 20 \\ \text { VII } & 3,4,5 \\ \text { VI } & 2,6,8,12,13 \\ \text { VII } & 1,2 \\ \text { XIX } & 19 \\ \text { II } & 19,21 \\ \text { II } & 15 \\ \text { II } & 13,18 \\ \text { XVI } & 13 \\ \text { XVI } & 12 \\ \text { XVI } & \end{array}$


D]

Dejaxpollenites foveoreticulatus nov. sp...................................................... 202

Deltoidospora hallii MINER..................................................................... 139

Densoisporites dettmannae (SRrvasTaVA) DejaX........................................ 166

Dicolpado Indeterminado I.................................................................................. 219

Dicolpado (?) Indeterminado II....................................................................... 219

Diporisporites sp. 1............................................................................................. 130

Diporisporites sp. 2.......................................................................................... 131

Divisisporites Sp......................................................................................................... 141

E

Echinatisporis sp. aff. E. varispinosus (Pocock) SRIVASTAVA............... 146

Echinatisporis longechinus KRUTZSCH...................................................... 145

Echinatisporis varispinosus (Pococx) SRIVASTAVA...................................... 146

Elateropollenites dissimilis RegaLI............................................................... 189

Elateropollenites praecursor REGALI........................................................... 189

Equisetosporites albertensis SincH............................................................. 190

Equisetosporites ambiguus (HEDLuND) SinghL............................................ 190

Equisetosporites concinnus Sinch............................................................. 190

Equisetosporites dudarensis (DEAK) LMaA................................................. 191

Equisetosporites laticostatus LIMA................................................................. 191

Equisetosporites leptomatus L LMA................................................................. 191

Equisetosporites luridus Lima....................................................................... 191

Equisetosporites maculosus nov. sp............................................................. 193

Equisetosporites minuticostatus Lima............................................................ 192

Equisetosporites ovatus (PIERCE) SiNGH........................................................ 192

Equisetosporites sp. $=$ Ephedripites sp. $($ artefato) DejaX............................. 192

Esporo de Fungo Tipo A................................................................................. 129

Esporo de Fungo Tipo B .................................................................................. 130

Esporo Trilete Indeterminado......................................................................... 168

Eucommiidites sp. 2. LiMA.......................................................................... 200

Eucommiidites troedssonii (ERDTMaN) Hugues......................................... 200

Exesipollenites laevigatus Pocock................................................................ 234

Exesipollenites scabratus (CoupeR) Pocock............................................... 235

Exesipollenites tumulus BALME...................................................................... 234

$\begin{array}{rr}\text { XIX } & 1-10 \\ \text { II } & 11 \\ \text { II } & 5,6,9,14 \\ \text { VI } & 5,11,14 \\ \text { XIX } & 13,14,15 \\ \text { XIX } & 21 \\ \text { I } & 8 \\ \text { I } & 4 \\ \text { VII } & 9\end{array}$

$\begin{array}{rr}\text { III } & 2,3 \\ \text { III } & 8,11 \\ \text { XII } & 5 \\ \text { XVI } & 3,4,6,11 \\ \text { XIV } & 9 \\ \text { XIV } & 12 \\ \text { XIV /XV } & 5,8,11 \\ \text { XIV } & 23 / 5 \\ \text { XIV } & 19 \\ \text { XIV } & 13 \\ \text { XIV } & 10 \\ \text { XIV } & 14,25 \\ \text { XIV } & 7,9,15,16,17 \\ \text { XIV } & 6 \\ \text { XIV } & 21 \\ \text { I } & 24 \\ \text { I } & 1 \\ \text { V } & 2 \\ \text { XVI } & 23 \\ \text { XVI } & 10,21 \\ \text { XXI } & 15,18,20 \\ \text { XXI } & 6-8 \\ \text { XXI } & 4,5,9 \\ \text { XIV } & 1-3\end{array}$

[F

Foveosporites canalis BALME...................................................................... 154

Foveosporites sp. 1........................................................................................ 154

Foveosporites subtriangularis (BRENNER) PHULIPS \& FELXX....................... 154

Fragmento cuticular com estômatos.

$\begin{array}{rr}\mathrm{V} & 6,7 \\ \mathrm{~V} & 10 \\ \mathrm{~V} & 5 \\ \mathrm{XXII} & 11\end{array}$

(6)

Gleicheniidites senonicus (Ross) SKARBY. 
Gnetaceaepollenites barghoomii (Pocock) LIMA......................................... 196

Gnetaceaepollenites chlatratus STOVER........................................................ 196

Gnetaceaepollenites jansonii (Pococx) LimA

Gnetaceaepollenites mollis (SRrvastaVA) Lima

Gnetaceaepollenites retangularis LimA

Gnetaceaepollenites sp. 1

Gnetaceaepollenites uesuguii LIMA

Gnetaceaepollenites undulatus (REGAL, BT AL), LIMA

Gnetaceaepollenites spp

[?]

Hamulatisporis albertensis SRIVASTAVA

Hamulatisporis sp. 1

Hifa de Fungo 132

]

Inaperturopollenites giganteus GóczAN.. 179

Imaperturopollenites simplex REGALI, UESUGU \& SANTOS......................... 180

Inaperturopollenites turbatus BALME (SENSU REGALI ET AL.)...................... 180

Incertae sedis = Equisetosporites? sp................................................... 193

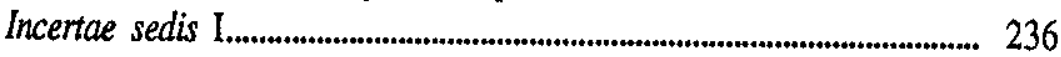

Incertae sedis II..................................................................................... 237

Incertae sedis III.

Incertae sedis IV.

$R$

Klikisporites foveolatus Pocock

Klukisporites pseudoreticulatus COUPER

Klukisporites variegatus COUPER

$\llbracket$

Laevigatosporites ovatus WILSON \& WEBSTER............................................ 168

Leptolepidites psarosus NoRRIS.

Leptolepidites verrucatus COUPER

M

Matonisporites silvai Lima

Matthesisporites sp. 1

Microfoveolatosporis daukiensis KAR \& SINGH

Microthallites sp.

Monocolpopollenites spheroidites JARDINE \& MAGLOIRE

Murospora sp. 1

(10)

Ovoidites sp.
XIV

XXII

XXII

XXII

$2-4,6,7,10$

V

VII 
P

Penetetrapites incipiens LM

Penetetrapites mollis HeDLund \& NoRris

Perotrilites sp. 1

Pilosisporites sp.

Pilosisporites trichopapillosus (ThIEGART) Delcourt \& SPRUMonT......... 146

Pluricellaesporites sp. cf. P. psilatus CLARKE......................................... 131

Poliplicado não Identificado....................................................................... 199

Properinopollenites sp. LIMA................................................................... 176

Psiladicolpites laevis REGALI................................................................. 218

Psiladicolpites papillatus REGALI.............................................................. 218

Psilatricolpites pachyexinus COUPER............................................................ 220

Pterodinium cingulatum (WETZEL) BELOW ................................................ 136

$\mathrm{XX}$

17,19

VI

III

XIX

XIX

XIX

(10)

圆

Regalipollenites amphoriformis (REGALI, ET AL.) LuMA............................. 199

Reticulosporis foveolatus (PIERCE) SKARBY............................................ 169

XVI

Retimonocolpites crassatus (SiNGH) SiNGH.

Retimonocolpites dividuus PIERCE.

Retimonocolpites excelsus WARD

Retimonocolpites fragilis PIERCE.

Retimonocolpites sp. (ReTTSULC-CAND-CROCHET SENSU HUGHES ET AL.).... 212

Retimonocolpites sp. 1

Retimonocolpites textus (NoRRIS) SINGH.

Retitriletes sp. cf. $R$. austroclavatidites (CoOKSON) KruTzsch................ 152

Reyrea polymorphus HERNGREen......................................................... 236

Rhodonascia sp. cf. $R$. bontei DEÁ.......................................................... 239

Rousea charma WARD..................................................................... 226

Rousea georgensis (BRENNER) DETTMANN................................................ 226

XVIII

XVIII

XVIII

XVIII

S

Schizosporis cooksoni Pocock.

Schizosporis scabratus STANLEY

Schweitzerisporites? sp.

Sergipea naviformis ReGaLI, Uesugur \& Santos.

Sergipea simplex REGALI.

Sergipea tenuiverrucata REGAL.

Sergipea variverrucata (ReGALI ET AL) REGALI........................................ 186

Singhia crenulata LIMA

Singhia elongata (HoRowTz) Lima.

Singhia multicostata (BRENNER) LIMA

Spheripollenites scabratus COUPER. 
Spheripollenites subgranulatus COUPER 184

Spiniferites multibrevis (DaveY \& Wllams) Lentin \& Wiluams........ 136

$\mathrm{XXI}$

Steevesipollenites sp. cf. S. binodosus STOVER 198

Steevesipollenites cupuliformis AZEMA \& BOLTHENHAGEN..

Stellatopollis araripensis LIMA 198

Stellatopollis barghoomii DoyLB

XVII

Stellatopollis densiomatus LIMA

XVII

16,17

XVII

Stellatopollis dubius (LMA) LIMA

XVII

Stellatopollis sp. 1. aff. $S$. sp. DoYLE ET AL.

Stellatopollis sp. 2

Striatopollis paraneus (NoRRsis) SNCH.

\section{9}

XVII

XVII

$\mathrm{XX}$

21,22

Striatopollis reticulatus (REGALI ET AL.) NOV. COMB.

Striatopollis sp. 1

T

Tetracolpites sp. 1....................................................................................... 230

Transitoripollis crisopolensis REGALI, NOV. СомB...................................... 214

Triangulopsis discoidalis DöRING............................................................... 182

Triangulopsis minor Pocock........................................................................ 182

Trichodinium castanea (DeflandRE) ClaRKE \& VerdiER......................... 137

Trichotomosulcites subgranulatus Couper....................................................... 229

Tricolpites micromunus (GROOT \& PeNNY) Singh.................................... 222

Tricolpites microreticulatus BELSKY ET AL................................................... 222

Tricolpites minutus (BRENNER) DetTMANN................................................... 224

Tricolpites sp. 1

Tricolpites vulgaris (PIERCE) SRIVASTAVA....................................................... 224

Tricolpites? sp. 2........................................................................................... 225

Trilobosporites apiverrucatus CoupeR........................................................ 159

Trilobosporites sp. cf. T. humilis Detcourt \& Sprumont...................... 159

Trilobosporites minor Pocock.

$\mathrm{XIX}$

XIX

XIX

XIX

(10)

Uesuguipollenites callosus nov. sp.

Undulatisporites undulapolus BRENNER.

(1)

Verrucatosporites chalonerii KREMP.

Verrucosisporites sp. 1

Verrucosisporites sp. 2

Verrucosisporites sp. 3

Vitreisporites microsaccus DE JERSEY.

Vitreisporites pustulosus REGALI. 


\section{ESTAMPAS}

São apresentadas a seguir 444 ilustrações do material analisado, distribuídas em 23 estampas. $O$ aumento das figuras pode variar levemente, em função da ampliação fotográfica. Visando minimizar este problema, principalmente no caso de cópias, utilizou-se escalas gráficas para comparação. Todas as figuras ilustradas foram aumentadas de aproximadamente $1000 \mathrm{X}$, exceto as indicadas na estampa XXII e todas as da estampa XXIII referente às palinofácies. Desse modo, o tamanho em $\mathrm{mm}$ do palinomorfo na fotografia corresponde exatamente ao tamanho em $\mu \mathrm{m}$ do espécimen original. Na estampa XXII, a escala situada na posição superior da estampa, refere-se apenas às figuras 1 e 5 , sendo a inferior válida para as demais.

Nas legendas das estampas, o nome da espécie é seguido de: a) uma explicação (quando necessária) da face focada e/ou do detalhe a ser ressaltado; b) o número da lâmina, da localização do palinomorfo na mesma, através das coordenadas do England Finder, e finalmente; c) a página de referência da espécie no capítulo da sistemática.

As lâminas estudadas, contendo os especimens ilustrados nesta tese, encontram-se depositadas nos arquivos palinológicos do Centro de Pesquisas e Desenvolvimento "LEOPOLDO A. MIGUEZ de MELLO" da PETROBRÁS (CENPES).

Os gêneros e espécies novos, bem como as novas combinações, aqui propostas, serão formalizadas em breve, quando da publicação dos dados desta tese. 


\section{ESTAMPA I}

FIGURA

PÁGINA

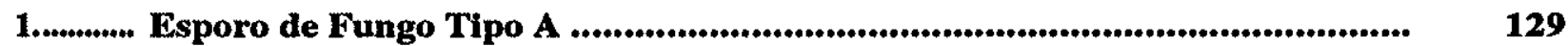

Lâm. TM5/09589, E49-3.

2............. Esporo de Fungo Tipo B Lâm. TM5/09589, T39-1.

3,9, 14. Botriococcus braunil KUTZNo Lâm. TM5/09589, H42-1 (fig. 3). Lâm. SO5/01902, F43-2 (fig. 9); F28-2 (fig. 10).

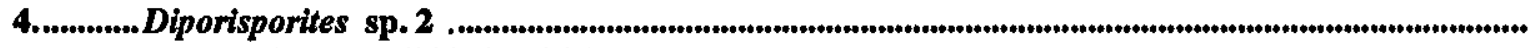
Lâm. TM5/000101, 025.

5-6. ........ Pluricellaesporites sp. c.. P.psilatus CLARKE Notar os septos bidentados caracteristicos. Lâm. TM5/000101, Z37-3 (fig. 5); T42-4 (fig. 6).

7............. Schizosporis scabratus Stanley Notar ornamentaçăo da exina. Lâm. CES7/02150, G26-3.

8............. Diporisporites $\mathrm{sp.} 1$ Lâm. FSM1/08841, P43.

10............ Microthallites sp

Exemplar com ostfolo bastante visível. Lâm. TM5/000101, 046-2.

11........... Schizosporis cooksoni Pocock Observar espessura da exina. Lâm. UB1/01887, E47.

12........... Hifa de Fungo Lâm. TM5/000101, N25-2.

13........... Ovoldites sp Observar ornamentação do grão. Lâm. RNS21/02480, Q42.

15............ Rhodonascia sp. \&. R. bontei DEÁK Lâm. RNS21/02787, K33-3. 


\section{I N 0,1992}
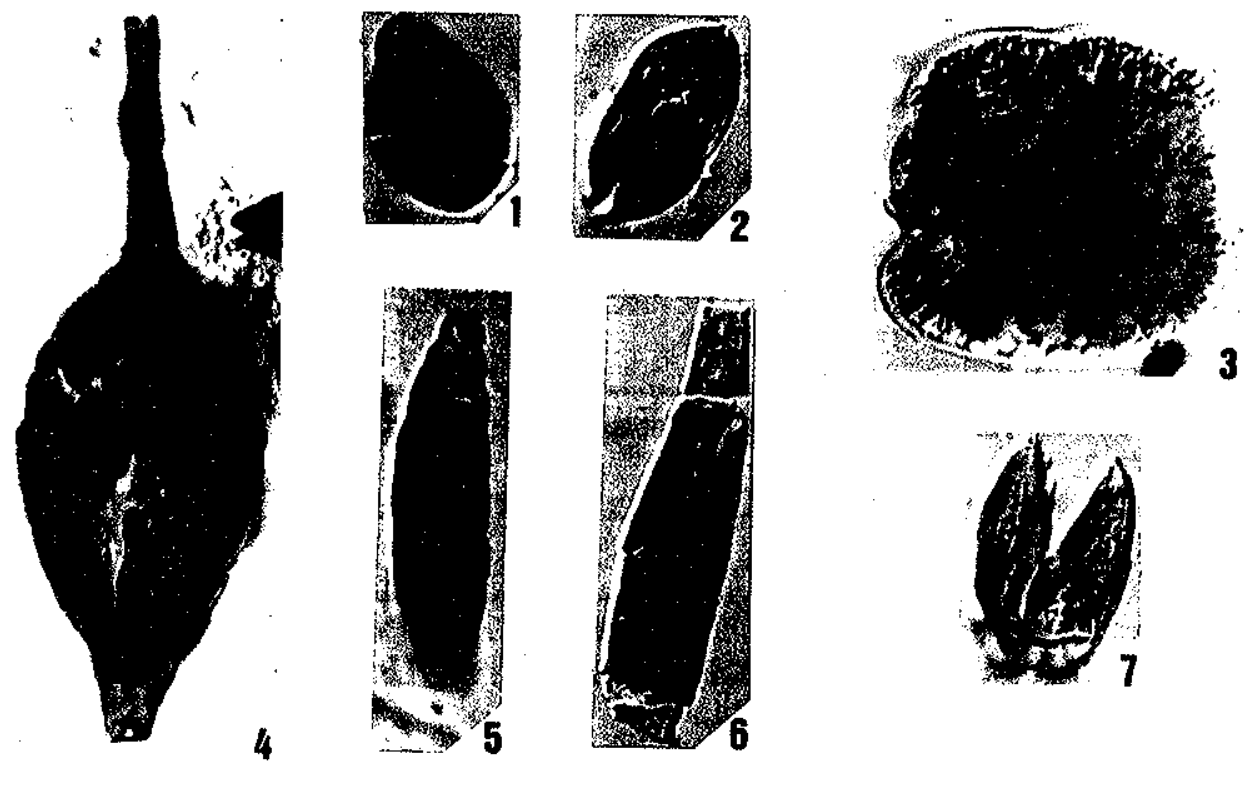

ESTAMPA I
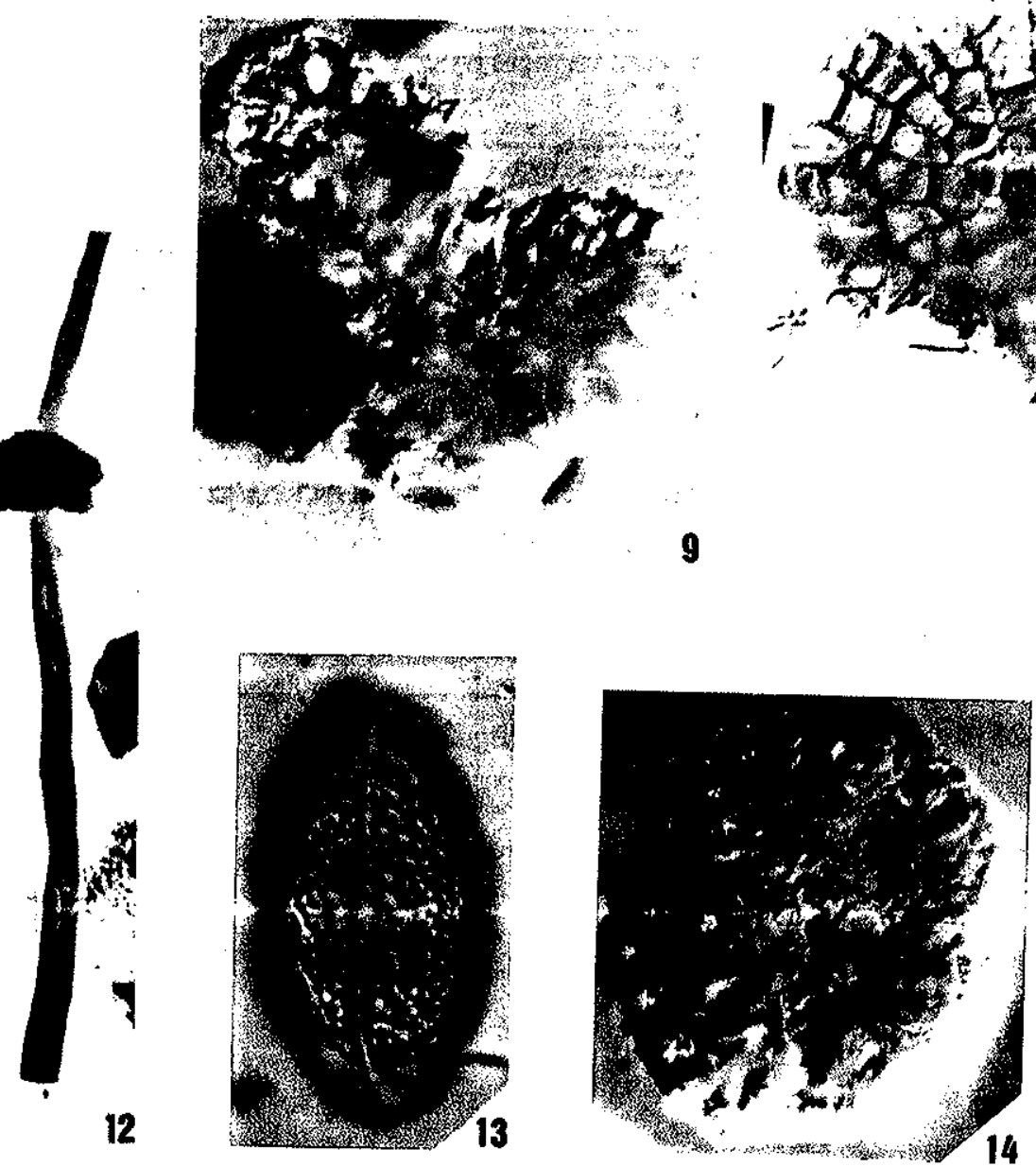
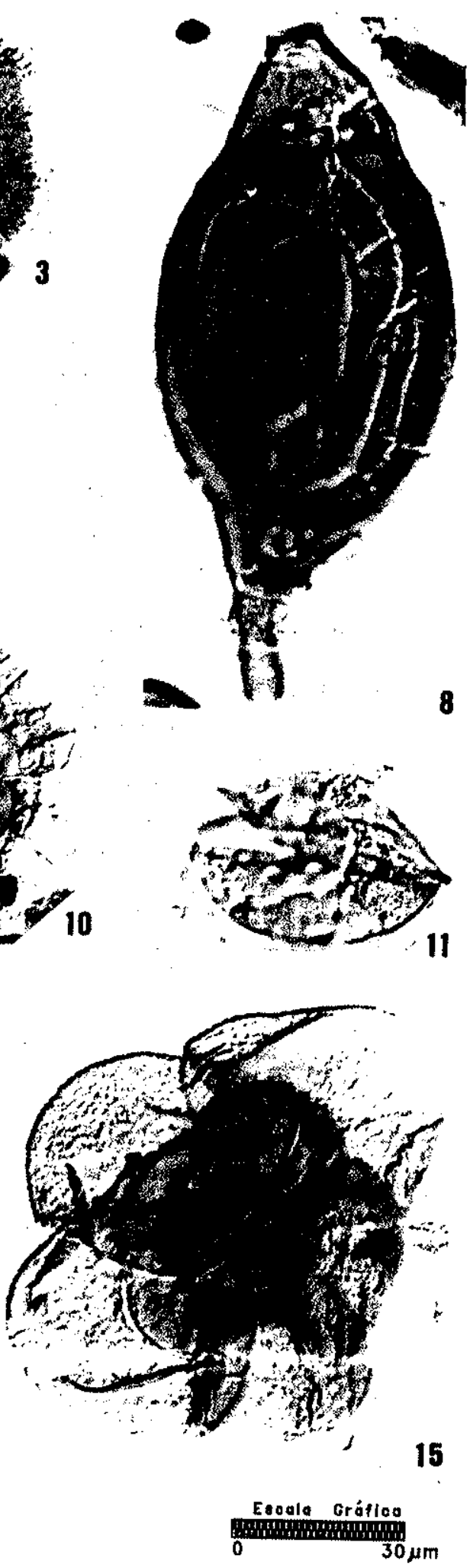


\section{ESTAMPA II}

FIGURA

PÁGINA

1, 2........ Biretisporites potoniaei DELCOURT \& SPRUMONT

Vista polar, evidenciando as lesuras com lábios elevados e espessados. Lâm. TM5/09589,

D65-2 (fig. 1); Lâm. SO5/01068, J30-1 (fig. 2).

3............. Undulatisporites undulapolus BRENNER Vista polar, onde são visiveis as ondulaçôes das laesuras, que definem o gênero. Lâm. RNS15/01905, E40-3.

4............ Concavisporites sp REOALI, UESUGUI \& SANTOS Lâm. NMR1/09775, E49.

5, 6, 9, 14.Deltoidospora juncta (KARA-MURZA) SwNGH

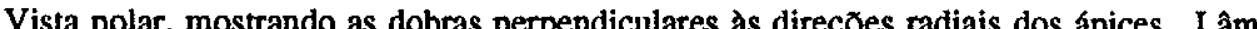
PD1/02151, W47-1 (fig. 5); Lâm. RNS21/02185, K33-2 (fig. 6); Lâm. NMR1/09769, E41-2 (fig. 9); Lâm. PD1/01058, F32-3 (fig. 14).

7, 8........ Leptolepidites verrucatus COUPER Lâm. SO5/1903, Z51 (fig. 7); F26 (fig. 8).

10.......... Leptolepidites psarosus NoRRus Vista polar. Observar omamentaçăo caracteristica, com verrugas proeminentes e irregulares. Lâm. PD1/02151, 032-4.

11.......... Deltoidospora hallit MNER Vista polar, evidenciando o contorno subtriangular arredondado. Lâm. FSM1/08842, M32.

12, 17.... Apiculatisporis laevis B ALME \& HeNNELY Notar laesuras pouco visíveis e espinhos curtos e esparsos. Lâm. NMR1/09769, B51-3 (fig. 12); Lâm. PD1/02151, ZA5 (fig. 17).

13, 18... Cyathidites minor Couper Lâm. SO5/01893, Q54-1 (fig. 13); Lâm. RNS21/02583,U42 (fig. 18).

15.......... Cyathidites crassiangulatus BALME O exemplar ilustrado mostra os pequenos espessamentos nos ápices, característicos do grão. Lâm. SO5/01893, W29.

16, 20.... Apiculatisporis sp. 1 . Notar laesuras longas e visíveis, espinhos esparsos. Lâm. BP1/02963, J45-3 (fig. 16); Lâm. CES7/02152, H35-2 (fig. 20).

19, 21.... Cyathidites australis COUPER

Lâm. RNS21/02583, L26 (fig. 19); Lâm. PD1/01057, P35-2 (fig. 21). 
D I N 0,1992
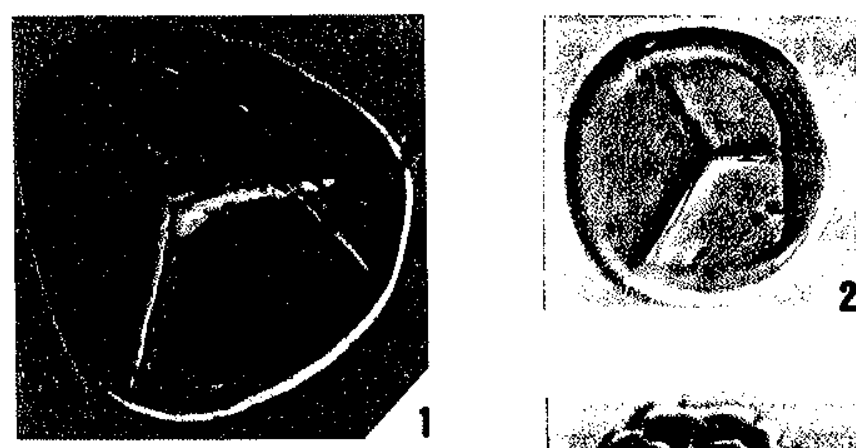

2
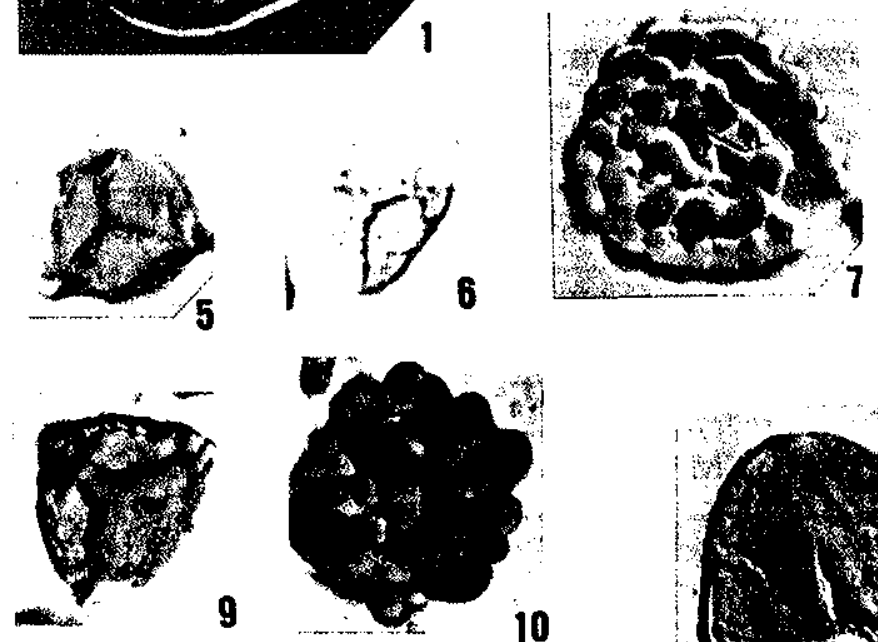

$\therefore 4$
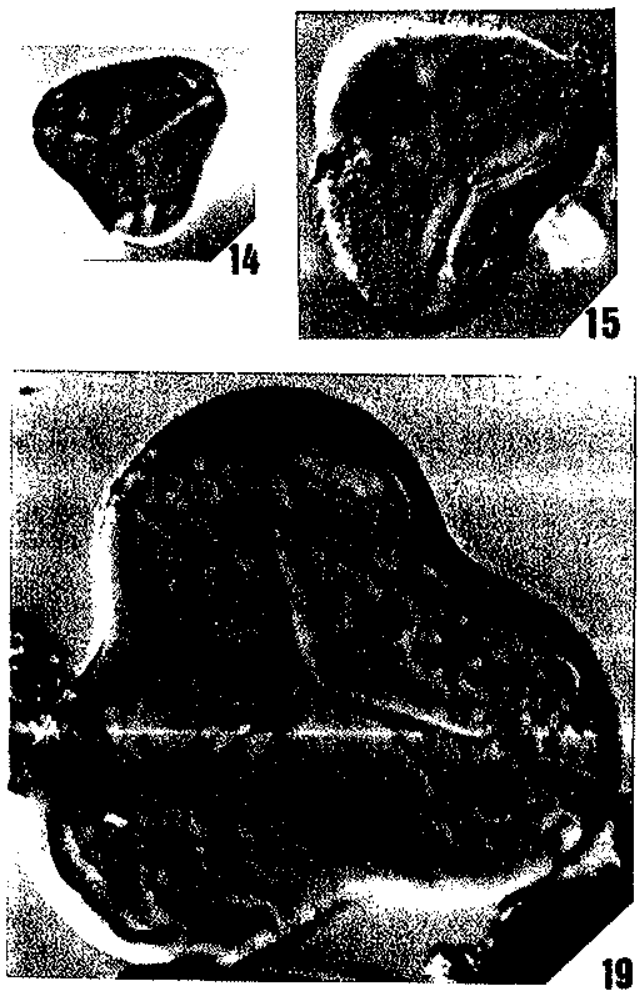

ESTAMPA II
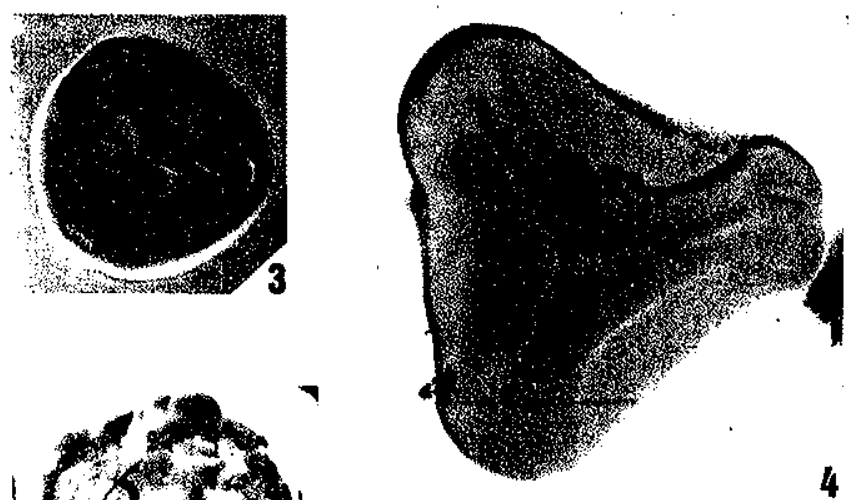

4
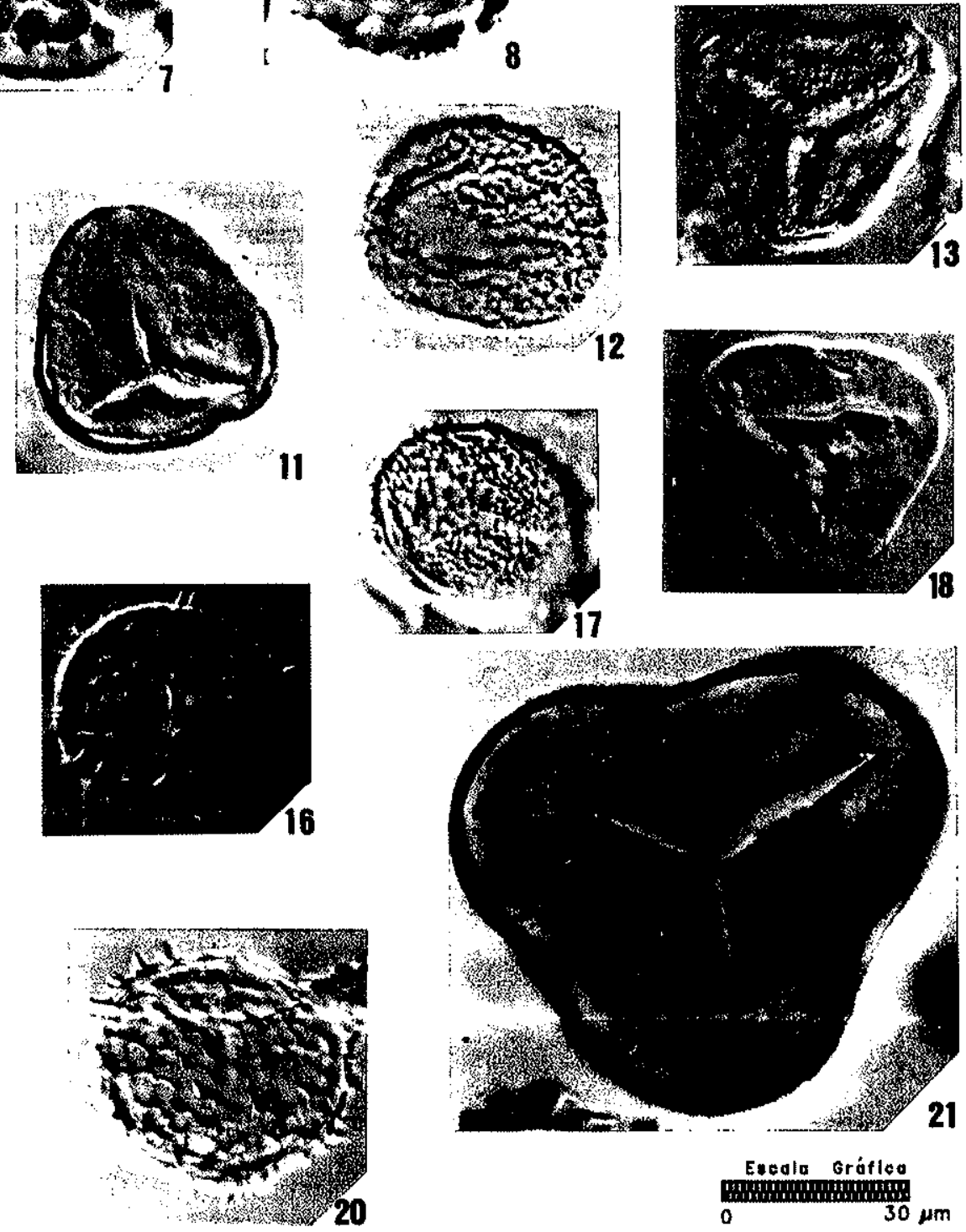


\section{ESTAMPA III}

FIGURA

PÁGINA

$1 . .00 .0 .0 .0$ Aplculatisporis sp. 2

Observar exina espessa e dimensơes do grăo e dos espinhos. Lâm. SO5/1894, K49-4.

2, 3....... Echinatisporis sp afi. E. varispinosus (Pocock) SRrvastava

Focos distintos, mostrando detalhes dos espinhos (bulbos). Lâm. TM5/000100, B41-1.

4............. Pilosisporites sp

Observar contorno do grăo e dimensōes dos espinhos. Lâm. PD1/02154, T53.

5............ Echinatisporis varispinosus (PocOCK) SRIVASTAVA .................................................. 146

Exemplar mostrando detalhes da ornamentação. Lâm. NMR1/09782, K38.

6, 9, 10. Converrucosisporites proxigranulatus BRENNER Lâm. SO5/1894, Q56-4 (fig. 6); Lâm. SO5/01900, W50-3 (figs. 9-10).

$7 . . .00 .0 .0$ Pilosisporites trichopapillosus (THEGART) DELCOURT \& SPRUMONT ...

Observar contorno e dimensőes. Lâm. TM5/000101, H50-2.

8, 11..... Echinatisporis longechinus KRUTZSCH .

Exemplares mostrando detalhes da omamentaçăo. Lâm. TM5/02670, R46-2 (fig. 8); Lâm. BP/02969, F45-1 (fig. 11). 


\section{DIN 0,1992}
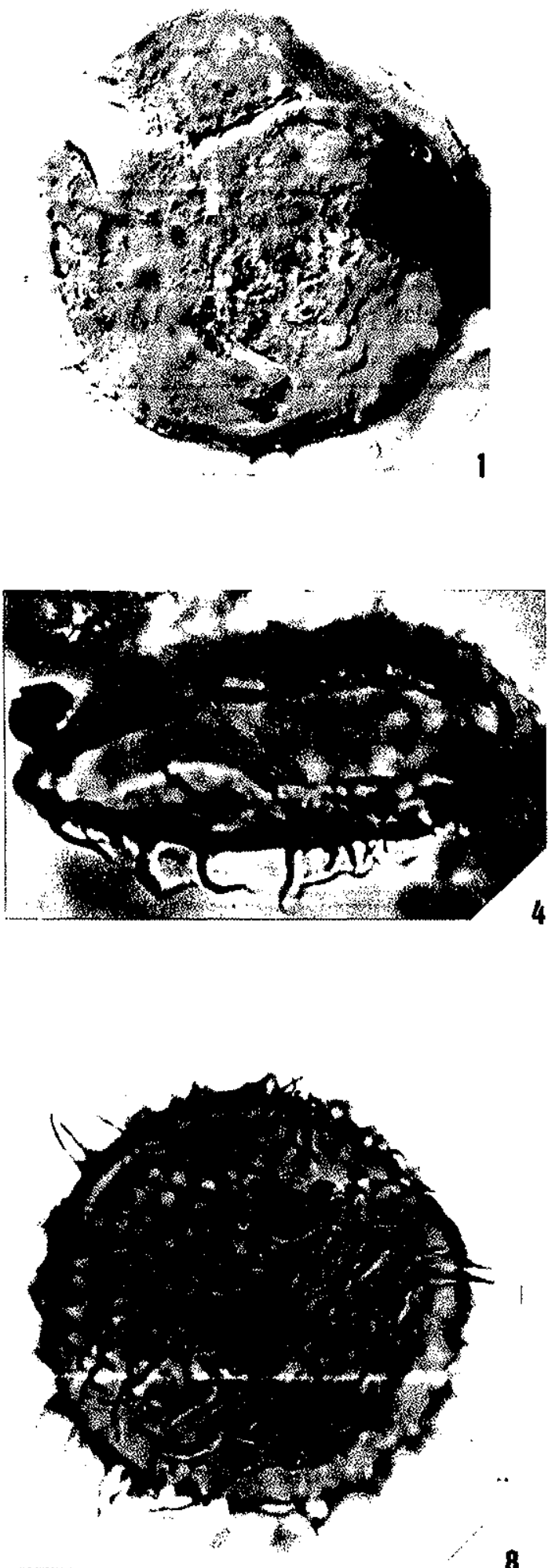

\section{ESTA MPA III}
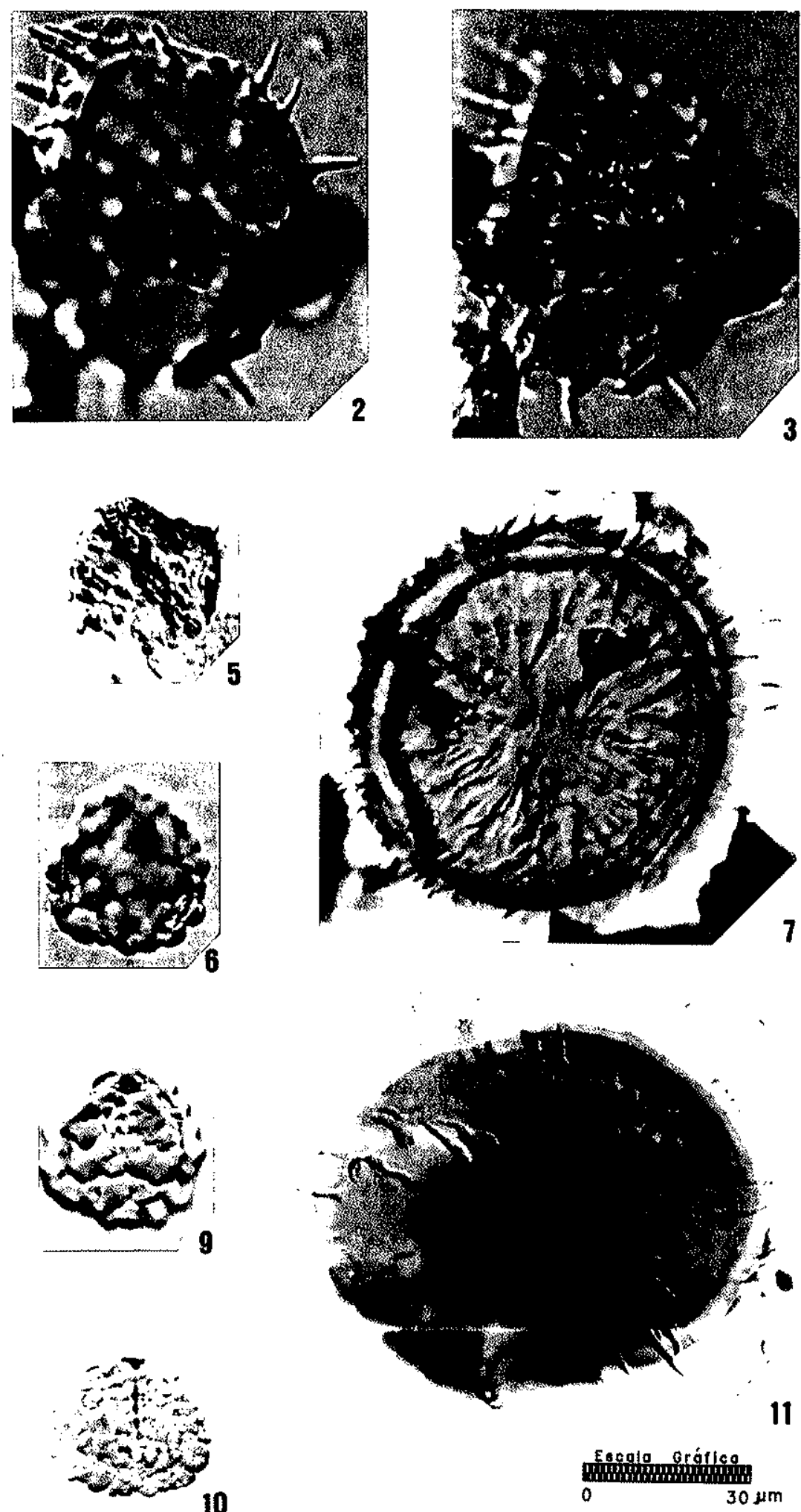


\section{ESTAMPA IU}

\section{FIGURA}

PÁGINA

1............. Verrucosisporites $\mathrm{sp} .1$

Vista proximal mostrando detalhes da ornamentação e sinuosidade das laesuras. Lâm. TM5/000101, G39-2.

2............. Cicatricosisporites sp. 2 . Vista polar, mostrando o contorno subtriangular e as costelas, poucas e grossas. Lâm. CES7/02156, H49.

3,4 ......... Cicatricosisporites sp. 1 Observar o arranjo das costelas na face proximal (fig. 4); detalhe da ornamentação na face distal (fig. 3). Lâm. NMR1/09772 C47-4.

5............. Cicatricosisporites sp. cf. C. sp. 1 LMA. Observar contorno, ornamentaçăo e leves espessamentos radiais. Lâm. BP1/02963, U23.

6, 9........ Chomotriletes almegrensis Pocock Notar exina espessa e ornamentação típica. Lâm. PM2/02932, P46 (fig. 6); Lâm. NMR1/09768, H49-4 (fig. 9).

7,8........ Cicatricosisporites brevilaesuratus COUPER Diferentes faces do mesmo exemplar. Notar o arranjo das costelas na face proximal (fig. 8) e detalhes da omamentaçăo na face distal (fig. 7). Lâm. NMR1/09782, K50-1.

10.......... Chomotriletes fragilis Pocock Observar a fraca ornamentação da especie. Lâm. SO5/01899, M36-3.

11, 14, 15. Cicatricosisporites avnimelechi HoROWIIZ Exemplares mostrando detalhes da ornamentação. Lâm. PD1/02151, K50-1 (fig. 11); Lâm. NMR1/09774, L35 (fig. 14); K30 (fig. 15).

12, 13.... Cicatricosisporites nuni HoRowTrZ Observar ornamentação. Lâm. CES7/02156, P46-3 (fig. 12); Lâm. FSM1/09797, F34-1 (fig. 13).

16, 17.... Cicatricosisporites microstriatus JARDINE \& MAGLORE Observar costelas bastante finas, que definem a espécie. Lâm. TM5/000101, K33 (fig. 16); Lâm. PM2/02931, P37-3 (fig. 17).

18........... Cicatricosisporites sp. cf. C. sternum VAN AMERON

Face distal. Observar detalhes da ornamentação e os leves espessamentos nos ápices. Lâm. SO5/1894, B34-2. 


\section{a}
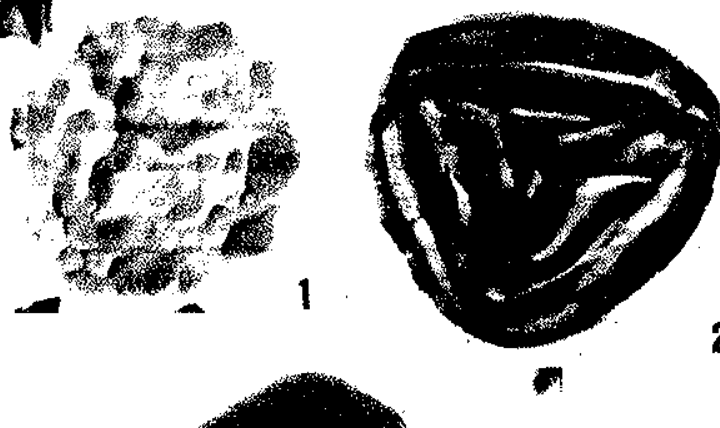

2
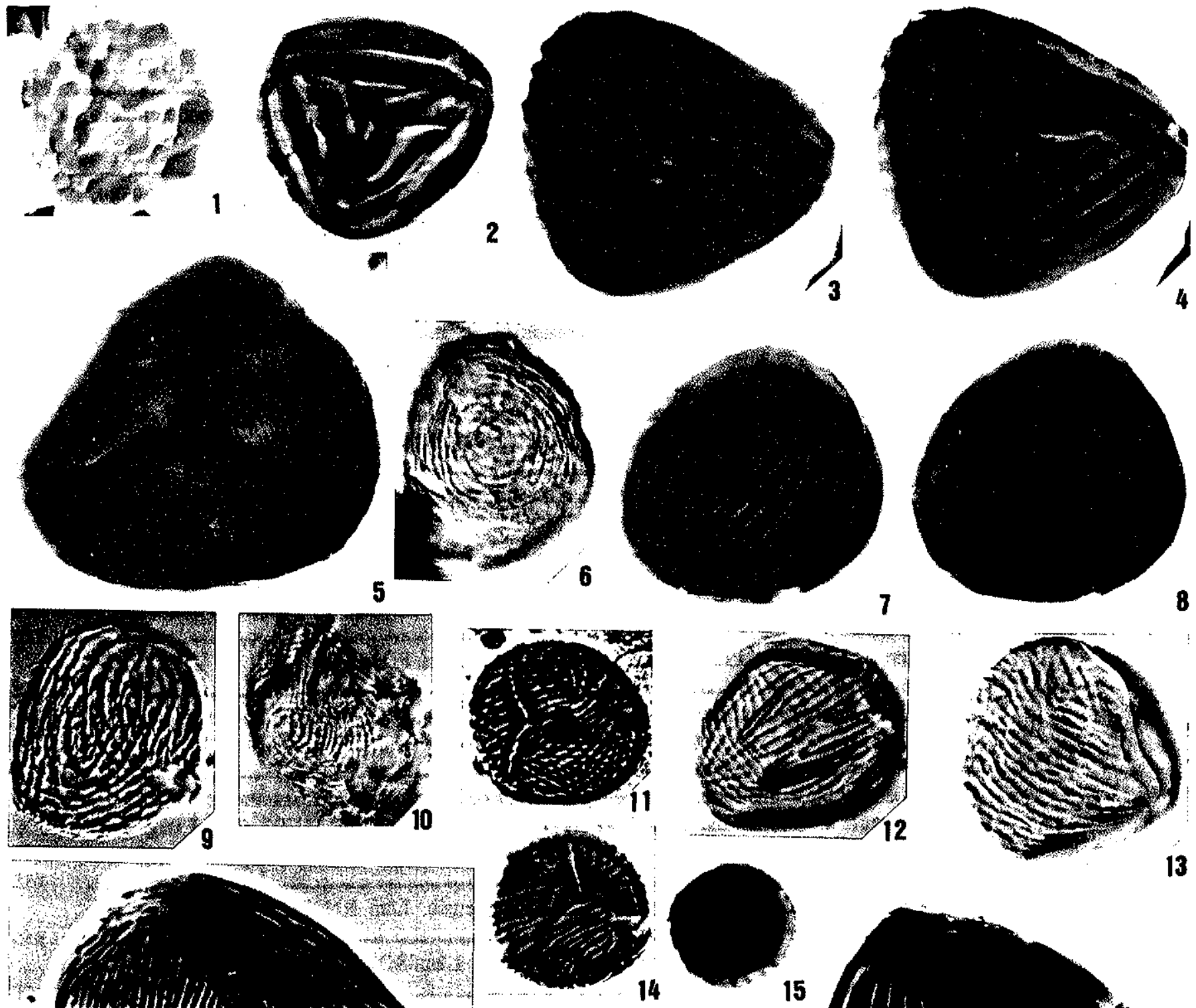

13
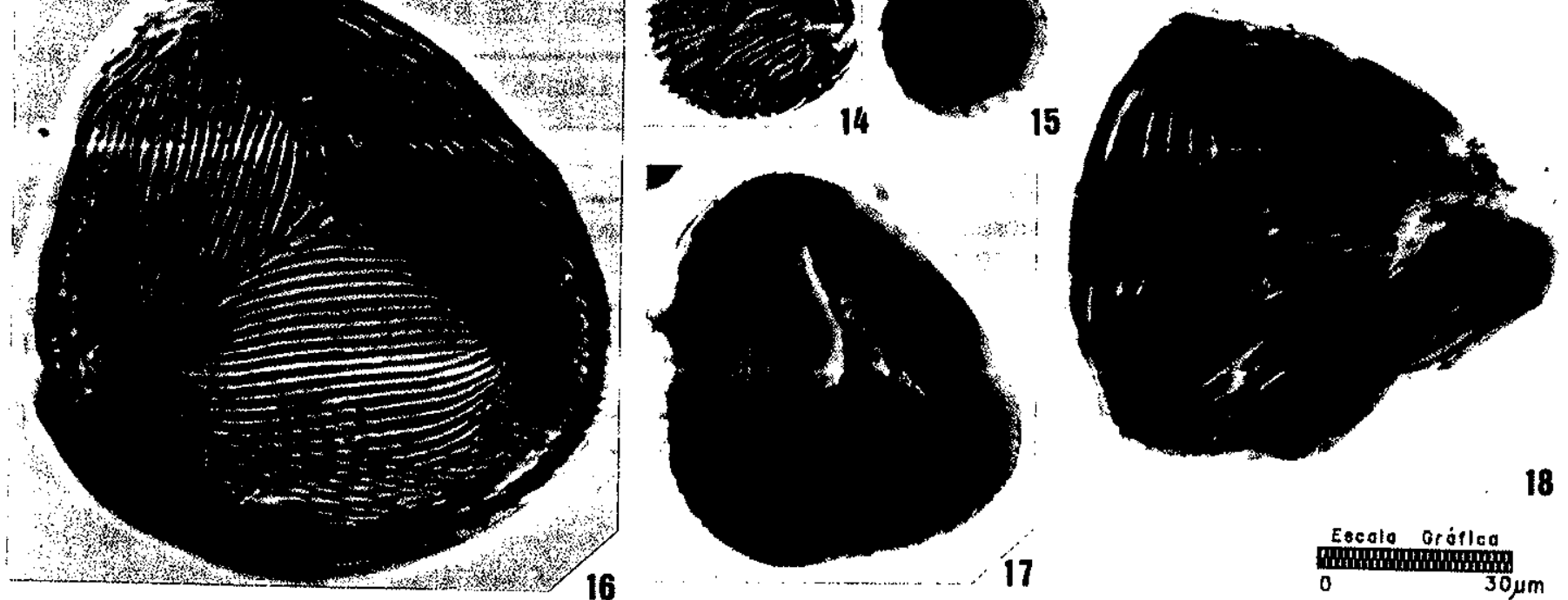


\section{ESTAMPA V}

FIGURA

PÁGINA

1............. Cicatricosisporites crassistriatus BURGER

Observar o padrão irregular das estrias na face distal e as estrias como um pseudo cingulo na regiăo equatorial. Lâm. CES7/01566, T41.

2, 3, 8.... Klukisporites pseudoreticulatus COUPER

Vista polar, onde nota-se detalhes do contorno e da ornamentaçao. Lâm. TM5/09589,

B43-1 (fig. 2). Lâm. O5/01900, P23-1 (fig. 3). Lâm. TM5/9589 P50-3 (fig. 8).

4............ Retitriletes sp. cf. R. austroclavatidites (CoOKSON) KRUTzSCH

Face distal, ressaltando a ornamentação reticulada. Lâm.TM5/09589, B46.9.

5............. Foveosporites subtriangularis (BRENNER) PrIIIJPS \& FELXX

O exemplar ilustrado mostra a ornamentação característica e o contomo. Lâm. TM5/09589, P60.

6,7........ Foveosporites canalis BALME

Observar detalhes da ornamentaçăo foveolada formando, por vezes, pequenos canais. Lâm. SO5/01903, F36-4 (fig. 6). Lâm. UB1/01915, N40-3 (fig. 7).

9, 13...... Klukisporites variegatus COUPER Vista polar, ressaltando o contorno e a omamentaçăo. Lâm. PD1/01058, L36-2 (fig. 9). Lâm. SOS/01894, O46-1 (fig. 13).

10........... Foveosporites sp. 1 No exemplar ilustrado ressalta-se a omamentaçăo grosseira e a espessura da exina. Lâm. SO5/1900, P25.21.

11.......... Klukisporites foveolatus Pocock.

Face distal mostrando detalhes da ornamentaçăo. Lâm. PD1/02154, J55.

12, 17. .. Camarozonosporites sp. 1

Vista polar ressaltando contorno e ornamentaçăo. Lâm. SO5/01894, F56-1 (fig. 12); E39 (fig. 17).

14, 15. .. Gleicheniudites senonicus (Ross) SKarBY

Os exemplares ilustrados mostram detalhes do contomo e os espessamentos equatoriais nas regiðes interradiais, característicos da especie. Lâm.TM5/00100, Q24-1 (fig. 14); M50 (fig. 15).

16........... Camarozonosporites sp. 2

Vista polar evidenciando o contorno e a ornamentação. Lâm. RNS21/02185, S40-3.

18.......... Hamulatisporis albertensis SRrvastava.

Vista polar, ressaltando a ornamentaçăo da exina. Lâm. SO5/01903, T27.

19........... Camarozonosporites sp. cf. C. insignis NoRris

Vista laterai mostrando detalhes da ornamentaçāo. Lâm.SO5/01892, 037-3.

20.............Matonisporites silvai LuMA.

Face proximal mostrando o contomo e o margo espesso e liso que acompanha as laesuras. Lâm. NMR1/ 09769, V53-4.

21, 22... Hamulatisporis sp. 1

Observar as espessas rúgulas da face distal. Lâm. PM2/0931, P37. (fig 21) Lam. RNS15/1905 P49 (fig.22).

23........... Esporo Trilete Indeterminado

Face proximal, mostrando detalhes da marca trilete e espessura da exina. Lâm.PM2/02943, P37-3. 
D I N 0,1992
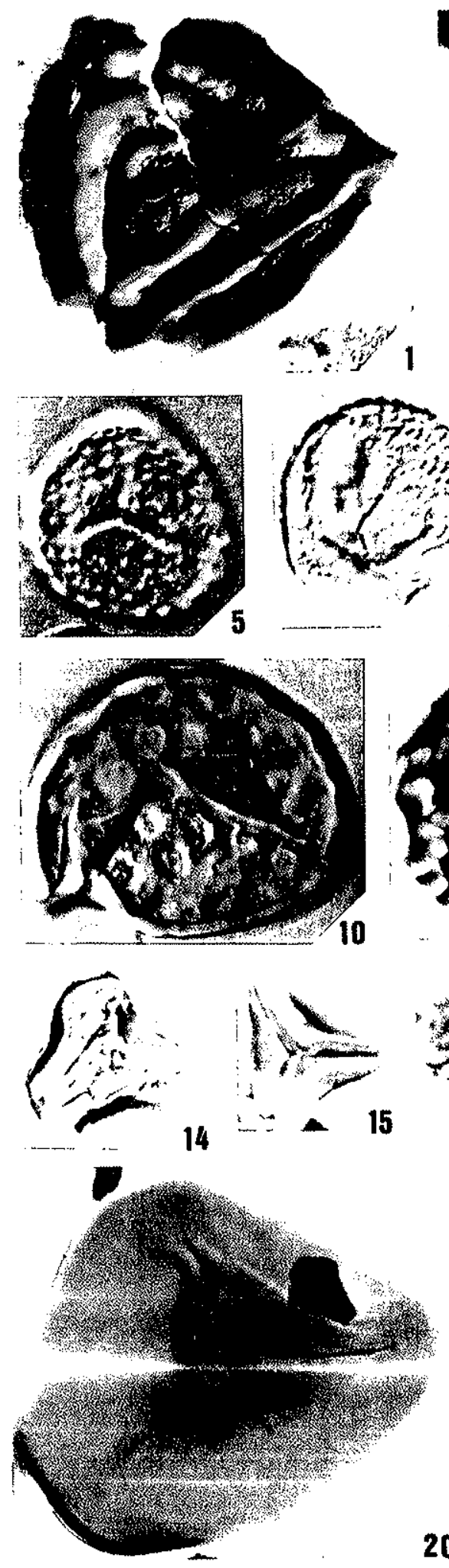
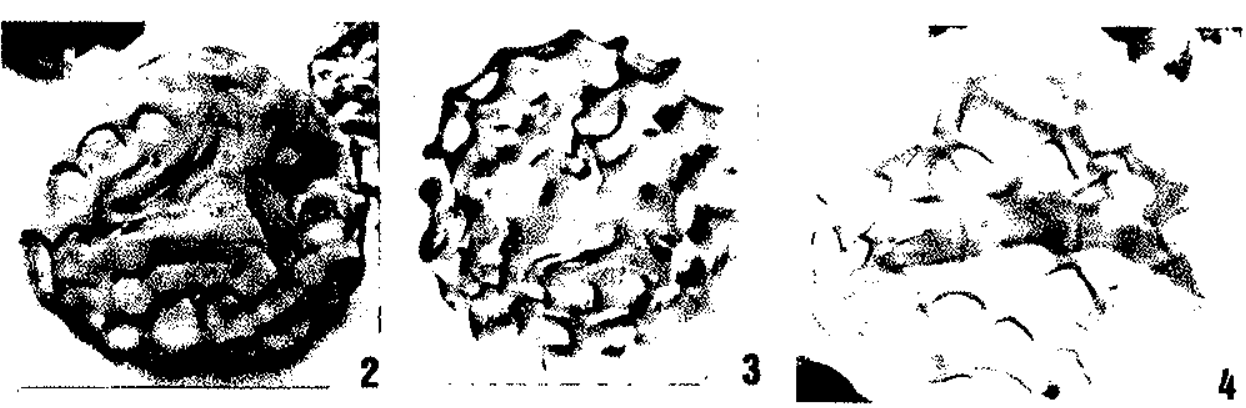

\section{ESTA M PA V}

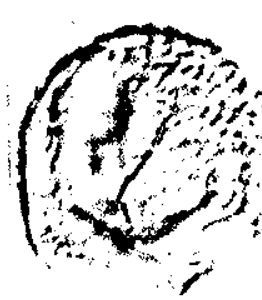

5
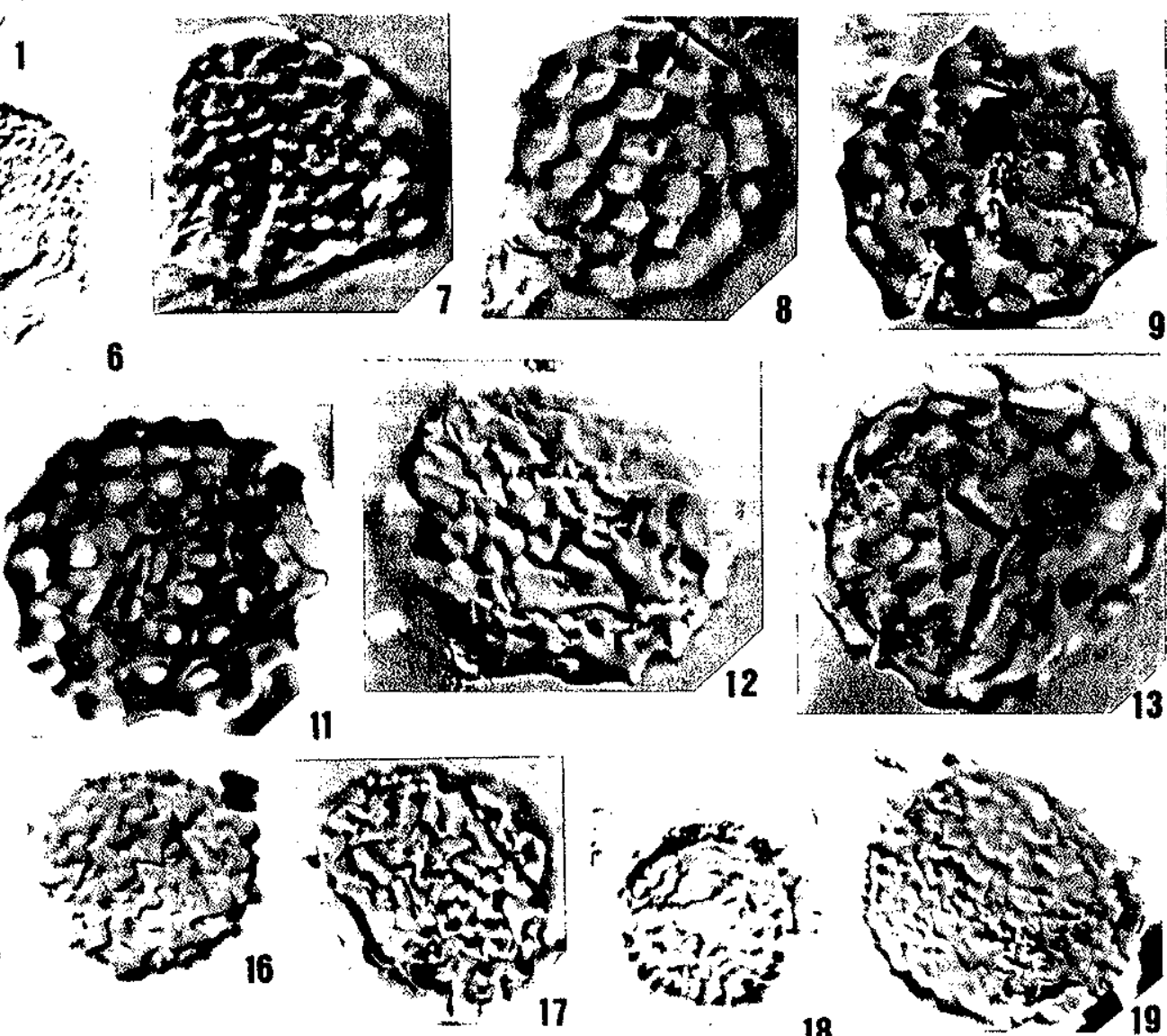

18
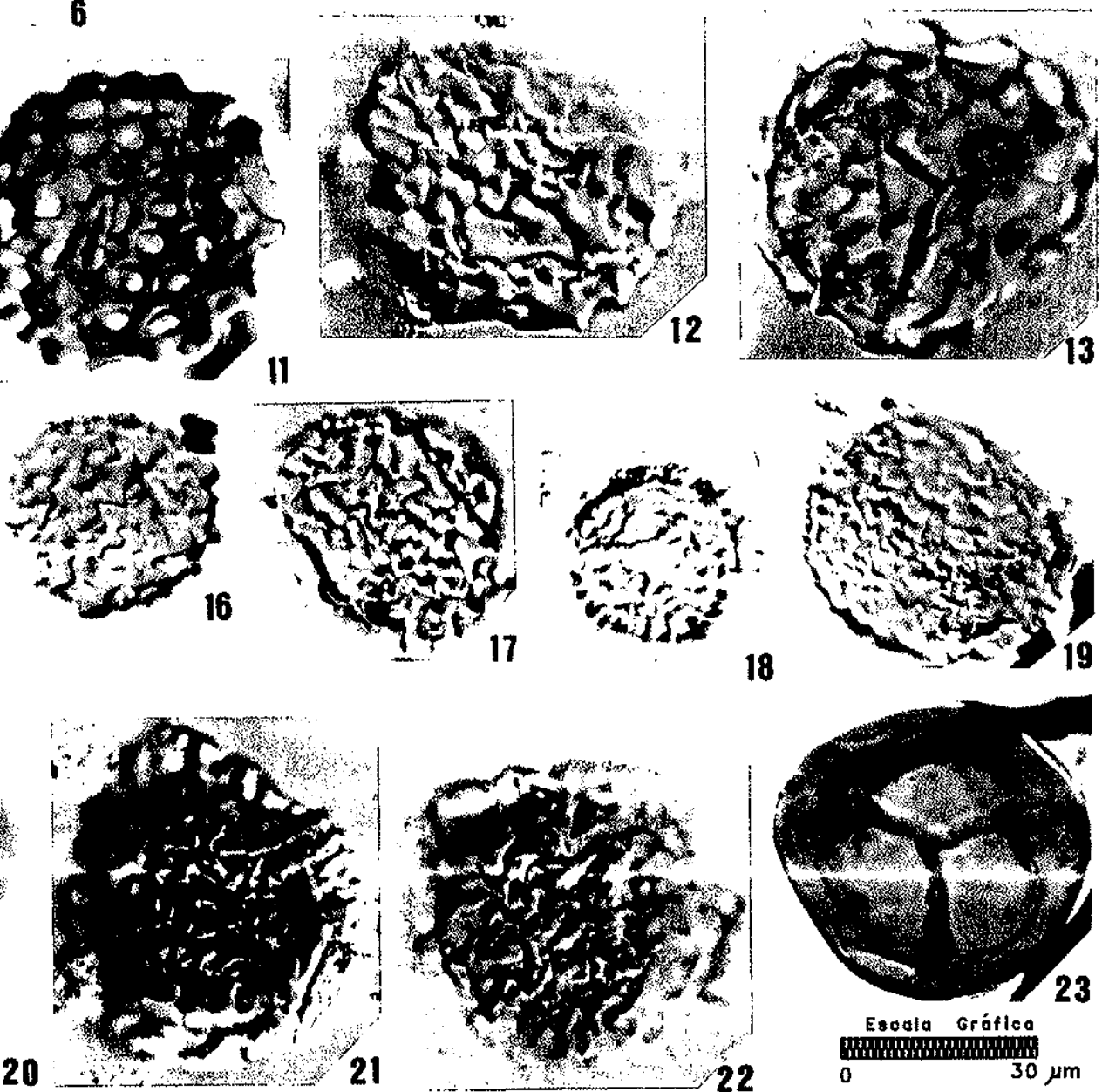


\section{ESTAMPA UI}

FIGURA

PÁGINA

1..............Auritulinasporites sp. 1 .

No exemplar ilustrado, săo visiveis o contorno e os espessamentos (margo?) que se estendem até os apices. Lam. NMR1/09771, B34-3.

2, 6, 8, 12, 13. Crybelosporites pannuceus (Brenner) SRIVAstaVA.

Nos exemplares ilustrados pode se observar detalhes do corpo central, marca trilete e "amarrotamento" do perispớio. Lâm. SO5/01895, X32-3 (fig. 2). Lâm. NMR1/9768, V52-1 (fig. 6); Z53-1 (fig. 8). Lâm. CES7/02150, T32-1 (fig12). Lâm. RNS21/02164A, Q36-2 (fig. 13).

3, 7.........Aequitriradites sp. 1 .

Nos exemplares ilustrados evidencia- se o contomo e a omamentação. Lâm. PD1/01058, T37 (fig. 3). Lâm. NMR1/09784, C44-2 (fig. 7).

4....on......... Perotrilites sp. 1

Notar espessura da exina. Lâm. RNS21/02471, N49-3.

5, 11, 14. Densoisporites dettmannae (DRUGG) DejaX

Os exemplares ilustrados evidenciam detalhes da ornamentação e da marca trilete. Lâm.

FSM1/09798, F34-1 (fig. 5). Lâm. NMR1/04183, Q45-2 (fig. 11); K33-1 (fig. 14).

9, 10...... Aequitriradites sp. 2

Face proximal, onde se ressalta o contorno e marca trilete. Lâm. SO5/01069, P49 (fig. 9).

Lâm. UB1/01890, S43-1 (fig. 10). 

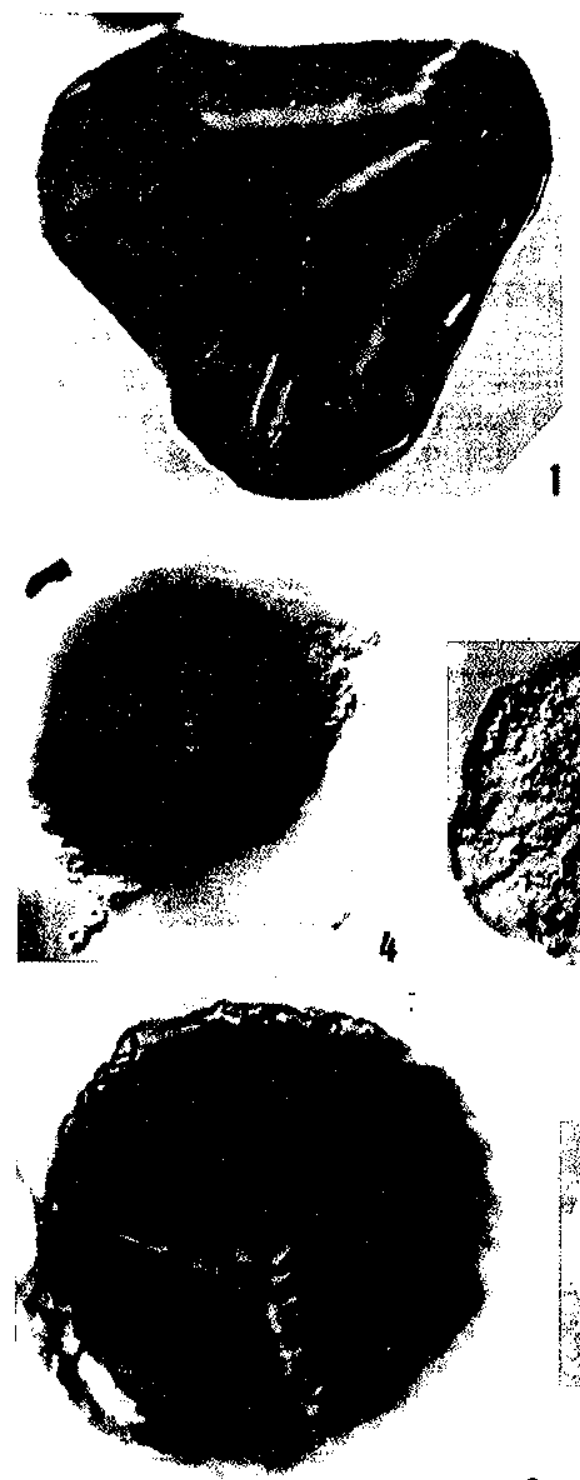

8

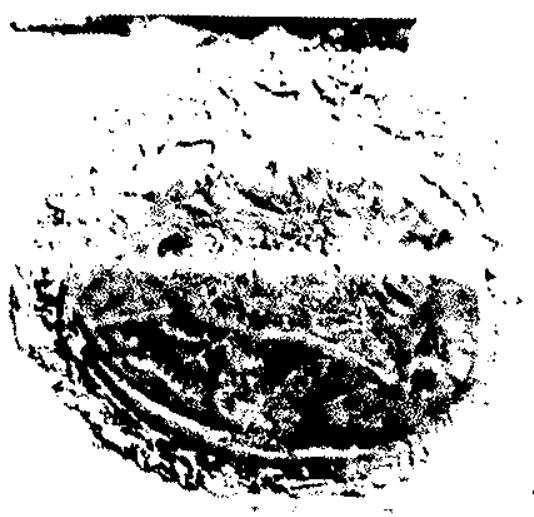

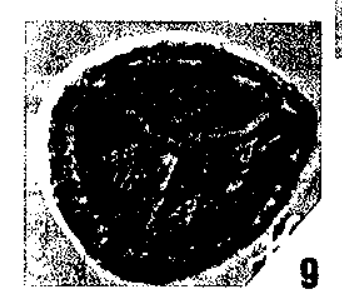

5

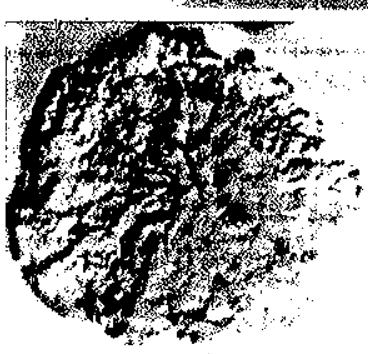

5
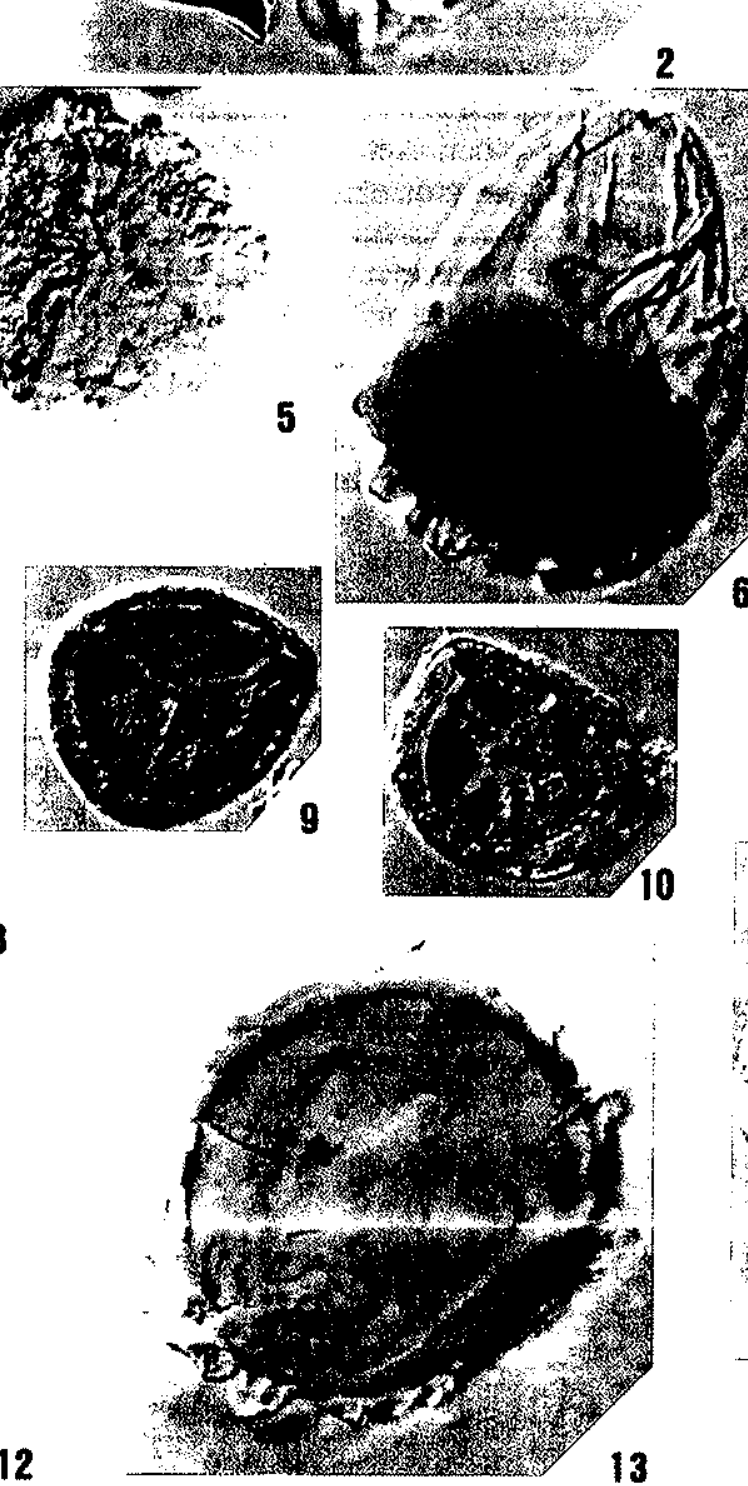
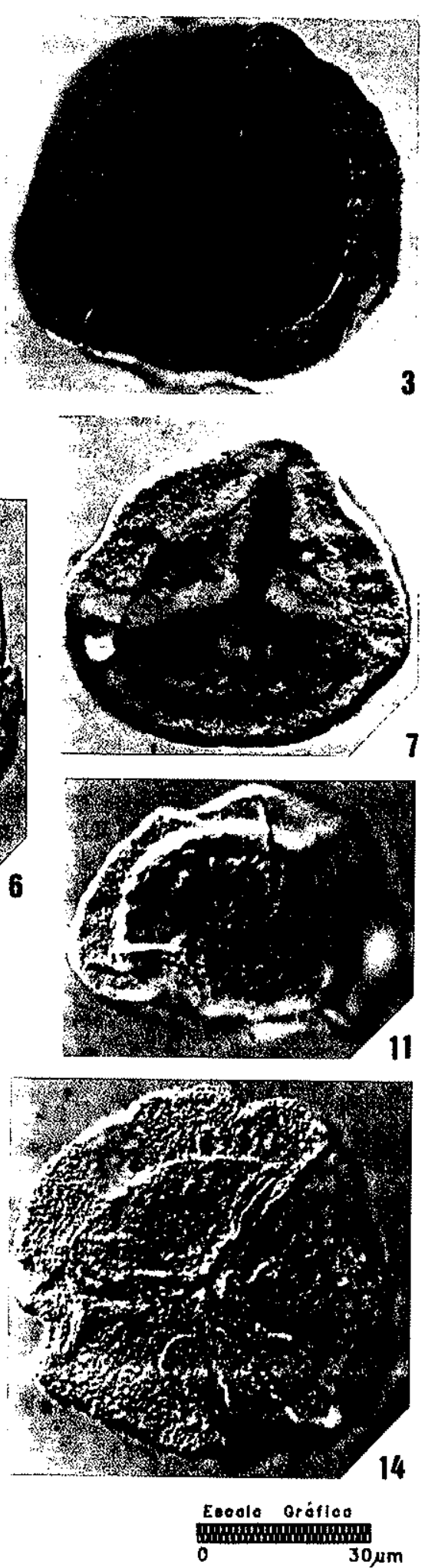


\section{ESTAMPA UII}

FIGURA

PÁGINA

1, 2......... Crybelosporites striatus (Cookson \& Detrmann) Dettmann

Vistas polar e lateral, evidenciando o corpo central circular, envolvido por um perispório com dobras orientadas na direção da projeção. Lâm. PD1/2154, G52 (fig. 1). Lâm. RNS21 /02476, Y32 (fig. 2).

3, 4, 5.... Crybelosporites brenneri PLAYFORD

Ilustraçōes ressaltando as dimensðes, o perisporio hialino com projeção de formato triangular. Lâm. SC1/08188, E48 (fig. 3). Lâm. PM2/09236, F53 (fig. 4). Lâm. NMR1/09784, O39 (fig. 5).

6, 12...... Trilobosporites apiverrucatus COUPER Nos exemplares ilustrados evidencia-se detalhes da ornamentaçăo e espessamento nos ápices, caracteristicos da espécie. Lâm. PD1/02151,K37-3 (fig. 6); K50-1 (fig. 12).

7............... Matthesisporites sp. 1 Faces proximal e distal de dois exemplares colados, ressaltando a marca trilete, o contorno equatorial e a ornamentaçăo grosseira. Lâm. PD1/02151, X44-1.

8, 11...... Murospora sp. 1 Os exemplares ilustrados mostram o espessamento equatorial caracteristico do gênero. Lâm. SO5/078 J27-1 (fig. 8). Lâm. CES7/01562, S32 (fig. 11).

9............. Divisisporites sp Notar o bifurcamento, nas extremidades, das laesuras. Lâm. PD1/02151, P33-2.

10, 13, 14. Collarisporites sp. cf. C. fuscus Deák Os exemplares ilustrados mostram detalhes do contorno equatorial e da ornamentação nas faces distal e proximal, bem como da área equatorial. Lâm. NMR1/09769A, F43-3 (figs. 10-13). Lâm. PD1/ 02354, LA6 (fig. 14).

15, 20... Cingutriletes sp Vistas proximal e distal do mesmo exemplar evidenciando crngulo, marca trilete e ornamentação. Lâm.TM5/09589, K46-4.

16, 17... Trilobosporites sp. cf. T. humilis DeLcoURT \& SpRUMONT Observar o aumento de tamanho das verrugas nos ápices e ao longo das laesuras, características da espécie. Lâm. PD1/02151, O55-2 (fig. 16). Lâm. PD1/01057, H25-4 (fig. 17).

18........... Trilobosporites minor Pocock Vista polar, mostrando o contomo equatorial e detalhes da ornamentaçăo. Lâm. SO5/01886, U41-2.

19........... Contignisporites sp. 1 Vista polar ressaltando contorno e ornamentaçăo. Lâm. SO5/01904, M26. 

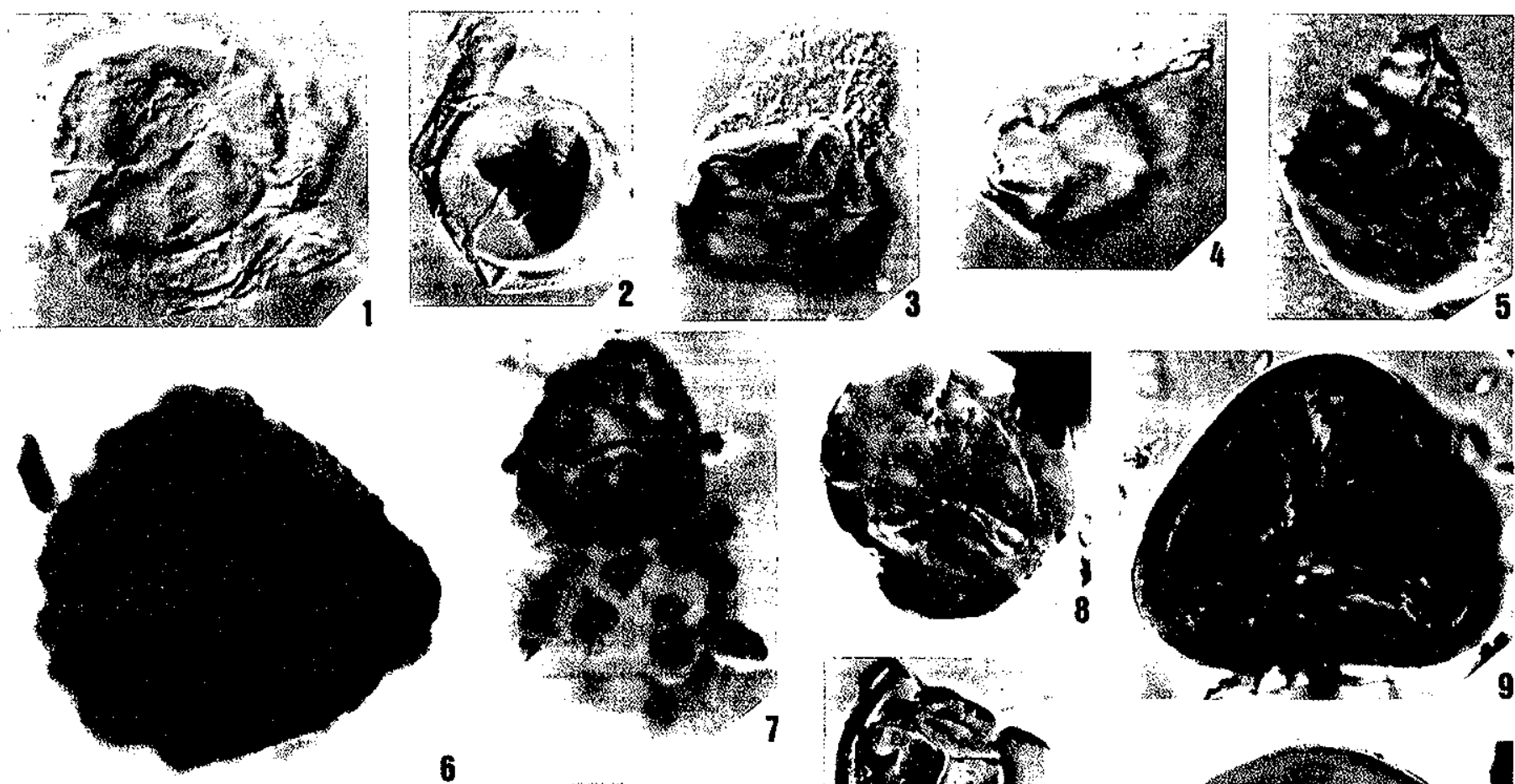

6
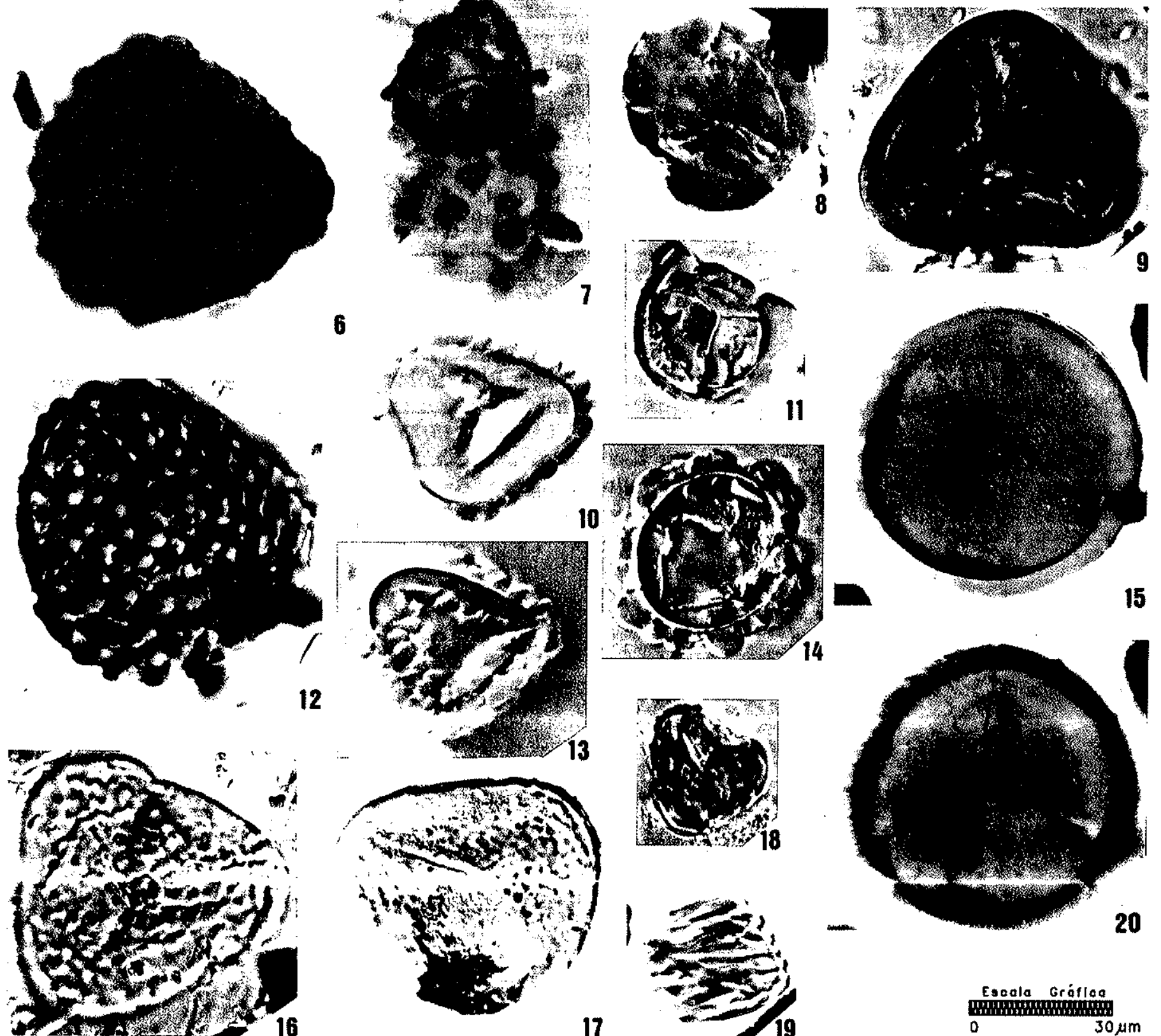

17
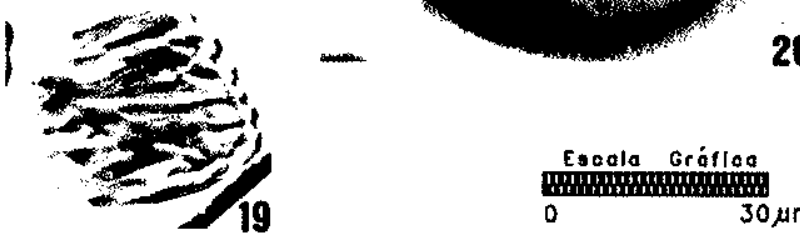


\section{ESTAMPA UIII}

FIGURA

PÁGINA

1, 2........ Verrucosisporites sp. 2

142

Vista lateral. Faces proximal e distal do mesmo exemplar, ressaltando ornamentação e marca trilete. Lâm. NMR1/09773, L30-1.

3, 7........ Appendicisporites sp. 1

Faces proximal e distal do mesmo grão, evidenciando detalhes da marca trilete e ornamentação. Lâm. CES7/02156, G46-2.

4............ Appendicisporites sp. cf. A. insignis (Markova Chlonova)

Notar no exemplar ilustrado a junção das costelas nos ápices. Lâm. TM5/09589, U54.

$5,6,10,12,16$. Antulsporites sp. cf. A. baculatus ARCHANGELSKY \& GAMERro Notar nos especimens ilustrados a ornamentação radiada do cíngulo e a ornamentaçáo nas faces proximal e distal. Lâm. CES7/01564, L.53 (fig. 5). Lâm. M2/ 02934, V41-2 (fig. 12). Lâm. SO5/01358, M50 (fig. 6); K32-3 (fig. 12). Lâm. PM2/02943, F56-1 (fig. 16).

8, 9, 14.. Verrucosisporites sp. 3

Nos exemplares ilustrados ressalta-se a ornamentação e o contorno equatorial. Lâm. TM5 09589, Q47-3 (fig. 8). Lâm. NMR1/09775, G46-3 (fig. 9). Lâm. NMR1/09775A, B37-3 (fig. 14).

11........... Verrucatosporites chaloneril KREMP

Vista lateral. Observar ornamentaçăo. Lâm. RNS21/02480, Q60-2.

13.......... Laevigatosporites ovatus WILSON \& WEDSTER

Observar marca monolete e contorno. Lâm. NMR1/09769, 047-1.

15.......... Microfoveolatosporis daukiensis KAR \& SINGH ............................................................

Vista lateral, mostrando detalhes da ornamentaçăo, e contorno.

Lâm.PM2/02932, F44-4. 


\section{N 0,1992}
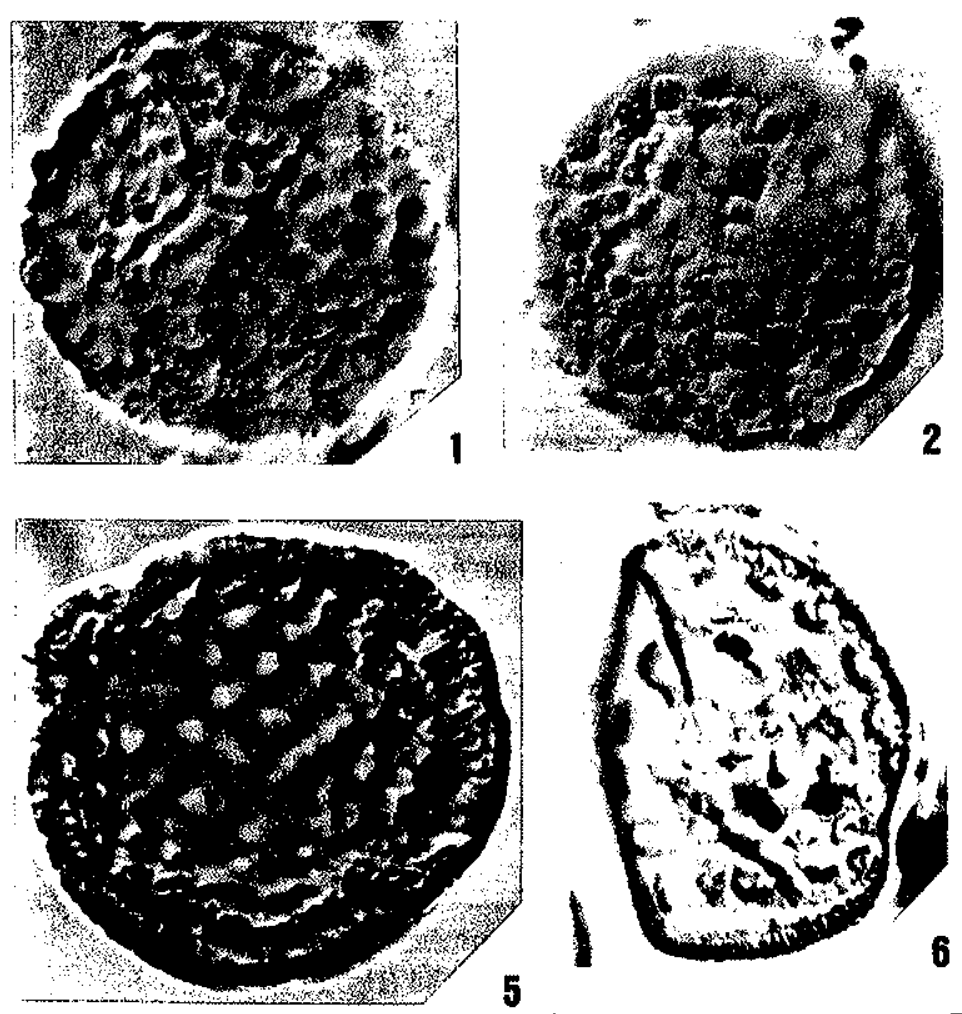

5 5
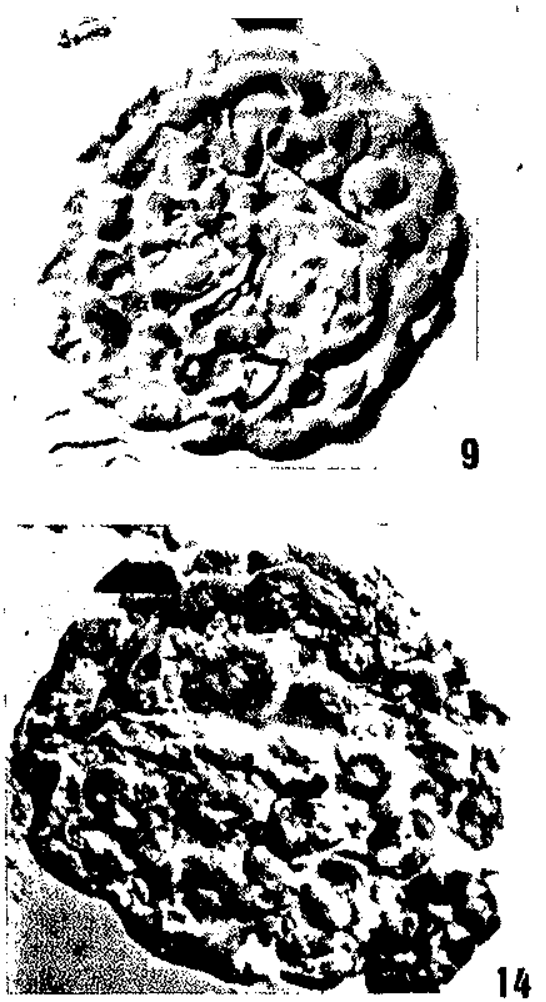
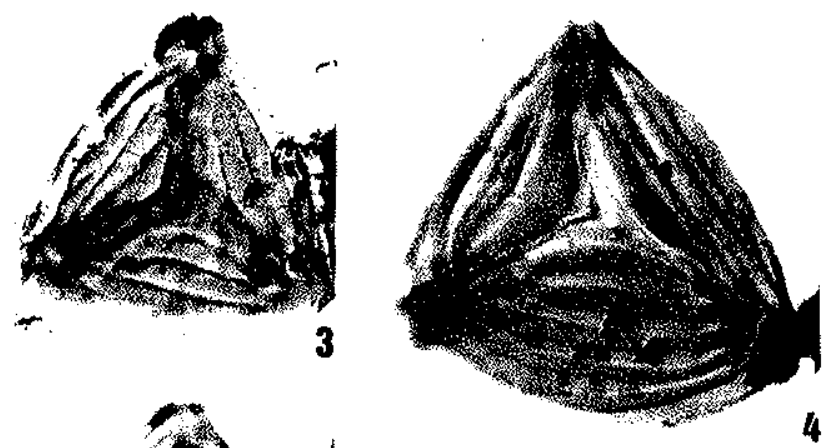

\section{ESTA M PA VIII}
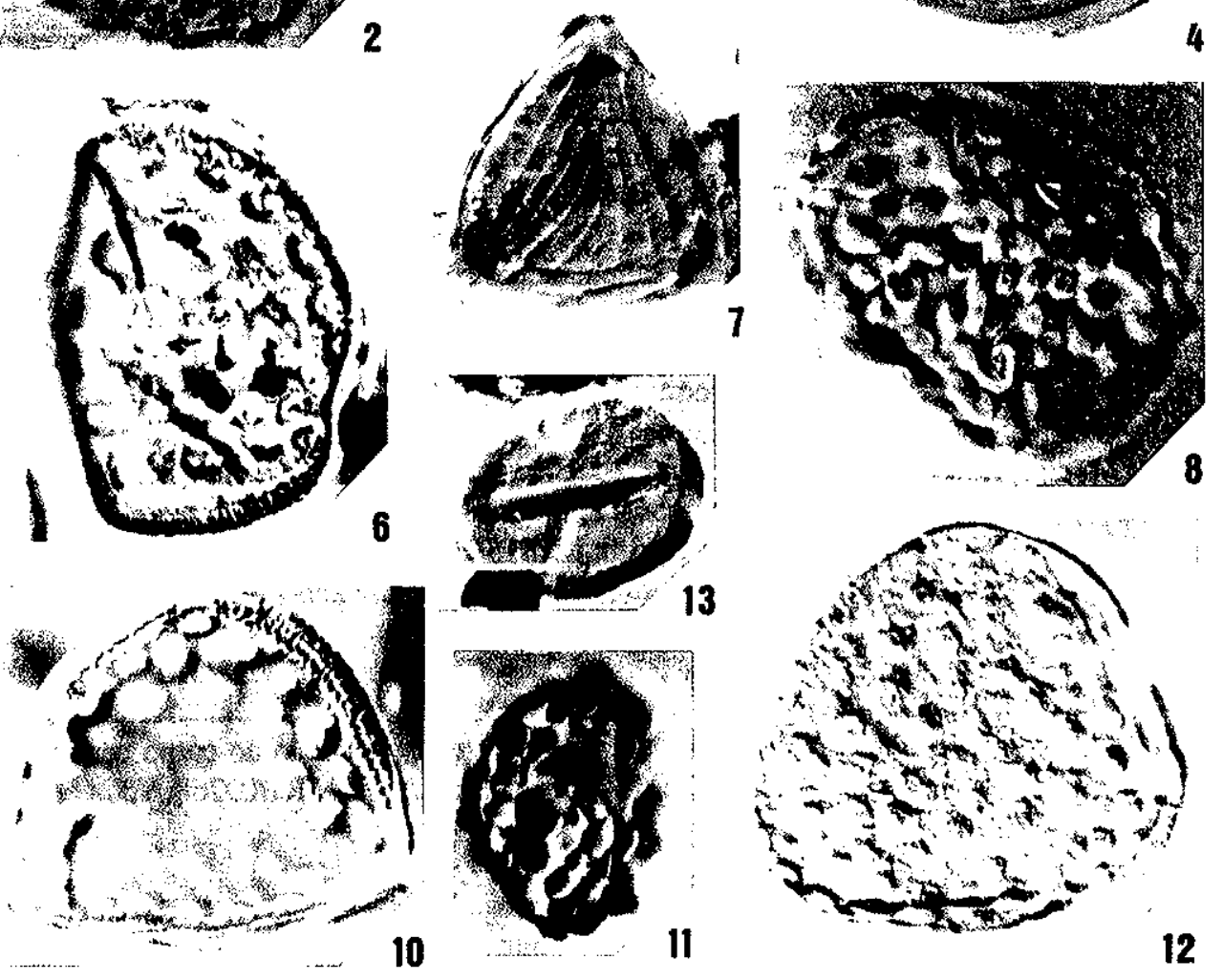

3

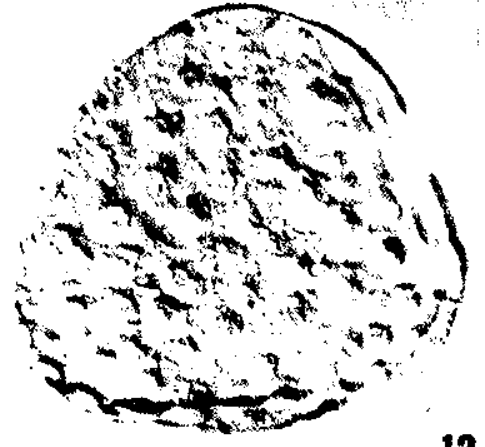

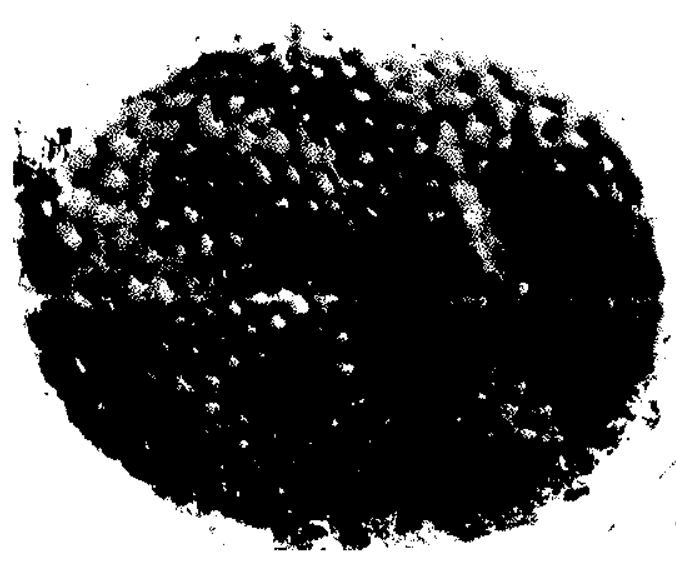

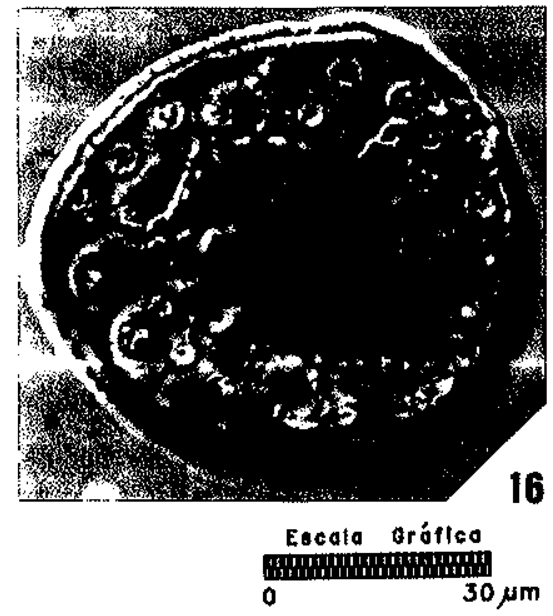




\section{ESTAMPA IH}

FIGURA

PÁGINA

1,6 ......... Schweitzerisporites? sp

Nos exemplares ilustrados, observar a espessura da exina e as dimensces dos lumina e dos muri. Lâm TM5/09589, Q47 (fig. 8). Lâm. NMR1/09784, P43-2 (fig. 9)

2, 3, 5.... Reticulosporis foveolatus (PIERCE) SkARBY Nos exemplares ilustrados observar o contorno e a ornamentaçăo. Lâm. SO5/1897, S53-2 (fig. 4). Lâm. UB1/01900, Q33-1 (fig. 5).

Microfoveolatosporis daukiensis $\mathrm{K} A \mathrm{~B}$ \& StNoH

Vista lateral, mostrando detalhes da omamentação, além do contorno e a marca de deiscência. Lâm. TM5/00101, M30.

7, 8, 11. Callialasporites dampieri (BALME) Dev Vista polar salientando o contorno geral e a inserçao dos sacos. Lâm. FSM1/09797, M31 (fig. 7). Lâm.PD1/02151, P31 (fig. 8). Lâm. SO5/01904, Q40-2 (fig. 11).

9............ Cicatricososporites sp. cf. C. norrisii SRrvastava Vista lateral mostrando marca monolete e ornamentaçăo característica. Lâm. SO5/01900, S46-3.

10........... Properinopollenites sp. Lima. Observar nos exemplares ilustrados o corpo central circular a ovalado e as dimensoes diminutas. Lâm. RNS15/1906, Y42 (fig. 16). Lâm. RNS21/2481, R34 (fig. 17).

12, 14. .. Callialasporites triangularis (LEVET-CARETTE) REYRE Notar o contorno e o afinamento da exina formando um corpo central triangular. Lâm.PD1/02151, V37-3 (fig. 12). Lâm. PD1/01058 U43-3 (fig. 14).

13, 15.... Callialasporites lucidus (Pocock) ReYre Vista polar, ressaltando a ornamentação do corpo central e a presença dos lobos. Lâm. PM2/02936, J54-4 (fig. 13). Lâm. NMR1/09768, V57 (fig. 15). 

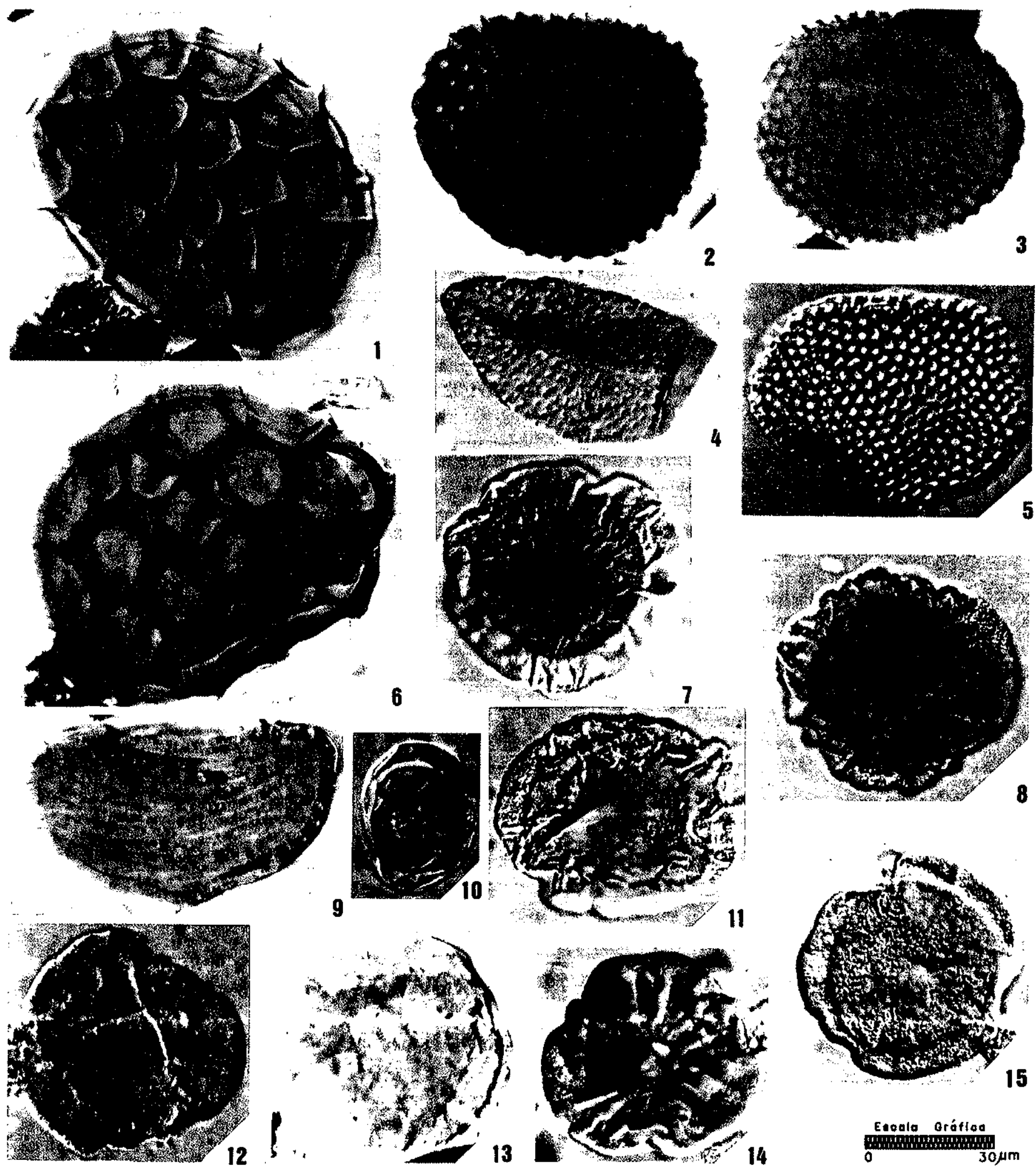


\section{ESTAMPA H}

FIGURA

PÁGINA

1. .........Callialasporites minus TraLAu) GuY

Observar dimensđes gerais e inserção do saco. Lâm. CES7/00011, R50 (fig. 8). Lâm.

TM5/00101, D48-2 (fig. 9).

2, 3, 17. Callialasporites segmentatus (BALME) SRIVASTAVA

Nos exemplares ilustrados ressalta-se o corpo central com contorno indefinido e o saco fortemente pregueado. Lâm. PD1/141-3 (fig. 2). Lâm. SO5/01900, J31-2 (fig. 3). Lâm. NMR1/09769, Q40-3 (fig. 17).

4. .........Callialasporites trilobatus (BALME) DEv

Vista polar ressaltando os três lobos que formam o saco. Lâm. NMR1/09780, D47-2.

5, 6, 9... "Complicatisaccus" cearensis ReCALU

Nos exemplares ilustrados, ressalta-se o contorno geral, do grăo e do corpo central, bem como a ornamentaçăo do saco. Lâm. PD1/02151, Q40-1 (fig. 5). Lâm. PD1/01057, Q42-3 (fig. 6). Lâm. RNS21/02471, L54 (fig. 9).

7..........Callialasporites turbatus (BALME) Schurz. Observar contorno e dobras no corpo central sugerindo a não existência de adesão das camadas da exina. Lâm. SO5/01897, Y27.

8. .........Callialasporites microvelatus Schurz

Vista polar mostrando se tratar de grăo cavado e ornamentação escabrada. Lâm. SO5/01071, R43.

10, 14...Vitreisporites microsaccus DE JERSEY

Vista polar mostrando contomo geral e inserção dos sacos. Lâm. SO5/01894, D55 (fig. 10). Lâm. SO5/01896, F32 (fig. 14).

11, 13, 16, 18. Vitreisporites sp. 1

Notar detalhes do corpo central e dimensđes. Lâm. UB1/01915, M30-2 (fig. 11). Lâm. SO5/01896A, U34-4 (fig. 13). Lâm. RNS21/02185A, P45-3 (fig. 18). Lâm. CES7/01566, P48-4 (fig. 16).

$12,15,19,20$. Vitreisporites pustulosus ReGAL.

Observar nos exemplares ilustrados, detalhes do corpo central, dos sacci, e as pústulas, que caracterizam a espécie. Lâm. RNS21/02471, U54 (fig. 12). Lâm. RAP3/09428, K38-4 (fig. 15). Lâm. NMR1/09806, D39-1 (fig. 19). Lâm. RNS21/02185A, F47-1 (fig. 20).

21, 24.... Cedripites cretaceus Pocock.

Observar dimensōes e omamentação dos sacci. Lâm. SO5/01892, V29-2 (fig. 21). Lâm. RNS21/02476, N48-2 (fig. 24).

22, 23.... Spheripollenites scabratus CoUPER

Vista polar. Nos exemplares ilustrados ressalta-se a omamentaçăo, dimensðes e espessura uniforme da exina. Lam. PD1/02151, M42-2 (fig, 22); J52 (fig. 23). 

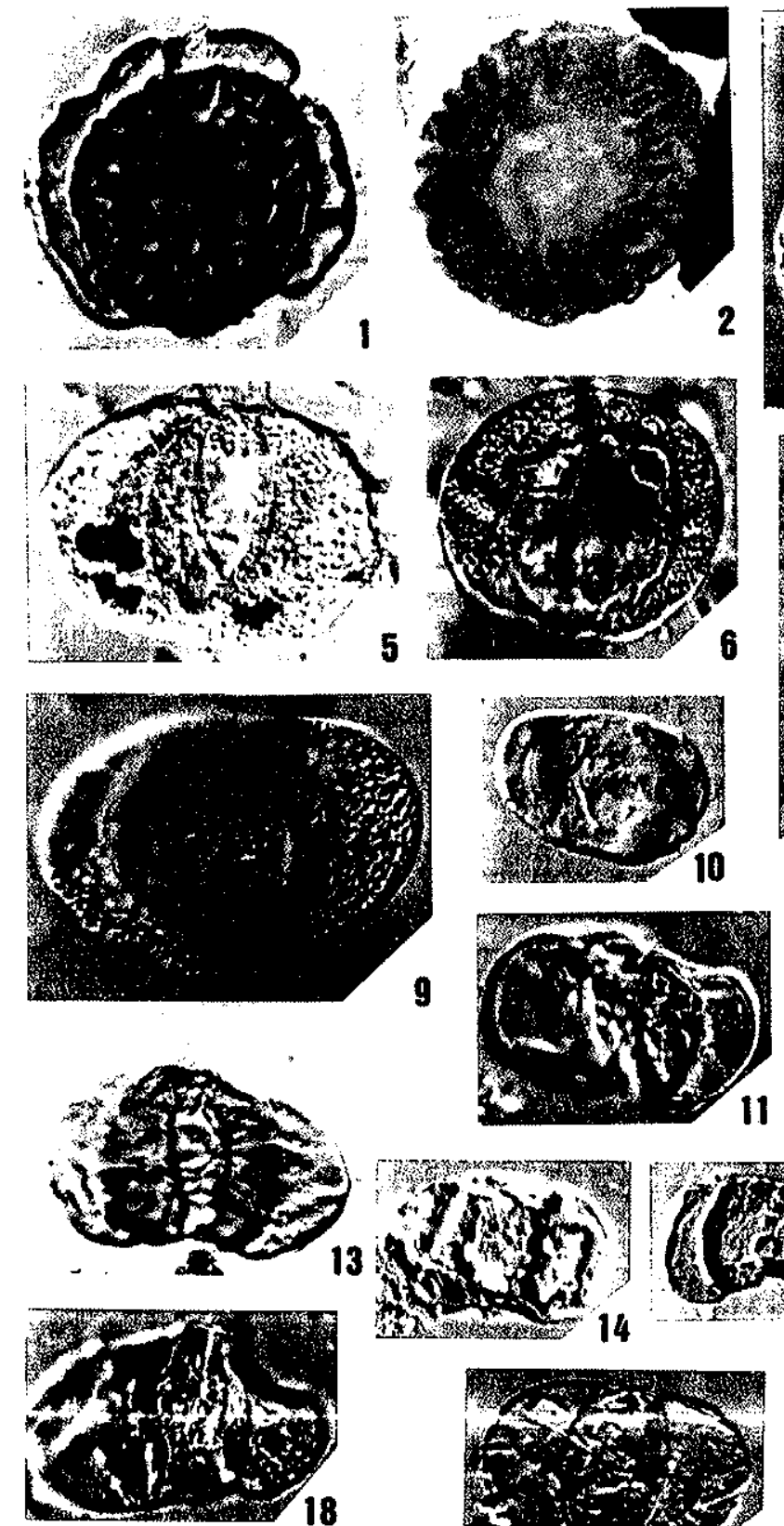

$135 \times 34$ 3014

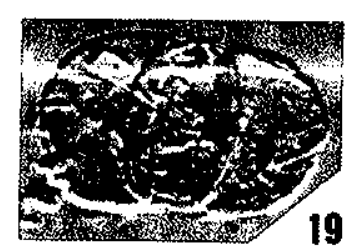

PJit

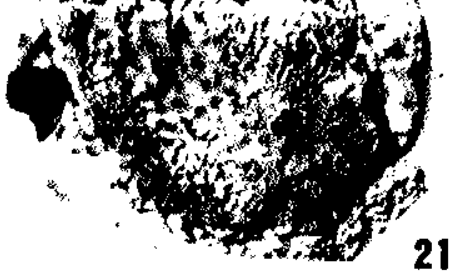

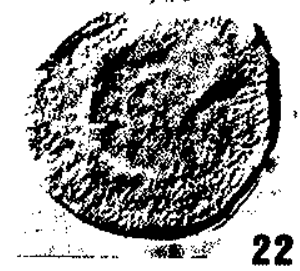

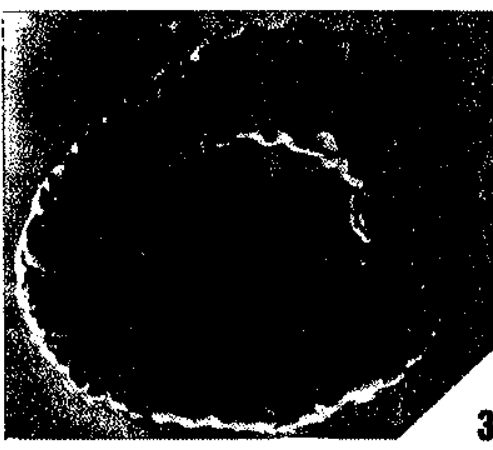
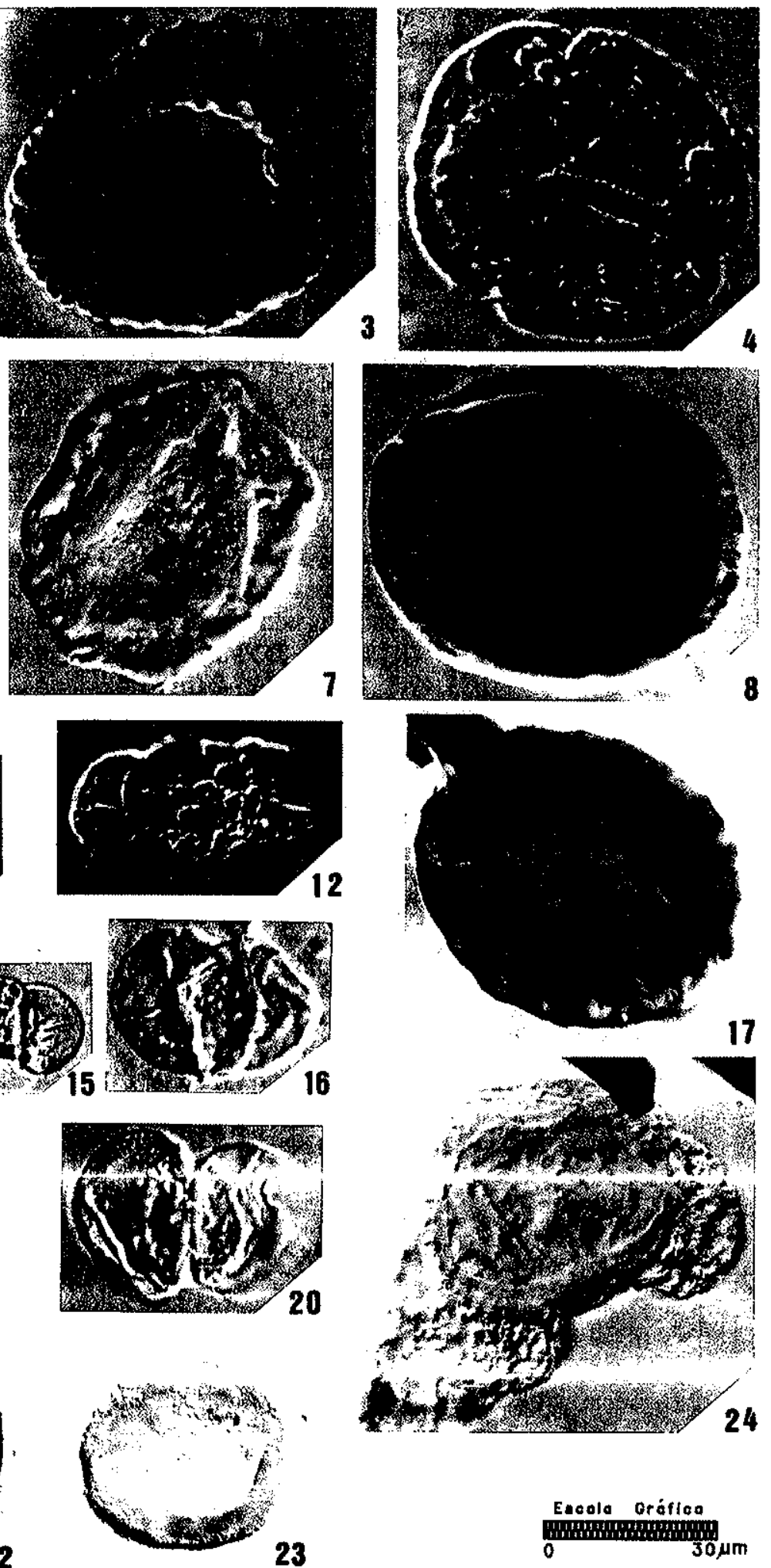

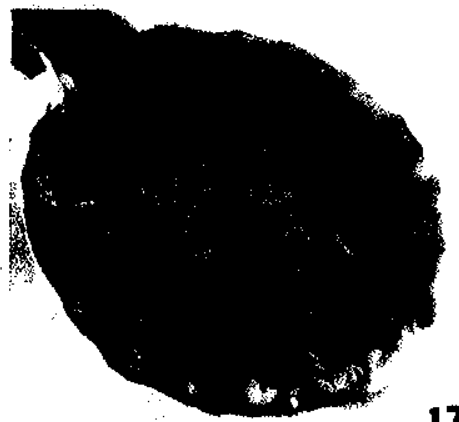

$+\cdots$

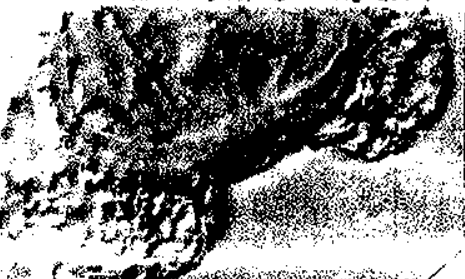

Eacola Oráfico

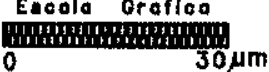

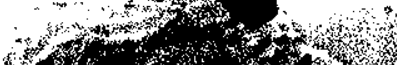
(1)

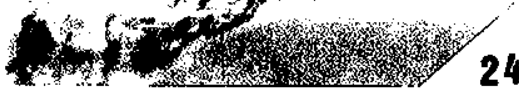




\section{ESTAMPA KI}

FIGURA

PÁGINA

1, 2. ......Spheripollenites scabratus COUPER .......................................................................

183

Vista polar. Nos exemplares ilustrados ressalta-se a ormamentaçăo, dimensóes e espessura uniforme da exina. Lam. PD1/02152, O50-2 (fig. 1). Lâm. SO5/01895, K55-1 (fig. 2).

3-8, 10. Vesuguipollenites callosus nov. $8 p$..................................................................

Nos exemplares ilustrados evidencia-se a ornamentaçăo escabrada, a calota central característica e as dimensões. Lâm. PD1/02151, W40 - holótipo - (fig. 3). Lâm. SO5/01890, M28-3 (fig. 4); V43-3 (fig. 8); L28-3 (fig. 10). Lâm. SO5/1896, Z46-2 (fig. 5). Lâm. SO5/01853, Z48-3 (fig. 6). Lâm. PD1/02152, N50 (fig. 7).

9. ..........Spheripollenites subgranulatus COUPER........................................................................

Notar dimensões extremamente reduzidas da espécie em questăo. Lâm. PD1/01057, Q53-2.

11, 14, 15, 16. Inaperturopollenites turbatus B ALME (SENSU REOALI ET AL). Os exemplares ilustrados mostram claramente o espessamento da exina na parte central do grăo, tornando-a mais escurecida. Notar também as dimensరes e ornamentaçăo. Lâm. NMR1/09806, D30-3 (fig. 1.1). Lâm. UB1/01915, P39-4 (fig. 14). Lâm. SO5/01903. D42-3 (fig. 15); F27-2 (fig. 16).

12. ......Inaperturopollenites giganteus GoCZAN Observar dimensóes e espessura da exina. Lâm. SO5/01358, T46-1.

13, 17, 18. Inaperturopollenites simplex ReoAl, Uesugu \& SANTos Vista polar. Ressalta-se a fina exina (nexina), que envolve o grăo. Essa camada é geralmente homogênea e excede uniformemente o grăo, em cerca de 2,0-2,5um. Lâm. TM5/00100, B39-1 (fig. 13). Lâm. SO5/01900, P32 (fig. 17). Lâm. RNS21/02185, F49-1 (fig. 18). 


\section{I N 0,1992}

\section{ESTA M PA XI}
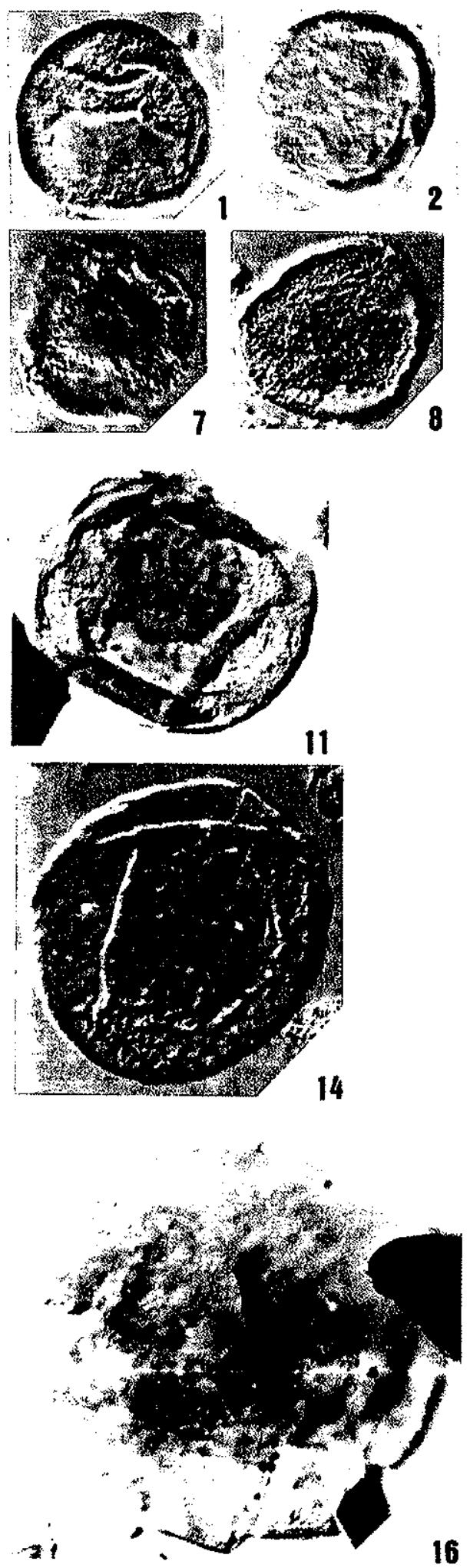
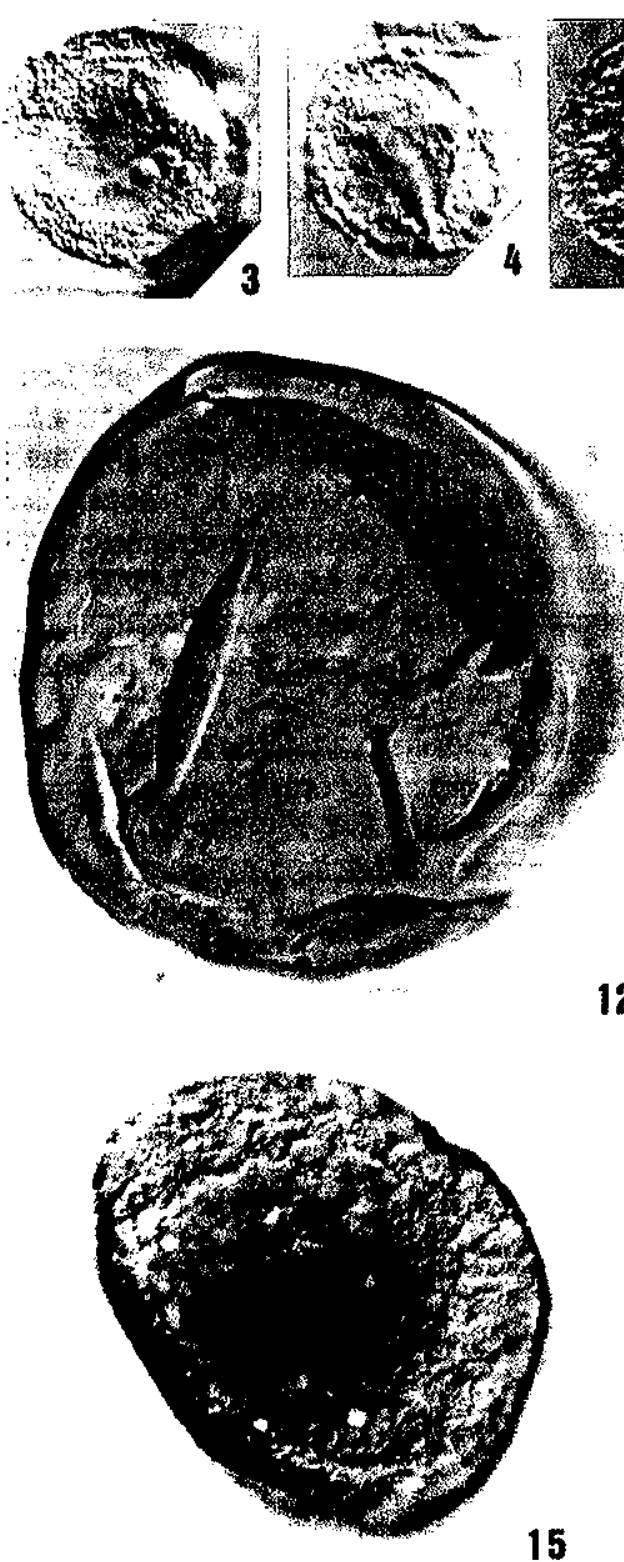

15

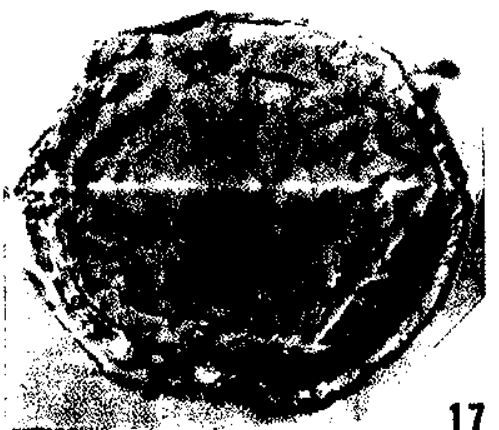

12
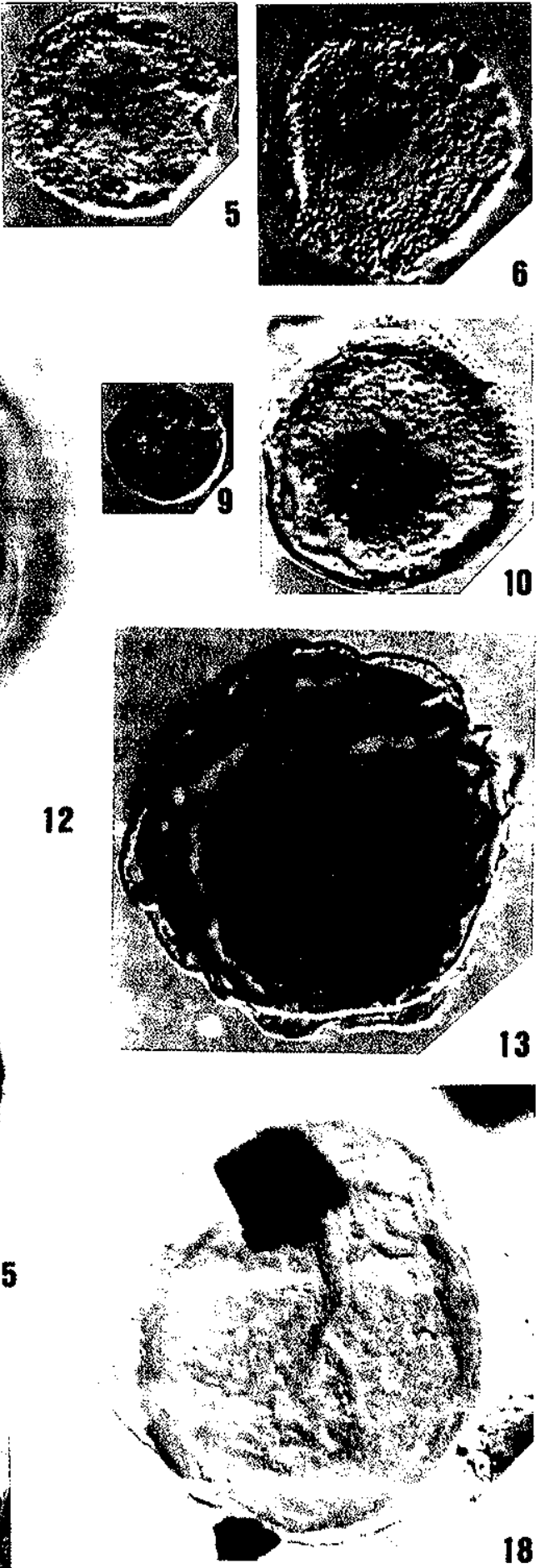

Encola Grofleo

0 


\section{ESTAMPA KII}

FIGURA

PÁGINA

1, 2, 3, 13. Araucariacites australis Cookson

181

Nos exemplares ilustrados, deve-se observar a ornamentaçáo escabrada e as dobras na exina. A figura 3 mostra também a presença de pequenos grânulos, denominados de "orbiculas" por Srivastava e de "esférulas" por Schrank, comumente encontradas em exemplares da espécie Exesipollenites tumulus. Lâm. RNS21/02185, P40-3 (fig. 1). Lâm. RAP3/09428, E55-4 (fig. 3); J46-2 (fig. 2). Lâm. PD1/02151, P33 (fig. 13).

4, 5. ...... Araucariacites guianensis VAN DER HAMMEN \& BURGER

Nos exemplares ilustrados evidencia-se a ormamentaçăo granulada e as dimensöes elevadas.

Lâm. FSM1/09798, Q39-2 (fig. 4). Lâm. TM5/09589, F57 (fig. 5).

6.............. Araucariacites limbatus (BALME) HABIB

Vista polar, mostrando a área mais fina (não definida) na região central do grăo. Lâm. FSM1/09797, M51-1.

7, 10, 11. Triangulopsis discoidalis DoRng

A vista polar ressalta aspectos da ornamentaçăo, contomo e dimensơes. Lâm. FSM1/09799, Q43-1 (fig. 7). Lâm. SO5/01894, X50 (fig. 10). Lâm. UPN1/10723, V37-4 (fig. 11).

8, 12...... Triangulopsis minor Pocock.

Observar ornamentação, dimensð̌es e contorno. Lâm. RNS21/02459, D48-2 (fig. 8).

Lâm. SO5/01886, L56-1 (fig. 12).

9............. Cingulatipollenites sp. cf. C. aegyptiaca SAAD \& GHAZALY

Vista polar, permitindo a observação do ćngulo e da exina, com ornamentação lisa a finamente escabrada. Lâm. SO5/01894, N44-2. 


\section{N 0, 1992}
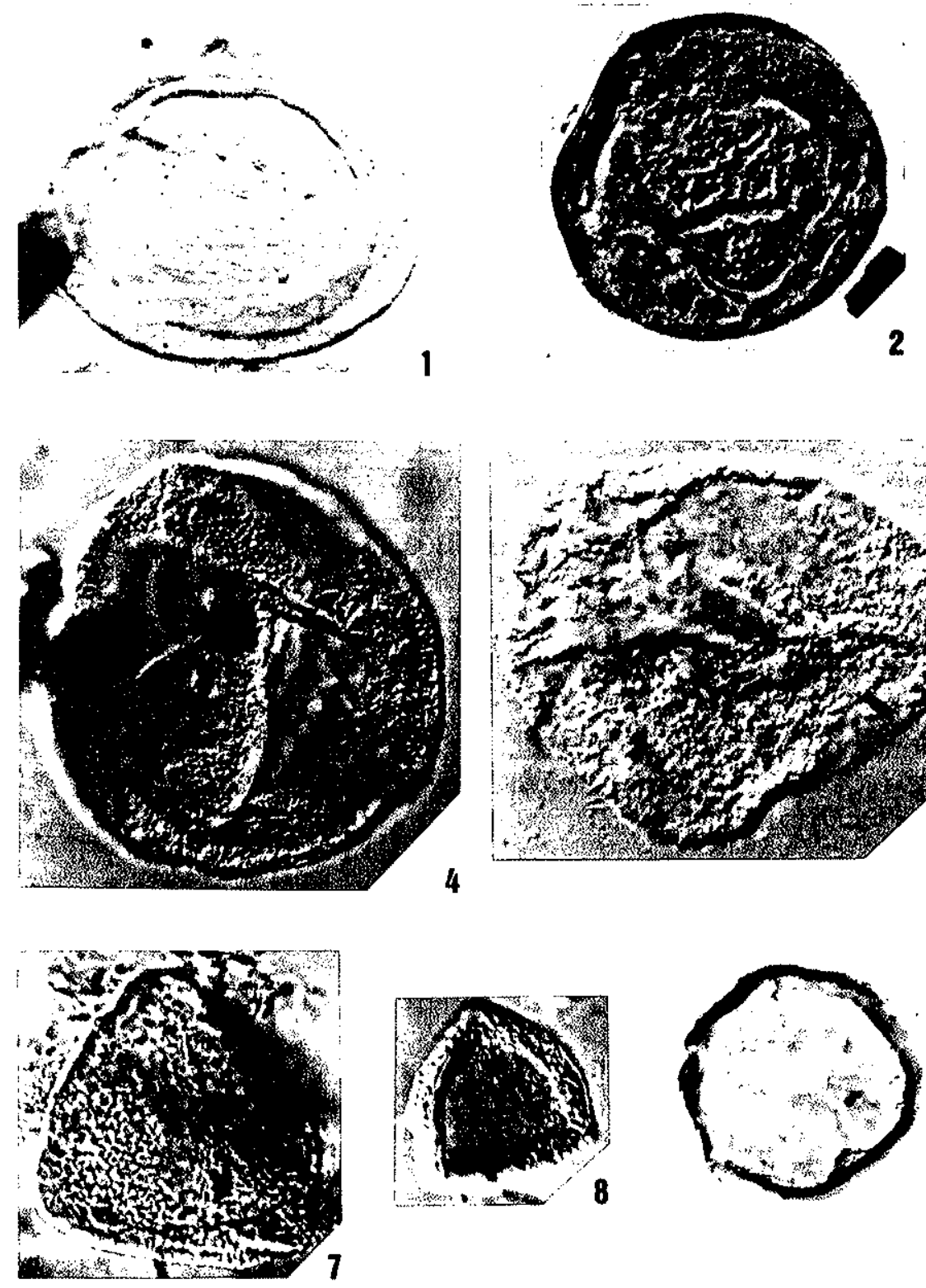

ESTAM PA XII
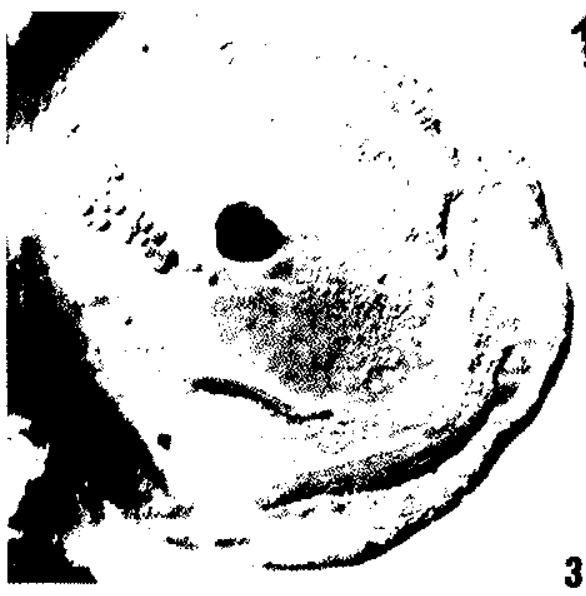

3

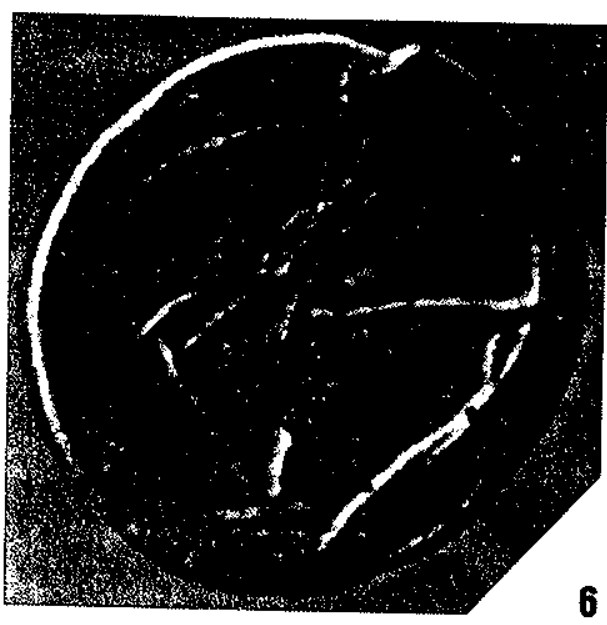

9

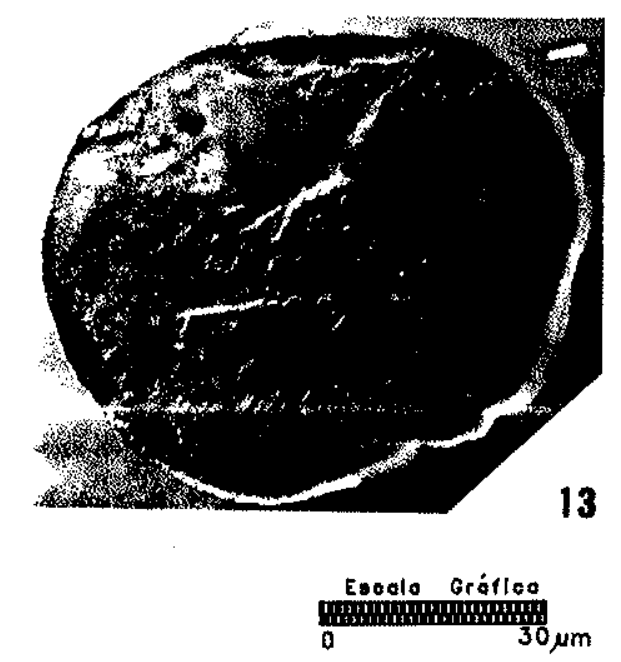

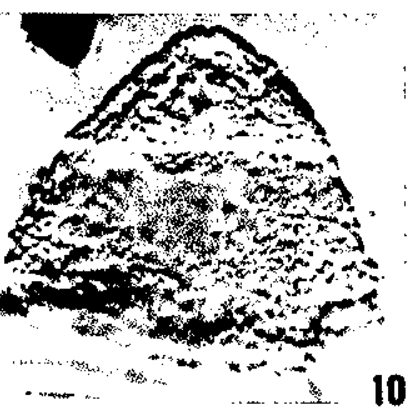
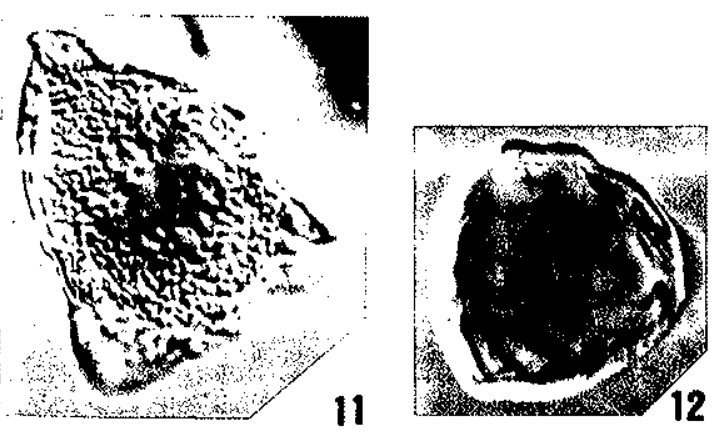

1 


\section{ESTAMPA KIII}

FIGURA

PÁGINA

1-4, 7, 9. Sergipea naviformis Regald, Uesugul \& Santos

Nos exemplares ilustrados, em vista lateral, observar detalhes da omamentaçăo e dimensð̌es. Lâm. PD1/02151, P31-1 (fig. 1). Lâm. SO5/01894, C30-2 (fig. 2, tétrade). Lâm. SO5/01903, Y47-1 (fig. 3), Lâm. TM5/00100, N36-4 (fig. 4). Lâm. SO5/01890, N36-2 (fig. 7). Lâm. SO5/01896, U47-4 (fig. 9).

$5,6,8,11,14-16,18$ 20. Sergipea variverrucata REOALI Destaca-se nos exemplares ilustrados, em vista polar e lateral, o contorno, a variedade e disposiç̧oo das verrugas, caracteristicas da espécie. Lâm. PD1/01057, D34 (fig. 5). Lâm. PD1/01058, C50-2 (fig. 6). Lâm. PD1/02151, Q36-2 (fig. 8). Lâm. FSM1/09798, C45-2 (fig. 11). Lâm. SO5/01890, K46-3 (fig. 14). Lâm. TM5/00100, P24-2 (fig. 15). Lâm. SO5/01358, Y34 (fig. 16); R23-1 (fig. 18). Lâm PD1/02152, E38-1 (fig. 20).

$10,12,13,17$. Sergipea simplex REGAU Observar as dimensōes e a ornamentação. Lâm. SO5/01894, E46 (fig. 10). Lâm. CES7/01566, J45 (fig. 12). Lâm. SC1/15392, P45-3 (fig. 13). Lâm. FSM1/09796, R39 (fig. 17).

19, 21.... Sergipea tenuiverrucata RegAu

Vista lateral, mostrando as dimensð̌es e pouca definiçăo das verrugas. Lâm. SO5/01900, S36-4 (fig. 19). Lâm. PD1./02151, Q36-2 (fig. 21). 


\section{I N 0,1992}
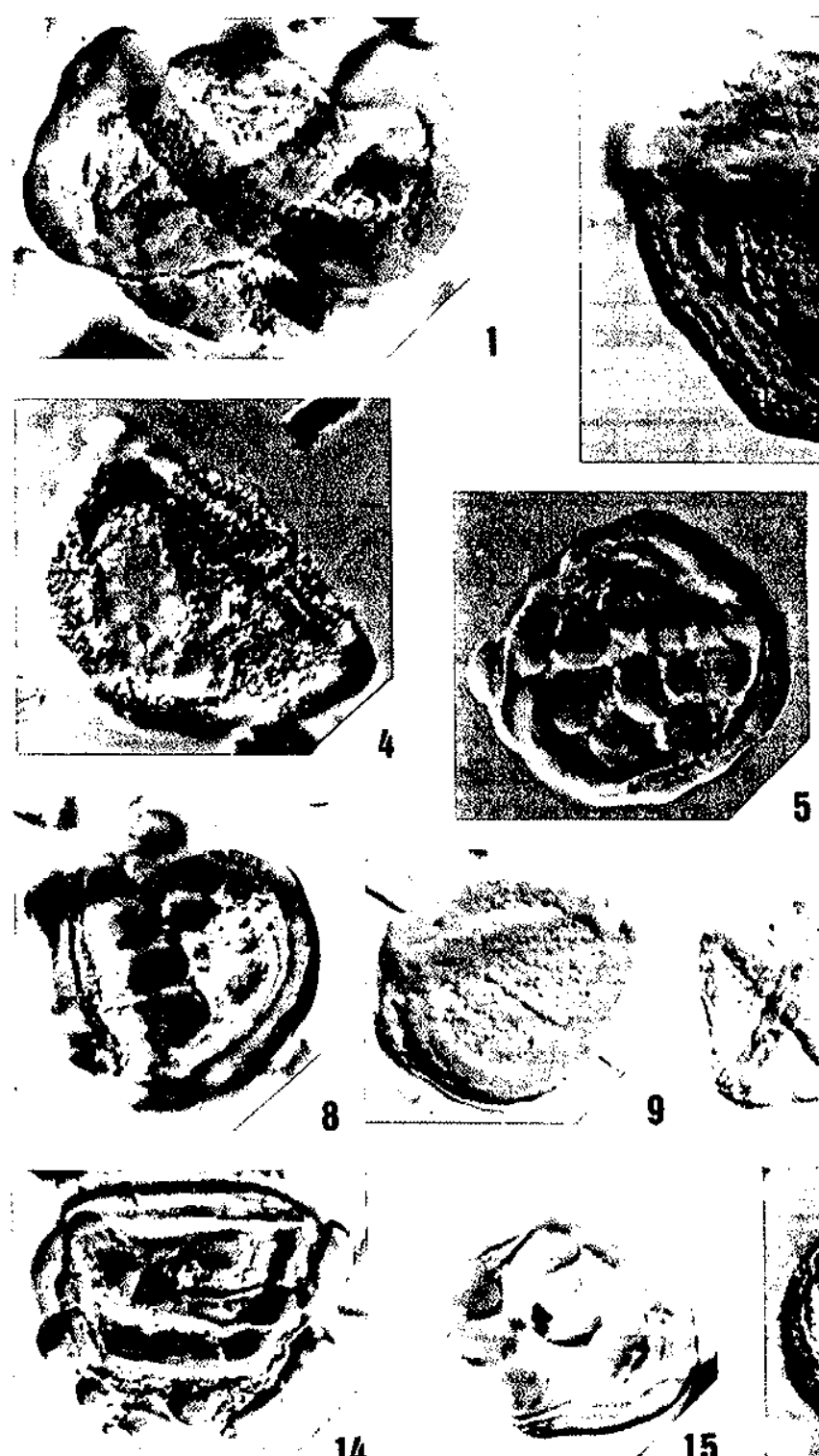

14
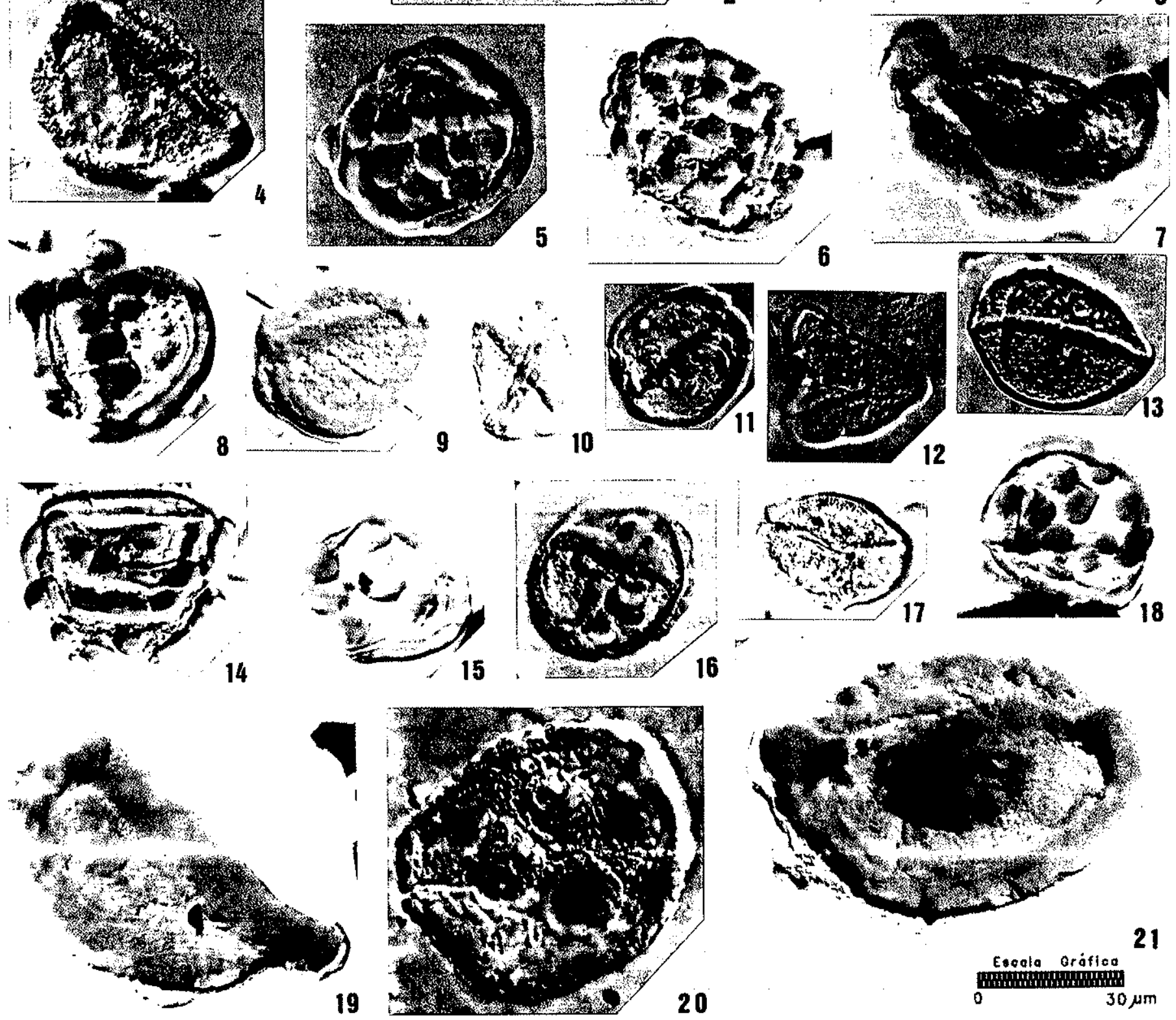

.
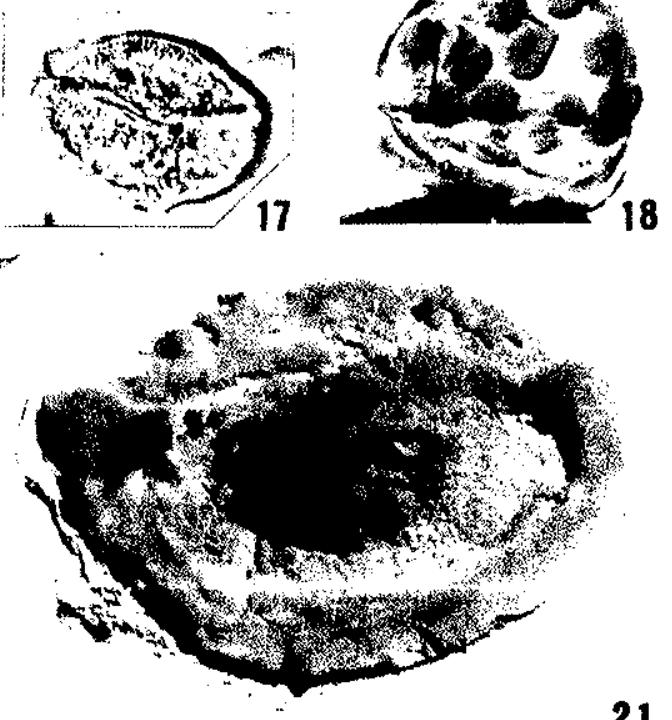

3 


\section{ESTAMPA KIV}

FIGURA

PÁGINA

1............. Classopollis alexi BURGER

Tétrade, mostrando as estrias. Lâm. RNS21/02185, M33-1.

2............ Classopollis torosus (REISSINGER) Couper

No exemplar ilustrado destaca-se o leptoma proximal e a ornamentaçăo. Lâm. RNS21/02185, R35-1.

3.............. Classopollis brasiliensis HeRNGREEN

No exemplar ilustrado destaca-se as dimensōes elevadas, a exina fina e a ornamentaçăo.

Lâm. RNS21/02185, Q38-1.

4............ Corollaria annularis MALYAWKINA

Vista polar, destacando a espessura da exina. Lâm. RNS21/02185, S27-351.

5, 8, 11.. Equisetosporites ambiguus (HeDLUND) SiNGH

Nos exemplares ilustrados, destaca-se a separaçăo das camadas da exina e onamentação.

Lâm. SO5/01904, E49-4 (fig. 5). Lâm. RBNS35/02153, S27-1 (fig. 8). Lâm. CES7/01563, \$21-2 (fig. 11).

6.............. Equisetosporites minuticostatus LiMA

Vista lateral, mostrando ornamentação. Lâm. SO5/01896, W51-4.

7, 9, 15-17.Equisetosporites maculosus nov. sp

Os exemplares ilustrados observar: o contorno elíptico, o grande número das costelas e a área central mais espessa e escura, que caracterizam a espécie. Lâm. SO5/01895, E58-1 (fig. 7, holótipo). Lâm. RNS21/08263, O36-2 (fig. 9). Lâm. SO5/01899, X51-2 (fig. 15). Lâm. CES7/01564, W39 (fig. 16). Lâm. CES7/01566, T23-2 (fig. 17).

10...n....... Equisetosporites leptomatus Lima

Vista lateral, mostrando ornamentaçăo e leptoma. Lâm. RNS21/02481, N32-4.

12........... Equisetosporites albertensis SiNGH Vista lateral, destacando as dimensões e a ornamentaçăo. Lâm. PD1/02151, G47.

13........... Equisetosporites laticostatus LIMA Apesar de mal preservado, é perfeitamente visível as costelas largas que definem a espécie. Lâm. SO5/01895, M54-4.

14, 25.... Equisetosporites luridus Lima Observar as áreas lisas nas extremidades, caracteristicas da espécie. Lâm. RNS21/02186, J45 (fig. 15). Lâm. SO5/01895, X35-3 (fig. 16).

18........... Incertae sedis $=$ Equisetosporites $? \mathrm{sp}$ Observar as camadas da exina e ornamentação. Lâm. TM5/09589, J62-1.

19.
No exemplar ilustrado evidencia-se as costelas largas e espessas, que caracterizam a espécie. Lâm. PD1/02151, P50-1.

20............ Singhia elongata (HoROWrrz) LIMA

No exemplar ilustrado ressalta-se a forma elongada e a ornamentação. Lâm. SO5/01886, E56.

21........... Equisetosporites ovatus (PIERCE) SINGH.

Observar as costelas espessas e retas. Lâm. SO5/01890, F46-4.

22.......... Singhia crenulata LIMA

Observar contorno e omamentação. Lâm. CES7/08815, M61-1.

23........... Equisetosporites concinnus SiNGH

Observar no exemplar ilustrado, além da ornamentaçăo e dimensøes, um lado mais fino que o outro, diagnóstico da espécie. Lâm. RNS21/02471, G49.

24.......... Equisetosporites $\mathrm{sp}=$ Ephedripites sp (artefato) DEJAX

Observar aspecto fusiforme, aparentemente monosulcado, em função da deformação no processo de fossilizaçăo, de acordo com o descrito por Dejax (1987). Lâm. NMR1/09772, D48-4. 
DI N 0, 1992

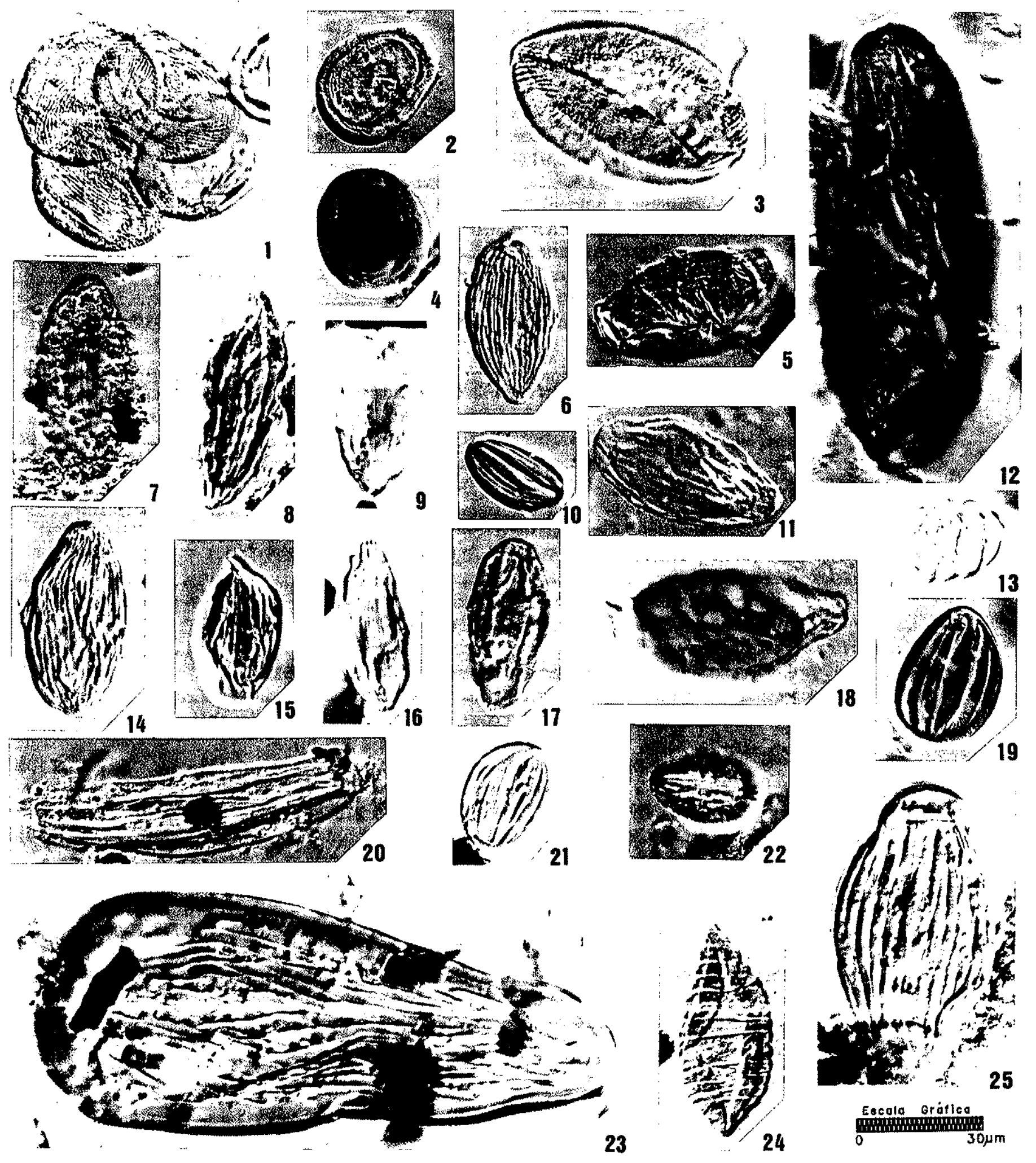

\section{ESTA MPA XIV}




\section{ESTAMPA KU}

FIGURA

PÁGINA

1, 13...... Gnetaceaepollenites barghoornü (Pocock) LMA

196

Observar costelas espessas e escuras, diagnósticas da espécie. Lâm. NMR1/09769, D52-3

(fig. 1). Lâm. SO5/01899, G33-1 (fig. 13).

2, 6, 7.... Gnetaceaepollenites uesuguii LMA

Observar o contorno e o arranjo das costelas. Lâm. SO5/01899, EA5-3 (fig. 2). Lâm.

PM2/01930, O29-1 (fig. 6). Lâm. PD1/02151, S48-2 (fig. 7 ).

3.............. Singhia multicostata (BRENNER) LMA

Observar as costelas irregulares que definem o grăo. Lâm. SO5/01894, V35.

4, 27...... Gnetaceaepollenites jansonii (Pocock) LMA.

Observar dimensð̌es e ornamentação. Lâm. SO5/01890, R42-4 (fig. 4). Lâm. SO5/01890, R42-4 (fig. 27).

$5 \ldots \ldots$ Equisetosporites concinnus SingH Observar no exemplar ilustrado, além da ornamentação e dimensões, um lado mais fino que o outro, diagnóstico da espécie. Lâm. NMR1/09773, R22-4.

8............ Gnetaceaepollenites mollis (SRrVASTAVA) L.MA Observar as costelas frouxamente dispostas, caracteristicas da espécie. Lâm. TM5/09589, K49.

9, 12, 23. Gnetaceaepollenites retangularis LIMA Nos exemplares ilustrados ressalta-se o contorno e o arranjo das costelas. Lâm. PM2/01929, P40-3 (fig. 9). Lâm. PD1/02151, J51-1 (fig. 12). Lâm. SO5/01895, H41-3 (fig. 23).

10.......... Gnetaceaepollenites sp. Forma poliplicada, cujo aspecto e contorno săo provavelmente resultantes do processo de fossilização. (não descrita). Lâm. PD1/02151, P31.

11......... Gnetaceaepollenites undulatus (REOAL, UESUGUI \& SANTos), LiMA..................................... Observar contorno e ornamentaçăo das castelas. Lâm. SO5/01892, L56.

14-16. ... Gnetaceaepollenites chlatratus STOVER Observar contorno e disposiçăo das costelas. Lâm. SO5/01896, W45-2 (fig.14). Lâm. CES7/01567, Q39-1 (fig. 15). Lâm.SO5/01900, L24-2 (fig. 16).

17, 18, 22. Steevesipollenites sp. cf. S. binodosus STOVER Observar contorno e espessamentos nas extremidades. Lâm. SO5/01894, H31-2 (fig. 17). Lâm. BP1/02963, Q29 (fig. 18). Lâm. RNS21/02786, P36-2 (fig. 22).

19.......... Steevesipollenites cupuliformis AzEMA \& BOLTHENHAGEN. Observar o contorno, as dimensठes e os leves espessamentos da exina nos extremos. Lâm. SO5/01068, H50-1.

20.......... Gnetaceaepollenites sp. 1 Observar ornamentação restrita a parte mediana das costelas. Lâm. NMR1/09772, K45.

21, 24-26. Gnetaceaepollenites spp Outros exemplares ilustrados, mostrado os aspectos que as formas poliplicadas tomam, possivelmente, como resultado da posição de fossilização. (formas não descritas). Lâm. PD1/02151, Y48-2 (figs. 24-26). Lần. TM5/0101, J52 (fig. 19). 


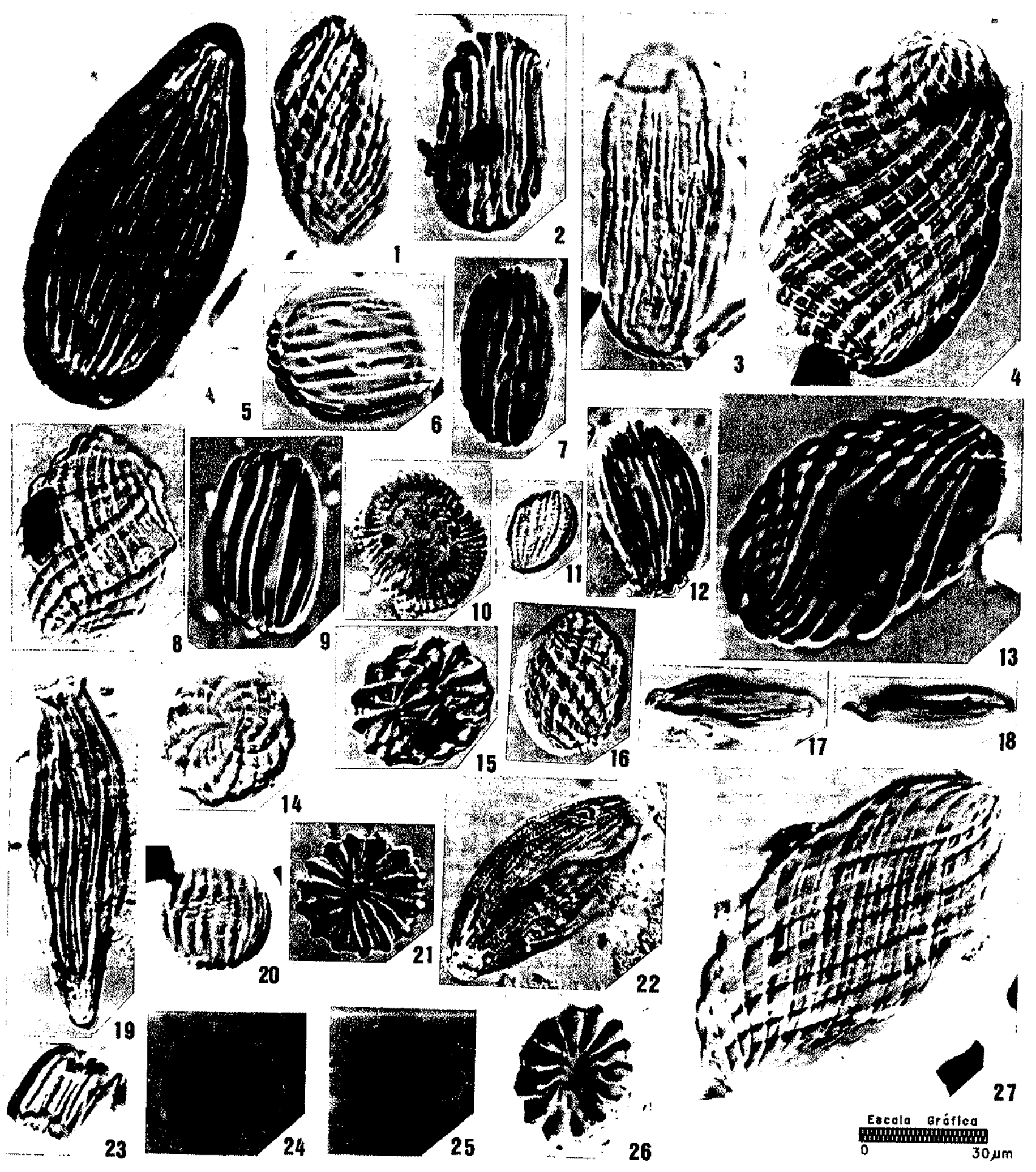




\section{ESTAMPA KUI}

FIGURA

PÁGINA

1, 2........Regalipollenites amphoriformis (REGAU, Uesugur \& SANTOS), LAMA

199

Observar o contorno e os espessamentos desiguais das extremidades. Lâm. SO5/01899, E38-3 (fig. 1). Lâm. NMR1/09772, C31-2 (fig. 2).

3, 4, 6, 11. Elateropollenites dissimilis REGAL Vista lateral. Notar nos exemplares ilustrados os apêndices pequenos, semelhantes a nódulos diagnósticos da espécie. Lâm. RNS21/02471, N58 (fig. 3); L45-1 (fig. 11). Lâm. RNS/02472, S56-1 (fig. 4); Q33-3 (fig. 6).

$5,8,16$. Cornetipollis perforata (Lima) nov. comb Observar nos exemplares ilustrados a ornamentação reticulo-foveolada das costelas. Lâm. PM2/02938, K46-4 (fig. 5). Lâm. SO5/01894, M44-2 (fig. 8). Lâm. PM2/02937, N47-3 (fig. 16).

7.............. Poliplicado não Identificado Observar ornamentação e "aurfculas" nas extremidades. Lâm. RNS21/01986, L49-3.

9.............. Elateropollenites praecursor REGALI Observar leves espessamentos nas extremidades do grằo. Lâm. RNS21/02471, N51-4.

10, 21.... Eucommiidites sp. 2. LiMA Observar os colpos e dimensరes. Lâm. PD1/02151, S50-4 (fig. 10). Lâm. NMR1/09772, P42-1 (fig. 21).

12........... Cycadopites nitidus (BALME) DE JERSEY Observar contomo e dimensōes. Lâm. SO5/01886, U55-4.

13........... Cycadopites carpentieri (DeLCOURT \& SPRUMONT) SNGH Vista proximal, mostrando sulco em toda a extensăo do grão e ligeiramente mais aberto nas extremidades. Lâm. SO5/01895, Q42-3.

14........... Cycadopites fragilis $\mathrm{SNGH}$ Notar ornamentaçāo e espessura da exina. Lâm. TM5/09589, J33-1.

15, 18, 20. Eucommiidites troedssonï (ERDTMAN) HugUes Nos exemplares ilustrados ressalta-se os colpos e os espessamentos nas extremidades. Lâm. NMR1/09772, L31 (fig. 15). Lâm. TM5/00100, X40-4 (fig. 18). Lâm. SC1/08188, E48-4 (fig. 20).

17........... Trichotomosulcites subgranulatus COUPER Observar contorno e abertura. Lâm. SO5/01905, N36-3.

19........... Monocolpopollenites spheroidites JARDANE \& MAGLORE Observar o contorno e o colpo com lábios espessados. Lâm. SC1/08188, J46-2.

22, 23... Bennettitaepollenites regalii nov. sp Observar dimensðes e espessura da exina. Lâm. NMR1/09769, G49 (fig. 22, holótipo). Lâm. TM5/09589, E40-1 (fig. 23).

24............ Confertisulcites sp. LMMA Observar dimensð̃es e espessura da exina. Lâm. SO5/01358, F56.. 


\section{N 0,1992}
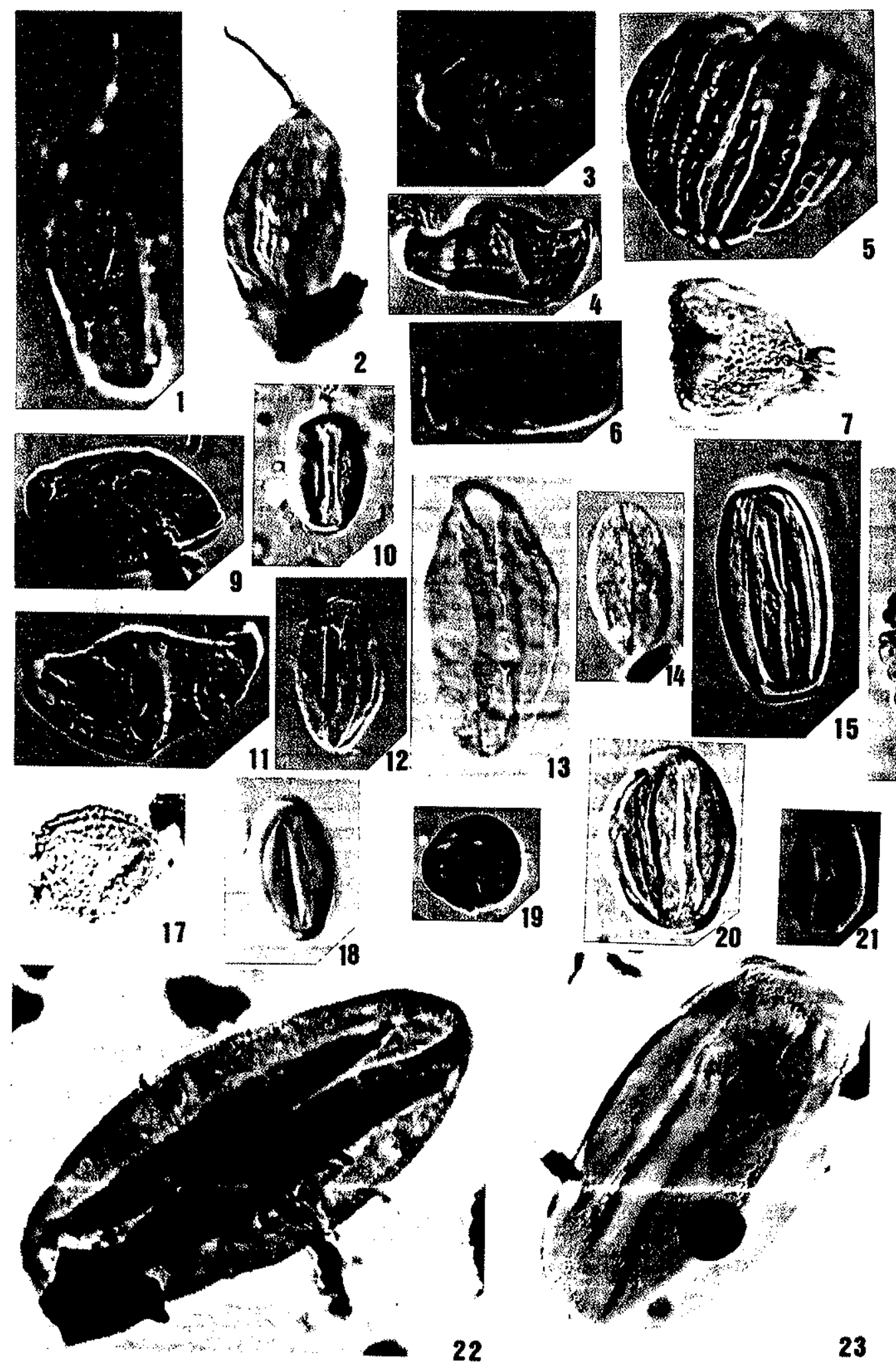

\section{ESTA M PA XVI}
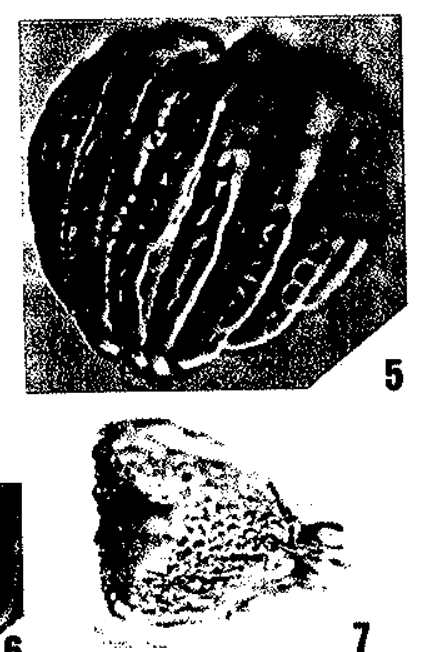

7

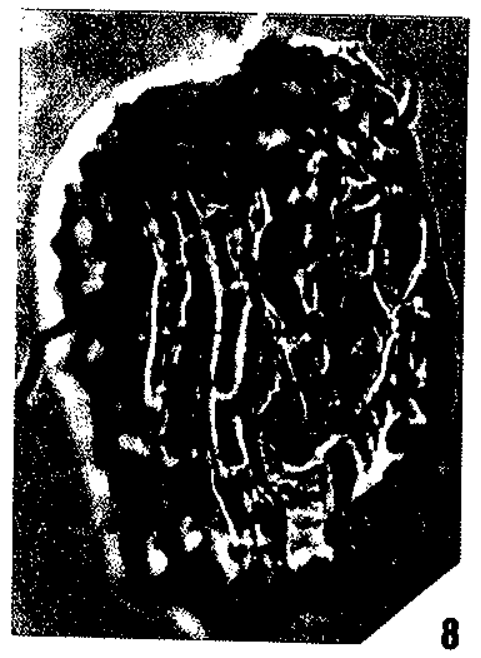

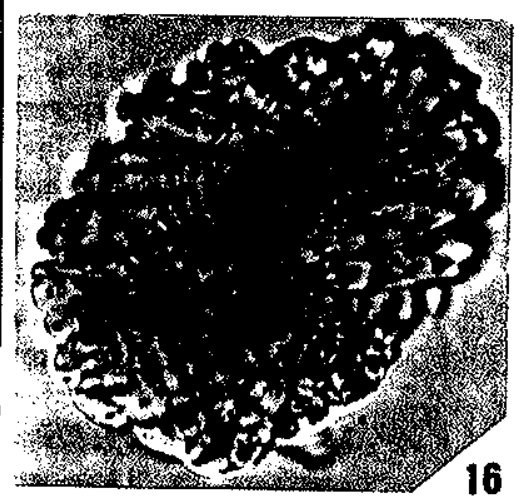

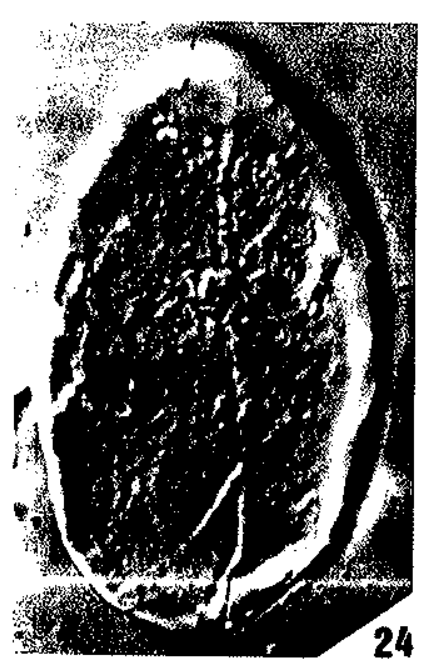

Encola Grática

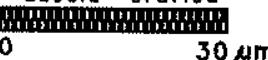




\section{ESTAMPA KUII}

FIGURA

PÁGINA

1, 2, 4.... Afropollis jardinus (BRENNER) Doyle, Jardine \& DoERENKAMP

Nos exemplares ilustrados, observa-se a presença ou não do corpo central e o caráter heteropolar dos grăos. Lâm. UB1/01899, M32-1 (fig. 1); R43-3 (fig. 4). Lâm. FSM1/09795, J45 (fig. 4).

3..............Stellatopollis dubius (LDA, 1978) LMA

No exemplar ilustrado ressalta-se a presença de áreas lisas no corpo do grão, e o maior adensamento da ornamentaçð̃o nas proximidades do sulco, características que definem a espécie. Lâm. SO5/01904, Y33.

5, 8, 9....Afropollis sp. aff. A. jardinus DoYLE, Jardine \& DoRrenxamp

Nos exemplares ilustrados ressalta-se a área de reticulado mais fina no polo, diagnóstica da espécie. Notar a presença ou não do corpo central. Lâm. RNS21/02185, R25-3 (fig. 5). Lâm. SOS/01894, O57-1 (fig. 8). Lâm. UB1/01899, R44-2 (fig. 9).

6.............. Stellatopollis sp. 2 Observar ornamentação e infrareticulo. Lâm. CES7/01566, T32.

7, 12, 13, 15. Afropollis operculatus DoYLE, JARDINe \& DOERENKAMP. Evidencia-se nos exemplares ilustrados a área polar operculada característica da especie. Lâm. SO5/02194, F41-3 (fig. 7). Lâm. RNS13/02182, R47 (fig. 13). Lâm.RNS10/0360, R41-2 (fig. 15); L38-3 (fig. 12).

10, 11, 18, 19. Afropollis zonatus DoYLe, JARDane \& Dokrenkamp Os exemplares ilustrados mostram claramente a área "zonasulcular" que define a espécie. Lâm. RNS13/02182, R37-4 (fig. 10); L33-2 (fig. 18). Lâm. RNS13/02181, J43-2 (fig.11).

14........... Stellatopollis densiornatus LMA Observar a densa ornamentação, diagnóstica da espécie. Lâm. NMR1/09775, H50-4.

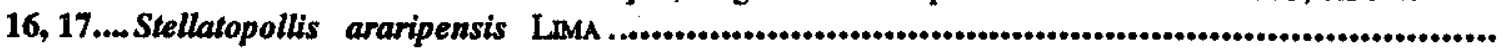
Observar contorno e ápices agudos das projeģes triangulares, caracteristicas da especie. Lâm. CES7/01566, R31 (fig. 16). Lâm. CES7/0011, P35-1 (fig. 17).

20........... Stellatopollis sp. 1 S. sp. DoYLE ET. AL (1977) Observar contorno e omamentação. Lâm. CES7/01566, K33.

21, 22.... Stellatopollis barghoornii DOYLE. Observar contorno e ornamentaçáo caracteristicos da espécie. Lâm. PM2/02931, 043-3 (fig. 21). Lâm. NMR1/19775, F45-1 (fig. 22). 


\section{ESTAM PA XVII}

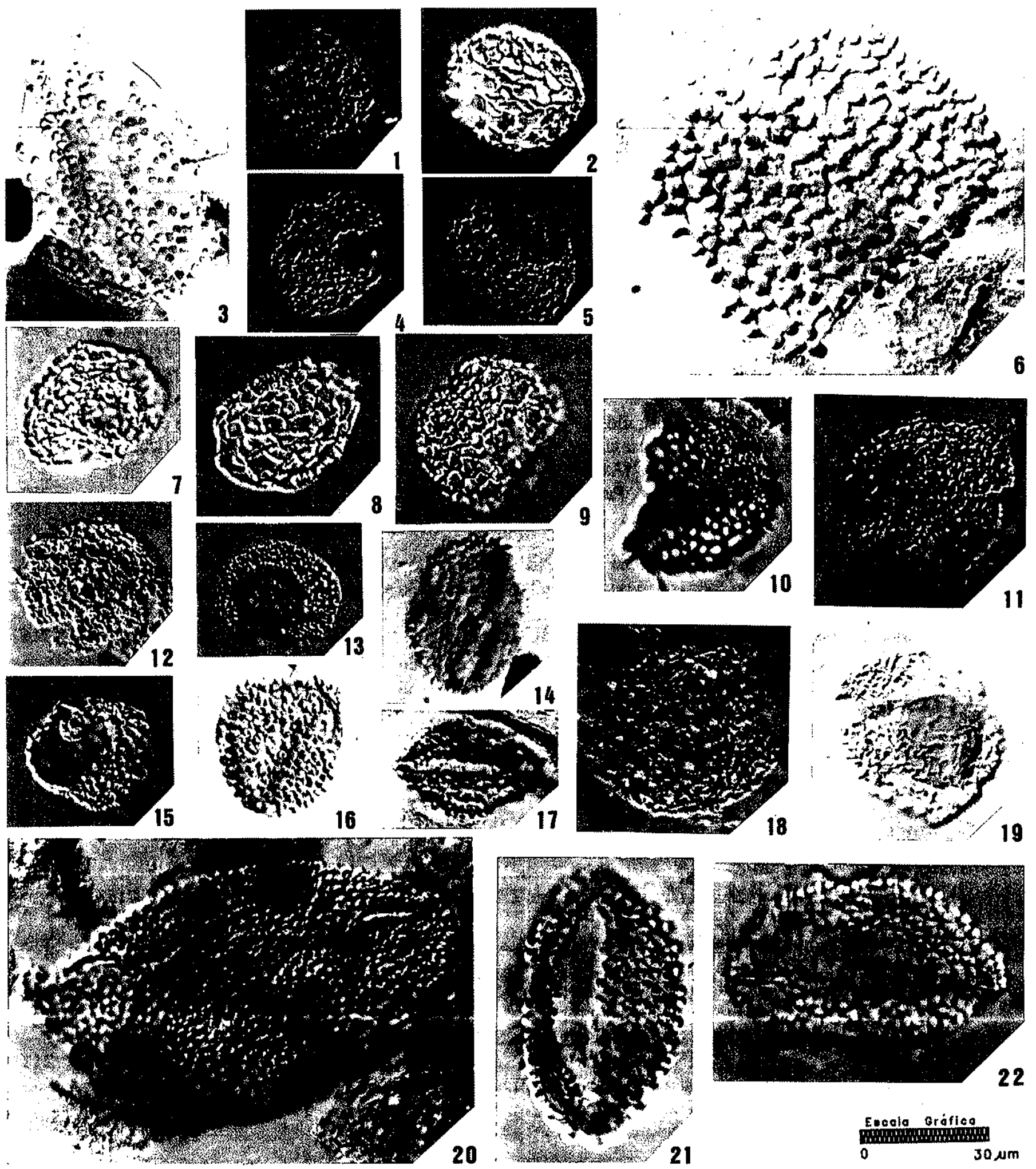




\section{ESTAMPA KUIII}

FIGURA

PÁGINA

1, 6......... Clavatipollenites hughesi COUPER

Observar contomo e ornamentaçăo. Lam. CES7/01564, V29-2 (fig. 1). Lâm. CES7/02156,

M37-3 (fig. 6).

2-4. ....... Clavatipollenites minutus BrenNar

Nos exemplares ilustrados ressalta-se as dimensðes e a ornamentaçăo. Lâm. SO5/01895, F48-4 (fig. 2). Lâm. SO5/01896, T39-1 (fig. 3). Lâm.UPN1/10722, R31-1 (fig. 4).

5............. Clavatipollenites tennelis PADEN-PtuLLPS \& FeIXX

Observar contorno subcircular e sulco largo, caracteristicos da espécie. Lâm. CES7/01566, T31.

7, 8......... Cavamonocolpites sp. 1

Diferentes focos do mesmo grão. Observar contorno, a fina espessura da exina e a ornamentação microfoveolada, diagnósticas da espécie. Lâm. RNS21/02471, H50-4.

9-10. ..... Cavamonocolpites punctatus LiMA

Nos exemplares ilustrados observa-se a nítida separação das camadas da exina e o colpo mais aberto nas extremidades, características que definem a espécie. Lâm. PD1/02151, Z44 (fig. 9). Lâm. SC1/08188, Q30-3 (fig. 10).

11.......... Retimonocolpites dividuus PIERCE Observar contorno e tendência de descolamento do retículo, caracteristica da espécie. Lâm. PD1/02154, Q51.

12-14. .... Brenneripollis peroreticulatus (BRENNER) JUHASZ \& GOCZAN Diferentes focos do mesmo exemplar, evidenciando aspectos da ornamentação e do sulco. Lâm. PD1/02154, V49.

15, 20.... Brenneripollis reticulatus (BRENNER) JUHASZ \& GOCZAN Observar ornamentação e sulco. Lâm. SC1/08188, F30-2 (fig. 15). Lâm. NMR1/09769, F34-2 (fig. 20).

16.......... Retimonocolpites textus (NoRrus) SnOH Observar dimensర̃es do grăo e do retículo. Lâm. SO5/01071, R50-1.

17, 18, 23, 25. Retimonocolpites excelsus WARD Observar nos exemplares ilustrados o contorno elíptico e a ornamentação grosseira, que definem a espécie. As ilustraçđes 17 e 18 mostram diferentes focos do mesmo exemplar. Lâm. RNS21/02480, L59-1 (figs. 17, 18). Lâm. RNS21/02459, H59-1 (fig. 23); S54 (fig. 25).

19, 28.... Retimonocolpites sp. 1 Observar contorno e omamentaço. Lâm. TM5/09589 K41-1 (fig 19). LAm PD1/02152 K54 (fig. 28).

21.......... Retimonocolpites fragilis PIERCE Observar contorno, ornamentação e espessura da exina. Lâm. SO5/01069, T54.

22, 24.... Retimonocolpites sp. (Retisulc-Cand-crochet, sensu HUOHEs, DREWRY \& LAINo) Nos exemplares ilustrados procurou-se ressaltar a ornamentação e o sulco. Lâm. RNS21/02185, D36-1 (fig. 22). Lâm. SO5/01899, W42 (fig. 24).

26, 27.... Retimonocolpites crassatus (SINGH) SiNGH. Observar contorno e ornamentaçăo. Lâm. CES7/01562, F27 (fig. 26). Lâm. UPN1/10721, O45-4 (fig. 27). 


\section{N 0,1992}
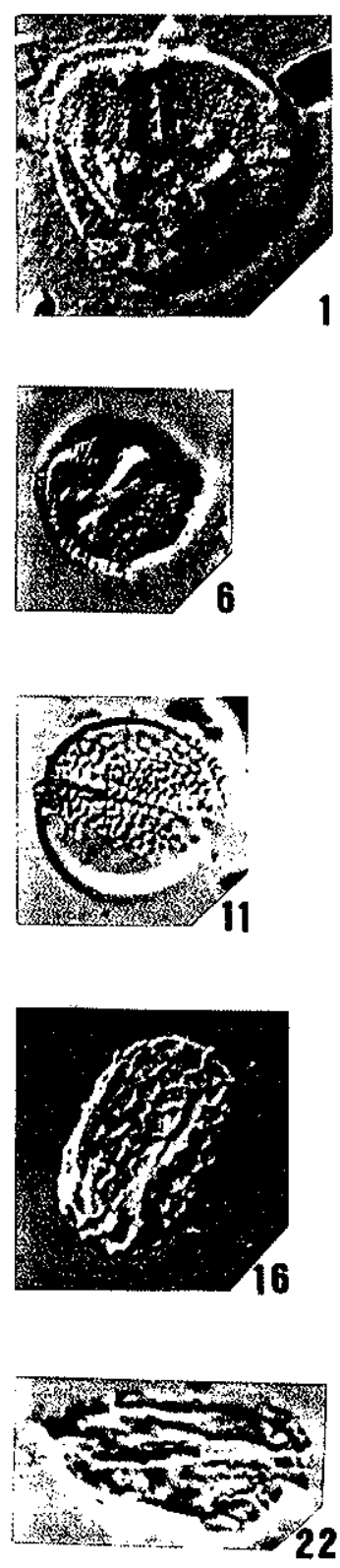

22
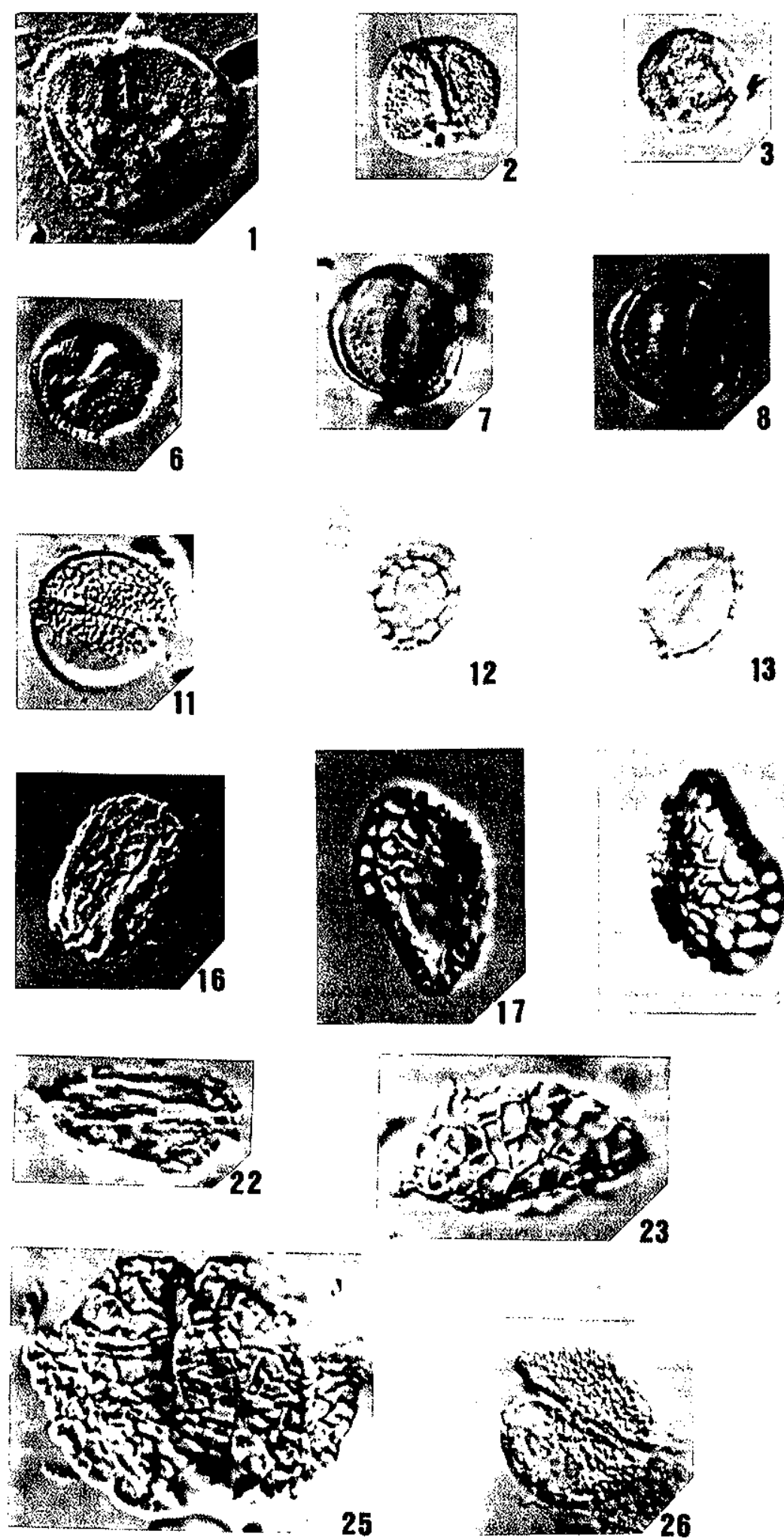

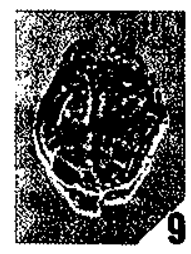

13

18

\section{ESTAM PA XVIII}
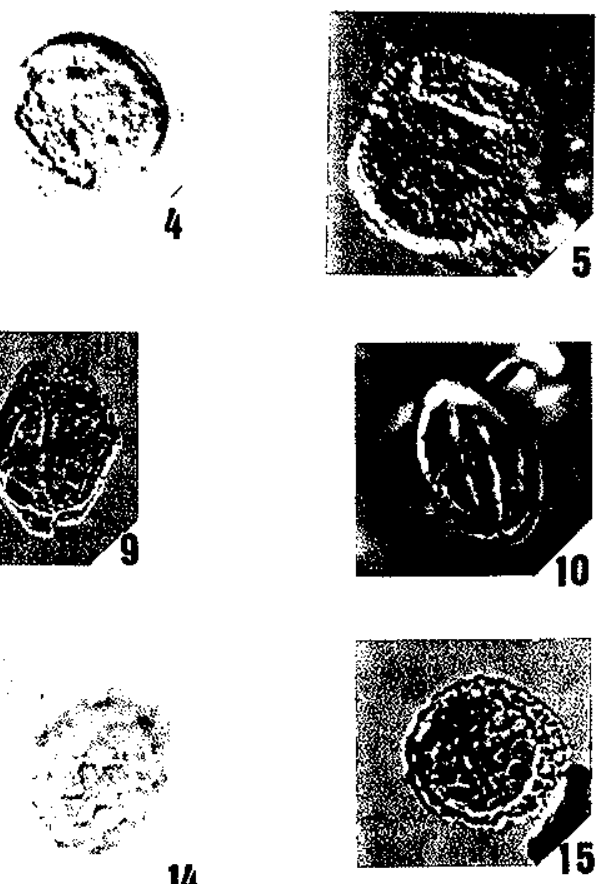

14
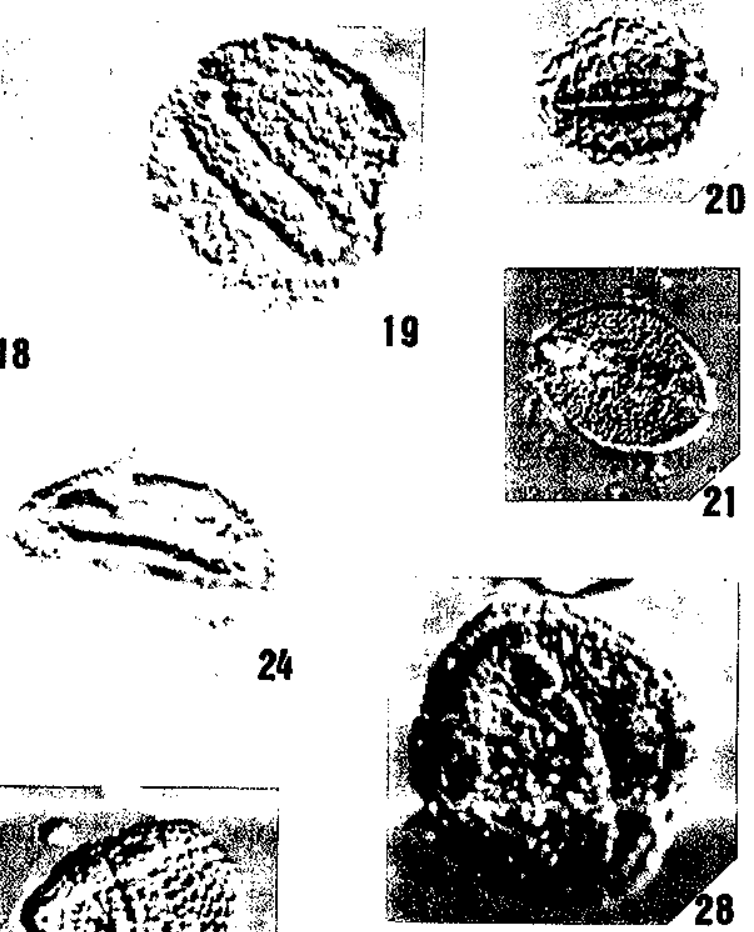

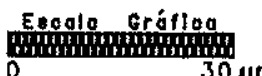




\section{ESTAMPA KIK}

FIGURA

PÁGINA

1-10. ..... Dejaxpollenites microfoveolatus nov. sp

202

Diferentes vistas dos exemplares ilustrados ressaltando a ornamentaçăo e abertura. Lâm.

CES7/01563, E37-3 (figs. 1-2). Lâm. NMR1/09782, H35-3 (fig. 3). Lâm. NMR1/09775, V50-2 (fig. 4), R25-2 (figs. 5, 10). Lâm. RNS21/01986, LA9-3 (fig. 6). Lâm. RNS15/01907, R43-4 (fig. 7); Q34 (fig. 9).

11.......... Psiladicolpites papillatus REGAL ..

Observar ornamentação e formato dos colpos. Lâm. CES7/02150, M32.

12.......... Psiladicolpites laevis REGALI Observar omamentação e formato dos colpos. Lâm. UB1/01895, L27-3.

13-15. ... Dicolpado Indeterminado I Observar dimensð̄es e ornamentaçăo. Lâm. RNS21/02479, F42-3 (fig. 13). Lâm. RNS21/02786, V44-1 (fig. 14); L29-4 (fig. 15).

16, 17.... Psilatricolpites pachyexinus COUPER Observar espessura da exına e ornamentação psilada. Lâm. RNS21/02471, F57-1 (fig. 16). Lâm. SO5/01894, P39-1 (fig. 17).

18.......... Tricolpites microreticulatus BeLSKY, Boltenhagen \& Potoní Observar ornamentaçăo e presença de manchas escuras nas regið̌es polares e bordas dos colpos. Lâm. SO5/01896, P34-4.

19.......... Cupuliferoidaepollenites parvulus (Groot \& PENNY) DetrManN Observar dimensరes e exina psilada. Lâm. SO5/01890, B41-1.

20.......... Tricolpites micromunus (Groor \& PeNNY) SiNGH Observar dimensðes do grão e da ornamentação. Lâm. SO5/01896, L55.

21.......... Dicolpado ? Indeterminado II Observar dimensões e ornamentação. Lâm. RNS21/02786, W37.

22, 23 . Tricolpites minutus (BRENNER) DetTMANN Observar dimensð̋es e ornamentação. Lâm. SO5/01894, 039 (fig. 22). Lâm. SO5/01896, X35 (fig. 23).

24........... Tricolpites? sp. 2 . Observar dimensð̄es, colpos e ornamentaç̆̃o. Lâm. RNS21/02471, R59.

25.......... Rousea charma WARD Observar ornamentação e dimensð̌es. Lâm. SO5/01895, O39-3.

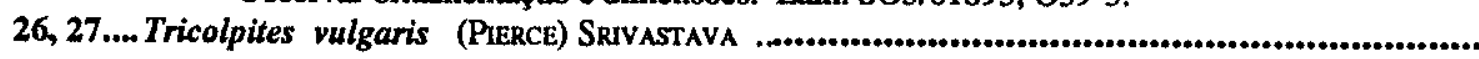
Notar contorno e omamentação. Lâm. RNS35/02153, N41-4 (fig. 26). Lâm. SO5/01899, T40-3 (fig. 27).

28, 29.... Rousea georgensis (BRENNER) DETTMANN Vistas polar e equatorial mostrando diminuiçăo gradativa dos lumina, a partir dos mesocolpos em direçăo aos polos e bordas dos colpos. Lâm. SO5/01068, G35-3 (fig. 28). Lâm. TM5/00101, Q33 (fig. 29).

30............ Tricolpites sp. 1 Vista polar, mostrando forma e detalhes da ornamentação. Lâm. CES7/01566, S28-2. 

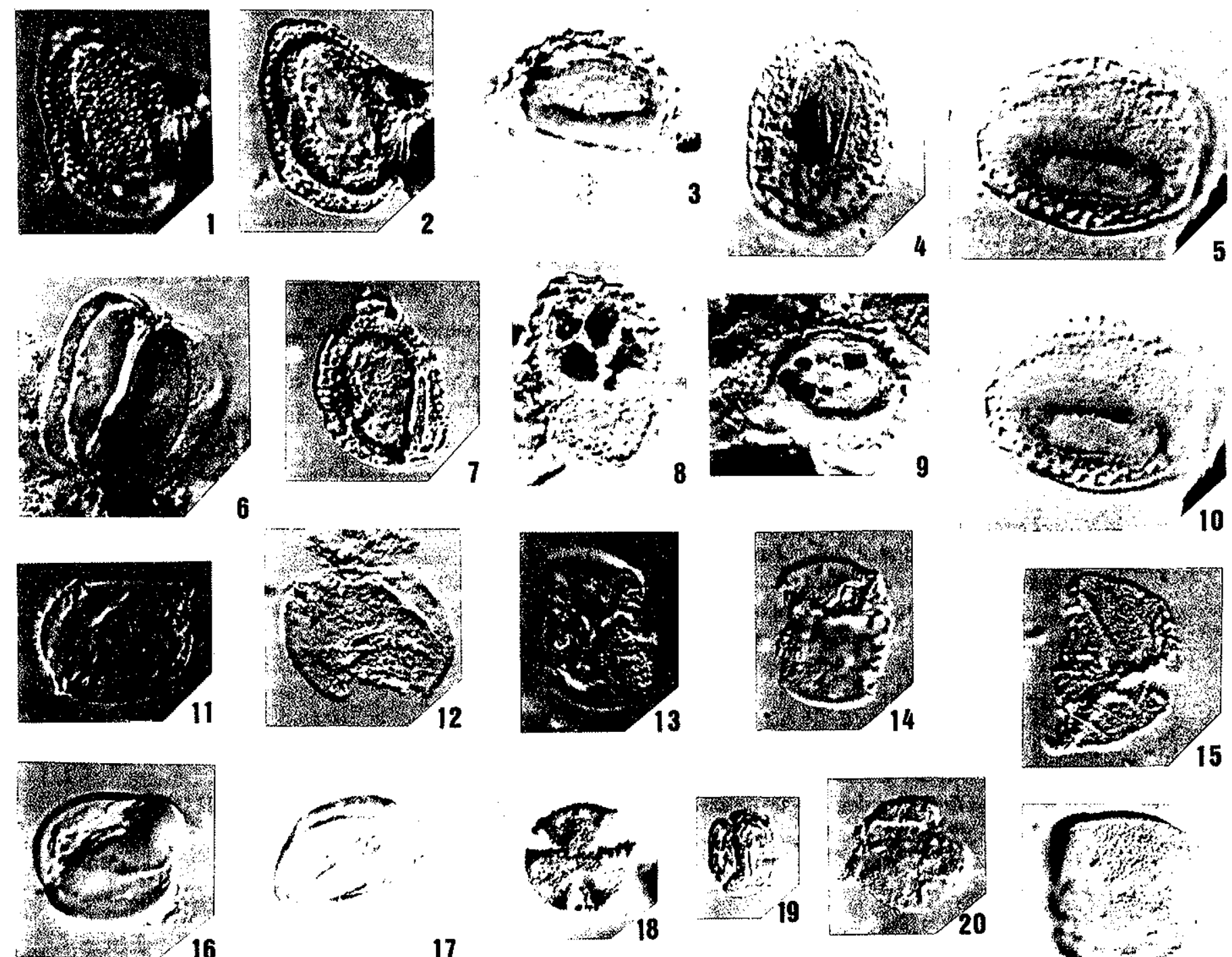

17
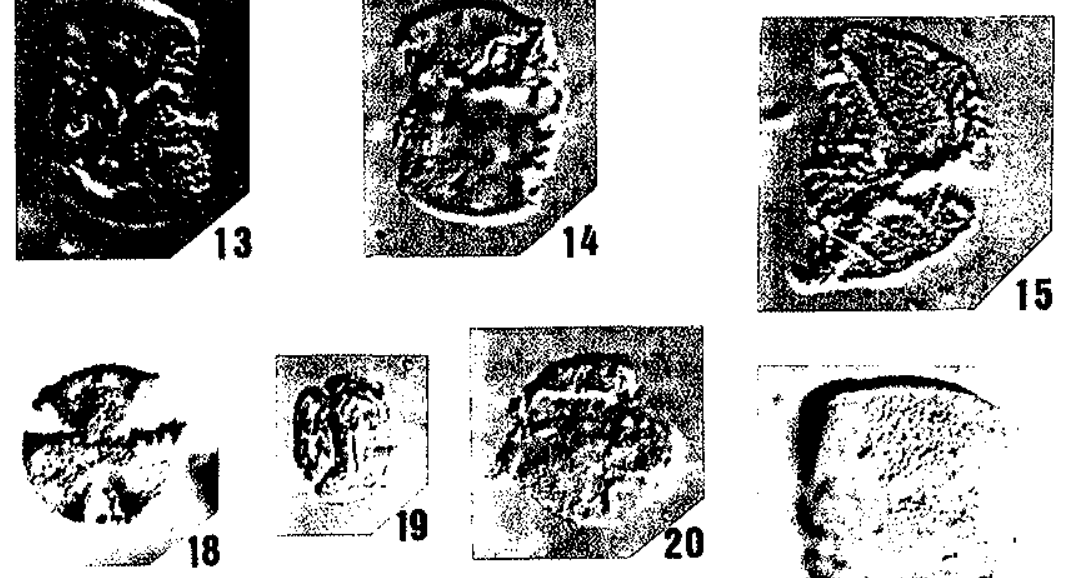

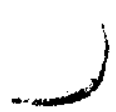

22

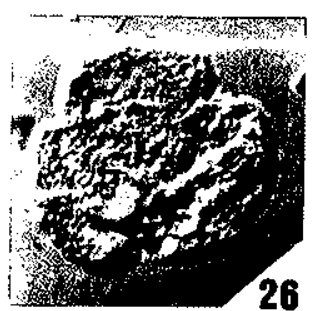

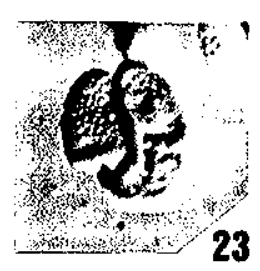

23

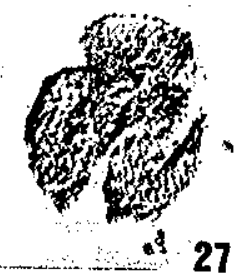

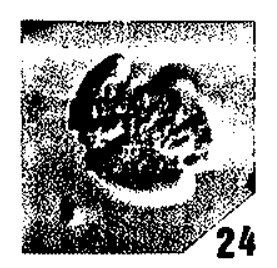

$-\quad k$

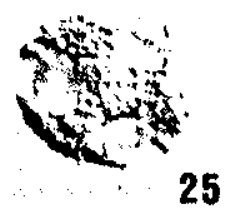

25

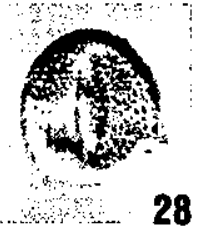

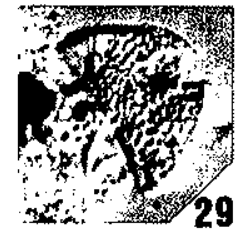
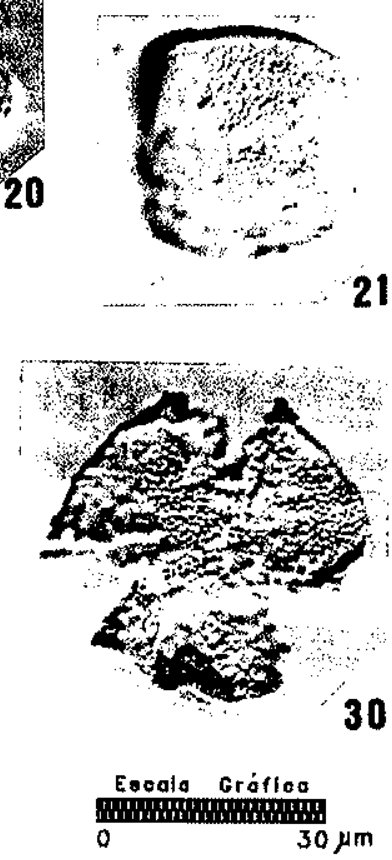


\section{ESTAMPA KH}

FIGURA

PÁGINA

1-5. ........Albertipollenites limae nov. sp.

228

Vistas polar e equatorial, mostrando detalhes da forma e omamentação. Làm. RNS35/02153,

U32 (figs. 1, 2 holótipo). Lâm. SO5/01358, P34-3 (fig. 3). Lâm SO5/01903, G28-1 (fig.

4). Lâm. UPN1/10721, M44-2 (fig. 5).

6-12...... Striatopollis reticulatus (REGAL, UESUGUI \& SANTOS) nov. comb

Nos exemplares ilustrados, em diferentes vistas, ressalta-se a ornamentação, tamanho dos

colpos e formas de fossilização. Lâm. TM5/09589, G58-3 (fig. 6). Lâm. SO5/01904, R36-3 (fig. 7); J34-3 (fig. 12). Lâm. CES7/02152, G33-2 (fig. 9). Lâm. TM5/00100, G43-4 (fig. 10).

13........... Striatopollis sp.1

Observar disposição da ornamentação. Lâm. TM5/09589, V41-2.

14............ Striatopollis paraneus (NORRIs) SINGH

15........... Tetracolpites sp. 1

Vista polar. Observar bordas convexas e ornamentação. Lâm. RNS21/02459, L50.

16, 20.... Quadricolpites reticulatus WINGATE

Observar omamentaçăo. Lâm. RNS21/02480, L51 (fig. 16). Lâm. RNS21/02459, D48-2 (fig. 20).

17, 19.... Penetetrapites mollis HeDLund \& NoRRIs

Observar aberturas. Lâm. SO5/01904, E48-1 (fig. 12). Lâm. SO5/01358, V24-2 (fig. 13).

18........... Penetetrapites incipiens LIMA.

Observar a degradação da exina nas aberturas, caracteristica da espécie. Lâm. RNS21/02185, N45-4. 


\section{I N 0.1992}
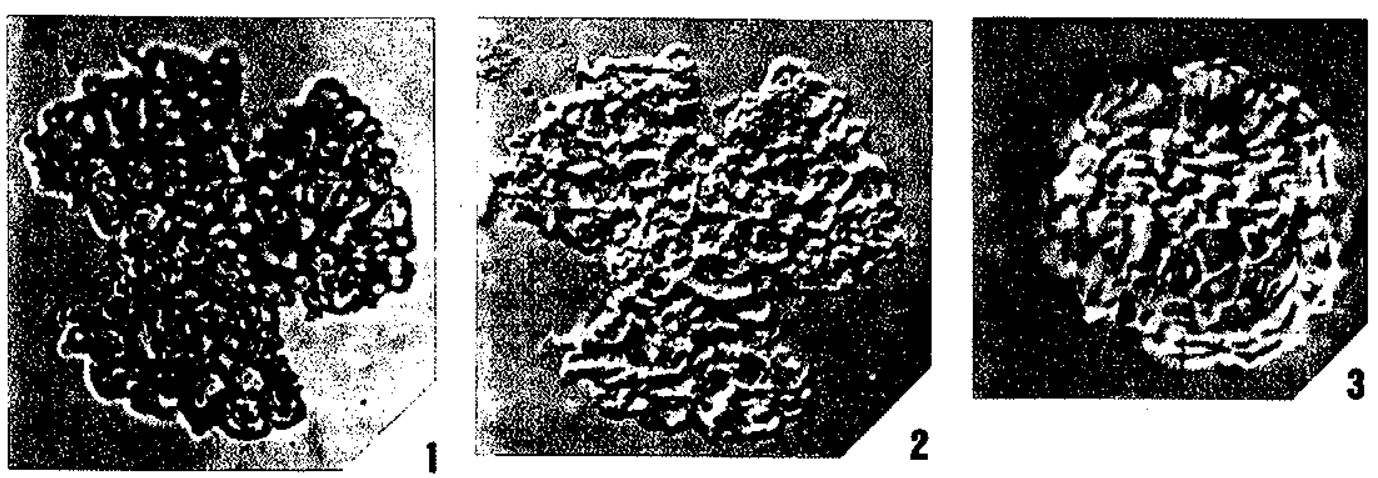
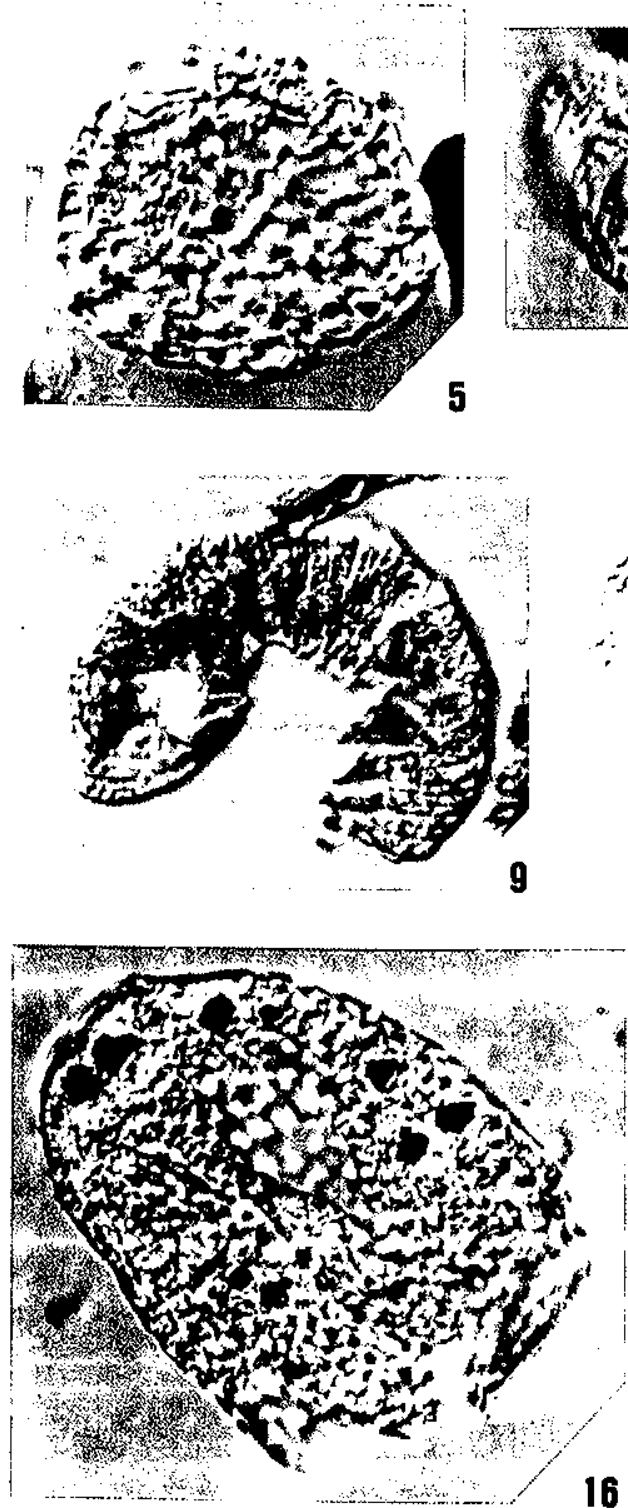

16

\section{ESTA M PA XX}
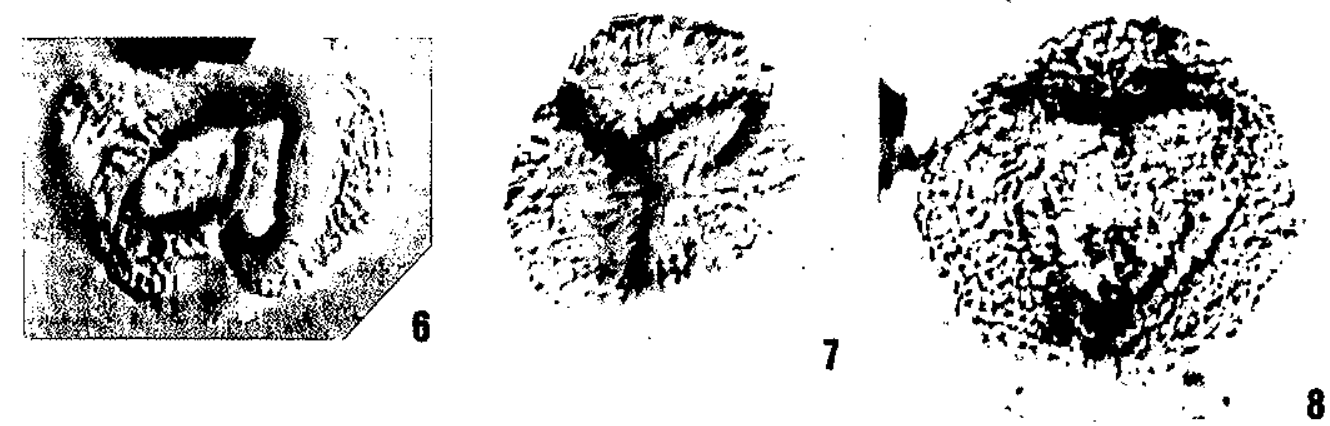
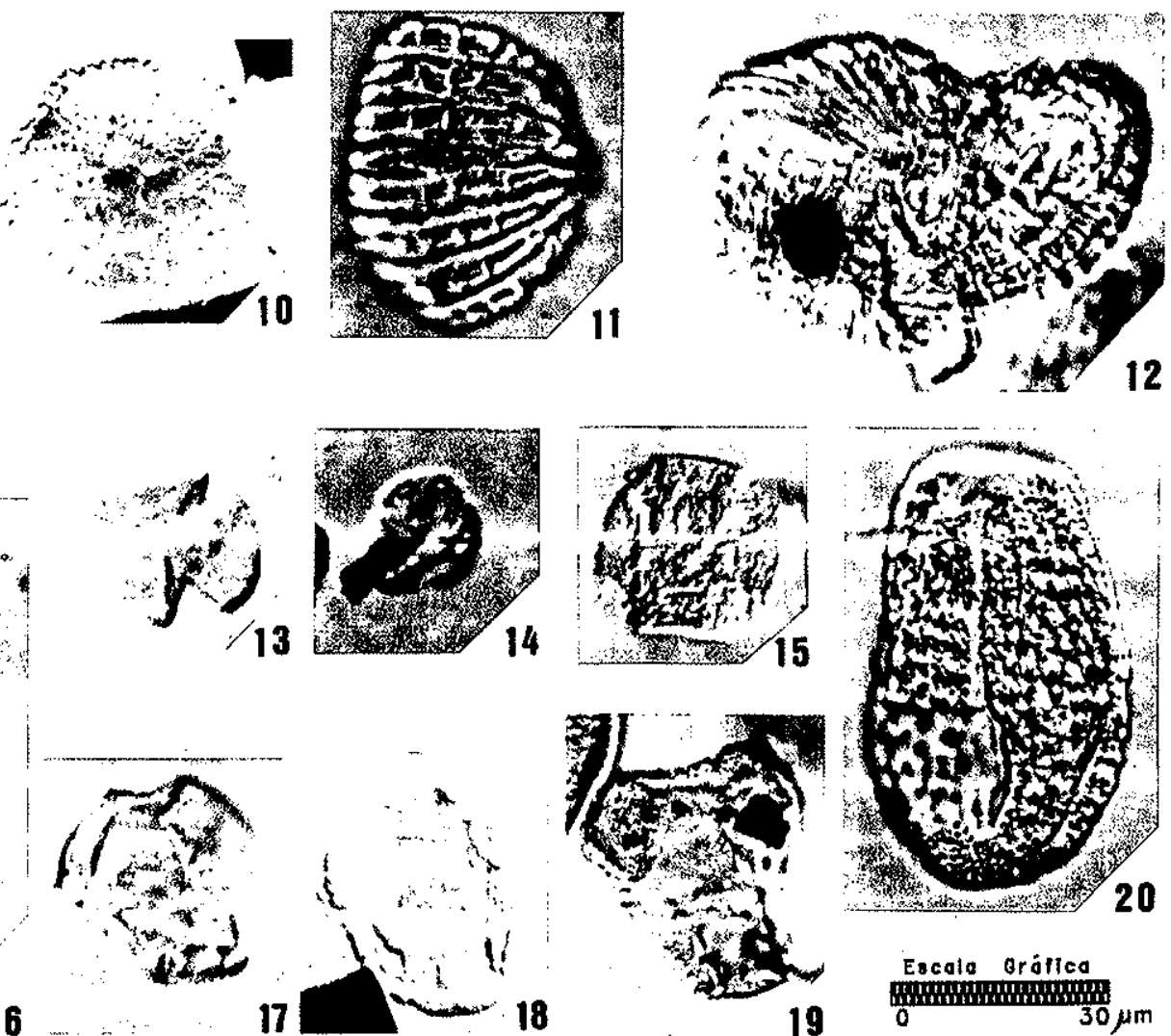


\section{ESTAMPA КИІ}

FIGURA

PÁGINA

1-3........ Exesipollenites tumulus B ALME

Os exemplares ilustrados (faces proximal e distal) mostram claramente o espessamento anelar e o poro central, diagnósticos da espécie. Lâm. RNS21/02481, H40 (fig. 1); M39-2 (fig. 2). Lâm. NMR1/09772, K35-1 (fig. 3).

4, 5, 9.... Exesipollenites scabratus (COUPER) Pocock

Observar dimensões e ornamentação, bem como o poro central. Lâm. SO5/01890, R49

(fig. 4). Lâm. RNS21/02786, M43-1 (fig. 5). Lâm. SO5/01894, E40 (fig. 9).

6-8. ....... Exesipollenites laevigatus Pococx

Observar dimensర̋es e omamentação. Lâm. SO5/01890, L49-2 (fig. 6). Lâm. FSM1/.......... E51-2 (fig. 7); S41-2 (fig. 8).

10-14. ... Transitoripollis crisopolensis (REGAL) nov. comb Nos exemplares ilustrados observar ornamentação e formato do poro. Lâm. CES7/01564, M37-3 (fig. 10). Lâm. CES7/01566, J43-2 (fig. 11). Lâm. NMR1/09786, H52-1 (fig. 12). Lâm. CES7/0011, O48-1 (fig. 13); M54-1 (fig.14).

15........... Cretacaeiporites polygonalis (JaRDINE \& MAGLOTRE) HERNGREEN Observar ornamentação e poros. Lâm. RNS21/02481, L35-2.

16........... Reyrea polymorphus HERNGREEN Observar as báculas alinhadas, caracterfsticas do grăo. Lâm. UB1/01899, F39-3.

17, 19.... Spiniferites multibrevis (DaveY \& WiluAMs) Lentin \& Wiunams

Lâm. RNS21/02476, R56 (fig. 17); U42 (fig. 19),
18, 21.... Trichodinium castanea (DEFLANDRE) CLARKE \& VERDIER Lâm. RNS21/02480, D65-2 (fig. 18); E32-3 (fig. 21).

20............ Cribroperidinium intricatum DAVEY Lâm. RNS21/02786, N33. Lâm. RNS21/02480, 043-2. 

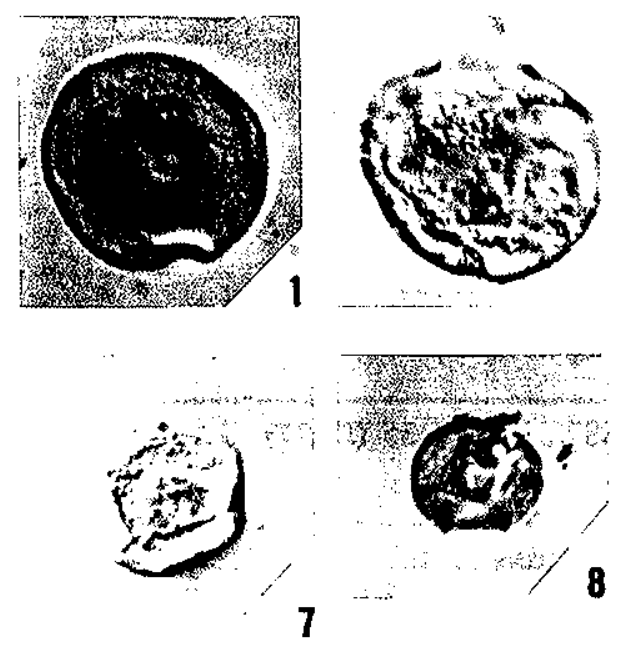

2
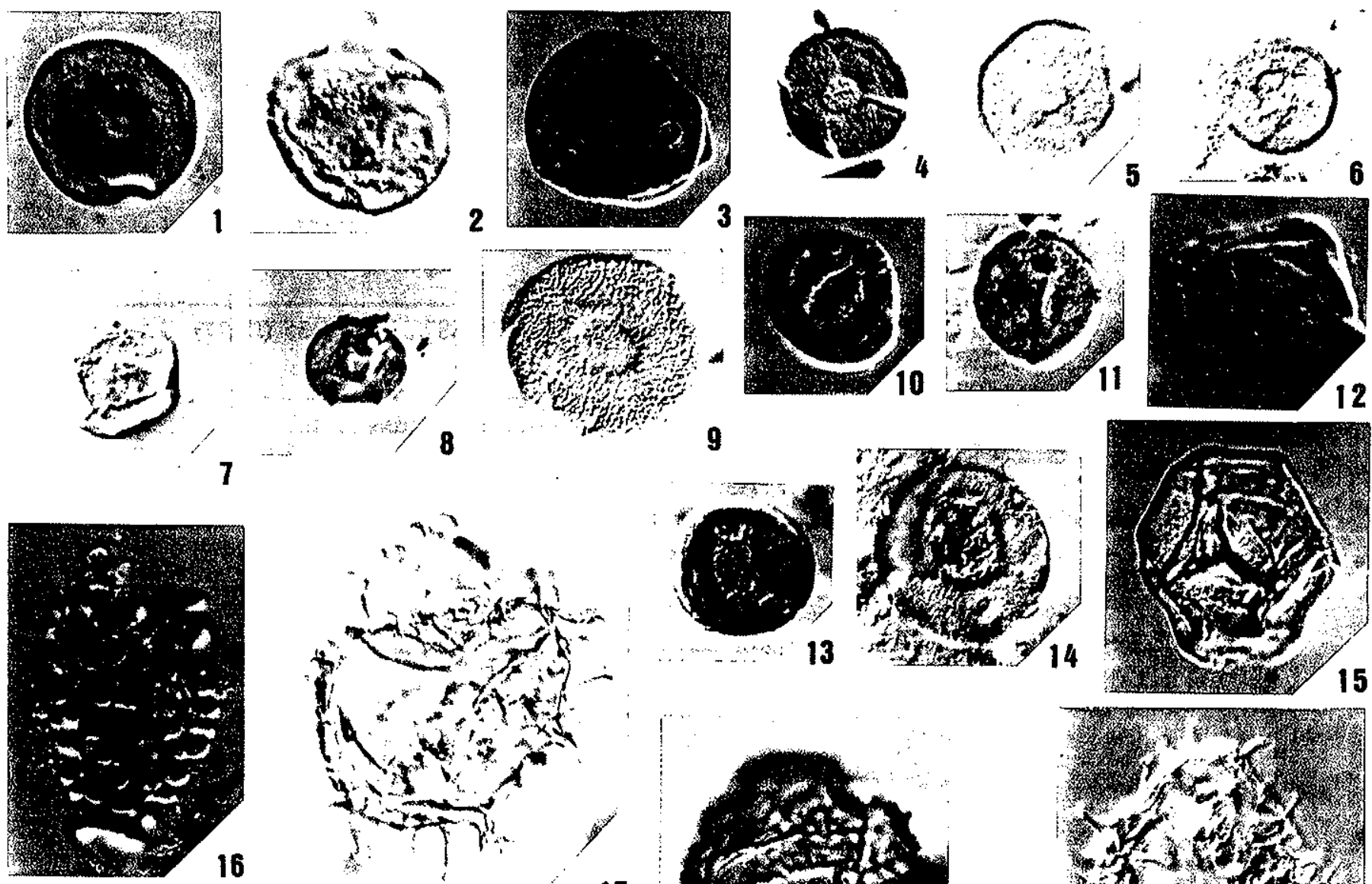

17
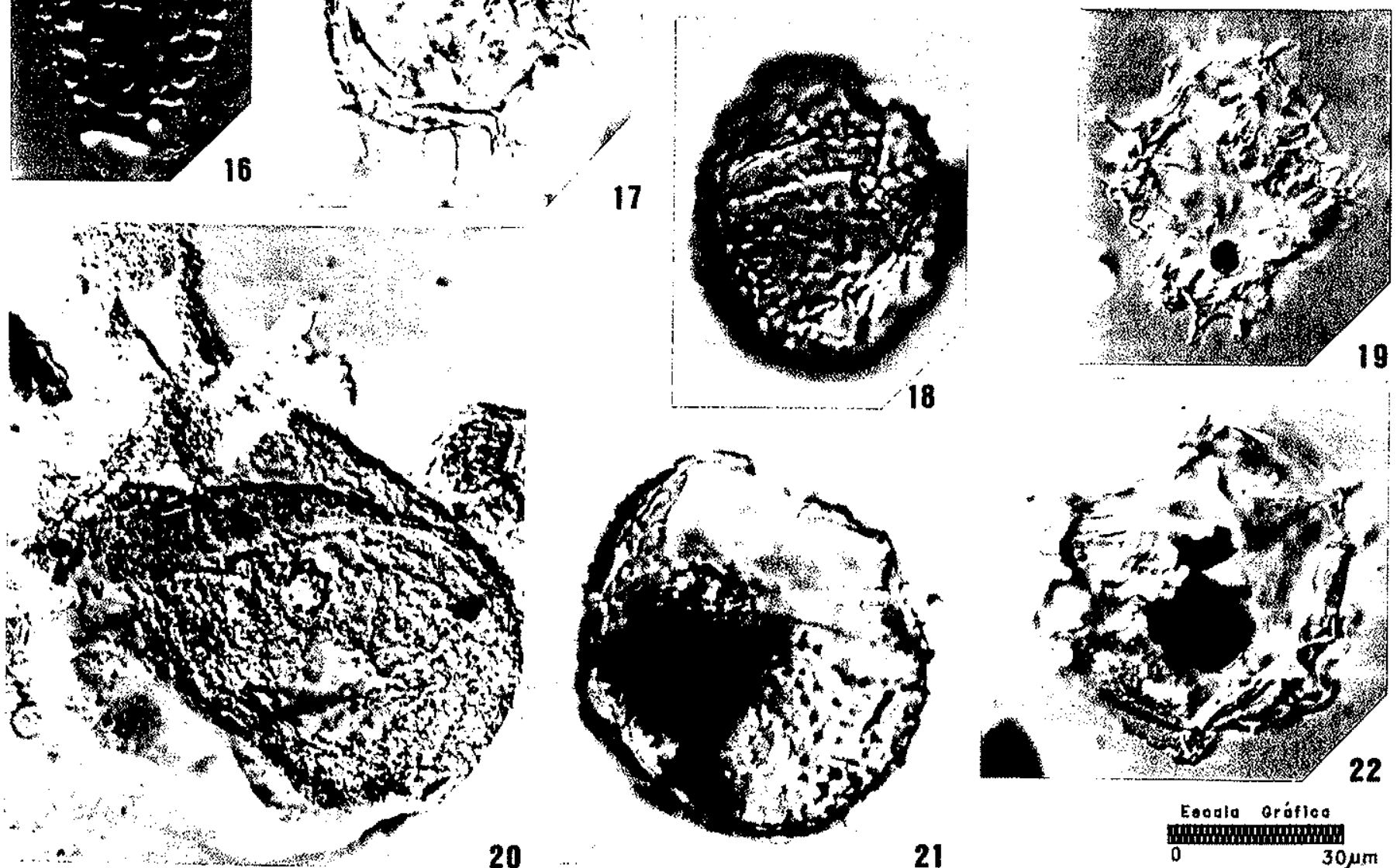

18
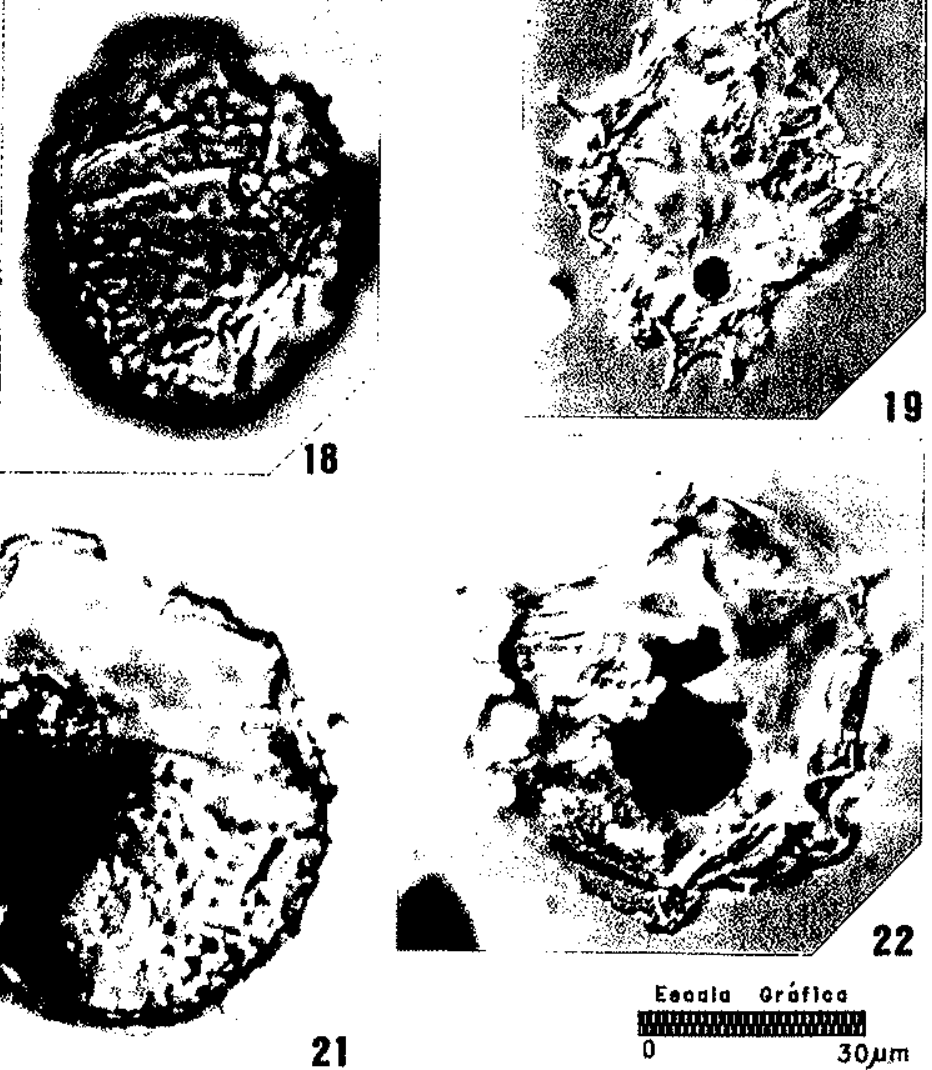


\section{ESTAMPA KRII}

FIGURA

PÁGINA

1,5 ......... Incertae sedis III.

Observar formato anelar e "estrias" radiais. Lâm. CES7/01566, O35 (fig. 1). Lâm.

PM2/02936, Q37-3 (fig. 5).

2.4, 6, 7, 10. Incertae sedis IV

Fragmentos quitinosos atribuíveis à carapaças de conchostraceos (Estheria ?). Observar ornamentação e linhas de crescimento. Lam. CES7/01566, S43 (fig. 4); J32 (fig. 7);

8............ Incertae sedis I

Q31-4 (fig. 6); M46 (fig. 3); N36 (fig. 2). Lâm. PD1/01058, L37-1 (fig. 10).

Observar forma do palinomorfo e a espessura da exina. Lâm. PD1/01058, N24-3.

9.............. Incertae sedis II

Observar formato e simetria. Lâm. CES7/01566, S38.

11........... Fragmento cuticular com estômatos

Lâm. PD1/02152, W44. 

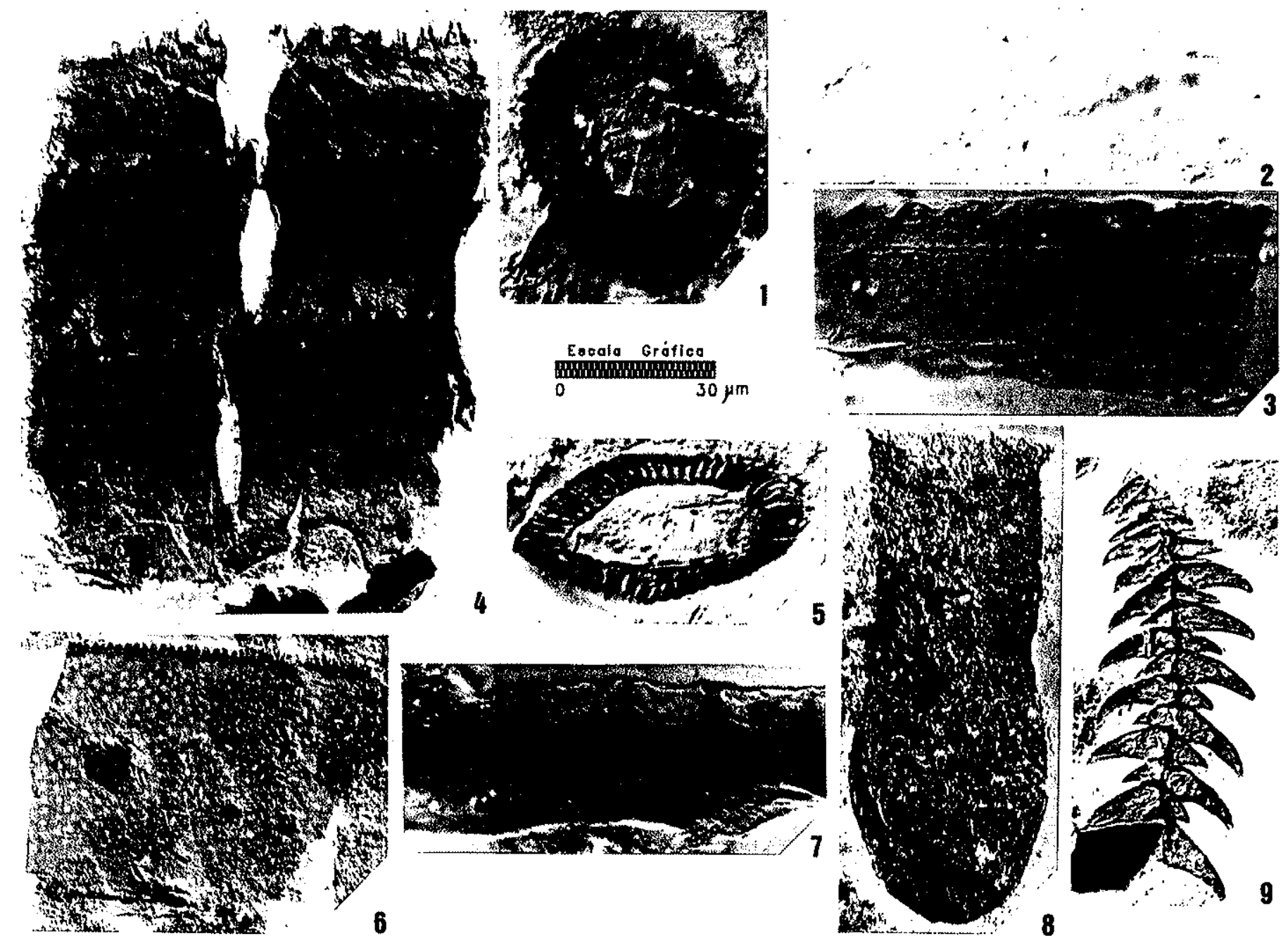

5
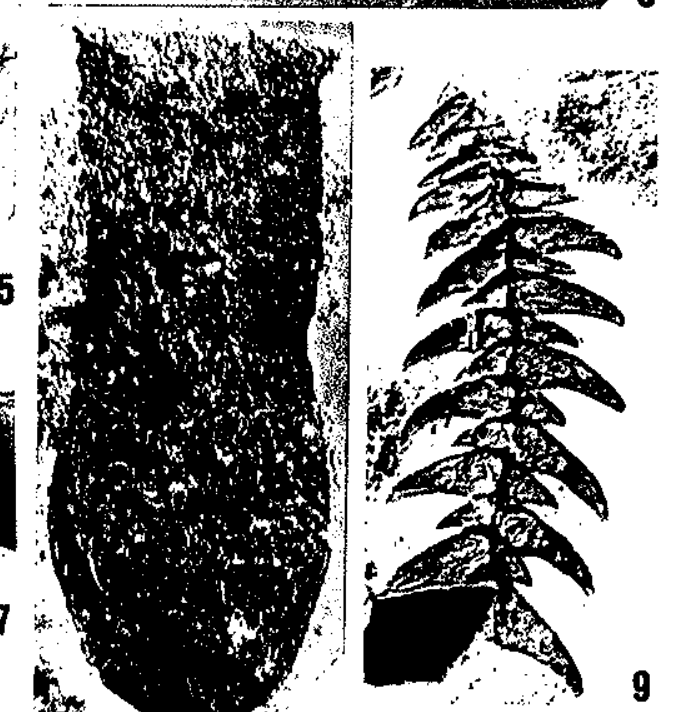

b.
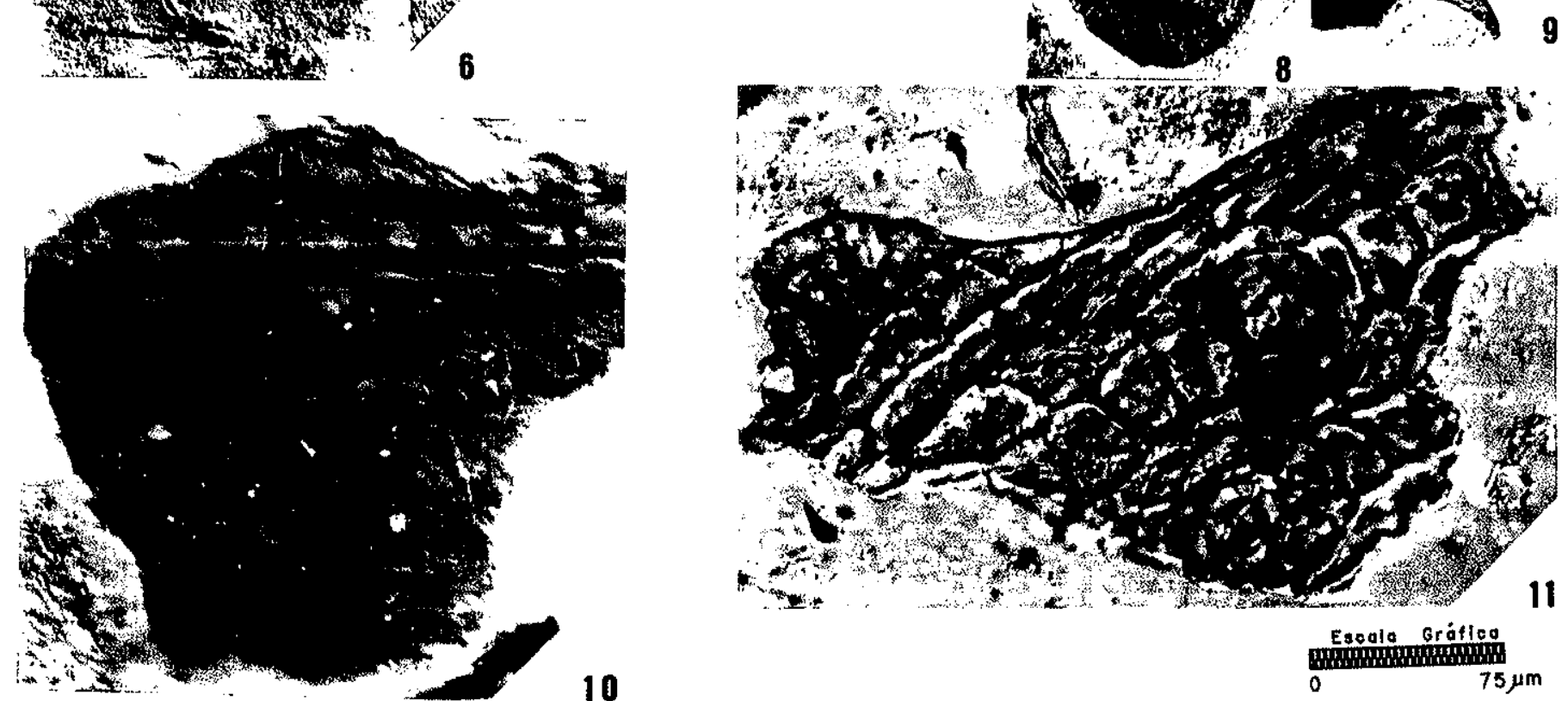


\section{ESTAMPA KKIII}

FIGURA

PÁGINA

A. ......... PALINOFÁCIES I.

Domínio de matéria orgânica lenhosa, preta, opaca e sem estruturas. Geralmente pobre em resfduo orgânico. Característica de ambientes proximais de alta energia (leques aluviais, fan-deltas, barras arenosas, canais). Notar as reduzidas dimensores dos palinomacerais.

B. ......... PALINOFÁCIES II .

Presença de matéria orgânica (amorfa + lenhosa), geralmente biodegradada. Característica de ambientes proximais de alta energia (canais meandrantes, planfcies aluviais). Notar as reduzidas dimensðes dos palinomacerais.

C, D. ... PALINOFÁCIES III.

Presença em percentuais complementares de matéria orgânica lenhosa e amorfa (fragmentos com estruturas ou não). Representa ambientes intermediários relativamente energéticos ou não (planície flúvio-deltaica, áreas protegidas). Notar as dimensðes relativamente grandes dos palinomacerais e sua angulosidade, além da frequeência de palinomorfos.

E, F. .... PALINOFÁCIES IV

Domínio de matéria orgânica amorfa (algas/bactérias). Virtual presença de palinomorfos. Característica de ambientes distais, com baixa energia e condiçбes de fundo estagnantes (lacustre). 


\section{DIN 0, 1992}
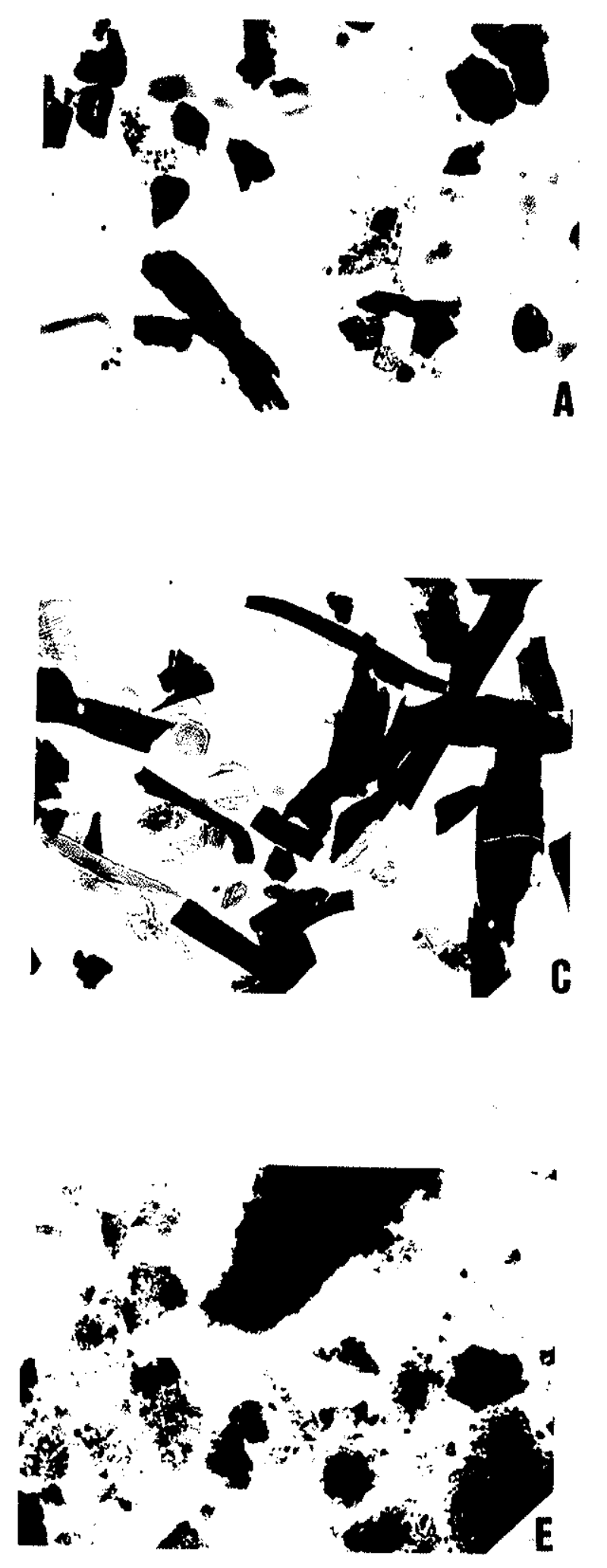

\section{ESTA M PA XXIII}
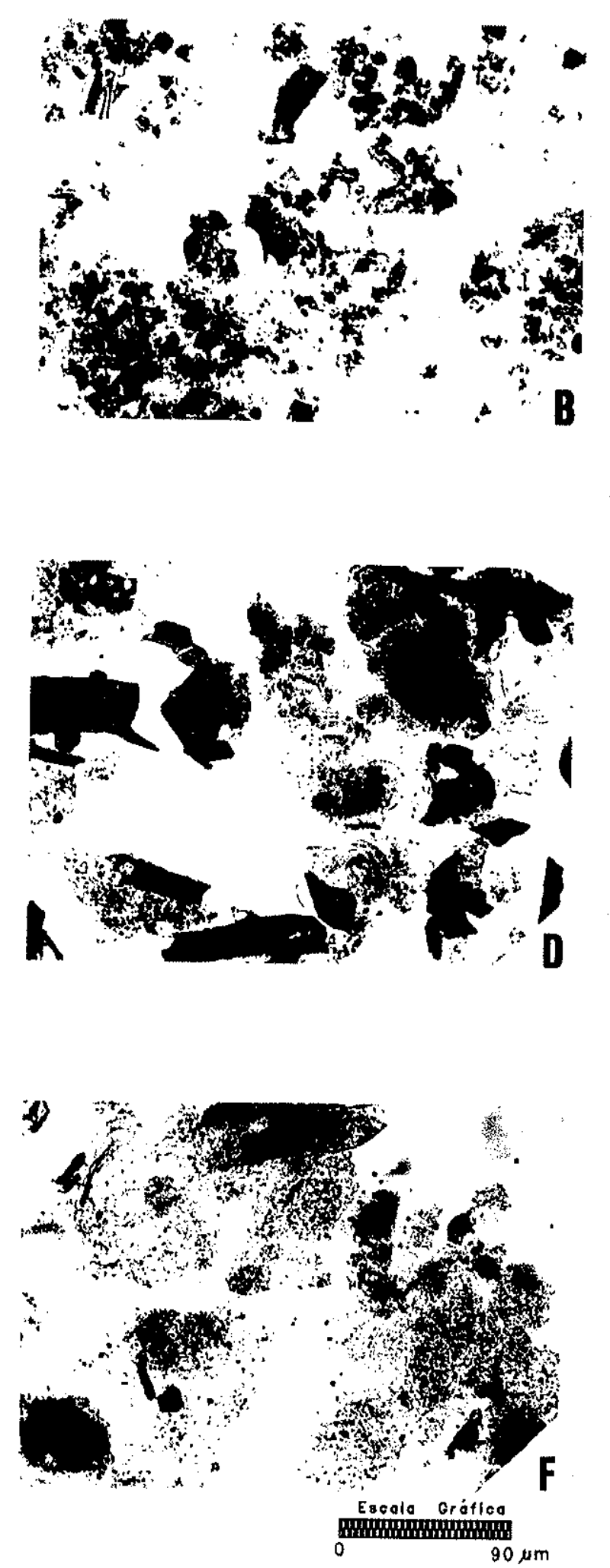